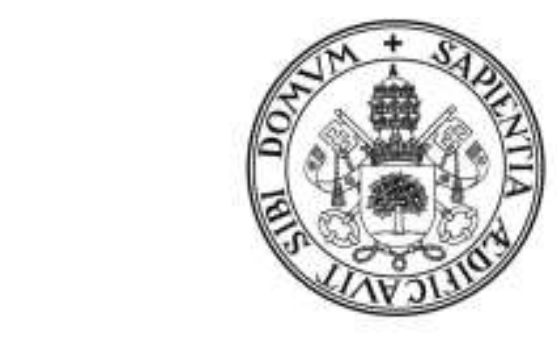

\title{
Universidad deValladolid
}

FACULTAD DE EDUCACIÓN Y TRABAJO SOCIAL DEPARTAMENTO DE PEDAGOGÍA

\section{TESIS DOCTORAL}

El pensamiento visual en la formación del profesorado: Análisis de los componentes del pensamiento viso-espacial y su importancia en la formación de los docentes de educación infantil y primaria

\footnotetext{
Presentada por D. Pedro Urchegui Bocos para optar al grado de Doctor por la Universidad de Valladolid
}

\section{Dirigida por:}

Dra. Rocio Anguita Martínez

Dra. $M^{a}$ Jesús Irurtia Muñiz

VALLADOLID, 2015 
DEDICATORIA 


\section{Indice de Figuras}

Fig. 01: Símbolos de representaciones antropomorfas

Página 35

Fig. 02: Grabados que describen la cámara oscura

Fig. 03: La linterna mágica y primera cámara fotográfica

Fig. 04: Primeras fotografías, heliografías o 'dibujos del sol'

Fig. 05: El perro "Albreckt" en la obra de Degas y en la foto de Sauvager

Fig. 06: Odalisque de Eugene Delacroix, 1857, y fotografia de la modelo para el pintor

Fig. 07: Claude Monet fotografiado en su jardín y la obra 'Nenúfares'

Fig. 08: La obra 'las bailarinas azules' de Degas y fotografías de las modelos

Fig. 09:

Burghardt Rezső y A. Mucha trabajando con la modelo

Fig. 10: Fotografías de Julia Margaret Cameron y obras de Rosetti y Burne-Jones

Fig. 11: Daguerrotipos y Cámara para daguerrotipo

Fig. 12: Calotipo y negativo del establecimiento fotográfico de Fox Talbot

Fig. 13: Pirámide de la lectura visual

Fig. 14: 'La traición de las imágenes' de René Magritte $\quad 47$

Fig. 15: $\quad$ Aplicaciones interactivas en educación $\quad 48$

Fig. 16: $\quad$ Curvas de Bezier y nodos en tipografía y formas $\quad 51$

Fig. 17: $\quad$ Códigos de imagen canvas y SVG $\quad 51$

Fig. 18: $\quad$ Descripción del código QR 53

Fig. 19: $\quad$ Muestras de aplicaciones educativas de realidad aumentada 54

Fig. 20: $\quad$ Modelos de realidad aumentada en relaciones espaciales 54

Fig. 21: Doble vía del procesamiento visual $\quad 59$

Fig. 22: $\quad$ Ejemplos de mimetismo en insecto y ejército. 'Pintos', acuarela de Doolittle 63

Fig. 23: $\quad$ Ilusiones ópticas de movimiento y de tamaño. 65

Fig. 24: Relación entre la distancia y el tamaño percibido (ley de la constancia) 66

Fig. 25: $\quad$ llusiones ópticas y ley de constancia 66

Fig. 26: $\quad$ Efectos de la distancia y del punto de posición en la percepción 69

Fig. 27: $\quad$ Experimentos visuales de luminosidad $\quad 70$

Fig. 28: Influencia del conocimiento en la percepción $\quad 71$

Fig. 29: $\quad$ Supuestos básicos de los sistemas de símbolos perceptuales $\quad 78$

Fig. 30: $\quad$ Tipología del conocimiento $\quad 79$

Fig. 31: $\quad$ Factores primarios de Thurstone $\quad 80$

Fig. 32a. $\quad$ Posibles funciones de las áreas visuales 86

Fig. 32b. Localización de la corteza visual 86

Fig. 33: $\quad$ Lobulos cerebrales (imagen LSDB). $\quad 87$

Fig. 34: $\quad$ Cuerpo calloso (imagen LSDB). $\quad 87$

Fig. 35: Dibujos de paciente con agnosia visual 88

Fig. 36: Resonancia magnética y tractografía; Tractografía invertida de la vía óptica: 90 nervio óptico 
Fig. 37: Diferencias entre estilos de procesamiento de los hemisferios

Fig. 38: Teoría del cerebro holoárquico-holístico 93

Fig. 39: $\quad$ Modelo cognitivo conjunto 94

Fig. 40: Daniel Tammet, Stephen Wiltshire y Kim Peek 96

Fig. 41: Imágenes en diferentes niveles de representación-abstracción 100

Fig. 42: $\quad$ Representación de mapa y de proyección 105

Fig. 43: $\quad$ Modelos de representación paralelo o diédrico y convergente cónico 108

Fig. 44: Concepto de competencia y su significado compartido con otros conceptos 116

Fig. 45: $\quad$ Competencias básicas, áreas y asignaturas de la educación primaria 117

Fig. 46: Evaluación de las competencias $\quad 123$

Fig. 47: $\quad$ Modelo de Ficha de evaluación $\quad 124$

Fig. 48: $\quad$ Asignaturas por áreas en educación primaria $\quad 126$

Fig. 49: $\quad$ Expresión visual de las emociones. Litografía $\quad 127$

Fig. 50: Modelo Experiencial de Kolb 130

Fig. 51. Modelo de Gregorc $\quad 131$

Fig. 52. Plantillas de organizadores gráficos para uso didáctico e infografías 133

Fig. 53: Combinaciones posibles entre modo y modalidad del material multimedia 134

Fig. 54: $\quad$ Memoria espacial 137

Fig. 55: $\quad$ Ejemplos de pares de dibujos en perspectiva presentados a los sujetos 141

Fig. 56: $\quad$ Alfabeto visual (Díaz, 1986), estiletes romanos y stylus digital 146

Fig. 57 .grafismos básicos y mandalas (Kellogg, 1973) 150

Fig. 58: Alumnos de la Clase de Arte Juvenil de Cizek (Ortega, 2009) 153

Fig. 59: Dibujos narrativos del 'realismo intelectual' (Luquet, 1978) 154

Fig. 60: Dibujos de figuras humanas de niños entre 3 y 4 años $\quad 158$

Fig. 61: $\quad$ Entrenamiento gráfico (Calmy, 1977) 159

Fig. 62: Técnicas estructurales y líneas de relieve para definir los contornos 162

Fig. 63: $\quad$ Técnicas de 'visual \& design thinking' 164

Fig. 64: Autorretratos pre y post entrenamiento. Manos realizadas por alumnos de 1ํㅡ 164

Fig. 65: $\quad$ Muestra de caligrafía y 'metadoodles' 166

Fig. 66: Tabla de competencias con menor valoración docente 172

Fig. 67: Tabla de competencias con mayor valoración docente $\quad 173$

Fig. 68: Reparto de créditos ECTS $\quad 175$

Fig. 69: $\quad$ Estructura de la inteligencia y capacidad espacial $\quad 181$

Fig. 70: $\quad$ Analogía entre los mecanismos mentales y los perceptivos 182

Fig. 71: Items PMA-Primary Mental Abilities 184

Fig. 72: $\quad$ Complejo ítem de desarrollo de superficies. Test informatizado VZ de 186

Fig. 73: $\quad$ Diferencias de ángulos entre modelos de visión y de perspectiva 187

Fig. 74: $\quad$ Ítem de rotación de figuras macizas-cubos $\quad 188$

Fig. 75: $\quad$ Ítem de plegado de cubo. Test informatizado VZ 189

Fig. 76: $\quad$ Tareas de interpretación de un sistema de coordenadas 190

Fig. 77: $\quad$ Estructura factorial de la inteligencia 191

Fig. 78: Representación plana esquemática (perspectiva visual) de la posición (PV) 192

Fig. 79: $\quad$ Modelo de visión frontal 193

Fig. 80: $\quad$ Modelo de visión oblicuo 194 
Fig. 81: Representaciones geométricas de la figura humana

Fig. 82: Ejemplos de tareas escolares de orientación estática del cuerpo 199

Fig. 83: $\quad$ Modelos de perspectiva curvilínea 202

Fig. 84a: Planos y líneas de tierra y visión según los modelos teóricos rectilíneos visual 202

$\begin{array}{lll}\text { Fig. 84b: } & \text { y axonométrico } & 203\end{array}$

Fig. 85: Paralelismo en diseño industrial e ilusión de paralelismo 203

Fig. 86: Sistemas de perspectiva axonométrica y vistas del sistema europeo 204

Fig. 87: Campo visual en ángulos de nitidez y eje de referencia del campo visual 205

Fig. 88 Mínima distancia entre dos rectas 206

Fig. 89: $\quad$ Prcesos de visualización en la cognición visual $\quad 207$

Fig. 90: Grafismos, secuencia de prueba y patrones emergentes de la imaginería 208

Fig. 91: $\quad$ Estudios de fuerzas perceptivas en patterns lingüísticos y ejemplos de figuras 209

Fig. 92: $\quad$ Algunos ejemplos de la consideración gráfica de los espacios negativos 212

Fig. 93: Técnicas visuales de doble espacio y configuración de rostros en una tinta y 213

Fig. 94: $\quad$ Ejemplos de modelos gráficos naturalistas y científicos 214

Fig. 95: $\quad$ Maestra de escuela, fotografía de A. Sanders $\quad 217$ y 258

Fig. 96a: Desarrollo del rectángulo aúreo y divisiones sucesivas 218

Fig. 96b: La proporción aúrea en el arte, en la web y en diferentes aplicaciones 219

Fig. 97: $\quad$ Puntos y líneas de fuerza de una imagen según la ley de los tercios y la regla 220

Fig. 98a: Modelos didácticos de representación axonométrica y proyecciónes 222

Fig. 98b: Modelos de proyección 223

Fig. 98c: Ítems de proporción doble y proporciones craneales de adulto y niño 224

Fig. 99: $\quad$ Plano frontal (frontoparalelo) de visión 229

Fig. 100: Disparidad binocular horizontal (DBH) entre dos puntos P1 y P2 230

Fig. 101: Sistema visual 230

Fig. 102: Pirámide visual e intersector de Alberti. Perpectógrafo y fotograma de 'El 231

Fig. 103: $\quad \begin{array}{ll}\text { Contrato del dibujante' } & 237 \text { y } 265\end{array}$

Fig. 104: Nivel de dificultad de los objetos y giros 239

Fig. 105: $\quad$ Item $6 \quad 250$

Fig. 106: Localización del ángulo menor respecto a la horizontal (ítem 12) 250

Fig. 107: $\quad \begin{array}{ll}\text { y del formado por las manecillas del reloj (ítem 17) } & 253\end{array}$

Fig. 108: Tipos de subítems de la prueba TPP 254

Fig. 109: Ítems 18 y 19. Relación de proporción de 1⁄2 (línea) y 2/3 (área) 256

Fig. 110: Percepción de la línea visual en relación a la cabeza 257

Fig. 111: Esquema del diseño de materiales didácticos $\quad 274$

Fig. 112: La imagen compleja $\quad 280$ 
Indice de Tablas

Tabla 01: $\quad$ Resolución de Bits por pixel 48

Página 50

Tabla 02: $\quad$ Principios de agrupamiento sensorial o leyes Gestalt

62

Tabla 03:

Resumen de pruebas visuales

Tabla 04:

Tests de referencia de los ítems propuestos

240

Tabla 05:

Resumen estadístico de las dimensiones

246

\section{Indice de Gráficos}

Gráfico 01: Concentración de la edad de la muestra total y diferenciada por sexo.

Página 245

Gráfico 02: Horizonte teórico y horizonte visual

Gráfico 03: Puntos de fuga y posición

Gráfico 04: Datos comparados en ítems de medición de ángulos

Gráfico 05: Items de visualización dinámica

Gráfico 06: Abatimiento del plano en el eje vertical (ítem 14)

Gráfico 07a: Histograma comparativo de las respuestas de los ítems de proporción (cuadrada, doble horizontal y doble vertical)

Gráfico 07b: Comparativa de las dispersiones de respuesta en los items

Gráfico 08: Histograma comparativo de los ítems de proporción matemática

Gráfico $09 . \quad$ Lineas de fuerza

Gráfico 10. Items 28 y 29: Posición del fotógrafo

Gráfico 11: Resumen estadístico de la escala Likert de valoración.

Gráfico 12. Item 34: talento artístico

Gráfico 13. Item 33: satisfacción con la formación

Gráfico 14. Resultados del modelo planteado

Gráfico 15. Resultados del factor de Visualización estática 
RESUMEN

El presente trabajo aborda el pensamiento visual como constructo relevante en la formación de los profesionales de la educación básica. A partir del análisis de la percepción visual y del razonamiento espacial, desde una triple perspectiva sociocultural, psicológica y pedagógica de los aspectos visuales y gráficos de la inteligencia espacial. Se plantea una investigación descriptiva del constructo en los estudiantes del último curso de Grado en Educación en la Universidad de Valladolid. Se analizan las referencias espaciales de la visualización estática y dinámica y se vinculan con el pensamiento proporcional y la lectura de imágenes. Destaca el déficit existente en las referencias visuales en la comprensión del campo visual de los estudiantes y en la lectura de imagen. El razonamiento de la proporción plantea mayor dificultad en el eje vertical que en el horizontal y el análisis de ángulos muestra diferencias, siendo inferior la respuesta cuando se analiza una forma. Plantea la relación de estos déficits con las dificultades de representación gráfica considerando los diferentes sistemas de representación en el plano, destacando la importancia de la información gráfica y el modelo en la educación, tanto de disciplinas artísticas como científicas.

Palabras clave: Pensamiento Visual, Razonamiento Espacial, Representación Gráfica, Pensamiento Variacional, Educación... 
This paper addresses the visual thinking as a relevant construct in the training of professionals in basic education. From the analysis of visual perception and spatial reasoning, from three perspectives sociocultural, psychological and educational aspects of visual and spatial intelligence charts, construct a descriptive research arises in the final year students of Degree in Education at the University of Valladolid. Spatial references of the static display and dynamic analyzes and linked to the proportional thinking and reading images. It highlights the gap in the visual references in understanding the visual field of students in reading and image. The reasoning ratio greater difficulty arises in the vertical axis on the horizontal angles and analysis of sample differences, the response being lower when a form is analyzed. Explores the relationship of such deficits with the difficulties of graphical representation considering the different systems of representation in the plane, emphasizing the importance of graphical information and education model in both artistic and scientific disciplines.

Keywords: Visual Thinking, Spatial Reasoning, Graphicacy, Variational Thinking Education ... 
ÍNDICE

PARTE TEÓRICA

$0 . \quad$ Introducción

página. 15

1. El Pensamiento Visual. Definición del constructo

2. El Pensamiento Visual en el ámbito cultural

2.1. Alfabetización visual y creación de materiales visuales

2.2. La lectura de imágenes y el desarrollo de la fotografía 35

2.3. Imagen y desarrollo tecnológico: la imagen digital

3. El Pensamiento Visual en el ámbito científico

3.1. Pensamiento Visual en la Psicología y las neurociencias

3.1.1. Pensamiento Visual en la psicología de la percepción

3.1.2. Pensamiento Visual en la psicología de la inteligencia: las habilidades visoespaciales.

3.1.3. Pensamiento Visual en la neurociencia

3.2. Lenguaje visual y representación

3.2.1. El análisis del lenguaje gráfico representativo

4. El Pensamiento Visual en el ámbito educativo

4.1. Pensamiento Visual y competencia básicas

4.2. Pensamiento visual y aprendizaje

4.2.1. La inteligencia espacial y la matemática 136

4.2.2. La cultura audiovisual y la educación artística

4.2.3. La educación del lenguaje visual

4.2.4. El gesto gráfico en la educación

4.2.5. Técnicas de representación gráfica

4.3. El Pensamiento Visual en la formación del Maestro 


\section{PARTE METODOLÓGICA}

5. Estado de la cuestión

página 181

5.1. Visualización y razonamiento espacial 184

5.2. Visualización y representación

5.3. Visualización y figuración (modelado) 206

5.4. Composición y pensamiento visual 216

5.5. Pensamiento y anisotropía visual 228

6. Planteamiento del problema 233

6.1. Objetivos. Hipótesis 235

6.2. Procedimiento 238

6.2.1. Descripción del cuestionario 240

6.2.2. Estudio piloto 241

6.2.3. Descripción de la muestra

7. Resultados 245

7.1. Visualización estática: referencias espaciales. 246

7.1.1. Horizonte visual y vertical de posición 247

7.1.2. Preferencia representacional 249

7.1.3. Medición de ángulos 250

7.2. Visualización dinámica: relaciones espaciales.

7.3. Constancia de la forma. 252

7.4. Pensamiento proporcional. 254

7.5. Lectura de imagen. 258

7.6. Valoración del constructo de pensamiento visual. 261

8. Discusión 265

9. Conclusiones y perspectivas de futuro 271

$\begin{array}{ll}\text { Referencias bibliográficas } & 281\end{array}$

Anexo Cuestionario $\quad 325$ 


\section{Introducción}

El presente trabajo de tesis doctoral aborda el constructo del pensamiento visual y su relevancia en la formación de los profesionales de la educación básica, de infantil y primaria. En la actualidad los ámbitos de estudio de la percepción visual, del pensamiento espacial o de la inteligencia visual no siempre están unidos bajo un mismo marco epistemológico.

Desde que en 1969, Rudolf Arnheim publicara la obra 'Visual Thinking' el uso del término Pensamiento Visual (PV) ha tenido diversas utilizaciones en ámbitos educativos y de la organización. El trabajo de Arnheim en el campo de la psicología se centra en el análisis de la percepción visual y su expresión se asocia con el arte. A partir de sus trabajos, la educación visual ha tenido una fuerte influencia desde el ámbito de las artes, el diseño y la estética visuales, pero al mismo tiempo, desde otros ámbitos, en especial el de la comunicación o el de las organizaciones.

La percepción visual se refiere a la capacidad que tiene el cerebro para comprender e interpretar lo que los ojos ven (Gardner, 1986). En este trabajo pretendemos extraer las conclusiones necesarias para entender que el pensamiento visual, como proceso cognitivo, tiene una serie de características propias que lo vinculan con el desarrollo de la inteligencia y el pensamiento humano en general, y que no parece exclusivo de las mentes artísticas o de las características de disciplinas artísticas. Por otro lado, el análisis de la comunicación y la semiótica visuales nos va a permitir analizar las diferencias cognitivas en el procesamiento de la información icónica y el lenguaje visual de una forma diferente al procesamiento del lenguaje verbal, a tenor de las investigaciones recientes en neurociencia.

$\mathrm{Si}$ el acto de pensar "se realiza independientemente de las palabras" (Zamora, 2007, p. 59), o si, como parece, existe una manera de pensar visual que, aunque relacionada, no siempre va en estrecha conexión con el pensamiento verbal; parece obvio que los métodos educativos necesitan adaptarse a nuevos postulados científicos a la luz de los nuevos planteamientos en neuroeducación. Los sistemas 
educativos basados en las estructuras de asignaturas repartidas según el paradigma científico-artístico deben dejar paso a una dialéctica educativa, a una pedagogía, que formule las necesidades educativas actuales superando este paradigma y planteando un individuo indivisible, un cerebro único, que no puede desvincular su actividad cognitiva entre el procesamiento de uno $u$ otro hemisferio.

Planteamos el análisis del constructo Pensamiento Visual desde una triple perspectiva: cultural, cognitiva y educativa. Lo hacemos con el fin de abordar, por una parte, de manera unívoca los aspectos biopsicosociales del ser humano, y por otro lado, con la intención de destacar los puntos de encuentro entre las diferentes disciplinas del conocimiento humano, que es la manera global en que entendemos la educación, como la trasmisión y construcción del conocimiento a través de la comunicación. A partir de este análisis conceptual, puede resultar más fácil la interpretación y evaluación del PV y sus repercusiones en el entorno de enseñanza aprendizaje.

La evaluación del PV se realiza a partir de la percepción visual y en forma de la denominada aptitud espacial y el ambiguo concepto de razonamiento espacial. Tal aptitud está estrechamente vinculada a la psicología de la inteligencia mecánica, aunque como veremos constituye la mayor parte del procesamiento sensorial que realizamos. El procesamiento cognitivo de la información visual lo podemos encontrar en la base del desarrollo del lenguaje, del desarrollo motor y del desarrollo emocional: en condiciones normales, estructuramos el lenguaje a partir de símbolos fonográficos que representan la realidad visual; el desarrollo motor está condicionado por los ejes espaciales y físicos de la fuerza de gravedad y del campo visual; e igualmente las referencias emocionales están en gran parte asociadas al reconocimiento de la expresión facial. Si entendemos la inteligencia como la capacidad de conocer, comprender, idear o resolver problemas a través de un conjunto de habilidades o experiencias (acepciones de la Real Academia Española RAE, 23a edición), dejar la valoración de las aptitudes espaciales reducida a aspectos de la inteligencia mecánica, supone reducir su potencialidad de desarrollo y su consideración determinante en la construcción mental del mundo. Creemos que el constructo del pensamiento visual tiene la suficiente repercusión en los ámbitos del desarrollo humano, como para 
atribuirle una entidad científica y pedagógica, y poder trabajar en definir y ampliar su campo de estudio.

Por otra parte, dotar de entidad propia a los aspectos visuales del pensamiento que van desde las leyes de la óptica y la fisiología de la visión hasta los procesos cognitivos visuales y de coordinación motriz, permitiría proporcionar un marco de referencia común para la multitud de enfoques que actualmente existen sobre el constructo del $\mathrm{PV}$, así como tambien avanzar en los planteamientos de la educación visual, empeño inicial de los investigadores en el ámbito de la llamada psicología del arte y en el de la comunicación visual.

El estudio de la anisotropía visual como característica fisiológica y óptica de la visión humana y el estudio diferenciado del procesamiento cognitivo de ambos hemisferios cerebrales, proporcionan una referencia científica aún por explorar, que permite entender la complejidad del pensamiento dual, científico y artístico, al tiempo que facilita la estructuración de la educación visual en el ámbito de la expresión y del razonamiento.

Para cualquier investigador de los procesos del pensamiento, éste solo es accesible a través de la expresión. El lenguaje verbal y el lenguaje no verbal expresan o permiten acceder al interior cognitivo y emocional de las personas. Otro tanto ocurre con la expresión gráfica: plasmamos una representación interior del mundo exterior, físico, y en gran medida esta representación es visual. Por lo general, este tipo de expresión se utiliza habitualmente en menor medida, con la excepción del periodo de la infancia, en la que constituye el principal lenguaje.

Representar algo significa situarlo en lugar de, sustituirlo o hacer presente algo que está ausente (Gombrich, 1979). La representación mental del mundo es espacial y responde a las formas y la luz cambiantes, y su expresión puede ser textual, pero su medio preferente y óptimo de expresión es el gráfico. En mayor medida la expresión gráfica resulta el vehículo más adecuado para exteriorizar esta forma de representación mental que se refiere a las cualidades visuales: distancias, tamaños, inclinaciones, formas, colores y texturas o gradientes. Sin embargo, es la expresión menos utilizada en la vida adulta. La necesidad que mostramos de recurrir al dibujo cuando el idioma no coincide con el del interlocutor, o de recurrir con más o 
menos intensidad al empleo de emoticonos, reflejan algunos aspectos de esta cuestión. En este trabajo aportamos una reflexión para encontrar las causas por las que no mantenemos y utilizamos este tipo de expresión en la vida adulta, que por otro lado es universal y previa al aprendizaje del lenguaje.

En la parte teórica abordamos el contexto en el que aparece el constructo de Pensamiento Visual. La influencia del arte visual contemporáneo (moderno y posmoderno) a partir de la tecnificación de la imagen fotográfica y digital, los descubrimientos científicos sobre la mediación del lenguaje en el procesamiento cognitivo de la visión y los planteamientos educativos diferenciados en las áreas de geometría y educación visual, son los ejes principales de los cuatro capítulos.

En la parte metodológica, centramos el estado de la cuestión en la evaluación de la psicología de la inteligencia, a partir de los conceptos de visualización y relaciones espaciales. También en el ámbito de la pedagogía, con el análisis de la utilización de modelos en el aprendizaje y del gesto gráfico en la educación visual. Igualmente, en el ámbito de la semiótica, con el concepto alfabetizador de la lectura visual o de la imagen. A partir de un intento por unificar las aportaciones de las diferentes disciplinas y construir un concepto unívoco del PV, que sirva como referente para el desarrollo de la competencia visual. Mostramos los resultados de nuestro estudio sobre una muestra de estudiantes del último curso del Grado en Educación. El estudio se centra en la valoración de aspectos de la competencia visual. Se analizan los resultados en aspectos cognitivos en torno a la visualización y al razonamiento espacial, así como su aplicación en la lectura de imagen. Estos, nos permiten extraer algunas conclusiones y proponer líneas de intervención para la aplicación del constructo del PV en la educación. 


\section{PARTE TEÓRICA}

\section{El Pensamiento Visual. Definición del constructo}

“...pensar en términos de cualidades es una exigencia tan severa para el pensamiento como el pensar en términos de símbolos verbales y matemáticos."

(Jhon Dewey)

El filósofo Oswald Spengler (1947) en su ensayo "El Hombre y la Técnica" (1932), ya expone y diserta sobre la diferencia entre el pensar con el ojo y el pensar con la mano. Una diferencia que parte de la descripción que realiza entre dos tipos de pensamiento con los que interactuamos con el mundo: uno teórico y contemplativo del ojo, y otro práctico e instrumental de la mano.

"El ojo del animal rapaz, en cambio, propone un fin, una meta... La fijación de los ojos dirigidos hacia adelante y paralelamente es, empero, idéntica al nacimiento del mundo, en el sentido en que el hombre tiene un mundo, es decir, en el sentido de imagen o mundo desplegado ante la mirada, como mundo no solo de color y de luz, sino, sobre todo, de lejanas perspectivas, de espacio y de movimientos en el espacio y de objetos situados en determinados lugares. En esta manera de mirar, que es exclusiva de los animales rapaces más nobles... reside ya la idea del dominio. La imagen del mundo es el mundo circundante dominado por los ojos. Los ojos del animal rapaz determinan las cosas en su situación y distancia. Conocen el horizonte... El mundo es la presa; y de este hecho, en último término, ha nacido toda la cultura humana... El ojo inquiere la causa y el efecto; la mano trabaja según los principios del medio y del fin."

(Spengler, 1947, p.8)

Este autor, sin definirlo como tal, ha inspirado la reflexión sobre el proceso del pensamiento visual en ámbitos como la arquitectura o el diseño, donde predomina la manipulación del espacio visual. Sin embargo, no es desde la arquitectura desde donde se va a desarrollar el concepto de pensamiento visual o visual thinking, sino principalmente desde la filosofía y la psicología; dando lugar a lo que 
consideramos hoy en día como un constructo. Entendemos como constructo la elaboración de un concepto para ser usado en la ciencia. Un concepto desarrollado teóricamente para ser observado y medido a partir de sus características constitutivas y operacionales (Kerlinger y Lee, 2002).

Es Robert Mckim (1973), quien introduce el concepto de pensamiento visual como estrategia en la resolución de problemas, al tiempo que Rudolf Arnheim (1979) se centra en el análisis de la percepción visual como actividad cognitiva a partir de las obras de arte visual. Si bien Mckim relaciona la atención visual con las estrategias de pensamiento y la resolución de problemas, es a partir de las aportaciones de Arnheim, que se comienza a considerar la percepción visual como una actividad indivisible del pensamiento. A partir de sus planteamientos, actualmente resulta dificil estudiar el pensamiento sin considerar el análisis de la percepción visual, como una actividad cognitiva principal. La percepción así entendida, junto con la atención y la memoria son los ejes cognitivos desde los que se aborda el estudio del PV.

A partir de los años ochenta, la literatura que hace referencia al constructo de pensamiento visual es abundante, principalmente en ámbitos relacionados con el arte y diseño, pero también con la comunicación, y, cada vez más, con la educación, a través de la llamada educación visual o audiovisual.

La corriente denominada de la psicología del arte, encabezada por Arnheim, promueve las denominadas Estrategias de Pensamiento Visual o Visual Thinking Strategies (VTS) que se extienden como un recurso educativo en el entorno de los museos norteamericanos y europeos, para, a partir de la observación de obras de arte, promover actividades didácticas de reflexión y análisis, así como desarrollar habilidades comunicativas, atendiendo al desarrollo cognitivo, social y emocional de los alumnos.

Aunque si bien son muchas las referencias al pensamiento visual en estos ámbitos, son escasas las definiciones. Habitualmente se entiende por pensamiento visual lo relacionado con 'pensar en imágenes' por un lado, y, por otro, con 'expresarse con imágenes'. Ambas concepciones muestran los dos aspectos, teórico y práctico del 
pensamiento humano: el meta-cognitivo y el instrumental. Pero también expresan dos procesos inherentes a la construcción del conocimiento y la comunicación humana: el pensamiento y el lenguaje, la formación de la idea y su expresión o representación, con el fin necesario de comunicar o comunicarnos.

Para Arnheim (1979) la percepción visual en sí misma es pensamiento visual. Entiende la propia percepción como un proceso cognitivo y lo justifica y defiende frente a una concepción clásica que considera la actividad de los sentidos separada de la cognición. Según ésta, al percibir algo visualmente, a partir de unas señales que llegan al cerebro por los nervios ópticos, y en el momento que llegan, sólo entonces, se producían unas conexiones, dando como resultado el pensamiento. Si la explicación fuera de esta manera lineal, encontraríamos problemas para explicar por qué dirigimos nuestra atención en la mirada o por qué la focalizamos o mantenemos en función de nuestros intereses o recuerdos.

Parece claro que pensamos antes, predisponiéndonos así a una acción perceptiva selectiva, que pensamos durante el acto de percibir (acción que discrimina y compara), dirigiendo la percepción, y que, además, pensamos después, a partir de la información recibida.

Arnheim (1979) define el pensamiento como una actividad psíquica de naturaleza cognitiva cuya función consiste en reflejar la realidad e interpretarla a partir del establecimiento de relaciones. Un tipo de estas relaciones son las de las cualidades observadas y experimentadas por los sentidos: alto, cálido, inclinado, distante, etc. Entre las principales funciones de esta actividad psíquica se encuentra la de resolver problemas, reflexionar sobre las cuestiones, y comunicar con claridad.

Podemos, por tanto, definir el constructo del pensamiento visual como un proceso, o conjunto de procesos cognitivos que realizamos de manera específica en torno a la información visual, con los que interpretamos la realidad y que nos conducen a la acción.

Este proceso cognitivo, en tanto que pensamiento, necesita de una herramienta para su articulación o expresión en el plano físico. A esta herramienta la denominamos lenguaje. El pensamiento se 
traduce o expresa en lenguaje y también se construye con lenguaje. En este caso, hablamos de la existencia de un lenguaje visual específico: la información visual, como cada información que llega a los sentidos, se encuadra en un código específico. Si mantenemos ese código en su aspecto original e interpretamos el código visualmente, entonces podemos decir que pensamos 'en' imágenes, como lo define Temple (1995); o bien, que pensamos 'con' imágenes, al decir de Jardí (2014). De esta forma, entendemos que existe la posibilidad de mantener el código visual en nuestro pensamiento, y que podemos traducir éste en algún tipo de lenguaje gráfico no verbal, expresándonos con una acción gráfica. Es el pensamiento "no dirigido", que "opera fundamentalmente con imágenes" definido por Vigotsky (1987, p.28), y al que caracterizaría como "estrictamente individual e incomunicable, como tal, por medio del lenguaje".

El pensamiento del tipo "no dirigido" parece ser el proceso cognitivo que caracteriza la infancia, al menos mientras completamos el aprendizaje lecto-escritor, que nos va a permitir adquirir el código simbólico del lenguaje verbal. No podemos considerar por tanto que no exista el pensamiento en ausencia de un lenguaje, aunque este tipo de pensar lo definamos como "egocéntrico" o "autista" (Vigotsky, 1987). Igualmente, este es el tipo de pensamiento que realizan aquellas personas que, por diferentes motivos, muestran dificultades o deficiencias verbales.

Los estudios de Piaget y Vigotsky establecen una marcada diferencia entre el pensamiento adulto, dirigido y el infantil, no dirigido, basándose en que el dirigido es un pensamiento social, que responde a leyes generales, es real, y puede ser comunicable a través del lenguaje. El pensamiento no dirigido o egocéntrico ocuparía un lugar entre el pensamiento social y el pensamiento autista. Enmarcan el tipo de pensamiento infantil en un umbral subconsciente, en una realidad interior (de imaginación y sueños) que no coincide con la realidad exterior adulta. Sin embargo, considerando la importancia que adquieren los procesos perceptivos, no podemos mantener que este tipo de pensamiento en imágenes sea ajeno a la realidad exterior que compartimos a cualquier edad. Cuestión diferente es la interpretación que hacemos individualmente de esa realidad y la forma o manera en que la trasmitimos a otros. 
En este sentido, no podemos desvincular el pensamiento visual del lenguaje. Son dos aspectos cognitivos del proceso de la expresión. Ahora bien, refiriéndonos estrictamente al lenguaje visual, en general, el lenguaje de la imagen se suele analizar a partir de una doble categoría (Acaso, 2006). Por un lado, la imagen "que produce placer visual' y aquellas que no se relacionan directamente con el arte y la estética, las cuales generalmente entendemos de manera utilitaria y cotidiana. Gran parte de este grupo de imágenes cotidianas las recibimos a través de los diferentes medios impresos y de comunicación, la publicidad y la world wide web (www) o red de Internet.

Esta división en tipologías de la imagen es posible que también esté generada por la separación que hacemos a nivel profano entre la herencia artística clásica de las artes visuales (pintura o escultura) y la más moderna producción visual, a partir del desarrollo de la imagen impresa y digital, la fotografía y el vídeo.

Los movimientos artísticos contemporáneos, caracterizados por el sentido trasgresor del arte moderno y posmoderno, si bien acentúan aún más esta distinción, también, y, quizás por ello, incluyen en la categoría de arte aquello que para muchos es simplemente visual. Por tanto, hoy día encontramos expresión artística en la publicidad, en el diseño gráfico y de la Web, así como en tantos productos audiovisuales asociados a las tecnologías de la información y la comunicación (TICs).

Creemos que esta discusión o paradigma, entre lo que es o no arte visual, aunque forma parte del estado actual del arte, se filtra en los planteamientos educativos del currículo, influyendo en la dificultad de determinar y delimitar con claridad las competencias visuales en educación o el ámbito de la llamada educación visual.

En cualquier caso, es esta consideración utilitaria, artística o no, la que adquirimos en este trabajo al referirnos tanto al pensamiento como al lenguaje visual. Asumimos una acepción cotidiana de lo visual y de la imagen, que creemos está en la acción educativa al referirnos al gesto gráfico, y que parece ajena a la influencia del debate estético. 
Esta consideración del pensamiento visual, más próximo a lo utilitario, es la adquirida por Roam (2010), que ha convertido su obra (The back of the Napkin) en un 'best-seller'. Roam toma como punto de partida la negación de una idea muy extendida, como es la consideración de que la competencia gráfica tiene que ver con la noción de talento artístico, o con considerarse una persona visual. Plantea un entrenamiento en pensamiento visual accesible "en cuatro lecciones" (p. 15) en torno a la generación, presentación y venta de ideas. Su premiado trabajo, basado en conceptos visuales, analiza destrezas cognitivas y gráficas (maneras de mirar y ver, imaginar y mostrar) para hacer más eficaces las reuniones empresariales. Invita a una manera nueva de mirar los negocios y plantea el pensamiento visual, el dibujo y la comunicación visual, como una manera más eficaz de abordar la resolución de problemas en el entorno de las organizaciones.

Además de mirar con los ojos, plantea la posibilidad que tenemos de mirar 'con el ojo de la mente'. La atención y la memoria visual resultan determinantes para poder desarrollar ideas que de otro modo pasarían inadvertidas, y poder compartirlas con otros que las puedan 'captar' fácilmente.

Creemos que algunos de los planteamientos de su obra se pueden extrapolar al ámbito educativo y resultan válidos para desarrollar destrezas en el ámbito de la competencia visual, ya que tanto la imaginación como la expresión gráfica tienen su mayor potencial en la infancia y a través de ellas se accede de manera más significativa al pensamiento infantil.

Pero también, creemos que el hecho de introducir el concepto de pensamiento visual en la educación conlleva una dificultad relacionada con la consideración artística de lo visual. La educación todavía mantiene en su estructura curricular una estricta separación entre las disciplinas consideradas científicas y las relativas al arte, y como veremos, disgrega disciplinas eminentemente visuales como la geometría y las TICs.

El hecho de participar conceptualmente de ambos ámbitos, artístico y científico, sitúa al análisis del pensamiento visual en un paradigma. Aunque parece existir un aumento del interés docente por 
lo visual, no está del todo definido que el pensamiento visual constituya como tal una forma de acceso y construcción del conocimiento. Por una parte, parece que resulta prescindible en el acceso al conocimiento ya que es habitual el reconocimiento de la dificultad para dibujar o para interpretar imágenes en el entorno académico. Un entorno donde la imagen está ausente en los criterios e indicadores de calidad de las publicaciones y son escasas las referencias a la inclusión de material gráfico o visual en las revistas científicas (Ruiz del Olmo, 2012).

Por otra parte, lo visual parece corresponder a un ámbito exclusivo o parcelado de las disciplinas artísticas, con su propio itinerario educativo, asociado al talento artístico. Esta situación, junto con otros factores que pretendemos analizar, conduce a un cierto nivel de confusión al abordar el constructo del pensamiento visual en la educación básica obligatoria.

Por todo lo dicho hasta aquí, partimos de las siguientes ideas o postulados, con la finalidad de establecer un planteamiento teórico en torno al constructo del pensamiento visual:

1.- El concepto o constructo de PV plantea una forma específica de conocimiento y un estilo de comunicación. Una forma de recibir información a partir de la interpretación de imágenes y una manera de trasmitir información y comunicar a partir de la construcción de imágenes, desde el simple gesto gráfico hasta la utilización de diferentes recursos y TICs.

2.- Aunque es abordado desde múltiples ángulos y en él intervienen diferentes disciplinas con sus propios planteamientos y enfoques, el PV es un proceso de carácter cognitivo y su estudio debe ser enmarcado en el ámbito científico de la educación, en especial de la psicología y la pedagogía.

3.- La creación de imágenes, si bien guarda relación con la creación artística visual, es una destreza común. La competencia gráfica no debe ser considerada necesariamente una competencia artística, y por tanto, el pensamiento y lenguaje visuales deben estar presentes en la formación genérica o común de los graduados en educación. 
Es por todo ello que, en este trabajo, analizamos el pensamiento visual desde tres ámbitos:

- $\quad$ El ámbito cultural del PV, en cuanto que es un proceso de comunicación visual, analizando el código de la alfabetización visual ('visual literacy') en ambas vertientes: receptora, en lo que se ha dado en denominar la lectura de imágenes, y emisora, como producción de materiales visuales ('graphicacy').

- $\quad$ El ámbito científico del PV, en cuanto que es un proceso cognitivo que relaciona percepción, atención y memoria, en lo que se define como inteligencia espacial; y en cuanto proceso sensorial, perceptivo y motor, vinculado a la física y leyes de la óptica.

El ámbito educativo del PV, en cuanto que éste da forma a un conjunto de habilidades o destrezas que no dependen tanto del talento artístico, sino que se pueden aprender o adquirir en la competencia visual y gráfica.

Este triple planteamiento obliga a un análisis interdisciplinar, sin por ello perder, sino por el contrario reforzar la idea de un concepto común para el pensamiento visual. 


\section{El Pensamiento Visual en el ámbito cultural}

El análisis del pensamiento visual pasa necesariamente por el valor que se le ha asignado en la historia de la cultura, ya que la cultura determina en parte la concepción social que tenemos de este tipo de pensamiento, así como las atribuciones que le damos. Cada generación parte de una situación heredada de generaciones precedentes en la historia. Cada civilización responde a un nivel del desarrollo humano que se beneficia de los conocimientos trasmitidos "con una continuidad y una necesidad de renovar lo que se quiere mantener" (Sebreli, 2013, p. 57).

A pesar del relativismo cultural, de la pluralidad de puntos de vista del perspectivismo, la historia de nuestra cultura se caracteriza por el pensamiento dual: la oposición dialéctica hace que la aparición de cualquier tendencia provoque "irresistiblemente la de la contraria" (Sebreli, 2011, p.12). Así convivimos actualmente, en la era de la modernidad o de la postmodernidad, con la herencia cultural de una humanidad transmitida a través de clasificaciones antagónicas, por lo general en etapas temporales linealmente distribuidas.

De esta forma, solemos ver el siglo XIX como la época del positivismo científico, pero también, y simultáneamente, como la época del romanticismo. Ambos 'ismos' se encuentran enfrentados por la utilización de la razón o la emoción para explicar el conocimiento y comportamiento humano. Algo parecido ocurre con el siglo $\mathrm{XX}$, al que vemos como la era del desarrollo tecnológico, o el siglo XXI, como del prometedor avance neurocientífico, pero al mismo tiempo, ambos siglos se caracterizan por el desarrollo humanista 0 ecológico. Nuestra época combina el auge del cognitivismo y construccionismo, con la aparición de la inteligencia emocional y el pensamiento flexible, con el rápido desarrollo de las tecnologías de la información y la comunicación, y de la inteligencia artificial.

Significar es expresar la identidad de un grupo humano (Debray, 1994). La Historiografía busca el significado de aquello que nos ha acontecido y nos acontece, entendiéndolo como sucesos. 
Abordamos el siglo XXI en un entorno cultural que se define entre la idea de la modernidad industrial y la postmodernidad tecnocientífica, que nos caracteriza por, en palabras de Lyotard (1998): "más saber y poder: sí, pero porqué: no" (p.61).

De manera genérica, desde el punto de vista cultural, atribuimos el inicio de la modernidad, entre otros sucesos, a la aparición de la imprenta. A la vista de los historiadores, la imprenta es el invento que ha devenido en "uno de los elementos determinantes del avance hacia la Modernidad" (Armillas, 2000). Febvre y Martín (2005) reconocen este invento en el origen de la universalidad en la trasmisión del conocimento: "Cuando el impresor Pfister, de Bamberg, tuvo la idea de ilustrar los textos con imágenes grabadas, el libro alcanzó su definitivo aspecto. Y conforme los discípulos de los primeros impresores se extendían por toda Europa enseñando tan revolucionario procedimiento, la imprenta se convertiría en el más eficaz y veloz cauce de difusión del pensamiento que ha conocido la historia de la Humanidad hasta nuestro tiempo" (p. 107).

Paralelamente al desarrollo de la imprenta y la escuela, desde un punto de vista político-económico, se asocia la edad moderna con la revolución industrial, el crecimiento urbano o la secularización de los Estados: entendemos la democracia y la laicidad como características de los estados modernos y sus redes de educación, que representan una sociedad desarrollada tecnológicamente y que se distingue en la posmodernidad por su proceso de globalización de la información y la comunicación. Desde este enfoque, se admite la existencia de una expresión y arte visual propio de la cultura moderna a partir del romanticismo y el posterior surgimiento de las vanguardias. Un arte y una expresión visual diferenciada del arte clásico.

El análisis moderno de las artes visuales ha dado lugar también a diferentes 'ismos' de vanguardia (simbolismo, impresionismo, futurismo, surrealismo, expresionismo, cubismo, prerrafaelismo...) a modo de estilos que se pretenden aúnar en la concepción de un arte moderno definido, de una manera muy general y en ocasiones contradictoria, por la expresión inmediata de las pasiones y las impresiones. Frente a esta impulsividad, se encuentra todo aquello que lo diferencia de un arte tradicional, que queda definido por los procesos de la representación visual realista o naturalista. Este 
movimiento de las vanguardias en las artes visuales ha generado de manera lenta a lo largo de un siglo, una opinión que ha ido calando en las personas, un paradigma cultural entre abstracción y figuración, enfrentando a los nuevos estilos experimentales con la idea conservadora de un estilo clásico, tanto en el arte como en la cultura moderna.

Sin embargo, a pesar de que el concepto de un arte moderno sustenta este paradigma, tal como afirma Sebreli (2011), existen diferencias considerables en las vanguardias y aun opuestas entre sí, que nos invitarían a dudar de la existencia real de un paradigma figurativo en la historia de los estilos artísticos visuales. Resulta revelador el análisis que hace este autor de los ambientes artísticos vinculados al interés por la teosofía en autores como Rudolph Bauer (discípulo de Kandinsky), Mondrian o Duchamp y sus promotoras: Hilda Rebay, relacionada con Solomon Guggenheim, y Katherine Dreier, fundadora del primer Museo de arte moderno en Nueva York (Sebreli, 2011). Concluye Sebreli que las vanguardias, aunque defensoras del racionalismo, se basan en la tradición clásica pitagórica de la proporción armónica y la geometría, y destaca la contradicción de que la vanguardia relaciona formas geométricas, pero según ritmos "que poco tienen que ver con la geometría" (p.124). Similar análisis hace sobre el interés en la física del color, resultando un periodo de "peculiares técnicas pseudoantiguas" (Rigui, 2006, p.32), que plantean en la actualidad serios problemas de conservación de las obras.

En la misma línea de contradicciones, Guasch (2000), cuestionando la idea de progreso de la cultura moderna, define como "antiguas identificaciones" (p.35) la asociación que la cultura moderna hace entre la abstracción y la experimentación y el progreso frente a la figuración y la represión o regreso. Define la actitud de estos artistas visuales con las siguientes palabras: "optan por una deformación deliberada de la forma e infringen las reglas del buen gusto con el objeto de plantear los mismos interrogantes metafísicos y espirituales que los artistas han planteado desde siempre, con independencia de su estilo" (p.70).

Sin querer entrar en el discurso intelectual del arte contemporáneo, la deformación de la forma, frente a las leyes visuales 
del naturalismo, es una licencia que se produce en los experimentos propios de los estilos del arte moderno. Sin embargo, la infracción de las leyes visuales no implica el conocimiento de éstas, y podemos suponer que no siempre la infracción ha sido deliberada, y por tanto, considerar que el motor de la experimentación no siempre ha sido la búsqueda de nuevas soluciones en la representación visual, sino en ocasiones el resultado de un desconocimiento de las leyes. Desconocimiento que no ha importado a los integrantes del mercado del arte. Consideremos que son los modernos mercados los que intervienen en decidir la tendencia artística que se impone sobre otras (Vallugera, 2011). Podemos incluso pensar que a los mercados del arte, lejos de importarles este desconocimiento, les ha interesado un cierto nivel de ignorancia que pueda permitir la ausencia de normalización (Unzueta, 2002), y así poder justificar los precios ininteligibles de las obras de arte visual, que las sitúa como la mercancía más cara de nuestra cultura (Dossi, 2007). Una mercancía con características interesantes de transacción comercial y especulación para el mercado financiero internacional, que nos puede hacer olvidar que tiene sus raíces en el coleccionismo y el interés individual por "apropiarse de lo bello" (Espel, 2013, p.40).

De manera más directa, también Chipp (1995) plantea la insuficiencia del paradigma figurativo, apoyándose en una entrevista realizada a Pablo Picasso: "No hay ningún arte 'figurativo' o 'no figurativo'. Todo se nos aparece como una 'figura'. Incluso en la metafísica las ideas se expresan por medio de 'figuras' simbólicas. Fíjate que ridículo es, por tanto, pintar sin 'figuración'. Una persona, un objeto, un circulo, todo son figuras; actúan sobre nosotros con más o menos intensidad. Algunas están más cerca de nuestras sensaciones y producen emociones que tocan a nuestras facultades afectivas; otras apelan más directamente al intelecto" (p.293).

Posteriormente, Arnheim planteará la existencia de la abstracción en todo lo referido a la representación. El paradigma figurativo lo resuelve en la consideración de que es abstracto todo lo representado, para hablar en todo caso de la diferencia de niveles de simbolización o esquematización en la representación visual: "Las imágenes son representativas, en tanto que captan con mayor o menor mimetismo las cualidades pertinentes -forma, color, dinamismode los hechos que describen" (Perez-Bermúdez, 2000, p.19). A 
nuestro entender, la difusión del concepto de figuración, resultaría de una justificación cultural necesaria para explicar de alguna manera el predominio mecánico de la imagen fotográfica y poder diferenciar y justificar la producción artística visual de la época a través de la antagónica abstracción, frente al realismo fotográfico.

Todos estos aspectos citados conviven en una amplia, y quizás vaga, definición del concepto de la cultura visual moderna, del 'mundo imagen' que habitamos (Mirzoeff, 2003), y resumida en el término iconosfera, creada a partir del contacto del hombre moderno con las múltiples fuentes de imagen (grabados, fotografías, televisión, cine), y cuya 'sofisticación tecnológica' alcanza la nueva producción icónica del imagineering (imaginerización), neologismo que funde los vocablos image (imagen) y engineering (ingeniería) (Gubern, 1996).

En un intento de trascender en nuestro estudio el antagonismo citado, destacamos y procuramos analizar dos hechos objetivos 0 sucesos que entendemos afectan al análisis del pensamiento visual. Creemos que historiográficamente son sucesos bien definidos y poco discutibles, que se producen en el transcurso del siglo XIX al XX, como son, por un lado, la aparición de la imprenta y la escuela como un espacio sistematizado (que no único) de alfabetización y educación, y por otro lado, el efecto que ha tenido y tiene en nuestras vidas, el desarrollo del invento de la fotografía.

\subsection{Alfabetización visual y creación de materiales visuales}

Alfabetismo y alfabetizar son los términos castellanos que traducimos del inglés 'literacy', para definir el conocimiento de la lectura y la escritura y su enseñanza. La aparición de este término parece situarse al cabo del siglo XIX, aunque está estrechamente relacionada con los efectos de la imprenta que a su vez condiciona la aparición de la escuela moderna (Mcclinntock, 1993), permitiendo a amplios sectores de población el acceso a la lectura: para Birkerts (1999), el cambio a los tipos mecánicos promueve la difusión de la alfabetización entre los laicos, contribuyendo a hacer posible la llustración. 
La alfabetización se entiende hoy día como un proceso de aprendizaje continuado, a lo largo de toda la vida, no solo del aprendizaje de la lectoescritura, sino de la adquisición de competencias que abarcan "nuevas competencias básicas necesarias en la sociedad actual y que van más allá del concepto convencional de alfabetización como adquisición de una serie de competencias relacionadas con la lectura, la escritura y la aritmética" (Decenio de las Naciones Unidas de la Alfabetización, UNLD, 2013, p. 37 C/58).

Todavía hoy día, la alfabetización es un derecho humano por conseguir. La UNLD cifra en casi mil millones los ciudadanos del mundo actual que "no pueden participar plenamente en el mundo contemporáneo basado en los textos escritos porque carecen de competencias en lectoescritura" (Op. cit., p.8). Pero, paralelamente a esta situación global, el programa PIPT (Programa Información para todos) plantea que la alfabetización moderna ofrece la posibilidad de combinar la adquisición de otras competencias con el aprendizaje de la lectura y la escritura, y considera así aspectos de alfabetización informacional, digital y visual:

"En un mundo digital, la alfabetización informacional requiere que los usuarios cuenten con las competencias necesarias para utilizar las tecnologías de la información y la comunicación y sus aplicaciones, a fin de tener acceso a la información y poder crearla. Existen otros dos tipos de alfabetización que están estrechamente relacionados con la alfabetización informacional: la alfabetización informática (conocimiento de técnicas de comunicación e información) y la alfabetización en los medios de comunicación (comprensión de las diversas clases de medios y formatos por los que se transmite la información). Por ejemplo, para navegar en el ciberespacio y utilizar documentos multimedia con vínculos de hipertexto se requieren competencias técnicas para utilizar Internet, así como competencias básicas para interpretar la información."

(Programa PIPT, UNESCO, 2011, párr.3)

De la misma manera que vinculamos el alfabetismo al aprendizaje de la lectoescritura en la necesidad de interpretar los códigos lingüísticos, asociamos el alfabetismo visual (visual literacy) a 
los códigos visuales, en la necesidad de interpretar los formatos gráficos de información.

El estudio de estos formatos y códigos visuales es abordado desde las Teorías de la Comunicación, que acometen el estudio empírico de la comunicación como ciencia social, principalmente a partir del desarrollo de los medios de comunicación de masas. De igual forma que la imprenta había generado el imperativo del alfabetismo verbal, la invención de la fotografía y "todas sus formas colaterales" ha generado una necesidad educativa para una capacidad humana que "parece haberse separado de la experiencia del hombre" (Dondis, 2008, p.9).

Esa capacidad que describe Dondis (2008) es la de diseñar, interpretar o producir, 'leer o escribir', imágenes. Es una capacidad que aparece tanto en los inicios del desarrollo humano individual como en los albores de la humanidad. Esta capacidad humana aparece asociada a una huella, a la imagen resultante de plasmar en un soporte una mano manchada. La curiosidad, como expresión del pensamiento (visual), guía la mano para producir una mancha que sorprende por su carga de significado.

Ambos procedimientos, interpretativo y representativo, han convivido y conviven culturalmente en la comunicación humana. La cultura anglófona diferencia con claridad los conceptos de 'literacy' para definir la experiencia verbal, y el de 'graphicacy', para la experiencia gráfica de la comunicación. La experiencia gráfica nos vincula con nuestro pensamiento, acción, cogniciones, emociones y deseos (Danos y Norman, 2009) ya antes de adquirir el lenguaje simbólico de la experiencia verbal.

El graphicacy, término difundido en el mundo educativo anglosajón a partir de los años 60, acuñado por geógrafos, se define como "la comunicación de la información espacial que no puede ser transmitida adecuadamente solo por medios verbales o numéricos" (Balchin, 1965, p.23). En cierta manera, disponer de un término específico para referirse a la habilidad gráfica en términos de comunicación facilitaría el trabajo en el área de la expresión gráfica en educación. Esta habilidad es universal y temprana, y sin embargo, por lo general la experiencia gráfica se pierde en el desarrollo. 
Los acuñadores del término entienden esta experiencia, como un lenguaje icónico que encierra la capacidad de entender y utilizar mapas, planos, símbolos y en general cualquier información gráfica. Este término lo propusieron William Balchin y Alice M. Coleman, por su analogía con 'literacy' y 'numeracy', para "nombrar el primer modo de comunicación, el lenguaje visual-espacial' (Peltzer, 1991: p. 25).

Balchin (1965) considera cuatro tipos de pensamiento abstracto que conllevan cuatro tipos de comunicación. Además de la comunicación verbal (literacy), aritmética (numeracy) y social (articulacy), está la comunicación visual-espacial o graphicacy. Peltzer (1991) prefiere definir el término como 'cultura visual', considerando una estrecha relación entre el alfabetismo verbal (literacy) y el alfabetismo gráfico (graphicacy), pero argumentando, en línea con otros autores, que la 'alfabetidad' gráfica es resultado de un pensamiento visual anterior al aprendizaje de la lecto-escritura. Este autor muestra como ejemplo la práctica educativa habitual de acompañar con imágenes el aprendizaje de fonemas y letras.

El hecho de que las imágenes se aprendan antes que las letras induce a creer que el pensamiento visual crea un tipo de lenguaje gráfico más familiar y anterior a la comunicación con 'extraños' signos. Aunque, si consideramos que la existencia de un lenguaje implica un sistema de signos, parece ser que los signos gráficos no responden de manera dócil a una clasificación y menos a una clasificación universal. Los intentos de 'esperantización', como detalla Peltzer (1991), parecen fracasar.

La Semiótica, al abordar el análisis lingüístico del signo, diferencia entre el significante y el significado en el proceso de lectura de la imagen (Ortega, 2003). Mientras que el significante tiene un carácter estable, correspondiente a la forma, la apariencia que adquiere el signo; el significado pertenece al ámbito cognitivo conceptual de un individuo, grupo o cultura, lo que le confiere un carácter variable, más subjetivo (fig. 01). Esta subjetividad puede ser la causa de la dificultad de etiquetar la función de la imagen en el ámbito de la comunicación visual (Elorza y Carbonell, 2010) y la dificultad de realizar un filtro o selección de las imágenes en función de los objetivos en el ámbito de la educación (Perales, 2008). Como 
afirma Malosetti Costa (2005) no existe un significado único ni privilegiado en una imagen.

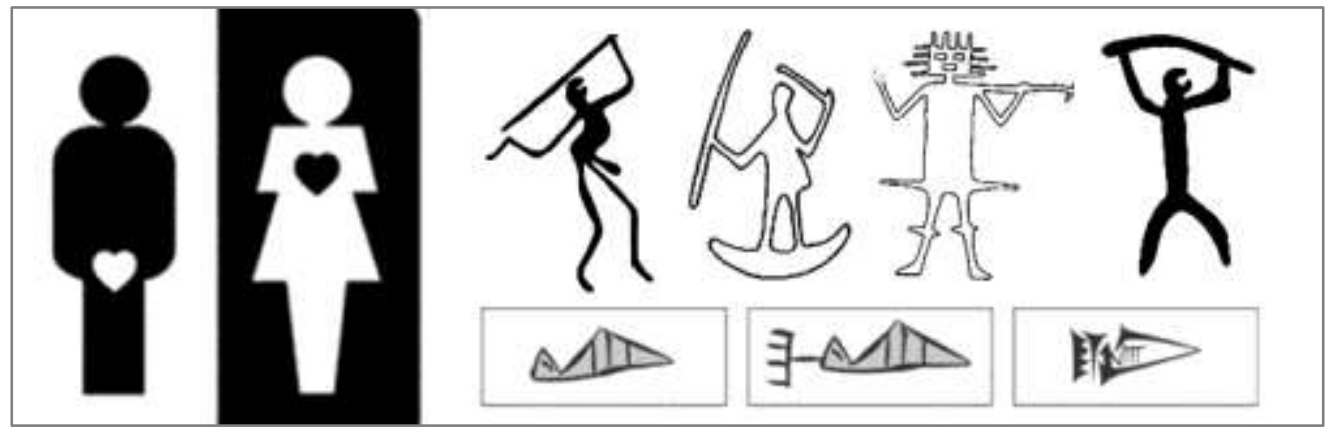

Fig.01: Símbolos moderno, precolombino y mesopotámico de representaciones antropomorfas (Ballestas Rincón, 2010; diloengrafico.wikispaces.com)

Sin embargo, y aunque resulta difícil establecer normas lingüísticas por la subjetividad en la conceptualización del signo, sí podemos hablar de una sintaxis común, de un conjunto de elementos gráficos con un significado cultural (Dondis, 2008; Gombrich, 1987), que permita establecer criterios más objetivos y estables con carácter universal.

2.2. La lectura de imágenes y el desarrollo de la fotografía. La imagen fotográfica.

Si tomamos, como parece ser más habitual, el resultado de la experiencia gráfica en el sentido de expresión artística, el arte y la estética acompañan el desarrollo de la cultura visual occidental, y lo hacen, generalmente en una parcela reducida de la población que tiene capacidad para interpretar o representar objetos o lugares (paisajes) o personas (retratos). En suma, nuestra cultura ha atribuido a lo largo de la historia estas funciones a aquellos sujetos, que, dotados de una especial habilidad, tienen la capacidad de producir imágenes, y a aquellos otros, dotados de una especial 'sensibilidad', la de interpretarlas.

En este contexto histórico, donde el conocimiento y la gestión de la imagen representativa son asignados a especialistas, se produce, principalmente desde la actividad de los artistas plásticos, 
pero también de científicos (químicos y ópticos), un interés histórico por mecanizar la obtención de una imagen, que posiblemente en su origen trataba de simplificar y perfeccionar el proceso del dibujo.

A finales del siglo $X$ ya se tenía conocimiento de este interés, por la descripción de la cámara oscura que hace Abu Ali al-Hasan, conocido como Alhazen (965-1038), a quien se considera padre de la óptica moderna y se le atribuye el invento (Belting, 2012, p.78). La cámara oscura es una estancia cerrada en la que entran los rayos de luz del exterior solo a través de un orificio. Este funciona como una lente convergente y proyecta en una superficie blanca el reflejo de la imagen del exterior, a la manera que según Alhazen se producía en el interior del ojo, como consecuencia de la incidencia de la luz. (Fig.02)
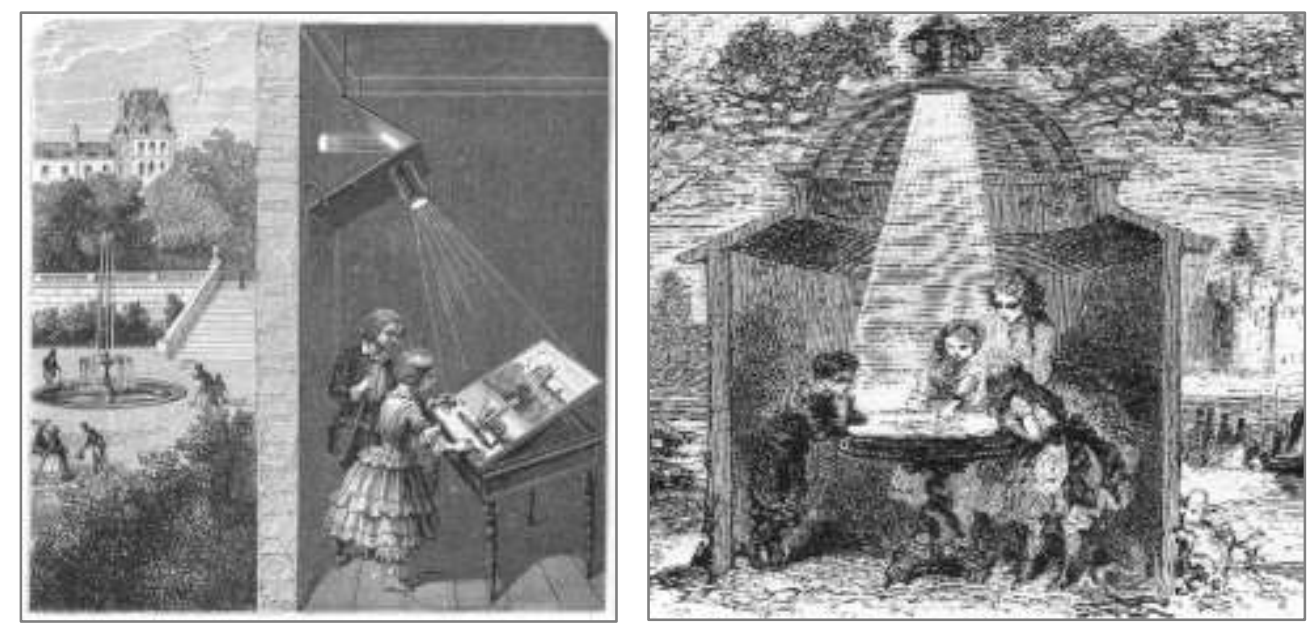

Fig. 02: Grabados que describen la cámara oscura (siglo XVIII)

En nuestra cultura, el origen del interés por conseguir una imagen de manera mecánica se reparte entre el mediterráneo y los países nórdicos. Lo podemos encontrar en la descripción técnica de la cámara oscura que hiciera Leonardo da Vinci, añadiendo una lente al orificio por donde entra la luz, con el fin de obtener imágenes más nítidas. En la Italia de 1558, el astrónomo Giovanni Battista Della Porta diseña la primera cámara oscura para dibujantes, pintores y grabadores, que posteriormente serían portátiles, y precursoras del primer proyector de imágenes: la linterna mágica (fig.03). En Alemania, otro astrónomo contemporáneo a éste, Johannes Kepler, retoma los estudios ópticos de Bacon en torno a la cámara oscura y la imagen retiniana: "los orígenes últimos de la fotografía no residen en la invención de la perspectiva del siglo XV, sino más bien en el 
alternativo modo pictórico del Norte (...) la imagen fotográfica, el arte de describir holandés y la pintura impresionista son todos ejemplos de esta opción artística constante en el arte occidental" (Alpers cit. en Crary, 2008, p.60)
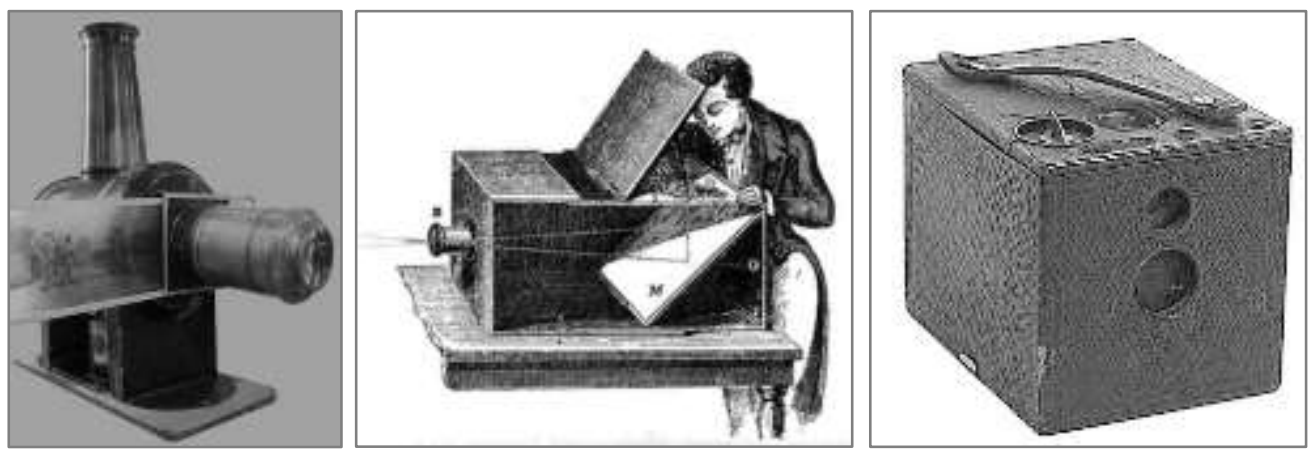

Fig.03: La linterna mágica (A. Praefcke) y primera cámara fotográfica (Kodak)

A principios del siglo XIX el desarrollo de estas cámaras, con un objetivo simple y un soporte con emulsión sensible, producen la primera imagen mecánica, la heliografía, un positivo único tras una exposición de ocho horas, desprovisto de detalles y con mucho contraste y grano (Fig. 04).
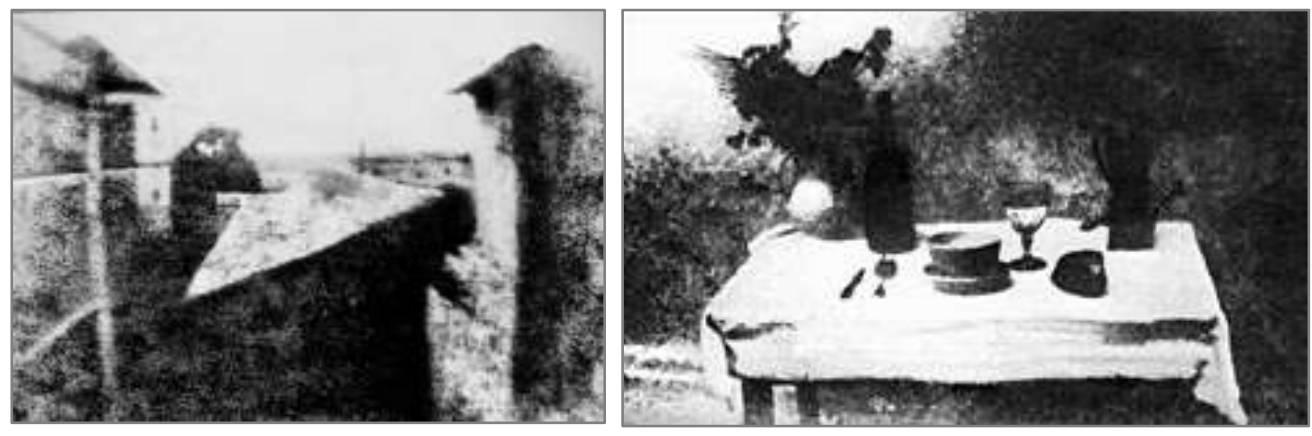

Fig. 04: Primeras fotografías, heliografías o 'dibujos del sol' (Joseph-Nicéphore Niépce, 1827)

Algunos estudios sostienen, al referirse al arte de las vanguardias, que "la fotografía alcanza gran difusión y se integra en estos movimientos" (Calbet, 1997), pareciendo que el invento surge y se difunde por un imperativo del desarrollo tecnológico. Pero, en realidad, son los integrantes de este ámbito artístico y científico del siglo XIX, quienes parecen dar origen al invento de la fotografía, gracias a sus aportaciones precursoras de los estudios ópticos y las mejoras técnicas de la cámara oscura de Della Porta. 
Los pintores y escultores que conocemos como románticos e impresionistas, están detrás, junto con químicos y ópticos, de este invento. Tengamos en cuenta que, en cierta manera, estos artistas visuales trabajaban con las leyes de la visión en sus construcciones de la perspectiva, aunque ésta no siempre fuera "racional" a causa de las exigencias expresivas (Bouleau, 1996, p. 115); y con la química del color y de los materiales para mejorar la luminosidad de la obra.

Muchos de ellos eran los pioneros fotógrafos o utilizaban estas máquinas en su trabajo: el paisajista Daubigny, considerado precursor del impresionismo, sostenía que lo que hacía al aire libre era la obra definitiva frente a quienes definían sus obras como bocetos poco elaborados entre el dibujo, el aguafuerte y la fotografía, ya que ponía su interés en la mancha y la pincelada suelta (Bennasar, 1985). Se dice de Monet que era un pintor tonal que estructuraba los paisajes registrados mediante el juego de contrastes entre blancos y negros, o que Degas realizaba monotipos (grabados únicos) y sobre las segundas copias trabajaba el pastel y la aguada (Kosinsky, 2000).
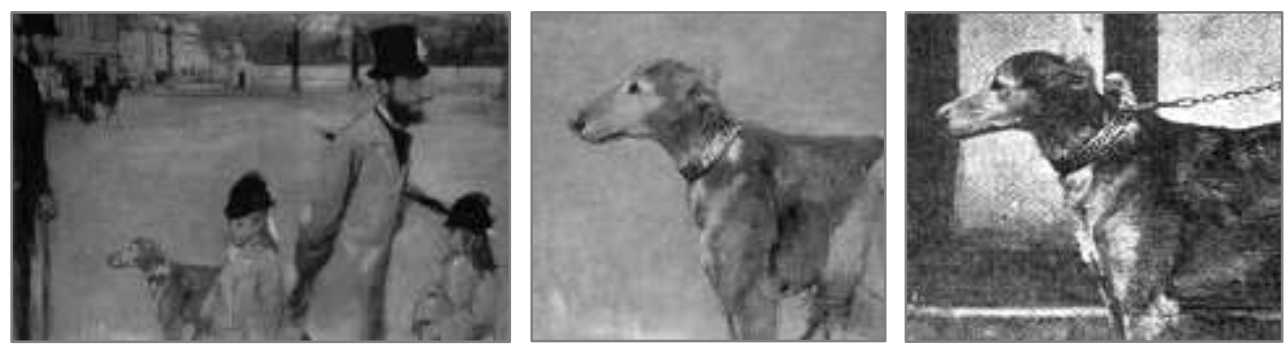

Fig.05: El perro "Albreckt", en la obra de Degas y en la foto de Sauvager.

Respecto al uso de la fotografía modelo para el perro en la obra 'Vizconde Lepic y sus hijas cruzando la Plaza de la Concordia' (1875, fig.05), se ha apuntado en el estudio del pentimenti (arrepentimiento) de la obra, que en las orejas y el hocico, el dibujo "lleva las huellas del estudio de la vida" (Wolohojian, 2003, p.98).

Este tipo de análisis de la obra artística refuerzan y anteponen el criterio y la técnica del autor frente a la utilización mecánica de la fotografía: ésta es vista como un medio, como un recurso para la representación humana. Para Delacroix, quien fuera socio fundador de la primera Sociedad Fotográfica de Francia, la fotografía (daguerrotipo) permite corregir errores visuales y dar importancia a los 
detalles (cit. en Bellido, 2007). Baudelere relata que Delacroix le dijo a un amigo suyo: "Si no sois lo bastante hábil para hacer el croquis de un hombre que se tira por la ventana durante el tiempo que tarda en caer desde el cuarto piso al suelo, jamás podréis producir obras maestras". (Baudelere, 2011, p.46).

La fotografía está inmersa en los estudios de los pintores como una herramienta más para complementar su trabajo de composición y sus estudios visuales de las formas y colores, posiblemente al igual o mejor, con más detalles y precisión, que lo hicieran con la cámara oscura (fig. 06).
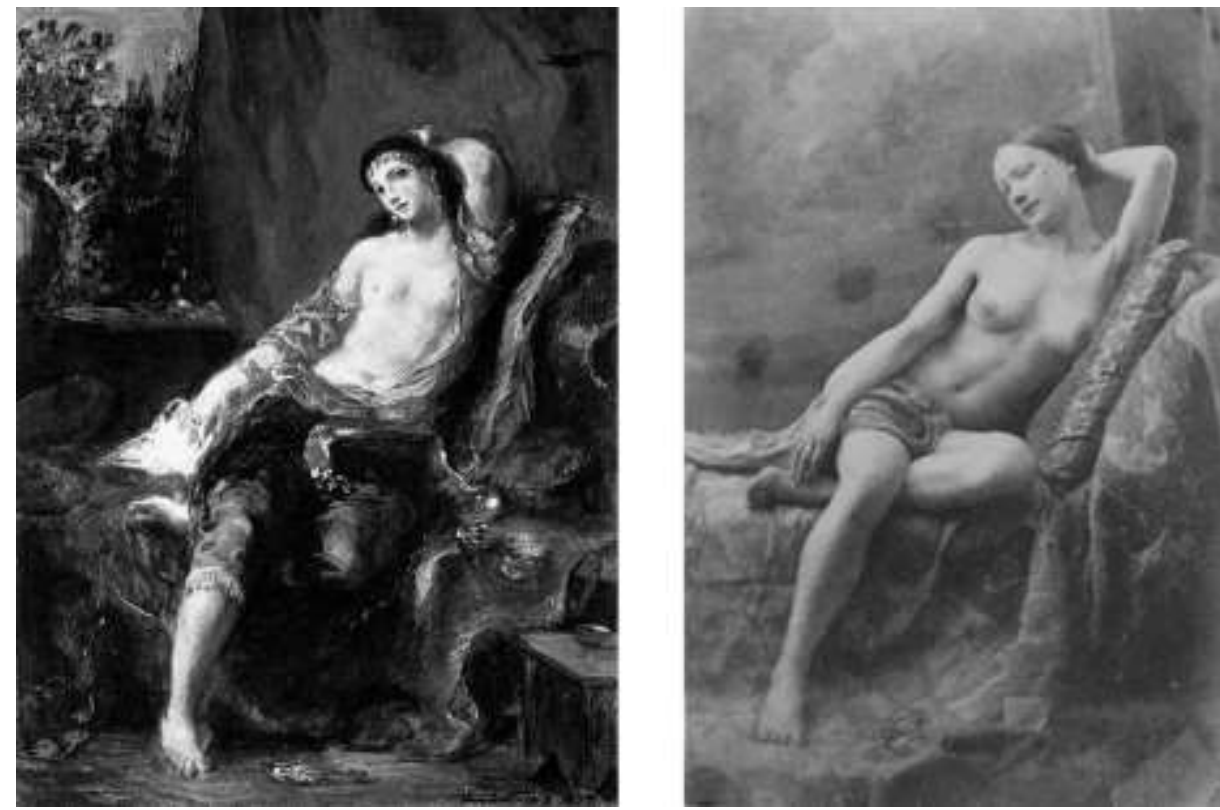

Fig. 06: Odalisque de Eugene Delacroix, 1857, y fotografia de la modelo para el pintor realizada por Eugene Durieu.

Parece ser habitual la utilización de la cámara en la captación mecánica del campo visual por parte de los artistas impresionistas y postimpresionistas, como procedimiento a desarrollar en la privacidad de su trabajo de taller. Su uso en el siglo XIX lo atestiguan los estudios previos de las obras de Gustave Moreau, Degas, Monet, Seurat o Picasso (Fig.07). Degas "fotografiaba pacientemente" las escenas sobre las que pintaría (Bouleau, 1996, p. 204) (Fig. 08). 

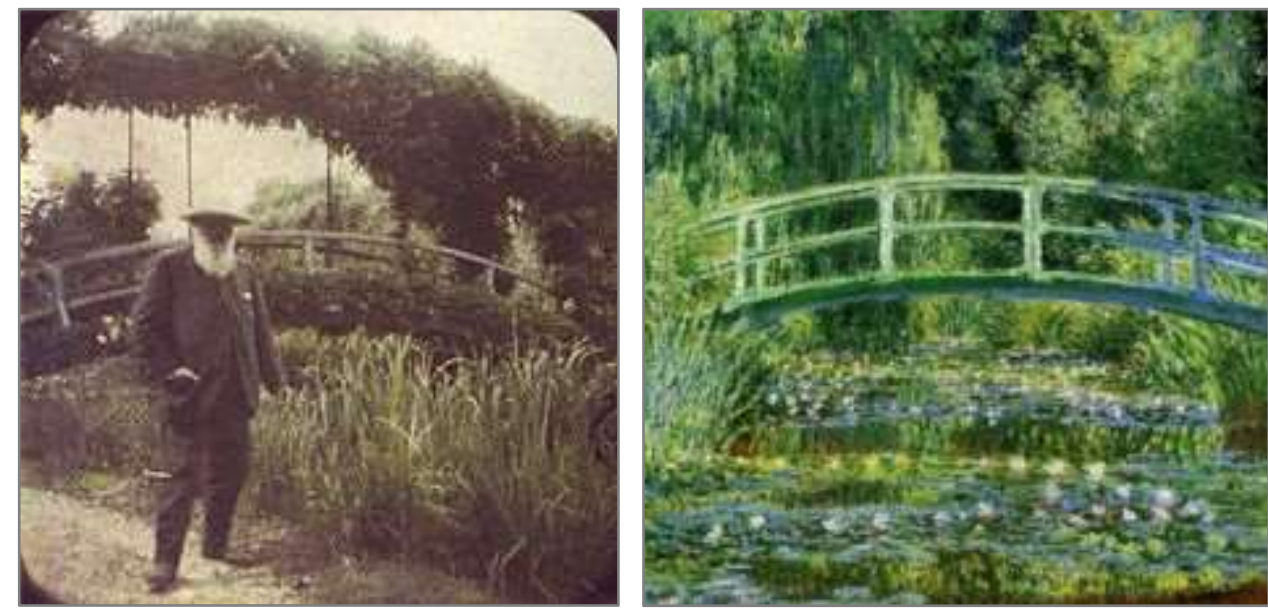

Fig. 07: Claude Monet fotografiado en su jardín y la obra 'Nenúfares' (1899)
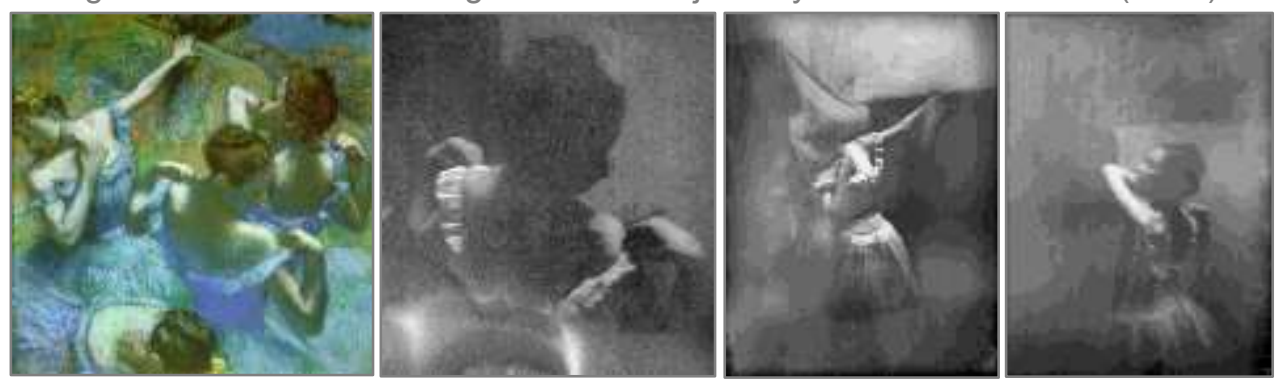

Fig.08: La obra 'las bailarinas azules' (1898) de Degas y fotografías de las modelos.

También los pintores plenairistas, caracterizados por trabajar al aire libre (plein-air), como Paul Gauguin, Alfons Mucha, Pierre Bonnard, Félix Vallotton, y Edouard Vuillard, utilizan los registros fotográficos realizados en muchos casos por ellos mismos, ya que las fotografías se encontraban en sus estudios. Estos realizan su primera exposición del grupo en el estudio fotográfico de Nadar, uno de los pioneros de la fotografía (Kosinski, 1999) (Fig.09). En el caso del grupo de pintores prerrafaelistas, utilizan los trabajos de fotógrafos, pero todos ellos ponen en evidencia las enormes vinculaciones entre la fotografía y los distintos movimientos artísticos (Bellido, 2007) (Fig.10). 


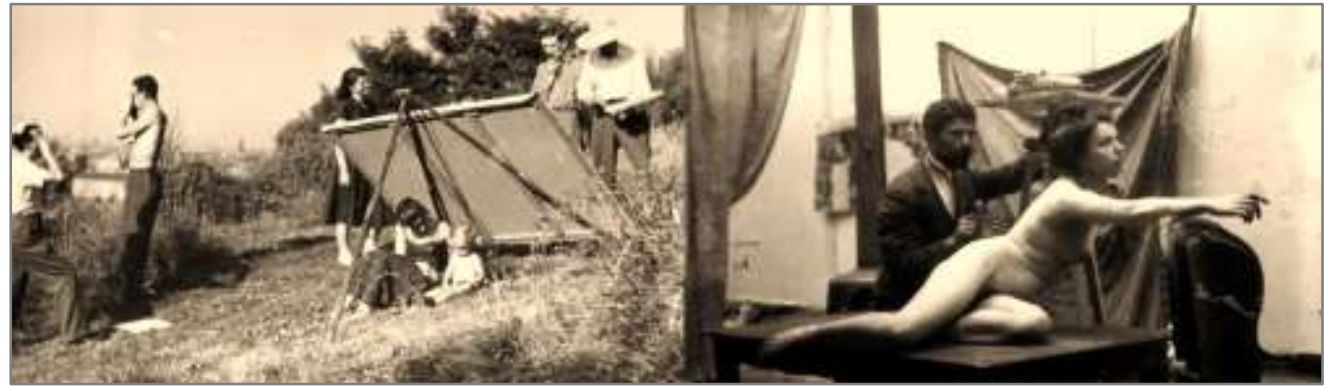

Fig.09: Burghardt Rezső (Budapest, 1954) y A. Mucha trabajando con la modelo.

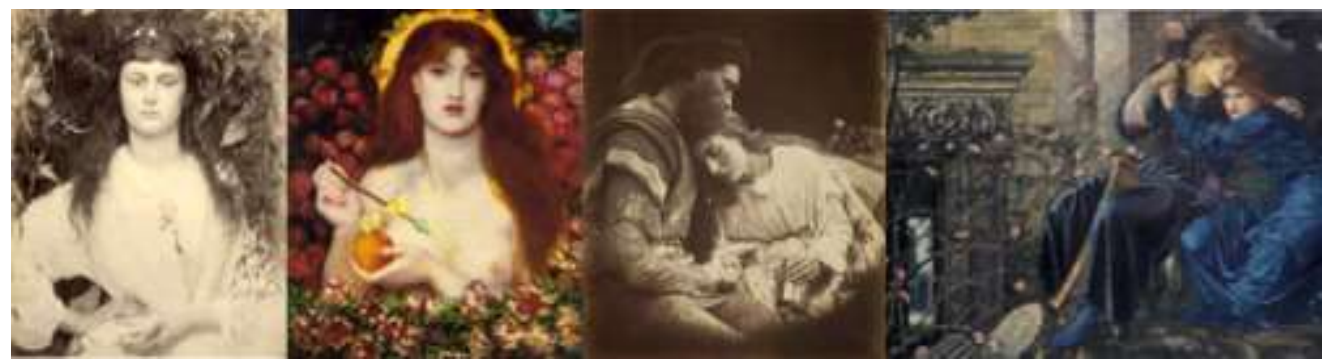

Fig.10: Fotografías de Julia Margaret Cameron y obras de Dante Gabriel Rosetti y Edward Burne-Jones.

Al mismo tiempo, es en este momento de las artes visuales cuando ese aparato, que registra y produce imágenes, comienza a ser accesible para el común de las personas, sin necesidad de ninguna preparación especial.

En 1839 se presenta el daguerrotipo en la Academia de Ciencias de Paris, un invento de Louis-Jacques Mandé Daguerre, preocupado por el perfeccionamiento de la cámara oscura, y a quien se definiera en su tumba cerca de parís, como: "Daguerre, pintor, químico, inventor de la fotografía". Se trata de un positivo logrado con vapores de mercurio sobre una superficie de cobre y con una exposición de unos minutos (fig. 11).
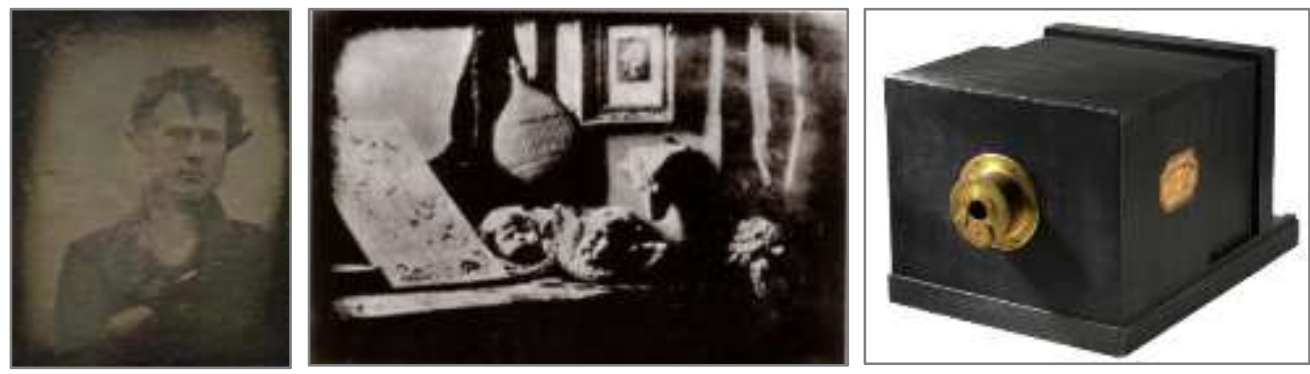

Fig. 11: Daguerrotipos: Daguerre y 'L’Atelier de l'artiste' (1837).

Cámara para daguerrotipo. 
En julio de 1839 el gobierno francés compró este procedimiento para que todo el mundo pudiera usarlo libremente y sin patentes (Gernsheim, 1965). Al mismo tiempo, el británico William Henry Fox Talbot (1844), autor del primer libro ilustrado con fotografías, desarrolla y patenta un procedimiento que utiliza un negativo para obtener copias con base en papel. Este método de Talbot, llamado calotipo, reduce el tiempo de exposición a unos 30 segundos para conseguir la imagen (fig. 12). El calotipo es considerado el método predecesor de la fotografía moderna, por el procedimiento de sensibilizar un papel para emplearlo como negativo a partir del cual podían obtenerse un número ilimitado de copias, a diferencia del daguerrotipo que sólo posibilitaba la obtención de la imagen única. No obstante aparecen varios procesos fotográficos (colotipo, argyrotype...) que responden al proceso creativo de quienes los utilizaron para desarrollar y expresar sus propuestas visuales (Valdez, 2009).
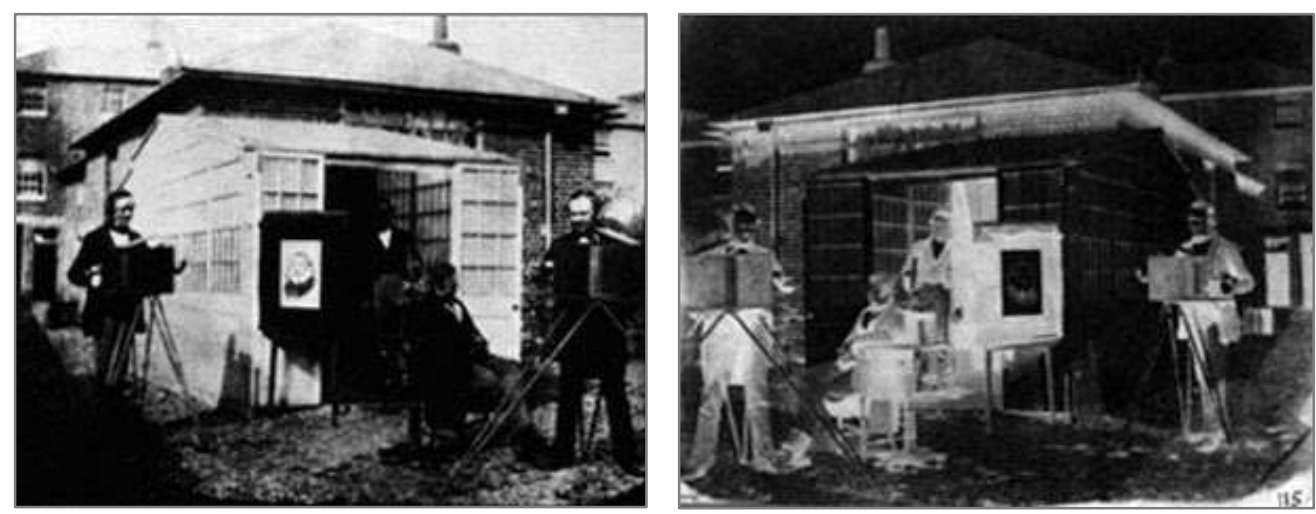

Fig. 12: Calotipo y negativo del establecimiento fotográfico de Fox Talbot. (Reading, 1845)

En 1888 Kodak comercializa la primera cámara cargada con película transparente, con el lema "Usted aprieta el botón, nosotros hacemos el resto", contribuyendo a restar valor a la destreza en el trabajo de composición de los artistas (Foster et al., 2006). Esta imagen fotomecánica recibirá definiciones, en plena euforia de expansión y comercialización, como "el lápiz de la naturaleza", "los dibujos del sol" o "el dibujo llevado a una perfección que el arte jamás podría alcanzar" (Fox Talbot, 2014). Quién sabe si la expresión de Matisse en el catálogo de su exposición en 1947: "l'exactitude n'est 
pas la verité" (Flam, 1995, p.179), no respondiera quizás al entusiasmo que generó el nacimiento de la fotografía.

En cierta manera, poco ha cambiado la situación. Las personas, por lo general, entienden que la fotografía realiza una perfecta imitación de la naturaleza, y que ésta lleva a la perfección el esfuerzo humano por representar la realidad visual. La extensión de la cámara fotográfica supone la "emergencia de un mecanismo de sustitución de la percepción" (Chaparro, 2006, p. 257). Son pocas las personas hoy en día que consideran que esta técnica mecánica, comparada con la técnica manual humana, ejecuta una pobre imitación de la realidad, bien por su simplicidad en la discriminación visual, o bien por la limitación de color de su 'paleta'.

Sin embargo, la utilización y sobrevaloración de la fotografía ha ido moldeando el hábito de adquirir gran parte de nuestra información visual a través de la imagen fotográfica, adaptándola como "norma de veracidad representativa y depositando en ella una fe que nunca se había puesto en las imágenes producidas por otros mecanismos" (Frutos, 2008, p. 7). Y ello ocurre aún a pesar de que se reconocían sus defectos (Rodriguez, 2010). Prueba de ello es la entusiasmada descripción que realiza el topógrafo Sebastián Camacho y Zulueta sobre el daguerrotipo:

"...se obtienen unos dibujos tan perfectos que nada dejan que desear. Es verdad que el azul purísimo del cielo, el verde encantador del campo y la expresión incomprensible que los colores imprimen a todos los objetos, se representan allí bajo un mismo aspecto monótono y sombrío; pero hay tal verdad en el dibujo y tal exactitud en todas sus partes, que casi compensan esta falta".

(Camacho, 1845, p.33)

A partir del desarrollo de la fotografía, y con él, el del cine y los medios audiovisuales, la imagen fotográfica fija o en movimiento adquiere una amplia y reconocida extensión como recurso visual. El perfeccionamiento de los sistemas fotomecánicos utilizados en la imprenta genera una gran demanda de fotógrafos que competirán con los ilustradores en periódicos y revistas (Aparici, 1987). También se produce una creciente demanda de retratos, que parece estar en el origen de los primeros estudios fotográficos (Sougez, 1988). Al mismo 
tiempo, la reducción del precio de las cámaras fotográficas, va a permitir acceder a la producción de imágenes a multitud de 'aficionados', personas atraídas por la característica de inmediatez del invento, aunque sin conocimientos de composición.

La composición determina "donde las cosas pueden ir ", y cómo la propia colocación de los elementos en una composición condiciona a estos elementos (Kress y Van Leeuwen, 1996, p.212). Visto así, la composición de una imagen implica diferentes grados de relevancia a sus elementos. Independientemente de donde se colocan, la prominencia o relevancia (salience) puede crear una jerarquía de importancia entre los elementos, seleccionando algunos como más importante, más digno de atención que otros.

Se ha estudiado la influencia desigual de la fotografía en la composición de la obra de los artistas. Mientras que algunos impresionistas gustaban de la composición instantánea, otros, como Degas, no admitían que su obra fuera "una ventana abierta a la naturaleza" en alusión a la fotografía, y elaboraban la composición tras numerosos cálculos (Bouleau, 1996, p. 206). Desde mediados del siglo XIX se empiezan a ver pinturas con composiciones fotográficas que utilizan un ángulo visual diferente al del plano del suelo, o delimitaciones del marco del cuadro (cadre) inimaginable en la composición artística y resultante de la fotografía de acción o movimiento. Sin embargo, no encontramos estudios sobre la influencia inversa, que han tenido los artistas en la composición fotográfica, a tenor de que esta técnica se iba haciendo cada vez más popular.

Estos aspectos de la difusión de la imagen fotográfica contribuyen a limitar $y$, en cierta manera desde un punto de vista cognitivo, a empobrecer el proceso individual de visualización de las imágenes. Crary (2008) analiza este aspecto y destaca cómo la antecesora cámara oscura mantenía el contacto del observador con la realidad visual, por la ausencia de representación, que si realiza la cámara fotográfica. Esta es la diferencia sustancial, de la que deriva la consideración de que un procedimiento mecánico puede mejorar la capacidad de la visión y cognición humana. Entendemos el déficit cognitivo en el sentido que al ser sustituida la capacidad visual y gráfica manual de la representación humana por la acción de una máquina, y atribuir a ésta un valor absoluto, el hombre moderno 
relativiza su propia habilidad. Creemos que esta relativización de la propia competencia visual y gráfica influye a su vez en los planteamientos que hacemos de la educación visual.

En este sentido de sobrevaloración, hemos atribuido a la máquina fotográfica una capacidad y una especie de inteligencia superior que sin embargo no asignamos a otros inventos. Pongamos el caso de los ordenadores o computadoras: aun considerando el ordenador más capaz y desarrollado, entendemos que éste ha sido creado por la inteligencia humana, y por tanto, existe alguna mente en algún lugar que programa sus funciones, escribiendo un código. Nadie se plantea que la máquina pueda pensar por sí misma, porque, aunque desconozcamos el código o lenguaje de la máquina, sabemos que éste lo escribe una mente humana, y que la máquina está 'programada' para ejercer una tarea específica, una función mecánica.

Sin embargo, este planteamiento referido a la máquina fotográfica no parece tan evidente. Es habitual considerar la creación visual humana en términos de comparación con la creación mecánica, y escuchar frente a una obra de arte visual que 'parece una fotografía'. Pudiera parecer que la mecánica visual nos supera, o, planteado de otra manera, que la inteligencia visual tuviera una parcela de conocimiento más limitado que otras, como pueda ser la inteligencia matemática. No hay duda que las operaciones mecánicas de una computadora son favorecedoras del proceso de pensamiento humano, al igual que los son las fotografías. La función calculadora de las máquinas favorece y abrevia muchas tareas que consideramos mecánicas, pero ello no ha impedido que continuemos enseñando cálculo en las escuelas, sino por el contrario, que insistamos más en él. Sin embargo, en el caso de la imagen técnica, tal vez atribuimos a las máquinas fotográficas la posibilidad de sobrepasar la capacidad humana de ver a través de ellas, y nos permitimos "únicamente controlarlas" (Flusser, 1990, p. 67).

Asumir una limitación en una capacidad humana, genera un importante problema con el conjunto de capacidades creadoras y con la propia noción de inteligencia. No creemos que las personas nos creamos limitadas visualmente, pero sí que hemos prescindido culturalmente y hemos excluido de la educación el análisis del proceso visual de lectura o interpretación de imágenes, al tiempo que hemos 
delegado los procesos de creación o producción de la imagen a la simplicidad de una máquina o a la exclusividad del talento artístico.

Parece razonable pensar que existe una situación intermedia en la que la inteligencia humana es capaz de mejorar la mecánica aunque no adquiera, en cuanto a la lectura y creación de imágenes, un nivel de erudición. En esta idea se basa el concepto alfabetizador crítico de la 'lectura de imágenes' (fig. 13).

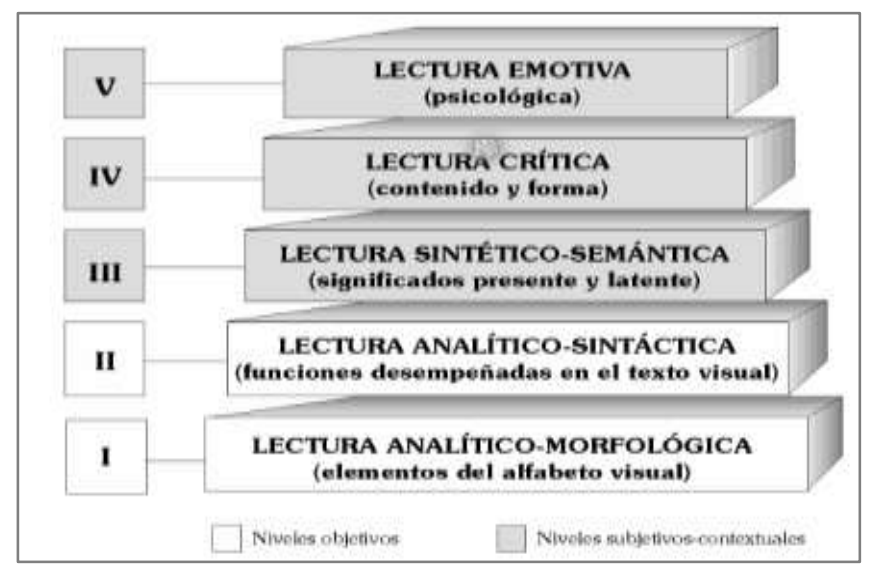

Fig.13: Pirámide de la lectura visual (Ortega, 1999)

Este proceso establece un principio diferencial entre el alfabetismo verbal y el visual: "la principal diferencia entre uno y otro es que el alfabetismo de la letra impresa se debe a un esfuerzo deliberado de adquirir tal aptitud por medio de la educación mientras que el de la imagen es aparentemente un proceso natural" (Aparici, 1987, p. 12).

Hemos comentado que la interpretación moderna del código visual de la imagen va unida al estudio del signo y del símbolo de una cultura, y estrechamente vinculado al proceso de la comunicación. Y en muchas ocasiones este proceso de lectura de la imagen es narrativo o estético y resulta mediado por el discurso verbal. Prueba de ello es la abundante literatura científica y filosófica que relaciona los estudios semióticos y las artes visuales. Probablemente esta literatura asigne más importancia en el análisis del lenguaje visual, al significado (emocional, crítico, político...) que al significante, y quizás por ello precise del código verbal del discurso, antes de considerar el análisis de los elementos gráficos básicos que constituyen el código visual en la construcción de imágenes. Desde la publicación del 
cuadro "la traición de las imágenes" de Magritte en 1926 (fig.14), en la que basa su obra Foucault (1989), se abre un prolífico debate sobre las relaciones entre el grafismo representativo de la imagen y el signo lingüístico.
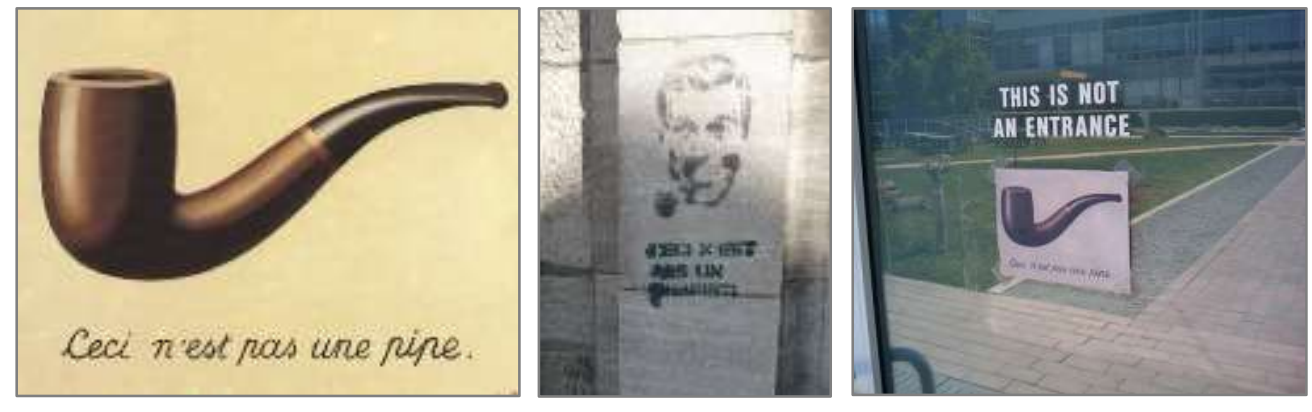

Fig.14: 'La traición de las imágenes' de René Magritte (1929)

Aunque nuestro pensamiento es preferentemente verbal y analítico, y a través de él abordamos el análisis de la imagen, es importante considerar que previamente al conocimiento del código de signos verbales, nuestro pensamiento es visual. Aunque sea recesiva o sumisa, la característica visual de nuestro pensamiento no desaparece. "Existe el pensamiento que ve y que puede ser descrito visiblemente", explicaba Magritte en una carta a Foucault (Foucault, 1989, p. 83).

Creemos que tener en cuenta esta consideración enriquece la lectura de imágenes, y ayuda a resolver el paradigma, permitiendo al significante la posibilidad de tener o no un significado verbal, relativizando la importancia del valor de la imagen por la sustitución o no de las palabras. Y, en suma, avanzar hacia la normalización en la necesaria convivencia de ambos lenguajes. Foucault (1989) nos revela en su obra "ceci n'est pas une pipe", que Magritte escribió al dorso de una de sus reproducciones: "El título no contradice al dibujo; afirma de otro modo".

\subsection{Imagen y desarrollo tecnológico. La imagen digital.}

Desde un punto de vista cultural, el ámbito abarcado por los medios de comunicación social que describen su desarrollo a partir de la imprenta y de la fotografía, está siendo sustituido por un entorno 
tecnológico caracterizado por la velocidad, y ello está repercutiendo en el estilo y hábitos de vida, en la educación, en la ciencia y el arte. Hoy hablamos de medios tradicionales cuando nos referimos al cine, la televisión, la prensa, libros, etc., porque atribuimos a estos medios la carencia de una interactividad que está caracterizando el desarrollo de la tecnología digital.
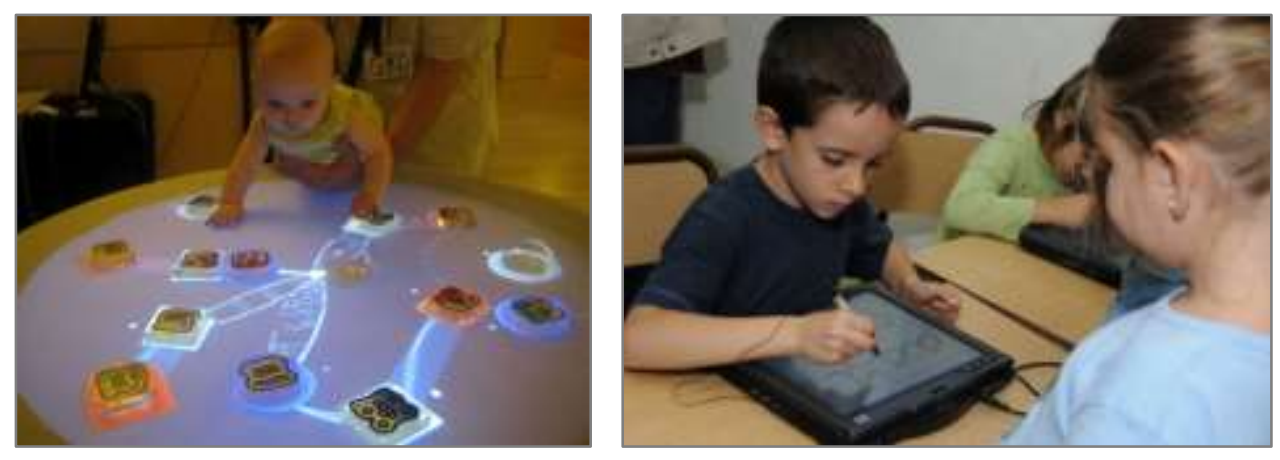

Fig.15: Aplicaciones interactivas en educación.

El tratamiento digital de la imagen, los sistemas electrónicos de grabación y de pantalla, están generando dispositivos basados en pantallas táctiles e imágenes interactivas, las cuales, a partir de nuestra acción (visual y motora) generan un mapa de sucesos. Los dispositivos móviles (teléfonos, tabletas, gafas o relojes...) son los protagonistas de una circulación de la información nunca antes conocida, y en la que la imagen cobra un especial protagonismo.

En el entorno digital de las organizaciones, entre ellas las educativas, destaca el auge de las infografías o la trasmisión de información apoyada en la imagen digital. Nunca antes cobró tanto protagonismo la idea de que 'una imagen vale más que mil palabras', como si se tratara de una sentencia premonitoria de la forma en que construimos las imágenes en el entorno tecnológico digital; aunque esta sentencia parte de la exclusión a priori de dos ámbitos cognitivos que hoy sabemos que son complementarios.

La imagen digital es denominada 'la nueva imagen' frente a la imagen impresa, aunque como objeto nuevo "su novedad no esté allí donde se la espera, en la calidad de las imágenes ofrecidas a la vista" (Renaud, 1990, p.6). Ambos tipos de imagen tienen en común la impresión por puntos, que es química en un caso, y electromagnética en otro. 
Consideramos que con el tratamiento digital de la imagen se está produciendo una brecha, en el sentido de aumentar el distanciamiento entre el tratamiento de imágenes y la creación de éstas. Si todos los procesos pueden ser expresados en formulas, como dice Flusser (2005), el pensamiento es sometido a "un código numérico que la sociedad en su totalidad no puede leer y que por ello mismo ha de seguir ciegamente como una vez lo hicieran los analfabetos con los textos de los literatti' (p. 103-104). Por lo general, pensamos que el trabajo con la imagen digital requiere un amplio conocimiento de un software específico, y ello nos hace considerarlo muy distante de la operación manual del trazado; sin embargo, cada vez son más las aplicaciones para dispositivos móviles que permiten interactuar con la pantalla en condiciones semejantes al soporte tradicional del papel.

Sin ahondar en aspectos técnicos más allá de lo que nos interesa destacar, esta nueva imagen está basada o es creada a partir de puntos luminosos (pixels) a diferencia de los puntos (grano) de la imagen impresa. Los pixels, término que se traduce como 'elementos de imagen' (picture elements), como datos o unidades de información que son, tienen una doble referencia: espacial, que sitúa el pixel en el sistema o mapa de coordenadas con el que poder interactuar, y cromática, que le proporciona una luminosidad específica. El resultado es una imagen que se 'construye' según las características del dispositivo que la presenta.

Su verdadera constitución responde a un código inherente que interpreta o lee la máquina. El código está escrito para que una máquina interprete el lenguaje y lo traduzca en formas y colores de manera similar a cómo nosotros podemos visualizar un paisaje a partir de una descripción textual más o menos poética. Pero la máquina lo hace de manera mecánica, respondiendo a la característica de textolatría, de extrema fidelidad a la escritura (Flusser, 1990). Es un código que está formado por más de mil palabras para construir una imagen en la pantalla.

Para entender que se cumple la sentencia en que la imagen digital 'vale más que mil palabras', consideremos la unidad mínima de información denominada 'bit'. La combinación de los valores 0 y 1 en 
secuencias binarias (dígitos binarios) producen diferentes resultados en cada pixel (tabla 01).

\begin{tabular}{|ccc|}
\hline Bits por píxel & Tonalidad & Resultado \\
\hline 1 & blanco y negro & dibujo \\
8 & 256 grises o colores & foto gris o icono \\
24 & 16,7 millones de colores & RGB, imágenes en color \\
32 & 16,7 millones + negro o alfa & CMYK para impresión \\
\hline
\end{tabular}

Tabla 01: Resolución de Bits por pixel

Una de estas secuencias más utilizada es el 'Byte', correspondiente a la secuencia de 8 bits, de manera tal que si una palabra se forma con unos 10 bytes (10B), para formar una pequeña imagen con una resolución mediana necesitamos un código de 100.000 bytes $(100 \mathrm{kB})$.

Los dispositivos citados permiten la visión de la imagen en la superficie (interface) gráfica correspondiente al lenguaje utilizado en su código, pero también permiten la creación de imágenes, a través de programas (software) que escriben código en ese lenguaje. Son muchos los lenguajes de programación y algunos, como los llamados de nivel alto, son más flexibles o adaptables a diferentes programas o softwares.

Sin embargo, estos lenguajes escritos que operan detrás de los dispositivos y sus programas guardan una estructura común a la hora de definir los pixeles para producir una imagen. Una estructura que va a permitir el paso de esa imagen de la "latencia a la emergencia en términos visuales" (Zunzunegui, 2006, p. 241). Si para obtener una imagen (digital o escaneada) necesitamos un mapa de bits latente, para crear una imagen gráfica escribiendo código de manera directa, sin la mediación de un programa gráfico, existe una estructura que va a recibir curiosamente el nombre del soporte tradicional utilizado por los pintores para plasmar sus representaciones: canvas o lienzo.

Canvas permite la generación de gráficos a partir de código en la pantalla de manera dinámica (fig.17). Estas imágenes vectoriales no son representadas de forma directa sino a través de "operaciones 
materiales, perceptivas y reglas gráficas y tecnológicas" (Vilches, 1997).
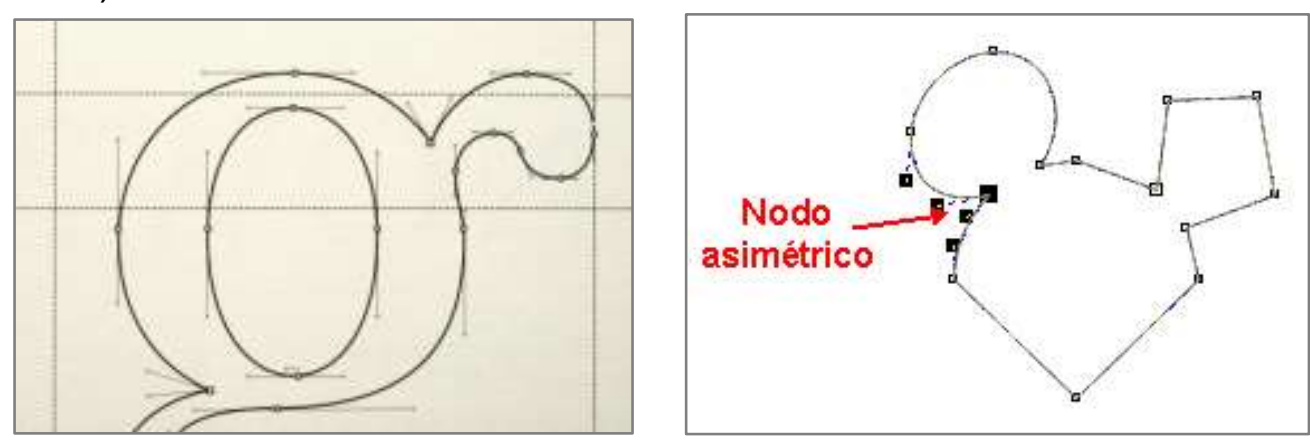

Fig. 16: Curvas de Bezier y nodos en tipografía y formas.

Los programas gráficos, con software propietario o libre, como los conocidos Illustrator, Freehand o Inkscape, permiten el trabajo directo en la pantalla con lápices, plumas o pinceles a partir del concepto de vector y la herramienta Bezier. Esta permite convertir las líneas en curvas a partir de unos puntos fijados o 'nodos' que tienen características modificables (fig. 16). El resultado es una imagen vectorial formada por objetos independientes definidos por cálculos matemáticos que permiten su adaptación a diferentes tamaños o escala.

En cualquier caso, el formato más extendido de imagen vectorial, el SVG (Scalable Vector Graphics) se define con un código compatible con Canvas (fig.17).
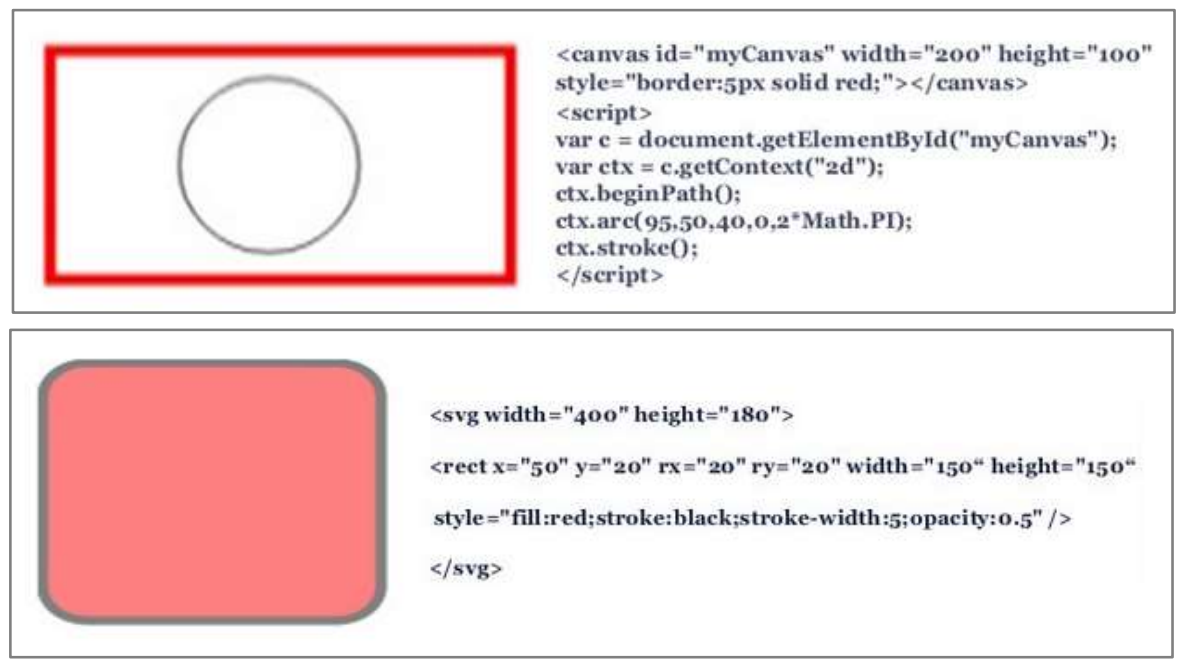

Fig. 17: Códigos de imagen canvas y SVG . 
Por tanto, podemos extraer como conclusión que, conociendo el código de la estructura del lienzo y de las herramientas de diseño, se accede a la construcción de una imagen con o sin necesidad de programas específicos. Conocer la estructura del lienzo supone una aplicación del sistema de coordenadas $X Y$ en el plano y la determinación de las dos dimensiones de anchura y altura de la forma, de manera que las herramientas resultan aplicables al tratamiento de vectores, ángulos y curvas. Ambos planteamientos forman parte de la formación básica en el área matemática. Sin embargo, el aprendizaje de las estructuras subyacentes en los lenguajes de programación parece encontrarse lejos de formar parte de las enseñanzas mínimas de nuestros programas de educación obligatoria, así como de la formación del profesorado, y mantenemos de esta manera una distancia cada vez mayor entre la latencia y la emergencia de la imagen digital.

Ciertamente, la repercusión de la tecnología digital en el ámbito cultural está produciendo muchos efectos en relación a un uso inadecuado o excesivo de los dispositivos, que denominamos tecnoadicciones, y las ciencias sociales se afanan por investigar sus causas. Pero también es cierto que existen problemas que, aunque se asocien al desarrollo tecnológico, siempre han estado, y tal vez las nuevas tecnologías lo aumenten. Creemos que es el caso de la dificultad y la distancia generada entre el gesto humano y el soporte para la representación gráfica, que en la actualidad puede ser un dispositivo digital. En este sentido, en línea con el informe de la Organización de las Naciones Unidas para la Educación, la Ciencia y la Cultura (UNESCO), hablamos de una brecha cognitiva en términos de formación y educación, de una "valoración dispar de unos determinados tipos de saber con respecto a otros en la economía del conocimiento" (UNESCO, 2005, p. 23), o, en términos culturales y por diferentes causas, de la existencia de una brecha digital cognitiva en cuanto a la privación de oportunidades y recursos que aportan las herramientas informáticas a la competencia gráfica (Aparici, 2013; Pérez Tornero, 2012; Necuzzi, 2013; Vega Montiel et al., 2008). Una prueba de ello es la proliferación de programas y aplicaciones pre compiladas en torno a la manipulación y creación de imágenes en todos los ámbitos del conocimiento. 
En línea con la afirmación de la existencia de una 'invasión' de imágenes en nuestra vida (Santos Guerra, 1984), la imagen invade los materiales y productos de la cultura digital, y la educación no puede permanecer ajena a esta realidad. El posmoderno concepto de la poli-alfabetización invita a considerar de una manera interrelacionada, la alfabetización digital y la visual, si creemos que la educación puede ayudar a las personas a filtrar la densidad de la iconosfera, y a mejorar la relación entre hombre y máquina en la producción de imágenes del moderno ciudadano hipervisual (Gubern, 1996).

La alfabetización digital-visual se apunta como un requisito académico si queremos desenvolvernos con las herramientas digitales que se están desarrollando y los nuevos escenarios que se plantean, como el de la Realidad Aumentada (AR, Augmented Reality) donde se hace necesario conocer, o al menos familiarizarse con la estructura que subyace en la ingeniería de la imagen digital tridimensional, en este caso basada en la holografía, o fotografía de varios planos .

La Realidad Aumentada es una tecnología que complementa la percepción e interacción con el mundo real y permite al usuario al mismo tiempo que está en un entorno real, interactuar con imágenes generadas por el ordenador. Para añadir esa información virtual se elaboran tarjetas o marcadores con un código QR (quick response code), que escanean los dispositivos móviles (fig. 18).

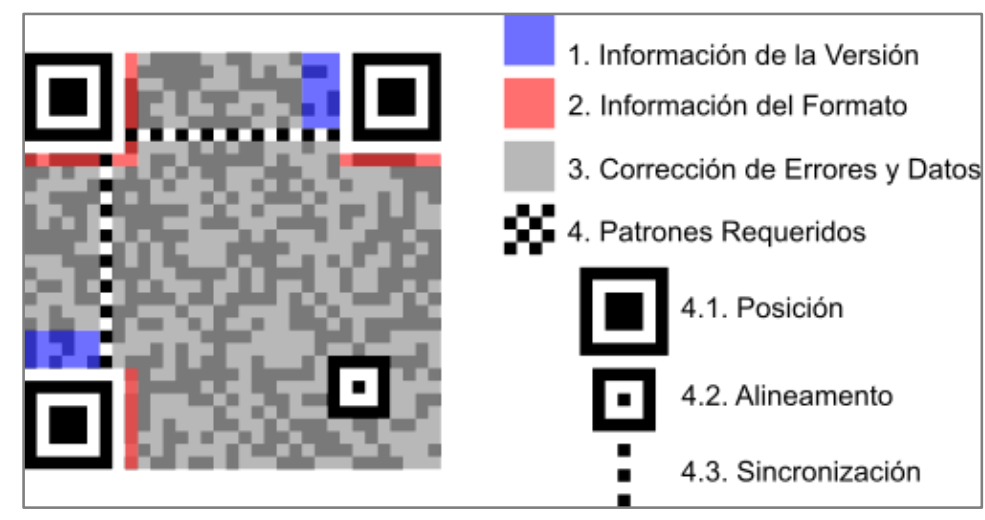

Fig. 18: Descripción del código QR

Este código de respuesta rápida (Quick Response Code) es una matriz bidimensional de puntos, a semejanza de un código de barras, que almacena miles de caracteres alfanuméricos, y puede traducirse en texto, audio o imagen, de manera tal que se pueden 
incluir tareas educativas, instrucciones o mensajes de refuerzo, abriendo interesantes posibilidades de aprendizaje en entornos mixtos reales y virtuales en la era de la hiperconectividad (Reig, 2013) (fig. 19).
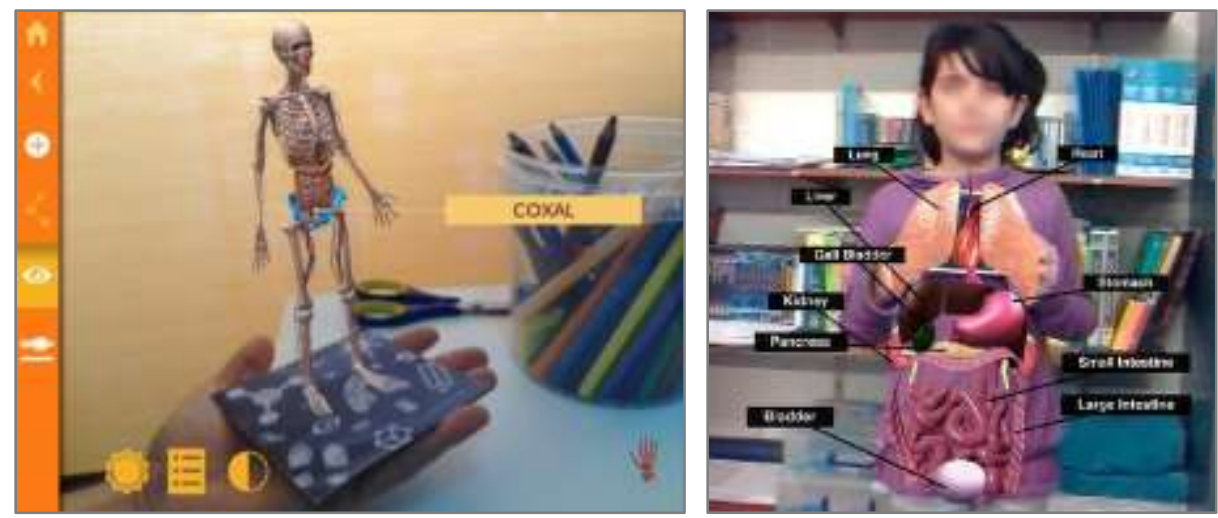

Fig. 19: Muestras de aplicaciones educativas de realidad aumentada

El conocimiento y la aplicabilidad de esta tecnología en la docencia es mínima (Basogain et al, 2007) por tener todavía un carácter experimental, y por el escaso uso y divulgación que se hace de ella, pero creemos que también por el déficit en formación en la estructura de la imagen digital y la falta de familiaridad con los lenguajes de programación. $Y$ tal vez por este motivo, cuando se utilizan estos recursos, los incipientes resultados por ejemplo en trabajos de geometría espacial con realidad aumentada (Martín Gutiérrez, 2012; De la Torre Cantero et al., 2013) se siguen los mismos patrones que los diseños no tecnológicos tradicionales, lo cual tampoco ofrece especiales garantías de que la tecnología por sí sola ofrezca beneficios en el desarrollo de las habilidades de visualización espacial (fig. 20).
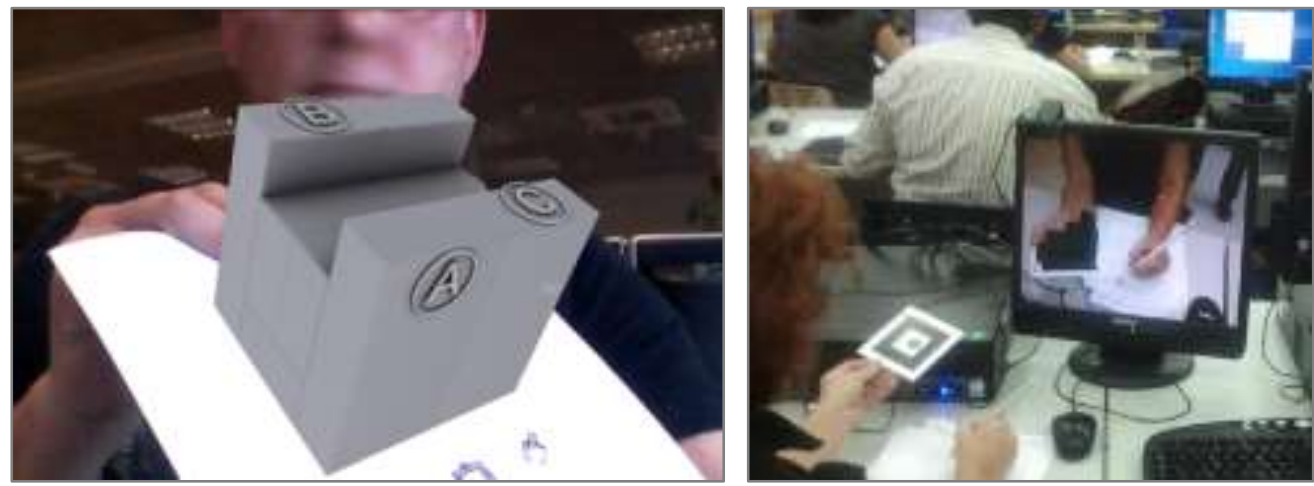

Fig. 20: Modelos de realidad aumentada en relaciones espaciales

(De la Torre et al., 2013) 
Por todo ello, consideramos necesario profundizar en el conocimiento de la percepción real y de los sistemas mentales de representación, para adentrarnos con seguridad en el mundo incipiente de la percepción virtual; de manera tal que, salvar la distancia y familiarizarse con la tecnología no suponga una mera sustitución de los modelos físicos por modelos digitales, manteniendo e incluso aumentando los déficits visuales y gráficos. En suma, que las máquinas resulten de óptima utilidad y no supongan una carga personal $\mathrm{o}$ académica.

El papel de la educación se encuentra no sólo en instruir o capacitar en la utilización de máquinas y aparatos, sino en favorecer la libertad de actuación frente a ellos. Que la imagen, pero tambien la máquina fotográfica, el programa o la aplicación, constituyan el problema educativo, de manera tal que en la imagen, en cualquier imagen creada, podamos incluir "algo que no está inscrito en el programa del aparato” (Flusser, 1990, p.75).

\title{
3. El Pensamiento Visual en el ámbito científico.
}

\author{
"La mayor parte de las ideas fundamentales acerca \\ la naturaleza, son esencialmente sencillas y por regla \\ general las ciencias las expresan a través de formas \\ visuales comprensibles y memorables"
}

Albert Einstein.

Afirmar que la visión implica construcción (Hoffman, 2000) indica que la visión, desde un punto de vista fisiológico, es, junto con el sentido de la audición, la principal fuente que tenemos de percepción de la realidad exterior, y por ello la principal fuente de construcción del conocimiento (interior) del entorno. Aunque también construimos la realidad a partir de la información táctil y olfativa recibida. En ausencia de información visual, ésta es sustituida por la información táctil hasta tal punto, que las personas con ceguera 
emplean las líneas y sus direcciones en sus dibujos y mapas al igual que lo hacen los videntes (Kennedy, 2003).

Por un lado está el contenido de la información que recibimos a través de los sentidos, y por otro, lo que hacemos con ella, el tratamiento que hacemos de esta información para construir pensamientos, movimientos y emociones, o en términos generales, para generar una respuesta, una acción. Así, la forma previa de orientar, organizar y estructurar esta información sensorial va a determinar la manera en que la procesamos en el cerebro. Todo apunta hacia el hecho de que el desarrollo cognitivo está relacionado preferentemente con el procesamiento, más o menos activo, de datos o información visuales, lo que ha configurado la evolución de un 'cerebro óptico' (Cuatrecasas, 1981).

Considerando esta preferencia óptica y desde el enfoque de la psicología de la percepción, la manera de procesar la información visual va a determinar el conjunto de imaginería (imágenes mentales) que vamos construyendo y que confiere aquello que denominamos el pensamiento visual (Arnheim, 1986). En la base de este pensamiento se encuentran los 'perceptos'. Percepto es un término atribuido al filosofo contemporáneo Gilles Deleuze (2005) que trata de definir la existencia de una estructura cognitiva previa al concepto, aunque él considera que el sentido no existe como tal, "lo expresado no existe fuera de su expresión" (p.49). Sin embargo, para Arnheim, los perceptos constituyen la percepción de las cualidades y características estructurales de las formas, ricos en detalles, que dan lugar a la generalidad del esquema y el concepto. El planteamiento de un pensamiento previo al concepto y a lo simbólico se debate así entre la experiencia cognitiva sensorial y el pensamiento proposicional.

Desde otros enfoques de la psicología cognitiva también se apunta hacia el hecho de que el pensamiento tiene sus bases establecidas en una estructura perceptiva visual: ya sea en las estructuras visuales 'icon' (Neisser, 1997), o bien en los pre-esquemas de las experiencias sensomotoras previas al concepto (Piaget e Inhelder, 1997). Similares a estas estructuras son las claves (clues) o datos sensoriales de la visión como sistema perceptual que precede y acompaña las distintas formas de categorización (Gibson, 1974). De 
igual forma ocurre con los 'priming perceptuales', que hacen referencia a la influencia que tiene un estímulo en el procesamiento determinado por las características físicas (Razumiejczyk, 2013), o con preconceptos como el de 'parole' o 'performance' de Saussure, a los que se refiere la psicolingüística, al hacer una reivindicación de la naturaleza de los procesos cognitivos humanos de la percepción y el aprendizaje (Chomsky, 1981, pp. 27-28).

Sin embargo para Arnheim (1986) "ver es comprender" y equipara los procesos del razonamiento conceptual a los de la percepción: "en la percepción de la forma reside el inicio de la formación de conceptos" (p. 40). Utiliza la metáfora visual para ilustrar este hecho analizando algunos conceptos verbales. Por ejemplo, el concepto de 'profundidad' se expresa igual para la profundidad física (por ejemplo, la de un pozo) que para la profundidad mental. Ejemplifica otras percepciones no visuales, como el 'apestar' de una organización corrupta, la 'tensión' de una situación, etc., que además de reforzar el hecho de que el pensamiento humano está organizado a partir de la percepción, sugiere también una estrecha relación entre percepción y lenguaje. Otra cuestión, que abordamos más adelante, es la de cómo se traduce el pensamiento en lenguaje visual y cómo se desarrolla éste junto al lenguaje verbal. La relación o convivencia entre ambos tipos de lenguaje nos plantea aquí la cuestión de si la percepción puede quedar limitada, o interrumpida como acción cognitiva, en el momento en que nuestro pensamiento asocia la forma que percibimos con el concepto verbal que se encuentra en nuestra memoria. Este planteamiento permite establecer al menos dos formas de pensamiento relacionadas a su vez con diferentes vías neuronales: una forma de pensar centrada en cualidades perceptivas visuales (formales y espaciales) del PV, y otra, centrada en categorías proposicionales, asociando el reconocimiento de formas y lugares al pensamiento simbólico del lenguaje.

El enfoque psicofisiológico refuerza la característica óptica del cerebro. El estudio sobre el crecimiento del córtex cerebral en los humanos vincula éste con la preponderancia de los estímulos de carácter visual (Smirnov et al, 1994). Ciertos estudios demuestran que deficiencias nutricionales y lumínicas, producen alteraciones en el desarrollo normal de la corteza visual y sus conexiones (Muñoz-Rivas y Agustín, 2005). Este desarrollo se vincula a su vez, con el de 
diferentes habilidades de las funciones ejecutivas como las de reconocimiento visual, orientación de objetos en el espacio, coordinación visomotora, y de la capacidad para organizar las ejecuciones en el tiempo y en el espacio (Verdejo-García y Bechara, 2010).

La mayor parte de la información visual, en torno al $90 \%$, se procesa en la parte frontal de la corteza cerebral, en ambos lóbulos, responsable de las funciones ejecutivas del pensamiento metacognitivo y emocional (Ardila y Ostrosky-Solís, 2008). Los aspectos visuales de la orientación espacial de objetos, asociados a las habilidades de supervivencia, se vinculan al tronco cerebral, también conocido como cerebro reptil (MacLean, 1970). La orientación espacial en gran parte viene determinada por la especialización de células espaciales: de lugar, de red, de dirección y de contorno, que establecen un mapa rudimentario del espacio (Langston et al., 2010) que evolucionaría de manera gradual. La actividad neuronal va reflejando la relación espacial entre un estímulo o respuesta y una parte del cuerpo. Su actividad estaría anclada al ambiente externo de manera 'alocéntrica' (centrada en todo el mundo), pero todas las representaciones son egocéntricas en términos de su marco de referencia espacial y las propias acciones. Los recientes estudios indican que algunas de estas células espaciales, que se encuentran en el hipocampo de los mamíferos, pueden representar la ubicación de forma independiente entre las señales sensoriales individuales que recibimos y las acciones concretas o movimientos que realizamos.

Moser y Moser (2011) describen las propiedades básicas de un sistema de representación espacial en la corteza entorrinal del cerebro de los mamíferos. Estas células red parecen proporcionar la base para un mapa cognitivo: una representación del medio ambiente y los lugares y objetos dentro de ella que inicialmente parece independiente de la postura y la orientación corporal. Esta característica ofrece a la memoria a largo plazo una referencia de las relaciones espaciales entre los lugares, las rutas entre ellos, los recursos, las metas y los peligros que contienen, que no requiere de la continua actualización. La existencia de células de contorno y frontera sugiere que las señales derivadas de la geometría del medio ambiente son algunas de las fuentes más importantes de información sensorial externa de apoyo a este mapeo cognitivo (Hartley et al., 2014). Estos estudios 
plantean la controversia, en base a la existencia de un procesamiento de ruta (espacial) y otro de objeto (no espacial), de si son preferentes los contornos o bien lo son los puntos de referencia en el desarrollo espacial del ser humano. Ello es debido a la diferencia de actividad neuronal que aparece entre la localización espacial de las células de lugar y el reconocimiento de formas y espacios de las células de contorno. En cualquier caso, destacan la interrelación entre ambos tipos en el recuerdo de la localización de objetos.

Los estudios del procesamiento visual plantean la plasticidad neuronal a partir de la existencia de al menos dos vías corticales. Las señales visuales pasan por los canales de cableado de la radiación óptica hacia la corteza visual primaria localizada en la parte trasera del cerebro. Aquí, los impulsos se dividen hacia los lóbulos temporales, donde se procesa la información (forma, movimiento, color), que reconoce e identifica los objetos (ruta ventral del qué) y hacia los lóbulos parietales, donde se procesa la posición y orientación de los objetos (ruta dorsal del dónde), sirviendo de guía para la intencionalidad de nuestra orientación y acción (Jiménez-Amaya, 2000; Portellano y García Alba, 2014). A partir de aquí, se cree que las señales visuales se reparten por la corteza visual donde los circuitos neuronales combinan información de diferentes procedencias, considerando que la percepción de cualquier estímulo activa numerosas áreas del cerebro (Muñoz Marrón, 2011; Carlson, 2006; Giménez-Amaya, 2000) (fig.21).

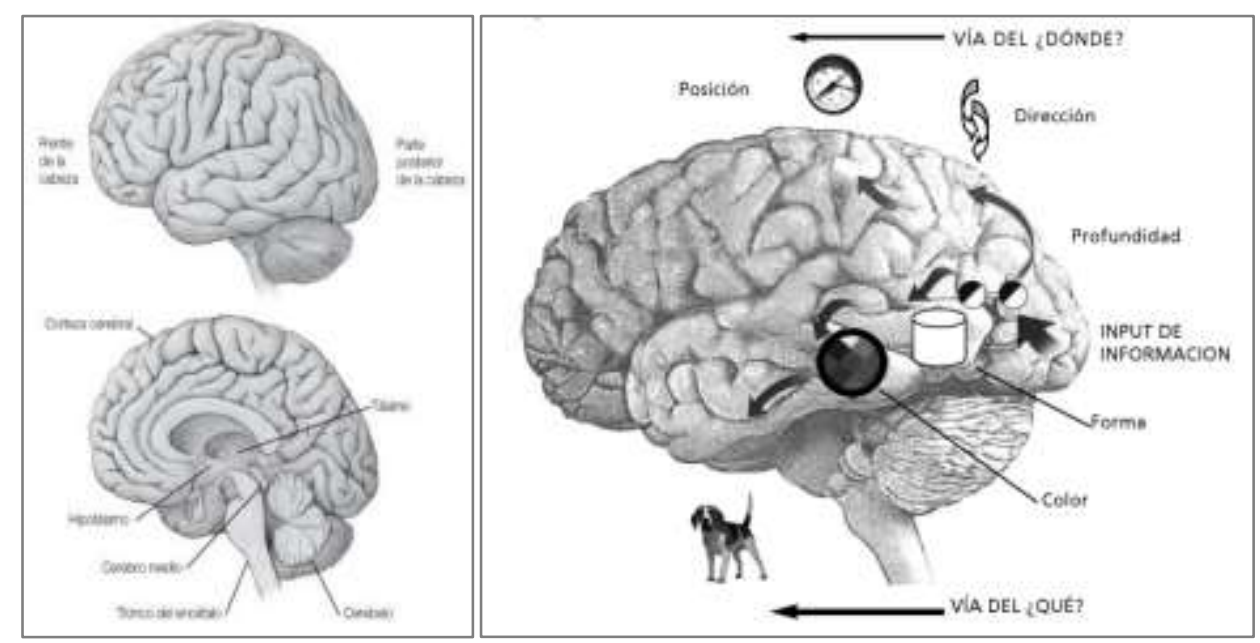

Fig.21: Doble vía del procesamiento visual (Muñoz Marrón, 2011) 
Parece claro por tanto, que existen un conjunto de estrategias (vías) cognitivas asociadas al sentido visual, que constituyen el aspecto viso-espacial del pensamiento. $Y$ parece que lo que llamamos inteligencia tiene mucho que ver con la interacción de estas redes neuronales (patterns) entre las áreas de la corteza prefontal (Hawkins y Blakeslee, 2005).

\subsection{Pensamiento Visual en la Psicología y las neurociencias.}

La moderna psicología, la neuropsicología y neurociencia abordan la investigación de los procesos cognitivos relacionados directamente con la visión desde diversas perspectivas. En el intento de analizar la influencia de estas ciencias y encontrar puntos de encuentro en los procesos relativos a lo visual, nos vamos a centrar en tres enfoques principales: Un primer enfoque basado en la forma 0 Gestalt (Wertheimer,1960; Köhler, 1930 y Koffka, 1922), que analiza lo visual centrado en la importancia de la propia percepción física. Un segundo enfoque, centrado en la inteligencia y el aprendizaje, que reparte la importancia de la percepción con otros procesos relacionados, como la atención y la memoria (Goldstein, 2006); y un tercer enfoque, centrado en el funcionamiento del cerebro, que indaga en la localización de las funciones mentales superiores (Luria, 1973; Roselli, 2010; Mora, F., 2011): "En contra de lo que todo el mundo sabe que es así, quizá no sea el cerebro, sino más bien la conciencia la que crea la apariencia del cerebro, la materia, el espacio, el tiempo y todo lo que nos gusta interpretar como universo físico" (Keith Floyd cit. en Jiménez, 2003, p. 47)

Aunque encontramos en los distintos ámbitos de la psicología aspectos de evaluación de las capacidades 0 habilidades visoespaciales, como veremos, el enfoque de la psicología de la inteligencia es el que transcurre más estrechamente vinculado al desarrollo de la psicometría, con un mayor interés en la medición de estas funciones o aptitudes.

El concepto del pensamiento abarcaría todos los ámbitos y características humanos. Al centrarnos en el constructo del 
pensamiento visual, sabemos que dejamos de lado otros procesos, como el de las emociones o el de la imaginación u otros umbrales inconscientes. Aunque no los abordamos por su extensión y menor pertinencia en el tema, consideramos que están incluidos en las funciones superiores relacionadas e inciden en el constructo.

\subsubsection{Pensamiento Visual en la psicología de la percepción.}

La psicología de la Gestalt aborda la percepción visual formulando principios o leyes que tratan de explicar parte de los procesos cognitivos visuales, a partir de las características física y óptica del estímulo. Valora la experiencia perceptiva, un tanto olvidada por la investigación psicológica, y aporta los pioneros estudios sobre la impresión o ilusión de movimiento en la sucesión de imágenes fijas, a la que denominan fenómeno Phi (Castillo, 2012). El interés del autor de la descripción de este fenómeno, Wertheimer (1960), junto a Kholer (1930) y Koffka (1922), en la primera década del siglo XX, se centra en los factores de la agrupación perceptual, a partir de la idea sinérgica de que el todo (la forma) no se limita a ser la suma de las partes (fragmentos). Lo que entendemos como 'forma' presenta propiedades y características que no se encuentran en cada una de sus partes al analizarlas aisladamente. A través de sus escritos, "impregnados de arte" (Arnheim, 1979, p. 19), la psicología de la Gestalt temprana culminó con la formulación de los principios de agrupamiento sensorial que dan sentido a la percepción de las formas (tabla 02):

- de proximidad: elementos que están cerca en el espacio tienden a agruparse y percibirse como uno.

o de continuidad: tendencia a dar continuidad a figuras discontinuas con el propósito de percibir una totalidad.

- de similitud: elementos de similares características tienden a estar agrupados.

- de superposición: entre elementos, se antepone en el espacio el superpuesto.

- de cierre: tendencia a completar una forma y establecer la relación figura-fondo. 
- de simplicidad o pregnancia: tendencia a organizar elementos en figuras o formas simples (Seel, 2012), o tendencia a percibir la imagen más sencilla estructuralmente (Furió, 2014).

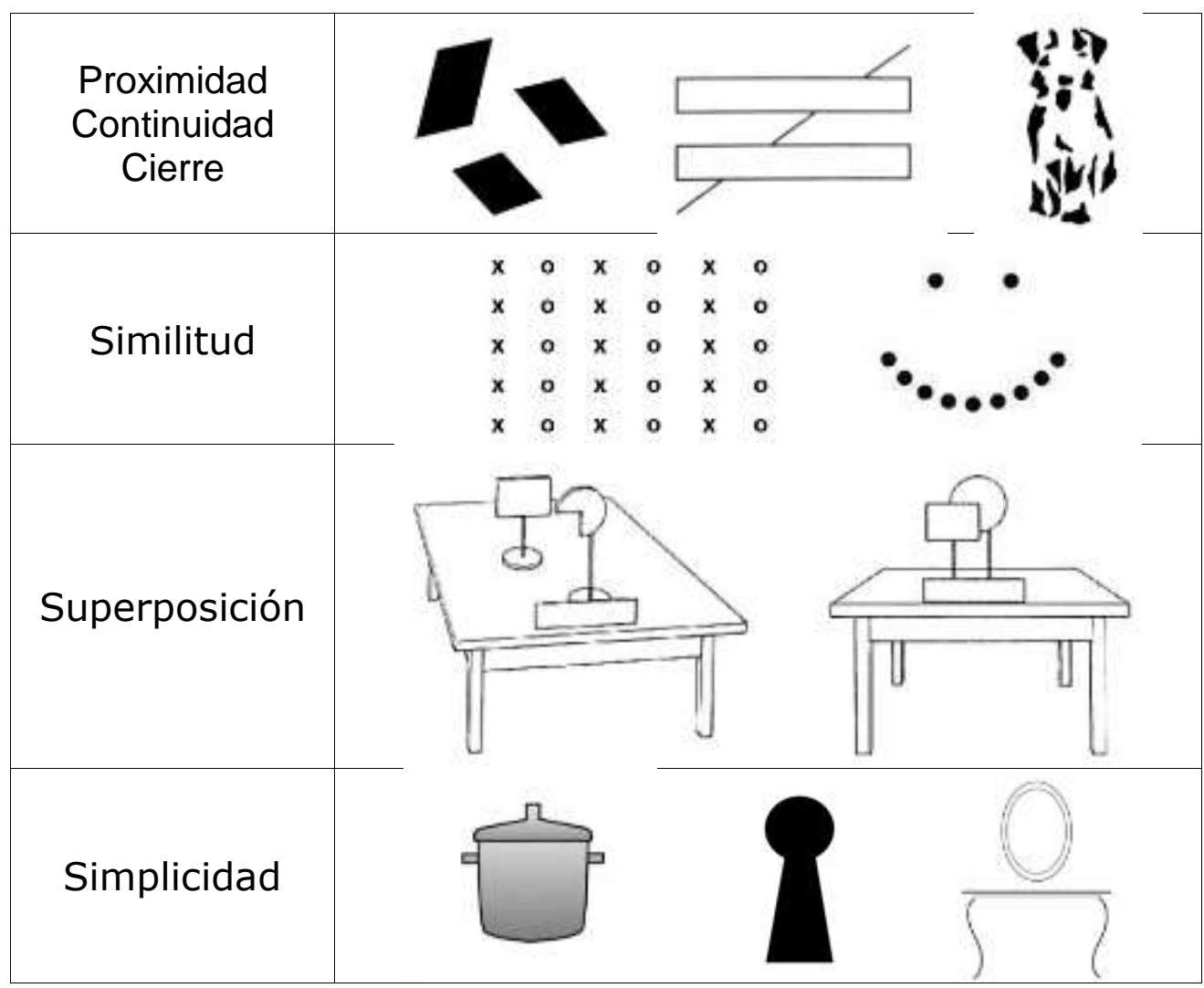

Tabla 02: principios de agrupamiento sensorial o leyes Gestalt

Estos principios no pertenecen propiamente a la física, pero son producidos por la combinación entre las propiedades físicas (distancia, luminosidad, tamaño, grosor...) de los objetos y las características fisiológicas de la visión. Los efectos de esta combinación son conocidos en las técnicas de camuflaje: se considera al pintor y naturalista Thayer (1918), el primero en interesarse en el tema y formular las leyes del mimetismo (Migliore, 2008) (Fig. 22). 

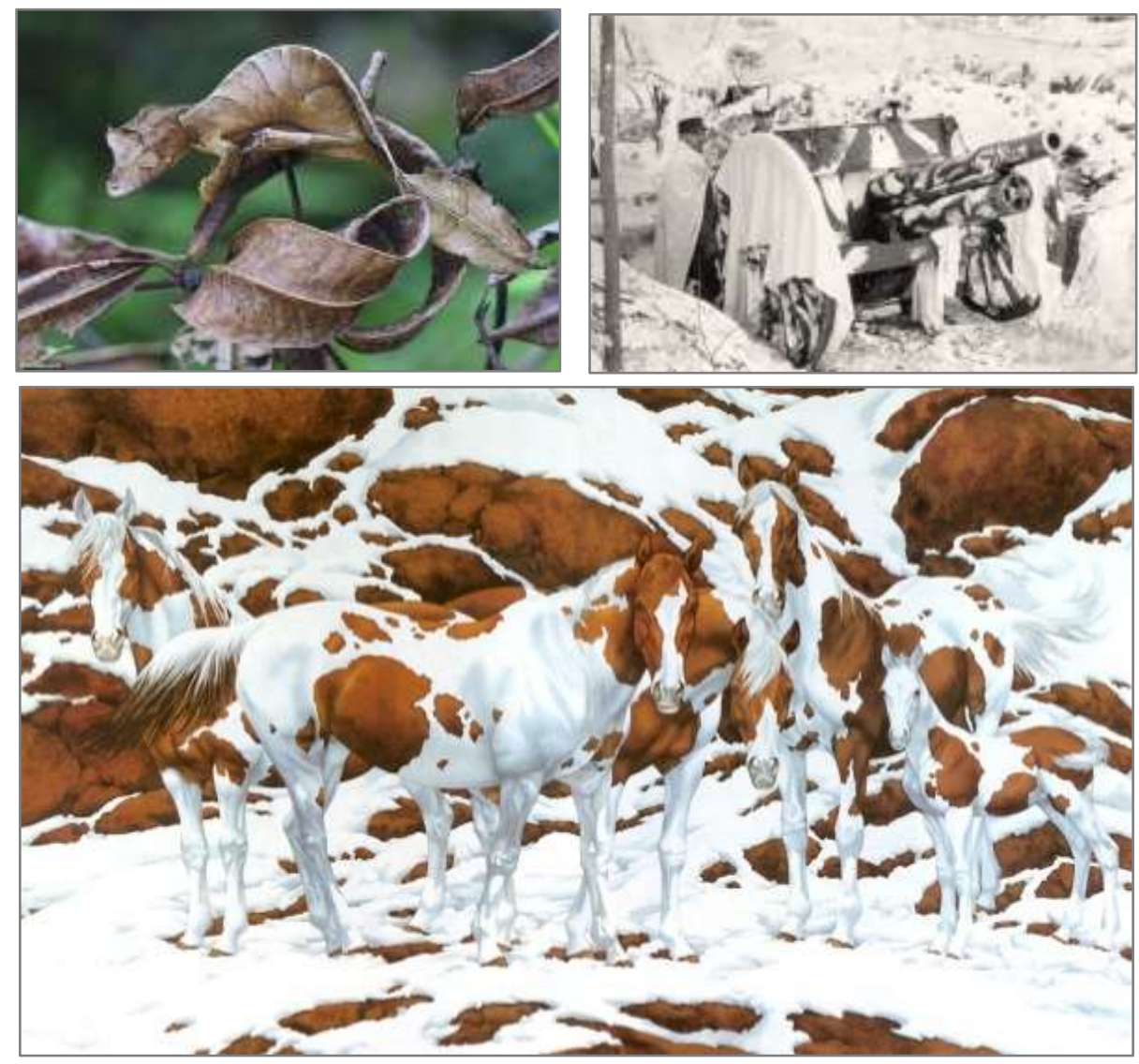

Fig.22: Ejemplos de mimetismo en insecto y ejercito.

'Pintos', acuarela de Bed Doolittle (1979)

Estos principios, muchas veces entendidos como las leyes de la percepción, que en sí se muestran como tendencias cognitivas inducidas por la física del estímulo visual, serán descritas posteriormente por Arnheim (1979) como fuerzas perceptuales, 'empujes y tirones' psicofisiológicos, sin importarle la discusión sobre si éstas son reales o ilusorias:

"A través de esas agrupaciones se obtiene una primera y elemental organización de la forma visual, muy próxima al nivel de estimulación retiniano. Al viajar los mensajes electroquímicos hacia su destino final en el cerebro, son sometidos a sucesivas conformaciones en otras estaciones del camino, hasta que el esquema se completa en los diversos niveles de la corteza visual. En que estadios de este complejo proceso se origina el homólogo fisiológico de nuestras fuerzas perceptuales, y por qué particulares mecanismos se produce, son cosas que rebasan nuestros actuales conocimientos. (...) El 
observador ve los empujes y tirones de los esquemas visuales como propiedades genuinas de los propios objetos percibidos."

(Arnheim, 1979, p.32)

Sin embargo, estas fuerzas psicofísicas descritas no pertenecen a los objetos y son relativas, en cuanto actúan solo en la consideración de la percepción humana. Los aparatos sensoriales de otros seres perciben frecuencias lumínicas (o sonoras) que pertenecen a la misma realidad, pero que a los humanos nos pasan desapercibidas (Rock, 1985). Aunque hablamos de un constructo mental, estas fuerzas perceptivas son leyes estables, como lo demuestra el hecho de que, aunque sepamos que una imagen impresa es estática, seguimos percibiendo el movimiento de las imágenes (ilusiones ópticas) de la figura 23, a poco que nos centremos en ellas. Lo mismo ocurre con la percepción del tamaño de los segmentos verticales y las formas $A$ y $B$, aunque sepamos que son iguales.
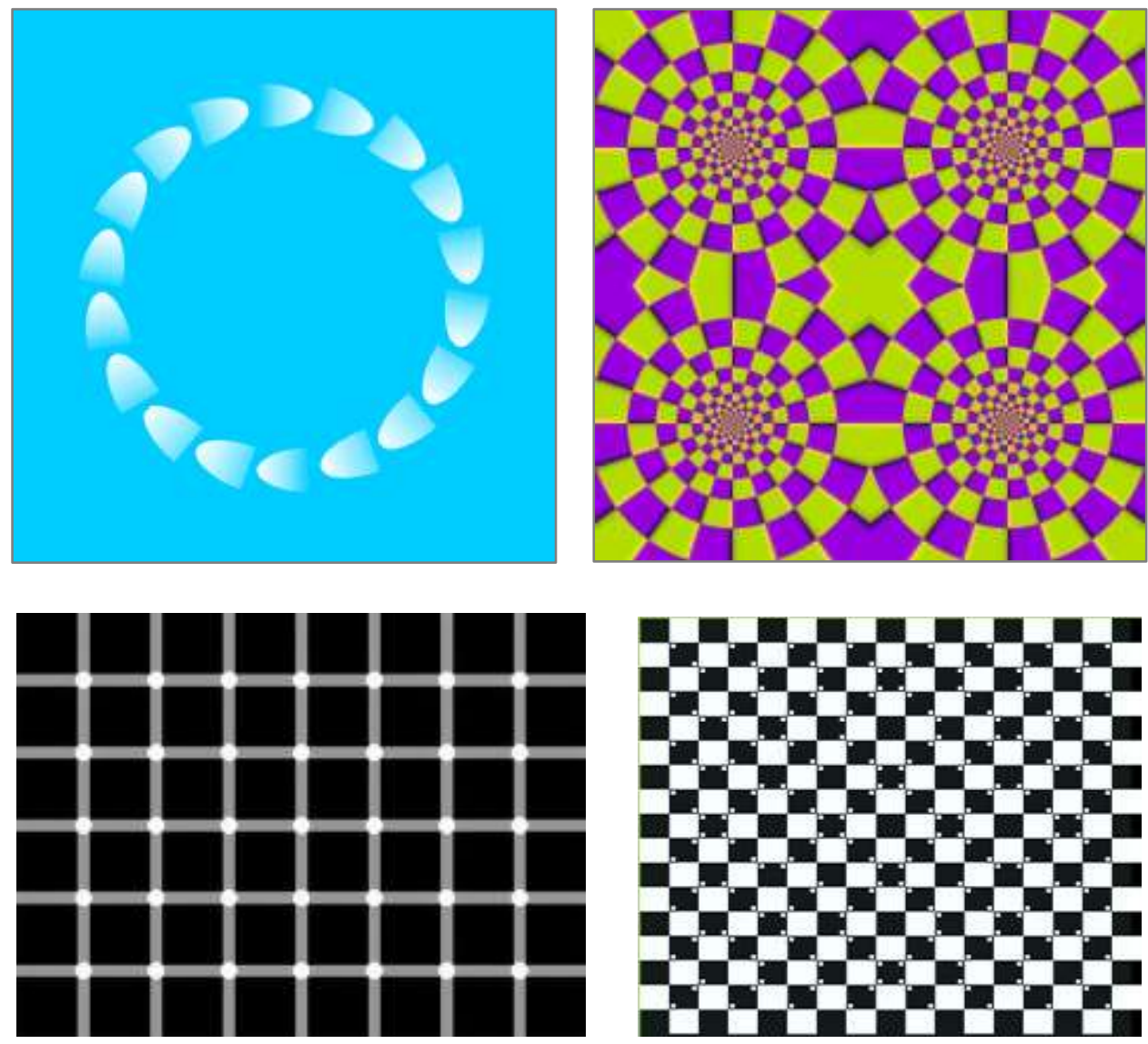

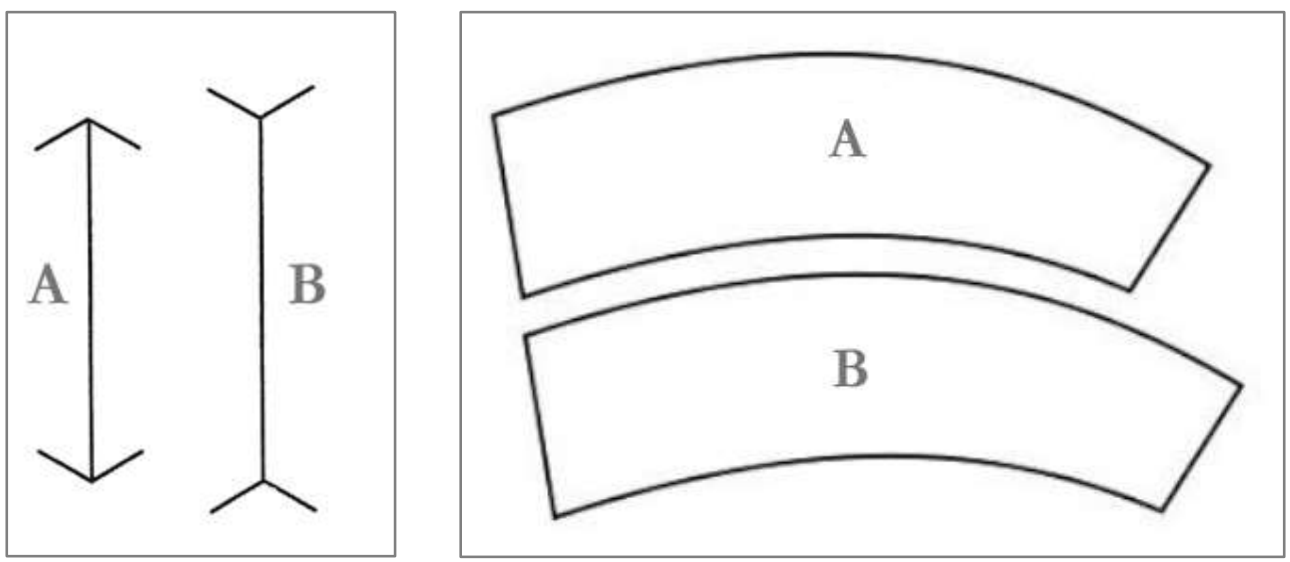

Fig. 23: llusiones ópticas de movimiento y de tamaño.

Los psicólogos gestálticos explican que si bien las sensaciones o estímulos se producen de manera separada y sin relación, las percepciones captan un todo global, unitario. Es plausible creer que, más allá de que estemos organizando una suma de sensaciones caóticas, el mundo perceptual de las formas esté ya organizado en virtud de leyes (Rock, 1985).

De esta forma, las leyes visuales, en una doble consideración física (óptica) y psicológica de fuerzas que interactúan, responderían a principios homeostáticos. Se considera la homeostasis como la propiedad de autoregulación o la tendencia de los organismos a mantener constantes las condiciones internas (Cannon, 1941). Si esta propiedad se altera, a nivel retiniano o neuronal, puede conducir a la muerte celular en los casos de neuropatías ópticas (Hauck y Ueffing, 2009; González-Quevedo, 2004). En estos casos, se analiza la "plasticidad homeostática" en el estudio de los microcircuitos corticales de la visión, en relación a la experiencia sensorial y en la integración de señales faciales (visuales) y vocales (auditivas) (Maffei y Turrigiano, 2008; Ghazanfar et al., 2005).

En condiciones normales, el sistema nervioso responde a la información visual recibida con una tendencia (fisiológica-psicológica) al equilibrio o a la estabilidad. En la búsqueda del equilibrio en el estímulo visual intervienen dos principios relevantes: la discriminación de la forma (con o sin el reconocimiento de la figura), y la constancia perceptual (fig. 24). 


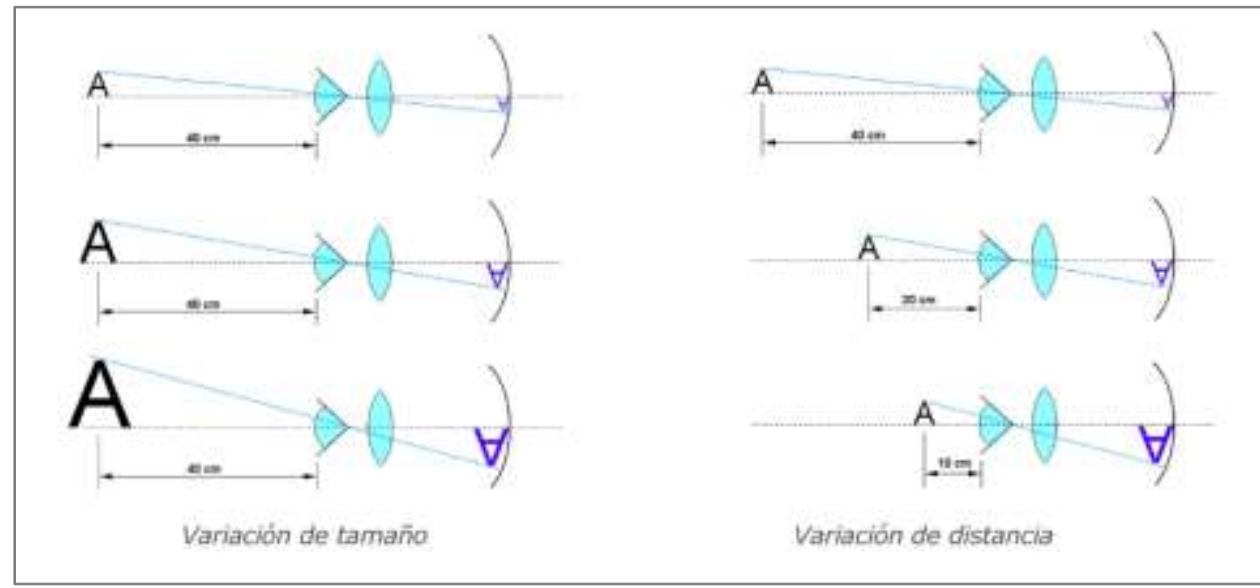

Fig. 24: Relación entre la distancia y el tamaño percibido (ley de la constancia)

Hemos comentado la estrecha relación que hay entre nuestra actividad cognoscitiva y la experiencia. Esta convierte a la percepción en un proceso cognitivo activo, que es selectivo y persigue unos fines (Arnheim, 1998; Hoffman, 2000). Fines que entendemos se relacionan con trasformar el mundo que nos rodea en un entorno significante. Esta consideración vincula la percepción con los procesos de la atención y la memoria (Civarolo et al., 2010), y la sitúa en la base los procesos superiores del pensamiento, la inteligencia y el lenguaje.

Considerando la percepción como un proceso cognitivo activo más o menos consciente, la constancia perceptual se define como una ley adaptativa o la capacidad de mantener las propiedades de un objeto a pesar de la variabilidad de su forma, tamaño, brillo o color (Neisser, 1967; Hochberg, 1968) (fig. 25).
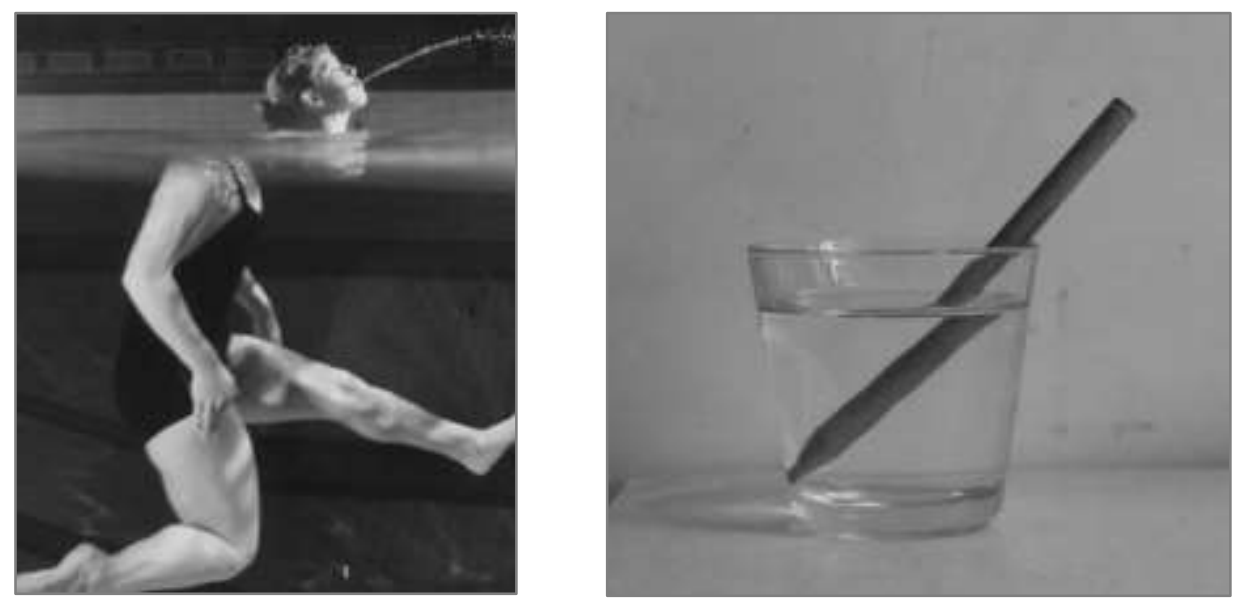

Fig. 25: Ilusiones ópticas y ley de constancia. 
Nos desenvolvemos en un mundo que suponemos invariante, del que esperamos siempre la misma apariencia, y aunque lo percibimos variable, "siempre encontramos unas constantes" (Aumont, 1992, p. 40). La constancia perceptual lleva implícita la idea de equilibrio (Bayo, 1987) y aparece, según la mayoría de los autores, en los primeros meses de vida con un componente innato y se desarrolla en función de la ampliación del "espacio vital perceptivo" (Bermejo, 1981).

Para discriminar esta variabilidad requerimos primero del reconocimiento de la forma, que estará determinada por sus límites. El reconocimiento de una forma, a nivel visual, es el resultado de un juego lumínico del entorno con el objeto dirigido a nuestro sistema nervioso. Remarcamos que el reconocimiento es visual, porque habitualmente se entiende el reconocimiento de manera verbal. Creemos importante resaltar que reconocemos una forma visualmente de manera previa a su denominación y asociación con un concepto verbal. Al mismo tiempo, la percepción de la variablilidad de la forma va a estar determinada por todas las experiencias visuales que hayamos tenido con ese objeto (Arnheim, 1979), y podemos añadir que también por todas las experiencias verbales, por los significados que les atribuimos a partir de nuestras experiencias pasadas y expectativas (Furió, 2014).

El planteamiento de la percepción como fenómeno se ha debatido entre si la realidad de las cosas son tal como son o tal como las pensamos. Hoy día podemos plantear si esa realidad responde a lo que percibimos o a lo que pensamos a partir de estas percepciones y del conocimiento de las leyes físicas, considerando que el lenguaje y la lógica, las palabras y juicios para referirnos a las cosas, no responden del todo a la experiencia directa de la percepción.

Los investigadores de la percepción concluyen que lo que percibimos no es exactamente el mundo físico que nos rodea pero "tampoco es algo completamente distinto e independiente de ese mundo circundante" (Cabanyes, 2000). Por lo que el reconocimiento de la forma en todas las posibles variaciones nos proporciona una especie de estándar visual que simplifica la percepción, la hace más operativa, sacrificando la intensidad y exactitud de la imagen formada 
en la retina, en alguno de los estadios hasta llegar a la corteza visual (Rock, 1985). Queda por ver en qué medida esta estandarización o simplificación visual está relacionada únicamente a un funcionalismo psicofisiológico de nuestras experiencias visuales, o responde también a la experiencia lingüística.

Resulta fácil entender que la constancia perceptual tiene una función adaptativa debido a la necesidad de controlar la amplitud y la naturaleza cambiante de nuestro entorno visual: el efecto de la luz modifica el color y el brillo o intensidad de un mismo objeto; y la distancia, altera el tamaño y la definición de éste. Además de ello, los diferentes posicionamientos que podemos adoptar en relación al campo visual, alteran la forma que adoptan los objetos a nuestra vista, en función del plano y ángulo de la visión (fig. 26).
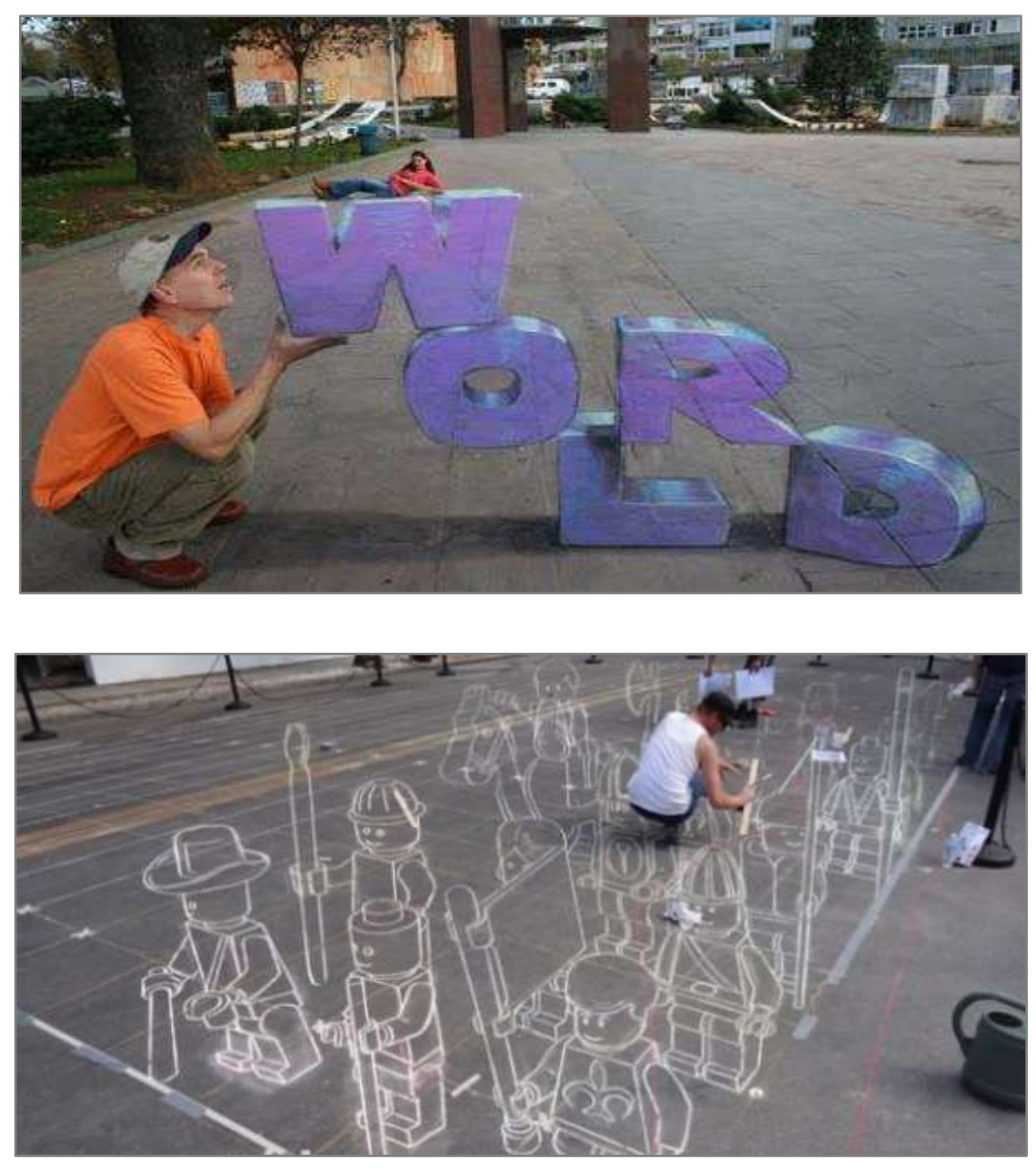

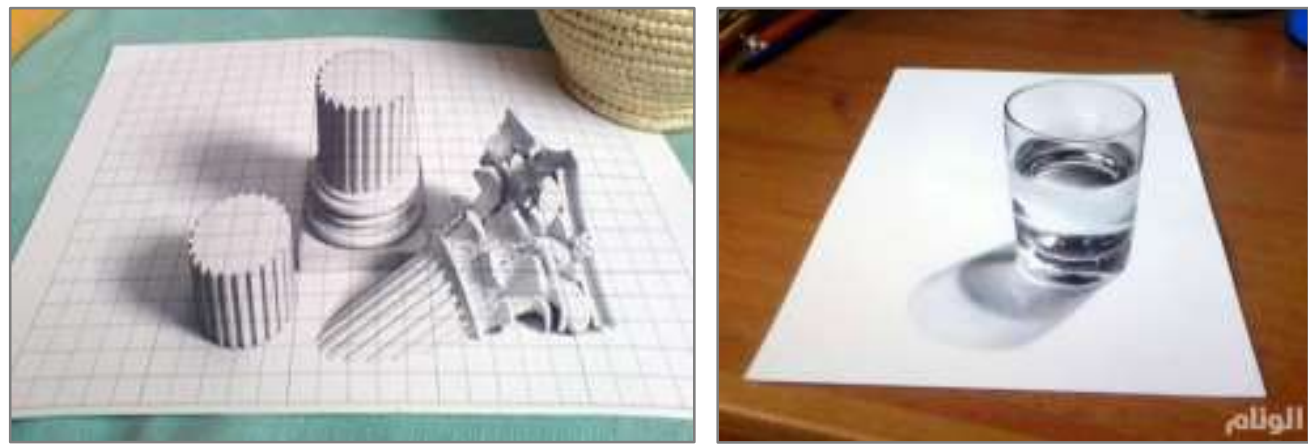

Fig. 26: Efectos de la distancia y del punto de posición en la percepción. (Street painting de Julian Beever y Leon Kerr; dibujos de Mr. Hou y Daily Mail)

La óptica geométrica explica cómo afecta la distancia y el plano de visión a la percepción del tamaño y la distorsión de la forma y color debido a la refracción de los rayos de luz. La investigación de los procesos cognitivos sugiere que la constancia de forma ya se da en bebes de pocas semanas, y que la de tamaño y luminosidad sería congénita (Rock, 1985). En cualquier caso, ésta se desarrolla y va refinándose, y en esta estructuración cognitiva van a tener un papel importante los calculos mentales basados en la constante de proporcionalidad y en la frontalidad del plano visual.

Ambos aspectos, la proporción y la frontalidad, son las nociones que sustentan el concepto de constancia. La idea de proporción, o relación que guardan las medidas en las dimensiones de un objeto frontal $o$ en la distancia entre objetos, mantiene la constancia de la forma y el tamaño, mientras que en la constancia de luminosidad, los estudios apuntan que la proporción interviene a su vez en la percepción del tono, en el caso de que los elementos estén en el mismo plano o formen parte de la misma forma.

Esto demuestra una relación significativa entre la percepción de los límites de la forma y el reconocimiento del color o tono, que requiere a su vez de cálculos complejos de los valores de la luminancia ambiental y reflejada, muchos de ellos basados a su vez en proporciones (Gilchrist et al., 1999), aunque creamos que la discriminación se realice a simple vista, como lo demuestra la imagen de la figura 27, donde las áreas A y $B$ tienen la misma tonalidad. 

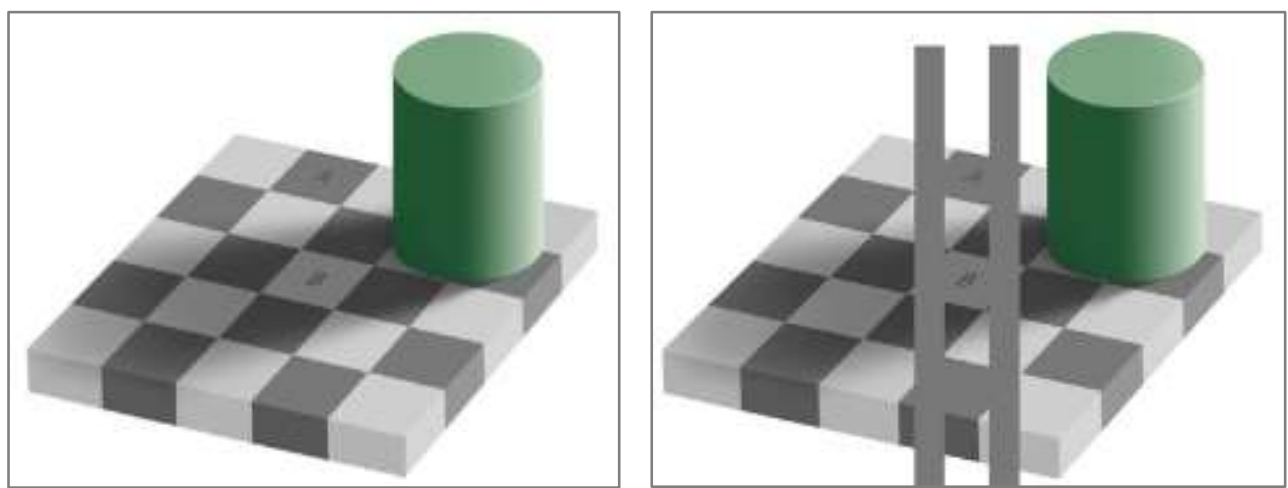

Fig. 27: Experimentos visuales de luminosidad (Adelson, 2005)

El logro de la constancia del tono que realizamos de manera espontánea es lo que persigue la colorimetría moderna que, tomando como referencia cognitiva los colores elementales, busca establecer descriptores perceptuales del color reduciendo los cambios de la condición de iluminación (Artigas, 2002). En esta dirección de uniformidad perceptual, se realizan cálculos de correlación matemática para las seis dimensiones definidas en la apariencia de un color: brillo o luminancia, claridad, colorido, croma, saturación y tonalidad (Valero Muñoz, 2012).

Entendida la percepción de esta manera, nos preguntamos en qué medida somos las personas conscientes de hacer todos estos cálculos, y quizás lo seamos en menor medida de lo que creemos. La psicología parece estar de acuerdo en que los estímulos desorganizados que recibimos, y definimos como sensaciones visuales, se organizan en perceptos de manera espontánea por sí mismos, y lo hacen en base a unos componentes preestablecidos congénitos y sobretodo a la experiencia que modela la percepción, y que permite que estas sensaciones sean recuperadas por la memoria e interaccionen con nuevas sensaciones, reorganizando los componentes cognitivos (Rojas, 2004; Robbins, 1996).

Esta conclusión tiene por sí misma una importante aplicación en el ámbito de la educación que creemos no está atendida en gran medida. Supone entender la percepción visual asociada a las sensaciones y procesos de la atención, la memoria y la emoción, pero como un proceso autónomo de pensamiento, el visual; y como tal, con un carácter holístico que no puede reducirse a la suma de las partes. Hemos de considerar que la memoria humana responde a un modelo 
estructural o modal, que hace hincapié en la existencia de varias estructuras o almacenes diferentes de memoria (Atkinson y Shiffrin, cit. en Ballesteros, 1999). Se entiende así la memoria de trabajo o episódica como un almacen temporal visual (Carrillo-Mora, 2010; Fernández, 2013). El estímulo visual y el espacial, y sobre todo la información contenida en ellos (priming o input), adquiere un papel importante en la experiencia y el aprendizaje, que permite hablar de un almacen de memoria para un sistema de representación perceptual (SRP). Experiencia que no se ha de limitar al desarrollo madurativo del sistema nervioso; y aprendizaje que no se ha de limitar al carácter fonológico incidental. La educación de hecho se define conceptualmente por su intervención en el potencial madurativo y por el control del aprendizaje.

Si bien se considera que la primera reacción sensomotriz es refleja, y, en este caso, las leyes de la percepción "parecen conocerse en un nivel inconsciente", no obstante hay muchos casos "en los que el saber consciente puede influir en la percepción" (Rock, 1985, p.229). Tales casos se producen por ejemplo, en la percepción tridimensional de un dibujo de líneas y en el reconocimiento de un rostro en las nubes o en una mancha de tinta. (fig. 28)

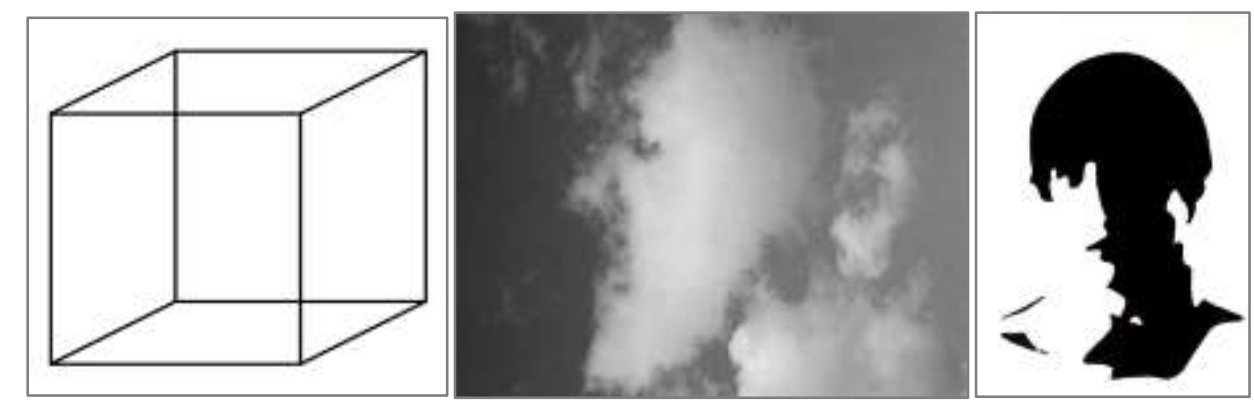

Fig. 28: Influencia del conocimiento en la percepción

Arnheim (1979) se plantea cómo puede la misma huella sobre la retina conducir a perceptos diferentes a distintos observadores. Explica esta diversidad en base a que la información se puede organizar (agrupar visualmente) según distintas pautas, y en ello influyen las fuerzas y tensiones vectoriales que describe en línea con las aportaciones gestalticas. La dirección de estas fuerzas varía según la experiencia del observador mediada por la actuación de la memoria y la atención. Es en esta experiencia donde creemos que interviene la educación: los diferentes perfiles profesionales de unos observadores 
hacen que estos recaben aspectos diferentes, y realicen organizaciones visuales diferentes. Así, un médico observa un rostro de diferente manera que lo hacen un artista, un maquillador o un policía. Pero no solo son las diferencias en la especialización del conocimiento profesional lo que influye en la formación de perceptos, sino, en general, son todos los componentes educativos, asociados a la mirada, los que conforman esta construcción, que dan lugar a que se hable hoy día de la inteligencia de la percepción, de inteligencia naturalista, o de inteligencia espacial (Civarolo et al., 2010).

Podemos por tanto entender que las experiencias, en la medida que afectan a la percepción, forman parte de nuestra inteligencia y del estilo cognitivo que desarrollamos. Aunque arrastramos un pasado científico y cultural que lo niega, que atribuye una acepción a lo sensorial como fuente de error, parece evidente que la experiencia sensorial está relacionada en cualquier caso con nuestra capacidad de razonar, aunque no siempre ocurra de manera consciente: "Nuestro ojo ve elementos individuales; nuestra inteligencia visual mira conjuntos" (Zamora, 2007, p. 245). Si podemos comprender que el pensamiento es resultante de un desarrollo evolutivo de la capacidad humana de organizar las "entradas estimúlicas ambiguas e incompletas" (Rock, 1985, p. 235), entonces concluiremos que la educación tiene que contribuir a facilitar esta capacidad de organización. Pero, ¿cómo aborda la educación la organización de la información sensible?

El modelo de educación sensorial basado en el método Montessori (1909), centrado en el desarrollo afectivo, surge en esta dirección y lo va a hacer relacionando las "funciones sensoriales con los primeros hábitos del desarrollo cultural, concretamente lectura, escritura y cálculo" (García Hoz, en Soler Fiérrez, 1992, p.13). Este modelo educativo científico, que en su origen parte de la noción de profesores preparados pacientemente "para la observación de la naturaleza" (Montesori, 1909, p. 11), se corresponde con el modelo de atención temprana en la actualidad. Este modelo actual está más orientado por el conocimiento neurocognitivo, que se preocupa de los procesos creativos en la infancia y alude a la sensibilidad estética, la creatividad, la memoria afectiva y la comunicación social (Aranda, 2008; Bisquert, 1977; Wallon et al., 1992). 
El principal problema que encontramos en la idea de organización sensorial está en la propia idea del percepto o preconcepto y en cierta manera de la consideración que hace la psicología de las funciones cerebrales a la hora de situar el priming perceptual. La división tradicional de estas funciones en la neuropsicología sitúa lo relacionado con el pensamiento senso-motor de la percepción, atención y memoria, en una categoría, las "funciones naturales" (Montesori, 1909, p.11), que está relacionada fuertemente con el componente genético y parece resultar poco susceptible de un control externo. Mientras que otras funciones en una categoría superior, como las funciones culturales que utilizan el lenguaje, son susceptibles a la interacción social y al aprendizaje y forman "el sustrato afectivo, cognoscitivo y de acción con el que la persona se enfrenta a la existencia" (Contreras González, 2013, p.75). Esta categorización poco permeable de las funciones y que permiten su evaluación, se muestra poco flexible y adaptable al planteamiento del desarrollo de los sentidos, tanto en términos de desarrollo cultural, como de desarrollo individual, desde una concepción múltiple de la inteligencia y del lenguaje.

La escasa flexibilidad en este sentido, creemos que ha podido condicionar la forma de analizar la organización estimular desde los diferentes enfoques de la psicología. Piaget (1948), en el estudio de lo que denomina "sistemas de referencias perceptuales", plantea que algunos conceptos físicos, como la conservación, el impulso o la resistencia, están en la base de la formación del pensamiento sensorio-motriz (Bayo, 1987, p.115). En este enfoque de la psicología del desarrollo, Vigotsky (2013) habla de pensamiento visual y supedita su 'lógica' al lenguaje: "Sólo existen dos vías para explicar las relaciones entre el desarrollo del lenguaje hablado y escrito, de la lengua materna y el idioma extranjero, de la lógica de los actos y del pensamiento, de la lógica del pensamiento visual y verbal' (Vigotsky, 2013, p. 257). Al igual que Piaget vincula la formación de esquemas perceptivos al desarrollo del lenguaje simbólico en el que adquieren significado.

En el análisis de estos autores, de referencia en las teorías del aprendizaje, los perceptos o los esquemas perceptivos no tienen una consideración por sí mismos asociada al carácter visual, sino que quedan supeditados a la interacción con el pensamiento lingüístico. 
Hotopf, refiriéndose a Piaget habla de una "denigración continua de la percepción en relación a la inteligencia" (citado en Bayo, 1987, p. 118). Sin embargo, para Arnheim (1979), la formación de perceptos visuales está más allá del mundo material y su análisis va más allá del estímulo o del mensaje enviado al ojo, abarcando la actividad de las fuerzas perceptuales.

La herencia gestáltica, que ve en el estímulo visual un desencadenante de inteligencia, cuestiona la escisión entre la visión y el pensamiento, que marcan otras corrientes psicológicas, las cuales se van a centrar en los aspectos referidos a la respuesta cognitiva como desencadenante de la acción humana: la conducta. Así, habilidades y aptitudes darán forma al constructo de la inteligencia. Dejando deliberadamente a un lado el paradigma o la controversia herencia-ambiente en la determinación del mayor o menor bagaje filogenético con el que partimos, nos centraremos en analizar la incidencia de los aspectos cognitivos visuales en este constructo de difícil definición, la inteligencia, en el que han intervenido especialmente la corriente de la psicología cognitiva y la psicometría, dejando los aspectos del aprendizaje para otro apartado.

3.1.2. Pensamiento Visual en la psicología de la inteligencia: las habilidades visoespaciales.

A la par que la psicología trata la percepción visual de una manera autónoma, tambien es analizada junto a los procesos de la atención y la memoria, ya que no se pueden entender independientes. Como referente de un enfoque centrado en el desarrollo evolutivo, Piaget (2001) sitúa la percepción como parte del aprendizaje sensoriomotor en la construcción del pensamiento inteligente (conceptual y abstracto). Contemporáneo a los psicólogos de la Teoría de la Gestalt, se refiere a ésta como "teoría reciente de la inteligencia que ha renovado las cuestiones de una manera muy sugestiva" (Piaget, 2009, p.25). Al igual que ellos, atribuye a la percepción una función adaptativa, pero resalta que sólo implica trayectos simples y que está supeditada a procesos más complejos del razonamiento: “...es el esquemático senso-motor, en su conjunto, el que determina los 
mecanismos perceptivos, en lugar de resultar de ellos" (Piaget e Inhelder, 1997, p.45).

Aunque es su inspiración en los principios matemáticos y las leyes físicas, la que construye los estadios de desarrollo de la inteligencia desde las pre-operaciones a las operaciones concretas y abstractas, Piaget entiende que el mundo externo a los ojos del niño es percibido por éste como un mundo desorganizado, sin estructura, con continuas transformaciones caóticas donde el sujeto construye un orden (Mounoud, 2001). La estructuración procede del sujeto a través de la acción sobre ese mundo. Un mundo que va adquiriendo una organización, que nunca sabremos así en que medida existía antes de la acción del hombre. De su teoría resulta una jerarquía en el desarrollo y el aprendizaje, que nos sitúa como adultos (inteligentes) en una posición privilegiada respecto a esta organización del mundo, en la medida que adquirimos o construimos el conocimiento de las leyes (físicas y matemáticas) que lo rigen.

No tiene aquí cabida el debate fenomenológico que influye en estos autores, en cuanto a si las leyes existen y se descubren y formulan, o si es cuando se formulan cuando existen; pero nos parece importante destacar que entre estas leyes que explican el mundo, están las leyes que formula la Optica como disciplina de la Física. En relación a esto, Piaget, ante los planteamientos de sus colegas gestálticos, sobre la posibilidad de la existencia de fuerzas perceptivas como leyes universales en la organización de categorías perceptivomotrices, él las describe como "fuente de relaciones extrañas o superiores a las suministradas por la percepción". Y añade: "es la estructuración la que enriquece las nociones de contenidos no perceptivos (además, naturalmente, de las informaciones obtenidas por la percepción)" (Piaget e Inhelder, 1997, p.52) ${ }^{1}$.

Sin embargo, como recuerda su discípulo Vergnaud (1990), quien desarrolla la teoría de los campos conceptuales, sus experimentos están basados en leyes físicas como la de conservación, fuerza y movimiento o acción-reacción, así como en invariantes matemáticos como el vector o la ley de proporción. Para él, el esquema lo forma una representación implícita o explícita de lo real,

1 El paréntesis es del propio autor. 
analizable en términos de objetos, de categorías (propiedades y relaciones) y de teoremas. Este conjunto de leyes físicas, por tanto, intervienen en la organización invariante de los esquemas como "teoremas en acción" (Vergnaud, 1996, p.202). Vergnaud (1990) llama esquema a la organización invariante de la conducta para una clase de situaciones dada: "Esta organización perceptivo motriz supone por tanto categorías de orden espacial, temporal, y mecánica (orientación en el espacio, distancia mínima, sucesión y duración, fuerza, aceleración y velocidad...) así como conocimientos en acto que podrían tomar la forma de teoremas de geometría y de mecánica, si fueran explicitados" (p.2). Esta característica invariante de los esquemas en experimentos realizados con niños en edades tempranas muestra que, al menos con tres meses de edad, los bebés responden a los principios de la Gestalt (Van Giffen y Haith, 1984).

Estos experimentos si bien analizan la posición de los objetos, y se centran en la coordinación de los movimientos de los ojos y los gestos del dedo y de la mano, no contemplan la posición o punto de vista del sujeto ni el control de la orientación de la mirada antes de detectar el estímulo y la secuencia y orden en que se produce. Estudios más actuales sobre las diferencias en la percepción de los zurdos muestran que, aunque el proceso de exploración que realizan es igual que en los diestros, se producen diferencias en el punto de vista que se adopta, y que hay distintas preferencias en la ubicación espacial (el espacio izquierdo para los diestros y el derecho para los zurdos); así como que las pautas que guían la orientación de la mirada son diferentes (Pellicer, 2000).

Es oportuno resaltar aquí que cuando utilizamos el término 'punto de vista' sobre una imagen o metafóricamente en un relato, nos referimos a la posición, real o figurada, en la que vemos los acontecimientos. La posición que adoptamos ha sido prevista, o se ha construido para nosotros, por la forma en que la imagen o relato se han elaborado.

Refiriendonos a una imagen, "el sistema de perspectiva es el medio más poderoso por el cual se crea el punto de vista" (Lewis, 2012, p.159). Cuando vemos imágenes, estas poseen una perspectiva. No sólo miramos la foto desde nuestra posición real frente a ella, sino que lo hacemos a través de la posición ocupada por 
el espectador original de la escena: el pintor, ilustrador o fotógrafo. Esto añade una carga subjetiva a la imagen, o más bien permite que el creador de la imagen controle en cierta manera nuestra subjetividad, para hacernos ver las cosas desde una posición, de una manera particular. Quizás por ello atribuimos a las imágenes un carácter subjetivo, pero obviamos que el componente de posicionamiento, real o figurado, es un componente objetivo de la optica.

Mientras que Arnheim (1998) atribuye características de inteligencia a los procesos sensoriales al mostrar experimentalmente que "la percepción discrimina y compara" (p.78-79), tanto Piaget como Vigotsky (2013) consideran la percepción sensorial una función natural, inferior (junto a la memoria y la atención), y que se produce a través de las funciones culturales superiores del pensamiento, la inteligencia y el lenguaje, en la medida que las palabras forman parte de una realidad social e interior. Los trabajos de Vigotsky y Luria (1973), de Leontiev (1981), de Wertsch (1984), analizan las operaciones psicológicas y los procesos de interiorización a partir de las acciones con signos como un proceso transformativo que implica cambios en las estructuras que se interiorizan (Cubero, 2005).

Si para Arnheim (1979) la atención y la memoria hacen que la percepción sea activa y resuelva problemas, la inteligencia entendida como la operación resultante de la (inter)acción del niño con el entorno físico la sitúa Piaget (1948) en la capacidad de razonamiento, de realizar operaciones mentales, al tiempo que Vigotsky (1934) la situa en la capacidad de expresión verbal como resultado de la actividad interna. Afirma que lo que no se expresa de manera verbal no tiene significado. Aunque, como hemos comentado, éste "se verá forzado" a admitir la existencia de un pensamiento no verbal, no obstante, a partir del trabajo de estos autores, el significado semántico va a ser preponderante en el estudio del pensamiento y las operaciones mentales que definen la inteligencia en una estructura tricotómica (imagen, palabra, pensamiento) todavía por resolver (Zamora, 2007, p. 67).

Sin embargo, la psicolingüística va atribuyendo cada vez más importancia a la experiencia perceptiva y a su efecto en la comunicación. El sistema de símbolos perceptuales de Barsalou 
(1999) establece que la percepción visual incorpora unos estados o 'priming perceptuales', que se almacenan en la memoria para funcionar como símbolos, con un formato "análogo al de la experiencia perceptual' (Ibáñez, 2007) (fig.29).

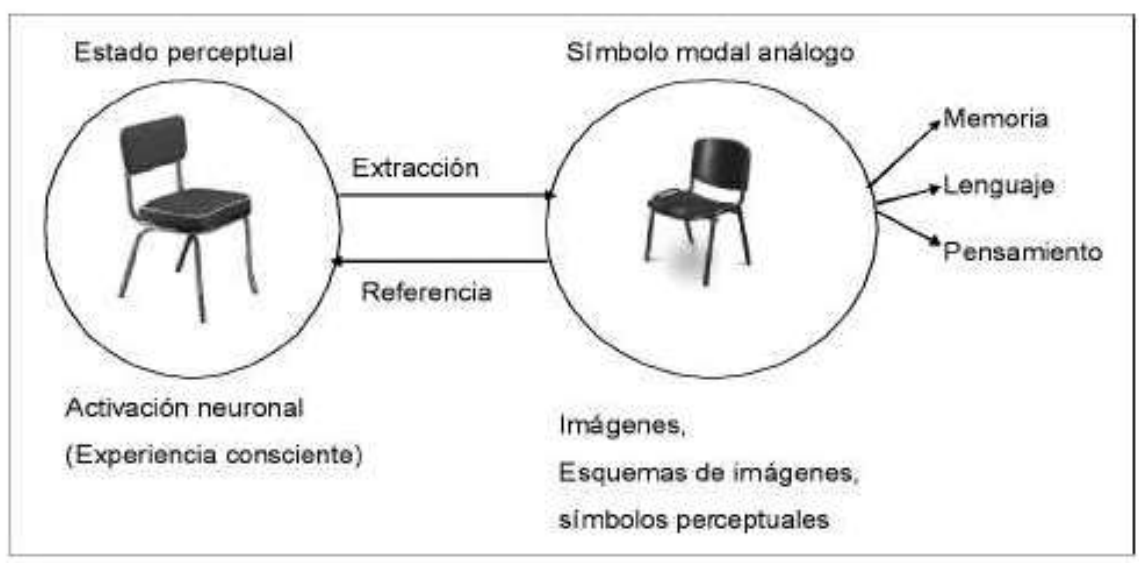

Fig.29. Supuestos básicos de los sistemas de símbolos perceptuales (Ibáñez, 2007)

Esta reflexión, que establece la analogía entre las cualidades perceptuales y el símbolo, como veremos, apunta directamente a los procesos cognitivos que definen las vías neuronales de la información visual. Pero este planteamiento, a pesar de ahondar en la explicación de un pensamiento visual en la construcción del símbolo, al considerar que todo proceso cognitivo es verbal, no tiene en cuenta el concepto de "percepción resolutiva" (Rodríguez y Bermúdez, 2002), acuñado recientemente para explorar el conocimiento de una manera global considerando la existencia de un pensamiento activo en la percepción visual (fig.30):

"Es poco probable defender con legitimidad el concepto de pensamiento visual por acciones o pensamiento visual por imágenes, pues la naturaleza del contenido de esos procesos psíquicos es bien distinta.

Aceptar tales conceptos es admitir la yuxtaposición conceptual de hechos psíquicos diferentes. La resolución de problemas no sólo es función del pensamiento, sino también de la percepción, razón por la cual hemos acuñado el concepto de percepción resolutiva que podría aproximarnos mucho más a la realidad psíquica" 


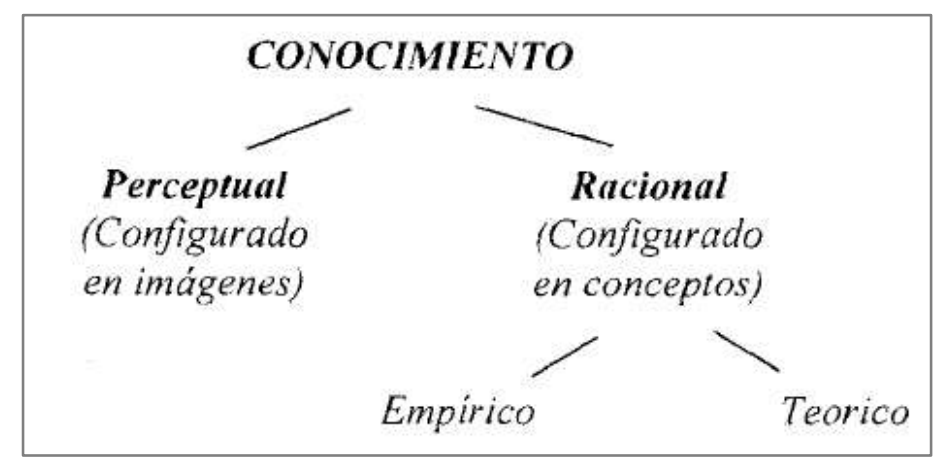

Fig.30. Tipología del conocimiento (Rodríguez y Bermúdez, 2002, p.187).

Pero, ¿cómo hemos llegado a atribuir inteligencia al proceso perceptivo? A la par que se formulaban teorías cognitivo conductuales para explicar el desarrollo del pensamiento inteligente y sus capacidades, emerge la especialidad de la psicometría, con la intención de proporcionar modelos matemáticos al desarrollo práctico de estas teorías y poder predecir cuestiones de interés como los problemas en el desarrollo o la adaptación escolar y profesional. Así, con un planteamiento más técnico que teórico, Binet (1902) desarrolla los primeros test de inteligencia, pruebas académicas con ítems de carácter sensorial en un principio y centradas en la medición de destrezas verbales y numéricas (Gardner, 2003). Pero hemos de resaltar que para Binet la percepción se encuentra alejada de la inteligencia. La percepción pertenece a una clase de "razonamientos inconscientes" similar a los reflejos, y supeditada al razonamiento verbal, donde "la repetición verbal sirve para vivificar la imagen visual" (Binet, 1902, p. 16 у p. 124):

“...si la percepción debe exceder de la sensación simple y llegar a ser una verdadera comprensión, ya da señales de debilidad. Se ha dicho del niño que es un buen observador; esto es una ilusión: puede ser herido por un detalle que nosotros no habremos observado, pero no verá un conjunto, un panorama de cosas, y sobre todo, resulta incapaz de discernir entre lo accesorio y lo esencial."

(Binet, 1985, p. 62)

En el estudio de la inteligencia factorial, Spearman (1927) define la inteligencia como una aptitud cognitiva general universal, para establecer relaciones entre aspectos específicos. A partir de él, se da la tendencia a negar la existencia de un solo factor general en el estudio de los test de inteligencia, aunque en una contradicción más 
aparente que real, ya que este factor explicaría una relación entre todas las aptitudes operativas y factores verbales, numéricos y espaciales (Ferrando et al., 2005). En palabras de Mora (1991, p.59): "La unidad típica de análisis en este modelo va a ser el "factor" y la metodología típica el análisis factorial. De mano de ellos se iniciaría la época que entre nosotros José Luis Pinillos denominó 'el Hombre factorial" ". Será Thurstone (1938) quien se refiera a la existencia de múltiples factores, y define unos factores primarios o aptitudes (fig.31), que pueden tener diferentes niveles de especialización: verbal, numérica, espacial, perceptual, de memoria y de razonamiento.

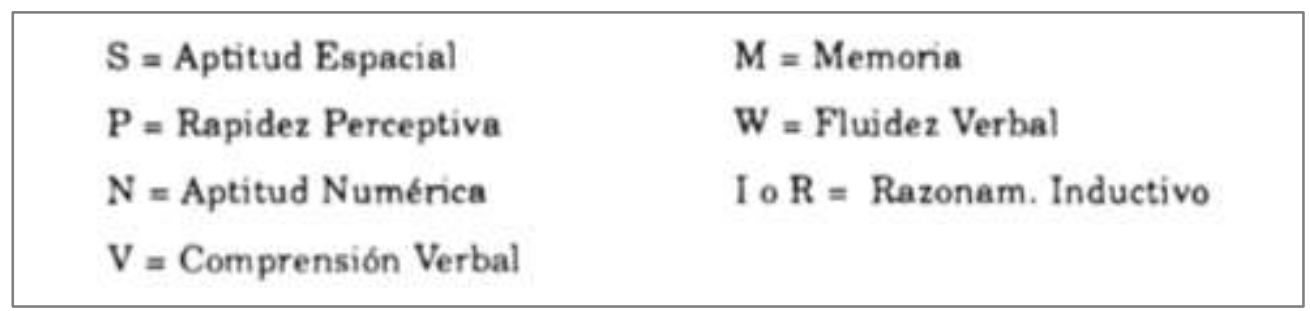

Fig. 31: Factores primarios de Thurstone (1924) (Mora, 1995)

Podemos observar que Thurstone define estos factores en términos de aptitud: para calcular, razonar, recordar, orientarse 0 comprender el lenguaje; pero la percepción se formula asociada con la velocidad. A partir de aquí, en las pruebas de aptitud, la percepción será evaluada en relación a la variable tiempo. Por lo general, aunque en algunas ocasiones, la aptitud espacial será analizada aplicando pruebas adultas sin considerar la rapidez perceptiva (Adánez y Vega, 1981), el análisis de la percepción se medirá en términos de rapidez, relegando aspectos cualitativos menos eficientes del proceso perceptivo.

En la misma línea, Guilford establece lo que denomina categorías de aptitudes, definiendo la inteligencia como un "conjunto sistemático de aptitudes o funciones para procesar diferentes clases de información de modos diversos" (Guilford, 1986, p.11). Guilford diseñó una serie de test con factores cognitivos de la trasformación figurativa junto a otros de tansformación semántica, tratando de medir la creatividad, que luego son desarrollados por Torrance.

A partir de estos trabajos, la evaluación de las aptitudes visoespaciales o habilidades visoperceptivas se concentran en la 
medición de aspectos como la velocidad de la percepción, la discriminación y coordinación visual, o de la destreza motora y manual; como métodos científicos para seleccionar o clasificar individuos por capacidades (Aragón, 2015).

- $\quad$ Primary Mental Abilities. PMA (Thurstone y Thurstone, 1962)

- Matching Familiar Figures Test. MFFT (Kagan, 1965)

- $\quad$ Career Ability Placement Survey. CAPS (Knapp y Knapp, 1976)

- Perceptual Speed, Identical Forms (Thurstone y Jeffrey, 1976)

- Minnesota Spatial Relations Test. MSRT (Dawis, 1979)

- $\quad$ The Reversals Frequency Test (Gardner, 1978)

- Closure Flexibility Test, Concealed Figures (Thurstone y Jeffrey, 1982)

- Closure Speed Test, Gestalt Completion (Thurstone y Jeffrey, 1983)

- The Hooper Visual Organization Test, Manual. HVOT (Hooper, 1983)

- Kaufman Assessment Battery for Children. K-ABC (Kaufman y Kaufman, 1983)

- Judgement of Line Orientation Test. JLO (Benton, Hannay y Vamey, 1983)

- Detroit Tests of Learning Aptitude, Adult Version. DTLA-A. (Hammill y Bryant, 1991)

- The Visual Object and Space Perception Battery. VOSP (Warrington y James, 1991)

- Benton Visual Retention Test. BVRT (Sivan, 1992)

- Birmingham Object Recognition Battery. BORB (Riddoch y Humphreys, 1993)

- Developmental Test of Visual Perception. DTVP-2 (Frostig et al, 1993)

- The Minnesota Paper Form Board Test. MPFB (Likert y Quasha, 1994)

- Rey Complex Figure Test and Recognition Trial. RCFT (Meyers y Meyers, 1995)

- $\quad$ Brief Visuospatial Memory Test, Revised Edition. BVMT-R (Benedict,1997)

- $\quad$ Detroit Tests of Learning Aptitude. DTLA-4 (Hammill, 1998)

- Woodcock-Johnson III Tests of Cognitive Abilities. WJ III COG (Woodcock, McGrew y Mather, 2001)

- Motor-Free Visual Perception Test. MVPT-3 (Colarusso yHammill, 2003)

- Test of Visual-Motor Integration. VMI (Beery y Beery, 2004)

- Test of Visual-Perceptual Skills. TVPS-3 (Martin, 2006)

Tabla 03: Pruebas visuales (Codina et al., 2009)

Sin embargo, esta evaluación, más allá de analizar cualidades visuales o hápticas, se realiza orientada a cubrir las habilidades necesarias para un puesto de trabajo o de un requisito académico (tabla 03). En este sentido, es interesante observar que el requisito de la lectoescritura marca los límites del desarrollo de la percepción y coordinación visomotora. Tal es el caso del método de evaluación de la percepción visoespacial, Test de Frostig o DTVP-2 (Frostig, 1964), prueba que detecta problemas perceptivos como la coordinación visomotora, discriminación figura-fondo, constancia de formas, percepción de posiciones en el espacio, relaciones espaciales, así como la dislexia en niños de cuatro a diez años. A través de habilidades como la de dibujar líneas rectas o curvas con precisión de acuerdo con unos límites visuales, la percepción y coordinación 
visuales son un repertorio básico para el aprendizaje de la lectoescritura y la discriminación de las letras frente a otros estímulos visuales (Aragón, 2015). A partir del logro de la escritura, la calidad de las aptitudes espaciales, la agudeza visual o manual, se relegan a una formación específica que afecta tan solo a ciertas profesiones, y hemos de apuntar que no parece que ha sido la profesión del docente o maestro una de ellas.

En el ámbito docente, la evaluación de las habilidades visuales, viso-perceptivas y viso-motoras, forma parte del desarrollo de la capacidad lectoescritora. Esta evaluación se centra en las alteraciones del procesamiento de la información visual que interfieren en la habilidad manual y en el aprendizaje escolar (Medrano, 2011). En la actualidad, los problemas de percepción y eficacia visual se analizan incluso en términos de 'terapia visual', para diagnosticar problemas en la lectoescritura (Morchón, 2011).

En el ámbito clínico, esta habilidades visuales se investigan actualmente en relación con déficits en la discriminación visual en personas con deterioro cognitivo medio, en casos de esquizofrenia, enfermedad de Parkinson o de Alzheimer. En todos estos casos, los pacientes parecen presentar daños en la región del córtex orbitofrontal (OFC): la corteza prefrontal parece jugar un papel en el aprendizaje normal de la discriminación visual (Chase et al., 2008). Igualmente se trabaja con pacientes con prosopagnosia o dificultad para reconocer los rostros de las personas. El trabajo con prosopagnósicos sugiere que la formación en la persona de impresiones de rostros, implica unos mecanismos funcionalmente independientes de los mecanismos para la codificación de la identidad de las caras (Todorov y Duchaine, 2008).

Se podría especular que más allá de las necesidades gráficas de la lectoescritura, cubiertas estas, y en ausencia de algún trastorno, la evaluación de las habilidades visoespaciales no parecen constituir en la actualidad un problema de investigación en la psicología y la pedagogía, las denominadas ciencias de la educación.

Por otro lado, y con un interés específico por explicar las diferencias individuales en la evaluación de la inteligencia, a partir del análisis de factores primarios y secundarios, converge la teoría 
triarquica de la inteligencia de Sternberg. Este enfoque considera el componente de las habilidades junto con una serie de componentes contextuales y cognitivos o metaprocesos. Explica la capacidad espacial con dos factores primarios: la visualización espacial y la orientación espacial, a partir de las formulados por Guilford (1972), y los correlaciona con los procesos individuales de la atención y la percepción (Sternberg, 1987).

En esta linea, se han desarrollado pruebas de evaluación (test perceptivos) que analizan el factor de dependencia-independencia de campo, como un constructo que correlaciona los componentes visoespaciales de la inteligencia con la personalidad. En estos trabajos se identifican y diferencian factores (clusters) como la habilidad perceptual-cognitiva y la percepción espacial (García Ramos, 1989).

El estudio de estos y otros autores en la búsqueda de factores detrás de las aptitudes o habilidades intelectuales, tal y como analizaremos posteriormente, establecerán las dimensiones de los componentes cognitivos en las pruebas de medición de la inteligencia y la creatividad.

Desde la perspectiva de la psicología moderna, el factor g se concibe como un metaproceso representante de la operación de procesos cognitivos de alto nivel que controlan los programas computacionales del cerebro y están implicados en la resolución de problemas. A partir de Sternberg, se han utilizado diferentes nombres para designar a los procesos cognitivos que subyacen al factor g: procesos de control, funcionamiento ejecutivo, metacomponentes, control ejecutivo, pero es el de funciones ejecutivas el que goza de mayor aceptación (García-Molina et al., 2010).

Este racimo de factores, aptitudes o funciones, cada vez serán más detalladas, con indicadores como la velocidad de procesamiento (PS) y la memoria de trabajo (MT) o la complejidad de la tarea (If), para explicar el control atencional. Pero todos ellos alcanzan un grado de especificidad o unicidad como formas de inteligencia, en la formulación del constructo de las inteligencias multiples (IM). Gardner (1994) conceptualiza a los seres humanos como poseedores de diferentes capacidades mentales en cierta manera independientes, que incluyen la inteligencia espacial, además de la inteligencia 
musical, lógico-matemática, cinética corporal y la inteligencia natural, y dos formas de inteligencia personal (interpersonal e intrapersonal) cercanas a la definición de Goleman (1996) de la inteligencia emocional, aunque también considera que puede haber otras, como alguna forma de "inteligencia espiritual" (Gardner, 1994, p. 9).

El autor del concepto de la inteligencia múltiple define la inteligencia espacial o visual como la capacidad de formarse un modelo mental del mundo espacial y maniobrar y operar con él. Ejemplifica este tipo de inteligencia refiriéndose a los modelos profesionales de ingenieros, cirujanos o marinos, al igual que pintores o escultores. En este aspecto, experimentos neurocientíficos apuntan a que el área del hipocampo responsable de la orientación espacial es mayor en algunas profesiones y muestra cambios susceptibles a periodos de aprendizaje (Cánovas, 2011).

Aunque algún autor vea en los "partidarios" del concepto de inteligencia visual a los continuadores de la psicología de la Gestalt (Català Domènech, 2011, p.81), estos también comparten la herencia del enfoque de la psicología del desarrollo y la psicometría, pero aportando su visión crítica. Gardner, por ejemplo, define a Piaget como el padre de la psicología evolutiva, pero no cree que estudiaba toda la inteligencia, sino el desarrollo de la inteligencia lógicomatemática. En su opinión, ésta, junto a la inteligencia lingüística, estarían en el "pedestal" de nuestros sistemas de evaluación (Gardner, 2011, p. 78).

El creador del constructo múltiple no niega de hecho la existencia de un factor general de inteligencia, pero cuestiona su alcance y posibilidad explicativa (Civarolo et al., 2010). Y, aunque se muestra favorable a la evaluación de la inteligencia, manifiesta críticas en la manera de hacer de la psicometría, especialmente por el resultado de etiquetar a las personas por sus respuestas, en función de los niveles de un coeficiente de inteligencia que define como moda parisina (en alusión a la escala que Binet desarrollara en las escuelas parisinas), defendiendo la diferencia individual y el estilo cognitivo en el proceso y la manera de aprender (Gardner, 1994, p. 29).

El concepto de estilo cognitivo, que tiene su correlato pedagógico en el estilo de aprendizaje, aparece en el ámbito de la 
psicología de la personalidad, como un concepto que responde a la necesidad de psicólogos y pedagogos por vincular de alguna manera las diferencias individuales con los procesos humanos involucrados en la adquisición del conocimiento. De todas maneras, y como apunta Mora, al estudiar las diferencias intelectuales entre los individuos, “también descubrimos en que se parecen" (Mora, 1991, p. 58).

En cualquier caso, la investigación en psicología, tanto en el campo de la percepción como del comportamiento, siempre ha ido acompañada de los resultados del estudio del cerebro. La neurociencia moderna está marcando muchas de las investigaciones actuales en psicología y también en el ámbito educativo, donde ya se empieza a hablar de neuroeducación como "necesidad de extraer los conocimientos que aporta la neurociencia cognitiva en conjunción con la psicología cognitiva y llevarlos a las aulas con la intención de aprender y enseñar mejor" (Mora, 2013, p.19).

\subsubsection{Pensamiento Visual en la neurociencia.}

Tras el denominador de neurociencias, son diversas las disciplinas, desde la neuroanatomía, la fisiología o la bioquímica, hasta la neurología, la neuropsicología y las ciencias computacionales, que persiguen un interés común: el conocimiento del cerebro y el sistema nervioso. Para ello, la neurociencia se centra en la localización de sus diferentes funciones, definiendo las áreas que intervienen en las diferentes entradas sensoriales y los procesos cognitivos que definen la forma en que nos movemos, sentimos o pensamos, y la forma en que aprendemos.

No vamos a extendernos en la descripción de las regiones cerebrales, salvo destacar las divisiones principales más básicas consideradas por las disciplinas citadas y referidas al pensamiento visual. Una división lateral del cerebro establece dos hemisferios: derecho e izquierdo, cubiertos por la corteza cerebral. En ella están las áreas sensoriales auditivas, somáticas y visuales (fig.32). 


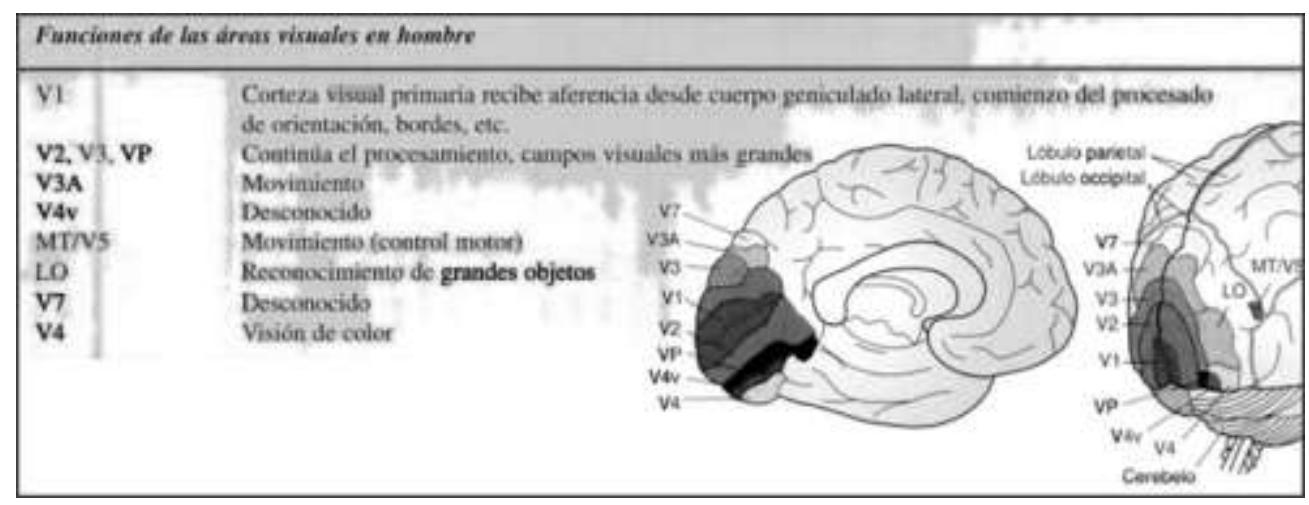

Fig. 32a: Posibles funciones de las áreas visuales (Cardinali, 2007)

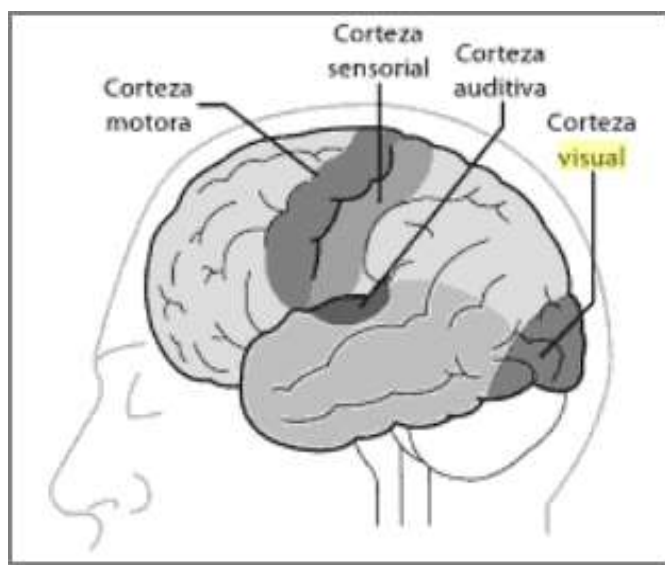

Fig. 32b: Localización de la corteza visual (Braidot, 2008)

La corteza o cortex cerebral, que supone el $85 \%$ del peso del cerebro y se considera la parte más reciente de la evolución humana, cubre el sistema límbico y procesa toda la información que llega al cerebro a través de los órganos de los sentidos coordinando los movimientos voluntarios (FitzGerald, Gruener y Mtui, 2012).

Expresado de otra manera, la corteza controlaría los input o entradas de información y los outpout de respuesta o actividad, por lo que le asignamos la actividad mental del pensamiento consciente.

Para su estudio, cada hemisferio se divide en cuatro lóbulos denominados por el hueso que los cubre (fig. 33). En el procesamiento visual y espacial están implicados todos los lóbulos en gran cantidad de áreas (Giménez-Amaya, 2000). Los lóbulos occipitales contienen la corteza visual primaria; los temporales están involucrados en el reconocimiento visual; los parietales, en la percepción y la orientación espacial. Los lobulos frontales, definidos como el cerebro ejecutivo, están vinculados con los procesos del pensamiento y el aprendizaje (Goldberg, 2009). 

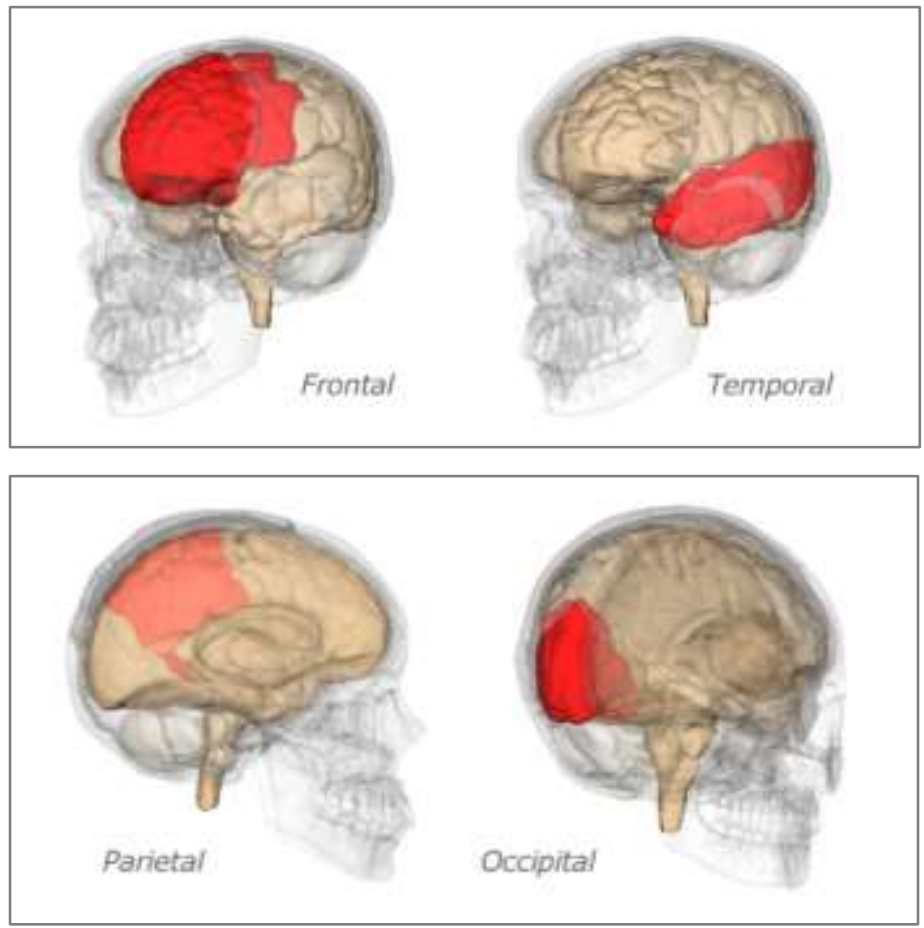

Fig.33: Lobulos cerebrales (generated by Life Science Databases-LSDB).

Debajo de la corteza se sitúa el cuerpo calloso (fig.34), uniendo, conectando e intercambiando información entre ambos hemisferios. Este tiene una diferencia de volumen mayor en la mujer que induce a establecer diferencias entre el cerebro masculino y femenino (Bruner et al., 2012). Esto ha generado abundante literatura que apunta a diferencias intersexo, en términos de superioridad femenina 0 masculina, respecto a determinadas tareas visuales.

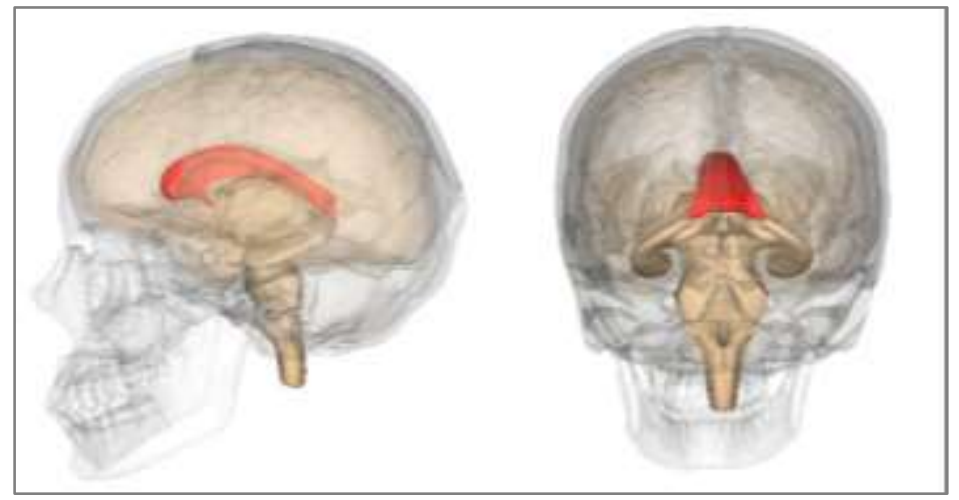

Fig.34: Cuerpo calloso (generated by Life Science Databases-LSDB).

Estas diferencias en habilidades cognitivas visoespaciales, tan solo parecen significativas o demostradas en los "diferentes tipos de 
pistas", o en la "forma en que ambos sexos utilizan la información espacial disponible" (Cánovas, 2011, p. 130), y se pueden explicar por la especialización adaptativa que realiza el cerebro a través del aprendizaje (Gazzaniga, 1998), y en el cual interviene el rol social desempeñado en la historia.

La comunicación entre ambos hemisferios interesa de manera significativa a la neurociencia ya que busca definir la especialización hemisférica y el concepto de dominancia cerebral. La especialización de las funciones de los hemisferios ha planteado una dicotomía entre dos maneras de procesar la información: una secuencial, verbal y lógica del hemisferio izquierdo y otra atemporal, espacial y holística del hemisferio derecho.

Ya en 1868, Jackson (citado en Springer y Deutsch, 2001, p.21) concluye que en la mayoría de las personas el lado izquierdo del cerebro es el principal, debido a la predominancia del habla. Pero también el mismo Jackson plantea la posibilidad de que la percepción pudiera estar situada en el hemisferio derecho. El concepto de dominancia, aunque dudoso a juicio de Springer y Deutsch (2001), todavía se utiliza.

El análisis de las respuestas a las pruebas de inteligencia estandarizadas citadas de sujetos con lesiones en el hemisferio izquierdo comprueba una incapacidad verbal (anomia) para recordar palabras; y las de sujetos con lesiones en el hemisferio derecho, muestran agnosia visual, espacial o facial, afectando a la orientación y al reconocimiento de formas y lugares. Estas conclusiones son confirmadas por posteriores estudios quirúrgicos de comisurotomía (sección del cuerpo calloso o cerebro dividido) (Gazzaniga, 1998).

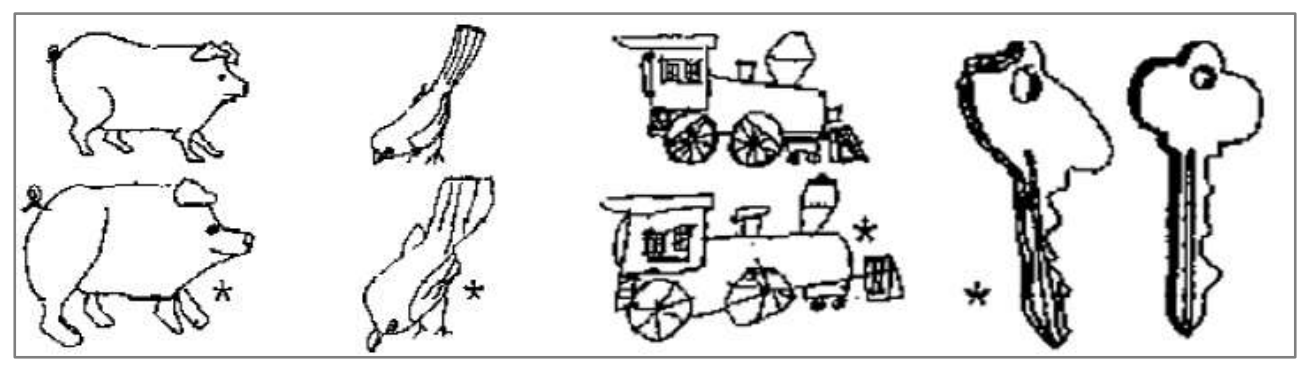

Fig. 35: Dibujos de paciente con agnosia visual (marcados con asterisco)

(Rubens y Benson, 1971) 
Posiblemente y como reflexiona Springer (2001), las lesiones del hemisferio derecho han pasado desapercibidas en el tiempo por no mostrar deterioros evidentes en contextos (incluido el académicocientífico) donde predomina el lenguaje verbal; mientras que leves lesiones en el hemisferio izquierdo afectan de forma severa al rendimiento académico o profesional. En el aspecto formal, el reconocimiento de los objetos no impide su descripción visual gráfica (fig. 35). Sin embargo, para Springer y Deutsch (2001), hoy está fuera de duda que ambos hemisferios, aunque de forma diferente, participan de la actividad mental compleja, en lo que denominan 'especialización complementaria' (p.25).

Los estudios funcionales del cerebro dan un importante paso con las técnicas de neuroimagen: Resonancia Magnética Funcional (RMf) y Tomografía de emisión de positrones (TEP). Las técnicas de neuroimagen más potenciadas, en el campo de investigación actual denominado Conectómica, se encuentran en la imagen por difusión (DWI, Diffusion Weighted Imaging) y Tactografía. Esta técnica de imagen computerizada con transparencia, que utiliza proteínas fluorescentes, permite cuantificar la movilidad de las moléculas de agua en el interior de los axones neuronales, lo cual posibilita la reconstrucción tridimensional de las fibras nerviosas cerebrales (Lopez Casillas, 2013). Tecnología que permite observar la actividad neuronal a lo largo del cerebro y muestra el concepto de plasticidad neuronal (fig. 36). La plasticidad es entendida como la capacidad de reorganización funcional y estructural de las células del cerebro.
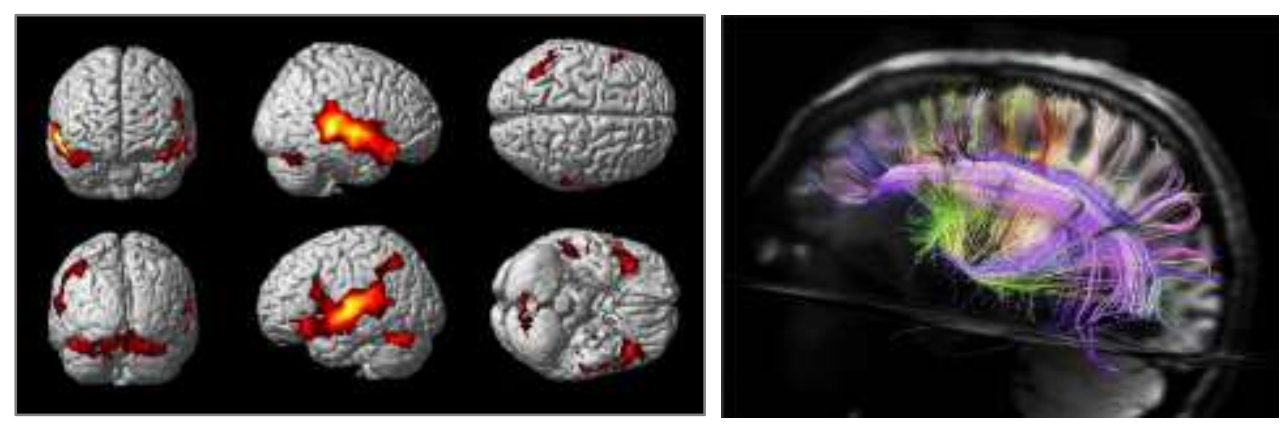


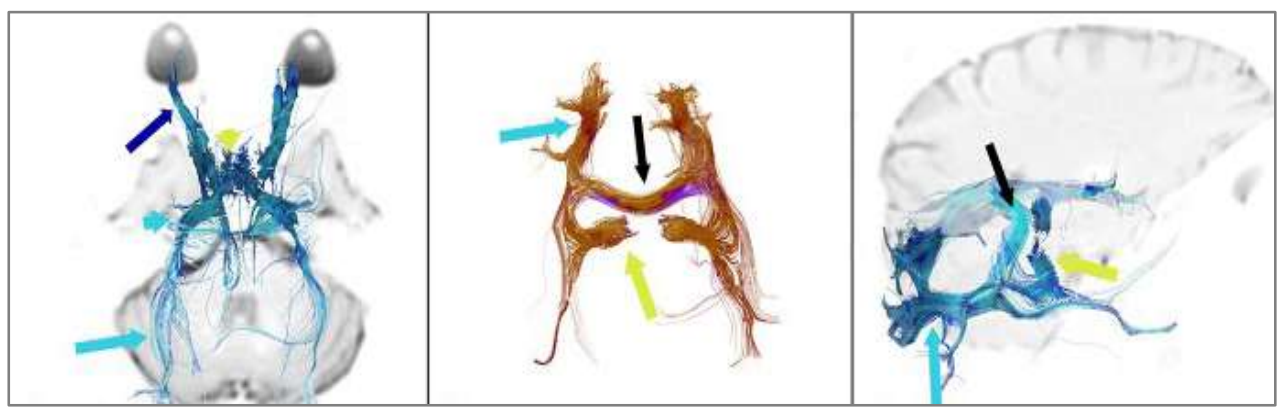

Fig.36: Resonancia magnética y tractografía;

Tractografía invertida de la vía óptica: nervio óptico (Rodríguez et al., 2013)

En un principio la plasticidad cerebral es un concepto asociado con las edades tempranas, y si bien es mayor alrededor de los primeros cuatro años, hoy es contemplada en todas las edades, y se vincula con las oportunidades de aprendizaje a lo largo de la vida. Aunque no se conoce exactamente qué ocurre en el cerebro, la neuroimagen muestra la influencia que tienen las experiencias de estimulación sobre la plasticidad cerebral, y permite suponer que, "la actividad neuronal mediada por la experiencia contiene la información necesaria para especificar los patrones de conectividad y organización neuronal, de forma que será diferente dependiendo de la información que se procese". (Hernández-Muela et al., 2004, p.S65). Pero también, dependiendo de cómo se procese la información, es decir, además del tipo de información, podemos tener en cuenta el nivel de consciencia que podamos alcanzar en cuanto a las vías y regiones que los estímulos recorran: Conocer el funcionamiento cerebral nos va a permitir, además de saber como trabaja, aumentar la atención individual sobre los procesos que realiza, o bien, que realizamos.

Disponemos de información visual de estas vías neuronales que vinculan las regiones de la corteza cerebral, en la medida que la respuesta del cerebro es traducida como la activación estimular de zonas de la corteza. Los órganos sensoriales poseen células especializadas en sus funciones y la corteza cerebral de humanos y primates se caracteriza por la especialización estructural y funcional de neuronas dedicadas al procesamiento de información visual (Giménez-Amaya, 2000).

"Las vías neuronales y sus proyecciones se someten a una organización topográfica, de forma que cada área visual se proyecta 
de manera diferente sobre la corteza visual occipital a través del tálamo. Las fibras que conducen la información visual procedente de la retina retienen esta distinta información conforme progresan hacia el tronco cerebral, el tálamo y la corteza visual, existiendo una continuidad en la representación sobre la corteza visual de áreas adyacentes del campo visual que se organizan en zonas con sensibilidad a una misma orientación y en forma de molinillo".

(Hernández-Muela et al., 2004, p.S59).

En este sentido, resulta interesante el concepto de especilización asociado a la hemisfericidad cerebral. Al demostrar la investigación neurocientífica la vinculación de los hemisferios con dos maneras de procesamiento cognitivo, pronto se produce la catalogación de éstas como dos estilos de pensamiento: verbal versus visoespacial (Gazzaniga, 1998). Destaca la comparación (fig. 37) del hemisferio derecho con los patrones de un caleidoscopio frente al izquierdo como un ordenador digital que "es lineal y secuencial, al pasar de una etapa a la siguiente por las reglas de la lógica y un lenguaje propio. El caleidoscopio combina simultáneamente sus partes para crear una rica variedad de patrones (...) En el ordenador cada paso determina qué pasos pueden seguirlo, mientras que en el caleidoscopio de las partes pueden relacionarse entre sí en un número casi infinito de formas" (Williams, 1986, p.4). Esta idea refuerza los conceptos (psicológico y pedagógico) de estilo cognitivo y estilo de aprendizaje, el primero en cuanto a la preferencia personal del individuo al procesar la información, y el segundo en la preferencia del medio en que se trasmite. La hemisfericidad, por tanto, no solo queda así referida a los procesos cognitivos de la percepción, sino también a las dimensiones de la inteligencia y la personalidad.

A partir de esta idea de antagonismo funcional, surgen pruebas o test de creatividad (TEAP -Tu estilo de Aprender y Pensar- de Torrance, 1980) y de personalidad (IDCH -Instrumento de Dominancia Cerebral- de Herrmann, 1991; DIDC -Diagnóstico Integral de Dominancia Cerebral- de Gardié, 1998), pero son escasas las pruebas científicas que vinculen la creatividad con el hemisferio derecho (Springer y Deutsch, 2001), y tampoco hay evidencias de que el estilo cognitivo se vincule con las estrategias de procesamiento holístico (Gras et al., 1992). 


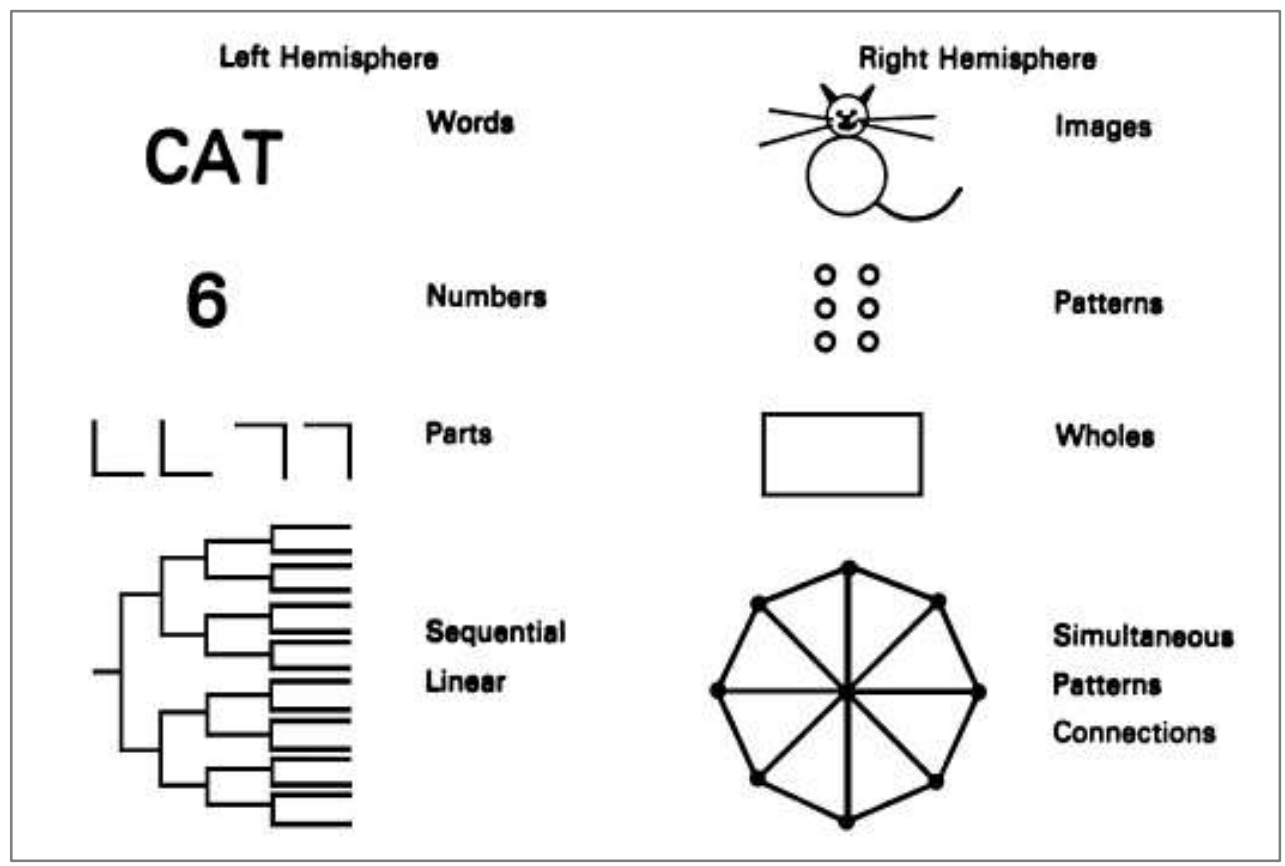

Fig. 37: Diferencias entre estilos de procesamiento de los hemisferios (Williams, 1986)

En cualquier caso, en línea con Romero (1996), tampoco parece muy útil la cuestión de su localización hemisférica, más allá de mantener la ya antigua dicotomía ciencia/arte, que poco parece favorecer al avance de la investigación y el conocimiento. En este sentido, parece que la joven advenediza neurociencia, como la define Ramachandran (2012), ya genera disciplinas como la neuroestética o neurología de la experiencia artística.

Las diferentes teorías sobre el funcionamiento cerebral se resuelven en cierta manera con el propio planteamiento holístico de la teoría holoárquica del cerebro (fig. 38), que permite la consideración flexible de la dominancia y los estilos de procesamiento cognitivo, donde cualquier cambio afecta al conjunto del pensamiento (Jiménez, 2003). 


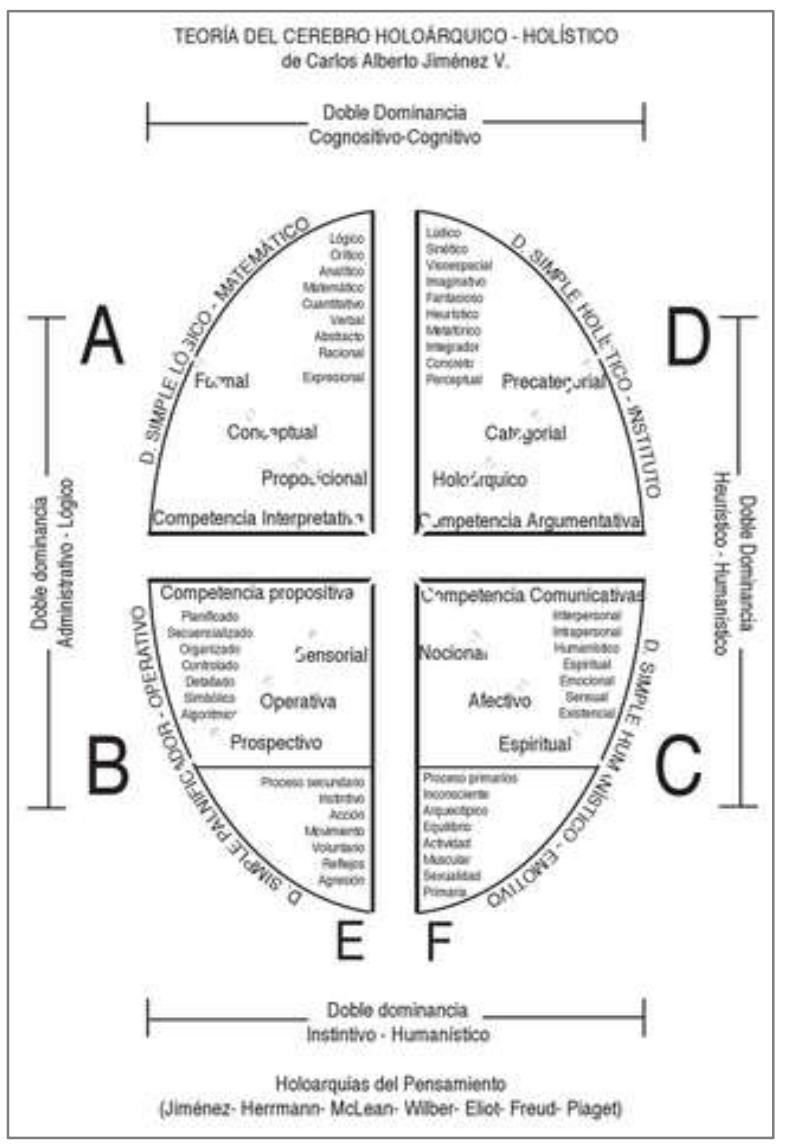

Fig. 38: Teoría del cerebro holoárquico-holístico (Jimenez, 2003)

Sin embargo, nos resulta de mayor interés conocer en qué momento se produce la diferenciación del procesamiento de la información por la vía visoespacial o por la vía verbal, y en qué medida podemos ejercer un control consciente de esta actividad.

Al parecer, el procesamiento visual se divide en dos rutas hacia la corteza visual primaria y, en las cortezas asociativas (temporales, parietales y frontales), las redes neuronales establecen circuitos bidireccionales dentro de cada área cortical, en "otro posible análisis modular de la información", asociando diversos aspectos de la percepción (Giménez-Amaya, 2000, p.661). La complejidad de estas redes y la relación a su vez con otras redes subcorticales, apuntan a la neurociencia, aunque poco documentada, a sugerir que "todos los sistemas de procesamiento inconsciente conectan con un sistema de conocimiento consciente" (Springer y Deutsch, 2001, p. 298). 
También apoyado en el conocimiento en neuroimagen, el modelo de la 'doble ruta' de la lectura (Jobard, Crivello y TzourioMazoyer, 2003) indica una ruta semántica de las palabras (significado), y otra ruta no léxica, llamada también pre-léxica que procesa los grafemas (formas). Este modelo se completa para la lectura y la escritura y el reconocimiento de objetos queda supeditado al sistema semántico (fig.39).

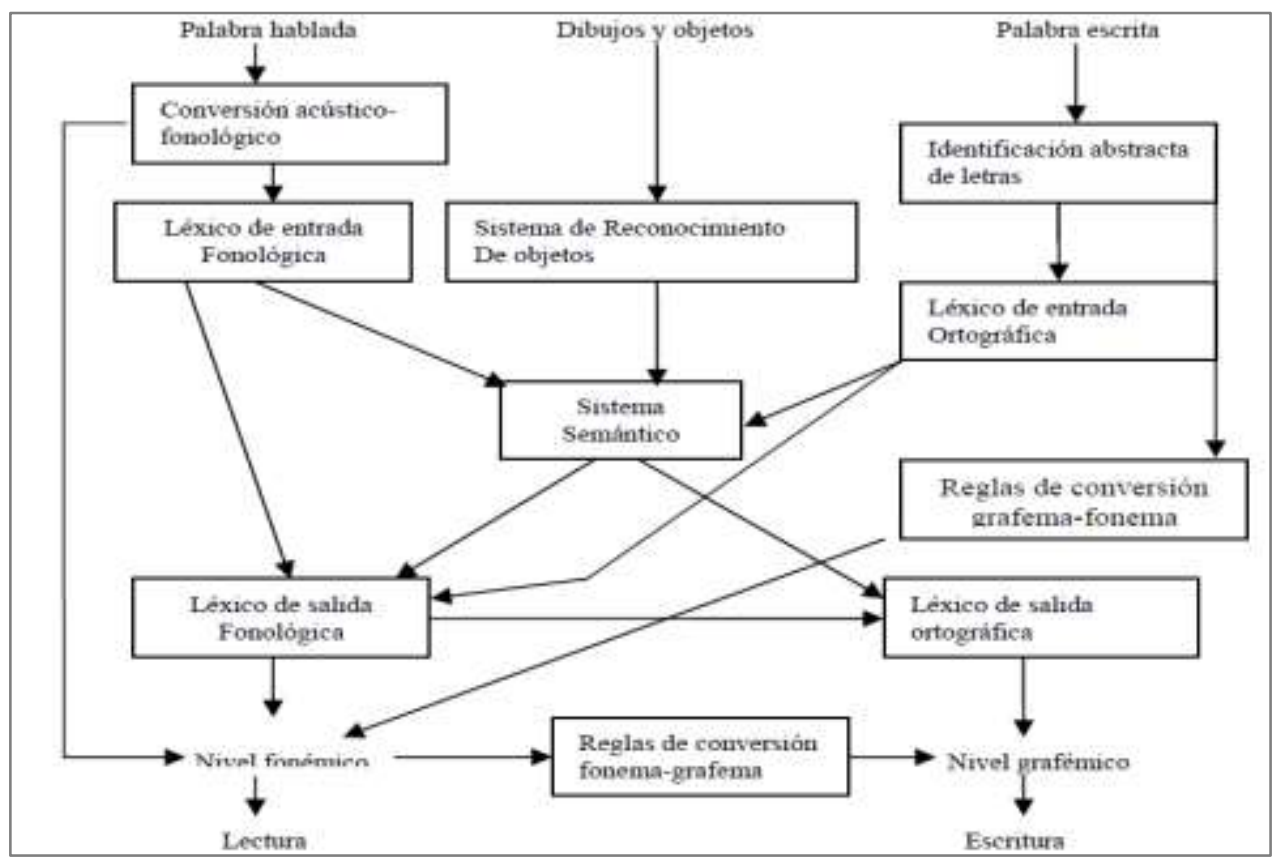

Fig. 39: Modelo cognitivo conjunto (Alvarez-Duque, Vega y Viñals, 2003)

El procesamiento de la forma para el reconocimiento léxico se produce en la denominada 'área de forma visual de la palabra' (VWFA, Visual Word Form Area) entre los lóbulos occipital y temporal. Se hablaba de la existencia de un léxico visual, pero los estudios actuales plantean áreas adyacentes sensibles a aspectos como la longitud y el orden. Se estima que el tiempo que va del inicio del proceso visual (aparición del estímulo) hasta el reconocimiento semántico es de 600 milisegundos (OCDE, 2009).

Se avanza en el conocimiento de los mecanismos cerebrales visuales que subyacen a las capacidades mentales y el aprendizaje, y el principal avance de la asimetría funcional del cerebro quizás sea descubrir que, reconociendo el valor del lenguaje verbal en la supervivencia y el desarrollo humano, este es resultado de la 
coexistencia con un pensamiento no verbal, y no reconocerlo, no considerar otros posibles análisis de la información, enlentece este desarrollo.

\subsection{Lenguaje visual y representación.}

Es habitual en el ámbito educativo, tanto en estudiantes como docentes, considerar las palabras como nuestro primer idioma, sin embargo existen personas que las perciben como un segundo idioma. Estas personas traducen las palabras, tanto las habladas como las escritas, a "películas de cine a todo color, acompañadas de sonidos, que pasan por la mente como una cinta de video" (Grandin, 2006, p.12). A quienes pensamos básicamente por medio del lenguaje nos cuesta entender que alguien traduzca instantáneamente las palabras en imágenes.

Esta peculiar forma de pensamiento visual se atribuye por un lado, a personas con un desempeño (verbal) pobre (asperger y autismo adulto), caracterizada por un pensamiento de tipo asociativo frente a la lógica verbal. En el autismo, es posible que el sistema visual se haya expandido para compensar los déficits verbales y de secuenciación. El sistema nervioso tiene una notable capacidad para compensar (plasticidad), y otra parte puede hacerse cargo de una parte dañada (Grandin, 2006).

Este tipo de pensamiento en imágenes, igualmente se atribuye, en el otro extremo del desempeño, a personas con altas capacidades (genios), asociado a un proceso de resolución de problemas complejos. Einstein afirmaba que raramente pensaba en palabras:

“...los físicos son cada vez más conscientes de que las teorías de Einstein no están basadas en arcanas matemáticas como en simples y elegantes imágenes físicas. Einstein comentaba a menudo que si una nueva teoría no está basada en una imagen física tan simple que un niño la pueda entender, dicha teoría probablemente carezca de importancia."

(Kaku, 2005) 
Entre ambos grupos, podemos encontrar un grupo excepcional de personas que son diagnosticadas con el 'síndrome de Savant'. Estas personas poco frecuentes en aproximadamente el 50 por ciento de los casos tienen la condición subyacente del trastorno autista. Este síndrome se produce en una de cada diez personas con autismo: el dato proviene de una encuesta a 5.400 niños con autismo, 531 de los cuales, basados en informes de los padres, tenía habilidades especiales en las áreas de habilidades típicas observadas en la mayoría de los 'savants': música, arte, matemáticas, calendario cálculo y habilidades espaciales (Treffert, 2011). Se caracterizan por una inusual habilidad espacial, de dibujo o modelado, y de memoria. Daniel Tammet se ha prestado a experimentos sobrevolando ciudades para dibujar a continuación hasta el mínimo detalle en paneles dispuestos durante días de trabajo (fig. 40). Aunque muchas de estas personas muestran problemas de comunicación, algunas como Tammet o la propia Temple Grandin (1992), describen su manera de pensar a través de imágenes: "los números van creando un paisaje mental, una imagen que evoluciona y gana nitidez a medida que me fijo en ella" (Tammet, D. en Gooder, 2006).

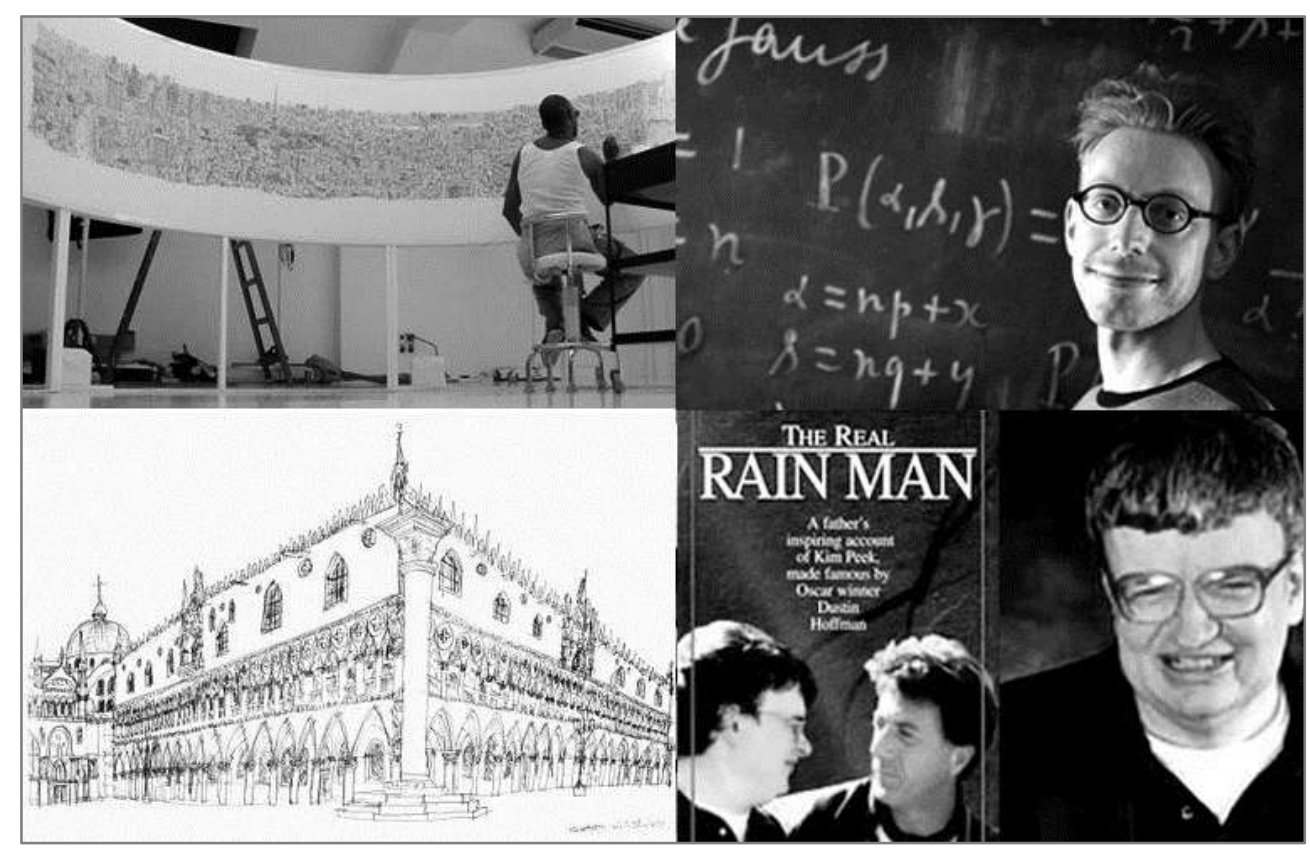

Fig. 40: Daniel Tammet (izq.), Stephen Wiltshire (sup. dcha.) y Kim Peek. 
Estas personas representan un porcentaje muy pequeño de la población, mientras que la mayoría de las personas consideramos el lenguaje de las imágenes, un lenguaje secundario al verbal. Esta consideración puede variar en función de las capacidades y de la formación y los estudios que tengamos. Así, solemos considerar que algunas profesiones (artistas plásticos, arquitectos, ingenieros o diseñadores), disponen de ciertas características que definimos propias del pensamiento visual. Más allá, si no tenemos una formación específica en estas u otras disciplinas afines, pertenecemos a una mayoría de la población que se auto juzga con una falta de formación en el ámbito visual, principalmente por un déficit en la representación gráfica. Creemos que este prejuicio existente se produce a dos niveles, con arreglo a la diferenciación genérica de cualquier actividad humana en términos de externalizacióninternalización (Talizina et al., 2010):

- Nivel Interpretativo: Presentando dificultades para leer imágenes, interpretar obras de arte y entender los principios que subyacen en sus estructuras.

- Nivel Creativo: Dificultades para producir o reproducir imágenes, grafismos, organizar el espacio o comprender las leyes ópticas.

La ciencia divide (o secciona) los aspectos del ser humano para su estudio. En cierta manera lo hace por la magnitud del ser humano y su conocimiento del mundo y de sí mismo. La ciencia aborda el estudio del pensamiento humano y el lenguaje, a un nivel estructural y funcional, principalmente desde la psicolingüística y la semiología. En la literatura científica de estas disciplinas no es extraño encontrar referencias al lenguaje visual, mientras que en ensayos sobre arte 0 diseño, es habitual. Aunque, en ocasiones, pareciera que no se están refiriendo al mismo concepto. Tanto las disciplinas científicas, que entran en una disyuntiva verbal-icónica, como las artísticas, limitadas por el paradigma figurativo-abstracto, o no parecen encontrar una concepción común acerca del pensamiento visual.

Existe la controversia científica entre unas teorías que proponen que las imágenes mentales dependen de la actividad sensorial primaria, relacionada con fases tempranas en la percepción, 
y aquellas que indican que las imágenes mentales dependen de las representaciones simbolicas similares al lenguaje, atribuyendo a éstas los procesos de atención (Drubach et al., 2007).

Para Barthes (1990), semiólogo pionero en la investigación del sistema de signos, "es difícil concebir un sistema de imágenes cuyos significados puedan existir fuera del lenguaje" (citado en Zamora, 2007, p.75). Otros autores también se manifestaron en el sentido improductivo de los signos no verbales. Podría parecer así que la ciencia moderna, tildada de logocentrica, tiene dificultades para entender lo visual desvinculado del lenguaje verbal. Barthes antepone la importancia del significado a la percepción visual, y llega a definir, curiosamente de manera sensorial, una capacidad, la del 'olfato semiológico': identificar mensajes allí donde sería más cómodo reconocer solo cosas (Eco, 2012; Barthes, 1990).

La semiótica, a través de la relación significante-significado, atribuye al objeto visual (signo) un papel mediador que nos conduce al significado. Pero también los signos desprovistos de significado (insignificantes) nos pueden aportar un significado: la visión de un objeto (abrigo) nos evoca un significado (proteger del frio), pero también sugiere el estatus social de quien lo lleva. A Barthes, y a la semiótica, les interesa conocer cómo hacemos significante lo insignificante (Beuchot, 2013).

El mundo de los significados lingüísticos y no lingüísticos de lo visual va a encontrar tanto en la psicología como en el arte un marco de desarrollo donde ambos compiten por el papel protagonista.

Arnheim (1998), aludiendo a la necesidad de clarificar significados en el análisis icónico, define tres funciones de las imágenes: la representación, el símbolo y el signo. Pero no como tres tipos de imagen ya que una misma imagen puede tener las tres funciones. Un signo (objeto visual) no es arbitrario ni establece por sí mismo analogías, y como tal no puede ser utilizado como un medio para el pensamiento. Las letras del alfabeto, los números y las formas geométricas se aproximarían a esta función ya que por lo general no retratan nada por sí mismos. Por retratar se refiere a desencadenar un nivel de abstracción en el pensamiento, que ocurre en la función simbólica y representativa. 
La función representativa se da cuando la imagen retrata algo situado en un nivel de abstracción más bajo (cercano a la percepción) que la propia imagen. Una fotografía o un dibujo tienen un nivel de abstracción que nos lleva a interpretar lo que retratan por sus cualidades (formas, colores). Al explicar esta función, Arnheim advierte sobre la errónea interpretación del concepto de abstracción y como ésta se suele asociar con lo incompleto, y afirma que una representación "es un enunciado sobre las cualidades visuales, y un tal enunciado puede ser completo a cualquier nivel de abstracción" (Arnheim, 1998, p.151). La abstracción es un concepto del pensamiento no de la forma o de la realidad, o dicho de otra manera, la representación siempre es abstracta, aunque en diferentes niveles para un observador.

La función de símbolo se da en la imagen cuando ésta retrata algo situado a un nivel superior de abstracción (lejano a la percepción) que el propio símbolo. Esta función se produce cuando la imagen evoca un concepto. La imagen simbólica puede hacer referencia a un concepto abstracto con rasgos determinados (casa, árbol) o a otro de cualidades complejas o indeterminadas (fuerza, paz, armonía o libertad), y también a ambas (el retrato de una persona como símbolo de la ley o la autoridad). (fig. 41)

Habitualmente los conceptos de abstracción versus figuración de la representación se asumen como estandarte de modernidad, y posiblemente, como hemos señalado, por inconfesos intereses de los mercados. Aunque se apunta hacia la superación del antagonismo, al mismo tiempo que podemos consultar obras de análisis de la abstracción en el arte paleolítico, que insisten en la falta de análisis formal más allá de la identificación de las figuras (Apellániz, 2001), podemos encontrar referencias al pasado artístico y literario adjetivado con características naturalistas y descriptivas, hasta la redentora aparición del arte no figurativo. $Y$ encontrar sentencias como que "para que la expresión plástica pura produzca alguna emoción, hay que abstraer de la figuración y llegar así a lo neutral" (Chipp, 1995); que resultan incongruentes incluso para el propio autor, que al abordar el arte surrealista, reconoce la importancia expresiva del tema y la narración. Pero la representación gráfica, frente a la literaria, arrastra desde la incipiente producción infantil confusas descripciones que la 
relacionan estrechamente con la imaginación y la 'rechazada' figuración. Figuración que es elogiada por Pushkin al referirse al verso que puede golpear el corazón: "sobre la figuración derramo mis lágrimas" (cit. en Vigotsky, 2003)

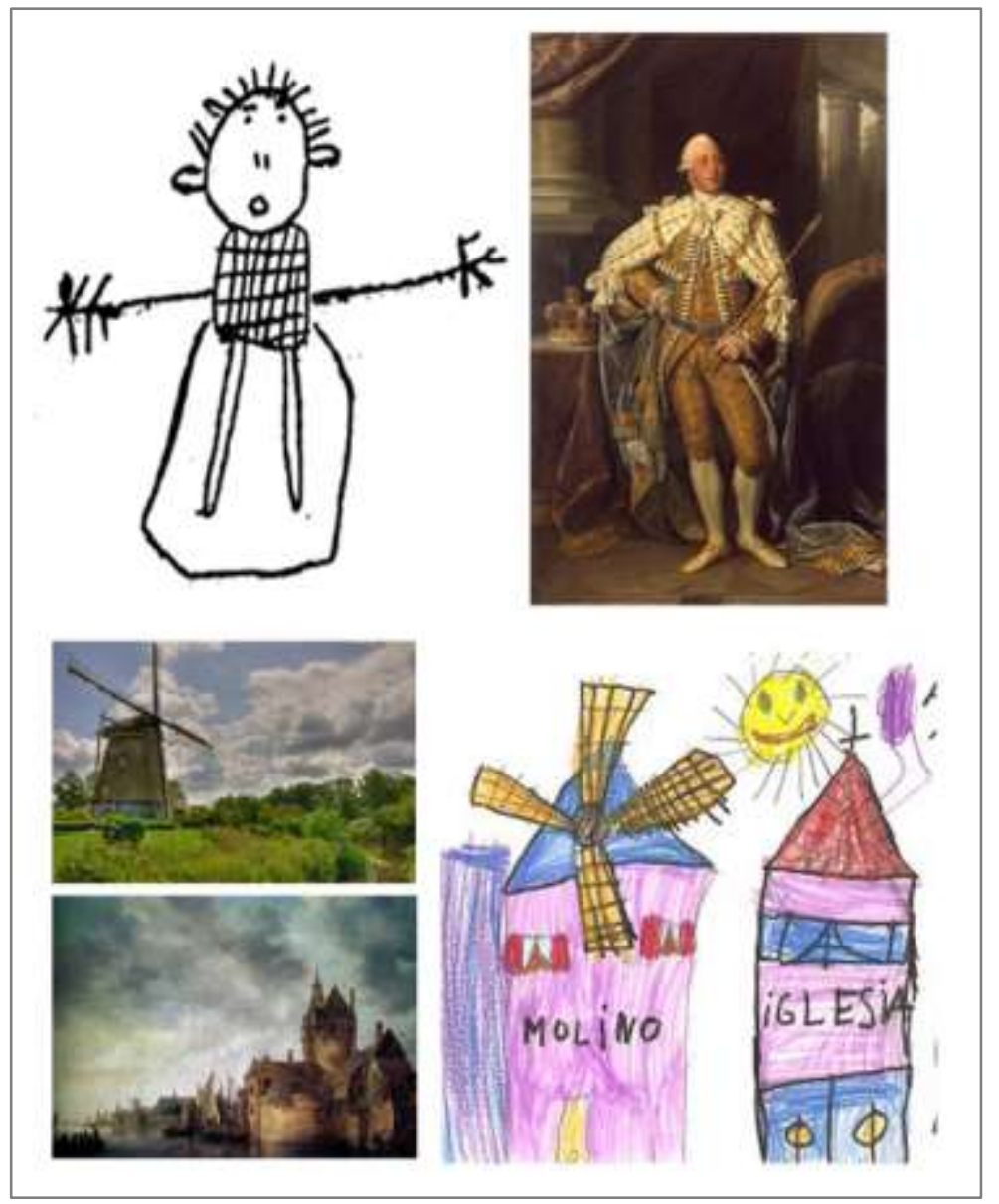

Fig. 41: Imágenes en diferentes niveles de representación-abstracción.

Relativizando el problema de lo descriptivo de la imagen y la figuración en el arte, para Arnheim (1998, p.155), la imagen de Magritte (fig.14) "desdichadamente" se trata solo de una pipa. La imagen puede evocar un pensamiento en el observador, pero el pensamiento no está en la imagen y ni siquiera en los signos. Observemos aquí que la obra de Magritte incorpora el texto escrito 'esto no es una pipa', y que en este caso lo que el autor provoca es la evocación del pensamiento verbal y no la que produce la imagen por sí misma, aunque esta también lo hace de manera simbólica. Es posible que este fuera su juego visual. 
Ambos, texto e imagen, comparten el poder desencadenante de pensamiento que poseen y que justifica el concepto de lenguaje visual en su función representativa y simbólica. La representación es una acción que separa el significante del significado. Todo apunta a que es el modo hemisférico o la opción de unas u otras vías neuronales quienes 'deciden' entre procesar el significante perceptivo o el significado simbólico, o ambos. Hemos comentado que se apunta hacia una dominancia del hemisferio izquierdo, que nos inclina al lenguaje, y por tanto al procesamiento simbólico del significado. La investigación neurocientífica en asimetría funcional indicaría que, aun pudiendo haber una tendencia filogenética por la preferencia verbal, también se produce en el desarrollo. En relación con estos estudios, los datos resultantes de medir la actividad cerebral funcional en ambos hemisferios es mayor en el hemisferio derecho que el izquierdo entre 1 y 3,5 años, y que en el cuarto año se producen los cambios de predominio de derecha a izquierda (Chiron et al., 1997).

Ahora bien, la capacidad de representación gráfica es anterior a la del lenguaje. Realizamos trazos y signos antes de alcanzar la capacidad de abstracción del pensamiento conceptual y simbólico que, al parecer, solo atribuimos al lenguaje. Si es así, podemos ver en esta antelación, la preparación motora para el aprendizaje de la escritura y el cálculo. En ese caso, la representación gráfica, no tiene un especial interés más allá del signo. Aunque se habla de razonamiento espacial, éste, junto a la visualización, se interpretan como "prácticas matemáticas específicas, operativas y discursivas que se ponen en juego ante determinados tipos de tareas" (Fernandez et al., 2008).

La representación gráfica, en el estudio de su desarrollo más allá del signo, siempre ha sido adjetivada como lúdica, ya desde los estudios del dibujo infantil de Luquet a comienzos del siglo XX. El dibujo, es esa actividad espontánea y predilecta para los niños en su expresión, que "empieza a decaer" al comienzo de la edad escolar (Vigotsky, 2003).

Para Luquet (1927), filósofo francés, influenciado por el realismo, toda la producción gráfica es figurativa, y analiza el dibujo infantil como resultado de lo que el niño sabe, anteponiendo deliberadamente el significado, al significante. Piaget, que no se 
refiere al dibujo en su obra de psicología de la inteligencia, se basa en el trabajo de Luquet para describir el dibujo infantil como resultado de un proceso de imitación. Aunque su búsqueda de los procesos cognitivos de la representación le lleva a aceptar que lo visual desempeña un papel a título de elemento del pensamiento. Pero este papel no es sino "como auxiliar simbólico complementario del lenguaje" (Piaget e Inhelder, 1997, p. 75).

El análisis de la producción gráfica infantil se perfila de esta manera hacia la consideración realista de la representación, centrada en el significado, con la consideración de los niños como artistas incipientes faltos de formación. Posteriores estudios sobre la representación gráfica infantil y su vinculación con el concepto abstracto del arte contemporáneo harán que ésta se sobrevalore por el significante, y se habla entonces de la obra, del arte infantil.

El valor que adquiere el significante en el grafismo infantil es inducido en parte por los estudios cognitivos que indagan en los procesos de representación, la categorización perceptual y la formación del símbolo (Piaget, 2009; Mandler, 1998; Arnheim, 1998). Pero especialmente por los trabajos en torno al concepto de creatividad (Lowenfeld y Lambert, 1993; Eisner, 1995; Read, 1982). Una línea de investigación con abundantes trabajos que mantienen una marcada referencia al desarrollo artístico, y muchos lo hacen con una visión diferenciadora hacia la formación específica en Bellas Artes. Estos estudios están centrados en el significado y valor del arte en la educación y en el desarrollo de la conciencia estética, con el fín de "educar la sensibilidad de una persona respecto de las experiencias perceptivas, intelectuales y emocionales" (Lowenfeld y Lambert, 1993, p. 337).

Entendemos que la creatividad no conlleva necesariamente una manifestación artística, sino que constituye una característica o rasgo de la inteligencia. Si la inteligencia como constructo multidimensional ya plantea dificultades en su definición, como hemos visto, la creatividad no plantea menos. Reducir la creatividad a la expresión gráfica es inconsistente. En cualquier caso, si asociamos la creatividad a la producción gráfica infantil, y hablamos de arte en la infancia, nada nos impide relacionar la creatividad con la producción literaria de los niños, a partir de sus escritos y narraciones. En ambos 
casos sin duda se expresa la creatividad, pero en el caso del lenguaje, el estudio pedagógico de la expresión narrativa infantil es un ámbito dedicado al logro del hábito de la lectura, con escasas referencias a la creatividad, y en el que no aparece el análisis de la producción literaria infantil en relación a la competencia literaria, como ocurre con el arte infantil.

Establecemos esta analogía para tratar de explicar que, considerando la expresión en ambos casos (gráfico-plástica y textualliteraria) como lenguajes artísticos, la producción textual infantil tiene una referencia en el arte adulto (la literatura infantil es un ámbito de producción editorial) y su educación se atribuye al estudio de la estructura gramatical y los sistemas de representación lingüísticos, incluidos los mapas mentales; mientras que la representación gráfica infantil, aunque tiene abundante referencia en el arte adulto (comic, cine infantil e ilustración en la propia literatura infantil), sin embargo, en su educación tienen poco peso tanto el estudio de la gramática visual como el de los sistemas de representación gráficos.

Una de las causas, que creemos explica en parte la falta de concreción de una didáctica en esta área, la encontramos en la excesiva influencia del debate estético-artístico en el ámbito de la educación visual que tiene como consecuencia una escasa formación docente en el ámbito de la expresión gráfica. Influencia que recibe de los estudios visuales, un entorno incierto de confusión disciplinar (Bal, 2004; Guasch, 2003; Mitchell, 2003; Klinkenberg, 2006), donde se realizan estudios que intercalan ambas formas de representación: estudios lingüísticos o semánticos de la imagen (semiología gráfica, semiótica visual) y estudios visuales de la representación lingüística (infografía, hipertexto, realidad virtual).

Aunque algún análisis en este entorno de la semiótica apunta a que los modelos lingüísticos de lectura y decodificación van cediendo paso a "modelos de recepción y visualidad", este cambio "en ningún caso supondría un retorno a las cuestiones naïves de parecido o mimesis, ni las teorías de la representación: se trataría más bien de un descubrimiento post-lingüístico y post-semiótico de la imagen como una compleja interrelación entre visualidad, sistemas, instituciones, discurso, cuerpos y figuralidad" (Mitchell, citado en Brea, 2005, p.64). 
Dejamos a un lado este debate de la representación en cuanto conexión entre lenguaje y cultura, que, por su magnitud, ha conducido a afirmar en el ámbito académico "que es imposible formar «especialistas» de todas las materias vinculadas a los Estudios Visuales" (Guasch, 2003, p.16), y, centrándonos en los aspectos pedagógicos, intentaremos clarificar el concepto de representación gráfica, concepto que es subyacente a la imagen y creemos que también, al análisis de ésta, como elemento comunicativo y cognitivo.

Todo material o producto visual responde en última instancia al concepto de representación gráfica, ya sea éste producido por la mano humana o por medios mecánicos, o por la combinación de ambos (Gordejuela, 2009). Por tanto, un simple boceto, una obra plástica, la fotografía y todos sus productos: animación, cine, imagen digital o realidad virtual; responden al mismo proceso cognitivo de representación visual del espacio en dos dimensiones. "Cualquier representación gráfica es siempre una interpretación, no importa qué tan fiel a la realidad esté la proporción y la atención al detalle. Los gráficos siempre intentan explicar la realidad" (Malamed, 2011). Tener esto claro, por una parte puede reducir la confusión, sobre la que se comienza a alertar y que se produce en la población más joven, entre los espacios virtuales (de realidad simulada) y los espacios materiales o reales (Baudrillard, 2000; Darley, 2002; Fernández Serrato, 2011); pero también, y principalmente, para resaltar la importancia que tiene como habilidad la representación gráfica en todos los aspectos de competencia (del manual al digital) en el ámbito de la formación.

\subsubsection{Análisis del lenguaje gráfico representativo.}

La representación visual del espacio tridimensional en una superficie de dos dimensiones (muro, papel, pizarra, lienzo o pantalla) acompaña al ser humano desde sus orígenes como habilidad expresiva y cognitiva. Cualquier representación gráfica plantea un proceso expresivo y construye a través de la forma, sea o no ésta geométrica, un conocimiento sobre el espacio. Esta representación espacial puede responder a dos tipos: al esquema del plano o mapa y al esquema de proyección visual (fig.42). 


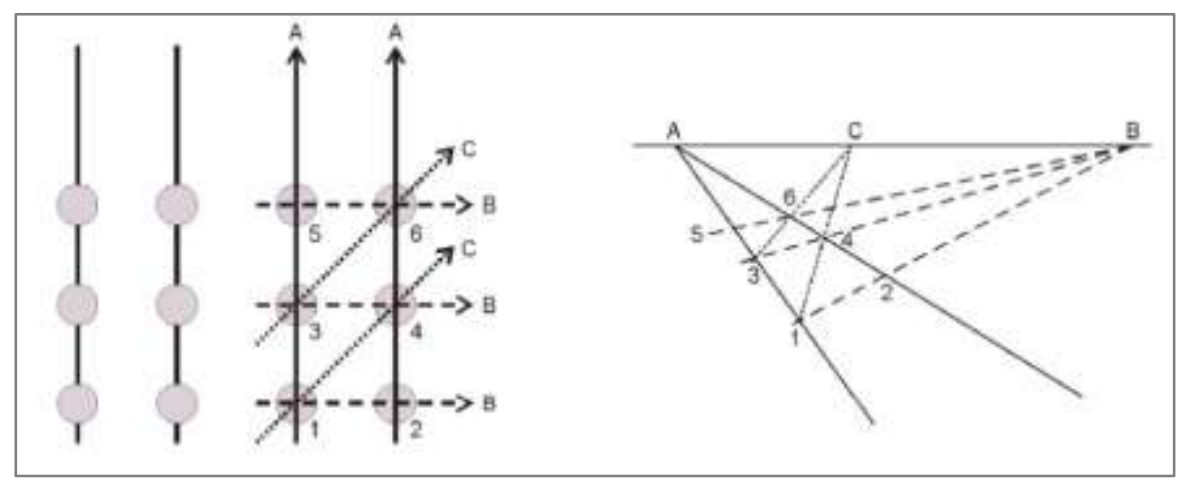

Fig.42: Representación de mapa y de proyección. (Gordejuela, 2009)

El estudio de la historia de la producción gráfica humana es una muestra de la lucha contra la dificultad de armonizar ambos espacios, el de la realidad y el espacio figurado bidimensional del plano. Esta dificultad la encontramos reflejada en estudios que tratan la opción individual entre representar lo que vemos o lo que sabemos (Edwards, 1994; Sainz Martín, 2013; Gómez Molina et al, 2005). Y también es la dificultad que se muestra en los estudios sobre el desarrollo gráfico de la representación, cuando se describe el paso de representar el niño lo que sabe primero, para después, representar lo que ve (Luquet, 1981; Piaget, 2001; Lowenfeld y Lambert, 1993; Vigotsky, 2003; Goodnow, 2001; Acaso, 2000). En ambos casos, entendemos que esta dificultad de armonizar los espacios, bidimensional y tridimensional, está condicionada por el aprendizaje, concebido en todo el desarrollo de la vida.

Esta dificultad en la representación del espacio visual se ha subsanado a través de la historia con diferentes estrategias que quedan definidas en los estudios sobre la Perspectiva (per-specere 0 mirar a través). Disciplina que, ya desde los clásicos, se discute su carácter científico para unos (Pacioli, 1991, p.38), mientras que para otros es un arte, y que para muchos es una disciplina que vincula ambas, ciencia y arte. Esto quizás sea debido a la evocación de figuras como Durero o Leonardo Da Vinci, a la que contribuyen obras actuales, como el best-seller de Atalay (2008), quien afirmara: ..."la practica debe cimentarse sobre una buena teoría, a la cual sirve de guía la perspectiva; y en no entrando por esta puerta, nunca se podrá hacer cosa perfecta ni en la pintura, ni en alguna otra profesión" (Da Vinci, L., 2011, p.11). 
El espíritu científico y artístico que ha acompañado siempre a la perspectiva como estudio, se muestra en el desarrollo conjunto de las artes visuales y de las ciencias matemáticas, físicas y ópticas, explicando los mecanismos y leyes de la representación visual. Una visión sintética que aporta la obra de Panofsky (1983), "que aún no ha sido igualada" (Mitchell, 2009, p.24); y que comparte también la obra de Pedoe, para quien la perspectiva "estimuló el desarrollo de la geometría" (Pedoe, 1979, p.10).

Pensemos por un momento en la diferencia entre considerar que la intensidad de la luz disminuye con el cuadrado inverso a la distancia de su fuente (ley inversa de la física), o apreciar que el color pierde nitidez en la distancia o que se difuminan las formas (perspectiva aérea). La estrecha vinculación entre la formulación de la ley y la observación en la que se sustenta, nos debe hacer reflexionar sobre la división bipolar que tiene nuestro pensamiento, resultante y resultado de la división en el corpus de conocimiento académico.

La relación estrecha entre los procesos cognitivos que hay detrás del razonamiento matemático y lo que se denomina actualmente inteligencia visual ocupa un importante espacio en la historia de la investigación científica. Baste recrearse en la descripción de los vínculos entre las definiciones del punto que hacen Euclides, Leonardo y Galileo (Pedoe, 1979, pp.74-75), o en los estudios sobre las distorsiones visuales que van desde la antigüedad hasta la óptica moderna y la ingeniería de interfaces visuales, que investigan en el concepto ya familiar de la calidad de imagen (Nava et al., 2006; Herrero-Solana y Hassan-Montero, 2006). Pero esta relación también está marcada por la separación académica, en el seno de la ciencia matemática, entre geometría y aritmética. No sabemos si la causa es la especialización o la abstracción de la matemática pura, pero en algún momento se produce la "separación de la práctica matemática de los problemas de la realidad" (Ruiz, 2003, p.537).

Como apunta Ruiz (p.124), esta separación supone la distinción entre los conceptos de magnitud y número, que, como veremos, condiciona de manera importante el desarrollo de la competencia gráfica. Si la matemática son sólo números, entonces básicamente hablamos de cálculo. Considerar que la matemática es algo más, no 
es solo atender a los procesos de razonamiento lógico-matemático, sino también a los procesos visuales. $Y$, considerando que la geometría plana y proyectiva están detrás del software de representación gráfica, ambos razonamientos, matemático y visoespacial, también han de convivir, en la educación, en lo que definimos como competencia digital.

La representación gráfica del espacio encuentra además, y queremos destacar especialmente, un conflicto cognitivo en cuanto al establecimiento del punto de vista. Mientras que la perspectiva visual avanza históricamente en la construcción del espacio en torno a un punto de vista "elegido a voluntad" para lograr "la transición de un espacio psicofisiológico a un espacio matemático" (Panofsky, 1983, p.49) hasta alcanzar las modernas pantallas y la realidad virtual; al mismo tiempo, la ciencia, en su sentido más empírico y cartesiano, va a utilizar la geometría para "la representación y determinación de los elementos de las máquinas" (Monge, 1803, p.VI).

De esta forma, y motivado por el desarrollo industrial (Monge está al frente en el origen de la escuela politécnica de París, en 1794), el sentido visual del espacio en su más amplia acepción artísticocientífica deja paso al sentido puramente racionalista, saturado de contenidos teóricos (Giménez Morell et al., 2010) que prevalece hasta hoy en la educación: "La educación nacional pues recibirá una dirección ventajosa familiarizando nuestros jóvenes artistas con la aplicación de la geometría descriptiva a las construcciones gráficas que son necesarias al mayor número de artes..." (Monge, 1803, p.VI).

A partir de aquí, la labor educativa de los dos últimos siglos, lejos de clarificar este conflicto cognitivo, ha contribuido a ponderar a favor de un sistema teórico de representación espacial, el diédrico, en cuanto modelo de representación gráfica (en la forma de dibujo industrial), dejando poco peso a los modelos experimentales 0 sintéticos, basados en la visión (fig.43). 


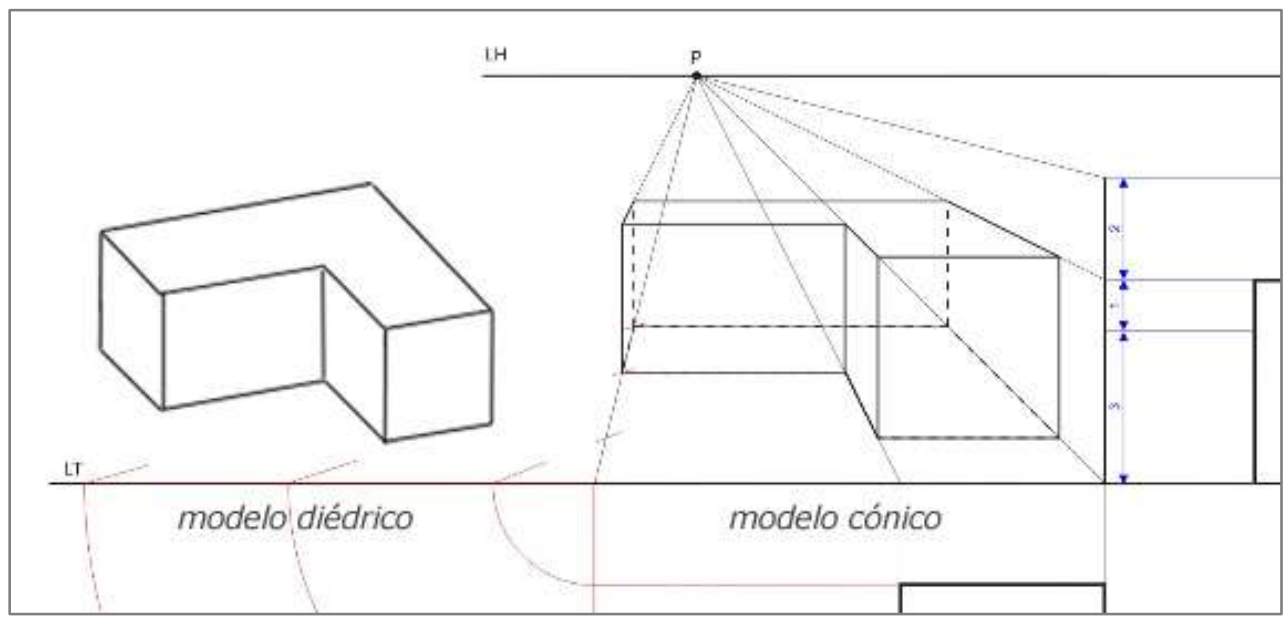

Fig. 43: Modelos de representación paralelo o divergente (diédrico) y convergente (cónico).

El sistema diédrico es un modelo teórico de perspectiva paralela (axonométrica) que no define el punto de vista o éste es infinito, por lo que todas las líneas son paralelas dando como resultado una visión estable y frontal, pero no real. Es un modelo práctico, válido para controlar las distancias y medidas, y se crea con el único fin del diseño para la fabricación de un objeto. Esto es una dificultad para la representación gráfica arquitectónica que a comienzos del siglo pasado hace una reformulación alternativa (Millar, 1922) denominada método directo (direct method), con la consideración de diferentes puntos de vista.

El modelo cónico, que parte igualmente de supuestos teóricos como la recta o el plano, responde mejor a la movilidad en el espacio, ya que considera los puntos de fuga (donde convergen las líneas paralelas) y aspectos perceptivos de la distancia. A diferencia de los demás sistemas de la geometría proyectiva, este modelo no es creado para algo específico, más allá de solucionar la dificultad de representación del espacio visual en el plano, y acompaña la historia de la investigación y el conocimiento humano.

En este sentido, en la actualidad, mientras que en el ámbito del diseño arquitectónico se cuestiona la poca espacialidad del modelo diédrico (Grassa-Miranda y Gimenez Morell, 2010), y en el ámbito de la ingeniería y el dibujo técnico-industrial se dirigen paradójicos elogios a Leonardo y sus diseños; en el ámbito de la educación poco parece moverse. 
El debate pedagógico se sitúa en torno a la aproximación de las matemáticas con el dibujo técnico (Luna et al., 2008; Giménez Morell et al., 2010) o en una discusión poco productiva ${ }^{2}$ sobre la discontinuidad entre la geometría sintética y la analítica (Gascón, 2002). En cualquier caso, y en la línea de algunos de estos estudios que entienden la percepción del mundo como una construcción cognitiva (Morell, 2010; Hoffman, 2000), creemos que el conflicto cognitivo ante la representación visual como tal en el plano (que es percibido por todos) no es abordado en la práctica educativa de manera efectiva, y, a su vez, en el ámbito de la investigación, "parece poco sensato continuar defendiendo el monopolio de la racionalización proyectiva como formulación desde la cual estructurar el pensamiento espacial del estudiante" (Gimenez Morell, 2010, p.118).

En este trabajo, pretendemos comprobar cómo, tanto a nivel de observador como de creador de imágenes, el estudiante del grado de educación no parece tener resueltas sus dudas en cuanto a la ubicación de su punto de vista en el espacio, y, por tanto, es mayor la dificultad que puede tener para entender y explicar los sistemas proyectivos de representación espacial, así como para expresarse gráficamente sobre las personas y los objetos de su entorno.

2 Poco productiva en el sentido que destaca el autor de que las imágenes geométricas "no provienen únicamente del espacio real ni tampoco del espacio matemático de la geometría euclídea". (p.20) 


\section{El Pensamiento Visual en el ámbito educativo.}

“...las disciplinas no educan la mente, sino que nos permiten ver qué significa tener una mente".

Paul Hirst.

Plantear el estudio del pensamiento visual en la pedagogía requiere de un análisis ecléctico de términos y conceptos que intervienen tanto en la didáctica plástica y visual como en la didáctica de las ciencias experimentales y sociales, con sus correspondientes planteamientos y enfoques de la educación. Una causa de dicho eclecticismo se halla en que tanto el pensamiento visual como la inteligencia espacial son constructos duales, vinculados al pensamiento científico y al artístico, y ésta parece ser la principal dificultad en el planteamiento pedagógico del constructo.

Podemos decir que los conceptos de pensamiento visual (visual thinking) y diseño visual (desing thinking) se han introducido en el terreno de la práctica y la investigación educativas, en el epicentro del paradigma arte-ciencia no resuelto. En este ámbito, aunque parece existir un aumento del interés docente por lo visual y una mayor consideración de su importancia en los procesos de aprendizaje, no parece que el pensamiento visual como tal esté considerado como una herramienta de acceso y construcción del conocimiento y, por tanto, nadie plantea que requiera de un cuerpo epistemológico o al menos de un tratamiento diferenciado.

Sin embargo, el término 'visual' posee la cualidad de alterar los significados de conceptos que habitualmente se utilizan en contextos educativos, tales como lenguaje, inteligencia, cultura, alfabetización, expresión, didáctica o competencia. Este último, el de competencia, adquiere diferente significado cuando se matiza con lo visual: ¿Qué ocurre si hablamos de competencia visual en matemáticas o si nos referimos a ella en historia, en biología o en arte? Parece que la precisión del término 'competencia', que induce a pensar en un conjunto de habilidades o destrezas, se dispersa y la 'competencia visual' es otra cosa diferente. Parece que el calificativo visual activa un tipo de pensamiento divergente o complejo, que sugiere distintos tipos de competencias: desde habilidades con números, símbolos, gráficos 
o imágenes geométricas hasta la interpretación de planos, mapas mentales, recursos audiovisuales y obras de arte.

Creemos que los procesos cognitivos visuales, por tratarse de un tema complejo y transversal, con implicaciones en las diferentes disciplinas del currículo, requieren de un estudio particular en el ámbito de la pedagogía, y un análisis del pensamiento visual como constructo, en el marco actual de la educación por competencias, puede contribuir a ello.

\section{1.- Pensamiento Visual y competencias básicas.}

El cambio del modelo de sociedad industrial al de la sociedad de la comunicación lleva consigo una actitud diferente hacia la preparación y formación de sus miembros y esta actitud la debe aportar la pedagogía. Parece claro que los planteamientos pedagógicos actuales deben ser diferentes en cuanto que son otras las necesidades educativas de la sociedad, y por tanto cambian sus requisitos de formación. Estos cambios sociales también son el reflejo de nuevos conocimientos, y los requisitos de formación plantean la reformulación de las habilidades a adquirir por los agentes educativos. En respuesta al interés de la sociedad por mejorar la educación en términos de calidad y satisfacer las demandas cambiantes de habilidades, la Red de Información sobre la Educación en Europa (EURYDICE, 2002) formula las competencias clave. El planteamiento surge como alternativa al término de cualificación, y con el fin de unificar en torno a ellas los principios de la educación básica en los distintos países europeos y a su vez los estándares de evaluación de los alumnos, pero también para profesionalizar la formación de los maestros en la educación superior.

Un concepto moderno, el de la innovación, se incorpora a la educación como respuesta a la necesidad de cambios en las actitudes hacia la transmisión del conocimiento y el significado de éste, así como a la necesidad de replantear el interés por aprender a cualquier edad. Cada vez más, se habla de la escasa permanencia de los contenidos de aprendizaje, de una mayor necesidad de generar preguntas que de ofrecer respuestas, de la adaptación a nuevos 
entornos y recursos, en una era de acceso, y también de exceso, de información. La tecnología está dirigiendo la alfabetización en múltiples direcciones (Reig, 2013). Los esfuerzos pedagógicos apuntan hacia una mayor precisión en las necesidades educativas y en los procesos de construcción del conocimiento. La explosión de cursos abiertos (Massive Open Online Course, MOOC), son muestra del avance de una pedagogía constructivista, innovadora, con un fuerte componente visual, que promueve el intercambio del conocimiento, acorde a la extensión de tecnologías y comunicaciones de la sociedad posmoderna.

Es este un nuevo escenario educativo que se basa en una definición más amplia o abierta de la inteligencia y el aprendizaje, que pretende la idea de que construimos el conocimiento (comprendemos) a partir de la forma en que organizamos la información recibida y de que lo hacemos más allá de las disciplinas (Gardner et al., 1994). Este escenario es el de un sistema educativo que debe adaptarse a los cambios de un "mundo en rápida mutación" formando "para la innovación de personas capaces de evolucionar" a este ritmo (Zabala y Arnau, 2007); y es en este contexto, que planteamos la necesidad de definir la competencia visual en la pedagogía.

El concepto de competencia ocupa un importante debate pedagógico en Europa. Para la Agencia Ejecutiva en el ámbito Educativo, Audiovisual y Cultural de la Unión Europea (EACEA), la definición de competencia es más "una cuestión de terminología que de concepto" (EURYDICE, 2002, p.31). Aunque la formulación del término reconoce su nacimiento entre la confusión terminológica y deja abierta su definición operativa a los países miembros, la competencia se define como "la capacidad efectiva para llevar a cabo con éxito una actividad plenamente identificada" (Proyecto DeSeCo, 2002). Así, el Centro de Investigación e Innovación Educativa (CERI, Centre for Educational Research and Innovation), en el marco europeo de la Organización para la Cooperación y el Desarrollo Económico (OCDE), adopta una definición de competencia en una triple acepción de capacidad como conocimiento (saber), habilidad (saber hacer) y actitud (saber ser). Mientras tanto, en lo terminológico, la Real Academia Española (RAE) vincula la competencia y la capacidad con la aptitud, que, al igual que la habilidad, es la capacidad para operar competentemente en una determinada actividad (define la 
competencia como aptitud y pericia o idoneidad para hacer algo, y la capacidad como aptitud y talento para el ejercicio de algo).

Recordemos que en la base de este esfuerzo para la creación de un marco de referencia europeo, se sitúa la tarea otorgada a la Comisión Internacional sobre la Educación para el Siglo XXI, fundada en 1993 y financiada por la UNESCO a través del Instituto Internacional de Planeamiento de la Educación (IIPE); tarea que encuentra su primer problema en el eclecticismo del terreno educativo y el exceso de información:

"El primer problema-y tal vez el más importante-con que se enfrentó la Comisión presidida por Jacques Delors fue la extraordinaria diversidad de situaciones, concepciones y estructuras de la educación. Otro problema, directamente relacionado con éste, era el que representaba la enorme cantidad de información disponible, con la imposibilidad evidente de que la Comisión pudiera asimilar algo más que una pequeña parte al realizar su labor. La Comisión tuvo, pues, que ser selectiva y escoger lo que era esencial para el futuro, teniendo en cuenta, por un lado, las tendencias geopolíticas, económicas, sociales y culturales, y, por otro, la influencia que pudieran tener las políticas de educación."

(UNESCO, 1997, p.41)

La selección de la información obliga a definir una estrategia de trabajo, más marcada por criterios profesionalizantes que pedagógicos:

"Se eligieron seis orientaciones para la investigación, que permitieron a la Comisión abordar su tarea desde el punto de vista de los objetivos, tanto individuales como sociales, del proceso de aprendizaje: educación y cultura; educación y ciudadanía; educación y cohesión social; educación, trabajo y empleo; educación y desarrollo; y educación, investigación y ciencia. Estas seis orientaciones se completaron con tres temas transversales más directamente relacionados con el funcionamiento de los sistemas de educación: tecnologías de la comunicación; los docentes y la enseñanza; y financiación y gestión."

(UNESCO, 1997, p.42) 
Desde una perspectiva cultural, las conclusiones de este proceso de armonización europeo de la educación apuntan hacia un futuro de la educación y la investigación, más definido por el interés de responder a las demandas laborales y económicas de un mercado global, que por el interés epistemológico de ambas (García Ruiz, 2008).

La aportación que realiza, desde una perspectiva pedagógica, parece poco significativa en el aspecto del desarrollo y el aprendizaje. Quizás debido al exceso de enfoques teóricos (Weinert, 1999), tal vez porque en la comisión base del estudio tan solo uno de los quince miembros tiene formación especializada en pedagogía; o tal vez por la ya existente falta de "univocidad" en el lenguaje académico y científico al respecto (Gimeno Sacristán, 2008, p.38). Lo que sí se ha de reconocer es que el análisis conceptual del término de competencia ha generado una considerable producción literaria en todos los ámbitos de la educación (Moya, J. y Luengo, 2010; Gimeno Sacristán, 2008; Romero, J. y Gómez, 2007).

El concepto de competencia fue definido por Greimas y Courtés (1982) como una estructura compuesta por cuatro dimensiones: por un lado, la dimensión volitiva o un querer hacer, la dimensión deóntica o un deber hacer, la dimensión cognitiva, es decir, un saber hacer y la dimensión potestiva o un poder hacer. Las dimensiones volitiva y deóntica dirigen las motivaciones de la acción pero no forman parte de lo que hace competente a un sujeto para el hacer (Serrano, 2003). En primera instancia, la competencia está compuesta o supraordina dos competencias: la competencia potestiva (poder hacer), que rige las condiciones objetivas, materiales y espaciotemporales, y la competencia cognitiva (saber hacer).

Esta definición resuelve que somos competentes en la medida que sabemos hacer algo $\mathrm{y}$, a su vez, en la medida que podemos hacerlo, aunque para producirse, la acción requiere que queramos o sintamos el deber de hacerlo. De esta manera, la habilidad se vincula a la destreza, referida al aprendizaje motor, y el aprendizaje se basa en la aptitud y la motivación, en lo que coincide la psicología de la inteligencia. Aunque deja sin resolver y queda abierta la discusión sobre la ubicación en esta estructura del aspecto genético de la competencia: el talento (fig. 44). 
El trabajo de la comisión europea, si bien resalta la importancia de "concebir la educación como un todo", define el aspecto cognitivo de la competencia (aprender a conocer), como el logro de "una cultura general lo suficientemente amplia" para combinarlo con la posibilidad de profundizar los conocimientos en una materia y aprendizajes futuros (UNESCO, 1997, p.34). En esta formulación, el término competencia recupera la ambigüedad clásica de la cultura general, que se define ahora como la capacidad efectiva para desarrollar una actividad. Los conocimientos del saber se convierten en las capacidades del hacer, dando a entender con un giro mercadotécnico, que hasta ahora intelecto y habilidad habían estado separados.

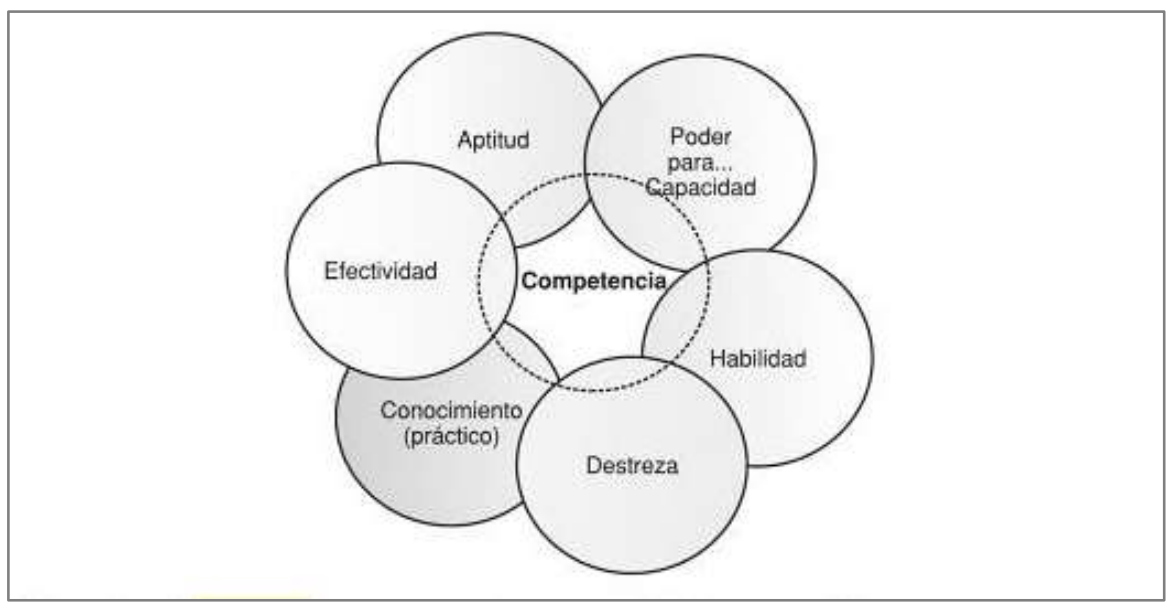

Fig.44. Concepto de competencia y su significado compartido con otros conceptos al uso (Gimeno Sacristán, 2008)

Esta referencia ambigua da lugar a que la comisión deje la concreción y el detalle de estas capacidades a las legislaciones educativas de cada país miembro, a través de la formulación de competencias básicas o competencias clave (key skills es el término anglosajón adoptado). En la actual legislación española se citan las recomendaciones del parlamento europeo sobre las competencias clave para el aprendizaje permanente, donde se definen éstas como "una combinación de conocimientos, capacidades y actitudes adecuadas al contexto" (CE, 2006) y en la declaración de las enseñanzas mínimas se relaciona la contribución que hace cada materia al desarrollo de estas competencias (RDL 1190/2012, de 3 de agosto, y RDL 1146/2011, de 29 de julio). (fig.45) 

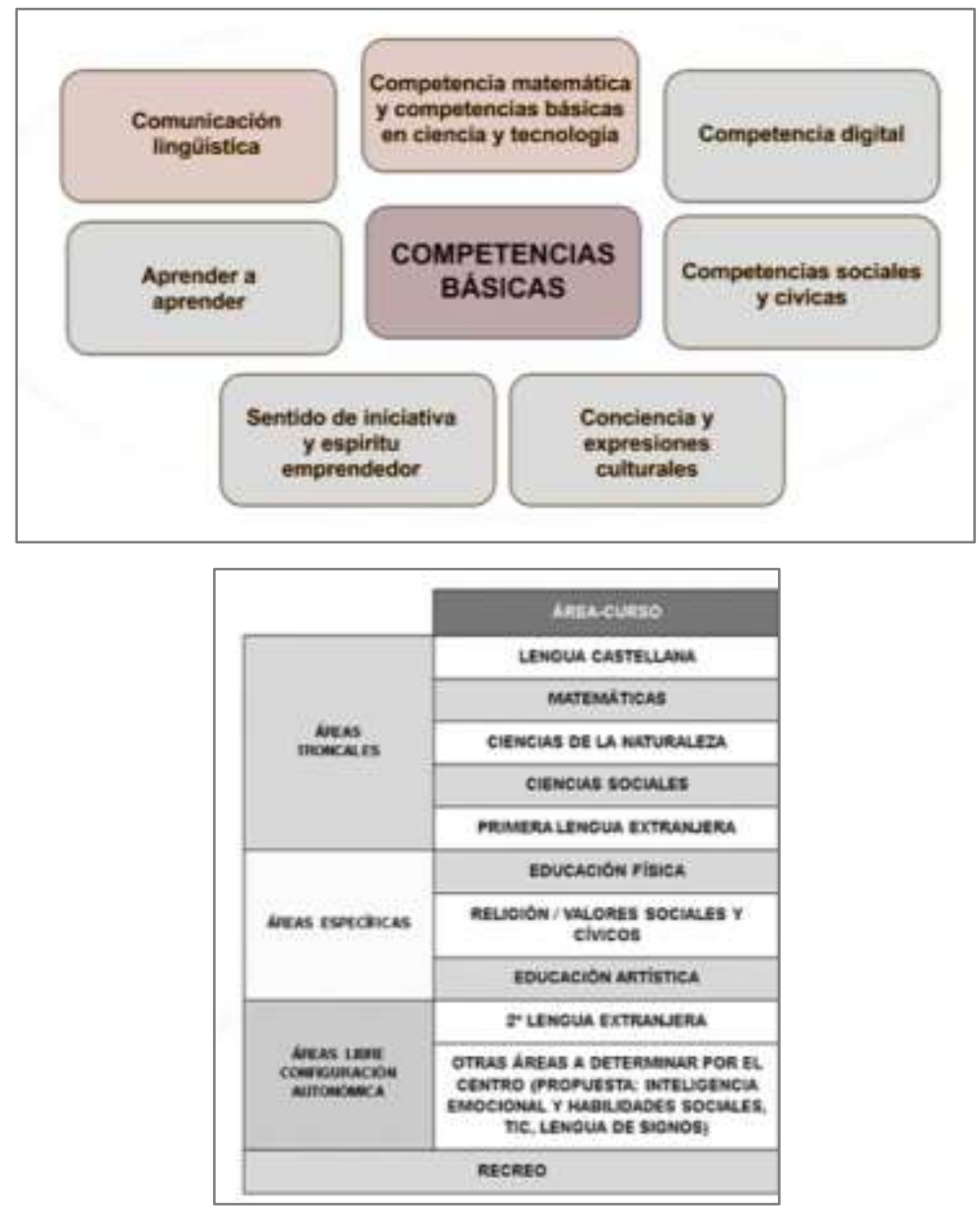

Fig.45. Competencias básicas, áreas y asignaturas de la educación primaria.

Conocer la situación actual del conjunto de habilidades visuales y gráficas reflejadas en el sistema educativo basado en las competencias requiere el análisis de las recomendaciones, pautas y normas que recoge la legislación referida a la educación básica, ya que estas son la referencia en la orientación la actividad de los centros educativos.

Los documentos marco europeos de referencia ${ }^{3}$ para la actual legislación educativa consideran que las capacidades básicas fundamentales de la lengua, la lectura y la escritura, el cálculo y las tecnologías de la información y la comunicación (TIC) constituyen el fundamento esencial para el aprendizaje, aunque admiten "una serie

Informe conjunto de 2010 del Consejo y de la Comisión sobre la puesta en práctica del programa de trabajo "Educación y formación 2010". - Conclusiones sobre un marco estratégico para la cooperación europea en el ámbito de la educación y la formación (ET 2020). - Recomendación del Parlamento Europeo y del Consejo de 18 de diciembre de 2006 sobre las competencias clave para el aprendizaje permanente. 
de temas que se aplican a lo largo del marco de referencia y que intervienen en las ocho competencias clave: el pensamiento crítico, la creatividad, la capacidad de iniciativa, la resolución de problemas, la evaluación del riesgo, la toma de decisiones y la gestión constructiva de los sentimientos" (Parlamento Europeo, 2006, p. 394/14).

Este documento, que define las competencias clave, distingue un modo de pensamiento espacial y destaca los aspectos gráficos en la competencia matemática, que: "...entraña en distintos grados la capacidad y la voluntad de utilizar modos matemáticos de pensamiento (pensamiento lógico y espacial) y de representación (fórmulas, modelos, construcciones, gráficos y diagramas)" (CE, 2006, p. 394/16). Todos los documentos aluden a aspectos audiovisuales en el establecimiento de las competencias clave (CE, 2006; Consejo Europeo, 2009; CUE, 2010).

En la actual ley orgánica de educación (LOMCE), aparecen referidos en las competencias del área de educación plástica, visual (y audiovisual): "utilizar diferentes representaciones y expresiones artísticas e iniciarse en la construcción de propuestas visuales $y$ audiovisuales" (Ley Orgánica 8/2013), y en la competencia de comunicación audiovisual dentro de la asignatura de Cultura Audiovisual. No aparece ningún aspecto visual en referencia a las competencias básicas en la legislación de las enseñanzas mínimas de la educación primaria, y es en la de la enseñanza secundaria obligatoria (ESO) donde aparece asociado a la competencia digital.

El diseño del currículo es entendido en la ley actual como la "regulación de los elementos que determinan los procesos de enseñanza y aprendizaje para cada una de las enseñanzas y etapas educativas" (Real Decreto 126/2014) y son numerosas las referencias al uso de los medios audiovisuales y tecnológicos en todas las áreas de la educación básica en este documento. Siguiendo la jerarquía de concreción curricular, en las disposiciones sobre el currículo que hace la comunidad autónoma (Orden EDU/519/2014), a partir del real decreto 126/2014, se refieren los aspectos visuales y gráficos de las competencias de cada asignatura de manera específica. Aspectos que dividimos en las áreas científicas: 
"Emplear correctamente planos y mapas interpretando su escala y signos convencionales y manejar programas informáticos para visualizar diferente cartografía, con base en la fotografía aérea e imágenes de satélite."

(Ciencias sociales, p.44283)

"Utilizar diferentes técnicas de exposición oral y escrita de los resultados obtenidos tras la realización de diversas experiencias, presentándolos con apoyos gráficos."

(Ciencias de la naturaleza, p.44226)

"Por ello se debe favorecer el desarrollo de estas capacidades (matemáticas) que facilitarán el razonamiento lógico de tipo inductivo y deductivo, la percepción y visualización espacial y el fomento del rigor y la precisión tanto en la exposición de argumentos como en la valoración de los razonamientos de los demás".

(Matemáticas, p.44408)

"El aprendizaje de la geometría requiere pensar y hacer, y debe ofrecer continuas oportunidades para clasificar, construir, dibujar, modelizar y medir, desarrollando la capacidad para visualizar relaciones geométricas."

(Matemáticas, p. 44409)

"Posibilidades sensoriales: Experimentación, exploración y discriminación de las sensaciones: visuales, auditivas, táctiles, olfativas y cinestésicas. Utilización de la percepción auditiva, visual y táctil en la realización de actividades motrices." (Conocimiento corporal-Educación física, 44627)

(ORDEN EDU/519/2014, de 17 de junio)

Y en el área artístico-plástica, exceptuando las referencias visuales a los aspectos artísticos propios del área: 
"Emplear correctamente planos y mapas interpretando su escala y signos convencionales y manejar programas informáticos para visualizar diferente cartografía, con base en la fotografía aérea e imágenes de satélite."

(Ciencias sociales, p.44283)

"Utilizar diferentes técnicas de exposición oral y escrita de los resultados obtenidos tras la realización de diversas experiencias, presentándolos con apoyos gráficos."

(Ciencias de la naturaleza, p.44226)

"Por ello se debe favorecer el desarrollo de estas capacidades (matemáticas) que facilitarán el razonamiento lógico de tipo inductivo y deductivo, la percepción y visualización espacial y el fomento del rigor y la precisión tanto en la exposición de argumentos como en la valoración de los razonamientos de los demás".

(Matemáticas, p.44408)

"El aprendizaje de la geometría requiere pensar y hacer, y debe ofrecer continuas oportunidades para clasificar, construir, dibujar, modelizar y medir, desarrollando la capacidad para visualizar relaciones geométricas."

(Matemáticas, p. 44409)

"Posibilidades sensoriales: Experimentación, exploración y discriminación de las sensaciones: visuales, auditivas, táctiles, olfativas y cinestésicas. Utilización de la percepción auditiva, visual y táctil en la realización de actividades motrices."

(Conocimiento corporal-Educación física, 44627)

(ORDEN EDU/519/2014, de 17 de junio)

Los ambiciosos, pero tan diferentes, contenidos de aprendizaje que engloba esta área, entendida muchas veces como un "cajón de sastre" (Cuenca, 1997), hacen que su formulación curricular no diferencie con claridad entre la producción artística y el desarrollo de las destrezas manuales básicas, tal vez por la dificultad de compartir espacio con la educación audiovisual y el dibujo geométrico, relacionados estrechamente con otras áreas, y que la vincula con la competencia digital y matemática: 
Bloque 1: Educación audiovisual. Está referido al estudio de la imagen en todas sus manifestaciones, tanto visual como audiovisual. En este bloque cobran una gran relevancia las aportaciones de las Tecnologías de la información y la comunicación, en especial a la fotografía y el cine.

Bloque 2: Educación artística. En este bloque se engloban las producciones artísticas más creativas, el uso de diferentes técnicas pictóricas, de modelado y construcción, así como el desarrollo de las destrezas manuales básicas.

Bloque 3: Dibujo geométrico. Se entiende como una aplicación directa de los conocimientos adquiridos en el área de matemáticas, representando gráficamente determinados conceptos geométricos. Se introduce el conocimiento y uso de las técnicas e instrumentos propios del dibujo técnico, y la valoración de la limpieza y exactitud de los trabajos realizados con ellos.

(Orden EDU/519/2014, p.44560)

Del análisis legislativo podemos formular tres consideraciones:

La primera, relacionada con este apartado, muestra la vinculación estrecha que hace el currículo entre la competencia digital, matemática y artística. Aunque puede responder a la teoría del 'cajón de sastre', parece más bien responder a la justificación de que las habilidades visuales y gráficas guardan relación transversal con las competencias; tal como se expresa en la formulación del área matemática, donde la geometría "debe ofrecer continuas oportunidades para clasificar, construir, dibujar, modelizar y medir, desarrollando la capacidad para visualizar relaciones geométricas. Todo ello se logra estableciendo relaciones constantes con el resto de los bloques del área y con otros ámbitos como el mundo del arte o de la ciencia" (p.44409). No se comprende entonces por qué la geometría se duplica en el currículo, dando a entender que existen dos geometrías, una simbólica en las ciencias exactas y otra visual en el diseño y el arte, lo cual no responde a ninguno de los criterios de clasificación existentes.

La segunda consideración se refiere a que no se plantea una estructuración de la capacidad visual y gráfica en función de la 
diferenciación comprensión-producción, que sin embargo queda delimitada en la competencia lingüística en sus dos ámbitos de la comprensión y de la producción de textos orales y escritos. La lógica de la separación entre lectura visual y producción gráfica, que creemos necesaria para abordar la capacidad gráfica se diluye en una triple y compleja combinación de contenidos: en la educación audiovisual, entre los soportes de la imagen fotográfica con los de la imagen digital; en la educación artístico-plástica entre el patrimonio artístico y las teorías del arte contemporáneo y, en el dibujo geométrico entre el dibujo artístico y el técnico. Parece inútil esperar que de la unión de estos tres bloques dispares configure un resultado armónico con el desarrollo infantil de la capacidad gráfica.

Y una tercera consideración trata sobre la contradictoria referencia a la investigación en la justificación de las áreas y la transversalidad de las competencias. El texto legislativo no referencia ninguna competencia gráfica o visual en el área artística como sí lo hace en la justificación de las áreas lingüística y matemática, como es el caso de la lengua extranjera: “...Así, numerosas investigaciones demuestran que, a nivel cognitivo, el aprendizaje de lenguas extranjeras en edades tempranas propicia una mejora de los resultados en otras competencias como la matemática, la artística o el dominio en la lectoescritura." (p. 44486); y en el caso de la matemática que "contribuye al desarrollo cognitivo a través de la obtención de destrezas en procesos de exploración, clasificación, análisis, estimación, relación, generalización, argumentación y abstracción. Por ello se debe favorecer el desarrollo de estas capacidades que facilitarán el razonamiento lógico de tipo inductivo y deductivo, la percepción y visualización espacial y el fomento del rigor y la precisión tanto en la exposición de argumentos como en la valoración de los razonamientos de los demás" (p.44408). Curiosa y contradictoriamente, se justifica el desarrollo de la capacidad de visualización y razonamiento espacial en el área científicomatemática, pero ésta se asigna a los objetivos y contenidos del área artístico-plástica.

La investigación en ciencias de la educación tiene sin duda su mejor campo de aplicación en el diseño del currículo, pero esta aplicación no se puede dar, mientras no se defina el ámbito de las capacidades visuales y gráficas que se sitúan en la raíz del lenguaje 
visual. De igual forma, el concepto de lenguaje visual como tal no es recogido en la justificación del área o queda diluido: "Los lenguajes artísticos, los plásticos y los musicales, nos permiten expresar y compartir ideas y sentimientos que son comunes a todas las culturas desde la antigüedad" (p.44559). Sin duda diluido, ya que en esta descripción podríamos incluir: ...junto a la pintura rupestre y los fractales, la literatura, la danza, y la poesía; o podemos preguntarnos si los números o las letras no conectan acaso con las ideas y los sentimientos. En lo referente al lenguaje visual, el texto legal manifiesta un grado de ambigüedad difícil de entender en la declaración de principios de un currículo educativo.

Volviendo al ámbito de competencias del currículo, éste se define, además de por sus objetivos y métodos, por los contenidos y actividades de aprendizaje, pero a su vez, por el tiempo que les dedica y por los requisitos o criterios para evaluarlos (fig. 46). Por la definición de los contenidos sabemos qué se enseña, pero no cómo se aprende ni las competencias o capacidades que se desarrollan. Para ello, el decreto que establece el currículo describe también indicadores que denomina estándares de aprendizaje evaluables.

\begin{tabular}{|c|c|c|c|c|}
\hline IV. GRADO DE ADQUISICIÓN DE LAS COMPETENCIAS & 1 & 2 & 3 & 4 \\
\hline 1. COMPETENCIA EN COMUNICACIÓN LINGÜISTICA & & & & \\
\hline 2. COMPETENCIA MATEMÁTICA Y COMPETENCIAS BÁSICAS EN CIENCIA Y TECNOLOGIAA & & & & \\
\hline 3. COMPETENCIA DIGITAL & & & & \\
\hline 4. APRENDER A APRENDER & & & & \\
\hline 5. COMPETENCIAS SOCIALES Y CIVICAS & & & & \\
\hline 6. SENTIDO DE INICIATIVA Y ESPIRITU EMPRENDEDOR & & & & \\
\hline 7. CONCIENCIA Y EXPRESIONES CULTURALES & & & & \\
\hline
\end{tabular}

Fig.46. Evaluación de las competencias (Orden EDU/519/2014, p.44772)

La evaluación de competencias plantea grandes dificultades en la evaluación, pero éste no es un problema nuevo. La decisión de qué aspectos cognitivos, emocionales, actitudes y valores se van a evaluar y el cómo hacerlo, siempre las ha planteado (Villardón Gallego, 2006; Zabala y Arnau, 2007; Cano García, 2008). Los estándares de evaluación guardan un estrecho vínculo con la declaración de intenciones en la formulación de los objetivos educativos, así como con la metodología de enseñanza-aprendizaje. La falta de ideas y debate en el origen de esta reforma portadora de 
competencias, la falta de "discurso curricular" (Gimeno Sacristán, 2008, p.207), deriva en la evaluación anecdótica de unas competencias (grado de adquisición en una escala de 1 a 4), frente a la evaluación eficiente, a través de exámenes 0 pruebas estandarizadas, de las competencias lingüística y matemáticocientífica (fig. 47).

Esta deriva puede estar convirtiendo la evaluación basada en competencias en un marketing de presentación de resultados, en una nueva mirada de apariencia técnica, cuando en realidad se mantiene una concepción tradicional: poner calificaciones y sobrevalorar las notas de unas capacidades, lingüística y matemática (lecto-escritura y cálculo), frente a otras capacidades y esa 'otra serie de temas'. Y quizás nos estemos olvidando, en un infructuoso debate terminológico, del objetivo inicial, que alumnos y profesores "aprendan mejor y estén más preparados para afrontar el futuro" (Cano García, 2008, p. 14).

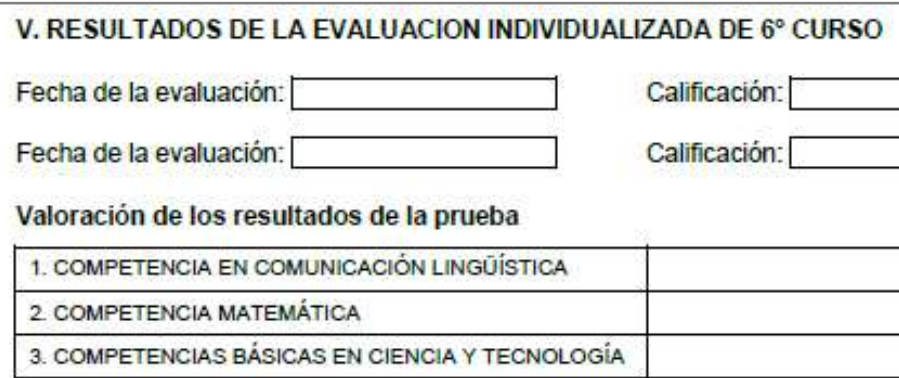

Fig. 47: Modelo de Ficha de evaluación (ORDEN EDU/519/2014, p. 44773)

Sin embargo, el currículo concretado en el sistema educativo, sí señala indicadores de evaluación acentuando el apoyo visual del aprendizaje y el uso de recursos audiovisuales. De forma específica, los aspectos de representación visual se recogen en todas las áreas a través de la evaluación del uso de técnicas dibujísticas, la interpretación del espacio, de planos y mapas, el manejo de software de imagen digital, el análisis de los elementos básicos de la imagen, la animación, etc. 
- Emplear correctamente planos y mapas interpretando su escala y signos convencionales y manejar programas informáticos para visualizar diferente cartografía, con base en la fotografía aérea e imágenes de satélite.

(Ciencias sociales, p.44283)

- Analiza de manera sencilla y utilizando la terminología adecuada imágenes fijas atendiendo al tamaño, formato, elementos básicos (puntos, rectas, planos, colores, iluminación, función...)

(Educación audiovisual, p.44562).

- Maneja programas informáticos sencillos de elaboración y retoque de imágenes digitales (copiar, cortar, pegar, modificar tamaño, color, brillo, contraste...) que le sirvan para la ilustración de trabajos con textos.

(Educación audiovisual, p.44562).

- Utiliza las técnicas dibujísticas y/o pictóricas más adecuadas para sus creaciones.

(Educación artística, p.44565)

- Utiliza el punto, la línea y el plano al representar el entorno próximo y el imaginario.

(Educación artística, p.44565)

- Organiza el espacio de sus producciones bidimensionales utilizando conceptos básicos de composición, equilibrio y proporción.

(Educación artística, p.44566)

- Identificar conceptos geométricos en la realidad que rodea al alumno relacionándolos con los conceptos geométricos contemplados en el área de matemáticas con la aplicación gráfica de los mismos.

(Educación artística, p.44567)

- Identifica los conceptos de horizontalidad y verticalidad utilizándolo en sus composiciones con fines expresivos.

(Educación artística, p.44567)

- Analiza la realidad descomponiéndola en formas geométricas básicas y trasladando la misma a composiciones bidimensionales.

(Educación artística, p.44568)

(ORDEN EDU/519/2014, de 17 de junio) 
El análisis del currículo oficial permite concluir que, si bien todos los aspectos citados aparecen considerados en la formulación teórica de los objetivos y métodos de la educación primaria, y, a su vez, están incluidos en la formulación de estándares evaluativos, no obstante, los aspectos del pensamiento visual aparecen dispersos y sin relación entre ellos a través de las áreas, sin referencias de transversalidad. A su vez, muchas actividades específicas de su desarrollo, que necesitan de tiempo real para llevarse a cabo, se encuentran dentro de áreas no troncales, resultando poco relevantes, por su poco peso en la distribución horaria. (fig.48).

\begin{tabular}{|c|c|c|c|c|c|c|c|c|c|}
\hline & & ÁREAS & \begin{tabular}{|c|}
\multicolumn{1}{|c|}{ otal } \\
horas \\
semana \\
\end{tabular} & $\begin{array}{l}19 \\
\text { curso }\end{array}$ & $\begin{array}{l}20 \\
\text { curso }\end{array}$ & $\begin{array}{l}\text { 3o } \\
\text { curso }\end{array}$ & $\begin{array}{l}40 \\
\text { curso }\end{array}$ & $\begin{array}{l}50 \\
\text { curso }\end{array}$ & $\begin{array}{l}69 \\
\text { curso }\end{array}$ \\
\hline \multirow{8}{*}{ 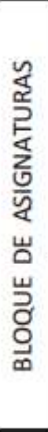 } & \multirow{5}{*}{ 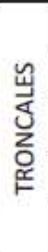 } & CIENCIAS SOCIALES & 12,5 & 1,5 & 1,5 & 2 & 2,5 & 2,5 & 2,5 \\
\hline & & CIENCIAS DE LA NATURALEZA & 12 & 1,5 & 1,5 & 1,5 & 2,5 & 2,5 & 2,5 \\
\hline & & LENGUA CASTELLANA Y LITERATURA & 32 & 6 & 6 & 6 & 4,5 & 4,5 & 5 \\
\hline & & MATEMÁTICAS & 28,5 & 5 & 5 & 5 & 4,5 & 4,5 & 4,5 \\
\hline & & PRIMERALENGUAEXTRANJERA & 16 & 2 & 2,5 & 2,5 & 3 & 3 & 3 \\
\hline & \multirow{3}{*}{ 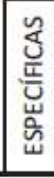 } & EDUCACIÓN ARTÍSTICA (*) & 13 & 2,5 & 2 & 2 & 2,5 & 2 & 2 \\
\hline & & EDUCACIÓN FÍSICA & 13,5 & 2,5 & 2,5 & 2 & 2 & 2,5 & 2 \\
\hline & & $\begin{array}{l}\text { RELIGIÓN / VALORES SOCIALES Y } \\
\text { CÍVICOS }\end{array}$ & 7,5 & 1,5 & 1,5 & 1,5 & 1 & 1 & 1 \\
\hline & & RECREO & 15 & 2,5 & 2,5 & 2,5 & 2,5 & 2,5 & 2,5 \\
\hline & & TOTAL & 150 & 25 & 25 & 25 & 25 & 25 & 25 \\
\hline & & $\begin{array}{l}\text { I horario destinado al área de Educa } \\
\text { s enseñanzas de Música. }\end{array}$ & Artis & as & al & 1 & sen & por & \\
\hline
\end{tabular}

Fig.48: Asignaturas por áreas en educación primaria (ORDEN EDU/519/2014, p. 44764) 


\section{2.- Pensamiento Visual y aprendizaje.}

A la pregunta de ¿cómo funcionan los ojos?, una niña responde: "Es como un espejo que refleja la imagen al cerebro, hay una retina que recoge la imagen y la manda, al revés, al cerebro, que la pone al derecho... ¿y qué pasa en el ojo?: Que lo analiza y busca lo que es y la relación que tiene contigo." (Escudero, 1975).

Los niños no solo analizan lo que ven, también analizan sus cogniciones. En la escuela moderna, los aspectos cognitivos visuales siempre han estado relacionados con la formación artística básica de los alumnos. En la actualidad, debido al recorrido del concepto de la educación visual, estos aspectos están tan vinculados o más (posiblemente por influencia de las ciencias cognitivas) a otros ámbitos de la formación docente, como las técnicas de aprendizaje, las nuevas tecnologías, la realidad aumentada o la inteligencia artificial. Hoy día utilizamos técnicas de exploración visual (eyetracking), extrayendo conclusiones de usabilidad que se utilizarán en entornos educativos (Montero et al., 2010), o analizamos la influencia de las pantallas en los procesos cognitivos de las emociones para reforzar la concepción comunicacional de la educación (Ferrés i Prats, 2014). En esta línea, solemos considerar la relevancia e inmediatez que tiene la imagen frente al texto. Las emociones tienen una carga evocadora visual muy importante, y su estudio se relaciona con la expresión facial. Las expresiones del rostro tienen un poder universal evocador y descriptivo en matices, superior a la palabra (fig. 49).

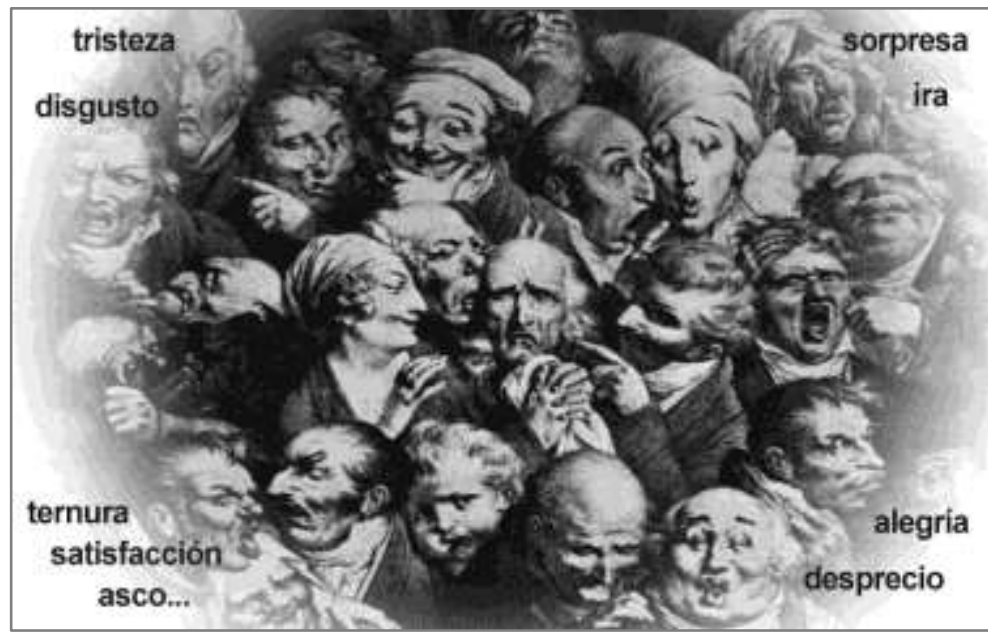

Fig. 49: Expresión visual de las emociones. Litografía (Fox Talbot, 1844) 
Nada apunta a considerar que los procesos cognitivos relacionados con la visión, que nos llevan a analizar rostros, formas y espacios y permiten su representación, sea una habilidad artística. El problema puede estar en la falta de un tratamiento educativo como competencia básica, pero en cualquier caso, se refieren a unas capacidades, habilidades o destrezas relacionadas con el gesto gráfico que están detrás del arte, pero igualmente tras el software, las pantallas, pizarras... y tantos recursos basados en la imagen.

Como hemos visto, las capacidades cognitivas basadas en la percepción visual y el control motor quedan vinculadas, dentro del currículo, preferentemente al área de competencia artística (plástica y visual), y arrastran consigo las capacidades expresivas no artísticas vinculadas al lenguaje visual, aspectos específicos de la semiótica de la imagen y del lenguaje gráfico científico.

Existe cierta confusión sobre la terminología educativa relacionada con los aspectos cognitivos del pensamiento visual. Aunque en ocasiones se mencionan de manera específica como competencias o capacidades (visuales y gráficas), generalmente estos aspectos se enmarcan dentro de otras competencias (artística, audiovisual, matemática, de comunicación o digital), que tampoco tienen siempre una definición unívoca. Cuestiones relacionadas con el $\mathrm{PV}$, que van desde el reconocimiento facial de la expresión emocional, de una cualidad como el color o la distancia, una medida, el cálculo de una proporción, de un ángulo, hasta trazar un croquis, describir una habitación o un movimiento, pueden enmarcarse en competencias dispares. $Y$ creemos que estas capacidades pueden presentar dificultades de desarrollo que, en muchos casos, pasan inadvertidas como consecuencia de una indefinición en el periodo educativo.

Desde la antigüedad, el ser humano se ha apoyado en ayudas visuales para pensar. Ciertos gestos, que producían los grafismos en las rocas o en el suelo, son los mismos que se han aplicado con el tiempo a diferentes soportes: las pizarras, pergaminos, y papel, hasta los modernos proyectores y pantallas.

A lo largo del siglo $\mathrm{XX}$, el estudio del pensamiento visual en el ámbito de las ciencias de la educación, refleja las aportaciones de la 
psicología en el aprendizaje, y terminando el siglo, el de las neurociencias. Para la pedagogía moderna, el aprendizaje, como proceso cognitivo es un proceso activo. El individuo no recibe el conocimiento (de alguien o de algo) sino que lo crea, lo construye a partir de la experiencia activa. La actividad se define como el conjunto de "procesos específicos que realizan una relación activa con la realidad" (Leontiev, 1981); un sistema que tiene su estructura y desarrollo propios. La teoría de la actividad habla de 'apropiación' como la manera de construir conocimiento, destacándolo como proceso social:

"Ese proceso (de apropiación) se realiza durante la actividad que el niño desarrolla con respecto a objetos y fenómenos del mundo del entorno, en los que se concretan esas adquisiciones de la humanidad. Dicha actividad no puede formarse por sí misma en el niño; se forma mediante la comunicación práctica y verbal con las gentes que le rodean, en una actividad común con ellos. Cuando el objetivo de esta actividad consiste precisamente en transmitir al niño unos conocimientos, prácticas y aptitudes, decimos que el niño aprende y el adulto enseña.

En algunas ocasiones, parece como si el niño, en ese proceso, no hiciera más que poner en práctica aptitudes y funciones psíquicas que la naturaleza le ha dado, que su éxito depende de ellas, mas no es así. Sus aptitudes humanas se van formando durante el proceso"

(Leontiev, 1981, p.262)

El conjunto de acciones visuales que realizamos para apropiarnos de la realidad, considerando su aplicación en la educación, se pueden reunir en dos grupos de actividad: perceptiva concreta (imagen visual del objeto) y perceptiva abstracta (traducida a esquemas y símbolos) (Talizina et al., 2010). La teoría constructivista y la de la actividad sitúan el conocimiento como algo abstracto, que se construye a través de experiencias concretas. De esta forma, tanto la ciencia como el arte y la filosofía, son entendidos como los entornos que proporcionan los medios para llevar adelante esa construcción.

En cuanto al análisis de la percepción como actividad, también se considera que ésta implica una toma de decisiones en relación a diferentes motivos (cualidades o creencias) que plantearán tres tipos de representación cognitiva: enactiva, icónica y simbólica (Bruner, 
1988). La primera queda asociada a la acción motora física, visual y manipulativa o kinestésica. Las representaciones icónica y simbólica requieren de una construcción a partir de esquemas espaciales tras la madurez del sistema motor: "Los más antiguos símbolos escritos eran representaciones pictóricas" (Bruner et al., 2001, p.270). Ambas son resultado del proceso de imaginación, pero aunque Bruner asigna a la representación simbólica el nivel superior del desarrollo, aconseja a los educadores que utilicen en las escuelas la representación por la acción y la representación icónica para dotar de significatividad al aprendizaje.

Desde este punto de vista de la psicología del desarrollo, a partir de las teorías constructivista y de la actividad, David Kolb (2005) desarrolla en la década de los setenta el modelo experiencial (fig. 50), que explica el aprendizaje con un ciclo continuo de cuatro etapas: Experiencia concreta, Observación reflexiva, Conceptualización abstracta y Experimentación activa. Las dos primeras relacionan al aprendizaje con la experiencia perceptiva y las otras dos al procesamiento cognitivo de los contenidos y su transferencia a la realidad y a futuros aprendizajes.

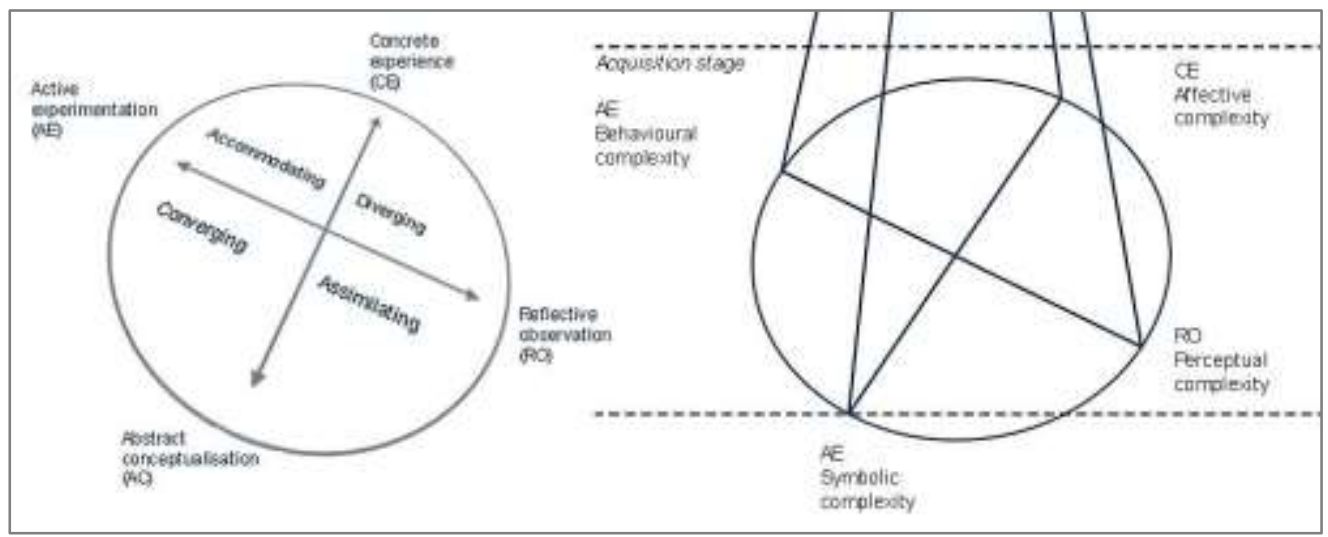

Fig.50. Modelo Experiencial de Kolb (Coffield et al., 2004)

Si el constructivismo indaga en cómo se producen los procesos cognitivos del aprendizaje de manera universal, a través de la asimilación y la acomodación de experiencias, la pedagogía moderna se va a centrar en la manera de procesar la información para construir conocimiento, para entender las diferencias individuales en el rendimiento educativo. Para ello utiliza el concepto de estilo de aprendizaje, que se define como el conjunto de "rasgos cognitivos, 
afectivos y fisiológicos, que sirven como indicadores relativamente estables, de cómo los discentes perciben, interrelacionan y responden a sus ambientes de aprendizaje" (Alonso et al., 1994). Y se van a plantear categorías de estilos de aprendizaje de diversa índole y en diferentes ámbitos de la educación.

El modelo de Kolb (fig. 51) de secuenciación del aprendizaje va a permitir la clasificación de estilos de aprendizaje por las preferencias de los alumnos: el activo aprende experimentando, el reflexivo aprende observando, el teórico aprende pensando, y el pragmático aprende haciendo (Seel, 2012). Asimismo, y a partir de los estudios sobre estilos cognitivos contempla la combinación de estas preferencias en el proceso del aprendizaje.

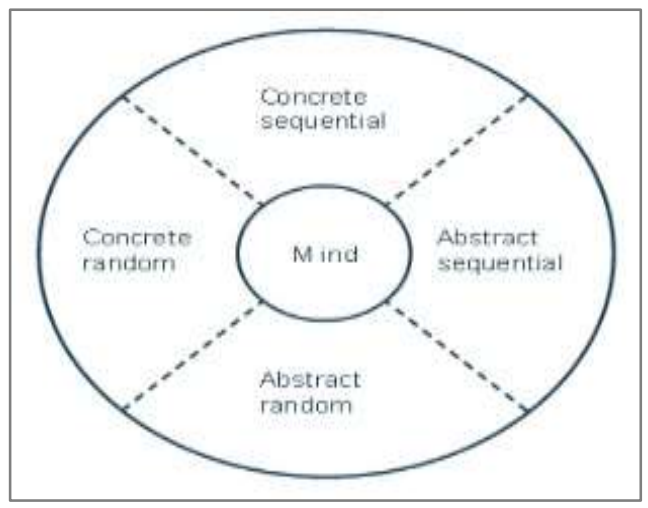

Fig.51. Modelo de Gregorc (Coffield et al., 2004)

Desde el punto de vista de la psicología cognitiva, en la misma década de los setenta, Gregorc (1982), trabajando con Sternberg (1987), plantea un modelo a partir de dos cualidades perceptivas generales: las concretas, o aquellas percepciones ligadas a la realidad y las cualidades abstractas, vinculadas al razonamiento. Así, las percepciones concretas implican el registro de información directa a través de los sentidos, mientras que las percepciones abstractas implican el procesamiento o la comprensión de cualidades, conceptos e ideas.

Las avanzadas investigaciones en neuropsicología le inducen a entender dos maneras de procesamiento de la información en este proceso de aprendizaje: una secuencial (sequential), que implica la organización de la información de una manera lineal, lógica y, otra aleatoria (random), que responde a la organización de la información 
sin un orden específico. Los dos tipos de percepción de las cualidades y las dos maneras de procesamiento cognitivo estarían presentes en cada individuo, y las diferencias individuales se explicarían a partir de la dominancia de unos u otros procesos (Gregorc y Butler, 1982). Este modelo de cuadrante guarda cierta semejanza con el modelo de cerebro total de Herrmann (1991). Los cuadrantes corresponden a cuatro modos específicos, distintos e independientes de procesamiento diferencial de información (Gardié, 2000).

Anteriormente, de acuerdo a los estudios de asimetría cerebral, Hudson (1968) había identificado dos estilos cognitivos o de pensamiento tanto en estudiantes como en profesores: los pensadores convergentes, buenos en la clasificación de material procedente de una variedad de fuentes para la solución de un problema, y los pensadores divergentes, que actúan de manera más creativa y flexible en su acercamiento a la solución de problemas. En el caso de los estudiantes, su planteamiento de convergenciadivergencia está referido al proceso de aprendizaje, más que a los resultados escolares, al considerar que la creatividad y el talento quedan fuera de la evaluación del sistema educativo (inglés), centrado en la valoración de la respuesta correcta.

Con un enfoque en las diferentes fuentes de información sensorial, se encuentra la consideración del estilo visual como uno de los tres estilos básicos de aprendizaje, junto con el kinestésico y el auditivo (Dunn, R. y Dunn, K., 1984). A partir de esta consideración, se van a establecer clasificaciones de tipos de alumnos en visuales, auditivos o kinestésicos en función de sus preferencias sensoriales o de su respuesta a los diferentes recursos de aprendizaje (Modelo VARK Fleming, 2006). Y es, a partir de este planteamiento sensorial, que se comienza hablar del aprendizaje visual que denomina al sistema de enseñanza-aprendizaje que utiliza métodos visuales, Organizadores Gráficos (OG), para presentar u organizar la información: mapas mentales o conceptuales, líneas de tiempo o infografías que reúnen ambos (fig. 52). Estudios realizados de contenidos de materiales escolares impresos, indican que en el último siglo se habrían multiplicado por más de diez la superficie de éstos dedicada a la imagen (Costa y Moles, 1992). A estos datos debemos añadir la preponderancia visual de las aplicaciones y recursos didácticos de las nuevas tecnologías en los últimos veinte años. 
Este planteamiento de una metodología visual se basa en que ciertas estrategias de aprendizaje requieren de representaciones mentales o esquemas visuales para que se produzcan, en la consideración de que el $80 \%$ de la información que se percibe es visual. Apoyándose en el concepto de inteligencia visual (Gardner, 1994), los organizadores gráficos se entienden como recursos, impresos y digitales, que van a permitir descubrir y diseñar conexiones y relaciones, recordar los detalles, facilitando la comprensión y la integración de nuevos conocimientos.

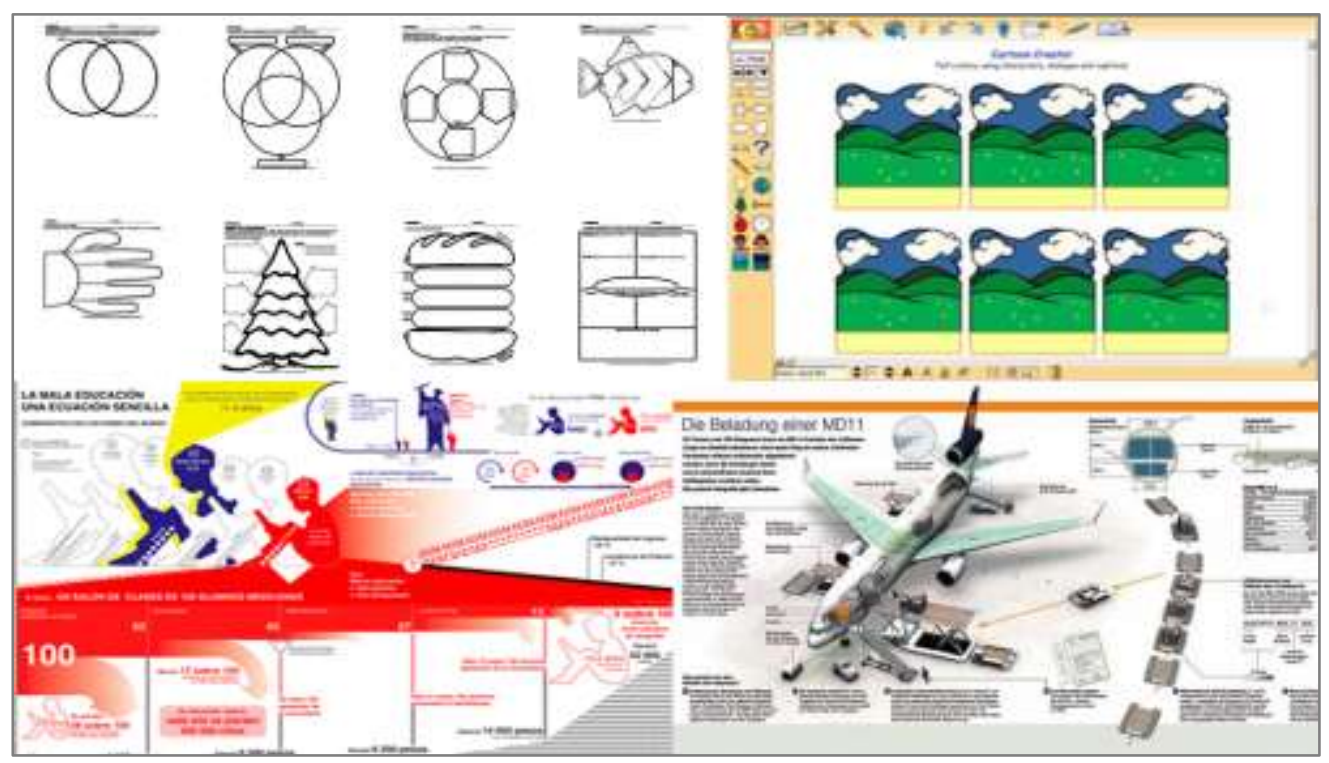

Fig.52. Plantillas de organizadores gráficos para uso didáctico e infografías (Fuente: www.organizadoresgraficos.com - www.inspiration.com - www.almamexico.info)

En el estudio "Organizadores Gráficos: Una revisión de la investigación científica" (Institute for the Advancement of Research in Education (IARE) at AEL, 2003), se concluye que la utilización de estos recursos mejora el rendimiento del estudiante en las áreas claves del pensamiento crítico, retención y comprensión, y en la organización y visualización de datos. Se basa en la investigación de las teorías cognitivas del aprendizaje: teoría de la codificación dual, teoría de los esquemas, y la teoría de carga cognitiva.

Por otra parte, algunos autores prefieren hablar de preferencias más que de estilos de aprendizaje, y utilizan el concepto de 
dependencia-independencia de campo para explicar las diferencias cognitivas. (Woolfolk, 2006; García Ramos, 1989). La dependencia de campo es un concepto sensorial que define a los individuos que muestran dificultades para separar un elemento de su campo visual total. Tanto la preferencia y características perceptivas como el concepto de asimetría hemisférica cerebral, marcan las principales consideraciones cognitivas en los estilos de aprendizaje, aunque también se manejan clasificaciones en base a aspectos emocionales, psicofisiológicos y de personalidad, generando abundante literatura de modelos e instrumentos de evaluación.

Aunque la investigación en este campo pone de manifiesto que los estilos cognitivos tienen una relación significativa con el rendimiento y los resultados académicos, sin embargo, los estilos cognitivos no mantienen relación significativa con pruebas de capacidad intelectual (Sternberg et al, 1999). En este sentido tampoco son muchas las investigaciones realizadas sobre las diversas maneras de enfocar el estudio de los estilos de aprendizaje (Cacheiro, 2014). Aunque, tanto los instrumentos como los propios modelos, en general tienen críticas sobre su validez y confiabilidad; no obstante, en los estudiados, los tipos de procesamiento -espacial, analítico, secuencial, verbal-, así como las respuestas perceptuales -visual, emotiva, auditiva-, responden bien a los análisis estadísticos (Salas Silva, 2008; Coffield et al., 2004).

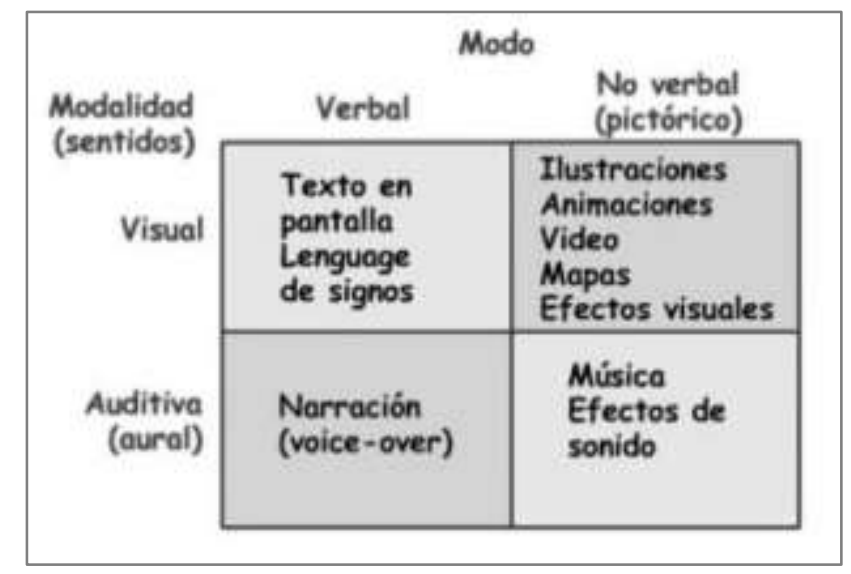

Fig. 53: Combinaciones posibles entre modo y modalidad del material multimedia. (Rodríguez y Chacón, 2008)

Resulta dudoso, por tanto, afirmar de manera científica que las personas tienen un estilo cognitivo o de aprendizaje propio por la 
preferencia hacia una fase cognitiva o hacia un sistema de representación sensorial, y arriesgado extrapolar por ello, las clasificaciones a los agentes educativos, estudiantes y profesorado. Pero sí parece clara la diferenciación genérica de al menos dos estilos, espacial y secuencial, en las preferencias cognitivas y en la presentación textual y visual de los contenidos de aprendizaje.

Entre las explicaciones cognitivas del proceso del aprendizaje, que no están en la línea de la diferenciación individual, la Teoría de la Codificación Dual (DCT, Dual Coding Theory) sostiene que los seres humanos codifican de manera separada la información auditiva y visual (fig. 53). Esta teoría, en la base del aprendizaje multimedia (Mayer, 2005), se apoya en trabajos que sostienen que el procesamiento de imágenes participa de los mismos mecanismos cerebrales que participan en la percepción visual (Paivio, 2013; Anderson, y Bower, 2014; Marr, 1985).

Esta teoría separa los códigos verbales de los no verbales. Tanto los formatos verbales (logogens) como los no verbales (imagens), estarían relacionados con la evocación de los aspectos cognitivos diferenciados al procesar la información (reconocimiento). La idea de una codificación dual parte de que las experiencias con palabras, y las experiencias con imágenes y objetos físicos dejan resultados diferentes en la memoria:

"En primer lugar, las personas no tienen que responder abierta $y$ verbalmente a un evento en el momento de ser testigo de él con el fin de mostrar más adelante la retención de conocimientos sobre ese evento.

Habitualmente estamos recordando escenas, episodios o imágenes con imágenes mentales que no tienen contrapartida lingüística."

(Anderson y Bower, 2014, p. 34)

A partir de esta diferencia dual, ambos formatos plantean dos tipos de esquemas cognitivos universales: el formato logogens con un carácter secuencial, lineal que lo define como habilidad o producción convergente, y el formato imagens de carácter holístico, global, no verbal, definido como habilidad divergente. Aunque resultan de procesos independientes, ambos pueden funcionar simultáneamente, 
lo que resulta óptimo para obtener beneficios en el aprendizaje (Paivio, 2013).

En la línea del enfoque cognitivo dual, la Teoría de la Carga Cognitiva (Cognitive Load Theory) sugiere que la información que se procesa en cada canal es limitada y, por tanto, se limita la carga o capacidad de la memoria de trabajo del ejecutivo central (Sweller, 2005). Esta teoría, que está detrás de los modelos cognitivos del aprendizaje virtual (e-learning), argumenta que si esa carga se excede, el aprendizaje no se produce. Si los organizadores gráficos se usan apropiadamente, puede reducirse la carga cognitiva y en consecuencia, permitir que más recursos de la memoria de trabajo se dediquen al aprendizaje. (Coll y Monereo, 2008).

A su vez, La Teoría de los Esquemas (Schema Theory) afirma que dentro de la memoria humana existen esquemas o redes de información. Término que acuñara Bartlett Frederic (1886-1969) para definir las construcciones cognitivas que permiten organizar distintos elementos de información (Sweller, 2005). Se apunta a la calidad y complejidad de los esquemas en la diferencia entre un aprendizaje mecánico y memorístico y otro más constructivo y significativo. El uso de organizadores gráficos ayuda a integrar el conocimiento nuevo con el conocimiento existente, organizado en esquemas (Rodríguez y Chacón, 2008).

A la par que los trabajos en neurociencia están mostrando la evidencia electrofisiológica del procesamiento audiovisual en el lóbulo parietal superior del cerebro (Molholm, 2006), los estudios sobre la memoria de trabajo (Baddeley, 1997; Burin et al, 2004) van a quebrar el concepto tradicional de 'almacén unitario' de la memoria planteando la estructura de la memoria a través de tres componentes (Etchepareborda y Abad-Mas, 2005, p. S80):

- Bucle articulatorio: encargado de mantener activa y manipular la información presentada por medio del lenguaje, está implicado en tareas puramente lingüísticas, como la comprensión, la lectoescritura o la conversación, así como en el manejo de palabras, números, descripciones, narraciones, etc. 
- Agenda visoespacial: encargada de elaborar y manipular información visual y espacial. La agenda visoespacial está implicada en la competencia espacial, como por ejemplo el aprendizaje de mapas geográficos, pero también en tareas que suponen memoria espacial, como el ajedrez o el dibujo.

- Ejecutivo central: Coordina los sistemas de memoria; una de las lagunas del modelo modal residía en la incapacidad para explicar en qué medida el sistema cognitivo tomaba parte activa en las operaciones de retención o recuperación del conocimiento. El ejecutivo central realiza una función relativa a la atención hacia las tareas a realizar, las demandas que requiere y su ajuste al contexto: si una tarea necesita menos atención, permite la ejecución de otras tareas compatibles.

De esta forma, el ejecutivo central, el centro de las funciones ejecutivas, que para la neuropsicología es el sistema encargado de las estrategias de pensamiento, es visto como un controlador de capacidad limitada que tiene dos "componentes esclavos": el bucle articulatorio encargado de procesar la información verbal y la agenda visuoespacial que procesa las imágenes y la información espacial (Rodríguez y Chacón, 2008, p. 14).

Las teorías cognitivas del aprendizaje están contribuyendo, en los últimos veinte años y a la par que se introducen las pantallas en los contextos educativos, a generalizar la idea de que "Ios artefactos

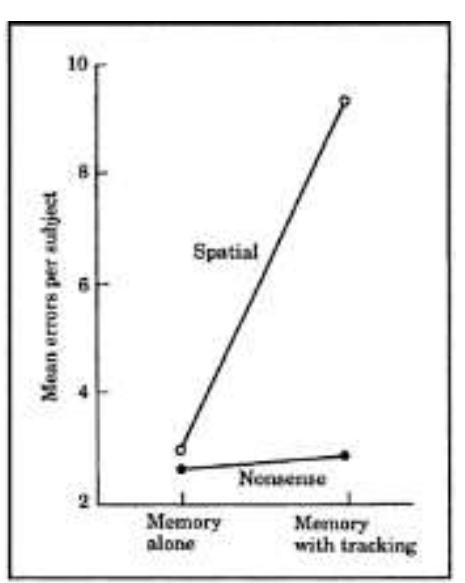

Fig. 54: Memoria espacial (Baddeley, 1997) visuales, como los mapas, dibujos, pinturas, diagramas y representaciones matemáticas, pueden servir como instrumentos intelectuales fundamentales" (Olson, D.R., 1998. p.18). Pero a su vez, de estas teorías también se están extrayendo conclusiones que pueden cambiar algunos de los principios en que está basado el currículo educativo. Los trabajos sobre la memoria visual muestran, entre otros resultados, que la capacidad para la imaginación (imageability) no se relaciona directamente con la característica espacial de la memoria (fig. 54), lo que puede cuestionar la asociación que se hace entre la 
percepción visual y el talento artístico, la imaginación o la creatividad. Del mismo modo, y referido a la memoria, los elementos concretos que nos permiten formar imágenes guardan más relación con la memoria semántica, lo que reforzaría la importancia de una mayor consideración de la percepción visual en el área lingüística: "Nuestros resultados son más consistentes con una interpretación que sugiere que los elementos concretos y capaces de formar imágenes se representan con mayor riqueza en el largo plazo del sistema de memoria semántica, una opinión que también ha sido recientemente propuesto por Jones (1988)" (Baddeley, 1997, p.77) .

El conjunto de teorías del aprendizaje subyace, en mayor o menor medida, en la formulación de diferentes propuestas curriculares, inspirando los principios educativos detrás del diseño de contenidos y métodos, así como en los criterios de evaluación de las competencias a desarrollar. En este aspecto va a influir la definición que se haga de las capacidades visuales y las aptitudes espaciales que forman parte de la competencia visual.

\subsubsection{La inteligencia espacial y la matemática}

Hemos analizado en el currículo la consideración que tienen los aspectos visuales y gráficos en contenidos y evaluación. Estos aspectos siempre se han destacado en el desarrollo de las aptitudes verbales y no verbales en el ámbito de la inteligencia; pero la formulación de un concepto de inteligencia espacial en la teoría de inteligencias múltiples aporta nuevos enfoques pedagógicos. El concepto de competencia espacial se revaloriza en las áreas matemática y artística del currículo, dos áreas polarizadas en relación al pensamiento lógico. De alguna manera entendemos que la matemática, además de contribuir al desarrollo del pensamiento lógico, permite, al establecer relaciones de medida y proporción, la configuración y análisis del espacio visual.

Pero esta doble consideración duplica el concepto espacial, que en ocasiones se define como competencia, razonamiento $u$ orientación, y otras, como aptitud o capacidad. Con algunos matices, y evitando las definiciones endogámicas en torno al logro escolar, todas 
estas consideraciones se refieren a un aspecto de la capacidad intelectual, que es unitaria en sí misma, compuesta de múltiples subhabilidades que influyen en el nivel de logros en diversos campos (Lohman, 1979, 1989). Estas habilidades espaciales se hallan implicadas en la construcción de los modelos geométricos, en el dibujo técnico, la interpretación de mapas, las actividades de manejo de naves, el diseño, las artes visuales, la educación física y la danza, entre múltiples actividades tanto académicas como de la vida cotidiana.

Referido al razonamiento espacial, de definición ambigua, en el ámbito investigador de la matemática numerosos autores defienden conceptos como pensamiento espacial, visualización y orientación espacial en la didáctica de la matemática moderna, aunque sin un modelo teórico de referencia, lo que dificulta la obtención de conclusiones válidas, y plantean la necesidad de un modelo cognitivo y otro didáctico para definir estas habilidades (Arrieta, 2003, Fernández Blanco, 2013).

Pero en esta didáctica, en el ámbito matemático de la ciencia, conceptos como visualización y percepción adquieren una dimensión intelectual alejada del mundo físico. Quizás por esta razón se esté lamentando la pérdida del sentido sensorial e intuitivo de la geometría, que la conecta con el mundo real. El Consejo Nacional de Investigaciones de Estados Unidos señala que las habilidades de percepción, imaginación y representación gráfica no se enseñan de un modo universal y explícito. El pensamiento espacial (spatial thinking) parece poco reconocido dentro de la 'familia' del pensamiento crítico, a pesar de hallarse correlacionado con los estándares nacionales en matemáticas y ciencias y de ser un prerrequisito para los logros en estas áreas, en particular en ingeniería y en tecnología:

"Los estándares de contenido científico reflejan necesariamente el pensamiento espacial y el razonamiento de una manera implícita, porque muchos de los objetos de estudio de la ciencia existen en el mundo real. Por lo tanto, es necesario colocar las cosas en ese mundo, para hablar de sus relaciones, y para hacer inferencias acerca de su estructura y función."

(National Research Council, 2006, p. 120) 
No hay una terminología y definición unitaria en cuanto a la competencia espacial que aparece dentro de la competencia básica en ciencias y de igual forma ocurre en la competencia culturalartística, pero sí existe cierto acuerdo en diferenciarla del razonamiento verbal y relacionarla con las habilidades de representar, generar, recordar y transformar información simbólica no lingüística (Linn y Peterson, 1985; Lohman et al., 1987; Gero, 2014).

Un planteamiento educativo actual sobre la didáctica de la geografía, centrado en cómo las ideas neurocientíficas podrían ayudar a diseñar mejores lecciones de geografía y matemáticas en Harlem (New York), basándose en la revisión de más de 3.200 estudios, describe ocho modos diferentes de razonamiento espacial en torno a las diferentes formas de organización espacial de la información entre los estudiantes. El estudio plantea cálculos prácticos de distancias y comparación de tamaños y ángulos, aplicados al conocimiento geográfico. Concluye que el tipo de pensamiento espacial, más que una inteligencia, parece ser un complejo conjunto de procesos paralelos que implican una serie de estructuras especializadas en diferentes partes del cerebro humano (Gersmehl P. y Gersmehl, C., 2011).

Como veremos en la parte metodológica, el pensamiento o razonamiento espacial se estudia a través de tres categorías principales: percepción espacial, visualización y rotación mental. A partir de estas aptitudes es como se estructuran las principales pruebas psicométricas de inteligencia. Sin embargo, la evaluación de la competencia en este ámbito permite estructurar su estudio en dos categorías de análisis: un análisis intrínseco de las formas y espacios, y otro análisis extrínseco de las relaciones que establecemos con ellos (Gero, 2014).

De esta forma, en el análisis extrínseco encontramos la percepción espacial como la capacidad de ubicar objetos y espacios y orientarse. En el análisis interno, la visualización es la capacidad de generar la imagen mental analógica del objeto y del espacio para efectuar transformaciones mentales y retener los cambios producidos, mientras que la rotación mental es la capacidad de girar mentalmente objetos (Gero, 2014; Shepard y Cooper, 1986) (fig.55). Estas transformaciones mentales son complejos procesos analíticos que 
pueden incluir la rotación de partes, pero también el plegado, reconocimiento de partes ocultas, diseños de bloque, etc. (Lohman, 1979). El desempeño exitoso, la competencia, requiere de flexibilidad mental para seleccionar la mejor estrategia (Guilford, 1986). Nos planteamos si esta flexibilidad es mayor en la medida que se relaciona con la experiencia física del espacio, o en que medida la visualización y razonamiento espacial, como ejercicios mentales, están relacionados con la percepción de las referencias espaciales.

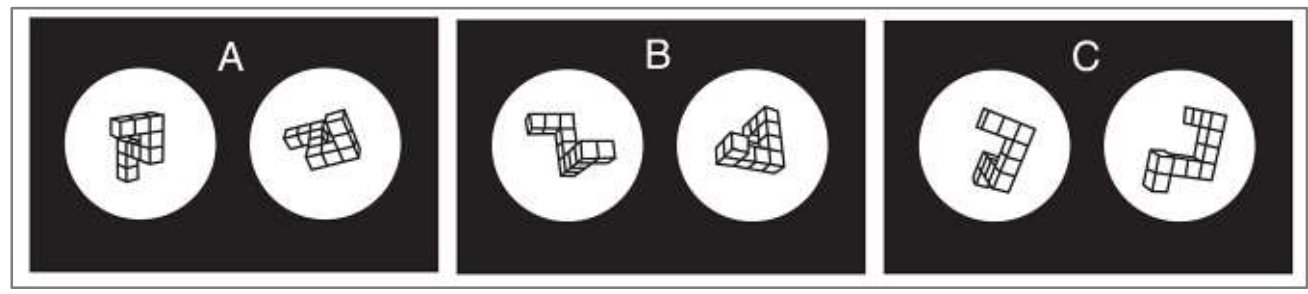

Fig. 55: Ejemplos de pares de dibujos en perspectiva presentados a los sujetos (Shepard y Cooper, 1986)

Este conjunto de tareas forman parte de las pruebas de aptitud e inteligencia de uso en el ámbito educativo, como el test de Aptitudes Mentales Primarias (Primary Mental Abilities, PMA) de Thurstone (1938), que incluye un factor de comprensión espacial, o la Escala de inteligencia infantil, WPPSI de Wechsler (1990), que incluye las aptitudes viso-espacial, la integración sensorial, y la cordinación visomanual. Este tipo de pruebas correlacionan el tiempo de respuesta y el ángulo de rotación: los trabajos de Shepard (1984), basados en la comparación de dos figuras en representación tridimensional y la velocidad en resolver si son el mismo objeto, constatan la existencia de relación entre la operación mental analógica y la rotación física real. En suma, la finalidad de estas pruebas tiene un carácter diagnóstico y evaluador, que no siempre se va a corresponder con los contenidos didácticos para el desarrollo del pensamiento espacial:

"En la actualidad, la visualización en el aprendizaje de las matemáticas no sólo es contemplada como una propuesta ilustrativa sino que está siendo reconocida como una componente clave del razonamiento, la resolución de problemas y la demostración, como se puede observar en Battista (2007); Presmeg (2006), Phillips et al. (2010) y Rivera (2011). Todos ellos inciden en que una de las vías que abre más líneas de trabajo para la investigación en geometría es la 
que contempla el uso de las nuevas tecnologías como entornos de aprendizaje y/o como herramientas. Ese camino no se puede recorrer sin tener en cuenta la presencia de la visualización (estática y/o dinámica), lo que necesariamente debe implicar la implementación de acciones formativas centradas en el desarrollo de habilidades $y$ procesos visuales para la enseñanza y aprendizaje de la geometría."

(Fernández Blanco, 2013, p.36)

\subsubsection{La cultura audiovisual y la educación artística}

Al tiempo que con el razonamiento lógico matemático, los contenidos educativos del pensamiento visual están a su vez vinculados a las competencias cultural y digital, en las que el currículo actual sitúa la educación artístico-plástica.

El área de la educación artística se ha caracterizado tradicionalmente, entre otros objetivos, por el desarrollo de la creatividad y la imaginación unidas a la expresión plástica infantil. Objetivos que se ampliaron con la exigencia del interés por la comunicación visual, por lo que pasa a denominarse educación plástica y visual. Actualmente, las reformas educativas que se suceden en el espacio europeo pretenden reflejar los cambios sociales y culturales que se están produciendo en torno a la extensión de las pantallas tecnológicas. Se introduce la competencia digital en el área, compartiendo el reconocimiento de que vivimos en un mundo de la imagen y entendiendo que el ámbito educativo específico de la comunicación audiovisual es el propio de la educación visual.

Este área, ahora de la educación plástica y visual y audiovisual, conforma unos contenidos mediados en gran medida por la creación artística, de manera que sus objetivos plantean una relación desde el enriquecimiento personal a partir del respeto y disfrute del patrimonio artístico y el conocimiento de las técnicas artísticas, por una parte, hasta el conocimiento de los nuevos entornos tecnológicos del lenguaje visual, el digital y la geometría, por otra. La combinación de artes visuales y nuevas tecnologías está dando lugar al concepto de la 'Educación Artística 4.0', como vehículo para la reflexión en los 
vínculos socioculturales y pedagógicos de la "educación por y para el arte". Reflexión que "siempre será prioritaria, sea en relación con la tecnología o con cualquier otra disciplina asociada al arte" (Escaño, 2010).

Pero tambien se cuestiona el hecho de que la educación artística pueda alcanzar a cubrir este ambicioso objetivo (Ballester, 2012). La consideración de la competencia digital en lo audiovisual plantea un doble análisis de las TIC, que por una parte se refieren a los nuevos formatos visuales de las tecnologías, pero por otra, a los lenguajes informáticos y sus repercusiones en los propios procesos de enseñanza y aprendizaje. En la educación artística plástica y visual 3.0 conviven, en "el impulso de disfrutar creando", la tradición de las manualidades con las TIC, en las que encuentran una fuente de innovación del concepto de la comunicación y por tanto de la educación, y también de la imaginación (Saura Pérez, 2012, p.79).

A la vez se está introduciendo en el currículo oficial de la educación básica de algunos países como Inglaterra o Estonia, y en otros como el nuestro, de manera extraoficial, asignaturas de programación, con el fin de conocer, familiarizarse con los lenguajes y estructuras básicas que operan detrás de las pantallas. Como hemos reflejado anteriormente, la imagen digital parece tener una estructura más vinculada con logaritmos y lenguajes alfanuméricos que con los esquemas geométricos o los códigos del lenguaje visual. En este sentido, el procedimiento que se está llevando a cabo en los planteamientos del currículo artístico es el mismo que fue planteado ante el auge de la fotografía y el cine, que ya forman parte del 'pasado audiovisual'. Si entonces se planteaba introducir en el área el manejo de las cámaras y el conocimiento técnico-artístico (proceso de revelado, color-tinta, rebobinado, composición y planos...), ahora toca el turno de la formación en el manejo de los dispositivos informáticos y el conocimiento técnico-artístico (software de imagen, diseño web front-end y back-end, color-luz...). Está por ver a qué ámbito del currículo le corresponderá esta formación, que se reparte entre el lenguaje visual y el informático, y que está planteando un amplio debate pedagógico en los diseños y modelos de aprendizaje, como lo muestra la campaña de The Guardian, para promover la alfabetización digital y actualizar la informática y tecnología de la enseñanza en las escuelas (McLean, 2012). 
El concepto de hipermedia irrumpe con fuerza en la educación de los "screenagers", como define Rushkoff (2010) a los estudiantes, asumiendo los cambios en la manera de escribir, diseñar y comunicar de las pantallas de las nuevas tecnologías. Los nuevos formatos de la imagen exigen un cambio en la consideración del lenguaje visual en el área artística. Un hiperdesarrollo del lenguaje que deviene en "hiperlenguaje", replantea en el área artística el propio sentido de la representación. En la educación artística se insiste en la producción audiovisual como creación de conocimiento y en el reconocimiento de la educación artística como contenido cultural transversal, dejando atrás el sentido manual de la creación y construcción de imágenes asociado a la representación (Acaso, 2009).

Por otro lado, en edades tempranas ya se vincula la competencia cultural con todas las áreas de conocimiento, y en ella se enmarcan todos los aspectos citados en el currículo oficial. Pero sus contenidos se irán relacionando progresivamente con los de la educación artística, las ciencias sociales y la lengua. De tal manera que, el caracter transversal del pensamiento visual y el razonamiento espacial, así como su medio de expresión, el lenguaje visual, va debilitando los conceptos, divididos en el currículo entre los lenguajes matemático y literario, así como los lenguajes alfanuméricos de programación. Todo este recorrido, va a dar como resultado la disociación que hace el currículo de los conceptos de imagen y dibujo o las diferencias entre iconicidad y graficidad, cuando encontramos más posibilidades pedagógicas en sus similitudes, por su propio origen común, sea éste manual o mecánico.

En una primera etapa de la educación, la expresión gráfica del niño es un lenguaje visual antes que verbal. Las primeras producciones gráficas del niño no apuntan a un grafismo lingüístico, sino más hacia una representación ideográfica, espacial y emocional de sí mismo y de su entorno (Machón, 2009). Estas producciones representan la capacidad de establecer relaciones visuales con esquemas gráficos, capacidad a veces definida como icónica. Esta competencia gráfica, aunque tiene sus componentes sociales y culturales, es universal y está detrás de la representación de las formas y los espacios en el dibujo, la pintura, la fotografía y el cine (Lizarazo, 2004). Una competencia que se debate en la pedagogía, 
entre una concepción como muestra del arte infantil que conecta con el arte primigenio y una concepción como muestra de la iconosfera gráfica infantil, que es "incitadora de la necesidad posterior de lectura" (López Tamés, 1990, p.359).

Las ciencias de la educación relacionan la capacidad gráfica con el desarrollo cognitivo del razonamiento espacial, pero también se relaciona con la representación gráfica, en un difícil equilibrio entre lo textual y lo visual en los procesos de aprendizaje.

No es nuestro objetivo analizar las características del desarrollo de la expresión gráfica infantil, pero podemos apreciar que ésta está muy valorada por los docentes en la educación inicial, para progresivamente ir dejando paso a la valoración preferente que hacemos de la expresión escrita, anteponiéndola a la todavía prolífica, pero ya algo decepcionante, representación gráfica del alumnado que está finalizando la educación primaria. $Y$ después nos encontramos con la casi ausencia de expresión gráfica y la aparición de la expresión de estereotipos adultos en relación a la representación gráfica y el dibujo: 'esto no es lo mío', 'no tengo ese don' o 'me sale mal, me resulta difícil'.

\subsection{3. - La educación del lenguaje visual}

En la introducción, hemos tomado la definición de Gombrich (1979) de la representación como la acción de sustituir algo o hacer presente algo que está ausente. Se suele decir que si la representación es natural, el referente y su imagen tienen una relación analógica (Sanchez Marcos, 2010). Sin embargo no parece haber acuerdo sobre los límites en los que deja de existir analogía entre ambos. Si entendemos la analogía como "la comparación entre fenómenos que mantienen una cierta semejanza a nivel funcional o estructural' (Farías, 2009), el pensamiento analógico está asociado con la aparición del lenguaje y con el aprendizaje (Curtis y Reigeluth, cit. en Oliva, 2004). En este sentido, tomamos la acepción de representación analógica didáctica que supone la definición de modelo mental (Galagovsky y Adúriz-Bravo, 2001) Evitamos entrar en la discusión epistemológica sobre los límites de la validez de la analogía 
(Oliva, 2003) o sobre los límites de la figuración o del lenguaje (Karam, 2007), y, en cualquier caso, adoptaremos el concepto más flexible y amplio de figuración y significación del lenguaje, acotado tan solo por los límites del propio pensamiento, como lo expresara Wittgenstein (1953), pero subrayando la consideración de todos los tipos de lenguaje humanos.

La consideración de representación analógica de lo visual como lenguaje implica la existencia de un código y, por tanto, uno de los esfuerzos que se han hecho en los últimos años es el de tratar de definirlo. Se intenta a partir del estudio de los elementos constitutivos de la imagen, descomponiéndola en sus elementos estructurales más simples. Esta descomposición va a permitir definir un alfabeto visual. Desde la educación artística se trabaja en esta línea de establecer las unidades básicas de un abecedario gráfico, a partir de la idea de universalidad de la expresión gráfica. Trabajar con este alfabeto visual en la escuela va a ayudar en la construcción y lectura de imágenes: "El niño ha de reforzar un lenguaje (el visual) que de modo espontáneo emplea con soltura, dominarlo y controlarlo, como cualquier otra rama del conocimiento" (Díaz, 1986).

Este abecedario básico o alfabeto visual (fig. 56), lo forman los elementos primarios de la cultura visual humana. Si nos preguntamos qué podemos hacer con una tiza frente a una pizarra, con un lápiz frente a un papel o con un estilete en la arcilla o un lápiz electrónico (estilete o stylus) frente a una tableta (tablet computer), la primera acción es la de chocarlo con la superficie, creando un punto como elemento original. Al punto le siguen la línea (horizontal, vertical y diagonal), recta o curva, en espiral, el circulo, triangulo, o el cuadrado, como elementos estructurales y creadores del lenguaje gráfico y simbólico.

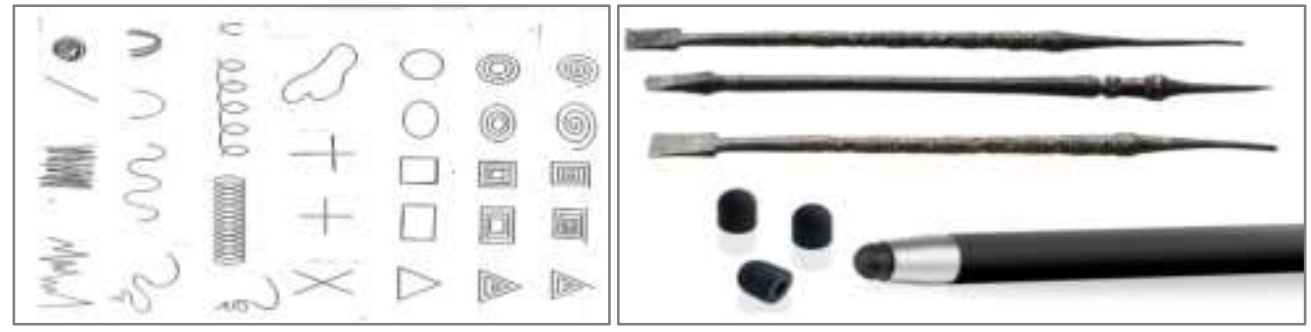

Fig.56: Alfabeto visual (Díaz, 1986), estiletes romanos y stylus digital. 
En semiótica visual, el análisis de signos del lenguaje gráfico vincula la importancia del nivel de congruencia entre los grafismos y el mensaje. Este análisis sígnico se hace de manera eficaz en el ámbito publicitario y comercial, escrupuloso con el mensaje que llegará al cliente final. En el ámbito educativo, el análisis pretende alcanzar ese nivel de profundidad con la llamada 'pedagogía de la imagen' que busca consolidar más allá de las modas, una "intervención pedagógica consciente de sus opciones éticas y políticas" (Dussel et al., 2010, p.16). Esta corriente pedagógica busca este objetivo en el uso y análisis de los medios audiovisuales en el proceso de enseñanza aprendizaje, en una escuela moderna que es "hija directa de la imprenta y la cultura letrada (...) aliada del texto escrito" (op. cit., p.27 y 45), y en la que se debe aprender a ver y a mirar. Esta intervención para dar respuesta a los profundos cambios perceptivos y comunicativos introducidos por las nuevas tecnologías visuales reclama un espacio educativo multidisciplinar:

“...combina los aportes de la historia del arte, la teoría del cine, el periodismo, el análisis de los medios, la sociología, la filosofía, la antropología, la teoría literaria y la semiología. Este campo se presenta a sí mismo como interdisciplinar y multimetodológico, un lugar de convergencia de múltiples enfoques. Desafiando la distinción entre las "bellas artes", como forma cultural elevada, y el resto de las manifestaciones visuales masivas y populares, los estudios visuales incorporan a sus análisis todas las formas de arte, diseño, el cine, la fotografía, la publicidad, el video, la televisión o internet".

(Abramowski, 2009, p.2)

En esta línea de intervención, Aparici y García Matilla establecen una sutil diferencia entre una pedagogía de la imagen y una pedagogía con imágenes. Mientras que la primera relaciona el lenguaje de la imagen, enfatizando las de los medios de comunicación, con un aprendizaje intencionado para descifrar su mensaje; la pedagogía con imágenes describe la utilización de los medios audiovisuales en la educación, pero no implica la descodificación del lenguaje visual (Aparici y García Matilla, 1987).

Llama la atención en este enfoque pedagógico, quizás porque se desmarca de las bellas artes, la escasa o nula referencia a la producción gráfica infantil como fuente de imágenes en el aula. Para 
este planteamiento de la educación visual, la imagen o representación icónica, no es tanto un producto artesano o artístico, sino el resultado de comunicar con un alfabeto visual y en esa línea se plantean algunas intervenciones educativas (Díaz, 1986; Aparici y García Matilla, 1987). Sin embargo, en el área artística encargada de la educación visual se tiende a considerar que la producción gráfica infantil es expresión plástica, lo que hace que algunos planteamientos de la educación visual choquen con otros enfoques en lo sensitivo, emocional y estético. En cualquier caso, dependerá de la consideración última que se tenga del concepto de arte, que sea la producción gráfica una muestra del arte infantil o de lenguaje, o la combinación de ambos. Así, cuando se habla del dibujo infantil, se combinan varias concepciones pedagógicas: la que lo ve como expresión artística con una intención conceptual o estética, la que ve el dibujo como expresión gráfica, con una carga más utilitaria, como interpretación espontánea del mundo visual, y la que ve en él, el prematuro síntoma de la necesidad de la escritura.

Ahora bien, frente al lenguaje como sistema de comunicación que requiere en gran medida de una estructura lógico-gramatical, el lenguaje gráfico, estructurado en un alfabeto visual, se revela como el medio narrativo preferente del niño (Sainz Martín, 2013). El estudio de la expresión gráfica infantil plantea su vinculación, por un lado con el desarrollo cognitivo del grafismo (nivel madurativo) y por otro, con la creatividad de la expresión (nivel artístico). Ambos planteamientos son simultáneos en los estudios de la educación artística plástica.

El enfoque del desarrollo vincula los primeros grafismos del niño con la imitación y el juego, para luego ir destacando su función semiótica (Delval, 2002; Bruner, 1988).

"Proseguir el problema de por qué ciertas propiedades del estímulo impresionan y son más preferidas que otras como bases para el agrupamiento del mundo, nos haría adentrarnos profundamente en el campo de la psicología de la percepción. Como ha sostenido persuasivamente Köhlero, hacemos bien en empezar con el mundo visual tal como lo encontramos: un mundo de objetos y cosas. Nuestro cometido primario no se refiere al examen de un atributo que le lleve a ser más 'eindringlich' (prominente) que otros, sino al modo en que tal 
propiedad afecta a la utilización del atributo en las decisiones sobre categorías.

Finalmente, está comenzando a acumularse evidencia acerca de otro factor que atrae la preferencia de varios atributos en la categorización. Se trata de la codificación lingüística de atributos, así como la codificación de distinciones existentes entre los diversos valores de un mismo atributo."

(Bruner, Goodnow y Austin, 2001, p.50)

Hemos de considerar que el comienzo de la imitación diferida (en ausencia del modelo) marca, para estos autores, el paso de una inteligencia de tipo sensomotor a otra de tipo representativa (Piaget e Inhelder, 1997).

Las relaciones del dibujo infantil con otras formas de representación, como la verbal o la expresión corporal, son difíciles de separar: los primeros dibujos surgen de una actividad motora exploratoria, muchas veces acompañada de narración, muecas y gestos. Pareciera que existe una comunicación entre el soporte y la visión del niño, por sus muestras de concentración y de satisfacción. Los estudios insisten en el carácter gratificante y placentero de esta actividad en mayor medida que lo hacen al analizar las restantes actividades de desarrollo. Al ser una actividad que implica control muscular se interpreta como idónea para el desarrollo del control motor fino que se va a dirigir al aprendizaje de la escritura.

A nivel cognitivo va a dar muestras de la concepción del mundo y de las relaciones que establece a través de la representación del espacio y de los objetos. A partir de estas representaciones se deducen procesos de pensamiento lógico, lingüísticos, pero también procesos emocionales, ya que el niño expresa en sus dibujos lo que le preocupa y lo que le interesa, seleccionando entre las primeras formas, aquellos diagramas y agregados que le servirán para reflejar objetos y personas de una manera particular (Goodnow, 2001). En ello se basan los estudios dirigidos al diagnóstico de dificultades de aprendizaje y psicoafectivas a partir de las producciones gráficas infantiles. Bender (1977), basándose en trabajos de la Gestalt, estudia los esquemas sensomotores subyacentes a los movimientos giratorios y los componentes direccionales (Wallon et al., 1992). Sin connotaciones diagnósticas, también hay estudios que abordan el 
análisis visual de estas preferencias en las primeras formas y ordenamientos de diagramas y agregados que, aunque se interpretan a partir de cogniciones y afectos, también responden a un principio armónico de equilibrio, por lo que Kellogg (1979) les atribuye el nombre de 'mandalas'. Esta autora establece también las pautas gráficas básicas (basic scribbles) que están en la base del alfabeto visual (fig. 57).
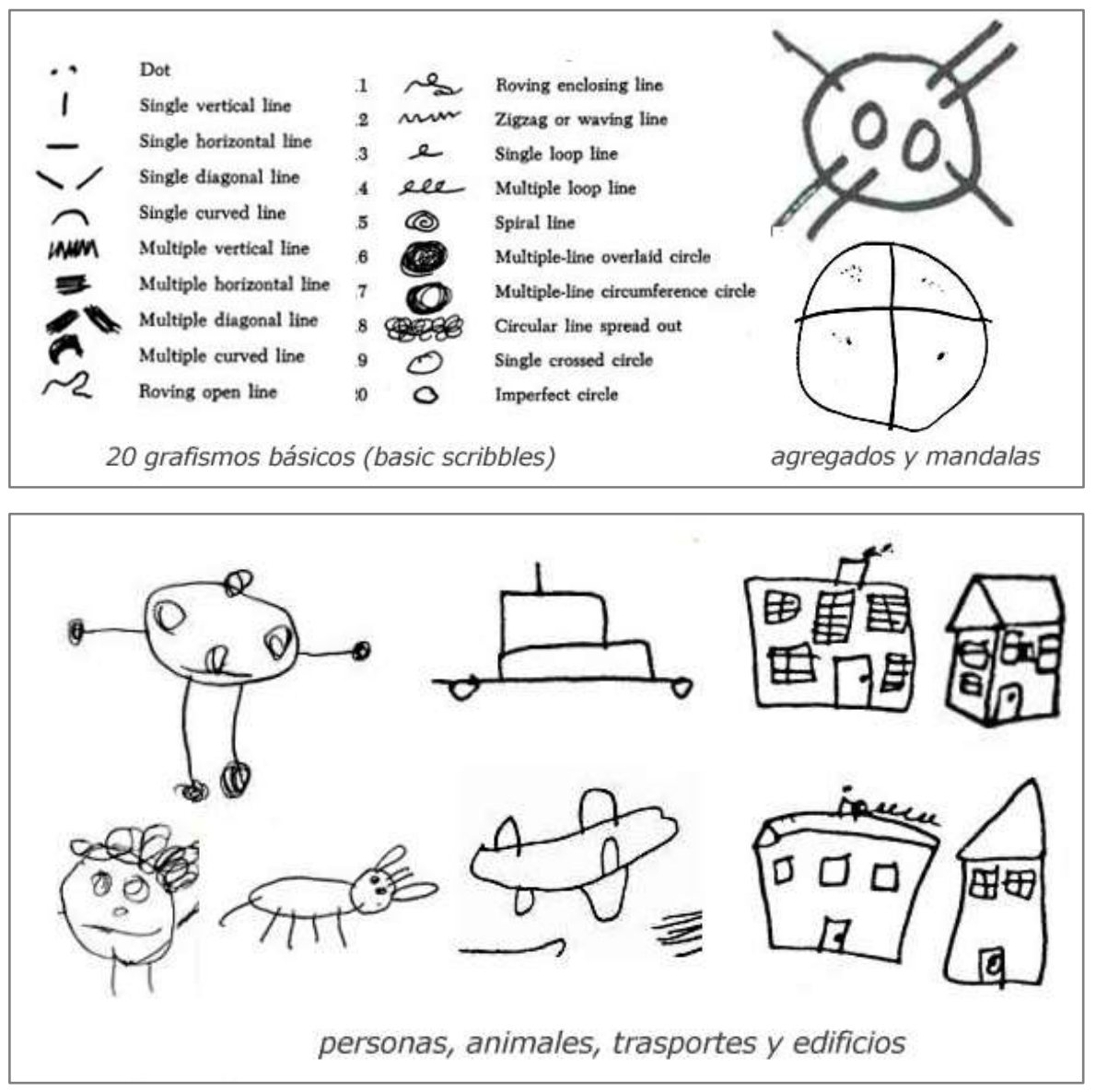

Fig.57. grafismos básicos y mandalas (Kellogg, 1973)

Por la consideración del grafismo infantil como juego simbólico, a estas primeras formas que surgen de las agrupaciones de diagramas, líneas y mandalas, se las considera resultantes de un proceso de imitación de los modelos de la realidad, o una imitación diferida en ausencia del modelo a partir de las imágenes mentales. Considerado así, el dibujo forma parte de la función semiótica entre el juego y la imagen mental (Piaget e Inhelder, 1997). A medida que el niño crece y madura su control motriz, los esquemas gráficos se van 
consolidando en ese proceso de imitación o de escritura realista, "pese a algunos errores, como la violación de la proporcionalidad o de las medidas" (Vigotsky, 2003, p.99).

Desde este punto de vista, llega un momento en el desarrollo, en el que las exigencias intelectuales de la percepción no se corresponden con la producción gráfica y resulta de ello la insatisfacción y el rechazo a la actividad. ¿Qué ha cambiado? El entorno de experimentación activa donde el individuo siente y explora, ensaya modelos y esquemas, y construye pensamiento, no ha cambiado. Y la destreza motora fina del adolescente se ha desarrollado lo suficiente como para seguir dibujando lo que ven, en ese proceso de imitación y juego simbólico. Según este enfoque, al parecer se produce un cambio cognitivo de manera tal, que si en un principio el niño dibujaba lo que sabe, el adolescente ahora quiere dibujar lo que ve.

La psicología del desarrollo explica el abandono de la actividad gráfica apuntando hacia la falta de dominio de materiales y técnicas artísticas en la parte motora y hacia la falta de imaginación, al tener imágenes mentales incompletas, en la parte cognitiva. Sin embargo, en edades adultas puede haber más similitud de lo que creemos entre hacer algo en la realidad o a través de imágenes mentales:

"La investigación reciente por el Dr. Pascual-Leone, del Instituto Nacional de la Salud indica que el ejercicio de una habilidad visual puede hacer que el mapa cerebro motor se expanda. La investigación con músicos indica que la práctica real en el piano e imaginando tocar el piano tienen el mismo efecto en los mapas cerebro motores, medida por los escáneres cerebrales. Los mapas motores se expanden tanto al tocar el piano real como hacerlo con imágenes mentales. Los atletas también han encontrado que tanto la práctica mental y la práctica real pueden mejorar una habilidad motora".

(Grandin, 2006, p.48).

La pedagogía, orientada por la psicología del desarrollo, percibe el concepto de crisis del dibujo con relativa naturalidad dentro de un proceso del desarrollo intelectual y tiende a atribuir la representación gráfica adulta al talento artístico, creyendo que de esta forma resuelve el problema. Es por ello que las competencias visual y 
gráfica en la educación se fomenten en el área artística, junto a la creatividad, la imaginación o el estilo, entendidas como componentes del talento. Cuando en realidad, en ausencia de talento, lo que se estaría fomentando es el conformismo con la insatisfacción gráfica de representación.

Consideremos por un momento que, si el análisis de la propia producción gráfica del adolescente satisface las condiciones que en su entender tiene que cumplir la representación, esta crisis del dibujo no debe darse. Entonces no hablaríamos de talento artístico, sino de capacidad o competencia gráfica. En pocas ocasiones la pedagogía actual atiende a otra consideración que no se explique por el desempeño. En esto han contribuido mayormente las contribuciones de los estudios sobre la inteligencia y el pensamiento visual. Sus aportaciones a la educación se basan en que la producción gráfica no debe ser analizada desde una óptica evolutiva en la dirección de alcanzar un "arte competente", sino según unos principios constructivos (Arnheim, 1979, p.213).

Este enfoque considera el análisis de estilo, igual de improductivo en el aprendizaje gráfico que en el aprendizaje de la matemática o la historia. Consideran que la crisis del dibujo no responde a la incapacidad, sino a la mayor exigencia perceptiva del entorno y cognitiva del pensamiento (Sainz Martín, 2013). Ven en la insistencia técnico-artística una dificultad en ocasiones de la propia expresión emocional, y llegaran a afirmar que la inteligencia visual como disciplina "no puede quedar confinada al taller de arte" porque el pensamiento visual es indivisible (Arnheim, 1979, p.215).

Desde este enfoque, la creatividad y el talento innato asociados a la representación gráfica son condiciones de la propia inteligencia (visual). Trata de resolver el paradigma evolutivo para explicar la representación gráfica de algo: entre lo que se ve o lo que se sabe de ello. La inteligencia responde a unos principios constructivos regidos por el entorno físico (sentido fenomenal) y regidos por los procesos cognitivos (sentido relacional) de manera que "nuestras experiencias visuales suponen nuestra interfaz de iconos fáciles de utilizar para acceder a las cosas que vemos relacionalmente" (Hoffman, 2000, p.27). De esta manera, la creatividad forma parte y tiene sentido tanto en la representación como en la observación. 
El concepto de inteligencia visual une la capacidad cognitiva y de observación con la habilidad gráfica motriz. La persona dibuja en todo momento tanto lo que sabe como lo que ve, dejando las intenciones que encierran expresiones como 'la visión de artista' y 'las manos de artista' en un tópico social de poco o nulo reflejo en la educación. De esta forma, resolviendo el paradigma de la representación gráfica entre lo cognitivo y lo visual, es como puede la educación visual trascender el área artística plástica.

La pedagogía del dibujo en el área artística plástica (dibujo artístico), aunque en la faceta investigadora muestra más un enfoque semiótico, en la práctica educativa refleja una estructura más vinculada al enfoque evolutivo. Asocia las aportaciones de la psicología del desarrollo gráfico infantil y la tradición del concepto de arte infantil, con una fuerte influencia de la historia del arte, definiendo y comparado la representación gráfica infantil con el arte de los primitivos, de los clásicos y los contemporáneos, según etapas, y analizándolo con el prisma de la teoría del arte.
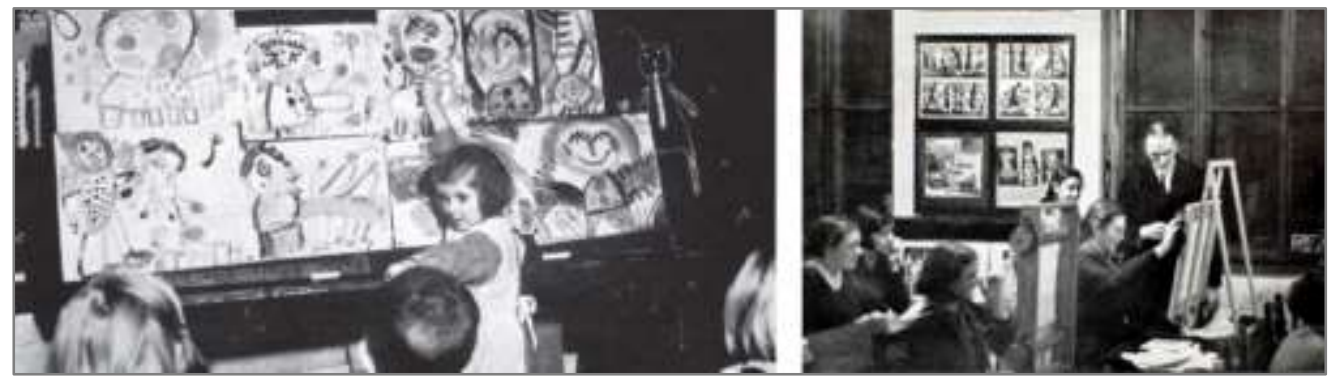

Fig.58: Alumnos de la Clase de Arte Juvenil de Cizek (Ortega, 2009)

El concepto de 'arte infantil' es atribuido a Cizek, artista pionero junto con Steinhof de la didáctica artística a comienzos del siglo XX. Ambos trabajan en la Escuela de Artes y oficios de Viena, en la que Cizek es director del Departamento de Experimentación e Investigación, y donde la asignatura más importante, la de Teoría de las Formas, tenía su apoyo teórico en la consideración diferenciada de cada una de las etapas de la Historia del Arte (Ortega, 2009) (fig. 58). Cizek afirma que la infancia es la edad del arte más puro: "Los niños tienen sus propias leyes. ¿Qué derecho tienen las personas adultas a interferir? Deben dibujar como se sienten y todos los niños tienen sentimientos y algo para expresar" (Wilson, 1921). 
El ambiente de las clases de Cizek y sus colegas se caracterizan por "el profundo sentimiento de rechazo hacia los métodos tradicionales, y hacia el tipo de arte que generaban" y encuentran en la raíz de su deseo de participación de muchos de estos artistas en tareas de docencia, "la difusión y extensión de sus propias preocupaciones formales y de los nuevos referentes que les servían de inspiración" (Ortega, I., 2009, p.52).

Pero es su contemporáneo, el filósofo francés G. Henri Luquet (1978), quien estudia el desarrollo evolutivo del dibujo infantil desde este enfoque, relacionándolo con el arte rupestre. No sabremos si éste influyó en Piaget o fue a la inversa, pero establece una categorización por etapas en torno a las nociones de realismo y narración (fig. 59), realismo visual que se alcanza en tres fases: fortuito, fallido e intelectual, siendo este último el "que tiene por esencia el de hacer figurar en el dibujo de un objeto todos sus elementos constitutivos" (Luquet, 1978, p.146).

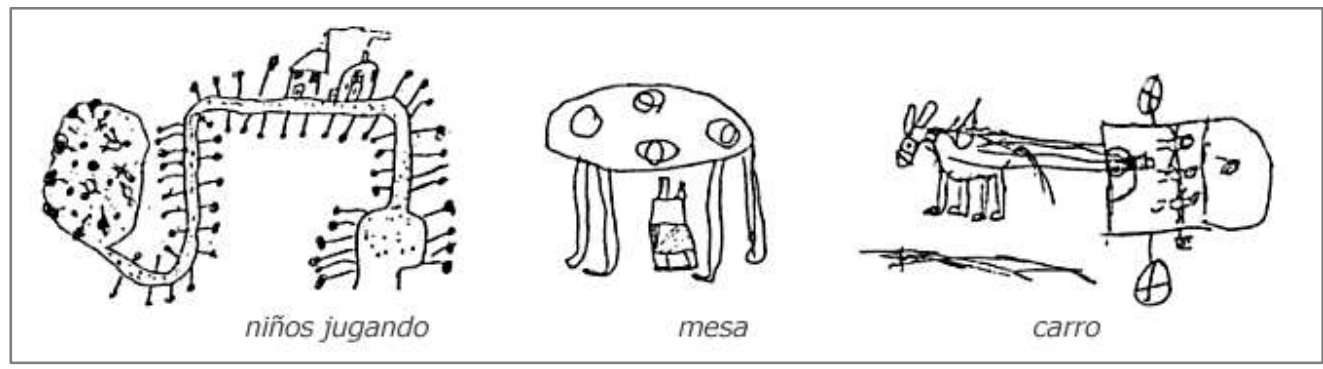

Fig.59: Dibujos narrativos del 'realismo intelectual' (Luquet, 1978)

A la fase de realismo intelectual en el dibujo debe sucederle el realismo visual adulto, que comprende las relaciones cambiantes de estos elementos por los diferentes puntos de vista. De esta manera, las contradicciones de las cualidades gráficas con las de la experiencia visual, explican el conflicto que se va a producir en un momento del desarrollo. Un conflicto del que habló Cizek situándolo en la pubertad: "puberty, as a rule, is the great caesura (la pubertad, por regla general, es la gran interrupción)" (Viola cit. en Kelly, 2004, p.84). Luquet muestra este conflicto como una lucha entre el empirismo y unos "hábitos contrarios profundamente enraizados" (Luquet, 1978, p.148), en la base del desconocimiento de las leyes de la perspectiva. Tanto Luquet como sus continuadores en esta línea del 
dibujo artístico verán en la práctica del dibujo al natural la posibilidad de superar todas las etapas de desarrollo.

Otras corrientes en el dibujo artístico entienden que estos planteamientos están en exceso basados en el aspecto narrativo de la expresión gráfica y resultan demasiado rígidos por diferentes motivos: el arte necesita libertad, el niño tiene pocas oportunidades en la escuela para expresar emociones y sentimientos, o el arte no entiende de eficacia, o tambien, y tal vez sea el principal motivo, el arte infantil entendido de esta manera fuerza a considerar la representación figurativa como un objetivo de desarrollo. Diferentes planteamientos centrarán su trabajo anteponiendo a la figuración otros objetivos como la creatividad o el pensamiento visual (Lowenfeld y Lambert, 1993; Eisner, 2004; Arnheim, 1979).

Pero todos estos enfoques artísticos se van a encontrar con el enfoque semiótico en el ámbito de la investigación actual de las artes plásticas y visuales. Mientras que unos reclaman mayor atención al desarrollo creativo aplicado al estudio del signo gráfico: "El tratamiento físico del signo gráfico difícilmente puede entenderse en el área plástica, por la reducción que tradicionalmente se hace de los campos de desarrollo creativo" (Loeck cit. en Mañero y Arañó, 2003, p. 29); otros expresan el cansancio por "la deslumbrante oscuridad del parloteo supuestamente artístico, el malabarismo de tópicos y conceptos estéticos deshidratados, el escaparatismo pseudo-científico (...)" para afirmar que "el arte es lo más concreto del mundo y nada justifica el sumir en confusión a quien quiera saber más acerca de él" (Arnheim, 1979, p.21)

En este sentido, se está despertando una sutil tendencia pedagógica hacia la interdisciplinariedad en arte y ciencia. En EEUU, la Asociación Nacional de la Educación Artística contempla introducir planteamientos científicos en el ámbito didáctico de la educación artística en base a las conclusiones de los trabajos sobre la creatividad. A la vez que se defienden los aspectos metodológicos de la investigación cualitativa, se ven débiles las conclusiones de las conexiones de los trabajos que relacionan la creatividad en el área artística en relación a las otras áreas: 
"La capacidad de generar ideas originales, encontrar nuevas asociaciones, y construir conexiones no convencionales innovadoras entre los conceptos que caracterizan el comportamiento creativo tiende también a estar asociada con el logro artístico.

Sobel y Rothenberg (1980) argumentaron que la creatividad artística se relaciona con el desarrollo de un pensamiento homoespacial, tipo particular de operación cognitiva que implica imágenes mentales muy complejas "donde las imágenes $y$ representaciones derivados de cualquier modalidad sensorial (incluyendo visual) son llevadas conscientemente a la misma ubicación especial".

La concepción mental resultante permite la producción de nuevas formas y estructuras, y su integración, lo que caracteriza a los esfuerzos creativos, como se documenta en la investigación de artistas distinguidos, músicos y personas creativas en otros campos (Rothenberg, 1979). Sin embargo, esta investigación ha dejado muchas preguntas sin respuesta en relación con los vínculos específicos entre los procesos homoespacial y su función creadora, ni ha dado ninguna indicación de que el desarrollo en el pensamiento homoespacial sería característico de desarrollo artístico en contraposición a la actividad creativa en otras áreas.

(Eisner, E. y Day, M., 2004, p.245)

Estudios científicos basados en los trabajos de Sobel y Rothemberg (1980) sobre pensamiento metafórico y creatividad, van a abordar ésta desde una triple perspectiva: la persona creativa, el proceso y los productos creativos. Concluyen que la creatividad constituye una forma de comportamiento aleatorio que interviene en la solución de problemas, independientemente de las características de la tarea (Simonton, 2003).

En nuestro país, el ámbito de la investigación en educación artística plástica apunta en la misma dirección: "arte y ciencia confluyen como expresiones de un mismo proceso, que es el ser humano, cuya identidad se expone en los lenguajes análogos en que se constituye" (Vallejo C. en Mañero y Arañó, 2003, p.377). , Citando a Nietzche (1987, p. 132): "Operamos mediante cantidades de cosas inexistentes, líneas, superficies, cuerpos, átomos, tiempos, espacios divisibles ¿cómo podríamos explicar, si hacemos de todo una representación, nuestra representación?", Vallejo realiza una defensa 
de la interdisciplinariedad de los contenidos, considerando que aspectos asociados al arte, como la intuición, la imaginación o lo onírico, están en la base del pensamiento y las deducciones de aquellos individuos que son referentes en la metodología científica.

Si partimos por tanto de que en las expresiones humanas se encuentran ambos aspectos del pensamiento artístico y científico, entonces podemos entender que están en todas las acciones que realizamos para construir conocimiento. Sin embargo, esta consideración no siempre está presente en una acción humana básica: la relacionada con el gesto gráfico.

\subsubsection{El gesto gráfico en la educación}

El gesto gráfico, como el resultado de una actividad motriz fina, de la percepción enactiva o de la acción guiada por la percepción visual, se estudia relacionado con la representación gráfica. Las ciencias de la educación se refieren a éste en el aprendizaje de la escritura y, en menor medida, en el desarrollo del dibujo, donde se refieren al garabato o pintarrajo.

Los estudios en educación gráfica tienen su referencia en la obra de Calmy-Guyot (1977), quien define el gesto gráfico como la consecuencia del movimiento corporal (condición de una vivencia en el espacio) traducida a una superficie. Aunque define el origen del gesto a partir del análisis espacial, diferencia desde un principio claramente entre dibujo y escritura:

"el objetivo final, que supera cada vez la expresión actual del movimiento, es simplemente la expresión libre en el dibujo y la copia de los signos convencionales de la escritura. Proporciona de alguna manera al niño un vocabulario gráfico, que él utiliza en seguida a su gusto."

(Calmy-Guyot , 1977, p.4)

Mientras que para Bernson (1962), el garabato es la más visible y duradera de las manifestaciones humanas en el origen de la 
representación gráfica. Su sensibilidad hacia el gesto le convierte en referente para la educación:

"Si por primera vez consigue agarrar un lápiz, ya no lo suelta. Se ha dado cuenta, por primera vez, de que el lápiz puede prolongar su mano. El papel que tiene delante electriza su mirada (...). El lápiz se posa sobre el papel y además se desliza sobre él. El niño siente la resistencia del lápiz sobre el papel, o la de la tiza sobre la piedra, y se divierte moviéndolos sobre este espacio limitado. Pero lo que más le sorprende es que su movimiento, su gesto, milagrosamente deja una huella. Se queda maravillado. Es aquí donde por primera vez su necesidad de expresarse encuentra la posibilidad de hacerlo."

(Marthe Bernson cit. en Piantoni, 1997)

Ambas líneas de estudio, la del garabato y la del vocabulario gráfico, describen el desarrollo del gesto gráfico en etapas y ven en el origen de éste una acción motora manipulativa (etapa vegetativomotriz), que, lejos de ser improductiva, predispone al aprendizaje infantil. Aunque Calmy en su obra hace notar a Bernson, cuyo análisis le parece insuficiente, que el estadio 'vegetativo-psicomotor' que él define, le parece más "una disposición permanente del ser humano, que debemos cultivar a cualquier edad" (Calmy, 1977, p.9).

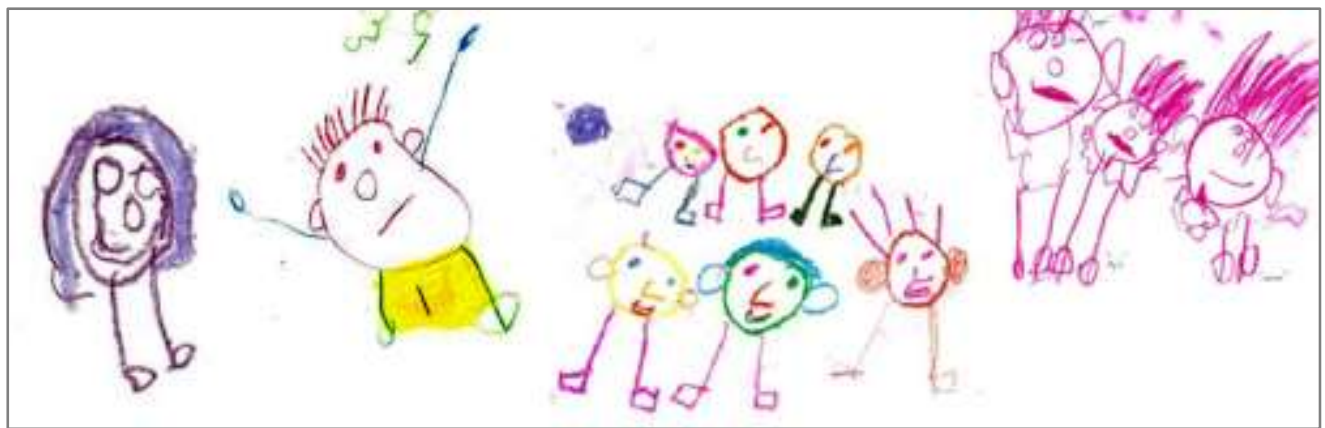

Fig. 60: Dibujos de figuras humanas de niños entre 3 y 4 años.

(arteinfantil.tripod.com)

La educación artística se va a centrar en el resultado de la acción, los garabatos, y en el placer motor descrito por Bernson que conlleva la acción. Estos garabatos parten de un reflejo de la actividad motora que irá cobrando sentido de representación (etapa representativa) a partir de los tres años de edad, en la figura humana 
de la "cabeza de rana" que es un círculo con ojos nariz y boca (Bernson cit. en Madi, 2012) (fig. 60).

La educación gráfica analiza el proceso diferenciando cuatro niveles del grafismo: dibujo, diversión, ejercicio y aprendizaje de la escritura. Deja apartado el nivel del dibujo (garabateo) como un área de expresión de libertad y afectividad, que va a atender la educación artística; y asigna a los demás niveles en la etapa comunicativo-social del nivel de la representación (ideogramas) una serie de "pautas pedagógicas" gráficas y sígnicas. De esta forma se inicia el entrenamiento gráfico en las convenciones del lenguaje a partir de la exploración, visual y motora, del espacio. En los ejercicios gráficos, las direcciones del gesto que marcarán la orientación espacial vertical responderá a las nociones arriba-lejos y abajo-cerca, y por tanto a las de 'avanzar' y retroceder'; mientras que la orientación espacial horizontal será de izquierda a derecha. La orientación del gesto gráfico en la dirección de derecha a izquierda queda supeditada al entrenamiento de los "hábitos motrices mayores", y "voluntariamente se olvida” (Calmy, 1977, p.11).

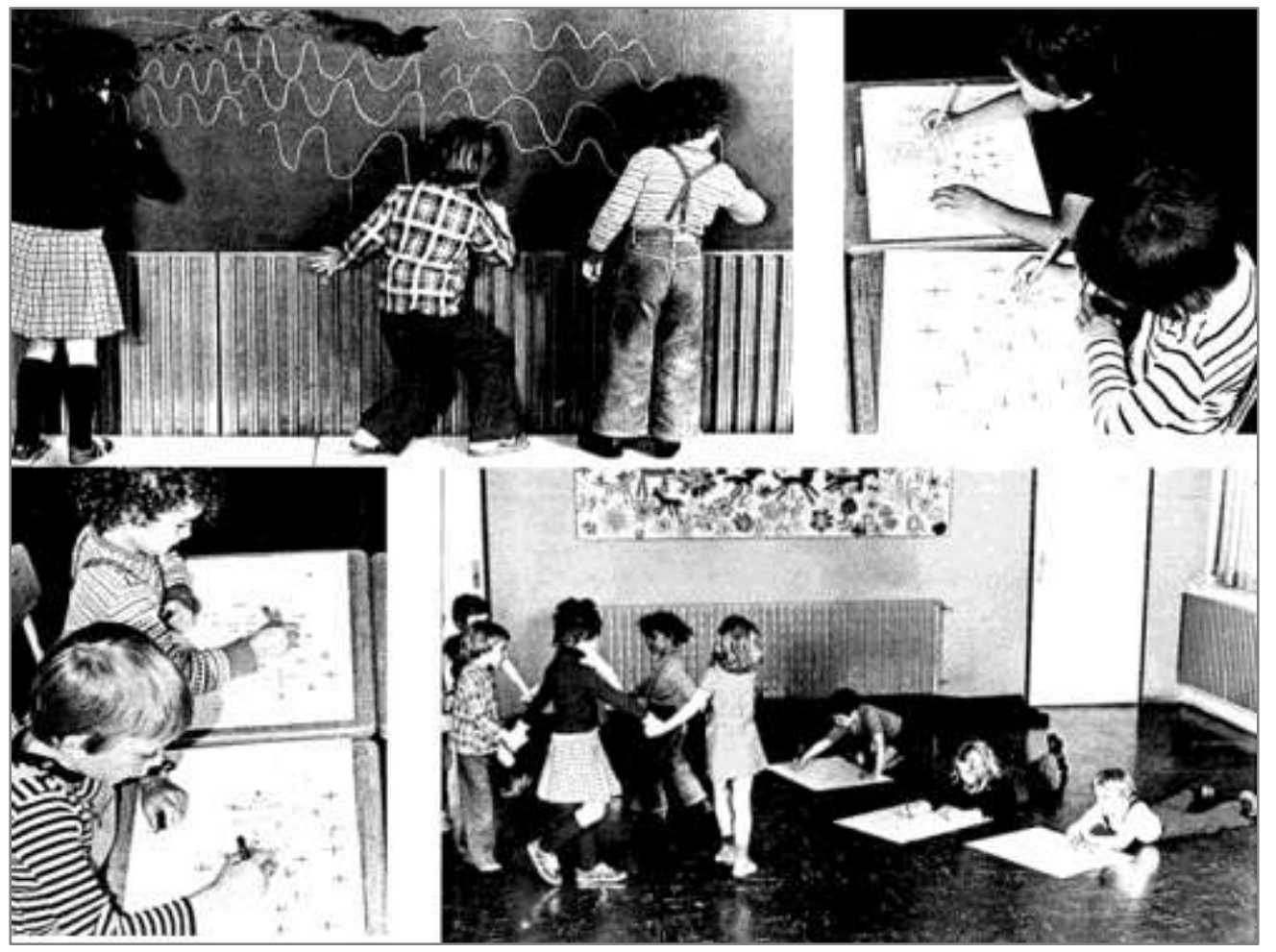

Fig. 61: Entrenamiento gráfico (Calmy, 1977) 
La maduración del gesto gráfico es un proceso que convierte a éste en 'trazados', del latín tractus (arrastrado). Los trazados son el resultado del control del gesto con la vista, y se produce en torno a los dos años con el desarrollo del musculo flexor del pulgar. La educación del gesto considera que cerca de los cuatro años ya disponemos de un alfabeto gráfico que permite cualquier trazado, pero quedan por adquirir el control de rotación (positivo-negativo) y el de traslación (movimientos en los ejes vertical y horizontal). Por lo general, se va adquiriendo este control con la repetición de ejercicios de trazos geométricos planos: líneas y formas circulares, ovoides, cuadradas y triangulares formarán así, a través de una insistente reproducción, parte fundamental del imaginario infantil.

Ambas líneas, la educación gráfica y la artística pueden coincidir en considerar que los modelos gráficos adultos aniquilan la creatividad, por proponer un modelo de formas estáticas, que por tanto frenan el dinamismo gráfico de los movimientos psicomotrices (Suárez Riaño, 2004). Sin embargo, y tal vez por diferentes motivos, ambas rechazan el modelo visual: aquel que vincula el gesto gráfico con la percepción visual. Unos lo hacen por considerar que la hoja en blanco es el marco ordenado de referencia gráfico, otros por despreciar la figuración de la "fase del pintarrajo" (Davido, 2006), pero como consecuencia, y a pesar de que los grafismos plasman el mundo tal como el niño lo ve, en la educación del gesto gráfico va a quedar desatendido el análisis del vínculo cognitivo entre el ojo y la mano en la experiencia de la representación gráfica, a pesar de los esfuerzos de la pedagogía de la imagen en 'educar la mirada' .

La maduración del gesto gráfico requiere tambien la aparición de la lateralidad, el predominio motor de un lado del cuerpo sobre otro, el sentido de equilibrio corporal, el control motor manual, la percepción del entorno y de las sensaciones que experimentan (Rollano, 2005). Al margen de la consideración figurativa de los grafismos infantiles, de su relación con lo representado, el desarrollo perceptivo y cognitivo continúa. La coordinación oculo-manual se contempla en la educación gráfica para el desarrollo de la habilidad manual, pero en este apartado, se descuidan habilidades visuales básicas relacionadas con el aprender a ver. Esta coordinación visomotora se analiza a partir de los movimientos manuales, atendiendo a aspectos como "la precisión, rapidez y seguridad de sus movimientos" (Rollano, 2005, p.52), por la 
consideración simbólica de la producción gráfica, pero en ningún caso se atiende a aspectos como el ritmo, la variación y la calidad del trazo.

Hemos comentado que desde Thurstone (1938) se evalúan los procesos perceptivos asociandolos estrechamente con la velocidad. Hoy dia sabemos que la percepción háptica es más eficiente de lo que se creía aunque se considera que las condiciones en que se ha estudiado el sistema háptico no han sido tan buenas o cuidadas como en el sistema visual (Ballesteros, 1993). Aun con todo, hoy podemos considerar al sistema manual con un grado de independencia del visual. Se tiene evidencia (Ballesteros, 1999) de que existe memoria sensorial asociada al procesamiento de la información en el sistema háptico, al igual que en el visual o auditivo. Ello nos permite aprehender propiedades de los objetos, y como sistema independiente, tiene la propiedad de ser procesado cognitivamente y comunicar con el sistema visual.

En este nivel de análisis del gesto gráfico, por uno u otro motivo, los resultados se suelen anteponer al proceso. El análisis de la representación gráfica del niño y su juicio adulto ocultan el análisis de los aspectos cognitivos de su pensamiento visual. En ocasiones encontramos en este análisis la confusión entre los contenidos estructurales (esquemas) y los contenidos perceptuales (cualidades) de los objetos (Rollano, 2005, p.47) y estamos poco o nada acostumbrados a considerar el retorno en la vía de la coordinación visomanual: la información visual que procesamos y la información háptica y táctil. Creemos que algunos aspectos del déficit cultural y competencial del aprendizaje visual en relación con el háptico, se pueden encontrar en los primeros momentos de la educación.

\subsubsection{Técnicas de representación gráficas}

De hecho, en la educación visual adulta, se plantea una reformulación de este aprendizaje en forma de técnicas visuales: 'aprender a mirar' es el slogan audiovisual y la fórmula de algunos métodos de enseñanza del dibujo para superar los conflictos que se establecen en la edad adulta "entre la visión-percepción y la representación-convención” (Gómez Molina et al., 2005, p.25). La 
percepción de bordes, formas, luz, espacios y toda una serie de relaciones constituyen el centro de estas técnicas. La habilidad gráfica se adquiere a la par que se analizan estas cualidades y sus relaciones. Se plantea la reeducación de la vista y en alguna medida la del gesto.

Podemos agrupar en tres tipos o categorías las actuales técnicas de la enseñanza del dibujo para resumir las características y diferencias principales en su concepción del gesto gráfico: estructurales, esquemáticas y visuales.

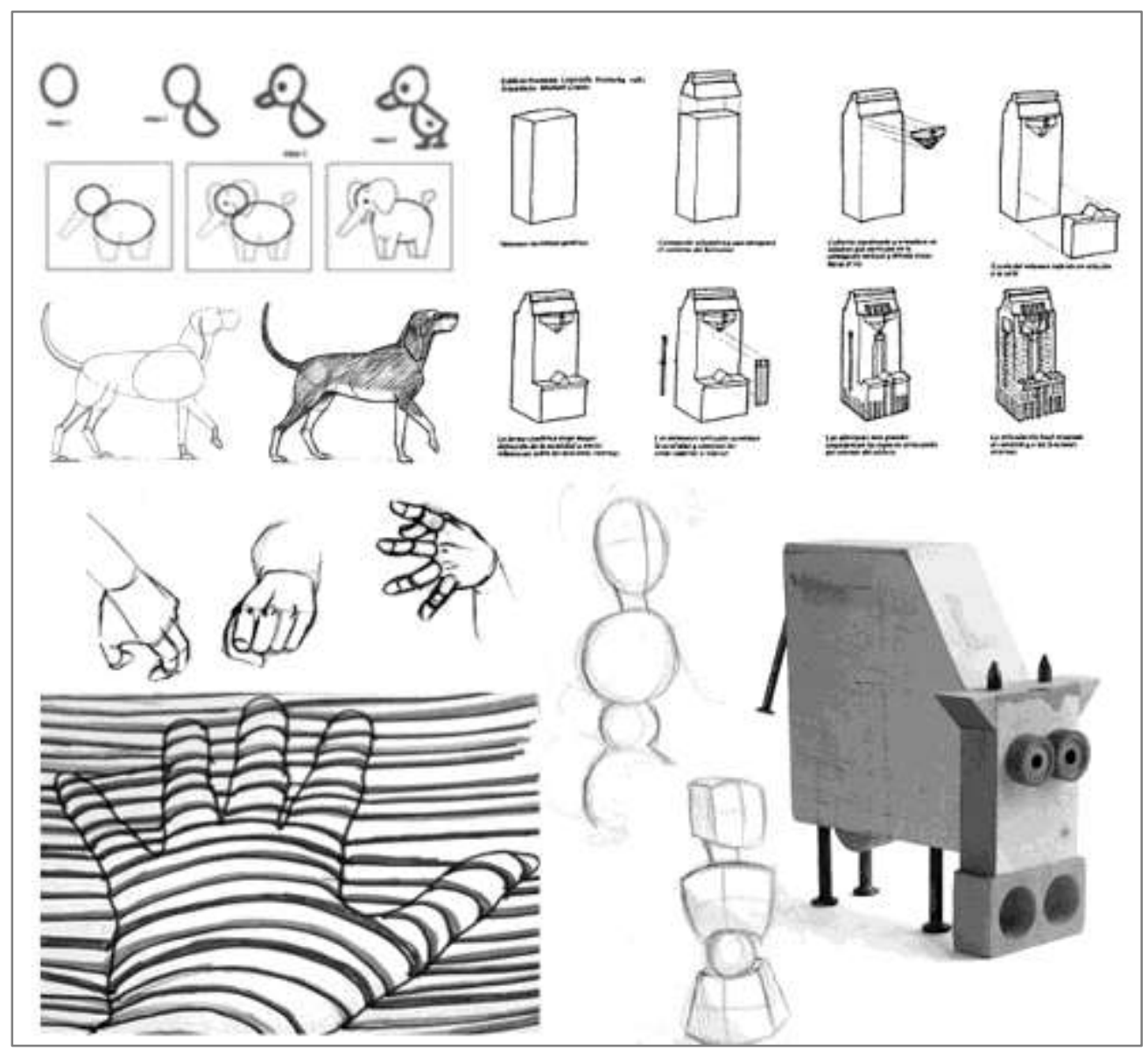

Fig.62: Técnicas estructurales y líneas de relieve para definir los contornos (Gámiz, 2003)

En primer lugar, las más utilizadas tradicionalmente, son un grupo de técnicas que para analizar y representar las formas, se basan en las formas geométricas y en menor medida, en las líneas de relieve, como aplicación del concepto de las "líneas geodésicas" a la 
definición de contornos (Dalí cit. en Gómez Molina et al., 2005, p.150). Este grupo de técnicas están basadas en un entrenamiento cognitivo y manual: requieren del conocimiento estructural de los objetos y se apoyan en la repetición (ensayo-error) de los entrenamientos (fig. 62), como modelo academicista. Son técnicas de uso habitual en los estudios de arte, arquitectura y diseño, que orientan a dibujar lo que se ve o la convención (figurativa, abstracta o simbólica) a partir de lo que se sabe (la estructura).

Un segundo grupo lo forman las técnicas más esquemáticas que plantean un mínimo entrenamiento manual, y se centran en los aspectos cognitivos con fundamentos semióticos y comunicativos. Son técnicas de dibujo simbólico, en las que se dibuja lo que se sabe de la convención, atendiendo a lo visual en un grado mínimo. Son técnicas muy cercanas a la construcción lingüística que requieren poca destreza gráfica, pero en mayor medida procesos de asociación de ideas y resolución de problemas (fig. 63).

En esta tipología están las técnicas del 'visual thinking' y del 'design thinking', que defienden la expresión gráfica manual en la creación de infografías. La infografía es entendida como una forma de presentación gráfica de la información, apoyada en imágenes. El recurso infográfico es cada vez más habitual en el mundo corporativo de las organizaciones, donde se utiliza de manera habitual el concepto de pensamiento visual para hacer más eficaz la comunicación. Quizás el más claro ejemplo de ello se encuentre en el desarrollo de la señalética y de los manuales de un producto o las instrucciones de montaje, en forma de mapas mentales. En este ámbito, el esquema de la figura humana y los signos utilizados marcan las diferencias entre los autores:

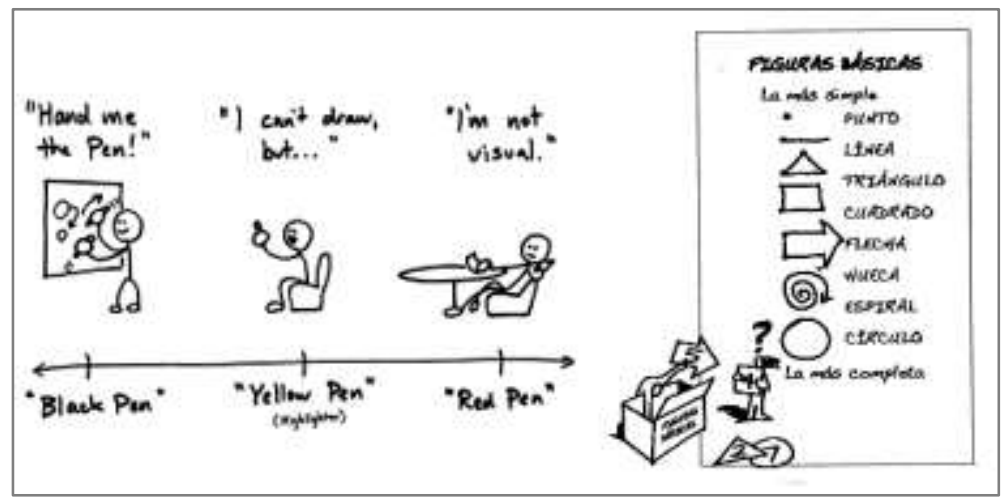



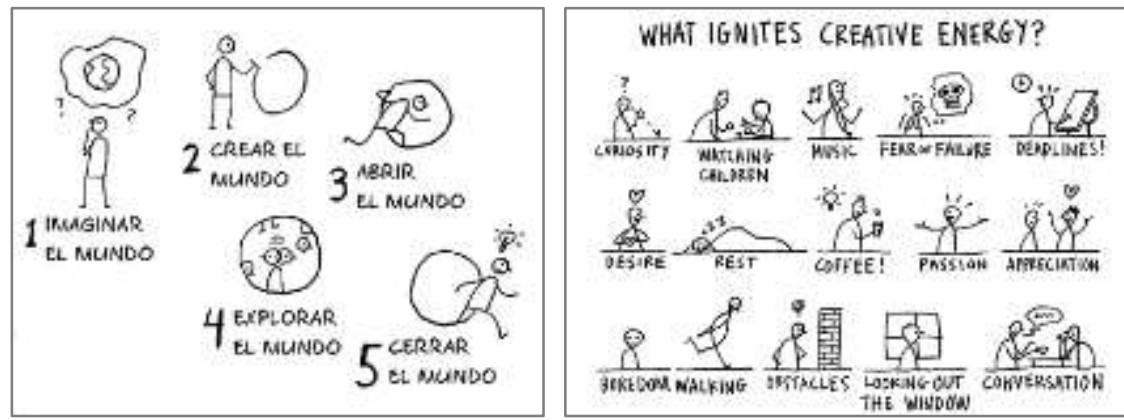

Fig. 63: Técnicas de 'visual \& design thinking'

(Roam, 2010; Sibbet, 2013; Gray, 2012)

En un tercer grupo, están las técnicas que se basan y atienden tanto al entrenamiento visual como manual, pero no requieren de tanto ensayo y entrenamiento como las primeras. Se apoyan en fundamentos neurocientíficos, y se centran en técnicas visuales y la maduración del gesto gráfico. Orientan a dibujar lo que se ve con ayuda de lo que es útil de lo que se sabe, pero desatiende la convención, recuperando un análisis visual espacial no simbólico. En cierta manera, buscan recuperar la visión inocente del niño que dibuja lo que ve y lo que sabe, pero con la conciencia adulta para permitir el control de la vía verbal y la no-verbal y elegir, consciente de la anticipación cognitiva motórica, una u otra opción en la representación gráfica (Edwards, 1994).

Estas técnicas no están tanto dirigidas a la educación artística como al desarrollo de la creatividad y habilidad visográfica, aunque Edwards, que recopila estas técnicas en su obra, reconoce con cierta sorpresa el arte de la producción gráfica de sus alumnos (fig. 64).

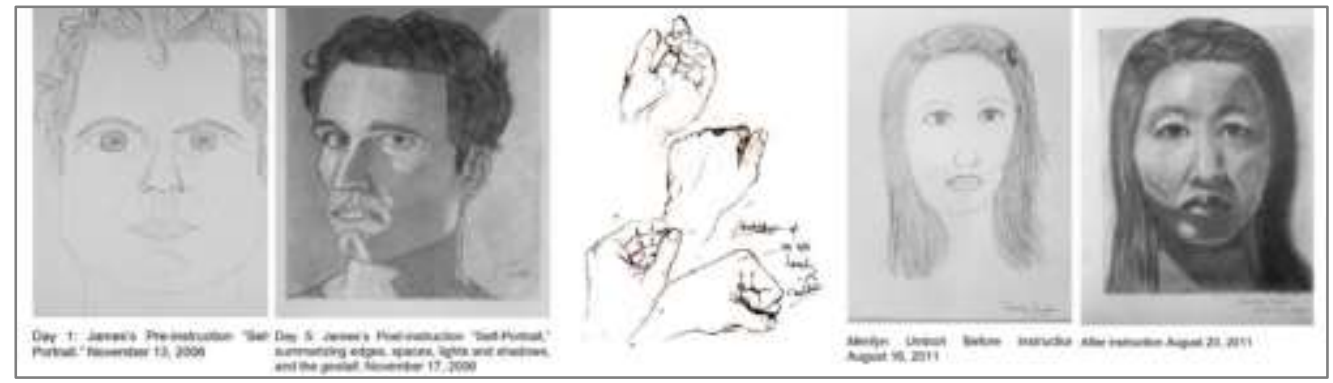

Fig.64: Autorretratos pre y post entrenamiento (Edwards, 2013). Manos realizadas por alumnos de 1ํ de E.S.O., después de cinco semanas de entrenamiento (www.joseluisabrain.blogspot.com.es) 
Su obra, en la que colabora el nobel neuropsicólogo Roger Sperry, se basa en la aplicación de técnicas de doble análisis visual de la forma, a partir de los modos de procesamiento cognitivo, y en la reeducación del gesto, a partir del autoanálisis del desarrollo gráfico:

"Hemos repasado el arte de nuestra infancia y el desarrollo del conjunto de símbolos que formaron el lenguaje infantil para dibujar. Este proceso se realizó paralelamente al desarrollo de otros sistemas de símbolos: el habla, la lectura, la escritura y la aritmética. Mientras estos otros sistemas de símbolos construyeron cimientos útiles para el desarrollo posterior de habilidades verbales y de cálculo, los símbolos infantiles para el dibujo parecen obstaculizar las fases posteriores del arte."

(Edwards, 1994, p.98)

Todas estas maneras y técnicas de entender la representación gráfica del dibujo no son incompatibles entre sí y tampoco se relacionan preferentemente con la educación artística. Se centran en las capacidades geométrica (estructural), espacial (visual) y de comunicación (esquemática) del pensamiento visual, las cuales se desarrollan en el currículo general afectando a todas las áreas de conocimiento.

El punto y la línea permiten como representación gráfica básica un análisis del ritmo, de la presión y de la trayectoria, que puede ir más allá del análisis de la eficacia y los rasgos de la escritura, mejorando al mismo tiempo su aprendizaje. Estas cualidades de la expresión gráfica son reflejo de estados de ánimo emocional, y de concentración para el aprendizaje, pero también de una construcción imaginaria del espacio, los seres y los objetos que nos rodean.

Hoy día alcanzamos a analizar desde la grafopsicología, los gestos y símbolos que discurren a la par del movimiento caligráfico, y extraemos conclusiones sobre el estado de ánimo emocional, rasgos de personalidad y hasta los actos fallidos que caracterizan a la persona que escribe (Moreno, 2007; Cerro Jiménez, 2010). Desde la arteterapia también alcanzamos a analizar los 'metadoodles' (fig. 65), término acuñado para esos dibujos inconscientes que hacemos cuando hablamos por teléfono, y lo hacemos para estudiar a través de ellos, en la repetición de punteados y líneas, los automatismos y su 
relación con estados alterados de conciencia (García Muñoz, 2008). Debemos preguntarnos desde las ciencias de la educación qué impide estudiar la capacidad constructiva que tiene el grafismo más elemental.

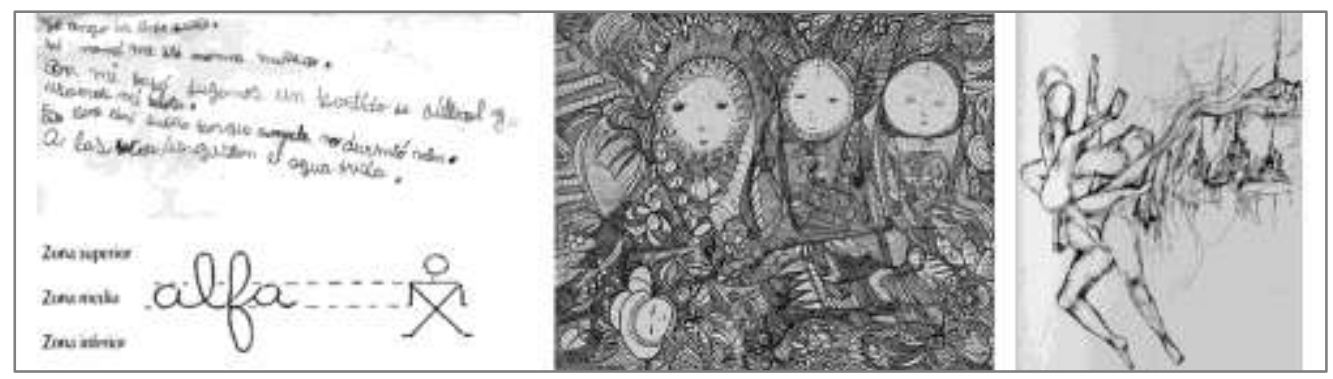

Fig.65: Muestra de caligrafía (Tesouro de Grosso, 2006) y 'metadoodles' (Maclagan, 2014)

El estudio del gesto gráfico desde la pedagogía, requiere de un replanteamiento con el fín de ir más allá de la mera descripción del trazo con una intención simbólica, y estudiarlo también como reflejo del análisis visual, perceptivo, y considerando las posibilidades de interferencia propias del sistema háptico. La educación del gesto gráfico se habrá de replantear por tanto, dejando a un lado la intencionalidad artística y las interpretaciones psicológicas, como el marco inicial de preparación para la exploración del espacio, las formas y las relaciones, conscientes de las diferentes vías de procesamiento cognitivo visual y de la percepción táctil, kinestésica y háptica.

\subsection{El Pensamiento Visual en la formación del profesorado en el Grado de Educación}

La reforma que plantea el Espacio Europeo de la Educación Superior (EEES) incluye un espíritu de innovación educativa y de profesionalización docente, cuestionado por un justificado escepticismo, que lleva a ver este nuevo proceso como una superficial adaptación a un sistema de créditos europeo y de homologación de títulos (Sola Fernández, M., 2004). Un escepticismo ante la 'europeización' de la universidad española, que se apunta clara y 
duramente: "hay innovaciones que cambian la realidad y otras que solo cambian los nombres o las formas de hablar de las cosas que dicen querer trasformar" (Michavila, 2005, p.37).

Pero al mismo tiempo, la formulación de esta reforma permite un replanteamiento optimista de la educación superior, de la universidad como espacio privilegiado de reflexión y pensamiento crítico, y de su papel social de capacitación profesional con el fin último de la formación integral de profesionales de calidad humana y ciudadana (Fernández March, 2008; Flecha et al., 2005).

Con este planteamiento positivo, surge la oportunidad de reformular la teoría y la práctica de la formación de los docentes, "a la luz de las nuevas exigencias de la sociedad de la información y de la incertidumbre, de las investigaciones nacionales e internacionales en el campo, así como de las experiencias internacionales en la última década" (Pérez Gómez, 2010). La definición de las competencias profesionales básicas, requiere la apertura a replanteamientos educativos que refuercen las ideas constructivistas y las metodologías activas que acompañan a los planteamientos de la educación en las últimas décadas $y$, en este sentido, la profesionalización de la docencia conlleva una exigencia de formación.

Las competencias básicas de la profesión docente se recogen en la propuesta o libro blanco que hace la Agencia Nacional de Evaluación de la Calidad y Acreditación (ANECA) para la adaptación del grado en Magisterio al Espacio Europeo de Educación Superior (EEES), y que envía al Ministerio de Educación y Ciencia y al Consejo de Coordinación Universitaria, organismo encargado entre otras atribuciones, de la programación del sistema universitario. Esta propuesta la realiza una comisión que recoge el trabajo de un buen número de personas de las distintas Facultades y Escuelas que forman maestros, y aboga por la profesionalización de los estudios de magisterio:

"En nuestro espíritu, al margen de la mera convergencia con Europa, siempre estuvo que nuestro país recuperara la primea línea en Formación de maestros de principios de los años 30, el llamado "Plan Profesional de la República". En ese momento, los maestros españoles, a pesar de no estar integrados sus estudios en la 
Universidad, recibían la más amplia formación que existía en Europa superior incluso a la que ofrecemos ahora en términos de formación práctica. A comienzos de la siguiente década, los maestros que sobrevivieron vieron cómo los "nuevos" maestros recibian una formación que se situaba en las antípodas del modelo anterior y que, además, se formaban en apenas 6 meses.

Desde entonces, la demanda de un mayor reconocimiento social de la labor del Maestro siempre ha estado vinculada con la necesidad de mejorar su formación inicial, que desde muchos y numerosos informes se ha venido considerado insuficiente..."

(Maldonado, 2005, p.19)

Frente a una serie de competencias transversales, planteadas a docentes de las distintas universidades, el citado informe muestra su sorpresa y decepción por la escasa valoración recibida por dos competencias básicas: el conocimiento de las nuevas tecnologías y la capacidad de gestión de la información, y el conocimiento de lenguas extranjeras, así como por la poca receptividad ante propuestas innovadoras del colectivo docente: "para quien la mayor parte de las propuestas de innovación educativa recogidas por la literatura de los últimos años permanecen al fin en un segundo plano" (p.86).

Las competencias específicas de formación disciplinar y profesional del grado de magisterio se analizan de manera común a las especialidades y a las áreas de conocimiento (Lengua, Matemáticas, Ed. Artística-Plástica, y Ciencias). En general existe una mejor valoración de los aspectos conceptuales (saber) de las competencias, que de los aspectos procedimentales (saber hacer) y actitudinales (saber ser).

El planteamiento del currículo de formación de los futuros maestros y maestras se centra en tres núcleos formativos:

- Adquisición de conocimientos e instrumentos que ayuden a fundamentar la reflexión psico-socio-pedagógica del hecho educativo.

- Adquisición de conocimientos y habilidades que le permitan el desarrollo de capacidades y actitudes que faciliten el nivel de 
madurez personal necesaria para poder asumir las responsabilidades que le son propias.

Creación de situaciones de enseñanza-aprendizaje que faciliten a los alumnos/as la construcción del conocimiento que le permita en su futuro trabajo plantearse una buena reflexión desde y sobre la propia práctica.

(Maldonado, 2005, p.19)

En relación a los aspectos de las aptitudes visuales y gráficas figuran tres competencias en Educación Infantil que ocupan diferentes posiciones en la valoración docente (entre 1 y 75). Entre las competencias docentes específicas, tiene mayor consideración la geometría, mientras que el dibujo y la relación con las nuevas tecnologías ocupan las últimas posiciones (se resumen los resultados por orden de valoración numerando entre guiones el puesto que ocupan en la valoración hasta el 75):

- Conocer las estrategias metodológicas para desarrollar nociones espaciales, geométricas y de desarrollo del pensamiento lógico. -24-

- Promover el uso del dibujo y de la creación de figuras como instrumentos del aprendizaje y como productos del esfuerzo personal. -68-

- Capacidad de gestión de la información. -71-

- Ser capaz de fomentar experiencias de iniciación en las nuevas tecnologías de la información y la comunicación. -75-

La mala posición de las nuevas tecnologías se corresponde con el desconocimiento del potencial didáctico de las TIC en los estudiantes de Magisterio y la consideración que tienen "como un añadido a su formación básica que podrán adquirir o no en su día dependiendo de las circunstancias" (Gutiérrez et al., 2010).

En la Educación primaria, las competencias a desarrollar se analizan en relación con los objetivos de las áreas de conocimiento 
para cada perfil, y se ordenan por el valor medio obtenido en la evaluación de los académicos.

Resumimos los aspectos visuales y gráficos de éstas, incluidos los específicos del área artística plástica, exceptuando los de carácter técnico-artístico, y los vinculamos con la posición en la valoración global de competencias que realizan los docentes de todas las áreas y especialidades (valores entre 1 y 149):

Area Lingüística:

- Ser capaz de usar los recursos audiovisuales y las nuevas tecnologías aplicadas a la enseñanza de las lenguas, de un modo creativo. -132-

- Incorporar a sus actividades docentes elementos informativos, publicitarios y recreativos procedentes de los medios de comunicación de masas, especialmente TV, desde una perspectiva crítica. -115-

Area Matemática:

- Usar y hacer usar a los alumnos los números y sus significados, ser capaz de medir y usar relaciones métricas, ser capaz de representar y usar formas y relaciones geométricas del plano y del espacio, ser capaz de analizar datos y situaciones aleatorias en situaciones diversas, tanto no escolares como escolares. -1-

- Conocer los procesos de simbolización matemática (de las representaciones enactivas a las simbólicas, pasando por las icónicas. La interpretación de fenómenos de la vida cotidiana mediante el lenguaje algebraico, las gráficas funcionales y otros sistemas de representación). -57-

- Saber diseñar actividades interdisciplinares de las matemáticas con otras áreas del currículum. -74-

- Mostrar habilidad en el uso de TIC en matemáticas elementales. -139-

Area de Ciencias experimentales: 
- Conocer y entender los contenidos actitudinales, conceptuales y procedimentales (experimentar, observar, describir, anticipar, argumentar, etc.), propios de las ciencias experimentales en los niveles de la enseñanza obligatoria, y cómo estos deben ser integrados para el aprendizaje de los alumnos. -2-

- Conocer los rudimentos de los diversos lenguajes (dibujos, tablas, fórmulas, gráficos, etc.) y formas de comunicación (descripciones, definiciones, justificaciones, etc.) propias de las ciencias experimentales. -51-

- Conocer las diversas aplicaciones de las nuevas tecnologías audiovisuales e informáticas en la enseñanza de las ciencias experimentales y cómo y cuándo utilizarlas para facilitar el aprendizaje de las ciencias experimentales -128-

Area de Geografia e Historia:

- Exponer y aplicar las técnicas y métodos propios de la Historia (categorías temporales, representaciones de ciclos y etapas, uso de fuentes históricas, empleo de vocabulario específico, elaboración de hipótesis etc.), la Geografía ( orientación y medida del espacio, representación gráfica y cartográfica, observación directa, análisis del paisaje, etc.) y de otras ciencias sociales (métodos cuantitativos y cualitativos de las ciencias sociales, estudio de caso único, etc.) -19-

- Saber integrar las nuevas tecnologías, tanto informáticas, como audiovisuales, en la enseñanza de la Historia, la Geografía y otras Ciencias Sociales. -en esta área se valora más que en ninguna otra el uso de las nuevas tecnologías. -97-

Area de Educación Artística:

- Conocer las características generales del lenguaje visual y los aspectos fundamentales de su sintaxis y semántica. -25-

- Ser capaz de analizar de manera crítica los mensajes y los mecanismos de control de la información utilizados por los medios audiovisuales. -118-

- Facilitar la representación a través de los lenguajes plásticos y visuales. -31-

- Favorecer la construcción y codificación de conceptos gráficos en relación a experiencias concretas. -145- 
- Fomentar el enriquecimiento de las percepciones visuales y táctiles del niño y la niña, incluyendo la observación, distinción, relación, selección, juicio, interpretación, análisis y síntesis vinculados a las mismas, así como las relaciones de carácter sinestético. -46-

- Potenciar la apreciación y valoración de cualidades plásticas y visuales. -42-

- Ser capaz de realizar un estudio crítico de los medios de comunicación (cine, TV, video, publicidad, lenguajes interactivos y multimedia), desde una óptica eminentemente visual y con perspectiva ética. -112-

De manera global, entre todas las áreas, y atendiendo a todos los perfiles profesionales, las peores valoraciones se encuentran en las competencias resaltadas, que implican el uso de los recursos audiovisuales y las nuevas tecnologías, al igual que la construcción de conceptos gráficos (fig. 66).

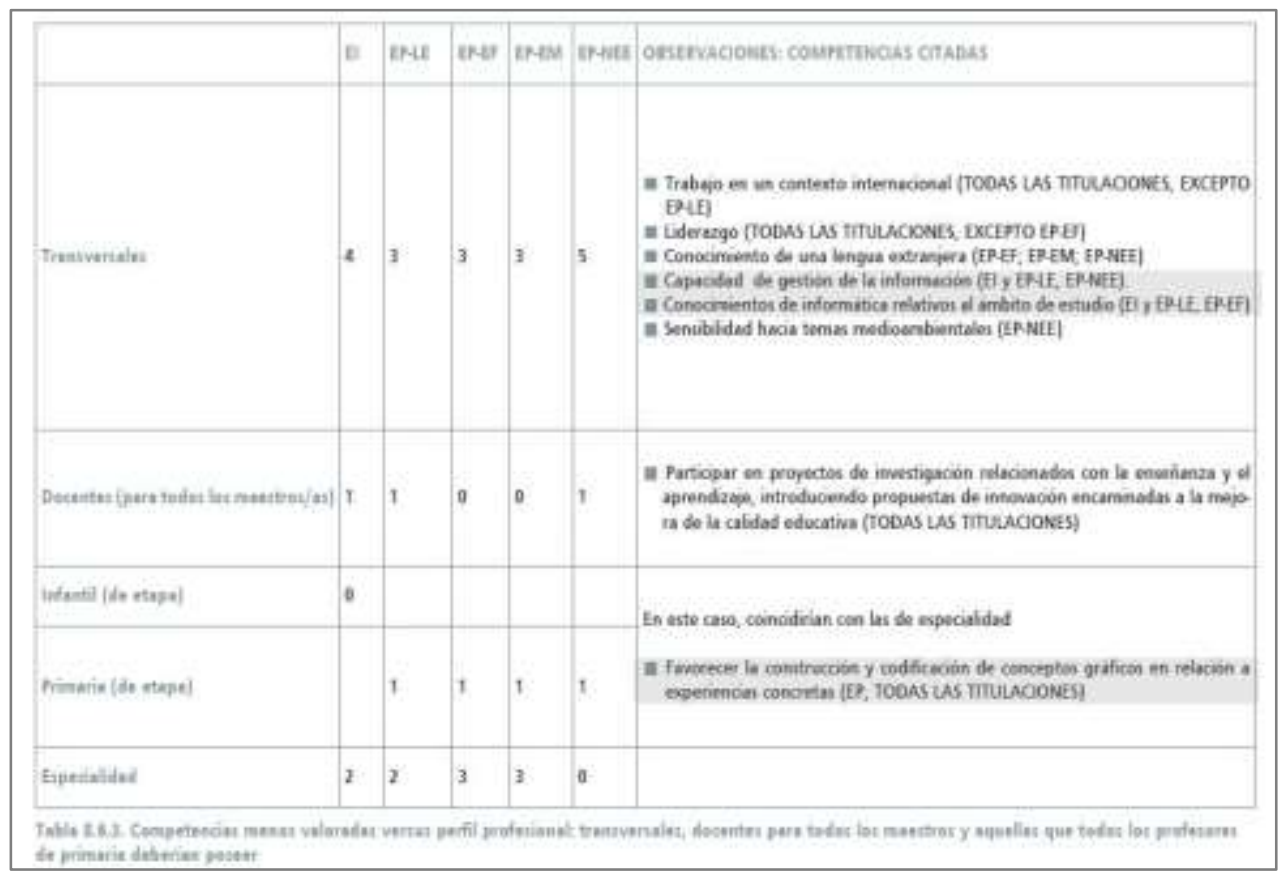

Fig. 66: Tabla de competencias con menor valoración docente.

Por el contrario, entre las mejores valoraciones globales en todos los perfiles, se encuentran las competencias que implican las relaciones espaciales y los procedimientos de observar y describir como propios del razonamiento científico (fig. 67). 


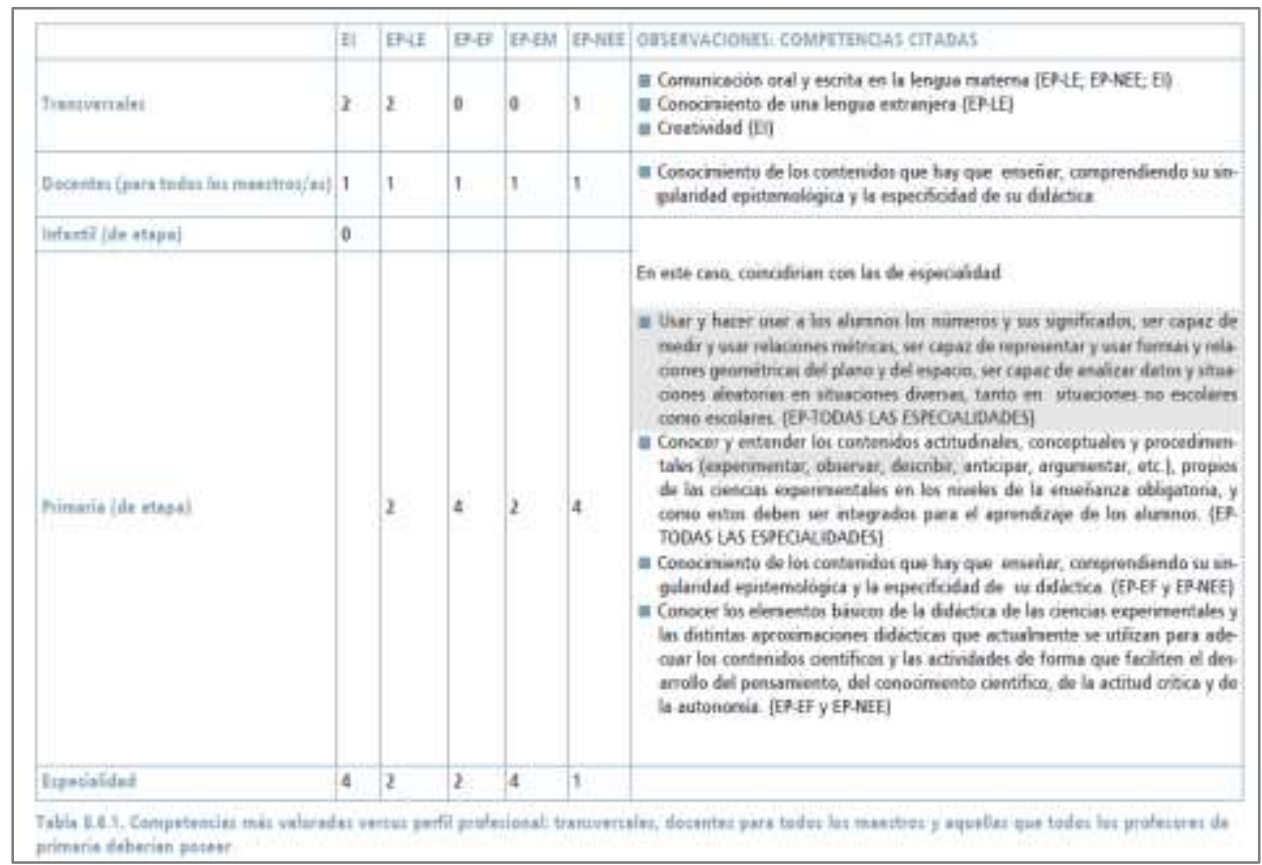

Fig. 67: Tabla de competencias con mayor valoración docente.

Cabe destacar que las técnicas de razonamiento espacial y las técnicas de observación científica, son los enunciados más valorados en la especialidad de ciencias y necesidades educativas especiales, mientras que en lengua, lengua extranjera, educación física y música ocupan la tercera posición. Por tanto, la competencia que se define como "ser capaz de representar y usar formas y relaciones geométricas del plano y del espacio" es preferente en todas las titulaciones del Título de Grado de Magisterio. Igualmente valorados son los aspectos cognitivos y de desempeño de la observación y la descripción junto a la argumentación. Esto nos permite concluir que entre las competencias preferentes de los docentes, al menos en su aspecto conceptual, se encuentran las técnicas de representación gráfica.

Sin embargo, el conocimiento de la construcción y codificación de conceptos gráficos en relación a experiencias concretas, competencia que supone el desempeño de la representación gráfica, tienen una valoración escasa o nula, en todas las titulaciones y curiosamente, en el área artística ocupa el puesto 145 de 149. 
Esto nos permite extraer una conclusión, al menos en la definición o descripción de competencias, de que existen dos interpretaciones en lo que a la representación gráfica se refiere: la primera interpretación apunta a que las implicaciones del concepto gráfico en las competencias científicas (gráficos de datos, modelos), no estarían vinculadas con las relaciones geométricas y espaciales. De otra manera no se entiende la valoración dispar de ambas competencias. Los docentes del área de ciencias no parece que encuentren en el dibujo geométrico y geográfico un aspecto procedimental de la competencia o el razonamiento espacial. Sin embargo, el estudio de la cognición espacial se destaca por su importancia para entender cómo los individuos representan el mundo físico en el que operan (Lohman et al., 1987); y parece más que probada la relación que la investigación establece entre la competencia espacial y los tipos de visualización en el aprendizaje, como un factor profesionalizante en diversas carreras científicas: "Numerous studies have been carried out to understand the role of visual-spatial representations in learning (e.g., Larkin \& Simon, 1987; Mandl \& Levin, 1989; Plass et al., 1998; Winn, Li, \& Schill, 1991)" (Kozhevnikov et al., 2002, p.72).

En una segunda interpretación, la representación gráfica no se vincularía con la competencia del lenguaje plástico infantil. Al parecer, los docentes del área artística plástica no relacionan, al menos directamente, la expresión plástica con el concepto gráfico del lenguaje visual, y se perciben como dos áreas de conocimiento, tal como refleja su propia denominación 'plástica y visual y audiovisual', en la que la primera se vincula al arte manual y la segunda a un concepto genérico de la imagen y los medios basados en ésta.

Creemos que se produce una disociación, que también existe en la propia investigación del pensamiento visual, entre la imaginería visual y la competencia o el razonamiento espacial. Como resultado, encontramos la desorientación en los propios estudiantes en relación a su propia experiencia visual y espacial, pero sobre todo, en la incidencia que puede tener este disociado enfoque en el desarrollo de la representación gráfica y en la formación del pensamiento visual de sus futuros alumnos: 
"However, most studies investigating the effect of mental imagery on learning have treated imagery as a general and undifferentiated skill. Our research provides evidence that imagery might rely on different types of representations, and different people might have a strong preference for one type or another.

It is remarkable that a significant group of college students, visualizers of the iconic type, had difficulty interpreting graphs as abstract schematic representations and instead interpreted them as pictorial representations. These students will clearly have difficulty solving science and mathematics problems that involve graphs."

(Sin embargo, la mayoría de los estudios que investigan el efecto de las imágenes mentales en el aprendizaje han tratado las imágenes como una habilidad general y no diferenciado. Nuestra investigación proporciona evidencia de que las imágenes podrían depender de diferentes tipos de representaciones, y diferentes personas podría tener una fuerte preferencia por uno u otro tipo. Es notable que un grupo significativo de estudiantes universitarios, visualizadores del tipo icónico, tenga dificultades para interpretar los gráficos como representaciones esquemáticas abstractas y en lugar de ellos interpretarlos como representaciones pictóricas. Estos estudiantes tendrán claramente dificultades para resolver problemas de ciencias y matemáticas que implican gráficos.)

(Kozhevnikov et al., 2002, p.72)

En gran medida, el conjunto de recomendaciones que hace la ANECA en el Libro Blanco del Título de Grado en Magisterio quedan plasmadas en la legislación educativa, configurando los estudios del Grado en Educación Primaria a través de tres módulos y un módulo de optatividad en torno a 30 créditos, con un total de 240 créditos (fig.68).

\begin{tabular}{|c|c|c|}
\hline \multicolumn{2}{|r|}{ Módulo } & Créditos ECTS \\
\hline \multirow{3}{*}{ De formación básica } & Aprendizaje y desarrollo de la personalidad & \multirow{3}{*}{60} \\
\hline & Procesos y contextos educativos & \\
\hline & Sociedad, familia y escuela & \\
\hline \multirow{6}{*}{ Didáctico-disciplinar } & E-A de las Ciencias Experimentales & \multirow{6}{*}{100} \\
\hline & E-A de las Ciencias Sociales & \\
\hline & E-A de las Matemáticas & \\
\hline & E-A de las Lenguas & \\
\hline & E-A de la Expresión Musical, Plástica y Visual & \\
\hline & E-A de la Educación Fisica & \\
\hline Prácticum & & 50 \\
\hline
\end{tabular}

Fig. 68: Reparto de créditos ECTS (Benarroch, A., et al., 2009) 
De tal manera que la Orden Ministerial ECl/3857/2007, de 27 de diciembre, establece un perfil profesional de Maestro de Educación Primaria, con un perfil generalista, con competencias específicas como docente en las áreas del currículo de Educación Artística Plástica, Matemáticas, Lengua, Ciencias, Geografía e Historia, y un perfil de especialización realizado mediante itinerarios en una de las áreas del currículo oficial: Educación Física, Lengua Extranjera, Educación Musical y Necesidades Educativas Específicas.

Extrapolando las conclusiones de los estudios analizados, y salvando las distribuciones de cada universidad, la distribución aproximada por créditos y grupos de materias atribuye a:

- Matemáticas y Lengua, con un número de créditos mayor de 20;

- Ciencias Experimentales y Ciencias Sociales, con un número de créditos de 15; y

- las que van a asociadas a menciones específicas, como Idioma Extranjero; Educación Musical, Plástica y Visual; y Educación Física, a los que se les adjudica 11, 10 y 9 créditos respectivamente. (Benarroch et al., 2009)

Si bien los principales contenidos de la educación visual se encuentran en el diseño curricular de la didáctica de la expresión plástica, la dedicación horaria del área gira en torno a nueve créditos a lo largo de todos los cursos del grado. La Educación Artística Plástica es la materia que mayor pérdida ha sufrido, que ha pasado del $23,6 \%$ de las horas de contenidos formativos comunes en el Plan de 1977 a sólo el 3,0\% en el Plan actual, de 2001 (Benarroch et al., 2009). Esta pérdida redunda en beneficio del aumento de créditos de las áreas de Lengua y de Matemáticas, en comparación con las de Ciencias Experimentales y Sociales.

En el total de este tiempo de formación en el área artística, los contenidos se distribuyen para cubrir diferentes ámbitos de las artes visuales, como son los relativos a la apreciación del patrimonio artístico, la actividad pedagógica de los museos, la historia del arte y los conceptos del arte contemporáneo, así como trabajos de taller propios del área, en el tratamiento de las técnicas y materiales 
artísticos y sus diferentes aplicaciones (dibujo, comic, títeres, stopaction,...). En estos contenidos hay que incluir los contenidos incorporados de la educación visual y audiovisual: la alfabetización visual, la lectura de imagen, la fotografía y la animación, o el cine. Resulta obvio, considerando el poco espacio que ocupa en el currículo general, el exceso de carga en los aspectos visuales y gráficos que recibe esta didáctica en la consecución de la competencia visual y espacial.

En la formación del grado en educación, para facilitar cualquier aprendizaje, las didácticas, más allá de hacerse específicas, han de pretender que los docentes tengan claros los procesos cognitivos. Hemos comentado que la tendencia del sistema educativo escolar es vincular los aspectos cognitivos visuales a la formación artística básica de sus alumnos, pero así ocurre igualmente en la educación superior del grado en educación. La distribución de créditos que se realiza, como causa o efecto de esta tendencia, asigna a los contenidos específicos del pensamiento visual una carga mínima, lo que creemos contribuye al ambiente de incertidumbre e imprecisión en la concreción de las competencias docentes que el futuro maestro habrá de asumir en el ejercicio de su profesión (Benarroch et al., 2009; Muñoz y Sacristán, 2006).

Aun reconociendo, de acuerdo con Romero y Gómez (2007), la dificultad para determinar empíricamente el cuerpo de conocimientos necesario para lograr un "profesional competente", consideraremos algunos factores que nos resultan poco convenientes en la distribución actual. El primero está en el hecho de asignar a un área con exclusividad, contenidos educativos que afectan en igual o mayor medida a otras áreas, con el resultado de una reducción perjudicial del tiempo global dedicado a los contenidos de la educación visual. Existe otro factor que no ayuda, como es la creencia compartida en considerar de menor importancia, en términos de empleabilidad 0 eficacia, los estudios artísticos del área donde se encuentran estos contenidos, que a su vez, no dispone de un perfil específico. $Y$ un tercer factor, como reflejo de los anteriores, está en la escasa formación resultante en el desempeño gráfico de los docentes, que son quienes adquieren la función de programar contenidos y actividades, y la competencia profesional para trabajar con estas capacidades en la educación básica. 
Se reconoce que, desde un punto de vista pedagógico, se facilita el aprendizaje cuando, además del discurso o la interacción verbal, las exposiciones son apoyadas con planteamientos 0 'discursos' visuales por medio de imágenes, mapas, esquemas y graficos, animaciones e interfaces. Sin embargo, aun valorando este desempeño, no se considera "la necesidad de prestar atención al desarrollo de las habilidades implicadas en la inteligencia espacial, a través de toda la etapa de escolarización" (Biggio, Vázquez y García, 2011) y, especialmente, en la formación de los profesionales de la educación en esta etapa.

En consecuencia, el itinerario a través del sistema educativo formal ofrece una dedicación horaria escasa o nula a la expresión gráfica del futuro profesional docente entendida ésta como un gesto didáctico relacionado con su propia competencia visual y espacial. Si la competencia docente se enmarca en la pretensión de llevar a los maestros 'expertos en rutinas' a la categoría de 'expertos adaptativos' entre la innovación y la eficiencia (Darling-Hammond y Bransford, 2007; Romero y Gómez, 2007), entonces se ha de considerar que la propia competencia gráfica del docente se refleja directamente en lo que definimos como entorno de enseñanza-aprendizaje, desde la pizarra del aula hasta la producción de materiales gráficos y recursos audiovisuales o digitales, y en cualquier caso, en la propia interpretación y utilización docente de los materiales existentes.

Compartimos en gran medida las percepciones que se expresan desde la docencia en el área de didáctica plástica, en cuanto a la valoración del dibujo didáctico: "la mayoría de maestros y maestras, de infantil, primaria y secundaria, no conceden el valor suficiente al potencial didáctico del dibujo, de la imagen, y del pensamiento visual en general' (Calbó, 2010, p.1). Pero consideramos que no se trata de una actitud deliberada, sino más bien es el reflejo de un déficit en la formación básica universitaria que repercute en la profesionalización del docente. Y ello, como apunta la autora, influirá desfavorablemente en la educación de los niños y jóvenes, en especial por la influencia que tienen las creencias y conductas del docente, en las actitudes de los alumnos. 
Igualmente compartimos la percepción de una falta de interés por las actividades del área: "de alguna forma existen actitudes negativas que obstaculizan el desarrollo de hábitos culturales relacionados con esta materia (Fundamentos de la Educación Plástica y Visual) como son las visitas a museos, dibujar, realizar fotografías, etc., viendo que no están entre sus preferencias de ocio y la realización de los mismos es muy escasa" (Salgado, 2013, p. 95). Estas actitudes percibidas por los maestros, como refiere la autora, muestran cierta indiferencia hacia los contenidos de la asignatura, que no es incompatible con que éstos les relajen o les resulten divertidos. Las actitudes que describe: "el desagrado manifestado por algún alumno hacia el arte contemporáneo, (...) la queja manifestada sobre la forma de impartir las clases de Plástica en los centros", reflejan una actitud social en relación a las artes plásticas de la modernidad. Una actitud reflejada en la expresión ¿Pero esto qué significa? que cita Calvo serraller (2014), y con la que describe el sentimiento de perplejidad que existe en el público desde que Duchamp definiera como arte (ready-made) la descripción de cualquier cosa trivial.

Pero estas percepciones no pueden llevarnos a generalizar una actitud contraria hacia la formación artística en los futuros docentes, como no podemos generalizar y convertir en falta de interés por la formación científica, las actitudes de antipatía por las matemáticas, que también se producen. $Y$ no parece existir ninguna relación significativa entre el conocimiento y las actitudes. Parece evidente que la enseñanza de conocimientos no fomenta por sí misma las actitudes en los futuros maestros (Escudero y Lacasta, 1984). En cualquier caso, si resulta difícil establecer un constructo único de actitud científica, no entendemos porque validarlo en la actitud artística, aunque esto no impide que tengamos en cuenta los vínculos entre el conocimiento, la experiencia social y la experiencia subjetiva (Contreras y Perez, 2010; Martínez Bonafé, 2004).

Más allá de la actitud, que tiene una estrecha influencia en la motivación y en generar ambientes óptimos de aprendizaje, en nuestro estudio hemos tratado de considerar aspectos más objetivos en relación a las competencias visual y espacial, que nos permitan formular criterios prácticos que orienten la acción educativa. No obstante se ha dedicado un espacio al análisis de la opinión sobre el 
valor del pensamiento visual en la educación, aun siendo conscientes de que este constructo no está del todo claro entre los participantes.

El presente estudio parte de la evidencia de una separación real, gráfica y cognitiva, entre las representaciones espaciales y las representaciones semánticas, a partir de la diferenciación del priming perceptivo y semántico (Razumiejczyk, 2013). Existe abundante literatura que sugiere la existencia de varias habilidades espaciales que son diferenciables de la capacidad general y de las habilidades verbales (Lohman et al., 1987), las cuales estarían relacionadas con un priming intramodal. A partir de estos trabajos analizamos el conjunto de habilidades visuales y espaciales, procurando no diferenciar entre su desempeño en el área científica o artística, a pesar de que muchos de los estudios consultados se refieren al rendimiento específico de estas competencias en alguno de los muy diversos campos académicos o profesionales, como la ingeniería, arquitectura, medicina, mecánica, matemática, el diseño o el pilotaje. 


\section{PARTE METODOLÓGICA}

\section{5.- Estado de la cuestión.}

Abordamos la parte metodológica del presente trabajo, conscientes de las diferentes definiciones de los constructos que manejamos. Hemos visto que las habilidades de pensamiento y las aptitudes de la inteligencia se entienden de muchas maneras, tanto intelectual como técnicamente, aunque hay coincidencia en atribuir un lugar destacado en los procesos del pensamiento, a la percepción y la capacidad visual y espacial (Fig. 69).

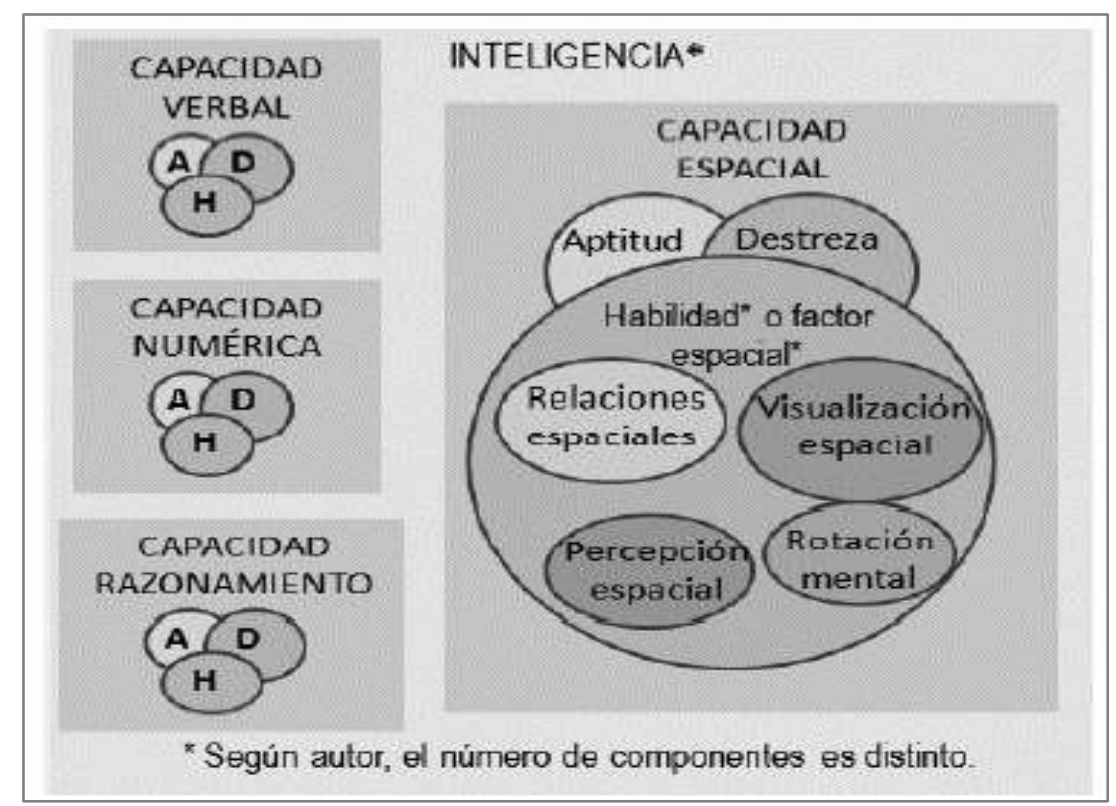

Fig. 69: Estructura de la inteligencia y capacidad espacial (Martín Gutiérrez, 2010)

El pensamiento visual y el espacial adoptan diferentes concepciones en la descripción y definición de los aspectos concretos para su análisis, aunque el funcionamiento mental muestra un paralelismo, una analogía con los mecanismos de la percepción (Villafañe, 2006) (Fig. 70).

Trataremos de unificar estos aspectos con el fin de definir el constructo de pensamiento visual y referenciarlo en el análisis ecléctico de los aspectos visuales del análisis de formas y espacios, 
colaborando de esta manera en la definición de factores de competencia visual, en el marco de la educación visual entendida como "capacitación para una dimensión visual de conocimiento y adaptación con el entorno” (García-Sípido, 2003, p. 62).

\begin{tabular}{|l|l|}
\hline \multicolumn{1}{|c|}{ Mecanismos mentales } & \multicolumn{1}{|c|}{ Mecanismos perceptivos } \\
\hline Exploración activa. & Fijación ocular. \\
Completamiento. & Superposiciones. \\
Simplificación. & Visión tridimensional. \\
Sintesis. & Visión cromática. \\
Corrección. & Constancias perceptivas. \\
Selección. & Abstracción visual. \\
Conceptualización. & Conceptualización visual. \\
\hline
\end{tabular}

Fig.70: Analogía entre los mecanismos mentales y los perceptivos (Villafañe, 2006. p.88)

Eludiendo el debate anacrónico respecto a quién compete responder a la necesidad de una educación visual en nuestro entorno social y educativo, pero asumiendo esta necesidad, entendemos el pensamiento visual como un aglutinante de los aspectos socio-psicoeducativos tratados, con muchas posibilidades en la educación actual. Es por ello que evitamos el análisis de los resultados de la producción gráfica o icónica, muy vinculado con criterios estético-artísticos, para centrarnos en los aspectos de la cognición y la representación visuales, aunando los conceptos de representación mental y gráfica, en torno a los elementos "morfológicos, dinámicos y escalares" del alfabeto visual propuestos por Villafañe (2006, p.95):

Morfológicos: punto, línea, plano, textura, color y forma.

Dinámicos: movimiento, tensión y ritmo.

Escalares: dimensión, formato, escala y proporción.

Se dan importantes argumentos a favor de la necesidad de admitir un nivel conceptual correspondiente a la representación mental de un objeto (Ballesteros, 2014). Sin embargo, no existe una fundamentación clara al respecto, y la diversidad de conceptos representacionales: códigos visuales, espaciales, verbales, isomorfismos, redes semánticas, representaciones proposicionales, 
rasgos, etc., solo contribuye a crear confusión en torno al tema (Ballesteros, 1993).

Pero consideramos que el análisis de las imágenes mentales a partir de un código de representación analógico, diferente del proposicional, se justifica por la naturaleza presemántica de los problemas espaciales y de las formas y estructura de los objetos en el priming visual. El priming es entendido como la percepción visual afectada por la memoria implícita asociada a la modalidad sensorial.

Parece estar claro que el sistema cognitivo almacena la información en un formato más abstracto que el de las representaciones simbólicas propias del lenguaje (Ballesteros, 1993). Esas propiedades analógicas se encuentran más próximas a la percepción de cualidades o 'perceptos', previos a los conceptos mentales y el lenguaje simbólico. (Shepard y Metzler, 2004; Paivio, 1990; Arnheim, 1979). A nivel visual, parece que existe un proceso de representación estructural relacionado con estas propiedades y un proceso episódico vinculado con la memoria, y ambos están íntimamente relacionados (Ballesteros, 1993). Mantenemos esta consideración analógica o estructural del análisis proposicional y lo hacemos referido tanto al aspecto simbólico como al aspecto icónico de los modelos mentales (Galagovsky et al., 2009; Paivio, 1990; Ballesteros, 2014).

En los trabajos sobre modelización, en ocasiones las referencias espaciales y visuales se solapan, como también se superponen el campo de la cognición y el de la representación gráfica. Observamos que por lo general, los enfoques psicométricos, cognitivos y técnico-científicos optan por utilizar el concepto espacial, mientras que los enfoques artísticos y de la teoría de la imagen prefieren el concepto visual. Como resultado, los planteamientos educativos utilizan ambos, en función de las preferencias didácticas, y hemos visto que ambos se utilizan simultáneamente en los planteamientos del diseño curricular. 


\section{1.- Visualización y razonamiento espacial.}

En el propio enfoque psicométrico de las ciencias de la educación existe disparidad en determinar los factores que componen los aspectos cognitivos espaciales (Lohman et al., 1987). En el estudio de la inteligencia técnica a partir de Spearman (1923), se realiza el análisis de la aptitud mecánica como su principal dimensión, a través de factores lógicos, perceptivos, imaginativos y psicomotores, pero su "núcleo distintivo y característico está constituido por el factor espacial. ¿Qué es el factor espacial? He aquí nuestro problema" (Yela, M., 1967, p.609).

El estudio factorial de Thurstone (1950) denomina ' $S$ ' al factor espacial. Debido a su complejidad, establece tres subfactores, dos de ellos $S_{1}$ y $S_{2}$, relacionados con los cambios de posición de los objetos en el espacio (variando o no su estructura interna), y un tercero $\mathrm{S}_{3}$ referido a localizar puntos del espacio respecto a un sistema de referencia, con preferencia en el propio cuerpo (fig. 71). Para Yela, son los mismos factores que Guilford (1972) denomina visualización y relaciones espaciales, las cuales, resultan "de naturaleza bastante compleja y no claramente conocida" (Yela, 1967, p.611). Pero la visualización parece un factor bien definido como la habilidad para generar una imagen mental, transformarla y retener sus cambios (Lohman, 1979). Se trata de la representación y trasformación mental de objetos o espacios. Como no podemos obviar la formación previa de los participantes, estudiantes del grado en educación, consideramos que esta definición debe incluir además de la habilidad de producir, analizar y trasformar objetos, el hacerlo con conceptos geométricos (Gutierrez, A., 2006)

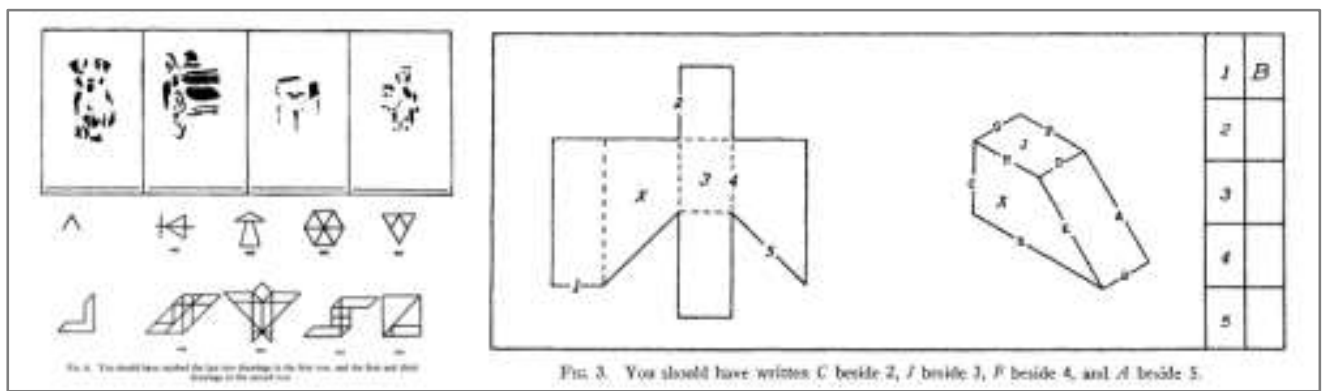

Fig. 71: Items PMA-Primary Mental Abilities (Thurstone, 1950) 
Respecto a las relaciones espaciales, existen al menos dos cuestiones principales: una sobre su validez como componente de la inteligencia visoespacial, y otra sobre el tipo o formato utilizado de representación (analógico o proposicional).

En cuanto a su validez, la psicología cognitiva mejora la definición de validez de constructo en los test de aptitud, determinando los procesos cognitivos implicados en las tareas que plantean los ítems (Prieto et al., 1993). Las tareas diseñadas en los ítems deben representar constructos teóricos previamente especificados, aunque se ha de considerar la manipulación inherente al aspecto flexible de estas definiciones:

"Sin embargo, el impacto flexible de las variables cognitivas en la calificación de la prueba es precisamente lo que permite el diseño de pruebas. Es decir, los ítems pueden ser seleccionados o construidos para medir aspectos específicos de las diferencias individuales si se conoce el impacto relativo de las diversas variables subyacentes en la resolución de elemento. Construir la investigación representación en el contexto de la CLTM (Component Latent Trait Models-modelos de rasgos latentes componentes) puede producir parámetros de los ítems que describen las demandas cognitivas del tema, que, a su vez, puede ser usado para manipular o seleccionar elementos."

(Embretson, 2013, p.198)

Considerando la influencia que tiene la variable individual en la definición de los factores de la inteligencia espacial, Yela (1967, p. 629) expresa: "Los factores están definidos por los tests saturados en ellos, pero, claro está, no dependen directamente de los tests, sino de las respuestas de los sujetos. Si un mismo test es abordado y resuelto mediante distintos procedimientos por distintos sujetos, cada procedimiento determina una distinta composición factorial del test'. Lo que le lleva a extraer dos conclusiones: una, que los sujetos distintamente dotados pueden resolver las tareas de distinto modo, y la otra, que las mismas tareas pueden reclamar distintas aptitudes, según su dificultad y el nivel mental y cultural o profesional de los sujetos. Este enfoque de las diferencias individuales del funcionamiento intelectual debe ser considerado "complementario y no sustitutivo o antagonista del enfoque factorial' (Fernández Ballesteros, 1995, p. 494). 
Estas tareas psicométricas se realizan respecto al concepto de la transformación mental de la imagen y responden a los continuos de simplicidad-complejidad y velocidad-potencia (Pellegrino y Kail, 1982). Las transformaciones mentales pueden ser de dos tipos: tareas de síntesis, con imágenes separadas (rompecabezas, figuras, tarjetas), o tareas que implican movimiento (plegamientos, desarrollo de superficies, doblado de papel) (Lohman, 1979). Estas tareas (Fig. 72) que resultan de cierta complejidad, son las más utilizadas en los modelos computacionales de la psicología cognitiva (Ballesteros, 1993).

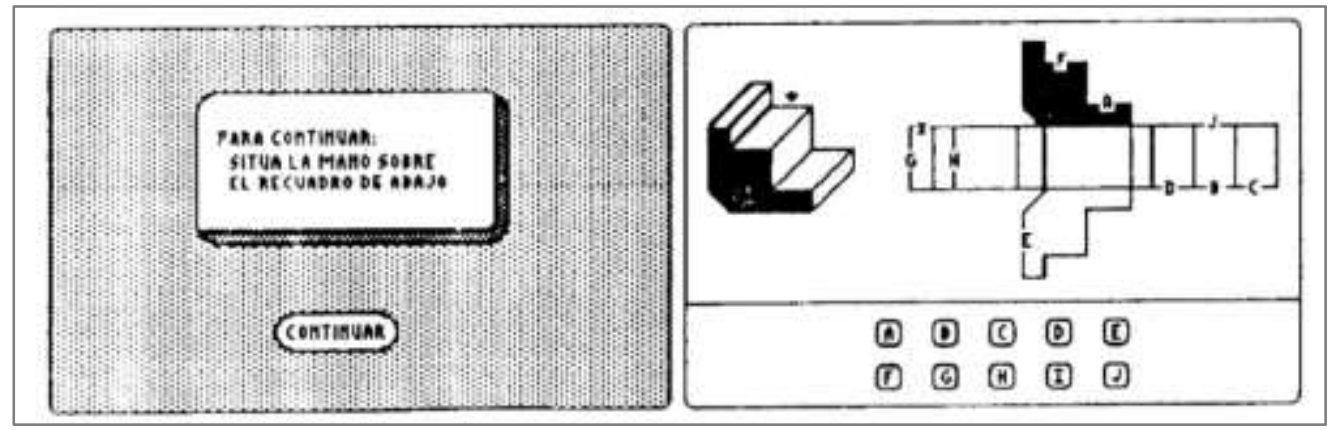

Fig.72: Complejo ítem de desarrollo de superficies.

Test informatizado VZ de visualización (Prieto et al., 1993)

Desde la óptica del modelo computacional, que busca la precisión del razonamiento espacial, las representaciones proposicionales se evaluarán como verdaderas o falsas con relación a un modelo mental del mundo, pero se ha de considerar que estos modelos tienen un componente de ambigüedad, ya que comparten la propiedad de representar la generalidad a partir de valores particulares que reúnen todas las relaciones de lo representado (Otero, 1999). Como es el caso de la perspectiva visual y la elección de los ejes dimensionales y sus respectivos ángulos, que van a variar en función de la posición adoptada en el caso del modelo visual o de la elección de un modelo teórico (Fig. 73). Si tenemos en cuenta el carácter constructivista e interaccionista del conocimiento, tanto el individuo como los objetos tienen sus características, y la representación, al igual que refleja las características dimensionales del objeto, reflejará el pensamiento del sujeto en la representación: sus preferencias y conocimientos. 


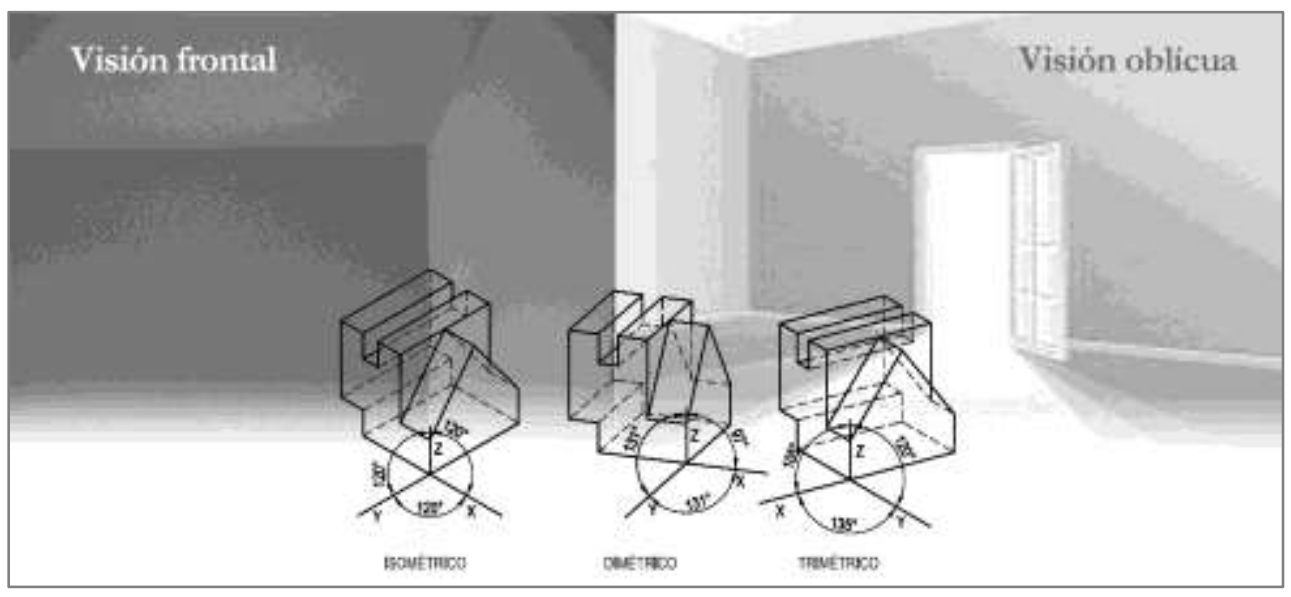

Fig. 73: Diferencias de ángulos entre modelos de visión y de perspectiva.

Respecto a la definición de la visualización, ésta parece menos confusa fácil que la delimitación del concepto de relaciones espaciales. Hay coincidencia en entender la visualización como la representación mental de objetos y espacios. Sin embargo, en la relación con el espacio, se han de considerar los propios planteamientos cognitivos comentados, y es posible que estos dificulten o faciliten a su vez la representación mental y gráfica.

Piaget (2001), supedita la visualización a un concepto abstracto de tipo geométrico, y de una manera descriptiva establece tres tipos de relaciones espaciales:

- Topológicas: como relaciones de proximidad, separación, orden, cerramiento y continuidad;

- Proyectivas, en función de la perspectiva;

- y Euclidianas, a partir de un eje de coordenadas.

Establece que estas operaciones se adquieren en torno a los nueve años, aunque las topológicas son preoperatorias y se consolidan alrededor de los siete. Por tanto, podemos deducir que las relaciones espaciales se construyen a partir de la consolidación mental de un eje de referencia y de un sistema perspectivo. Si esto forma parte del razonamiento abstracto, parece claro que su consolidación va a depender en gran medida de la experiencia perceptiva (cognitiva temprana) del espacio. Pero no hemos encontrado referencias concretas, en los estudios sobre 
representación, de la influencia directa entre razonamiento espacial y percepción visual.

Como una dimensión de la inteligencia, el razonamiento espacial muestra multiplicidad e interdependencia de componentes: la distinción de estos múltiples componentes muestra su complejidad, mientras que la interdependencia de éstos muestra la unidad de un factor espacial (Yela, 1967). Tras un análisis de estos componentes en 42 pruebas estandarizadas, Yela identifica en sus estudios hasta seis factores espaciales, según funcionan de manera estática, dinámica, topológica, orientativa, cibernética y cinestésica:

- El factor de visualización estático $\left(S_{1}\right)$ se refleja en aquellas tareas en las que el objeto cambia de posición manteniendo su forma y no hay manipulación o ésta es mínima: "Nuestros resultados confirman la existencia de esta dimensión como una aptitud distinta de las otras espaciales (...) Existe una dimensión de 'visualización estática', claramente distinta de las otras dimensiones espaciales" (pp. 613-614). Este factor estático no es independiente y en los trabajos de Thurstone y Guilford, se confunde en las tareas que implican rotación en el espacio.

El factor estático se define en las pruebas o test de figuras, tarjetas, y rotación de figuras macizas (fig. 74).

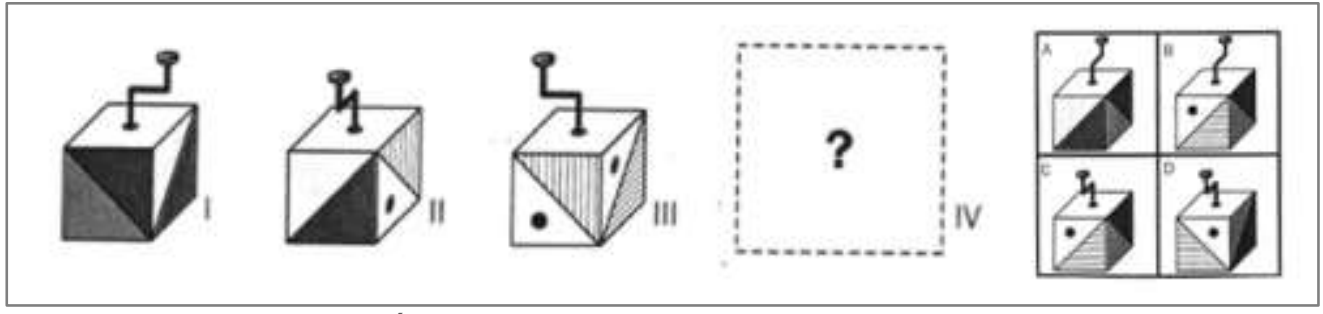

Fig. 74: Ítem de rotación de figuras macizas-cubos

(Ferrero L., en Gonzato et al., 2011)

- El factor de visualización dinámico $\left(\mathrm{S}_{2}\right)$ supone la capacidad de someter al objeto a transformaciones en el espacio, de manipularlo. Los objetos cambian su estructura interna, las relaciones entre sus partes. Este factor se vincula directamente con la inteligencia técnica, y es el factor que más discrimina en los resultados académicos. 
Se encuentra en las pruebas de cubos, desarrollo de superficies, movimientos mecánicos y doblados de papel (fig. 75).

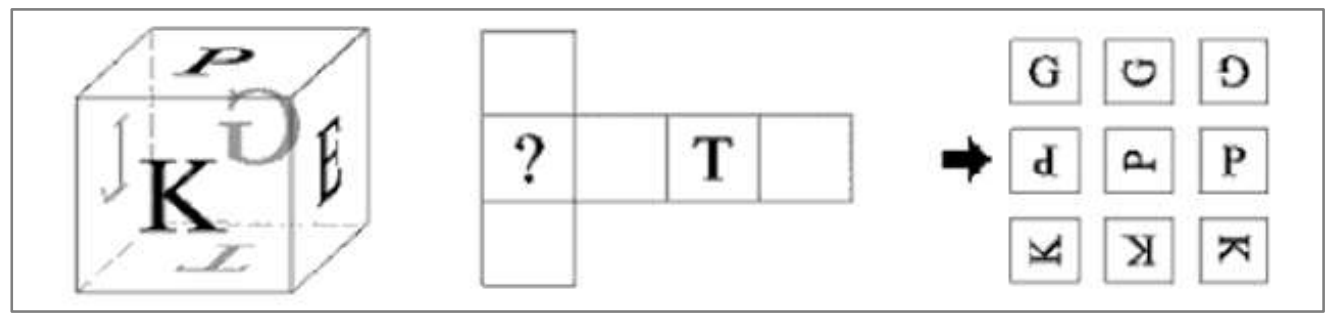

Fig.75: Ítem de plegado de cubo. Test informatizado VZ (Prieto et al., 1993)

- El factor topológico $\left(S_{3}\right)$ es de naturaleza perceptiva. Se identifica con la localización (del griego 'тómos' o 'lugar'). Semejante al factor $(P)$ de otros autores, procura clarificar la interpretación de las relaciones espaciales: "en los análisis de Guilford los test no puramente perceptuales (coordinación psicomotora, orientación espacial) reparten sus saturaciones entre $(P)$ y un factor de 'relaciones espaciales' distinto de visualización o (S2)" (Yela, 1967, p.618). Yela, que reconoce que esta es una discusión prolija y poco clara, concluye que el factor $(P)$ de Guilford, aunque más complejo que el $(P)$ de Thurstone, es netamente perceptivo, más que el $\left(S_{3}\right)$ que él define. Por tanto, este factor topológico $\left(\mathrm{S}_{3}\right)$, es considerado a su vez como un factor de percepción de relaciones espaciales, que supone la comprensión perceptiva e imaginativa del espacio, relacionando formas, líneas y puntos, según sus magnitudes, trayectoria y su referencia a los ejes de coordenadas. Este factor resuelve los problemas de relación con el espacio, "sobre todo, teniendo en cuenta al sujeto como punto de referencia, y exigiendo comprender o responder en términos de arriba o abajo, derecha o izquierda, delante o detrás" (Yela, 1967, p.619).

Este factor perceptivo se muestra en tareas con trayectorias rectas y curvas, laberintos, localización, coordenadas, identificación de figuras y de caras. $Y$ en otros específicas para pilotos (ejército del aire) de lectura coordinada y de Gráficos (fig. 76). 


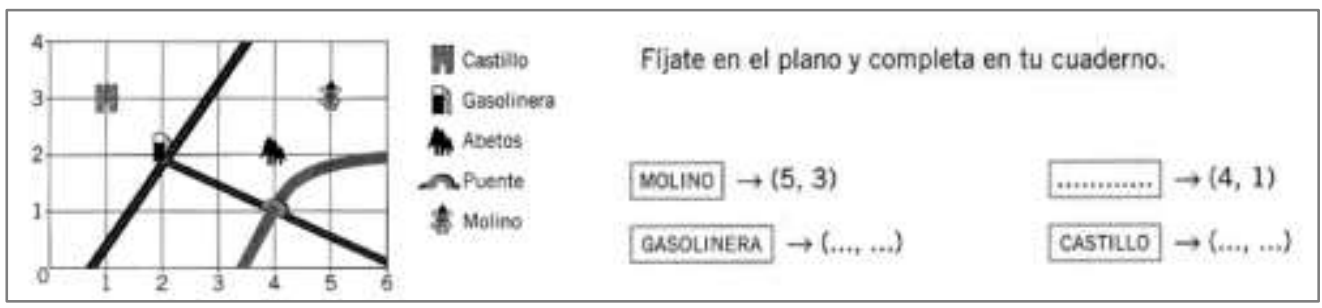

Fig. 76: Tareas de interpretación de un sistema de coordenadas

(Gonzato et al., 2011)

Estos tres factores o dimensiones explicarían por sí mismos gran parte de los procesos de visualización y relaciones espaciales, ya que los otros tres indican menor peso en las correlaciones con éstos. El factor cibernético $\left(S_{4}\right)$ representa el aspecto directivo y psicomotor. Aparece en las pruebas de coordinación visomotora, comprensión mecánica y de instrumentos, así como control de mandos. El de orientación espacial $\left(S_{5}\right)$ se ve como un factor residual del topológico, que se encuentra mezclado con los tres anteriores de relaciones espaciales en las pruebas de orientación y direcciones (norte-arriba, sur-debajo...). Y el factor cinestésico $\left(S_{6}\right)$ se encuentra en pruebas específicas que requieren imaginar los movimientos del propio cuerpo (manos, giro de tornillos). Estas son pruebas de experiencia y comprensión de una dimensión kinestésica y cibernética que requieren un razonamiento específico de problemas de tipo mecánico.

El proceso más característico de la visualización es el que involucra la representación y trasformación mental de las figuras espaciales (Prieto et al., 1993). De tal manera, podemos concluir que los factores estático y dinámico $\left(S_{1}\right)$ y $\left(S_{2}\right)$ son los factores visuales básicos que permiten definir un proceso más o menos dinámico de visualización general (Gv), como factor independiente (factor espacial) o interdependiente con el factor verbal en línea jerárquica con el factor general de Spearman (Fernández Ballesteros, 1995) (fig. 77), pero entendemos que considerando que el factor topológico $\left(S_{3}\right)$ nos involucra personalmente en el análisis perceptivo individual del espacio. 


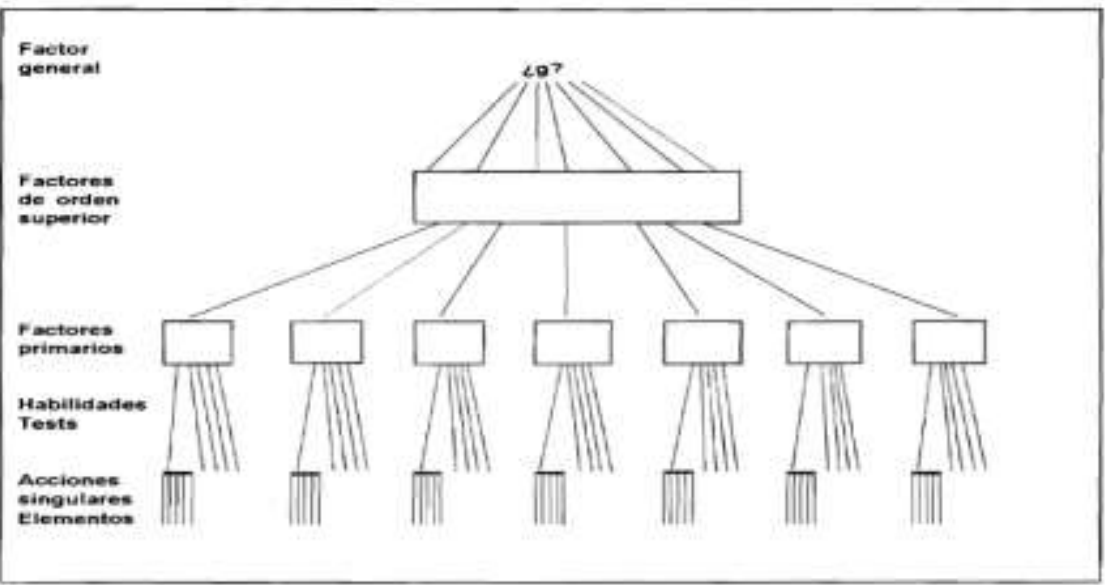

Fig. 77: Estructura factorial de la inteligencia (Fernández ballesteros, 1995)

Este proceso de visualización se define como la capacidad de "resolver problemas mediante la representación imaginativa de objetos que se mueven en el espacio y que al moverse, cambian de aspecto $y$, muy particularmente, de estructura interna" (Yela, 1967, p.626). El movimiento y los cambios estructurales de los objetos en el espacio conforman, junto con la constancia cognitiva, los referentes de la visualización. Aunque son definiciones diferentes a las que se dan en el ámbito educativo (muchas, obviando la investigación, confunden orientación con relaciones espaciales), trabajamos con la coincidencia común en establecer la visualización como una habilidad específica del razonamiento 0 inteligencia espacial para crear imágenes mentales (Badillo Jiménez, 2013; Gonzato et al., 2011; Escarza et al., 2008). Es esta definición como habilidad la que nos permite la reflexión sobre la estructura de los objetos y el espacio, y su representación. La cantidad de técnicas heterogéneas existentes conducen a demandar la necesidad de establecer un modelo común de visualización:

"El espacio en el cual se plantean las visualizaciones puede pensarse como uno de alta dimensionalidad dominado por cuatro factores principales: las necesidades del usuario que se traducen en los requisitos que deberá cumplir la visualización, los dominios de aplicación para los cuales se construyen las visualizaciones, los conjuntos de datos particulares de dichos dominios con las características que los distinguen y las técnicas de visualización aplicables en determinados dominios y sobre ciertos conjuntos de 
datos. Las múltiples combinaciones posibles de estos factores originan una gran diversidad de Visualizaciones".

(Escarza et al., 2008, p.297).

Esta habilidad de visualizar implica, en muchas ocasiones de forma simultánea, la actitud mental simple de ser observador (ver un objeto o espacio), y la actitud compleja de verse a uno mismo como observador (verse observando el objeto o espacio). En este caso, la reflexión se hace sobre el objeto de la observación pero al mismo tiempo sobre la situación del observador (Hershkowitz et al., 1997). Ambas actitudes no serían posibles sin un modelo mental de referencia espacial que no es ajeno a nuestro propio cuerpo, y como veremos, ningún modelo teórico de referencia espacial es ajeno a la situación que ocupamos en el espacio físico real de nuestro planeta (fig. 78). Estos modelos mentales son las estructuras topográficas que nos van a permitir trazar líneas, calcular distancias y realizar operaciones con las formas y el espacio.

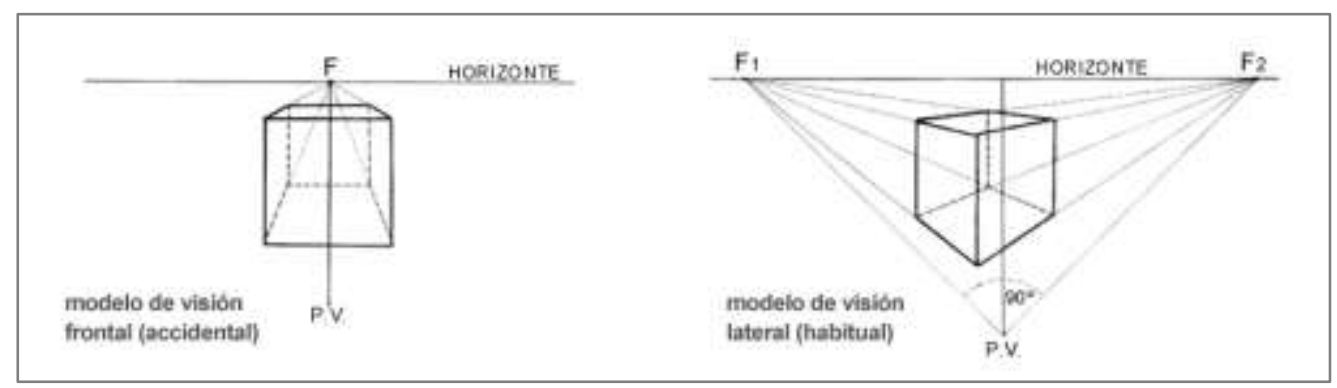

Fig. 78: Representación plana esquemática (perspectiva visual) de la posición (PV)

El factor estático, como factor simple de visualización, requiere de una manipulación mental mínima, referida a los movimientos de derecha a izquierda donde "el sujeto es meramente el origen de coordenadas" (Yela, 1967, p.620). Este planteamiento coincide en el modelo óptico de la visión con el plano frontoparalelo descrito en la figura 79. En este modelo se plantean diferentes sistemas de perspectiva plana, donde el eje vertical de posición del cuerpo y el eje horizontal de la visión constituyen el punto origen de las coordenadas mentales del espacio. Un espacio en el que los objetos son relativamente estables y responden a un modelo teórico. 


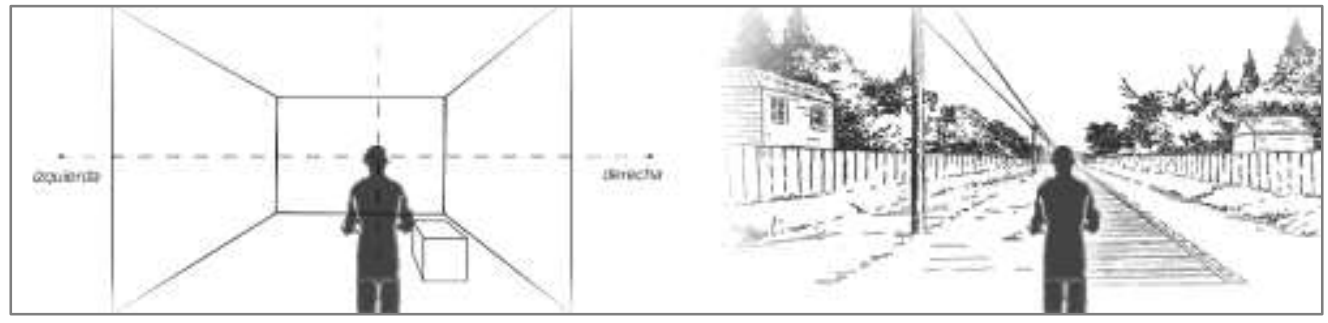

Fig. 79: Modelo de visión frontal.

Al explicar este factor de visualización estático, parece que está suficientemente clara la causa por la que el sujeto interviene. El propio sujeto como el origen de coordenadas, resulta necesario para discriminar derecha-izquierda y arriba-abajo o delante-detrás. Pero el hecho de sugerir que el sujeto no interviene en el factor dinámico, por implicar este factor un razonamiento o manipulación mental, creemos que no está lo suficientemente explicado. Sentenciar que el sujeto permanece "fuera de la configuración" (Yela, 1967, p.621), nos lleva a preguntarnos cómo es posible que el sujeto intervenga en unos factores de visualización y que no lo haga en otros, cuando se trata de un mismo proceso donde difícilmente podemos separar percepción, organización y coordinación. Un proceso en el que nos estamos refiriendo al mismo sujeto y al mismo ejercicio mental, el de visualización espacial. Creemos que esta expresión puede explicar el significado conceptual del sujeto, que no resulta necesario en la representación, pero de cuya existencia no nos podemos abstraer en ninguno de los dos tipos de visualización.

En ambos factores de visualización se realizan operaciones mentales de manipulación de objetos y configuraciones espaciales, y por tanto, nada indicaría que para explicar la complejidad propias del factor dinámico el sujeto no intervenga, aunque la actividad no requiera de coordinación motriz. En nuestra opinión, la complejidad de una mayor manipulación mental radica en la mayor complejidad del modelo visual no frontal, que además es el habitual en nuestra experiencia visual (Fig. 80): en la mayoría de las ocasiones el plano azimutal cero no es perpendicular al plano de visión frontal (fig. 99) y no nos colocamos en los planos frontoparalelos de las personas, edificios, lugares para observarlos. Los sistemas de perspectiva del modelo visual oblicuo explican las transformaciones más complejas del objeto, definidas como dinámicas, y lo hacen en referencia al sujeto, implícito en la visión, sea ésta física o mental. Son ambos 
modelos ópticos, frontoparalelo y oblícuo, los que analizan todas las posibles disposiciones espaciales, y por tanto permiten un mejor conocimiento estructural de los objetos.

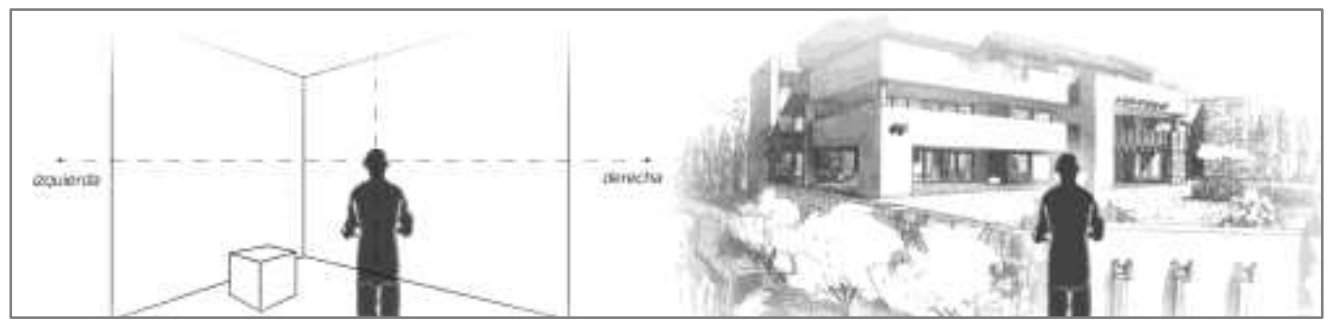

Fig. 80: modelo de visión oblicuo.

Si los planos son oblicuos en la mayor parte de nuestras orientaciones en el espacio, podemos concluir que la disposición a realizar operaciones mentales es la circunstancia más natural. Por ello el factor espacial es característico de las operaciones mentales: potenciar estas operaciones espaciales conlleva un razonamiento más exacto en lo concreto y a la vez más fluido y variado. Es un factor que relaciona el pensamiento convergente con el pensamiento divergente (Méndez, 2000).

\section{2.- Visualización y representación.}

Sin embargo, si los planteamientos técnicos en los modelos de representación visual no se corresponden con ambos modelos ópticos, se podría pensar que el razonamiento espacial, como factor de inteligencia, no es universal. Pero al analizar la modelización técnica, podemos ver que igualmente está basada en los modelos visuales (Torrents Gómez, 2011). Ello explica por qué cuando queremos saber cómo es un objeto, lo tomamos con las manos y lo giramos observándolo. De la misma manera, mentalmente necesitamos observar todas las posibilidades espaciales de un objeto. Pero estas no las podremos conocer si no tenemos referencias. $Y$ estas referencias son físicas o fisiológicas en primera instancia, tanto como la coordinación motriz que desplegamos para coger el objeto y girarlo: 
"Adicionalmente, cuando queda clara la finalidad de una descripción, los estudiantes se sienten inclinados a abordar los temas de representación relacionados con los niveles adecuados de precisión, exactitud, puntualidad, etc. Por consiguiente, cuando se facilita una descripción inicial, casi siempre es necesario ampliarla, afinarla o revisarla con el fin de hacerla suficientemente aplicable. Por tanto, las soluciones implican una serie de ciclos de afinamiento de la representación".

(Lesh, 1997)

Las referencias físicas (ópticas) y fisiológicas de la realidad están en la raíz de nuestro pensamiento y de gran parte de los razonamientos matemático-geométricos, pero creemos, en línea con gran parte de los trabajos revisados, que no están lo suficientemente consideradas en el currículo. En este punto conviene aclarar que no participamos de la discusión sobre la correspondencia objetiva de la imagen visual de una realidad definida independientemente de ella. Toda la gramática visual de la representación se basa sin duda en "estándares determinados culturalmente e históricamente de lo que es real y qué no lo es" (Kress y Van Leeuwen, 1996, p.168). El valor de verdad de una imagen (diagrama, esquema, símbolo o modelo) es alto, pero no lo es por su mimetismo con la realidad visual. Aludimos al nivel de referentes tanto en el espacio real como en la representación mental, para analizar la competencia cognitiva. No nos ocupa el análisis de resultados, como productos de representación gráfica 0 imágenes. Este es un análisis que va a variar considerablemente según se haga desde el diseño, la matemática o la comunicación, donde los diferentes patrones de significado lingüísticos, simbólicos y visuales se refuerzan de manera desigual en el discurso. Toda imagen tiene un componente de representación y también de interacción con el observador, y ambos están combinados: Incluso en una imagen exenta de perspectiva, asumimos al observarla la ausencia de un punto de vista o sus referencias planas (gráficos, mapas). Pero, incluso en las dos dimensiones, los aspectos de arriba/abajo e izquierda/derecha adquieren un significado interactivo, ampliamente analizado en la gramática visual por Kress y Van Leeuwen (1996).

En cuanto a los referentes reales, se argumenta la existencia de una situación de incomprensión de los procesos globales de la 
geometría a partir de los modelos cotidianos y los niveles de razonamiento (Van Hiele, 1986, Huerta, 1999): conceptos habituales relativos al paralelismo y a los cuadriláteros no se resuelven en un sentido global durante los niveles de la educación superior. Si esto es así, hemos de considerar en este sentido que los sistemas de representación o modelización actuales, los que utilizamos para educar en esta sociedad de la información, se utilizan para crear sistemas conceptuales que van a funcionar como objetos concretos en el mundo del mañana (Lesh, 1997).

La geometría explica el mundo a partir de las estructuras del ser humano, de los objetos y del espacio (fig. 81). Con la finalidad de estudiarla, necesitamos acudir a recursos gráficos y numéricos para crear los sistemas de representación. Este contexto de trabajo permite un "interjuego", una interacción cognitiva entre la percepción visual, el razonamiento y la representación simbólica (Douady y Parzysz, 1998, p. 160). Los trabajos de Parzysz (1991) sobre la concepción del espacio y su representación en los estudiantes, muestran la relación entre la realidad física y los modelos teóricos. Valorando la capacidad gráfica de sus estudiantes, concluye que los modelos visuales frontales resultan adecuados con su concepción de los diagramas básicos: consideran más importante la preservación de algunas propiedades de una configuración dada en dibujos que representan especialmente el paralelismo. La perspectiva paralela parece una buena herramienta para representar el espacio en la geometría de la escuela, incluso si su pertenencia a este tipo de representaciones no se menciona (Hershkowitz et al., 1997).

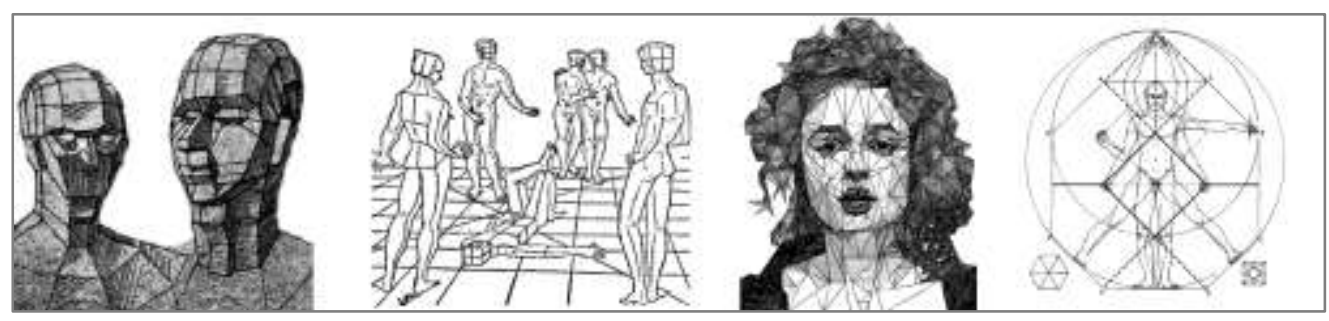

Fig. 81: Representaciones geométricas de la figura humana

(De izquierda a derecha: Durero, Erhard Schön, Josh Bryan y Keith Critchlow)

En nuestro trabajo constatamos este aspecto, pero nos preguntamos que, si es así ¿por qué no se continua por esta línea de trabajo? Creemos que es debido a que la perspectiva frontal no 
responde por igual a las necesidades de todos los niveles educativos. En un momento del desarrollo madurativo no parecen que los modelos de representación ofrecidos sean lo suficientemente significativos en el aprendizaje:

"Hay varias razones posibles para el abismo entre la importancia teórica de las habilidades espaciales y su utilidad práctica en los estudios predictivos o en los estudios de ATI (Aptitude Treatment Interaction). En primer lugar, puede ser que, más allá de un cierto nivel mínimo de competencias, las habilidades espaciales, simplemente no son tan importantes para el éxito en la escuela o el trabajo. En segundo lugar, la fuerza de la capacidad espacial en relación con otras habilidades, en particular habilidades verbales y de razonamiento, puede ser más importante para predecir cómo se representan y se resuelven, más que si se pueden resolver los problemas. En tercer lugar, las medidas criterio utilizadas en la mayoría de los estudios pueden estar sesgadas en favor de otras habilidades, como habilidades verbales o de razonamiento".

$$
\text { (Lohman, D.F., 1979, p.182) }
$$

Mientras estos autores indican que se da menos importancia al desarrollo visoespacial y más a que se resuelvan los problemas teóricos en base al éxito escolar, otros estudios indican que el éxito académico no estaría relacionado con el desarrollo de estas capacidades, o al menos en la manera en que se evalúan: muestran cómo alumnos con un rendimiento alto en algebra y geometría, presentan dificultades en procesos de visualización espacial, confundiendo la distinción de los bordes y de los planos de un objeto representado (Ryu et al. 2007).

La perspectiva, con sus diferentes modelos se presenta como un sistema de referencia de los factores de visualización y relaciones espaciales, aunque con diferentes fines, tanto en el ámbito matemático-geométrico como en el geométrico-artístico. En ambos, las formas geométricas participan en la construcción visual del espacio y en la comprensión de las estructuras internas de los objetos, y se graban en la base de nuestra expresión gráfica desde la infancia temprana. Las figuras geométricas básicas (círculo, rectángulo, triángulo) están detrás de la interpretación cognitiva del mundo físico: 
"Ils servent donc d'intermediaire entre une figure et son étalement dans l'espace" (Wallon y Lurçat, 1958, p.210)

La investigación en matemática y geometría establece dos criterios o factores para el estudio de la competencia o aptitud espacial en la didáctica: la orientación (de sujeto y objetos) y la interpretación perspectiva. La visualización se explica a partir de los modelos de perspectiva $y$, en cierta manera, reduce el concepto complejo de relaciones espaciales analizado anteriormente al concepto de la orientación, residual en el trabajo de Yela. A partir de una categoría de acciones como "desplazar, encontrar, describir, comunicar la posición de objetos" (Berthelot y Salin, 1994), se interpreta la orientación del cuerpo del propio sujeto, y en relación a él, la orientación de los objetos. La orientación involucra el conocimiento del esquema corporal y la proyección de este esquema en el objeto (Gonzato et al., 2011). Por tanto, el eje de referencia del propio cuerpo se proyecta al espacio que hay frente a él, su campo visual. Podemos afirmar que estructuramos el espacio físico en relación a las propiedades de nuestro cuerpo, siendo la visión la propiedad principal:

"La distinción entre delante/detrás de una persona se define por el hecho de que el cuerpo está orientado, es decir, tiene una parte considerada como delante por su forma y funciones y otra como detrás. La orientación de la forma es, por tanto, una condición necesaria para poder usar un objeto como referencia para identificar la combinación delante/detrás. La distinción de izquierda/derecha, asume que el objeto de referencia tenga un plano de simetría, como el cuerpo humano que se caracteriza por su lateralidad, es decir, dos partes iguales de forma y función, pero cuyos movimientos tienen sentido contrario. La distinción cerca/lejos es una relación que involucra al menos a tres cuerpos, uno de los cuales sirve de referencia para establecerse y comparar las distancias de los otros. Es, por tanto, una noción de tipo métrico que se necesita para evaluar las distancias entre objetos y ponerle un orden, aunque no estén alineados en el plano o en el espacio. Implica entonces la capacidad de reconocer la conservación de las longitudes al variar la orientación de la referencia o de los objetos".

(Gonzato et al., 2011, p.104) 
Se considera además una apreciación en cuanto al movimiento del sujeto. Mientras que en la orientación, el punto de vista del sujeto cambia de manera continua a lo largo de su desplazamiento, es decir, su visión del espacio está vinculada a un movimiento continuo, la interpretación perspectiva va a requerir que el sujeto cambie o adapte su punto de vista, que se imagine en una determinada posición con respecto a una composición de objetos. Al mismo tiempo, se plantean diferencias entre espacios en función de su tamaño y la posibilidad o no de movimiento del sujeto (Gonzato et al., 2011; Gorgorió, 1998; Berthelot y Salin, 1994; Gaulin, 1985).

Las tareas al respecto se multiplican en los niveles educativos combinando los factores anteriores de visualización con los topológicos y de orientación (Fig. 82). Las tareas que implican una posición estática requieren comprender el esquema corporal como referente: arriba-abajo, izquierda-derecha, delante-detrás, respecto a uno mismo, y las posiciones de objetos con respecto a otros objetos: el propio planteamiento visual de estas tareas, habituales en la etapa infantil en torno al esquema corporal y lateralidad, no siempre van a tener en cuenta los referentes perspectivos y estructurales en la propia presentación de las actividades visuales, y realizan un modelado negativo de cara a las futuras construcciones mentales y gráficas del sujeto.

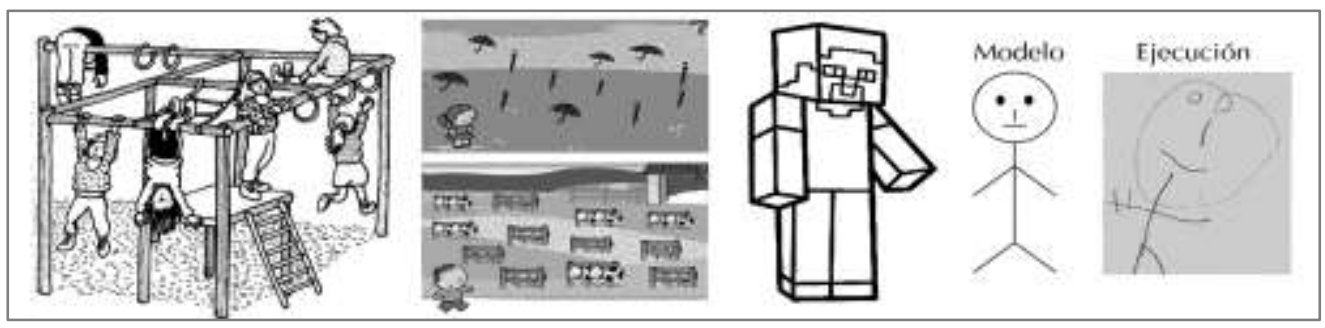

Fig. 82: Ejemplos de tareas escolares de orientación estática del cuerpo.

Otro grupo de tareas más avanzadas suponen cambiar el punto de vista e imaginar la rotación de objetos además de interpretar sus perspectivas (Gonzato, 2011). Los propios planteamientos didácticos que el área matemático-geométrica plantea en este nivel llevan implícitas ciertas consideraciones que diferencian entre una representación plana y otra tridimensional o de los cuerpos o sólidos. Entendemos que esta distinción sugiere algunos problemas ya que los estudios sobre representación establecen esta diferencia en relación 
al soporte, pudiendo ser este plano (modelos planos en papel, pantallas, pizarra...) o con volumen (modelos tridimensionales). $Y$ en educación artística, la diferencia se establece entre las técnicas de representación gráfica del dibujo y las del modelado, aunque a su vez, el término modelado es utilizado como 'modelizado' (participio de construir un modelo), en los estudios cognitivos de la representación.

Por otro lado, la geometría, aunque está siempre referida a la representación gráfica plana, diferencia entre figuras planas y espaciales en relación al nivel cognitivo de la representación. Confunde en ocasiones el plano de la visión frontal con la superficie plana de la propia representación. Aunque las figuras planas se analizan como estructuras básicas que corresponden a un único punto de vista, estático y frontal, también se considera su 'deformación' al romper el plano frontal de visión y desplazarlo. Pero esta es una cuestión que no se aborda en las edades tempranas de la enseñanza. En las etapas de infantil y primaria se plantea el trabajo con estas estructuras básicas planas y se hace de manera estática o regular (polígonos regulares), sin apenas analizar estas deformaciones, para pasar, en niveles superiores, a plantear figuras tridimensionales (volúmenes o poliedros) y sugerir entonces diferentes puntos de vista.

Entendemos que con este planteamiento, el estudiante se encuentra con el problema de las relaciones espaciales cuando se inicia en el estudio de las figuras tridimensionales. Pero el análisis del espacio ya lo estaba haciendo con sus desplazamientos, a pesar de que los modelos planos le llevaran a una posición fija y estática. Combinar ahora ambas posibilidades le va a plantear una serie de dificultades añadidas. Es por ello que la investigación en el área se va a centrar en las dificultades para desarrollar estas habilidades visuales y espaciales, en relación a los diferentes sistemas de perspectiva de cuerpos tridimensionales. Las tareas de este tipo se clasificarán en función de la reversibilidad del proceso de representación plana al de volumen: construir figuras a partir de sus vistas (planos) o construir las vistas ortogonales a partir de la proyección de las figuras.

Se plantea un modelo de perspectiva técnica que no es del todo coincidente con el modelo visual de referencia, pero que sin embargo surge del modelo visual, con el que apenas o nada se ha trabajado. Si entendemos la inteligencia en cierto sentido como capacidad de 
adaptación, sin duda el aspecto de la aptitud espacial se nos antoja aquí como la mejor muestra "que permite justificar que unas personas se adapten mejor y más exitosamente al ambiente que otras" (Sternberg, 1985, p.55).

En nuestra opinión debe haber un modelo que clarifique que la realidad física, el espacio en el que nos desenvolvemos, siempre es tridimensional. El plano es la superficie de representación, que es bidimensional (altura y anchura) aunque representemos en él una tercera dimensión figurada (profundidad). Con el fín de resolver esta cuestión de la tridimensionalidad y simular la profundidad en el plano, son varios los modelos de perspectiva que hemos creado para representar los objetos en el espacio y el propio espacio.

Debemos considerar previamente que ningún modelo de los utilizados en el aprendizaje es del todo correcto o acorde a la experiencia visual, ya que todos ellos parten de la consideración del horizonte como una línea recta de referencia de la profundidad lineal del campo visual, siendo que el horizonte físico es curvo: de ahí, la definición de recta "como circunferencia de radio infinito" (Navarro, 2008, p. 15). Considerar el horizonte y las líneas de profundidad como curvas supondría establecer cálculos trigonométricos y trabajar con arcos y ángulos curvos, que evitamos al considerar nula la curvatura de la esfera del planeta en comparación con la escala humana. Igualmente en las medidas de las superficies de representación la combinación de profundidad y escala genera grandes deformidades. Por otro lado, los edificios y espacios que construimos, en pocas ocasiones plantean superficies curvas, pero lo más importante es que las superficies de representación que utilizamos habitualmente, son planas. Aunque se comienzan a ver pantallas curvas, las dificultades de esta perspectiva en aplicaciones arquitéctonicas y técnicas son todavía notables (Heidrich y Redondo, 2011; Regot, 1986). Sin embargo, si tuviésemos que elegir el sistema teórico de representación de la realidad visual, sin lugar a dudas el que mejor responde es la perspectiva curvilínea (fig. 83), que "concuerda más con la realidad fisiológica y psicológica que el que subyace a la construcción rectilínea de Brunelleschi” (Panofsky, 1969, p.193). 


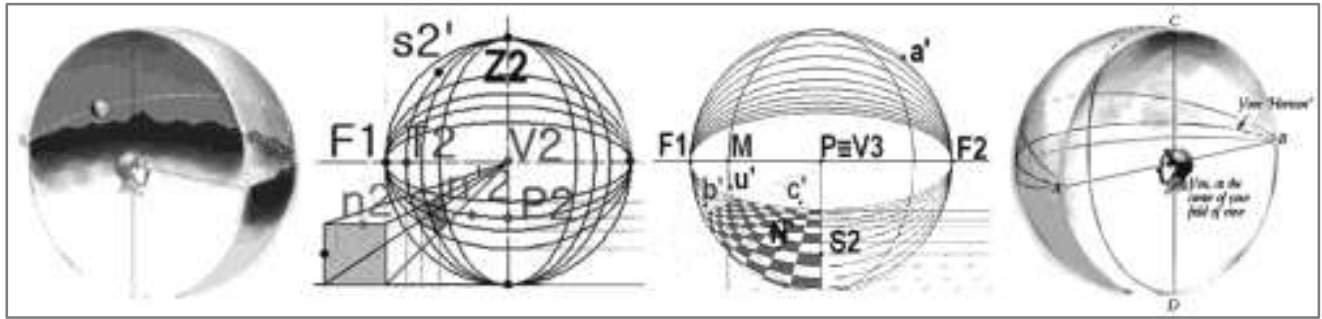

Fig. 83: modelos de perspectiva curvilínea

(fuente: www.diseñobasico.com y www.perspectiva-curvilinea.blogspot.com.es)

Por tanto adaptamos el mundo físico complejo a nuestra experiencia visual y el pensamiento actúa para explicarlo. Y lo hacemos con la geometría descriptiva, que nos proporciona un modelo teórico aproximado en el que se define un ojo geométrico y un objeto geométrico, situado entre un plano de suelo (PT) y un plano de horizonte $(\mathrm{PH})$ en el infinito, a partir del modelo visual (fig. 84). Con el fin de proporcionar una proyección del espacio visual, a base de puntos y líneas que son consideradas teóricamente rectas:

"Pero estas representaciones proyectivas tienen, como observa Villanueva (1996), importantes diferencias tanto en lo que se refiere al proceso de formación de las imágenes como en la eficacia perceptiva de los resultados, porque no son equiparables a la riqueza perceptiva que nos proporciona la contemplación directa del modelo tridimensional, y del movimiento incesante del ojo en la visión de un objeto"

(Heidrich y Redondo, 2011, p.3)

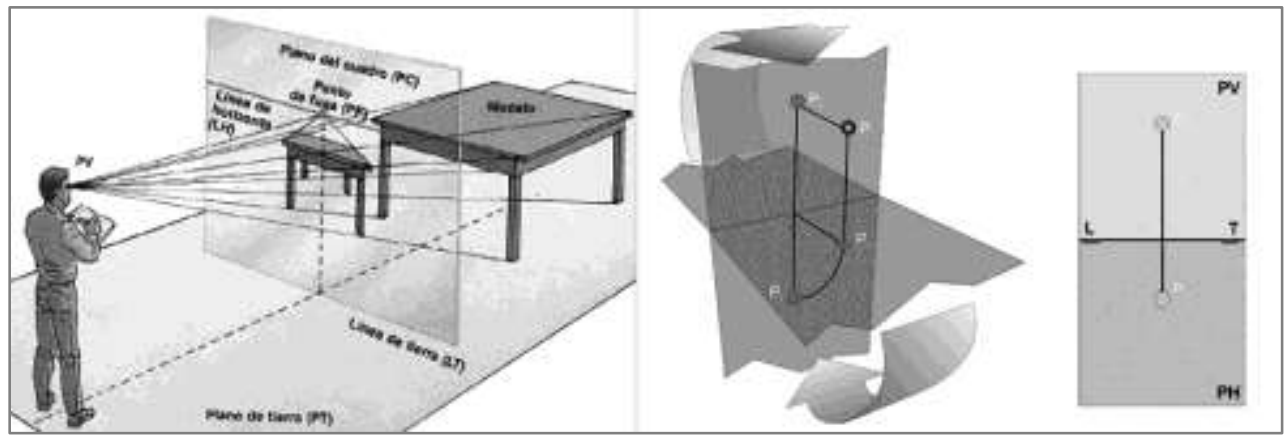

Fig. 84a: Planos y líneas de tierra y visión según los modelos teóricos rectilíneos: visual y axonométrica. (elblogdeeducacionplasticayvisual.blogspot.com.es)

A partir de la geometría, la investigación es prolífica en diferentes sistemas de representación y graficación, con diferentes finalidades teóricas y técnicas. No tiene lugar exponer aquí este 
recorrido, pero desarrollaremos algunos aspectos que creemos inciden en la formación de los conceptos visuales.

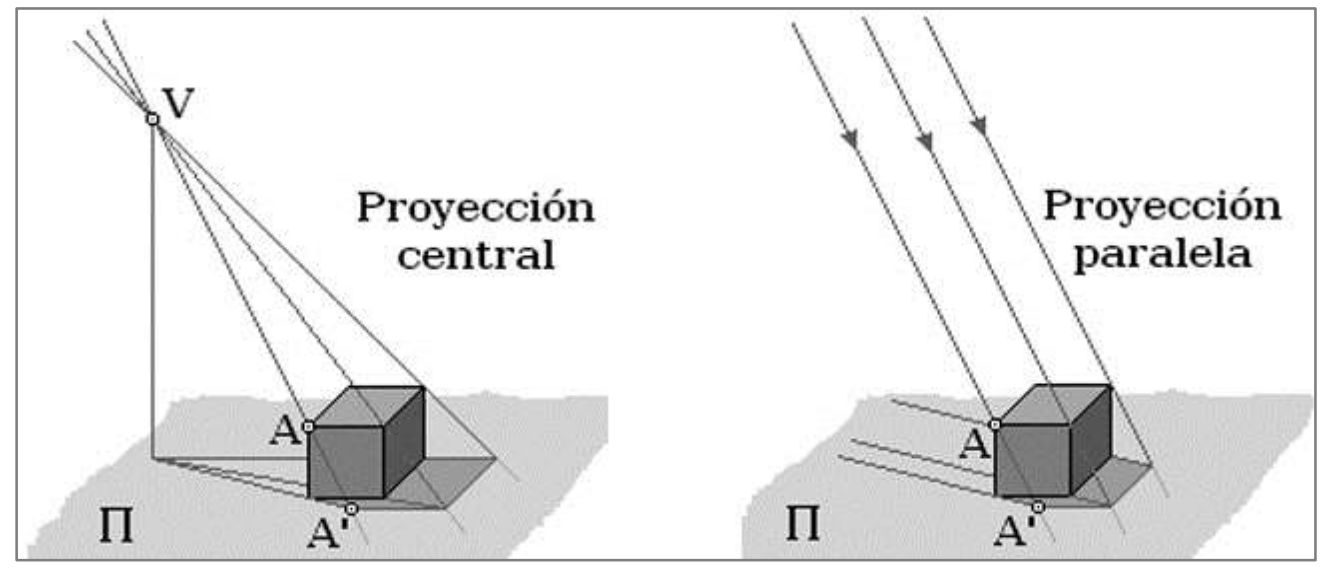

Fig. 84b: Covergencia visual y axonometría de la luz (Wikimedia Commons).

La perspectiva axonométrica, para cumplir con los fines de la ingeniería y la industria, establece dos propiedades importantes que la distinguen de la perspectiva visual. Una es que el objeto representado no puede depender de su distancia al observador: sitúa al observador como si estuviera en el infinito, para que no afecte a la escala 0 tamaño del objeto. El foco de proyección no converge en un punto (fig. 85). Y como consecuencia, la otra propiedad es que las líneas son siempre paralelas en su representación axonométrica, mientras que en la visual sólo son paralelas en la visión frontal, e incluso en ese caso, pueden no parecerlo (fig. 85).

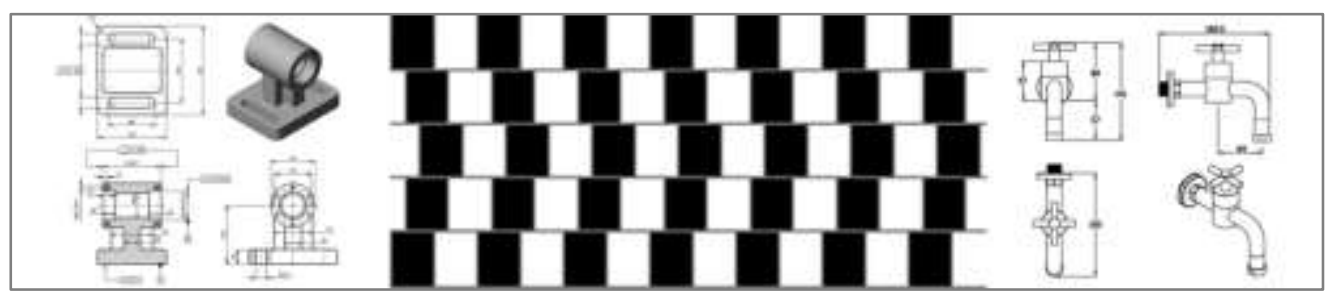

Fig. 85: Paralelismo en diseño industrial e ilusión de paralelismo.

Esta propiedad de divergencia visual produce el resultado teórico de perpendicularidad y paralelismo, que van a permitir que las referencias a las dimensiones reales del objeto (líneas de longitud, anchura y altura) sean estables al igual que los angulos de sus intersecciones, lo que se hace para proporcionar las medidas en el plano o diseño, y que va a facilitar la manipulación y la fabricación o construcción del objeto. 


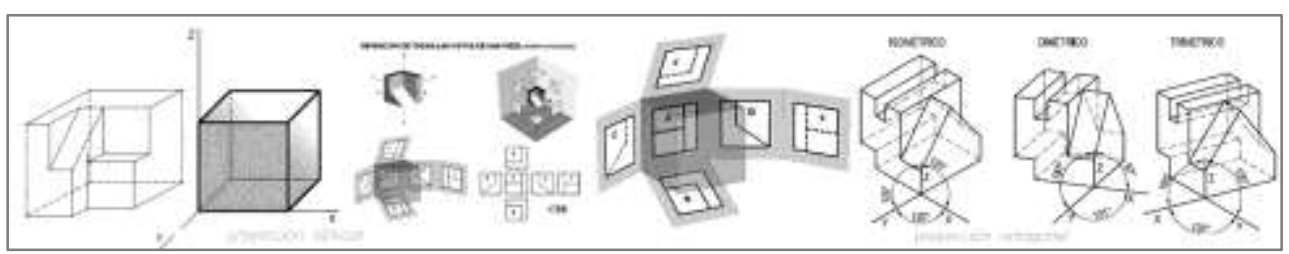

Fig.86: Sistemas de perspectiva axonométrica y vistas del sistema europeo.

(dibujotecnico.com)

El sistema de perspectiva de referencia elegido en la educación básica responde a este modelo teórico (fig. 86), que tiene su sentido en el mundo industrial, pero al reducir la importancia del punto de vista humano en el sistema de representación, obvia los procesos mentales de la experiencia visual en la tarea (educativa) de estructurar el pensamiento espacial del estudiante: "Las imágenes mentales, implicadas en la mediación del fenómeno de la representación tridimensional, subrayan la necesidad de entender la percepción del mundo como una construcción cognitiva consistente en reorganizar datos y experiencias para llegar a una síntesis sobre la que poder establecer conceptos y relaciones" (Giménez Morell et al., 2010, p.118).

De esta manera, la posición real en el espacio se diluye de forma teórica y plantea un paradigma al considerarse como modelo válido en la representación visual del espacio y a la vez estar alejado de la experiencia individual. El punto de vista consecuente a la posición que adoptemos, surge de la unión de dos líneas: una vertical tanto de la gravedad que sentimos en el plano de tierra o suelo y nos obliga al equilibrio, como de la simetría que percibimos en nuestro cuerpo, y otra horizontal del campo visual o plano visual que proyectamos al horizonte. La vertical, es la línea de referencia que une los puntos extremos de la columna vertebral (el atlas y el coxis), y la horizontal se traza por la unión de los ojos o focos de la visión binocular. Ambas líneas forman en nuestro propio cuerpo 'la cruz que todos llevamos' (fig. 87). Esta expresión, más allá de un significado trascendental, refleja la referencia espacial de nuestro campo visual. El resultado ante nosotros es un espacio dividido en cuatro cuadrantes, que son los marcados en un visor que nos ayuda a 'poner el ojo' donde queremos apuntar: Superior derecho e izquierdo e inferior derecho e izquierdo. 


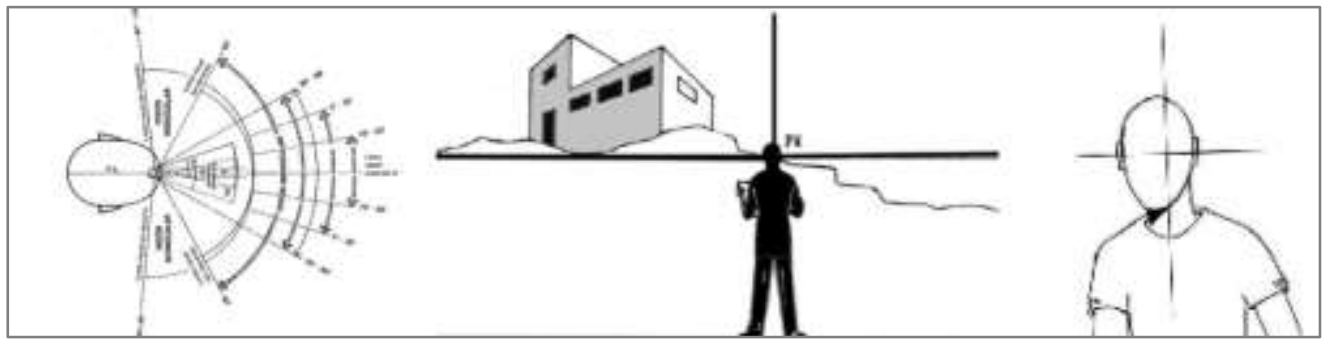

Fig.87: Campo visual en ángulos de nitidez (www.ecured.cu) y eje de referencia del campo visual.

Los diferentes sistemas de proyección geométrica surgen de este esquema de cuadrantes, que como pretendemos analizar no parece estar claro en la mente de los futuros docentes, o desconocen su relación directa. Los principales procedimientos que caracterizan las habilidades de visualización en la representación gráficogeométrica son las rotaciones mentales, y por tanto, la orientación del punto de vista psicológico respecto a la situación de la configuración espacial (Grassa-Miranda, 2014).

Esta cruz referente resuelve el eje de coordenadas en la orientación espacial, tanto real como representada, pero a su vez es el referente en la medición de los ángulos que forman las líneas oblícuas, que, en el plano figurado, representan la dimensión lineal de profundidad. Este referente de las operaciones con ángulos es de hecho la principal diferencia entre los propios sistemas de proyección ortogonal y oblicua en la perspectiva axonométrica (fig. 86). Sus aplicaciones están en todos los ámbitos de la arquitectura, la ingeniería, el arte y la topografía con diferentes resultados: acotación de piezas, proporciones y escalas, distancias...

Sin embargo el discurso de las ciencias de la educación en relación a este paradigma proyectivo se resuelve a favor del sistema paralelo: el concepto espacial mecánico-proyectivo que intenta conciliar formalización y percepción en el campo aplicado del diseño mantiene una estructura obsoleta de enseñanza en torno al problema de visualización que subyace a la representación espacial. El aparatoso planteamiento geométrico de la fig. 88, al fin y al cabo se reduce a la expresión de la distancia entre dos líneas. En la medida en que la representación se codifica para alcanzar mayor abstracción, disminuyen las posibilidades de encontrar referentes visuales (GrassaMiranda, 2014). Esta ausencia de conciliación da lugar a "importantes 


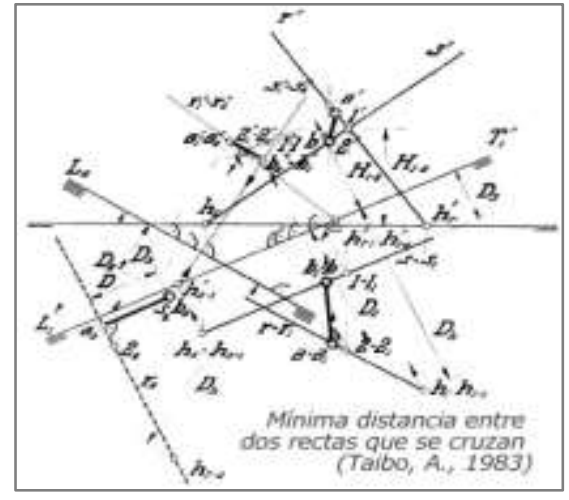

Fia.88.

contradicciones metodológicas debido a la imposibilidad fenoménica de la visión" (Gámiz, 2003, p. 136) y en consecuencia, dificulta la integración de la experiencia visual en su código (Giménez Morell et al., 2010).

Utilizando la expresión de André Breton, consideramos, en favor de la conciliación de los sistemas de representación y resolviendo este paradigma de una $u$ otra manera, que el plano de la expresión gráfica al final es "una ventana que mira hacia algo externo; la cuestión es: ¿hacia qué?".

\section{3.- Visualización y figuración (modelado).}

En otras líneas de la investigación científica de la visualización y la representación espacial no se consideran las relaciones espaciales en el sentido dinámico, pero se consideran las relacionadas con el factor topográfico. En esta línea situamos los trabajos sobre mapas cognitivos o mentales, infografías o imágenes, que tienen en común el tratamiento del carácter simbólico de la representación. Algunos estudios sobre mapas cognitivos, la entienden como una representación de nuestra comprensión personal del entorno, como resultado de procesos mentales referidos a un "ambiente espacial, a la gente y objetos de ese entorno", y vinculan estos mapas con procesos adaptativos y toma de decisiones espaciales (Downs y Stea, 1973, cit. en Caballero, 2002, p. 49).

Desde la ciencia cognitiva computacional, se analiza la formación de imágenes mentales en términos de las estructuras de datos y procesos que manipulan la información durante el pensamiento visual (Pinker, 1988). La visualización se analiza así como un proceso cognitivo de interpretación visual que discrimina la percepción de la forma y su calidad (resolución), y la analiza en base a la composición de la imagen y la trasformación de ésta (rotación mental), en base a unos ejes (fig. 89). 


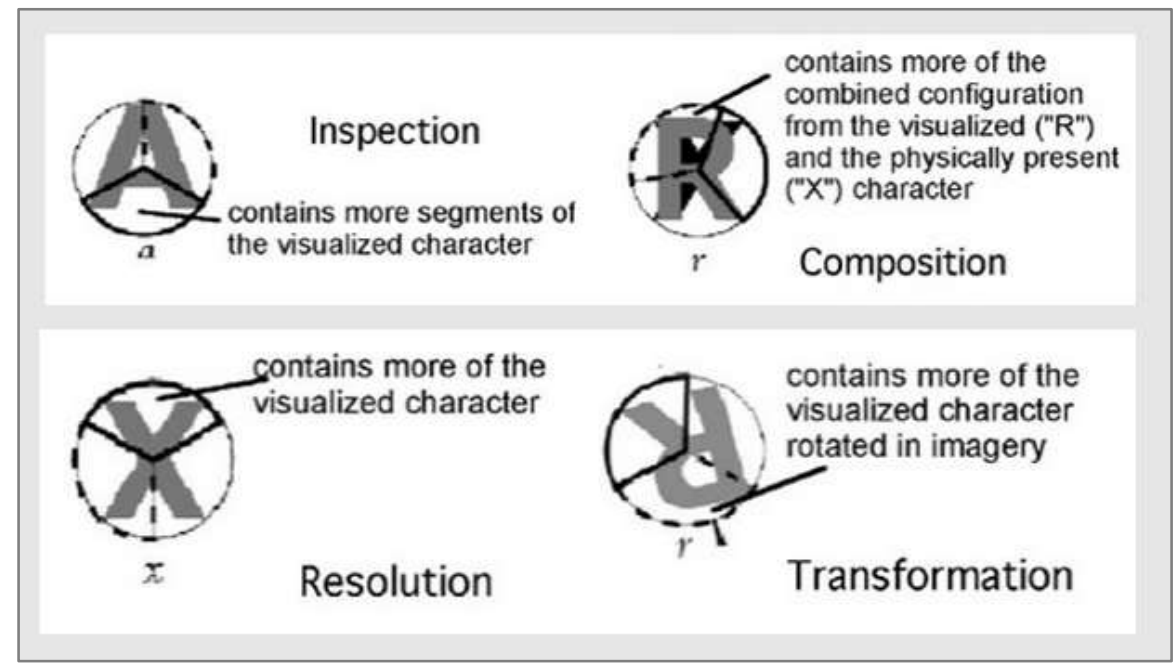

Fig.89: Prcesos de visualización en la cognición visual (Mast y Kosslyn, 2002)

Cualquier representación mental o gráfica incorpora una noción de espacio en sí misma, pero estos trabajos se centran en los conceptos o significados que transmiten. Parten del presupuesto de que la manera de representar el espacio es arbitraria en cuanto a la elección de uno u otro sistema de coordenadas o ejes, y puede reducirse a la representación de diagramas (Markman, 2013). En el ámbito de la psicología ambiental o del enfoque ontosemiótico, se diversifica el propio concepto de espacio, atendiendo a la subjetividad y la falta de un marco espacial común, a variables como la familiaridad con el entorno (urbano o rural) o la vinculación emocional con el ambiente (Caballero, 2002; Presmeg, 2008). En general, estos estudios parten de que los diagramas y signos gráficos tienen cierta capacidad de evocación del pensamiento espacial como patrones de visualización y tienen mucha influencia en el diseño gráfico moderno.

Estas imágenes mentales son representaciones que pueden ser interpretadas de maneras novedosas (Hyman y Neisser, 1991). En este sentido, determinados grafismos (patterns) funcionarían como detonantes visuales de un razonamiento más o menos creativo (Finke et al. 1989), que sugieren los dos tipos de procesamiento, verbal o visual, en la formación de las estructuras anticipatorias de las imágenes mentales (fig.90). 


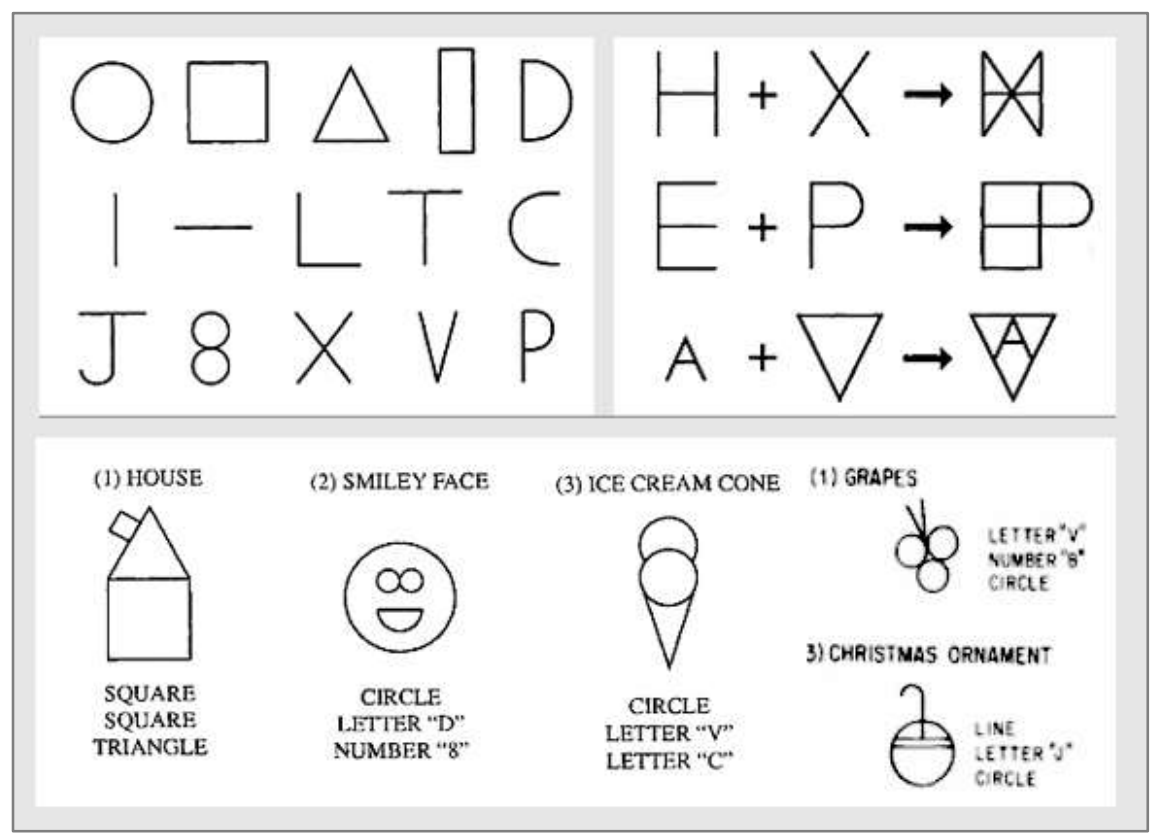

Fig. 90: Grafismos, secuencia de prueba y patrones emergentes de la imaginería visual (Finke, 2014)

Las cualidades intencionales y estructuradas del pensamiento creativo se contrastan con las cualidades espontáneas, no estructuradas, a partir de formas geométricas, líneas y caracteres alfanuméricos por su familiaridad y facilidad de identificación. Hemos aludido a estas técnicas en tres ítems con la intención de correlacionarlos con los de competencia, aunque consideramos que estos trabajos basan sus conclusiones, con cierta exclusividad, en un sistema de representación paralelo alejado de la experiencia visual:

"Todos estos objetos tienen un conjunto de relaciones espaciales entre sí, con una distancia y dirección a cada otro objeto. Lo que yo percibo como espacio real tiene tres dimensiones. Desde mi punto de vista actual, si puedo solucionar un origen directamente entre mis ojos, puedo pensar en la ubicación de los objetos en el mundo en términos de sus coordenadas en tres dimensiones: Una es vertical $y$ pasa directamente entre los ojos; la segunda es horizontal y pasa a través de cada ojo; y la tercera es la profundidad, que es perpendicular (u ortogonal) a las otras dos dimensiones y cumple con las otras dimensiones en el origen."

(Markman, 2013, p.28) 
Como hemos comentado en el apartado anterior, en la concepción matemática teórica de la linealidad, el que dos vectores sean linealmente dependientes implica que geométricamente sean paralelos, y ello está relacionado conceptualmente con la idea de paralelismo entre rectas en el plano cartesiano (Acosta et al. 2013). El hecho de que los estudiantes asuman la perspectiva paralela como la manera de procesamiento cognitivo de la representación espacial, reduce la generalidad de sus conclusiones y las condiciona al entrenamiento geométrico visual (Kosslyn et al, 1984; Richardson, 1994). Este entrenamiento se produce en la población general por efecto de la educación formal en matemática.

Pero por otra parte, aunque se plantea la subjetividad en la ambigüedad de estos patrones imaginarios, ya que pueden ser reinterpretados (fig. 91); es posible que los individuos que reinterpretan los objetos en las imágenes pudieran recordar diferentes estímulos asociados a la imagen sin que por ello la imagen pierda su poder evocador objetivo (Mast y Kosslyn, 2002). Los resultados de estos trabajos indican que los objetos en imágenes mentales pueden ser ambiguos, pero al menos algunas personas pueden detectar una interpretación no reconocida previamente. $Y$ curiosamente son los sujetos que muestran mayor facilidad para rotar la imagen, los que detectan con más facilidad la interpretación alternativa de la imagen ambigua mostrada.

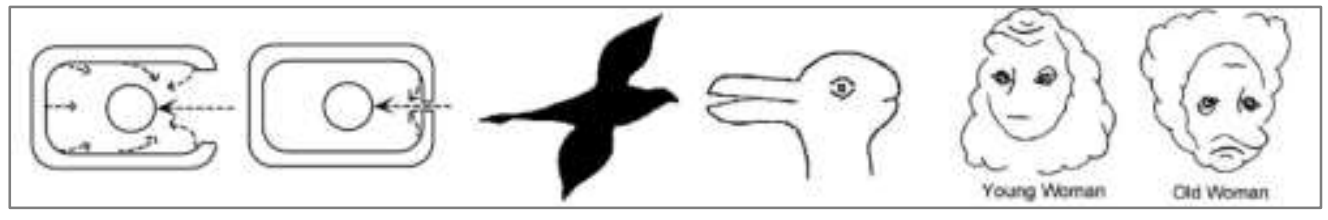

Fig. 91: Estudios de fuerzas perceptivas en patterns lingüísticos (Grady, 2005) Ejemplos de figuras ambiguas de diferentes estudios (Mast y Kosslyn, 2002)

En general, estos enfoques proposicionales consideran ciertas cualidades en los esquemas perceptivos (Grady, 2005) y se basan en formas estructuradas en la construcción de la imagen mental de los objetos, a modo de arquetipos y símbolos. En este caso, la construcción del espacio tiene cierto carácter arbitrario, y en la representación tridimensional solo se consideran los ejes cartesianos. Aunque estos enfoques son conceptuales, sin embargo, algún estudio apunta a la correlación existente entre el aumento de la formación 
académica y la reducción de la comprensión de las representaciones gráficas cartesianas en el nivel conceptual (García y Perales, 2005). Este estudio atribuye a la escasez de actividades de interpretación de gráficas cartesianas como la causa del déficit en el procesamiento de la información gráfica conceptual.

Existe a su vez una manera no geométrica y que no responde a una estructura reconocible, de representación tanto del espacio como del ser humano y los objetos. Obviamente está en la antítesis de los planteamientos de la inteligencia técnica y la ingeniería, y en buena parte de los planteamientos cognitivos del análisis visual; pero creemos que también se encuentra en la interpretación y representación del pensamiento visual. Se basa en formas visuales que no responden a estructuras geométricas o simbólicas. El análisis del espacio, más intuitivo aunque también técnico, no responde aquí a la posición del observador sino a aspectos puramente cualitativos.

La investigación pone de manifiesto la existencia de estos dos conceptos espaciales diferenciados, uno más cercano a la experiencia y otro centrado en modelos lógicos o matemáticos de la realidad (Grassa-Miranda, 2014). Ambos comparten características en mayor medida de lo que se piensa, y aunque son difíciles de separar, a nivel técnico plantean recorridos diferentes. Los modelos estructurales se basan en principios geométricos, mientras que estos modelos propios del diseño artístico lo hacen en las formas no geométricas.

Estos análisis de las formas y el espacio requieren una diferente concepción de la línea como contorno. La noción de eficacia en la escritura y en la construcción de polígonos regulares nos obliga a concebir la ejecución de líneas como la unión entre dos puntos en términos de velocidad y precisión simbólica o geométrica. Hemos comentado la ausencia de trabajos de investigación del gesto gráfico y en este sentido, adolecemos de un análisis cognitivo del trazo que vaya más allá de lo grafologico. Normalmente se atribuyen las cualidades de la línea y la forma no estructurada a la ambigüedad e irregularidad. Sin embargo la línea es relevante, no solo marca contornos de las formas, sino que analiza delimita espacios: son los espacios negativos o vacíos, equiparables a los silencios en la música. 
"La percepción de la relevancia, en el habla como en la música, es resultado de una compleja interacción entre una serie de factores auditivos: la duración de los elementos fuertes y débiles del ciclo (largo-corto), el paso de los fuertes y los débiles (alto-bajo) su sonoridad (fuerte-suave) (...) lo que puede crear un contraste entre sonidos sucesivos puede servir para darse cuenta de la relevancia"

(Kress y Van Leeuwen, 1996, p.213).

Si pensamos en el valor que asignamos a los silencios en la música, podemos percatarnos de que son éstos los que determinan su ritmo y así la armonía, pero por el contrario, difícilmente consideramos el valor de los espacios como formas vacías en la armonía visual. Las personas habitualmente no vemos esos espacios, pero no por falta de capacidad, sino sencillamente porque nunca nos han entrenado a verlos.

"Los rasgos negativos se ligan con los espacios física y psicológicamente cerrados (...) En cambio, los espacios abiertos evocan emociones positivas y conducen más efectivamente hacia la comunicación" (Wolf Unruh, 1983, p.197). Sin duda, la identificación de las formas por sus contornos desencadenan el pensamiento simbólico, el lenguaje y la comunicación, pero los espacios denominados negativos no son espacios cerrados en lo visual, y lo que cerramos con las líneas de contorno son en realidad las formas y las estructuras, que nos ayudan a comprenderlas y manejarlas.

El concepto de espacialidad en este sentido negativo permite a la vez su consideración positiva en el ámbito denominado socioespacial de la arquitectura, en tanto que toda acción establecería una direccionalidad, una fijación de objetivos, con su correspondiente marca de positividad (Tapias, 2014). Este enfoque aborda el concepto en el ámbito de la geometría proyectiva como 'contraespacio', en la consideración de que la línea surge "armada contra el espacio" con la finalidad de que el objeto representado no se desborde (Op. cit., p.129). En el marco de los procesos socio-espaciales Tapias defiende la utilidad del espacio vacío en tanto que es un concepto fiable que utiliza la ciencia astrofísica en la comprensión del cosmos. 
La consideración del espacio negativo también se realiza desde el análisis de la creatividad: "dado que la verdad no siempre es evidente, a veces conviene cierta aproximación desde el otro lado" (Rabazas, 2002, p.437). Asumimos de manera física (fuerza casimir) que tanto a nivel cuántico como a nivel biológico, hay una energía inherente entre las partículas y a su alrededor, y que ésta produce un movimiento que es parte de su mismo ser (Beattie, 2011). Igualmente se asume que esto ocurra de una manera visual a través de las fuerzas perceptivas (Grady, 2005; Arnheim, 1979); nos preguntamos por qué no considerar que esas interacciones se puedan dar a nivel cognitivo en la estructuración del espacio.

La doble visión resultante, que utiliza la Gestalt y la teoría de la imagen y que reflejamos en nuestro trabajo, no es tratada en el ámbito investigador de las ciencias de la educación. Sin embargo, más allá de la identificación de formas positivas y de su uso en la composición, creemos que puede permitir un mayor dominio y comprensión del espacio visual.

En el ámbito artístico, la percepción del espacio negativo, más allá de su aplicación en las diferentes disciplinas, es una constante en toda sensibilidad creadora en todos los tiempos y en todas las culturas (Garrido-Román, 2011). Lo atestigua una importante producción de obra gráfica y plástica y su utilización como técnica visual (fig. 92).

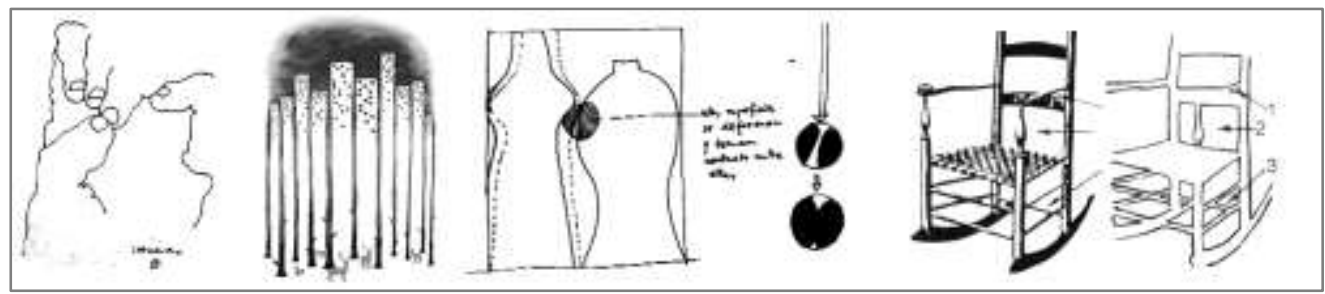

Fig. 92: Algunos ejemplos de la consideración gráfica de los espacios negativos. (Chillida E. y Tang Yau Hoong, Valldosera E. en Rabazas, 2002; y Edwards, 1994)

Estos autores emplean técnicas que encuentran su razón en la doble consideración de la línea, como contorno de formas y delimitadora de espacios que se hacen reconocibles al enmarcarlos dentro de un visor. Esta técnica produce un concepto de visualización diferente del analizado hasta ahora. Una visualización que resulta extraña, pero que se hace familiar al contemplar la figura y el rostro humanos (fig. 93). 


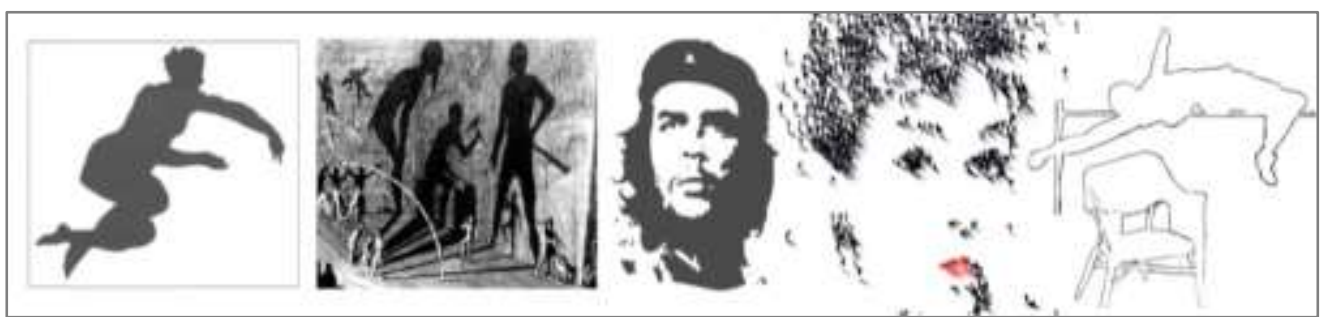

Fig. 93: Técnicas visuales de doble espacio y configuración de rostros en una tinta y en el espacio físico (Edwards, 2012; Martí Ferrer, 2009; Gómez Molina, 2002)

La complejidad manifiesta de la representación no estructural y del dibujo anatómico en especial, se comprueba en la didáctica artística plástica y visual, al momento de abordar la representación del cuerpo humano desde un enfoque no geométrico. Además de referirse a este aspecto de discriminación del espacio, aquí la línea se encuentra estrechamente relacionada con lo comentado sobre el gesto gráfico.

La utilidad de atribuir a la línea una mayor expresividad, aunque tiene su repercusión principal en el diseño artístico, igualmente se presenta útil en el material gráfico didáctico de las ciencias, el dibujo científico o la ilustración naturalista. Las representaciones gráficas adquieren aquí la consideración de modelo (fig. 94). Para la investigación científica un modelo es una construcción imaginaria funcional, que "debe ser contrastable y útip", de un objeto, teoría o proceso que "reemplaza a un aspecto de la realidad" a fin de poder efectuar su estudio (Bunge, 1976, p. 236). En este sentido, las representaciones gráficas se consideran explícitas y concretas, frente a las representaciones instrumentales que se obtienen a través de dispositivos (Galagovsky et al., 2009).

Para la didáctica de las ciencias, los modelos mentales, que incluyen representaciones proposicionales e imágenes, permiten a los individuos entender fenómenos, hacer inferencias y predicciones, decidir las acciones a tomar y controlar su ejecución (Vergnaud, 1990; Moreira, 2004). La construcción del conocimiento consiste, entonces, en la progresiva construcción de representaciones mentales que son homomórficas a la realidad, para algunos aspectos y para otros no (Vergnaud, 1990, p. 22). 


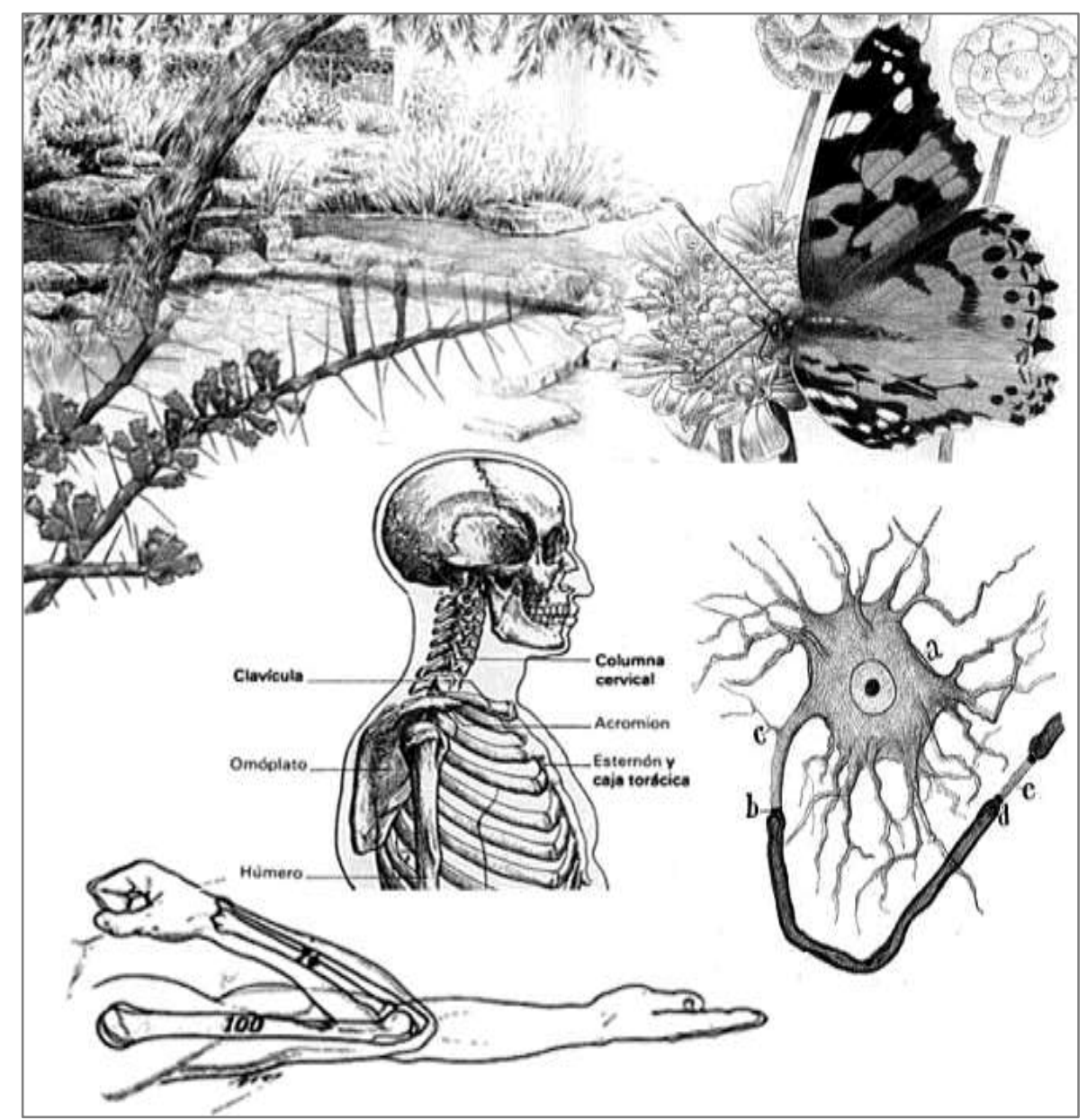

Fig. 94: Ejemplos de modelos gráficos naturalistas y científicos (Puche, 2002; Moreaux, 2005)

La idea de que las representaciones ofrezcan posibilidades de inferencia va a permanecer, aunque el modelo sea correcto o no (en el sentido de que sus previsiones no son correctas científicamente), sea vago, confuso o incompleto, pero en cualquier caso será funcional para su constructor y puede ser modificado recursivamente hasta alcanzar dicha funcionalidad (Johnson-Laird, 1987, Moreira, 2004).

Experimentos diseñados para poner a prueba una teoría de la inferencia espacial basado en los modelos mentales, indican que los problemas de un modelo fiable resultan más fáciles que los problemas que requieren más de un modelo (Byrne y Johnson-Laird, 1989).

En este sentido, la idea de inferencia y fiabilidad, que subyace en la teoría científica, obliga a aceptar un modelo con la condición de que cumpla cierto grado de consistencia. Nosotros encontramos que 
la mayor representación de consistencia formal se halla en la proporción o ratio, en su acepción anglófona. Esto hace que la representación gráfica en el ámbito de las ciencias experimentales, además de interactuar entre significante y significado (Vergnaud, 1990), esté sometida al requisito de la ley de proporción que opera en la naturaleza. Ahora bien, es posible que este rigor aplicado tenga más sentido en el modelo científico que en el modelo didáctico, pero, al respecto, coincidimos en la íntima relación entre ambos:

"Todas las consideraciones previas nos llevan a proponer un marco teórico en el cual los dibujos, esquemas, maquetas y tantos otros recursos didácticos expresados en lenguaje gráfico sean considerados como las "representaciones concretas" a las que recurre un experto (docente o científico) para explicitar parte de su "modelo mental experto".

(Galagovsky et al., 2009, p.13).

Los lenguajes expertos de la información científica, el verbal, con fórmulas y códigos específicos, y el gráfico, con diagramas y dibujos se encuentran parejos tanto en la comunicación en el aula como en las reuniones científicas. Partiendo de la premisa de que "el conocimiento que maneja un experto docente no se transmite directamente desde su cabeza a la del estudiante" (Giudice y Galagovsky, 2008, p.654), y partiendo de que la construcción y representación, a través del esquema y el concepto, conducen al análisis visual, consideramos que en éste, la proporción se encuentra detrás de la composición de la imagen como modelo (didáctico o experto).

Por tanto, entendemos la habilidad cognitiva de modelizar, definida en estos trabajos, como una capacidad inherente a la competencia profesional del docente, que no debe limitarse a analizar el 'modelo mental' del saber, sino que debe traducirse en el saber hacer de la representación gráfica. Quizás más allá del debate sobre si los modelos explícitos remiten o no a los mismos significados en la mente de expertos y estudiantes, resulte más ventajoso analizar la estructura y los componentes de estos modelos. 


\section{4.- Composición y pensamiento analógico}

En esta línea argumental, tanto la investigación del pensamiento visual en la teoría proposicional, como el análisis semiótico de la imagen comparten su naturaleza científica. La lectura de la imagen es entendida como un proceso lingüístico visual, donde intervienen los modelos referidos, junto a todo tipo de imágenes (publicitarias, simbólicas, artísticas, etc.). Se refiere a la lectura que requieren los conceptos educativos de la alfabetización visual y, en la medida en que es un medio formado por imágenes, de la alfabetización digital.

Para realizar esta lectura se propone un doble análisis, del significado y de la composición del significante, en relación a la realidad. Es un proceso de descodificación del lenguaje visual y audiovisual (Hall, 1980). Un proceso de lectura visual que dirige la atención a los esquemas anticipatorios que orientan la percepción (Ortega, 2003). Este proceso permite una lectura subjetiva de la imagen en cuanto a la experiencia personal: el proceso de identificación (percepción subliminal) e interpretación que establecemos con el mensaje visual.

Pero al mismo tiempo permite una lectura más objetiva, basada en la organización de la percepción del receptor, que es tenida en cuenta (de manera más o menos consciente) en la composición de la imagen (mensaje) del emisor (Aparici y García Matilla, 1987; Villafañe, 2006; Ortega, 2003). El análisis de la lectura objetiva lo encontramos en la organización del formato y sus divisiones y distribución de líneas de fuerza, y a su vez, en la utilización de las medidas y dimensiones como valores manejables. En el manejo consciente de estos aspectos podemos encontrar la intencionalidad o la 'manipulación' del mensaje que se recibe, o que se interpreta en términos subjetivos.

Aunque en un trabajo anterior recogimos aspectos de interpretación en la lectura de la imagen de la fig. 95, en éste hemos referido la lectura de la misma imagen a aspectos más objetivos de la composición. Consideramos que previamente, o simultáneamente con la interpretación, se ha de producir la comprensión del mensaje, y ésta lectura de la imagen va a ser traducida por ciertas reglas morfológicas 


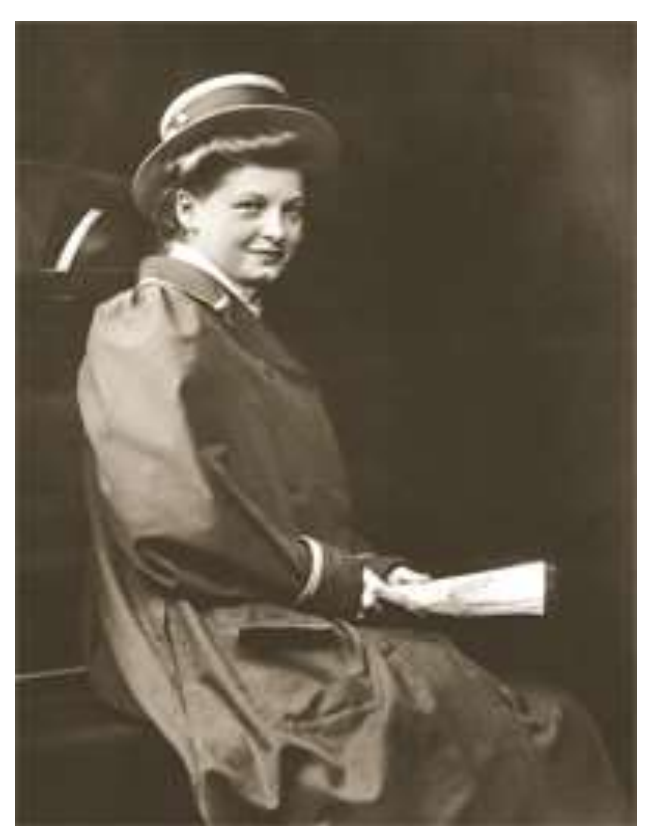

Fig. 95: Maestra de escuela, fotografía de A. Sanders, 1904 y estructurales de su composición; al tiempo que creemos que las referencias espaciales influyen en esta lectura.

\section{El análisis semiótico}

establece en la lectura visual un nivel denotativo y otro connotativo, que no son independientes y que están influidos a su vez, por los mensajes verbales y sonoros (Martin, 1987; Eco, 2011). Mientras que el connotativo se diversifica en la interpretación de pensamientos y sentimientos, el nivel denotativo se entiende de lectura literal, con características universales y naturales. En él se encuentran los elementos que componen la imagen: las cualidades, situación, valor o inferencia, están presentes en el signo visual, como un significado (Villafañe, 2006; Barthes, 1990; Aparici y García Matilla, 1987; Hall, 1980).

Los elementos básicos de la imagen a que refieren estos trabajos, en cierta manera coinciden con los que encontramos en el abecedario gráfico, pero se refieren a ellos desde el enfoque de la composición y lo denominan alfabeto visual: elementos morfológicos, dinámicos y escalares (Villafañe, 2006): Puntos, líneas (como puntos en movimiento) y planos, mantienen relaciones de fuerza (tensión), equilibrio (movimiento) y ritmos que crean las formas en base a dimensiones y proporciones. Estos elementos, junto con la luz (color), darán lugar a la composición de la imagen. En el análisis o lectura de esta composición destaca el estudio de la proporción y ángulos en las líneas que dividen la imagen (líneas de fuerza y equilibrio), junto a, en algunos casos, la relación entre las formas positivas y los espacios negativos.

En estos estudios, la proporción en las dimensiones y el formato regula la propia visión y lectura de la imagen. La proporción es la relación cuantitativa entre las partes constitutivas de un objeto 
(Villafañe, 2006). Cualquier imagen va a plantear dos centros, visual y geométrico, y unas líneas de fuerza, en relación al formato del plano o ventana y a las divisiones que hagamos en él, correspondientes a una razón o proporción. Este planteamiento recoge el legado del monje franciscano Luca Pacioli (1991) terminando el siglo XV, que establece una razón de referencia para la geometría. La relación $(a / b=c / a)$ en la división de cualquier segmento o medida proporcionaba la base de construcción de una figura (fig. 96a). Los trabajos de Pacioli recogen las primeras proporciones establecidas en los Elementos de Euclides, si bien aquel sustituye las complicadas demostraciones geométricas por sencillas demostraciones aritméticas (Pedoe, 1979).

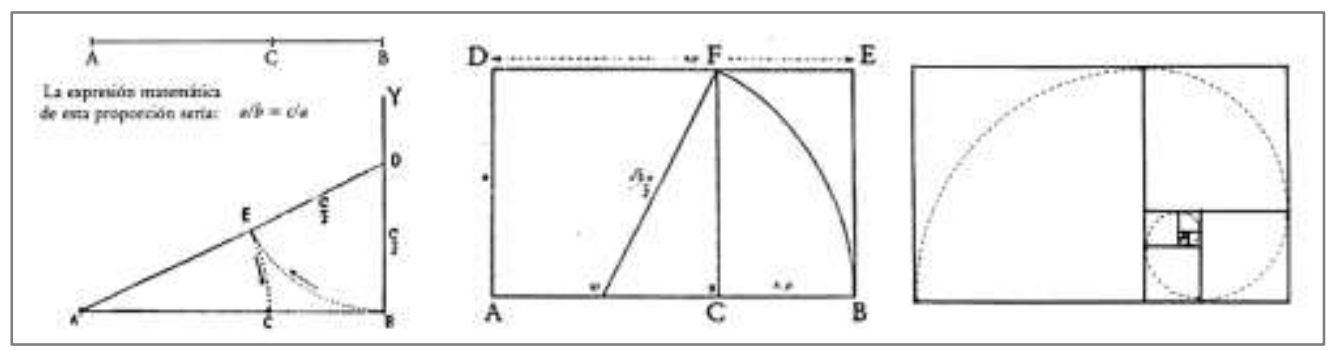

Fig.96a: Desarrollo del rectángulo aúreo y divisiones sucesivas (Pacioli, 1991; Pedoe, 1979)

Los efectos de esta 'divina proporción' y sus propiedades establecen las bases de muchas aplicaciones basadas en sistemas reticulares, desde el diseño tipográfico hasta las ratios de las pantallas y los formatos impresos (Elam, K., 2006) (fig. 96b). Pintores, arquitectos y diseñadores incorporan a sus trabajos la 'sección aúrea' (rebautizada por $\mathrm{Da}$ Vinci) de forma consciente, pero es también la proporción más encontrada estructuralmente en la naturaleza, lo que induce a pensar que pueda formar parte de una preferencia elemental y subconsciente por la estética de la proporción (Lidwell et al., 2011). Esta consideración se apoya en los trabajos de Gustav T. Fechner, que afirmara, que aunque parece existir una tendencia hacia los formatos en sección aúrea, la mayor preferencia de los experimentos se decantó hacia los formatos más comprimidos (ratios de 1:1,2 y 1:1,5), coincidente con el campo útil de la visión humana (Arnheim, 1979).

Compartimos la conclusión de que en cualquier caso, la elección de los formatos en una u otra proporción, ha estado marcada 
por la búsqueda de un equilibrio entre lo formal y la pura utilidad visual (Castillo, 2012).
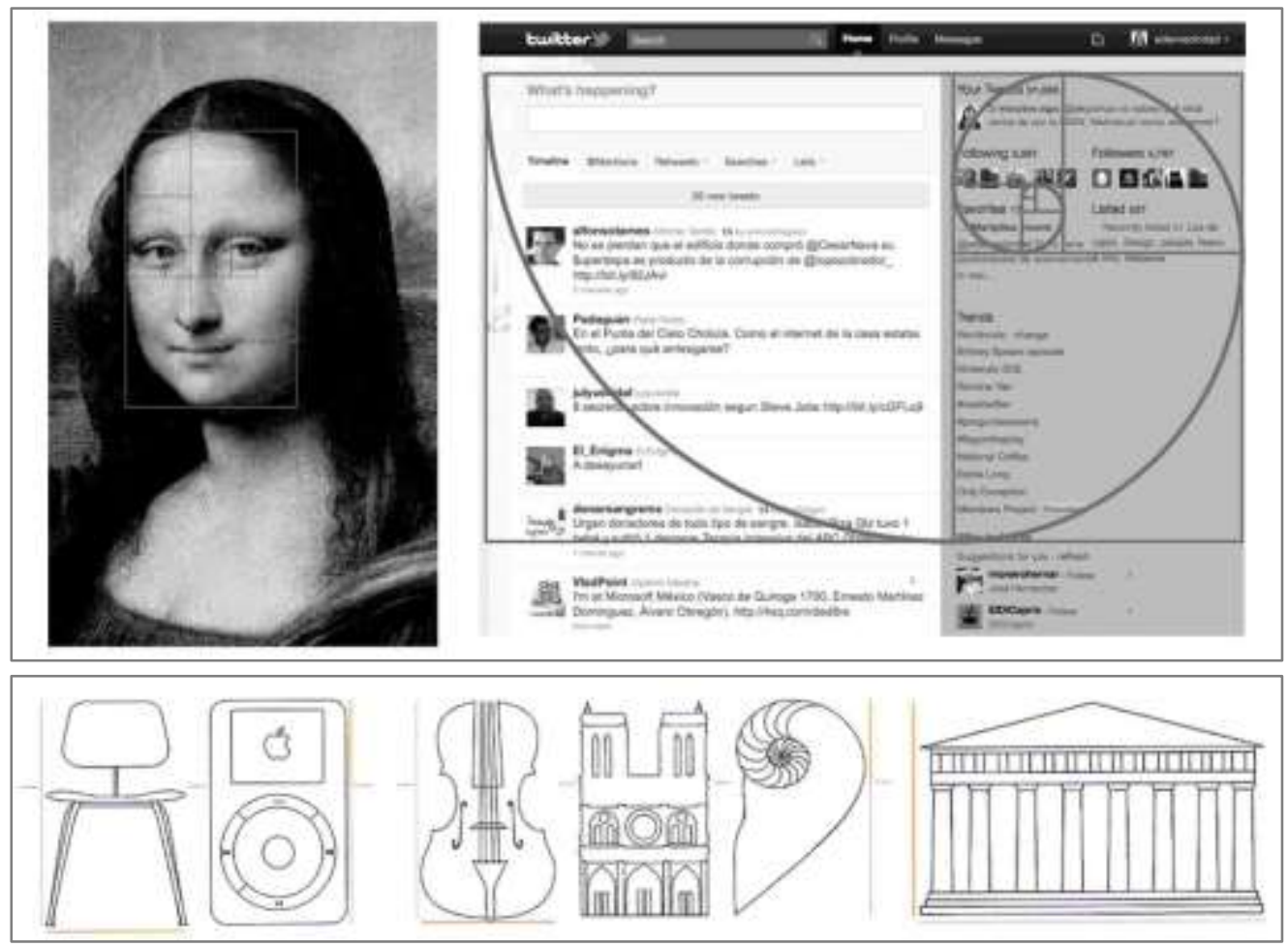

Fig.96b: La proporción aúrea en el arte, en la web y en diferentes aplicaciones (www.duonet.es; Lidwell et al., 2011)

El análisis de la proporción, es compartido tanto por el enfoque estético como por el técnico, y va a requerir una toma de decisiones en torno al formato, las proporciones y la composición, e influirá por tanto en la interpretación y lectura de la imagen. En la didáctica, la proporción en el formato de los recursos (papel, pantallas, pizarras, fotografías...) cobra cierta importancia, al igual que en la interpretación del material visual. Estos aspectos combinados con la situación espacial del observador y la adopción de la perspectiva, van a influir en la lectura visual, debido a la modificación de los puntos y líneas de fuerza de la composición, que se hace en base al estudio de las divisiones del formato (fig. 97).

La proporción de la sección aurea ya tenía una formulación matemática ( $\Phi$ phi) en la conocida serie de Fibonacci, en la que cada número resultante es la suma de los dos anteriores 
$(1,1,2,3,5,8,13,21,34 \ldots)$, que fuera expuesta, a finales del siglo XII, por Leonardo de Pisa. La sucesión de Fibonacci es un objeto matemático de sorprendente ubicuidad: aparece de forma recurrente en los patrones geométricos de la naturaleza y sus huellas están en ramas de las matemáticas inconexas a primera vista, como la teoría de la decisión o los conjuntos fractales (Alonso y Bermúdez, 2002). En este sentido, estudios de medicina forense concluyen que en la arquitectura de la cabeza ósea se encuentran relaciones proporcionales: encontraron 42 relaciones de proporcionalidad aurea entre rectas formadas por la unión de puntos específicos del macizo cráneo-facial, constantes en los cráneos estudiados (Suazo et al., 2008). El estudio de Suazo relata a su vez otros trabajos que encuentran esta proporción en toda la anatomía. Anteriormente, los pitagóricos descubrieron que los componentes musicales (tonos e intervalos) podían ser expresados en términos precisos por razones numéricas, resultando armónicos en esta proporción (Correa Pabón, 2010).

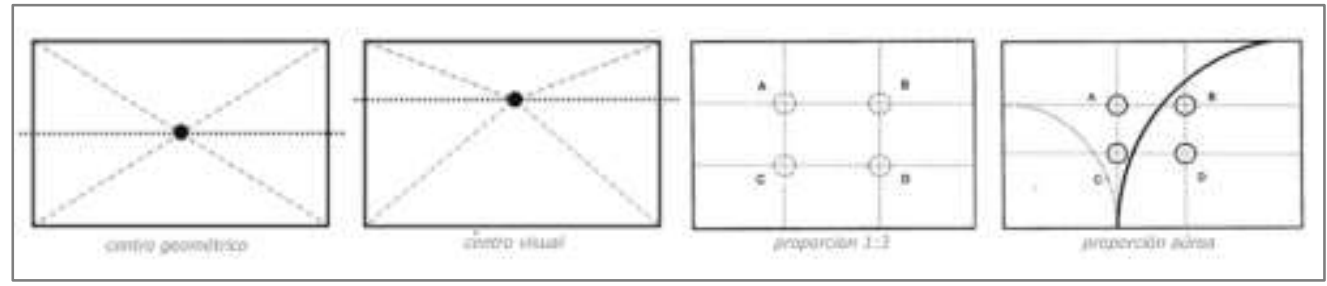

Fig.97: Puntos y líneas de fuerza de una imagen según la ley de los tercios y la regla de oro (Aparici y García Matilla, 1987)

Tanto esta proporción como la formulación de la ley de los tercios (fig. 98), que responde a la división del espacio con una aproximación aúrea (Goldstein, 1989; Lidwell et al., 2011), se encuentran generalizadas en las relaciones de las formas y espacios, pero no hemos encontrado estudios que establezcan una relación estrecha con el concepto anterior de relaciones espaciales. En el anterior trabajo comprobamos el escaso conocimiento geométrico de los números reales o geométricos (constantes), a excepción de m (pi). Aunque la proporción como magnitud es un concepto matemático relacionado con la medida, sin embargo, es como relación o razón (ratio), cuando se encuentra en todos los ámbitos del currículo: en las ciencias naturales y sociales, en el diseño, la educación física o la musical. La ratio es "una especial de relación entre los tamaños de dos magnitudes del mismo tipo" (Euclides, def.3, en Corry, 1994, p.2). 
De hecho, muchas secciones del plan de estudios de primaria y secundaria se refieren, directa o indirectamente, al concepto de relación, y muchos de los fenómenos estudiados se puede definir como una relación entre dos magnitudes (Ben-Chaim et al., 2012).

La componente de proporcionalidad en el modelo matemático al mismo tiempo, representa la habilidad para resolver problemas lineales, incluyendo el reconocimiento de las relaciones de segundo orden que implica establecer una relación de equivalencia entre dos razones. Parece demostrado que el razonamiento proporcional es extremadamente útil en la interpretación de fenómenos reales debido a que muchos aspectos de nuestra vida operan de acuerdo con esta estructura (Van Dooren et al., 2008). De hecho, el razonamiento proporcional ha sido descrito como la consolidación del conocimiento aritmético en la escuela primaria y la cimentación de conceptos posteriores en la escuela secundaria (Acosta et al., 2010).

Mientras que desde la didáctica artística (visual y musical) se trata la estética de la proporción (Goldstein, 2006; Joao Abdounur, 2009), en la didáctica de las ciencias se critica que las razones, las proporciones y la proporcionalidad se aborden desde contextos y situaciones que solo aluden al pensamiento numérico, y que en dicho tratamiento se establezcan pocas o ningunas conexiones con el pensamiento variacional (Correa Pabón, 2010). El enfoque del pensamiento variacional analiza la dificultad en encontrar los patrones que rigen las estructuras de la forma y las relaciones entre medida y espacio en la realidad cotidiana, lo que supondría un planteamiento metodológico más activo y exploratorio (Silvestre y Ponte, 2011). El pensamiento variacional es un modelo dinámico del pensamiento matemático que define el reconocimiento, la percepción, la identificación y la caracterización de la variación y el cambio en diferentes contextos, así como con su descripción, modelación y representación en distintos sistemas o registros simbólicos, ya sean verbales, icónicos, gráficos, virtuales o algebraicos (Villa-Ochoa y Ruiz, 2010; Salazar y Díaz, 2009).

En esta línea existen planteamientos didácticos del grupo de investigación 'Comunicación Visual HUM 228' de la universidad de Granada que, apoyados en figuras de alambre con la proyección de un foco de luz intenso, conjugan la visión real con los sistemas de 
representación diédrico, para ayudar a entender la perspectiva axonométrica a través de su fundamentación visual (fig. 98a). Recuerdan el modo de hacer de los artistas de Florencia del siglo XV, que basaban sus dibujos perspectivos en la optica de euclides y en los estudios de los matemáticos de la edad media, como Grossetête o Bacon (Bouleau, 1996).

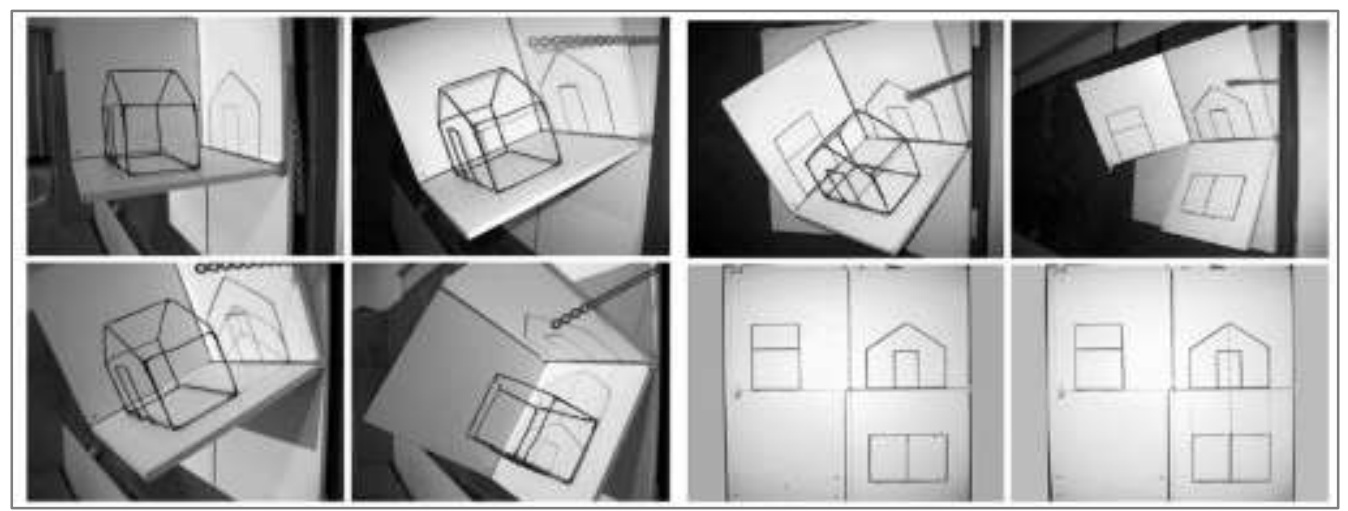

Fig. 98a: Modelos didácticos de representación axonométrica y proyecciónes

(Beltrán y Beltrán, 2011)

Los autores de este trabajo entienden la perspectiva axonométrica como el resultado de una situación visual figurada, en la que la proyección cilíndrica ortogonal "puede ser concebida como una observación desde una cámara de vídeo ideal situada (en términos geométricos) en el infinito, y provista de un zoom también ideal que amplíe la imagen también infinitamente" (Beltrán y Beltrán, 2011, p. 16). A partir de relacionar el modelo de visión cónica real con el modelo de representación plana, existen tres modos de plantear la proyección: como sombra, como imagen en la cámara oscura y como vista proyectada en el plano del cuadro (fig. 98b).

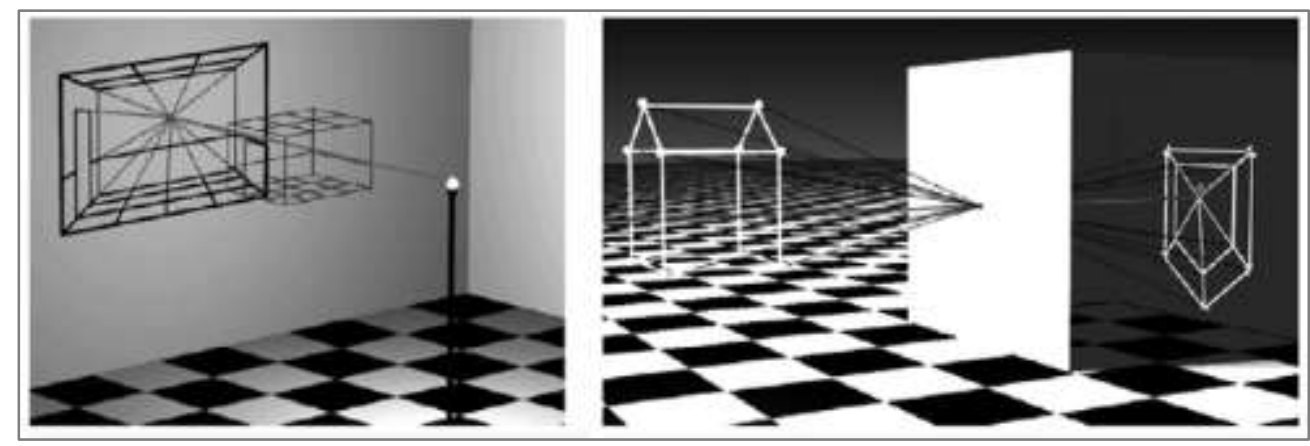




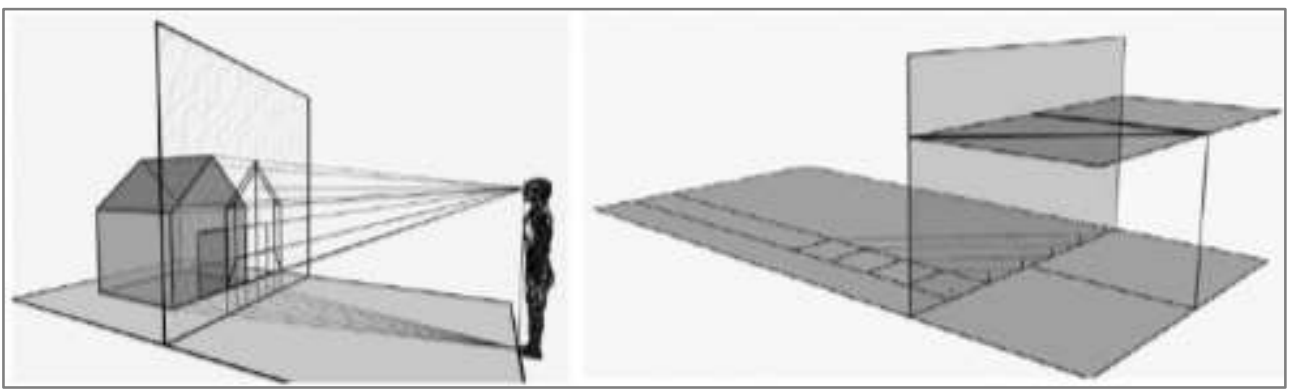

Fig. 98b: Modelos de proyección (Beltrán y Beltrán, 2011)

Al igual que la perspectiva, creemos que el análisis de la proporción es una actividad visual continua, que realizamos al comparar magnitudes externas e internas en las estructuras de los objetos y del espacio. Partimos de que el periodo escolar obligatorio desarrolla parcialmente el pensamiento cualitativo de los estudiantes en torno a la proporcionalidad, y se centran en una de las dimensiones de las figuras (Ruiz y Lupiáñez, 2009). Queremos relacionar el razonamiento proporcional que se produce en la percepción visual de formas geométricas planas que identifican objetos (fig.98c), y el que subyace en el reconocimiento familiar del rostro, con los mismos factores proporcionales en la lectura de la imagen.

Las tareas planteadas responden a la combinación de dos aspectos formales de la percepción con tareas simples de razón y proporción. La literatura sobre el pensamiento proporcional, interasada en el aprendizaje de los conceptos numéricos racionales, como el Proyecto Número Racional de la Universidad de Minnesota (Cramer y Post, 1993), entre los tipos de tareas, plantea un tipo de estimaciones o cálculos diferentes, que requieren comparaciones que no dependen del valor cuantitativo:

"Los estudiantes lidian con los tres tipos de tareas que la literatura de investigación ha reportado como adecuados para evaluar el razonamiento proporcional: a) ausencia de variable en el problema, en el que se dan tres valores, y el cuarto debe ser encontrado; b) los problemas cuantitativos de comparación, en el que se da la relación de los componentes, y las comparaciones deben hacerse entre ellos, por ejemplo, cual es el de mayor ratio), y c) los problemas de estimación cuantitativa y comparación, que requieren comparaciones que no son dependientes en valores cuantitativos (por ejemplo, la 
determinación de si la densidad de animales es mayor en el norte o en el sur del país)".

(Ben-Chaim et al., 2012, p.17).

La comparación cualitativa se analiza a partir de cuestiones que requieren del sentido figurado o la percepción de la ponderación (ponderare, pesar), del tipo:

"Hoy, Sara ha mezclado menos cacao con más leche que ayer. La leche tendrá un sabor:

a) más fuerte a cacao,

b) más suave a cacao,

c) exactamente el mismo sabor,

d) No hay suficiente información para contestar a la pregunta. Explica tu respuesta”

(Versión modificada, Cramer \& Post, cit. en Fernández Verdú y Llinares, 2012, p.17).

En relación al pensamiento visual, este tipo de tareas se refieren al equilibrio del peso formal y de la magnitud lineal (ancho y alto). Las imágenes y gráficos que se utilizan responden a la consideración de las gramáticas de simbolismo y lenguaje matemático, que replican como metáfora nuestra experiencia perceptual del mundo (O'Halloran, 2008).

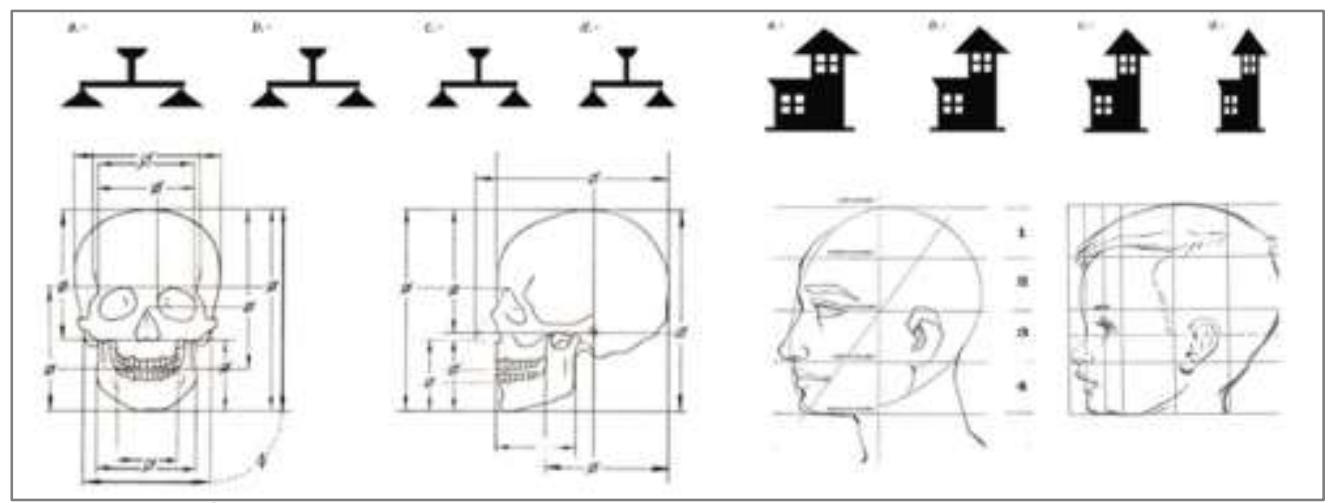

Fig. 98c: Ítems de proporción doble y proporciones craneales de adulto y niño (Carmiol, 2013 y Loomis, 1956)

En nuestro trabajo, se han utilizado gráficos del test de percepción de la proporción (TPP, Carmiol, 2013). El trabajo de Carmiol aborda el estudio de la proporción desde una perspectiva, 
novedosa en el tratamiento del pensamiento matemático, que contempla la representación gráfica fundamentalmente como una destreza visual: La representación gráfica está influenciada por la percepción y ésta necesita primero captar la configuración que ordena los elementos y entender las relaciones que existen entre estos elementos (Taylor, 1749). La característica de la proporción se situa así como la relación que destaca por encima de las demás variables que definen el objeto a nivel formal (Carmiol, 2013).

Tomamos la acepción de proporción de la principal definición que hace el diccionario de referencia para la Matemática: "una relación lineal entre dos cantidades variables o sus inversas; elementos correspondientes de dos conjuntos que están en proporción están en una relación constante. (A linear relationship between two variable quantities or their inverses; corresponding elements of two sets that are in proportion are in a constant ratio)" (Borowski y Borwein, 2002, p. 474). La comparación entre dos valores está en la base del razonamiento proporcional y del pensamiento variacional.

Aunque existe abundante y diversa literatura sobre el razonamiento proporcional a partir de Piaget e Inhelder (Obando et al., 2014), muchos estudios sobre el tema muestran un nivel bajo de este razonamiento específico en la población escolar incluidos niveles universitarios (Cañizares y Batanero, 1997; Silvestre y Ponte, 2011; Mohamed Maanan y Ortiz de Haro, 2012); o bien, indicarían que el éxito en la resolución de problemas proporcionales no implica necesariamente que los estudiantes hayan sido capaces de construir el significado de la idea de razón (ratio) (Fernández Verdú y Llinares Ciscar, 2012).

Este tipo de razonamiento se vincula con la probabilidad y con la linealidad. Con la primera el vínculo es matemático y operacional, mientras que con la linealidad es una relación conceptual y epistemológica: el análisis de estos conceptos en los libros de texto muestra que ambos conceptos, proporción y linealidad, tienen un cierto paralelismo, funcional y no estructural, con los procesos cognitivos de los estudiantes, en aspectos precientíficos (Acosta et al., 2010). Acosta define la noción de linealidad como antecedente de la proporcionalidad, que subyace en la idea germinal de 'ratio mutabilitas constant' de la que "se desprenden definiciones, teoremas y teorías; $y$ 
su acervo conceptual recae en la definición de transformación lineal" (p.20). Ambas son nociones que han evolucionado en la historia en base a necesidades cotidianas, creando un cuerpo teórico formal, aspecto poco o nada analizado en la didáctica. Extraemos y destacamos dos conclusiones de su trabajo a considerar:

- "La enseñanza temprana de la razón (ratio) y la proporción debe iniciar en aspectos cualitativos empleando esquemas $y$ representaciones que allanen el desarrollo de patrones de percepción, como respaldo a los procesos de cuantificación que activan el pensamiento proporcional.

En el movimiento rectilíneo uniforme, el referente de lo lineal es la velocidad, la cual se puede considerar como ratio mutabilitas constant. Si se toma en cuenta la expresión conocida (de la velocidad constante) como $x=x 0+v t$, es posible identificarla a su vez como una función lineal. Circunstancia que no se explicita en la didáctica, por lo que es importante incluir representaciones analíticas, numéricas, gráficas y contextuales."

(Acosta, 2011, p.199)

Referimos el trabajo de Acosta en cuanto que relaciona dos aspectos citados en el nuestro, la percepción y la proporcionalidad, aunque nuestra referencia a los aspectos perceptivos en la consideración del pensamiento proporcional no es matemática, o si acaso, la planteamos como noción protomatemática (Chevallard, 1991). Estas nociones se entienden como aquellas propiedades que utilizamos en la práctica cotidiana para resolver ciertos problemas, pero de manera tal que la noción misma no es reconocida de forma explícita como objeto de estudio, aunque es reconocible como parte implícita del pensamiento matemático.

La variable de velocidad no se aborda en este trabajo, pero a nuestro parecer, esta variable se muestra en el desarrollo del gesto gráfico dirigido a la educación de la escritura. Para la psicología cognitiva no está claro si el sistema de codificación háptico construye el mismo tipo de representaciones mentales sobre la estructura de los objetos que las encontradas en la investigación sobre percepción y memoria visual, o si por el contrario el sistema háptico dispone de unos sistemas representacionales propios: 
"Me gustaría hacer hincapié en la importancia de extender los resultados actuales con el sistema háptico, que es mucho menos investigado. Estudios hápticos, así como los estudios intermodales (visuales y táctiles), teorizan en el ámbito de la representación mental de los objetos percibidos visualmente y hápticamente, y contribuirían a una mejor comprensión de la unidad y/o la diversidad de los sistemas perceptivos así como los mecanismos de representación subyacentes. Un objetivo importante de esta investigación es estudiar los efectos de diferentes estrategias de codificación en el rendimiento en tareas de memoria háptica implícitas y explícitas como una manera de caracterizar mejor las propiedades y características especiales de la percepción táctil activa."

(Ballesteros, 2014, p. 13).

Los aspectos cognitivos involucrados en la motricidad fina visomanual tienen como resultado gráfico la línea, elemento básico de la gramática visual tanto en la escritura como en la representación gráfica. La forma así entendida desde su trazo, en la representación gráfica matemática conecta con las nociones de linealidad y dependencia lineal (paralelismo) desde edades tempranas y se va a reflejar en la representación de la forma de los objetos, las fuerzas (vectores) y el movimiento (trayectorias).

Desde la perspectiva del pensamiento variacional, los fenómenos naturales tienen un comportamiento que siempre los lleva a transitar al menos una vez por lo que suele llamarse promedio, (pro y medieu) como un valor intermedio entre dos o más valores de aquello que varía (Acosta et al., 2013). La mejor muestra de ello es el uso de la media aritmética o geométrica, en la base del cálculo diferencial. El hombre ha usado el promedio de una manera intuitiva antes de calcularlo, hasta que Arquímedes lo tomó como un elemento epistemológico fundamental en la construcción de su conocimiento para el cálculo del centro de gravedad, que es una forma de promedio (Parra Salazar, 2008).

Este centro de gravedad permite establecer tanto el plano vertical de equilibrio corporal (promedio de gravedad) como el plano de visión (promedio visual). Tanto es así que nuestro cráneo establece la línea visual como la división horizontal media del esqueleto de la cabeza, y la columna vertebral como la división vertical media del 
esqueleto del cuerpo. La configuración espacial, a pesar del movimiento de la mirada, siempre va a estar sujeta y referida a la situación ósea de nuestro cuerpo en el espacio.

Si nuestra constitución corporal responde a leyes físicas de gravedad y movimiento, ello nos permite conjeturar que las leyes visuales como el equilibrio y la constancia perceptual, respondan también a las mismas leyes. Y si así fuera, la representación de las formas y el espacio responderían a las mismas leyes en la forma protomatemática de la simetría de lineas y ángulos; considerando la definición del término simetría ('sym metron', con medida o medida conjunta), como la referencia a la (justa) proporción y la correspondencia regular (que no siempre es de igualdad) entre las partes, y con el todo que integran (Martín et al., 2003). Esta consideración bastante confusa en los conceptos de simetría y proporción conducen a trabajos que concluyen que la concepción de la simetría en estudiantes es un obstáculo epistemológico para el aprendizaje de los propios conceptos geométricos (Bohorquez et al, 2009), y tal vez un obstáculo tambien para entender otros conceptos visuales relacionados con aspectos y habilidades del propio aprendizaje.

\section{5.- Anisotropía visual y pensamiento .}

Habitualmente utilizamos términos visuales para definir otros procesos: 'como pueden ver...', 'ver las ventajas o el peligro en algo', 'no me veo' o 'no lo veo'... Para la ciencia óptica, la visión es un proceso concreto que supone que el mapa visual que se forma en la retina es una representación punto a punto del campo visual. En función del fotorreceptor sobre el que se forma la imagen, el sistema visual asocia a cada punto del campo visual una dirección espacial concreta según leyes de la óptica geométrica. Este fenómeno se denomina signo local, uno en cada ojo, que el sistema visual unirá posteriormente para proporcionar una única percepción o visión binocular.

El sistema de referencia tridimensional del espacio tiene tres ejes: transversal $(x)$, vertical $(y)$ y sagital $(z)$ que representan lo que 
comunmente entendemos como altura, anchura y longitud de los objetos. Este sistema de ejes tiene como origen de coordenadas el centro de proyección del ojo que, en función de los autores, puede ser el punto nodal del ojo o el centro pupilar.

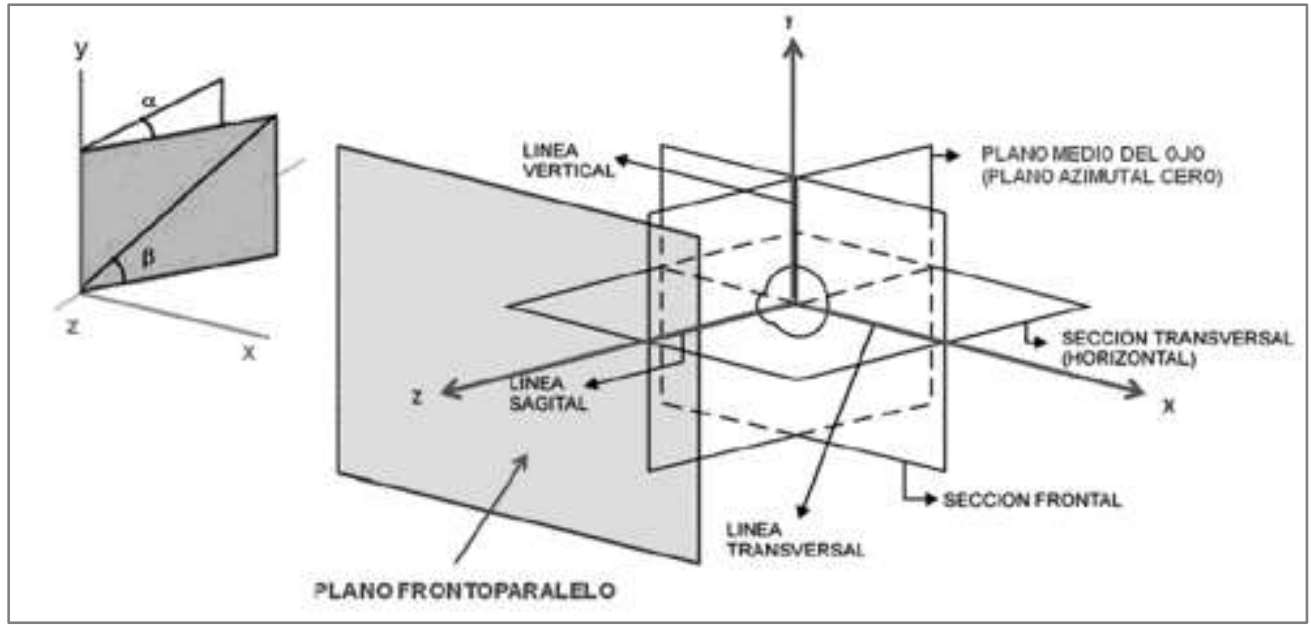

Fig. 99: Plano frontal (frontoparalelo) de visión (Torrents Gómez, 2011)

Para entender la visión frontal (fig. 99) podemos imaginar cualquier plano (azimutal) que contiene el eje vertical. El plano azimutal cero es el que contiene el eje visual en posición primaria de mirada: la posición del ojo cuando la línea de mirada es perpendicular al plano frontal de la cara, estando ambos meridianos verticales de las córneas paralelos al plano medio de la cabeza.

En la figura siguiente podemos identificar los tres planos: El plano medio de la visión es el azimutal cero $(\mathrm{YZ})$. El plano de posición frontal $(X Y)$ y el plano de horizonte $(X Z)$. El plano frontal y el de visión son los planos de referencia que nos proporcionan ángulos azimutales $(\alpha)$ y ángulos de elevación ( $\beta$ ) con el plano transversal (XZ), para situar cualquier punto $(\mathrm{P})$ del espacio, que se traduce en dos puntos ( $P_{1}$ y $P_{2}$ ), reflejados o formados en la retina de cada ojo (fig. 100). 

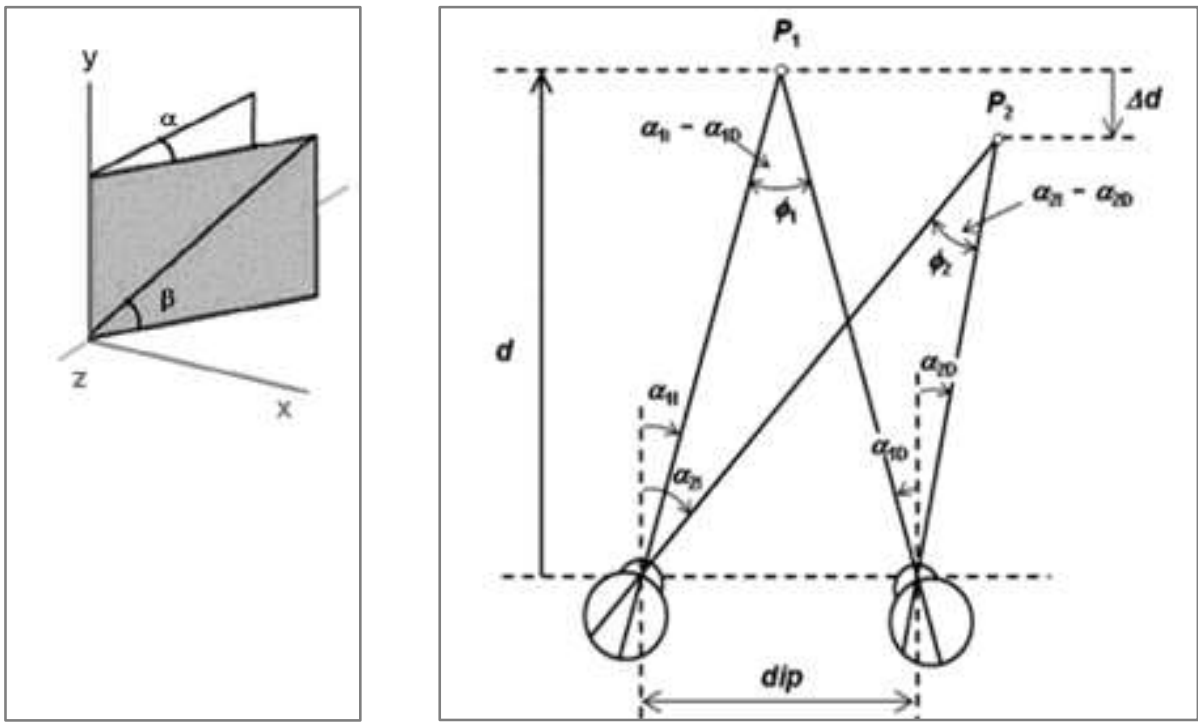

Fig. 100: Disparidad binocular horizontal (DBH) entre dos puntos P1 y P2

(dip es la distancia interpupilar)

Como la retina es bidimensional, la disparidad binocular tiene dos componentes independientes: horizontal y vertical. El sistema visual tolera una mayor disparidad horizontal que vertical, debido a la distancia interpupilar, estando la disparidad binocular horizontal (DBH) relacionada con la sensación de profundidad: el estereoscopio (Wheatstone, 1838) define la percepción de distancias relativas en profundidad entre objetos basada en la DBH. La agudeza visual estereoscópica (AVE) es la mínima disparidad binocular que da lugar a una sensación de profundidad, es decir, el mínimo umbral de discriminación de profundidad expresado angularmente, entre 2 y 6 segundos de arco (Torrents Gómez, 2011).

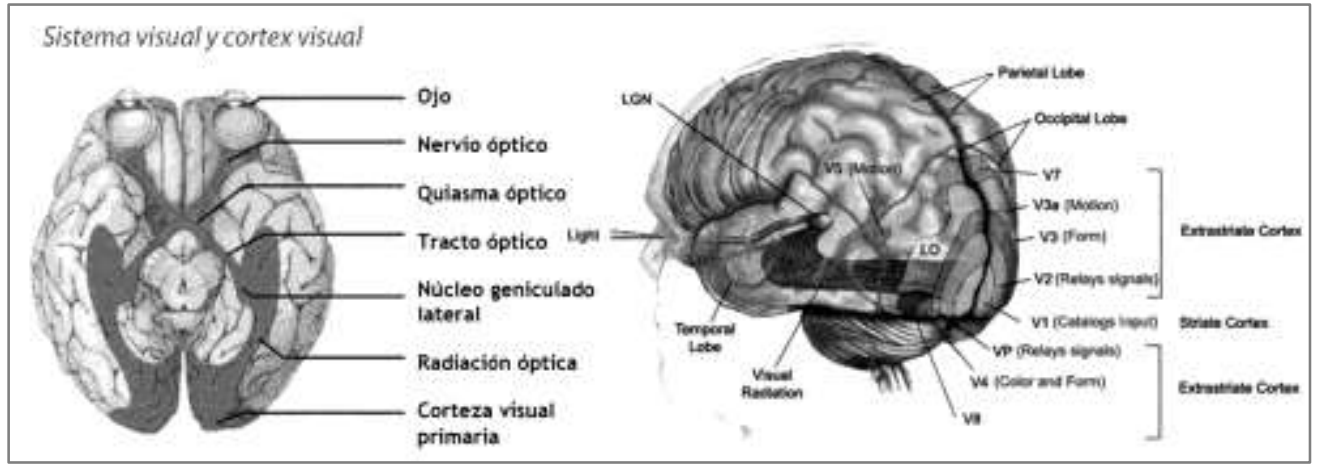

Fig. 101: Sistema visual (Torrents Gómez, 2011, p. 15).

Hemos visto que la corteza visual primaria descompone el mundo visual por varias vías, en segmentos de líneas de varias 
orientaciones, lo que supone un paso inicial para el análisis de la forma y del movimiento. Asimismo, combina la información de ambos ojos (neuronas binoculares) y realiza el primer paso del análisis cromático (fig. 101).

Las distancias en el espacio físico son métricas constantes con independencia de donde se sitúe un objeto. Sin embargo, el espacio visual no presenta la misma métrica, por lo que una misma distancia o tamaño puede ser sobreestimado o subestimado en función de la posición de los objetos. Mientras que el plano frontoparalelo es euclidiano o plano, los demas planos horizontales son hiperbólicos y muestran cierta curvatura (Indow y Watanabe, 1988). Esto revela la existencia de una anisotropía en el espacio visual (variaciones según la dirección), por lo que resulta más facil extrapolar los resultados obtenidos sobre el plano frontoparalelo bidimensional plano al espacio tridimensional hiperbólico (fig. 102).

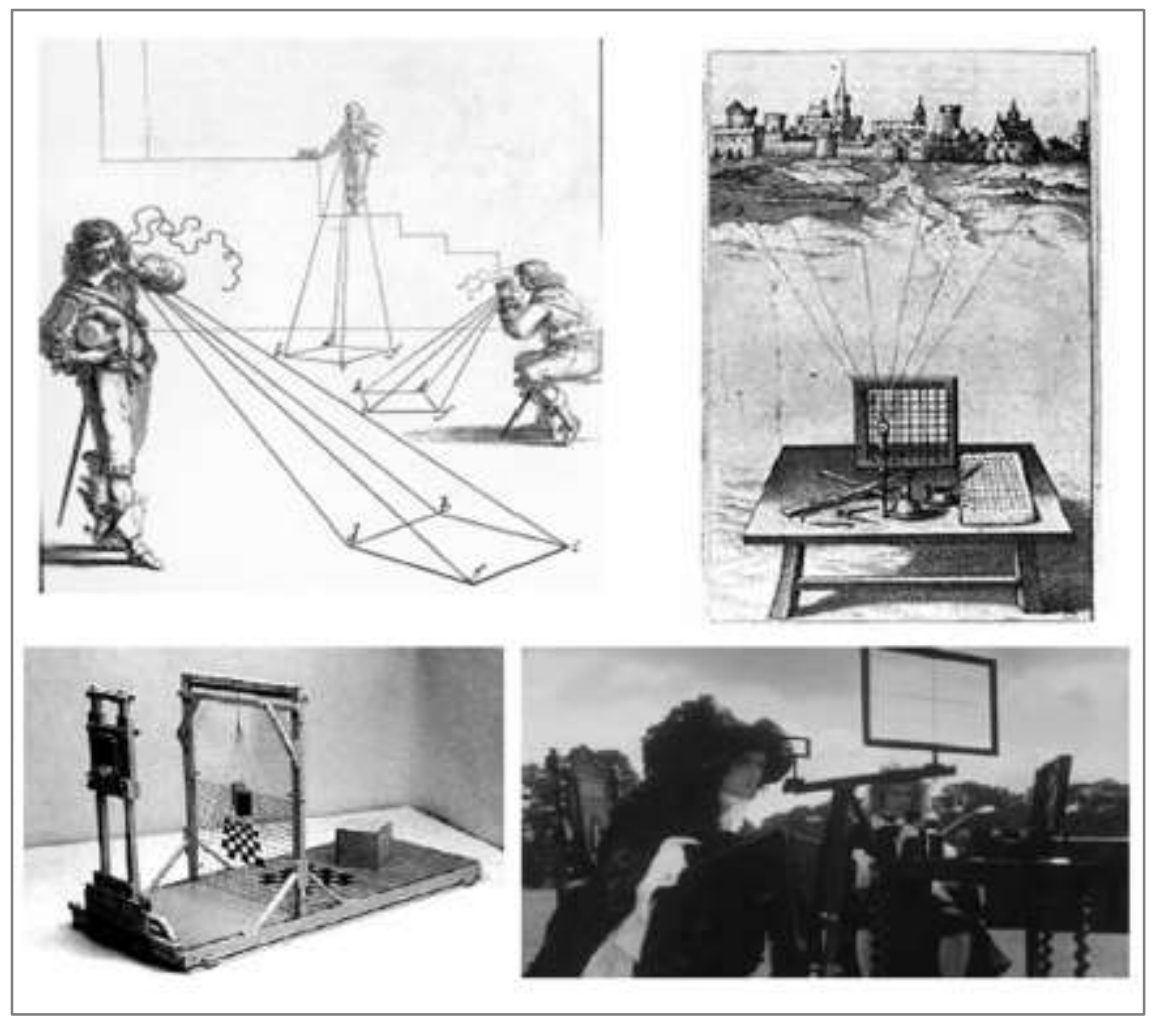

Fig. 102: Pirámide visual e intersector de Alberti (Grabado de Abraham Bosse, 1648) Perpectógrafo y fotograma de 'El contrato del dibujante' de P. Greenway, 1982 (Martí Ferrer, 2009) 
Ahora bien, la característica métrica exclusiva del plano frontal condiciona, a nuestro parecer en exceso, la falta de consideración de los demás planos, ya que podemos discriminar métricamente los ángulos y calcular visualmente las magnitudes. En este sentido, junto con los ejes de referencia asumidos, el cálculo y la proporcionalidad de magnitudes y ángulos visuales, consideramos que tiene un papel fundamental en el razonamiento espacial, cualquiera que sea el sistema de perspectiva visual adoptado.

Sin embargo, el estudio académico de estos aspectos no parece establecer relación con la experiencia física de las personas: "La frontera entre lo que se deja a la responsabilidad del estudiante y lo que es apoyado por la enseñanza de los ángulos no parece adecuadamente situado con respecto al espacio y la geometría" (Berthelot y Salin, 1994b, p.69). Aunque podamos pensar que el interés espacial no estaría necesariamente ligado a un interés geométrico, sin embargo, el uso de contextos y entornos diferentes, el análisis de las diferentes experiencias espaciales, van a permitir el progreso en la construcción del concepto de ángulo (Munier et al., 2006).

La construcción geométrica y la formación de conceptos cartesianos requieren sin duda más pasos de los necesarios para determinar una inclinación angular o una relación de proporción básica entre dos segmentos o líneas, pero resulta obvio que esta percepción o concepción más básica es fundamental para el desarrollo de otros conceptos avanzados.

La percepción de los ejes cartesianos en la experiencia vital y el pensamiento tiene un importante componente intuitivo, es decir, apreciamos la verticalidad y horizontalidad en el espacio visual sin necesidad de un aprendizaje. Sin embargo, las aplicaciones de estos ejes en el razonamiento espacial y en la representación gráfica con diferentes intenciones (gráficos de datos, mapas, o modelos) sí requieren de un aprendizaje. $Y$ este aprendizaje hace referencia a la experiencia física, a partir de la cual construimos nuestras cogniciones. Considerar la percepción de los ejes de referencia espacial optimiza el proceso de enseñanza aprendizaje y la construcción del pensamiento tanto científico como artístico, sin requerir su diferenciación. 


\section{6.- Planteamiento del problema}

Pensar visualmente además de comprender la acción física de la visión y la cognitiva del reconocimiento y la orientación, incluye aspectos cognitivos de la propia percepción y razonamiento del cálculo proporcional de tamaños, distancias e inclinaciones, adoptar diferentes puntos de vista, analizar y relacionar formas e imaginar sus cambios.

Definimos el pensamiento visual en términos de competencia, como la capacidad de identificar, comprender y practicar la información visual y llegar a juicios bien fundamentados sobre el papel que desempeñan los códigos visuales, conforme sea necesario para la vida privada, laboral y social como ciudadano constructivo, comprometido y pensante.

Las aptitudes visoespaciales implican la capacidad de plantear y resolver problemas matemáticos en una variedad de contextos, al igual que la inclinación a hacerlo, lo que a menudo depende de características personales como la confianza en uno mismo y la curiosidad. Estos aspectos responden a la definición amplia de aptitud, que se emplea en PISA, como el enfoque explícito de un cuerpo de conocimientos y habilidades que se requieren para desempeñarse eficazmente en la vida cotidiana (OCDE, 2002).

Situamos el trabajo realizado como evaluación en el ámbito de la evaluación de valor agregado, entendido como el aprovechamiento de las materias académicas en las habilidades para la vida (Aiken, 2003), entre las que situamos la lectura de imágenes, la habilidad de representación gráfica y del pensamiento variacional (Correa Pabón, 2010).

Un constructo psicológico como el pensamiento visual es un concepto hipotético para explicar el comportamiento humano, que incluye atributos o cualidades que pueden ser objeto de evaluación, como la habilidad espacial y la interpretación y creación de imágenes. Concebido teóricamente, un constructo no puede ser observado directamente, por lo que se debe tener una forma de inferir su 
existencia. En este sentido, los reactivos realizan la función de mostrar los constructos. Un reactivo es entonces un descriptor, un formato para que las personas ejecuten un comportamiento del que se puede inferir el grado en el que un constructo existe (Osterlind, 1998).

Para transformar su definición en una evaluación del pensamiento visual, identificamos tres aspectos generales para indicar los reactivos y descriptores de las habilidades 0 aptitudes que pretendemos valorar. Los aspectos son los siguientes:

\section{Procesos:}

Los reactivos están estructurados alrededor de diferentes tipos de aptitudes necesarias para el pensamiento visual. Dichas aptitudes se catalogan en tres conjuntos de competencia: el primer grupo, visualización estática, se compone de planteamientos sencillos 0 definiciones del espacio visual real y representacional; el segundo, relaciones espaciales o visualización dinámica, requiere de la reunión de procedimientos para resolver problemas sencillos de la forma y la posición en el espacio; y el tercer conjunto, proporción, se basa en procesos de razonamiento y generalización y requiere practicar análisis proporcional, que identifican relaciones de dos dimensiones en imágenes sencillas.

\section{Contenido:}

Se organiza el contenido en relación con las dimensiones analizadas, haciendo énfasis sobre temas como la referencia espacial, la medida, los ángulos, la forma, el cambio y las relaciones.

\section{Contexto:}

Un aspecto importante de la aptitud visoespacial consiste en practicar y emplear sus dimensiones en una variedad de situaciones. En nuestro caso, hemos utilizado la lectura de una imagen como aplicación de las variables analizadas. El concepto de competencia visual sugiere la capacidad de aplicar los conocimientos y las aptitudes visoespaciales de manera funcional, más que sólo dominarlas en el contexto de pruebas específicas o un plan de estudios. En este sentido, hemos optado por una prueba de interpretación visual, que aglutina diversos aspectos que normalmente se miden de manera aislada. Aunque igualmente un tipo de prueba manual, de representación gráfica, hubiera sido viable, creemos que la 
sospecha de que fuera evaluada la capacidad gráfica habría introducido una variable extraña.

Esta investigación se plantea a partir del modelo aptitudinal del doble factor de visualización de Yela (1967), de la percepción de la proporción (Carmiol, 2013) y del modelo de lectura de imágenes (Villafañe, 2006; Aparici y Garcia Matilla, 1992; Aguaded y Perez, 1995). Por ello, los ítems de nuestro cuestionario se elaboran teniendo en cuenta los componentes del factor espacial estático y dinámico, del pensamiento proporcional y del análisis estructural 0 de la composición de una imagen.

\section{2.-Objetivos e hipótesis.}

Planteamos una delimitación de los factores integrantes del constructo del pensamiento visual en términos de competencia 0 habilidad. Esta delimitación se corresponde con las dimensiones:

- Visualización estática: referencias visuales y capacidad de orientación en el espacio real y representacional (topología y perspectiva).

- Visualización dinámica: capacidad de imaginar mentalmente cambios en las formas y en sus relaciones con el espacio.

- Pensamiento proporcional: capacidad de discriminar y comparar la medida en las diferentes dimensiones espaciales.

Los dos tipos de visualización se corresponden con los factores principales establecidos por Yela (1967): espacial estático (S1) y espacial dinámico (S2). La proporción se analiza a través del cálculo de las proporciones cuadrada y doble en los ejes vertical y horizontal, utilizando imágenes del Test de Percepción de la Proporción de Carmiol (2013).

Proponemos una lectura objetiva de imagen como el factor de aplicación de estas dimensiones. Este tipo de lectura se refiere a aspectos compositivos de la imagen y a la posición del espectador. Se pretende detectar no una deficiencia, sino el nivel de la habilidad visual, para contribuir a definir las características de este tipo de 
habilidades cognitivas. Desde todos los enfoques analizados, tanto la percepción y visualización, como la proporción, constituyen destrezas indispensables para pensar visualmente. Aunque es dificil establecer el grado de equivalencia que existe entre la habilidad perceptual y la habilidad manual, creemos que es más fácil hacerlo entre la habilidad perceptiva y la lectura visual, situadas ambas en el plano cognitivo.

Creemos que tanto la percepción visual de las formas y el espacio como su manipulación visual tienen una relación directa con las referencias espaciales del observador: su posición, teórica o real, explican los cambios estructurales de la imagen; y con el esqueleto estructural y proporción de la figura observada (Arnheim, 1998; Villafañe, 2006).

A su vez, los trabajos de Michelon y Zacks (2006) sugieren que la toma de perspectiva abarca, al menos, dos procesos cognitivos cualitativamente diferentes: uno que actualiza la perspectiva imaginando la posición (punto de vista) del espectador, y otro que traza líneas de visión en relación al objeto. Ambos procesos sugieren que diferentes sistemas superpuestos a nivel neuronal se dedican a diferentes transformaciones de imagen (Zacks et al., 2003). Partimos, por tanto, de que la percepción de los cambios en la constancia y la proporción de las formas, así como el sistema de perspectiva influyen directamente en la formación de los modelos mentales de representación y, por tanto, en la visualización y la forma de abordar lo que se define como relaciones espaciales a partir del trabajo de Yela (1967): topológicas o estáticas, de orientación, y dinámicas, de manipulación mental.

Por tanto los objetivos que nos proponemos son los siguientes:

- Delimitar los factores integrantes del constructo del pensamiento visual en términos de competencia o habilidad.

- Analizar la competencia o habilidad de los sujetos participantes en relación a la visualización estática, dinámica y proporcional tal y como lo hemos descrito anteriormente.

- Detectar el nivel de habilidad visual, de los integrantes de la muestra, para contribuir a definir las características de este tipo de habilidades cognitivas en relación con la expresión gráfica y el trabajo con imágenes en el ámbito profesional docente. 
Nos planteamos tres hipótesis principales:

- Los estudiantes de los grados de educación (infantil y primaria) apenas establecen relacion, o ésta es debil, entre sus propias referencias espaciales (esquema corporal) y el campo visual.

- Los futuros docentes de educación básica encuentran dificultades para vincular su eje de referencias espaciales en los sistemas de representación mental y gráfica, del que se deducen los cálculos de distancias, ángulos y dimensiones.

- El pensamiento proporcional de los futuros docentes de educación básica muestra deficits en el análisis visual de los objetos y espacios.

Consideramos que este tipo de dificultades no aparecen reflejadas en las pruebas de aptitud visual y espacial estandarizadas, ya que, por lo general, no se asocia la referencia física u óptica de la propia experiencia visual con la construcción mental del espacio y las formas. Por ello alternamos en la prueba algunos ítems de elaboración propia con otros adaptados de pruebas estandarizadas. No es un objetivo de este trabajo la validación de un instrumento que pueda medir los aspectos del pensamiento visual, pero sí es un objetivo el de relacionarlos y estructurarlos y, en este sentido, el planteamiento que proponemos puede servir como una guía en esta dirección para futuros trabajos.

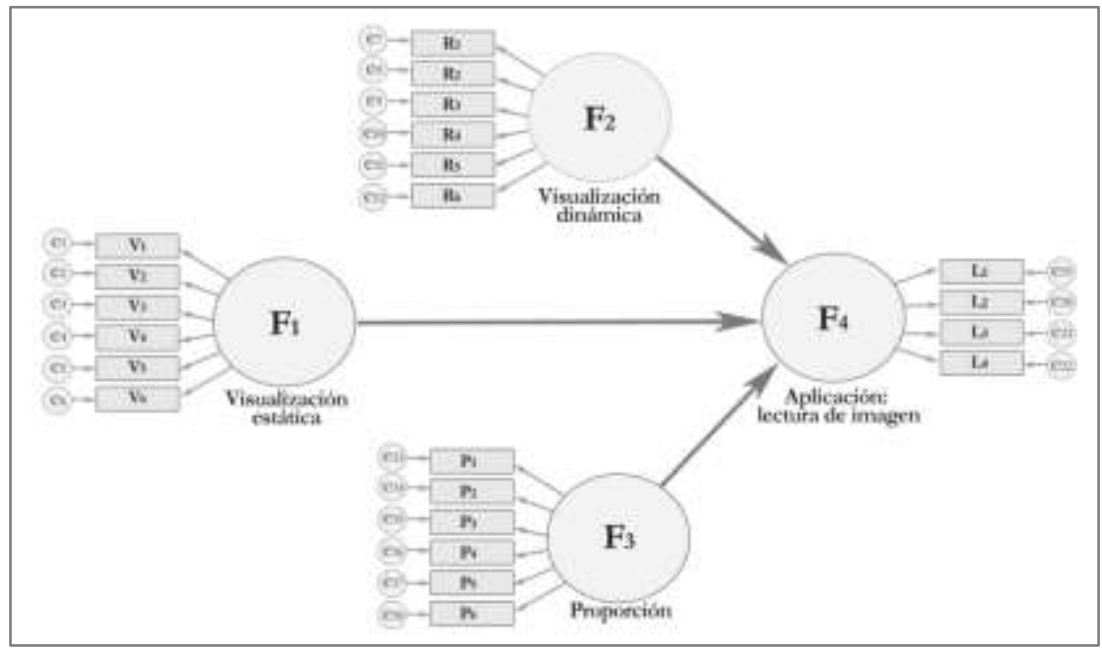

Fig. 103: Modelo teórico factorial planteado. 
En un nivel operativo, planteamos la hipótesis de que a mayor habilidad visual, mejora el proceso de lectura y construcción de imágenes.

Planteamos un modelo teórico en el que la visualización estática (V), el razonamiento espacial (R) del factor de visualización dinámico, y el razonamiento proporcional $(\mathrm{P})$; van a influir en el proceso de lectura e interpretación de imágenes (L) (fig. 103).

Consideramos que estas dimensiones o factores afectan al proceso de la lectura e interpretación de imágenes en sus aspectos de composición estructural (formato y distribución de líneas de fuerza) y espacial (posición del observador). En la medida que la representación mental de las imágenes está influenciada por la visualización y la proporción, de igual forma estos factores van a incidir en la construcción de materiales visuales (gráficas, esquemas, infografías y modelos) que son habituales en el entorno docente más allá del análisis de la habilidad gráfica.

\section{3.- Procedimiento}

El planteamiento de una valoración o evaluación a cierta escala, implica un procedimiento automatizado que sea objetivo, válido y confiable. No obstante, los trabajos consultados al respecto (Yela, 1967; Arias, 2008; Fernández Pulido, 2008; Carmiol, 2013; etc.) nos proporcionan la impresión de que el rigor aplicado en la medida en los análisis de datos, en este caso de pruebas psicométricas, no está reñido con la flexibilidad y relatividad en la extracción de conclusiones a partir de los datos analizados. Es más, podríamos decir que la reflexión humilde como resultado de estos análisis es prueba de los principios de rigor y honestidad aplicados.

El procedimiento que hemos utilizado se basa en la aplicación de la Escala de Valoración del Pensamiento Visual (EVPV), realizada ad hoc, con preguntas de opción múltiple, que ofrece ventajas en relación a la objetividad y el nivel de dificultad, aunque plantea inconvenientes. En este caso, la limitación para valorar ciertos niveles 
de complejidad de las taxonomías del conocimiento y la distancia que guardan con el uso auténtico del conocimiento en condiciones donde se aplica (Tirado et al., 1997). De igual forma, las desviaciones que se introducen con las respuestas correctas dadas por azar o la facilidad de copiar respuestas reduce la fiabilidad de la prueba. No obstante, confiamos extraer algunas conclusiones a modo de consideraciones sobre el aprovechamiento o el nivel de desempeño de las habilidades espaciales en la competencia visual.

Se utiliza un criterio de dificultad que tiende a la formulación de los items con un nivel alto de facilidad de acuerdo a los criterios de trabajos sobre visualización espacial (fig. 104):

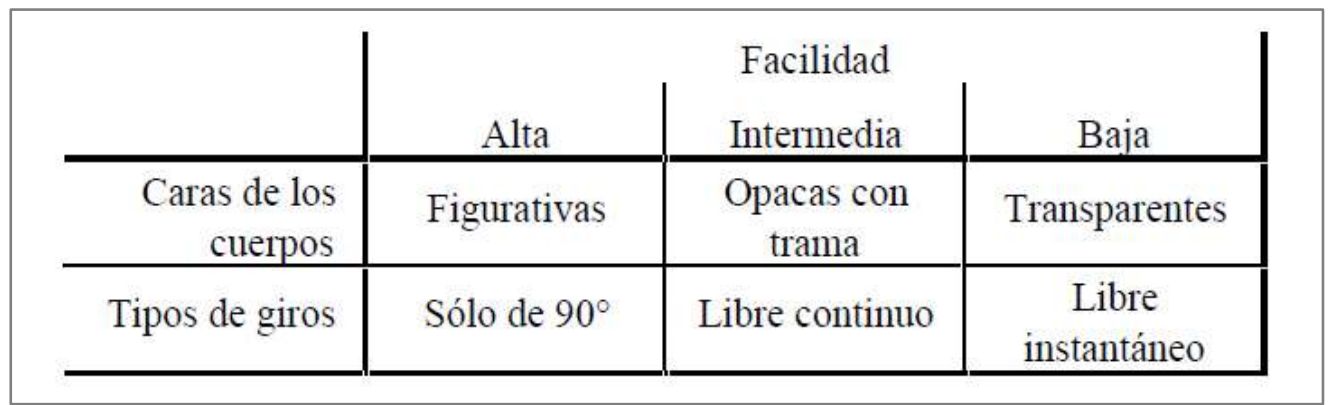

Fig. 104: Nivel de dificultad de los objetos y giros (Gutierrez, 1991)

Creemos que las dimensiones establecidas de visualización estática y dinámica y, en menor medida la proporción, son constantes en los trabajos relativos a la inteligencia espacial, y su aplicación en la lectura de imágenes cubre el aspecto semiótico del análisis visual de la representación. El análisis de estos factores parte de la existencia de una correlación, al menos conceptual, entre las variables, de manera que nos permita trabajar con una estructura más simple para explicar los datos obtenidos.

Para el tratamiento estadístico de los resultados del cuestionario se han utilizado los paquetes estadísticos Statgraphics Centurion y SPSS Statistics, los programas para análisis factorial confirmatorio LISREL 8.30 (Jöreskog y Sörbom) y de análisis TRI, con expresión de la frecuencia y porcentajes de respuesta y el índice de discriminación de cada ítem que admite una respuesta correcta. 


\subsection{1.- Descripción del cuestionario.}

La Escala de Valoración del Pensamiento Visual (Anexo 01) tiene un total de 35 ítems y se divide en cinco partes:

- La primera responde al factor de visualización estática: los ítems 1 a 5 plantean cuestiones relacionadas con los ejes de referencia espacial de posición y orientación (horizontalvertical), y los ítems 12 y 17, dos cuestiones de la percepción de ángulos.

- La segunda parte, los ítems 8 a 11, 15 y 16, analizan las relaciones espaciales (constancia, giro, desarrollo de superficies y doblado de papel) del factor de visualización dinámica.

- La tercera parte se refiere al concepto de proporción (18 a 23) en la relación horizontal y vertical del formato.

- La cuarta es una aplicación de los planteamientos anteriores en la lectura de una imagen (27 a 30).

- Y la última parte la forman cinco ítems en escala de Likert (31 a 35), de valoración personal sobre el constructo del pensamiento visual en la educación: su importancia en la formación docente, grado de satisfacción y su relación con el talento artístico.

A su vez y a lo largo del cuestionario, se incluyen tres ítems de patrones visuales $(7,13$ y 26) que pretenden identificar una tendencia cognitiva de preferencia visual en el reconocimiento de las imágenes presentadas (Paivio, 1990).

Se ha pretendido no repetir ítems y buscar la brevedad del cuestionario para que la atención se mantenga todo lo posible de forma sostenida durante la realización de la prueba, y reducir al máximo la ausencia de respuesta.

Algunos de los ítems del cuestionario se construyen siguiendo los propuestos en test estandarizados de aptitud espacial y de percepción visual (tabla 04). Su sistema de respuesta se adaptó a un modelo de respuesta nominal aleatoria en su administración, mientras que el modelo es ordinal y graduado en el grupo de ítems de valoración del constructo de pensamiento visual (31 a 35). 


\begin{tabular}{|c|c|c|c|}
\hline $\begin{array}{l}\text { No de } \\
\text { ítem }\end{array}$ & $\begin{array}{l}\text { Tipo de } \\
\text { prueba }\end{array}$ & Respuestas planteadas & $\begin{array}{l}\text { Test de } \\
\text { referencia }\end{array}$ \\
\hline Ítem 9 & $\begin{array}{l}\text { Desarrollo } \\
\text { de } \\
\text { superficies }\end{array}$ & & $\begin{array}{c}\text { Test informatizado } \\
\text { de visualización VZ } \\
\text { (Prieto et al., } \\
\text { 1993) }\end{array}$ \\
\hline Ítem 10 & $\begin{array}{l}\text { Doblado de } \\
\text { papel }\end{array}$ & & $\begin{array}{c}\text { Paper Folding Test } \\
\text { (Ekstrom, French \& } \\
\text { Harman, 1976) }\end{array}$ \\
\hline Ítem 11 & $\begin{array}{l}\text { Percepción } \\
\text { visual }\end{array}$ & & $\begin{array}{l}\text { Test of visual } \\
\text { perceptual skills } \\
\text { (TVPS-3). } \\
\text { (Martin,2006) }\end{array}$ \\
\hline Ítem 15 & $\begin{array}{c}\text { Rotación } \\
\text { mental }\end{array}$ & & $\begin{array}{l}\text { Mental Rotation } \\
\text { Test MRT-A } \\
\text { (Vandenberg \& } \\
\text { Kuse, 1978) }\end{array}$ \\
\hline Ítem 12 & \multirow{2}{*}{$\begin{array}{l}\text { Discriminac } \\
\text { ión de } \\
\text { ángulos }\end{array}$} & & \multirow{2}{*}{$\begin{array}{c}\text { El Test del Dibujo } \\
\text { del Reloj (TDR) } \\
\text { (Battersby, } \\
\text { Bender, Pollack y } \\
\text { Kahn, 1956) }\end{array}$} \\
\hline Ítem 17 & & & \\
\hline Ítem 20 & \multirow{3}{*}{$\begin{array}{l}\text { Percepción } \\
\text { de la } \\
\text { proporción }\end{array}$} & & \multirow{3}{*}{$\begin{array}{c}\text { Test de Percepción } \\
\text { de la Proporción } \\
\text { PPT } \\
\text { (Carmiol, 2013) }\end{array}$} \\
\hline Ítem 21 & & & \\
\hline Ítem 22 & & & \\
\hline Ítem 7 & \multirow{3}{*}{$\begin{array}{l}\text { Síntesis } \\
\text { mental de } \\
\text { patrones } \\
\text { visuales. }\end{array}$} & \multirow{3}{*}{ is } & \multirow{3}{*}{$\begin{array}{c}\text { Patrones visuales } \\
\text { creativos } \\
\text { (Finke, 1990) }\end{array}$} \\
\hline Ítem 13 & & & \\
\hline Ítem 26 & & & \\
\hline
\end{tabular}

Tabla 04: Tests de referencia de los ítems propuestos.

\subsection{1.- Estudio piloto.}

En un trabajo previo, en 2011, recogimos información a través de un cuestionario de 14 preguntas en torno al nivel de conocimiento práctico de nociones visuales de proporción y la mayor o menor conciencia de los ejes de referencia espacial en una muestra de 190 estudiantes de magisterio. Queríamos saber de su conocimiento teórico del número racional o geométrico y como se relaciona éste con la destreza visual en el análisis de las formas y el espacio. Comprobamos la dificultad de tratar con el concepto geométrico del número racional. En este trabajo vinculamos directamente la 
percepción visual con el pensamiento proporcional, reduciendo 0 eliminando los contenidos más teóricos.

Considerando que el análisis que hacemos de los objetos y el espacio que nos rodea va a condicionar la capacidad de representación mental y gráfica, la manera de valorarlo planteaba la duda principal de construir un cuestionario netamente visual o textual, a traves de preguntas directas. Se opta por una solución intermedia: preguntas simples y directas con apoyo visual repartidas en ítems con cuatro opciones de respuesta.

Se ha evitado la complejidad en la presentación formal de las imágenes, planteando imágenes simples para evitar que la atención se disperse por el exceso de estímulos visuales. El planteamiento de los ítems visuales se basa en que los mecanismos que habilitan la percepción de la forma se consolidan en un canal de procesamiento visual que transporta la información acerca del contraste y los contornos del objeto (Arnheim, 1998). Estos se alternan con preguntas textuales simples de conocimiento sobre la propia percepción de las referencias espaciales, de la constancia de la forma y de la proporción.

A partir de la prueba citada, se elabora un cuestionario colectivo, la escala de valoración del pensamiento visual (EVPV), y se desarrolla un estudio piloto. Son abundantes los test diseñados para detectar principalmente problemas neuropsicológicos y de aprendizaje que identifican habilidades visuales y espaciales, pero sólo hemos encontrado uno que vincula estrechamente el análisis de la proporción con la percepción, el TPP, Test de Percepción de la Proporción (Carmiol, 2013). No hemos encontrado ninguno que vincule la percepción o la conciencia de las referencias espaciales con la representación mental y los sistemas de representación, y ninguno que relacione ambos aspectos con el proceso de lectura de imagen. Nos planteamos vincular este doble análisis del razonamiento espacial y proporcional para relacionarlo con los resultados de la lectura objetiva de una imagen. Aunque en la prueba inicial citada se plantearon preguntas narrativas en la interpretación de la imagen (en relación a la edad y actitud de la modelo), en el EVPV hemos optado por simplificar este aspecto y limitamos su lectura a aspectos relativos 
a la composición y el punto de vista del espectador en la observación de la imagen.

Se realiza una prueba piloto del cuestionario para determinar el nivel de comprensión de los ítems y las instrucciones de la prueba, así como la validez de contenido y de criterio. Aunque el tiempo o la velocidad de respuesta es habitual en las pruebas de percepción y de aptitud espacial, en esta prueba no se considera, ya que el planteamiento inicial del cuestionario no es el de evaluar la aptitud, sino el de valorar aspectos de competencia.

El estudio piloto se realiza con una muestra aleatoria de 60 estudiantes y profesores de diferentes cursos de educación. Estos profesores ejercieron de expertos en la medida que proporcionaron cierta validez de contenido o relevancia a los planteamientos de los ítems. La intención era realizar un análisis preliminar de cierta consistencia del instrumento y eliminar los ítems con varianza cero (ausencia de discriminación). Se estima la fiabilidad y validez de los ítems con el fin de poder hacer los correspondientes ajustes. Como consecuencia de estos análisis, cambian su redacción algunos ítems de la prueba piloto, y otros se eliminan y sustituyen por ítems utilizados en pruebas estandarizadas y adaptados a ésta (tabla 04). Los resultados del nuevo cuestionario se presentan aquí.

Algunos de los ítems se han mantenido tal como estaban planteados en el cuestionario inicial. En concreto los ítem 1(V1), 2(V2), 5(V3) y 23(P6), que analizan respectivamente las referencias visuales, el horizonte, el punto de posición y la proporción del rostro. Los datos de estos ítems en concreto se comportan como valores atípicos (outliers), y han registrado en todas las aplicaciones de la prueba un bajo nivel de saturación o escaso valor de discriminación, pero creemos que resultan altamente significativos en el análisis descriptivo univariable.

\subsection{3.- Descripción de la muestra}

Una población es un conjunto de elementos sobre los que se desea realizar una inferencia (Scheaffer et al., 2007). Los elementos 
en nuestro caso son las personas sobre las que se procura tomar una medición o realizar una evaluación. Esta población se corresponde con las personas cualificadas profesionalmente para ejercer la docencia en los niveles educativos de infantil y primaria, en el marco actual de los estudios europeos del Grado en Educación en la Universidad de Valladolid (UVa). El número total de estudiantes en las Facultades de Educación de esta universidad asciende a 1905 en el curso 2014-15 (Gabinete de Comunicación de la UVa, noviembre 2014). El total nacional de estudiantes del grado de Educación en el curso 2012-13 era de 105.373 (Secretaría General de Universidades del Ministerio de Educación, Cultura y Deporte). A partir de este marco se realiza un muestreo casual de conveniencia, que recoge una muestra del total de los últimos cursos del Grado del Campus de Valladolid, en condiciones de similitud a la población objetivo.

La tasa de no respuesta en la muestra es muy reducida: $<1,5 \%$ (entre 0 y 3 por ítem), con la única excepción del ítem 5 , donde se da un 14\%; 27 sujetos, que no responden a la cuestión de la situación del punto de fuga. Salvando esta excepción, en el análisis se opta por incluir este error de no respuesta como respuesta fallida. El análisis y lectura de la imagen no forma parte de las actividades rutinarias de los estudiantes y partimos del supuesto que no se profundiza en los niveles de interpretación visual. Asumimos la pequeña tasa de no respuesta dentro de la descripción de dificultades en la competencia visual.

La escala de valoración del pensamiento visual (EVPV) se ha administrado a una muestra de 193 personas, todos ellos estudiantes del cuarto curso del Grado de Educación, de las especialidades de Educación Infantil (64) y Primaria (129). La aplicación de la prueba se realiza por parte del autor del estudio en situaciones normales de las clases con la colaboración de los docentes de todos los grupos de cuarto curso del grado. Se aplica a lo largo del primer cuatrimestre lectivo, entre los meses de octubre y diciembre. Del total de los 193 cuestionarios, corresponden un $90,4 \%$ a mujeres y un $9,6 \%$ a hombres, mientras que seis personas no informan del género. A pesar de que la variable de género parece mostrar diferencias en el rendimiento visoespacial (Echavarri et al, 2007; Rubio, 2000), esta variable no resulta significativa en este estudio. 
El rango de edad oscila entre 21 y 56 años. La media de edad es de 24,2 . Un $3,1 \%$ de los sujetos (6) no informan de su edad (gráfico $01)$.

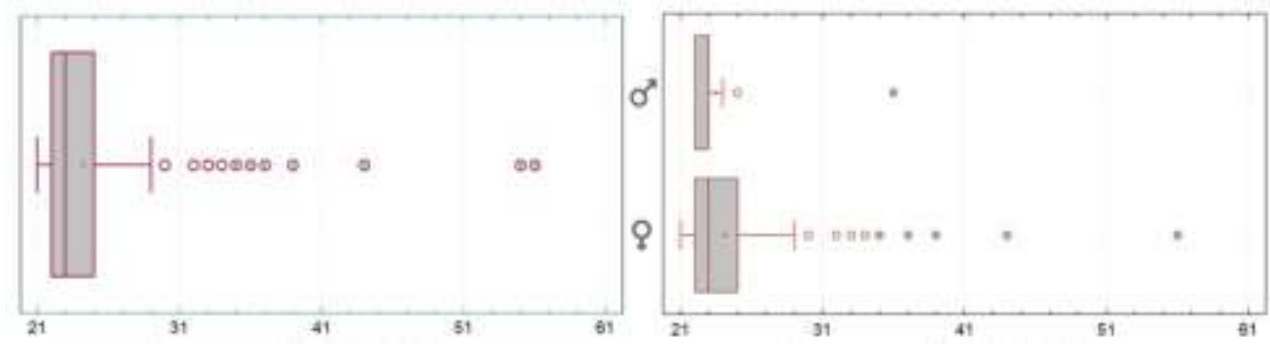

Gráfico 01: Concentración de la edad de la muestra total y diferenciada por sexo.

La muestra se obtiene en el curso 2014-2015 en la Facultad de Educación y Trabajo Social de la Universidad de Valladolid, afectando aproximadamente al $90 \%$ de los alumnos matriculados en todos los grupos del último curso. De los 64 estudiantes de la especialidad de Educación Infantil, 21 son alumnos de mención en Expresión, Comunicación Artística y Motricidad. De los 129 de educación Primaria, son 41 los alumnos con la mención en Lengua Extranjera.

\section{7.- Resultados}

Evaluar o valorar algo supone realizar un proceso objetivo en el que se recogen datos, se analizan y se interpretan para producir información o juicios: "When the cook tastes the soup, it is formative evaluation; when the dinner guest tastes the soup, it is summative evaluation." (Harvey, J. cit. en Cowan y George, 2004, p.1)

Las taxonomías elaboradas para evaluar habilidades 0 competencias de tipo cognitivo (Bloom, 1977; Anderson et al., 2001) resumen una serie de procesos mentales, de los que destacamos y vinculamos con el pensamiento visual los siguientes:

- Reconocer y recordar: percepción y memoria de trabajo.

- Elaborar y organizar perceptos y conceptos (comprender): analizar formas, signos y símbolos, datos, resultados gráficos y modelos.

- Indagar y resolver problemas: pensamiento crítico y creativo. 
- Crear: juntar elementos para formar un producto visual coherente y funcional.

La evaluación de estos aspectos cognitivos requiere del concepto factorial en la medida que no son variables observables. Los resultados que se muestran a continuación recogen un análisis descriptivo exploratorio de los ítems de respuesta correcta, seleccionados como reactivos, y agrupados por los factores 0 dimensiones citados (tabla 05). Los ítems de opinión son tratados en el apartado de valoración del constructo PV.

\begin{tabular}{|c|c|c|c|c|c|c|}
\hline Visualización estática & V1 & $V_{2}$ & V3 & 174 & $V 5$ & V6 \\
\hline Recuento & 193 & 193 & 193 & 193 & 193 & 193 \\
\hline Promedio & 0,92228 & 0,0829016 & 0,487047 & 0,476684 & 0,953368 & 0,26943 \\
\hline Varianza & 0,0720531 & 0,0764249 & 0,251133 & 0,250756 & 0,0446891 & 0,197863 \\
\hline Desviación Eständar & 0,268427 & 0,27645 & 0,501132 & 0,500755 & 0,211398 & 0,444818 \\
\hline \begin{tabular}{|l|} 
Coeficiente de Variación \\
\end{tabular} & $29,1047 \%$ & $333,468 \%$ & $102,892 \%$ & $105,05 \%$ & $22,1738 \%$ & $165,096 \%$ \\
\hline Curtosis & 8,19257 & 7,37347 & $-2,0183$ & $-2,01211$ & 16,9605 & $-0,912201$ \\
\hline Visualización dinámica & $R I$ & $R 2$ & $R 3$ & $R 4$ & $R 5$ & $R 6$ \\
\hline Recuento & 193 & 193 & 193 & 193 & 193 & 193 \\
\hline Promedio & 0,943005 & 0,823834 & 0,917098 & 0,803109 & 0,57513 & 0,673575 \\
\hline Varianza & 0,0540263 & 0,145887 & 0,0764249 & 0,158949 & 0,245628 & 0,221017 \\
\hline Desviación Estándar & 0,232436 & 0,381952 & 0,27645 & 0,398684 & 0,495609 & 0,470124 \\
\hline Coeficiente de Variación & $24,6484 \%$ & $46,3627 \%$ & $30,144 \%$ & $49,6425 \%$ & $86,1734 \%$ & $69,7954 \%$ \\
\hline Curtosis & 12,9704 & 0,945554 & 7,37347 & 0,364409 & $\mid-1,92622$ & $\mid-1,45848$ \\
\hline Proporción & $P 1$ & $P 2$ & $P 3$ & $P 4$ & P5 & P6 \\
\hline Recuento & 193 & 193 & 193 & 193 & 193 & 193 \\
\hline Promedio & 0,772021 & 0,595855 & 0,321244 & 0,196891 & 0,590674 & 0,165803 \\
\hline Varianza & 0,176921 & 0,242066 & 0,219182 & 0,158949 & 0,243038 & 0,139033 \\
\hline Desviación Estándar & 0,42062 & 0,492002 & 0,468169 & 0,398684 & 0,492988 & 0,372871 \\
\hline \begin{tabular}{|l|} 
Coeficiente de Variación \\
\end{tabular} & $54,483 \%$ & $82,5708 \%$ & $145,736 \%$ & $202,489 \%$ & $83,4621 \%$ & $224,888 \%$ \\
\hline \begin{tabular}{|l|} 
Curtosis \\
\end{tabular} & $-0,294994$ & $-1,8644$ & $-1,41939$ & 0,364409 & $-1,88144$ & 1,29422 \\
\hline Lectura & $L 1$ & $L 2$ & $\angle 3$ & $L 4$ & & \\
\hline Recuento & 193 & 193 & 193 & 193 & & \\
\hline Promedio & 0,61658 & 0,523316 & 0,243523 & 0,544041 & & \\
\hline Varianza & 0,23764 & 0,250756 & 0,185179 & 0,249352 & & \\
\hline Desviación Estándar & 0,487484 & 0,500755 & 0,430325 & 0,499352 & & \\
\hline Coeficiente de Variación & $79,0625 \%$ & $95,6888 \%$ & $176,708 \%$ & $91,7856 \%$ & & \\
\hline \begin{tabular}{|l} 
Curtosis \\
\end{tabular} & $-1,78503$ & $-2,01211$ & $-0,555047$ & $-1,98895$ & & \\
\hline
\end{tabular}

Tabla 05: Resumen estadístico de las dimensiones.

\section{1.-Visualización estática: referencias espaciales.}

Los ítems 1 a 6 responden a criterios de visualización estática (V) en relación a nuestras referencias espaciales. Estas referencias responden al esquema corporal, a partir de dos ejes, horizontal y vertical. Con este eje de referencia dividimos el espacio visual en cuatro cuadrantes topológicos: norte-sur y este-oeste. El primer ítem 
(V1) discrimina estos ejes en los cuatro cuadrantes de un círculo desde el propio punto de vista (superior-inferior y derecha-izquierda). Los ítems 2(V2), 3(V6), 4 y 5(V3) recogen las referencias física horizontal y vertical en el campo visual, en relación con el concepto de profundidad del campo visual. Se introduce aquí el concepto de punto de fuga como la proyección del punto de vista o de posición, como consecuencia de la convergencia del campo visual. El ítem 6 plantea la preferencia que tiene la persona sobre un sistema gráfico de representación espacial: entre convergente y divergente o paralelo.

\subsection{1- Referencias espaciales: Horizonte visual y vertical de posición}

Los ítems V1 y V2 plantean una cuestión simple perceptiva sobre el comportamiento de la línea de horizonte o visual horizontal, a dos niveles. El primer ítem lo hace de una manera abstracta, conceptual, dividiendo un círculo en cuatro cuadrantes a la manera del campo visual, con una imagen que recuerda el objetivo de un visor telescópico o de una cámara. El segundo ítem plantea un ejercicio de imaginación de situación frente a un horizonte despejado (mar-cielo) y del movimiento de agacharse. Los resultados nos muestran que en torno al $93 \%$ de los participantes resuelven el primer supuesto, pero el mismo porcentaje no resuelve el segundo. Para la mayor parte, el horizonte sube cuando se desciende en el plano vertical o permanece donde estaba (gráfico 02).

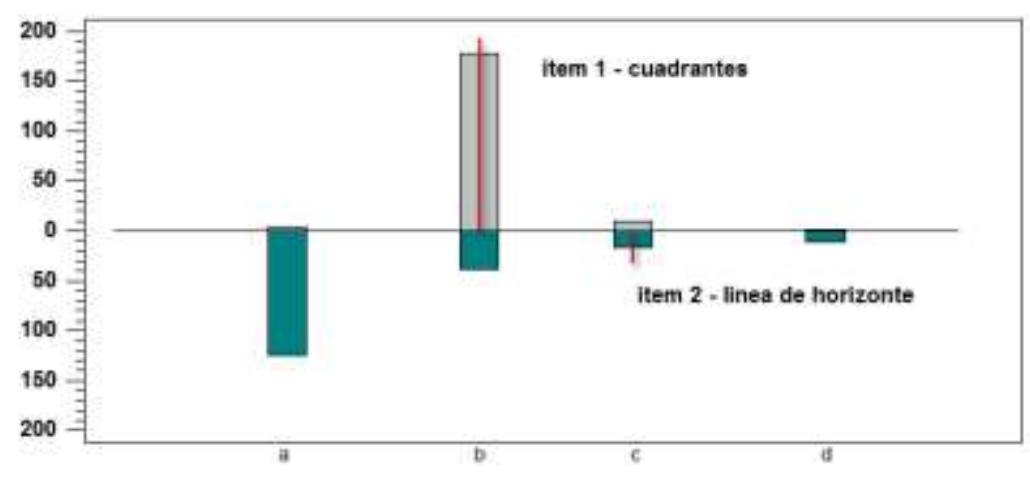

Gráfico 02: Horizonte teórico y horizonte visual

Porcentajes similares se producen con el mismo ítem en las anteriores aplicaciones, tanto del primer cuestionario como el de la prueba piloto (88\% y $94 \%$ ). Llama la atención, la aparente dificultad 
para discriminar perceptivamente el comportamiento de una línea real, el horizonte, con la que se puede experimentar ópticamente, de referencia física y espacial. Referencia topológica que existe claramente en la mente de los participantes, como lo confirma el resultado del ítem $\mathrm{V} 2$ respondiendo a un nivel de abstracción geométrico, y que sin embargo, no parece tan clara a nivel visual.

Resulta curioso, que cuando imaginan agacharse, a la pregunta de que creen que hace la línea de horizonte (si sube, baja, o no se altera), para un $66 \%$ de los participantes la línea sube, es decir, es tratada como una línea ajena a su movimiento. Al igual que un $21 \%$, para los que la línea permanece donde está, y un $6 \%$ explicita que la línea no tiene que ver con su movimiento. Solo un $7 \%$ de los participantes resuelve que la línea baja al tiempo que imaginan que ellos reducen la altura de su posición, como realmente ocurre, ya que la línea es la proyección de la propia visual horizontal. El ítem plantea la interiorización de la horizontal visual y cómo la relacionamos en dependencia con nuestro movimiento físico en los límites del campo visual (planeta físico).

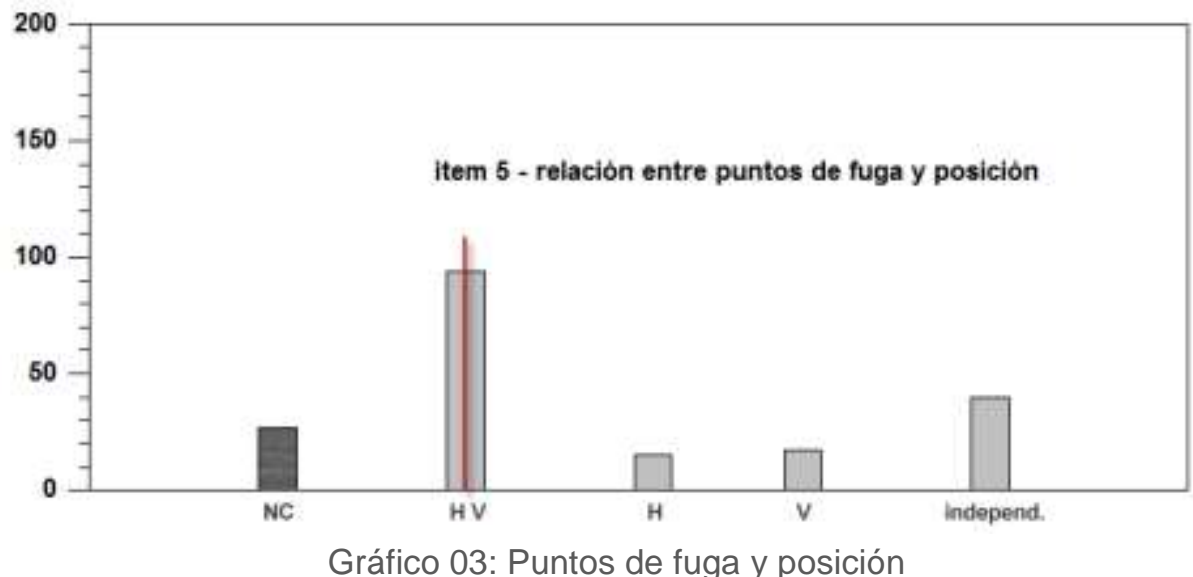

Obviamente, sabemos que los objetos están por encima o por debajo de nosotros, y que su posición es relativa y varía según nuestra posición (una mesa está habitualmente debajo nuestro, pero si nos metemos debajo de una mesa, esta se encuentra encima). Sin embargo, aunque el item constata la ausencia de relación del movimiento vertical con la modificación del campo visual, parece existir de una manera intuitiva, la percepción de que la posición en el espacio influye en nuestro campo visual. A la pregunta directa del ítem 
5 sobre la relación de la posición respecto al punto de fuga del campo visual, sólo el $21 \%$ de la muestra afirma que el punto de fuga no depende de su posición (gráfico 03).

Parece estar claro en la mitad de la muestra el concepto o la idea de que el punto de posición físico en el espacio, como centro del doble eje visual horizontal-vertical, resulta el punto de convergencia del campo visual.

El ítem 5 (V3) no proporciona un dato significativo, ya que el $14 \%$ no responde a esta cuestión, y a su vez, en el ítem 3 (V6), un $30 \%$ dicen desconocer el significado del 'punto de fuga', mientras que el $40 \%$ no lo relacionan con el campo visual y resuelven que este punto es el de convergencia de todas las líneas en el horizonte. De manera que proporcionan la respuesta correcta y relacionan la fuga $o$ convergencia visual con el propio campo visual, apenas el $27 \%$ de la muestra. A pesar de ello, solo corresponde a un $3 \%$ la consideración de que este punto sea aleatorio.

Por su parte, los resultados del ítem 4 referidos a la referencia vertical, confirman la falta de relación, desconocimiento o la existencia de un grado de confusión en cuanto al punto de posición definido por la vertical del equilibrio. En este ítem se espera como respuesta una sólida referencia ósea a la estructura vertical del cuerpo (nuca y coxis) y ésta es apreciada solo por el $37,8 \%$ de la muestra. La opción preferida es la de 'la nariz y el ombligo' (51\%), junto al resto de opciones de referencias no óseas.

\subsection{2- Preferencia representacional}

El ítem 6 no plantea una respuesta correcta, y solo pretende discriminar el sistema preferente de la representación mental de un cuerpo solido tridimensional, de un cubo (fig. 105). En él se muestran las opciones (b y d) del sistema divergente paralelo (diédrico) y el cónico convergente (visual) entre otras dos opciones (a y c) que corresponden a representaciones 'pre-realistas' (Mitchelmore, 1980). A excepción de dos sujetos que optan por el sistema cónico, todos 
(99\%) resuelven la representación diédrica como la que mejor responde a su visión de un cubo.
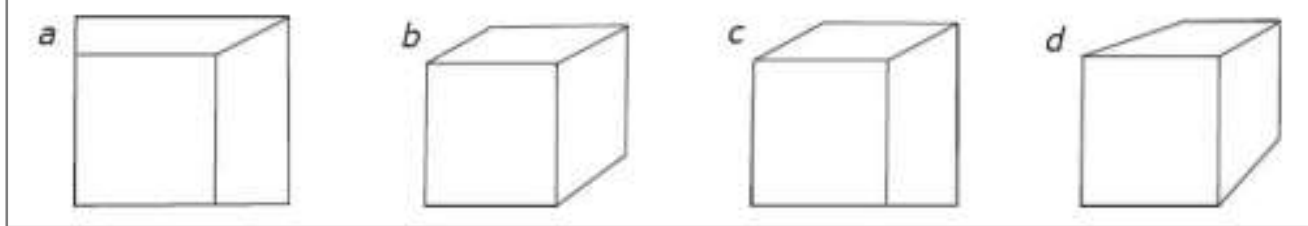

Fig.105: Item 6

La poca discriminación en la respuesta de este item no permite ningún análisis bivariable que nos conduzca a relacionar las respuestas con los aspectos anteriores, salvo concluir que no se establece relación gráfica entre el modelo visual y el sistema de representación de los estudiantes universitarios de la muestra.

\subsection{3- Referencias espaciales: Medición de ángulos}

Incluimos en este factor, los ítems 12 (V4) y 17 (V5) que plantean la percepción de la medida de los ángulos. La referencia del eje horizontal-vertical plantea la perpendicularidad de referencia. Consideramos que para medir aparentemente un ángulo, se deduce que es menor ( $<90^{\circ}$ o agudo) o mayor ( $>90^{\circ}$ u obtuso) que el ángulo recto de referencia.

Ambos items plantean hallar el ángulo menor de los cuatro propuestos (fig.106). El ítem 12 plantea la medición en un esquema espacial similar a una esquina en relación a la horizontal, y el ítem 17 plantea la misma cuestión con las manecillas de un reloj. La respuesta correcta en el primero es del 52,6\%, mientras que en el segundo es el $95,8 \%$.

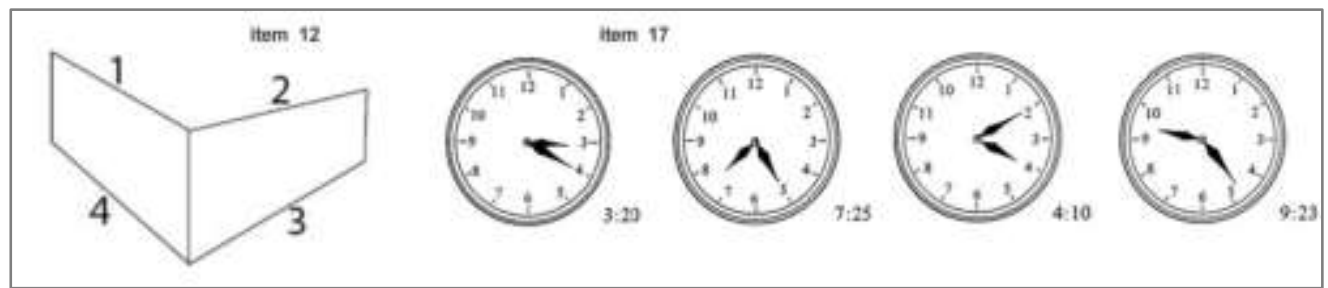

Fig.106: Localización del ángulo menor respecto a la horizontal (ítem 12) y del formado por las manecillas del reloj (ítem 17) 
Ambos ítems tienen similar comportamiento en las opciones que presentan. Aunque el ítem 12, de los ángulos en esquinas, muestra mayor dispersión en relación al ítem 17, de los ángulos encerrados en el círculo-reloj (gráfico 04).

Se observa que no existe ninguna dificultad en la apreciación de los ángulos por los estudiantes. Sin embargo, éstos muestran problemas cuando tienen que incorporar su sentido de la horizontalidad a la medición del ángulo.

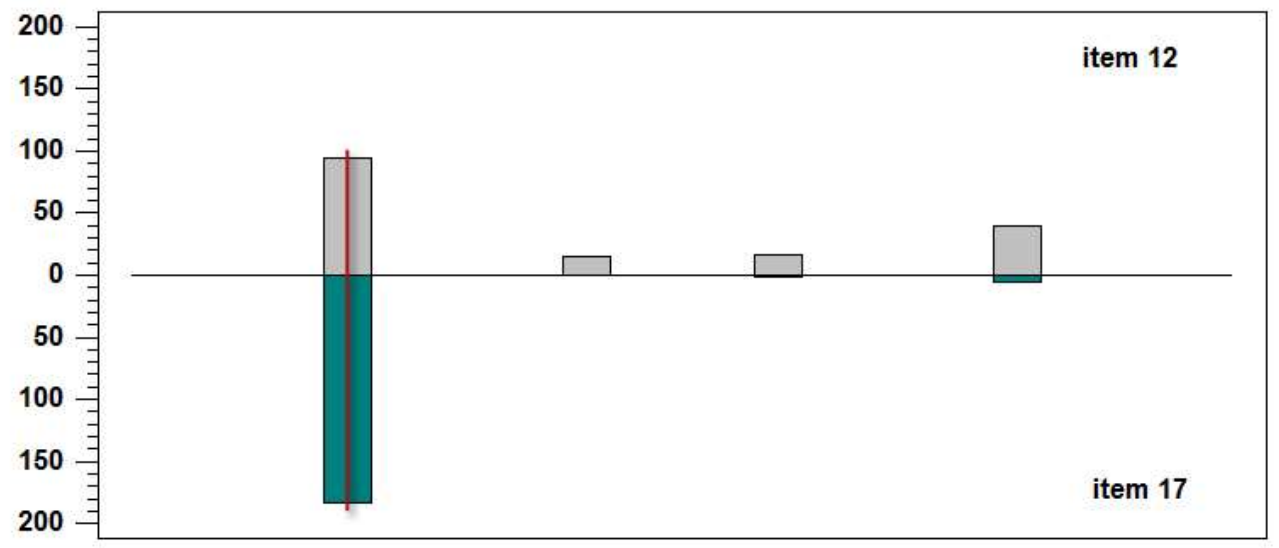

Gráfico 04: Datos comparados en ítems de medición de ángulos.

\section{2.- Visualización dinámica: relaciones espaciales.}

Los ítems 8 a 11 (R1 a R4) y 15 (R5) son similares a los de las pruebas de relaciones espaciales $(R)$ en que se basan y que implican giro $(R 1, R 5)$, desarrollo de superficies (R2), doblado de papel (R3), figuras (R4) y la idea de constancia perceptual (R6).

Este grupo de ítems plantea buenos resultados en general (Gráfico 05). Estos ítems, que tienen un nivel muy bajo de dificultad, pretenden confirmar la buena respuesta general de los participantes a este tipo de pruebas. 
Los porcentajes de acierto son:

R1.- 94,3\% / R2.- 83,7\% / R3.- 92,2\% / R4.- 81,3\% / R5.- 60,3\%

El ítem 15 (R5), con el porcentaje menor, plantea un grado mayor de dificultad en el sentido que establece la relacion espacial de giro de la figura con la posición interna de un elemento.

Los resultados confirman el nivel universitario de los participantes y la buena apreciación de los aspectos de relaciones espaciales, en un sentido básico. Podemos pensar que existe un nivel de entrenamiento en estos aspectos, pero también que se ha dado un aprendizaje básico en geometría.

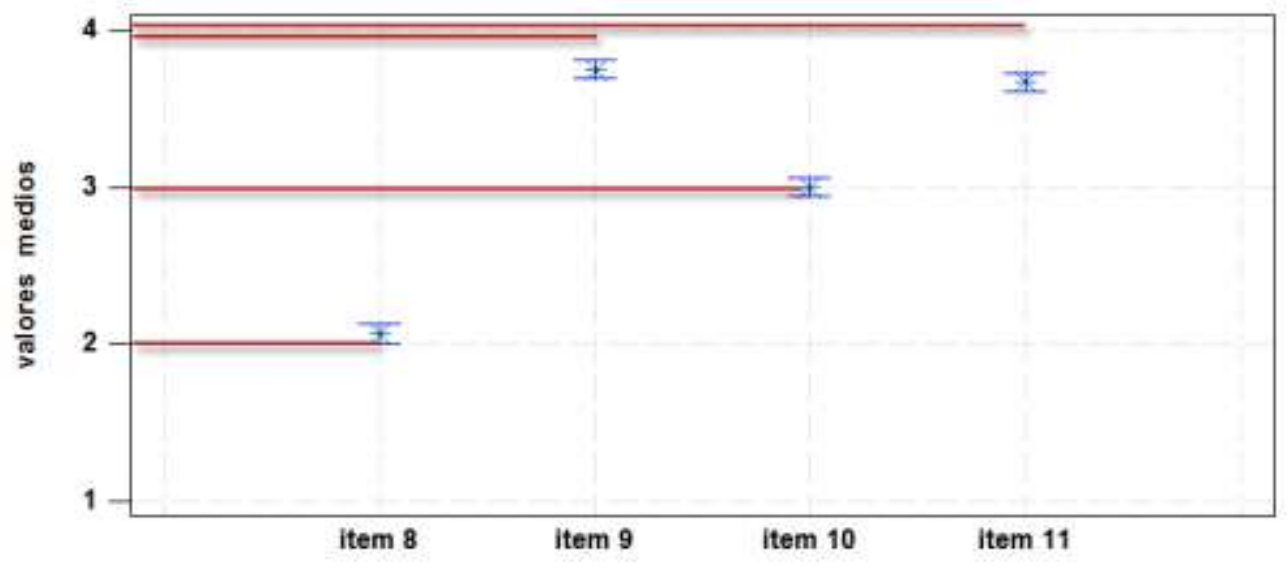

Gráfico 05: Items de visualización dinámica.

7.2.1- Constancia de la forma.

El reconocimiento de objetos a pesar de sus cambios estructurales en el espacio, entendido como constancia de la forma, se analiza en los ítems 14 y 16. El ítem 16 es textual, de elección de la afirmación más correcta: la opción 'los objetos adoptan diferentes formas' supone el $68,1 \%$ de las respuestas. Mientras un $12 \%$ afirma no poder establecer una forma simple a un objeto, para el $16,8 \%$ la forma de los objetos es una, lo que es en realidad. En este grupo los resultados son algo inferiores a los de la muestra del grupo anterior. 


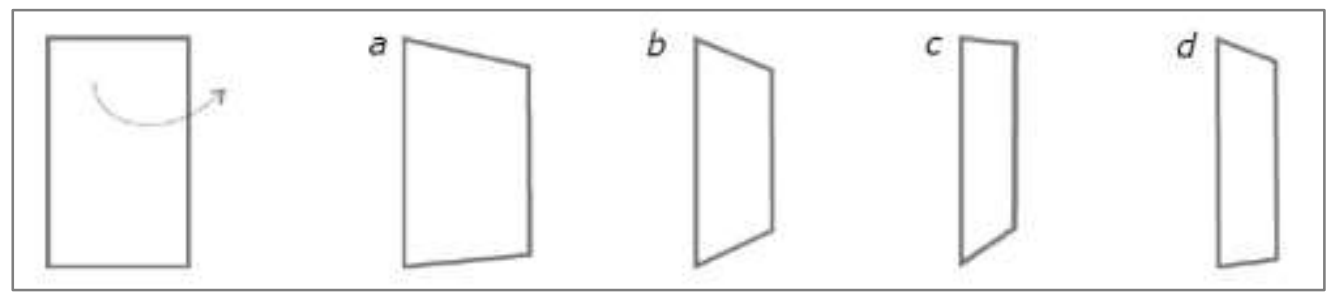

Fig.107: Abatimiento de plano vertical (item14)

El ítem 14 no plantea una respuesta correcta, ya que está en relación con la preferencia de perspectiva del ítem 6 . Si bien en la preferencia de modelo de perspectiva, la respuesta es rotunda hacia el modelo diédrico, en este caso, en el que se plantea el abatimiento vertical de un plano, la respuesta se diversifica (fig. 107), aunque a la opción b, más equilibrada visualmente en relación a la visual, le corresponde el $47,6 \%$ (gráfico 06).

Esta preferencia puede responder a la tendencia natural homeostática al equilibrio que encontramos en la posición de la altura de los cuerpos, incluido el nuestro. La respuesta elegida mayormente confirmaría que esta tendencia es inherente a los referentes visuales, aunque estos no se consideren en el sistema de representación preferente, pero al mismo tiempo la dispersión demuestra que no está clara esta relación.

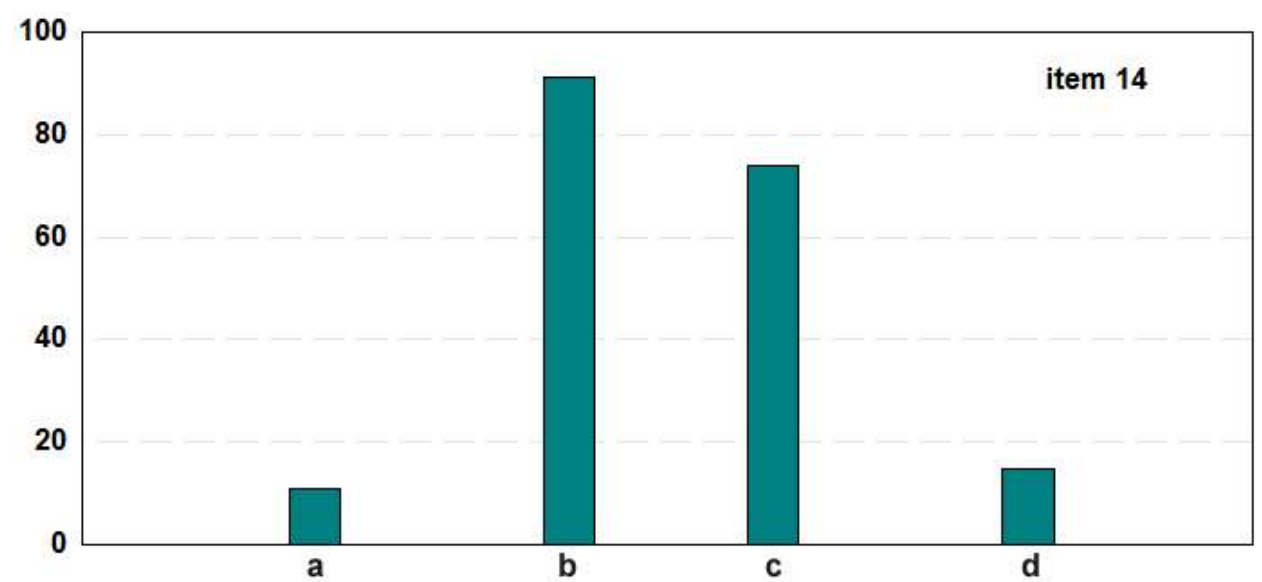

Gráfico 06: Abatimiento del plano en el eje vertical (ítem 14) 


\section{3.- Pensamiento proporcional.}

Este grupo lo forma 6 ítems visuales (18 a 23) que plantean la relación de la forma con la medida. El reconocimiento de las formas que observamos implica el análisis visual de sus medidas. La proporción o razón de esas medidas la expresamos en una fracción o un número racional. Los ítems 24 y 25 son textuales y registran si existe la percepción de una proporción calculada (sin especificarla) en los soportes utilizados habitualmente en el entorno académico: los folios de papel y las pantallas de los dispositivos electrónicos.

Los ítems 20, 21 y 22 (P3, P4 y P5) son adaptados de la batería del test TPP, de percepción de la proporción (Carmiol, 2013). Esta prueba originalmente se plantea con la proyección colectiva de este tipo de imágenes (fig. 108) y la identificación, en una respuesta individual, de la proporción entre cinco imágenes similares, con modificaciones de su proporción horizontal, vertical o entre figura y fondo. Las imágenes utilizadas responden al diseño industrial, por ser la Escuela de Ingeniería en Diseño Industrial, el ámbito de aplicación de este estudio, realizado por el Departamento de Pedagogía de la Universidad de Valencia.

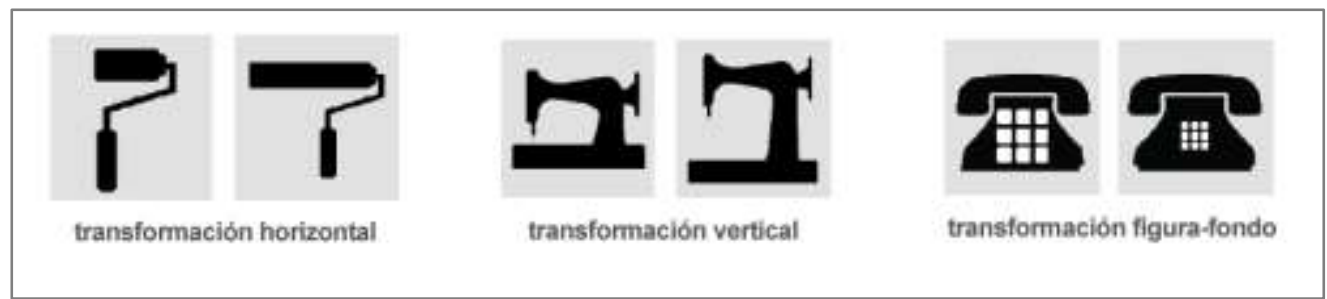

Fig. 108: Tipos de subítems de la prueba TPP (Carmiol, 2013).

Los ítems incorporados se han seleccionado en función de la proximidad de su simbolización con el eje horizontal o vertical que se pide analizar en cada caso. Se alinean las imágenes a la misma altura y sobre el mismo plano horizontal para facilitar el análisis en ambos ejes a través de la comparación entre las diferentes opciones de figuras. Se establece la relación cuadrada (1:1) en el ítem 20 (P3), la relación de doble cuadrado horizontal (2:1) en el ítem 21 (P4), y la relación de doble cuadrado vertical (1:2) en el ítem 22 (P5). Las tres relaciones requieren de los participantes un análisis simple de la proporción, a través de la comparación visual o la medida entre las 
cuatro figuras, para elegir la adecuada a un cálculo de relación simple entre los ejes vertical y horizontal.

El mejor resultado de los tres ítems (61\% de acierto) se produce en la proporción doble en el eje vertical (1:2 - ítem 22). Mientras que el peor resultado $(20,5 \%$ de acierto) se da en la proporción doble del eje horizontal (2:1 - ítem 21). La proporción cuadrada es la más dispersa y reparte la mayoría de las respuestas entre los subítems c $(36,5 \%$ de acierto) y d (37,1\%) (gráfico 07a).

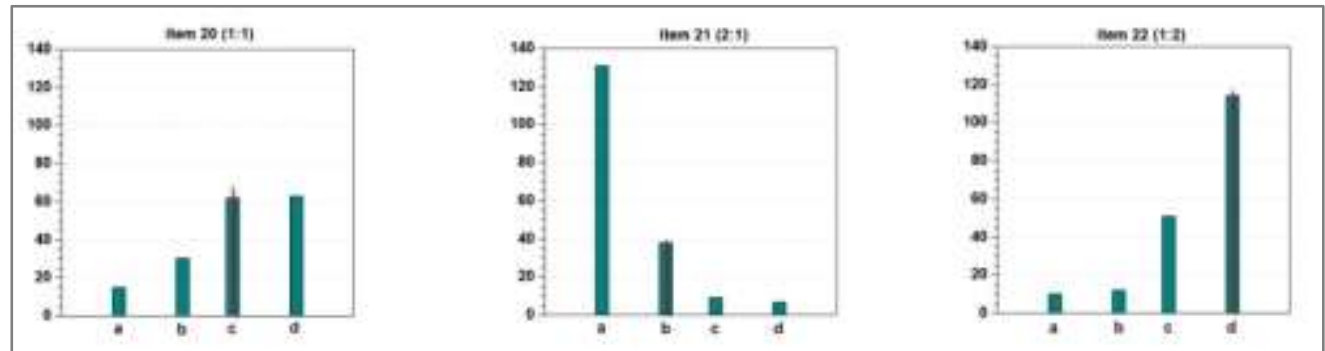

Gráfico 07a: Histograma comparativo de las respuestas de los ítems de proporción (cuadrada, doble horizontal y doble vertical)

Al estar las figuras modificadas secuencialmente en la proporción, los valores medios indican la aproximación visual a la respuesta correcta (gráfico $07 \mathrm{~b})$.

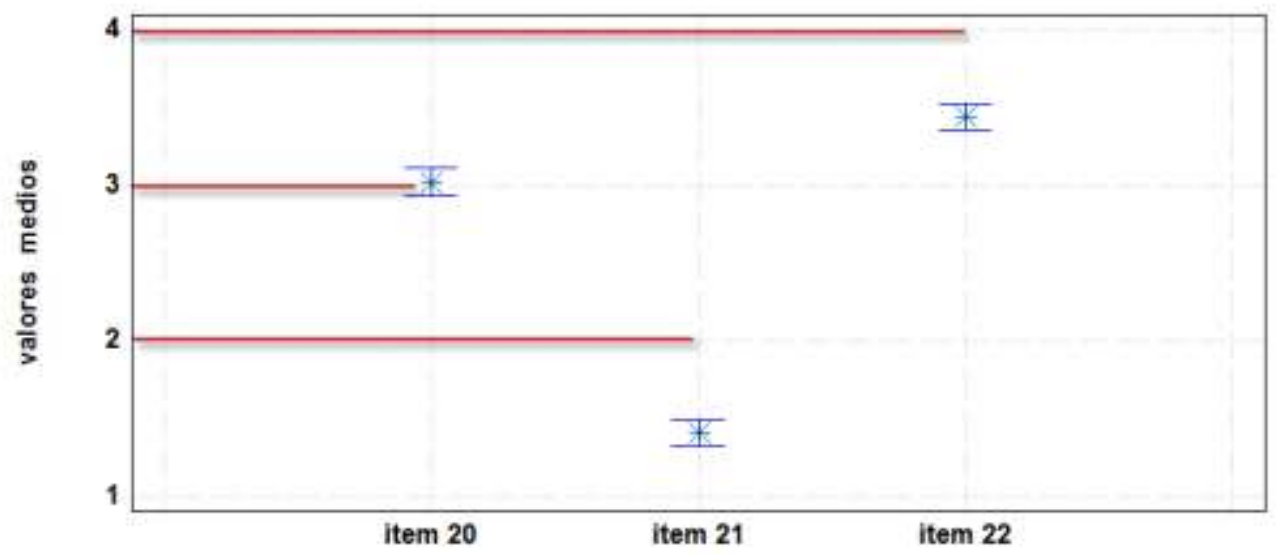

Gráfico 07b: Comparativa de las dispersiones de respuesta en los items de percepción de la proporción.

Los ítems 18 (P1) y 19 (P2) discriminan la misma operación, pero lo hacen con un planteamiento geométrico de la proporción y una 
respuesta como número fraccionario. Se pide el cálculo proporcional en relación a la línea y a la superficie de un rectángulo (fig. 109).

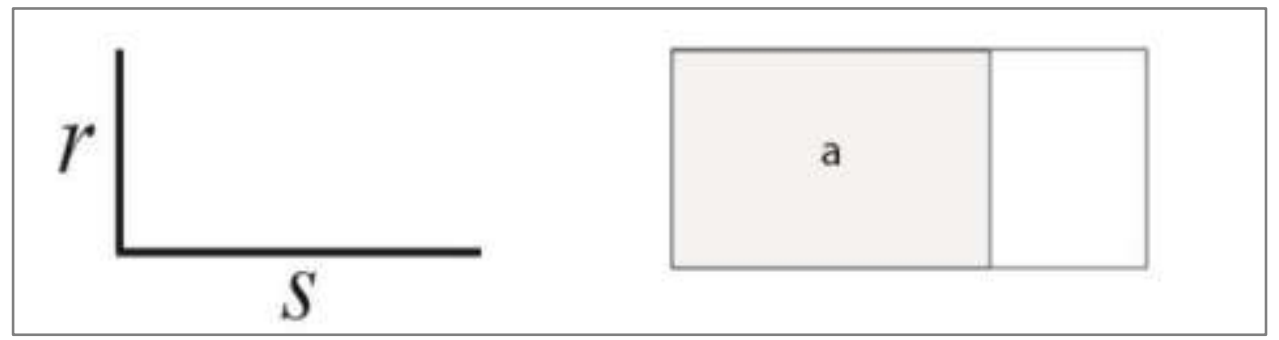

Fig.109: Ítems 18 y 19. Relación de proporción de 1⁄2 (línea) y 2/3 (área).

En este planteamiento matemático visual, los resultados son mejores que en los ítems anteriores del test TTP. La proporción de acierto en la relación lineal $(1 / 2)$ es algo superior $(78,8 \%)$ a la relación (2/3) en el área del rectángulo (59,6\%), en la que la respuesta de $1 / 3$ la plantean el $22,3 \%$ de los resultados, pero estos resultados se asemejan si incluimos estas respuestas considerando que se ha podido invertir la identificación del área mayor por la menor (gráfico 08).

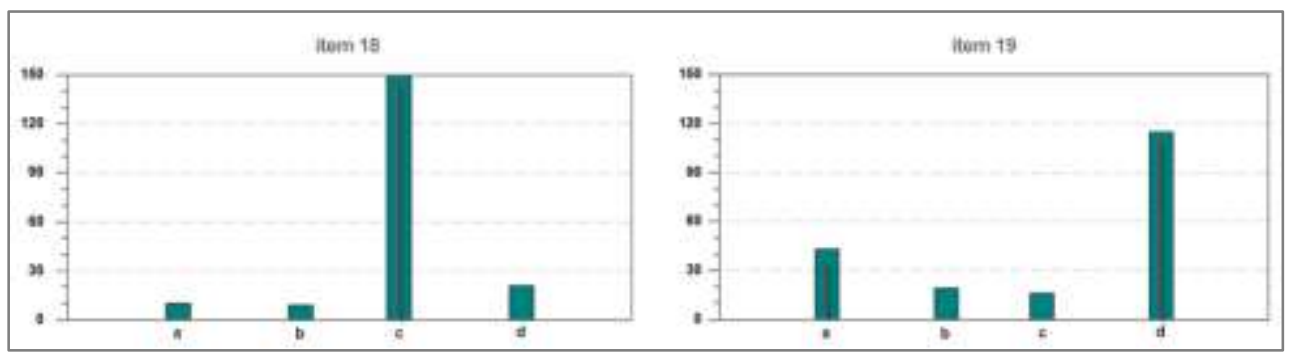

Gráfico 08: Histograma comparativo de los ítems de proporción matemática

Por último, el ítem 23 (P6) registra la percepción de la situación de la línea de los ojos en la vertical de la cabeza de un adulto, simplificada en la forma de un ovalo. La línea de la visión divide el cráneo en la proporción de 1/2 (línea 3), e incluso, considerando el volumen del cabello, esta división puede aproximarse a la línea 4 . El $82,8 \%$ de los participantes consideran esta línea en la división 2, que se aproxima a la proporción de 1/3. El 16,7\%, asigna el valor correcto. Solo un participante indica el nivel 1, ninguno elige el nivel 4, y uno no contesta (fig.110). 


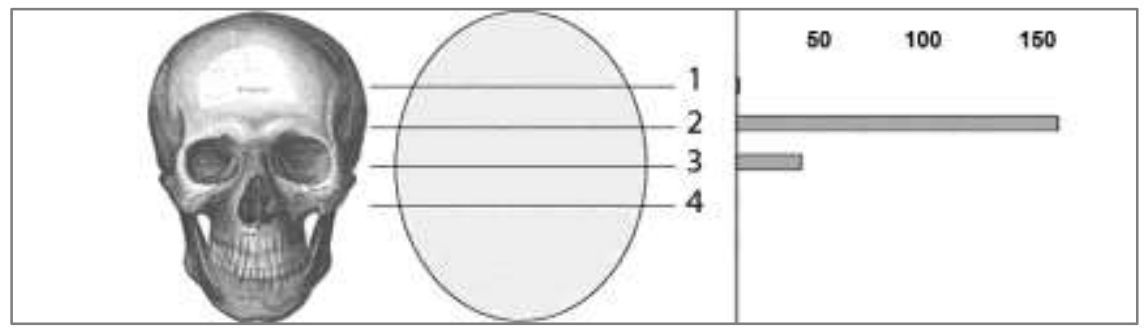

Fig.110: Percepción de la línea visual en relación a la cabeza.

Se plantea una dificultad para ubicar la línea de visión en la cabeza. Dificultad, que se interpreta en el hecho de que atribuimos mayor información a la parte inferior de la cabeza (rostro), ya que en ella se encuentran los principales musculos y rasgos de expresión.

Los ítems 24 y 25 registran la impresión que se tiene sobre la existencia de una proporción deliberada en los folios y pantallas que utilizamos. En ambos, las respuestas son similares: existe una relación de proporción del $73,3 \%$ y del $70 \%$ en ambos supuestos. Si unimos las respuestas a las de relación de fabricación, entendiendo que ésta incluye un cálculo, el porcentaje de respuestas está en ambas en torno al $87 \%$. Son solo 13 , el $6,8 \%$ de los participantes, quienes niegan cualquier relación.

Si bien podemos establecer que la discriminación matemática de la proporción es buena, ésta muestra diferencias entre la medición lineal y la de superficies, que empeora los resultados. $Y$ las pruebas con las formas del TPP lo confirman.

El análisis de la proporción en las formas simbólicas aprecia mejores resultados con diferencia en el eje vertical que en el horizontal, lo que confirmaría el efecto de la anisotropía visual y el hecho de que nuestro sistema visual tolera una mayor disparidad horizontal que vertical, mientras que la dispersión en la respuesta de la proporción cuadrada confirma la tendencia al equilibrio. Hemos de observar que el planteamiento de la prueba permite la posibilidad de medir sobre el papel el ancho y la altura de las imágenes. 
7.4.- Lectura de imagen.

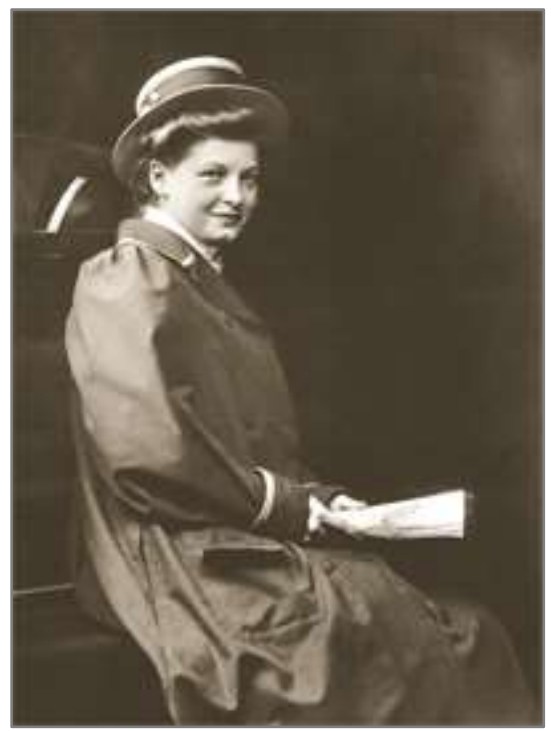

Fig. 95: Maestra de escuela, fotografía de A. Sanders, 1904

Este apartado del cuestionario plantea la aplicación de las dimensiones desarrolladas, en la lectura de la fotografía Maestra de escuela (Fig.95). La lectura que se pide no es interpretativa, y responde a criterios objetivos sobre la composición de la imagen. Se realiza a dos niveles: el primero es el reconocimiento de la composición (peso) de la imagen en la relación figura-fondo del ítem 27 (L1) y en la división del formato (línea de fuerza) a partir del eje de la figura del ítem 30 (L4). El segundo nivel plantea la situación del fotógrafo o la posición en que sitúa al espectador respecto a los ejes vertical y horizontal de referencia de los ítems 28 (L2) y 29 (L3).

En relación a la línea de fuerza, la división del formato por el eje de la figura es percibida de forma correcta, como un tercio de la anchura del formato horizontal (opción b), por un 55\% de la muestra; mientras que un $28,8 \%$ se aproximan a ella en la proporción de $2 / 5$ (opción c).

En relación a la relación figura-fondo en el peso de la composición, el $61,7 \%$ de la muestra discrimina correctamente el espacio negativo de la imagen (opción b), y otro $35,2 \%$ se aproxima con la respuesta a. Las respuestas $\mathrm{c}$ y d solo corresponden a tres participantes cada una $(3,2 \%)$. En todos los casos las figuras han sido 
modificadas para plantear diferentes espacios negativos, pero sin perder la proporción original de 1/3 en la anchura del formato.

Existe un reconocimiento general bastante alto de la relación figura-fondo, pero el reconocimiento de la división proporcional (ítem 30) plantea mayor dispersión en las respuestas: 1/3, 2/5 y 1/4 (gráfico 9).

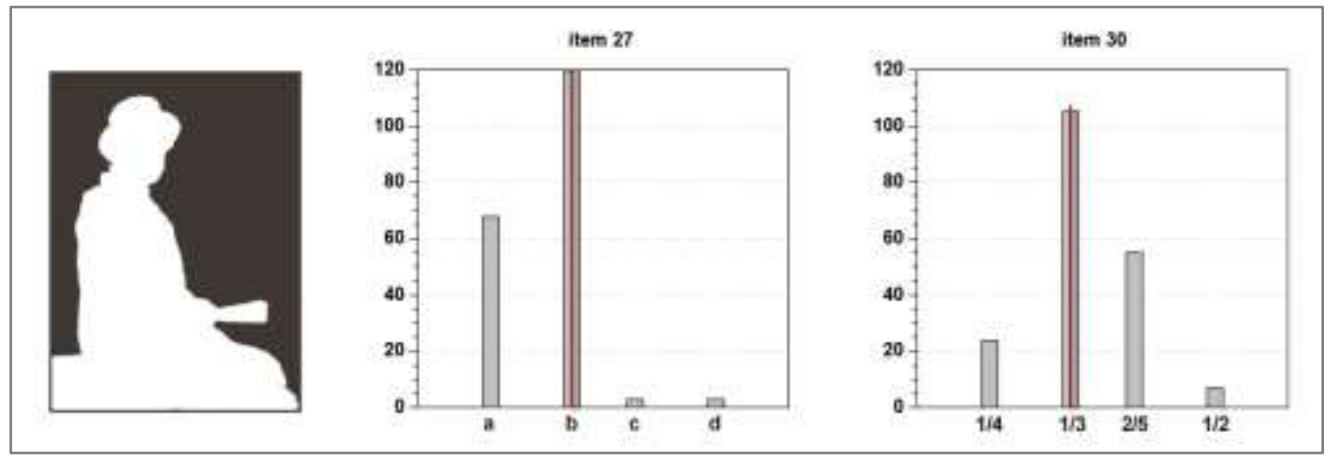

Gráfico 09: Lineas de fuerza.

La conciencia de donde se encuentra el observador es considerada un aspecto de la capacidad de la orientación y el razonamiento espacial (Martín Gutiérrez, 2010). En relación a los dos ítems que discriminan la posición vertical y horizontal del fotógrafo, se produce un mejor reconocimiento del desplazamiento en la vertical (arriba-abajo) sobre el eje horizontal (ítem 28), que del desplazamiento horizontal (izquierda-derecha) sobre el eje vertical (ítem 29).

Un total de 101 sujetos (52,3\%) reconocen el eje de posición horizontal como espectadores que les asigna el fotógrafo, y se sitúan ligeramente por debajo de la modelo. Mientras que solo 47 (24,5\%) reconocen el eje de posición vertical, situándose ligeramente a la derecha de la modelo (gráfico 10). La opción cuarta corresponde a la respuesta 'no lo puedo saber'. 


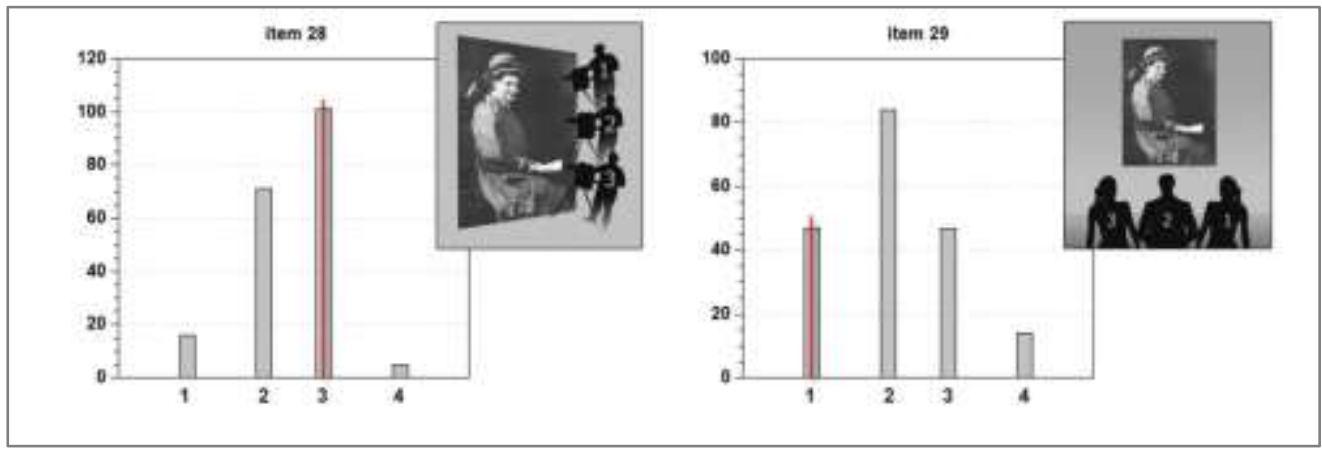

Gráfico 10: Items 28 y 29: Posición del fotógrafo

Podemos decir que se reconoce con más facilidad la posición vertical en relación al horizonte, si se está por encima o por debajo de la figura modelo; mientras que plantea más dificultad la referencia al eje vertical propio. Esto confirmaría a su vez la disparidad visual que es mayor en el desplazamiento horizontal.

Sin embargo, la conciencia del horizonte se ha planteado con más debilidad en los ítems relativos a la visualización estática, lo que nos permite diferenciar en los participantes una sensibilidad mayor a la referencia horizontal en relación con los otros, con otras personas, que cuando se trata del horizonte visual propio. Esta consideración de la perspectiva del propio observador y de la modelo en el análisis de la altura, facilitaría la discriminación perspectiva, confirmando la posibilidad de que la experiencia con las figuras humanas es más variada que la que tenemos con objetos, ya que incluyen las interacciones en las que hay que estimar la perspectiva de la otra persona (Zacks y Tversky, 2005). 


\section{5.- Valoración del constructo de pensamiento visual.}

Este apartado analiza la actitud como un constructo teórico destinado a definir las relaciones entre el sujeto y su propio concepto del pensamiento visual. Esta actitud se infiere de la valoración del sujeto, entendida como una mezcla de pensamientos y opiniones acerca del constructo.

Los ítems 31 a 35 se plantean en una escala de valoración de la respuesta de 0 (nada) a 5 (mucho), ya probada en la prueba piloto. La fiabilidad de esta escala, calculada con el coeficiente de consistencia interna de Cronbach a partir de la media de las correlaciones de los 5 ítems, es $\alpha=0.77$.

En las afirmaciones se relaciona el pensamiento visual y la inteligencia espacial con el grado de importancia que se le atribuye en la elaboración de recursos educativos (ítem 31), y en las nuevas tecnologías (ítem 32). Se relaciona la competencia gráfica del dibujo con la formación docente (ítem 35), y en qué medida esta habilidad está relacionada con el talento artístico (ítem 34). El ítem 33, por otro lado, registra el nivel de satisfacción en los estudios de grado en relación a la formación en competencia o inteligencia espacial.

\begin{tabular}{|l|l|l|l|l|l|}
\hline & item 31 & item 32 & item 33 & item 34 & item 35 \\
\hline Recuento & 191 & 192 & 192 & 192 & 191 \\
\hline Promedio & 3,56021 & 3,61979 & 2,14583 & 3,21875 & 3,40314 \\
\hline Varianza & 1,02662 & 1,26306 & 1,28752 & 1,34457 & 1,08399 \\
\hline Desviación Estándar & 1,01322 & 1,12386 & 1,13469 & 1,15956 & 1,04115 \\
\hline Coeficiente de Variación & $28,4596 \%$ & $31,0476 \%$ & $52,8788 \%$ & $36,025 \%$ & $30,5937 \%$ \\
\hline Desviación Media Absoluta & 0,825306 & 0,914822 & 0,91276 & 0,906901 & 0,853485 \\
\hline Curtosis & 0,812122 & 0,797362 & $-0,475254$ & 0,28232 & 0,376197 \\
\hline
\end{tabular}

Gráfico Caja y Bigotes

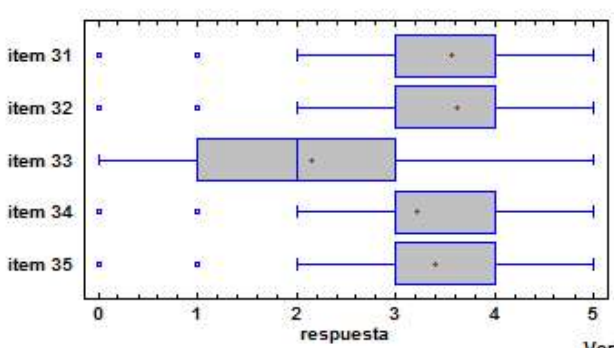

Gráfico de Medias
Con intervalos LSD del $95,0 \%$

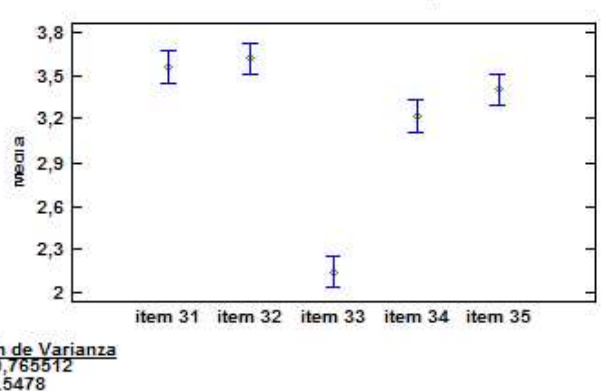

Gráfico 11: Resumen estadístico de la escala Likert de valoración. 
Excepto en los resultados del ítem 33, los valores promedio son relativamente altos, en torno a la puntuación de 3,5; con una concentración similar en los ítems 31,32 y 35 , que valoran la atribución de importancia de la competencia espacial y gráfica en la formación y el desempeño profesional (gráfico 12).

Los valores más altos los recibe la apreciación de necesidad de la competencia o inteligencia espacial en el uso de nuevas tecnologías en educación (ítem 32): 46 sujetos dan una puntuación de 5; 64 sujetos la valoran con un 4 , y 56 con un 3 . El $86,5 \%$ de la muestra considera necesaria la competencia espacial para el uso de las TICs.

En la apreciación de relación de la competencia con la elaboración de recursos educativos (ítem 31), el valor más alto lo asignan 30 sujetos, 81 dan el valor de 4 , y 54 de 3 . Igualmente, el $86,4 \%$ de la muestra considera que el pensamiento visual guarda relación con la elaboración de materiales gráficos.

En la apreciación de la importancia de la competencia gráfica en la formación del Grado en Educación (ítem 35), 26 sujetos le asignan el valor más alto, 67 el valor 4 y 66 el valor 3 . En este caso, el $82,4 \%$ de la muestra considera importante el dibujo en su formación docente. Aunque en general, se relaciona positivamente la habilidad del dibujo con el talento artístico.

El ítem 34, que plantea el vínculo con el talento artístico, muestra resultados similares, con un promedio de 3,2. Esto supone que cerca del $80 \%$ de los participantes consideran la existencia de un vínculo, en mayor o menor medida, entre la competencia y el talento artístico (gráfico 12).

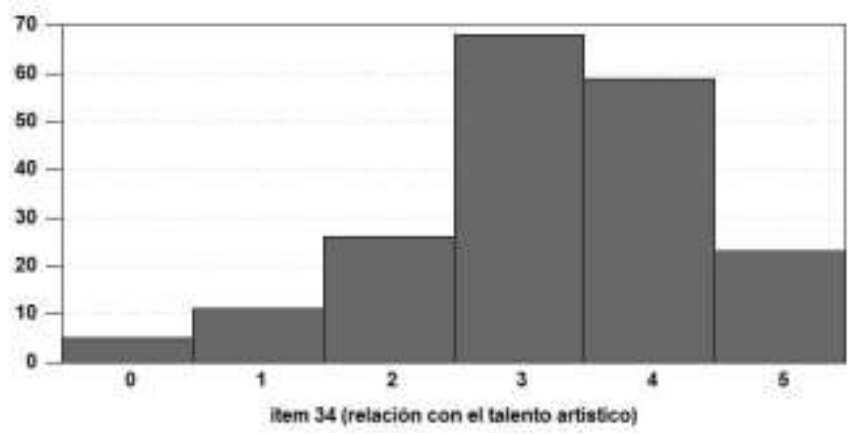

Gráfico 12. 
La menor dispersión de los datos está en la valoración de la formación del grado en competencia espacial del ítem 33, donde el peso medio es de 2,1. En este caso, seis de cada diez participantes expresan un nivel de insatisfacción o insuficiencia en la formación referida a la inteligencia espacial (Gráfico 13). Solo dos participantes valoran con un 5 este aspecto de su formación.

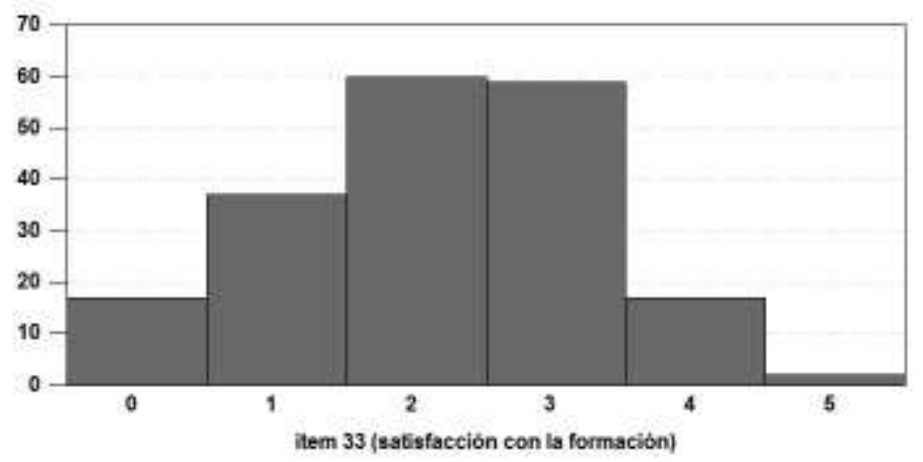

Gráfico 13.

$\mathrm{Si}$ consideramos que los individuos se sitúan en las dimensiones de actitud ordenados según su posición favorable o no hacia una afirmación (Alaminos y Castejón, 2006), podemos concluir que, en un nivel de opinión, los participantes de la muestra valoran positivamente los contenidos del pensamiento visual en su formación como profesionales de la enseñanza, y que consideran insuficiente esta formación en su recorrido universitario.

$\mathrm{Si}$ bien el concepto de talento no queda definido en el planteamiento del cuestionario, habitualmente se entiende como la disposición o capacidad innata hacia ciertos aprendizajes. En este sentido, aunque la mayoría atribuye el desarrollo de la habilidad del dibujo en gran medida al talento artístico (3.2), la importancia atribuida al aprendizaje de la competencia gráfica muestra un valor algo superior (3.4). 


\section{8.- Discusión}

Hemos procurado analizar los datos en función de la interdependencia de las variables 0 aspectos analizados del pensamiento visual, y a través de los factores estructurales que hemos determinado: visualización estática, dinámica y razonamiento proporcional. Son las mismas dimensiones con las que se trabaja en la evaluación de la percepción visual y la inteligencia espacial. Queríamos saber en qué medida influyen estos factores en la lectura e interpretación de una imagen, y por tanto en la interpretación visual del entorno, e inferir a partir de ello su influencia en la generación de imágenes didácticas.

El análisis factorial, como técnica de reducción de la dimensionalidad de los datos obtenidos, a través de un número mínimo de dimensiones o factores, procura explicar la varianza común a todas las variables (Ferrando y Anguiano, 2010). Entendemos que, tanto los factores de visualización como el factor de proporción, pueden explicar los resultados obtenidos en la prueba. De igual manera, el factor de lectura, puede exlicar el rendimiento en la aplicación de los tres factores analizados.

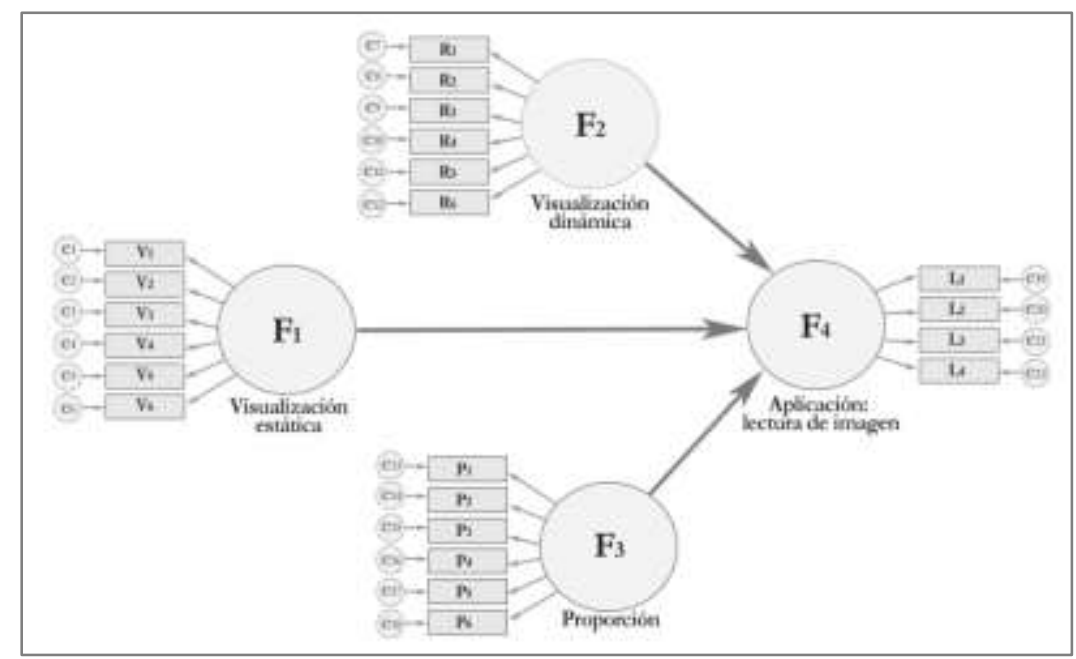

Fig. 103: Modelo factorial.

En el modelo teórico de la figura 103, definimos tres factores del pensamiento visual, como variables independientes:

- Un factor de referencia visual o visualización estática $\left(F_{1}\right)$ que se define, por su vínculo físico y experimental, en relación con 
la percepción, el equilibrio psicomotor y la orientación espacial (Thurstone, 1938; Yela, 1967; Fernández Ballesteros, 1995; Pascual, 1997). Este factor reune 6 reactivos: ítems V1 a V6.

- Un factor de razonamiento espacial o visualización dinámica $(\mathrm{F} 2)$, caracterizado como un amplio factor de relaciones espaciales que está ligado de forma compleja tanto a la experiencia como a otros factores verbales, de razonamiento y psicomotores (Yela, 1967; Pascual, 1997) (Items R1 a R6).

- Un factor visual de razonamiento proporcional (F3), como la relación protomatemática que destaca en la percepción de los objetos y formas (Chevallard, 1991, Carmiol, 2013) (Items P1 a P6).

Consideramos que estos factores influyen de diferente manera en el proceso de interpretación y lectura de imagen ( $F 4)$, que se ha definido como variable dependiente, con cuatro reactivos (ítems L1 a L4).

El análisis factorial es utilizado para determinar la unidimensionalidad y colinealidad de las variables descritas bajo el modelo de Rasch. Este tipo de análisis procura simplificar un grupo de variables relacionadas en factores independientes, que contienen la síntesis de la información recogida en un número menor de elementos. En la realidad es muy difícil que un solo factor explique el $100 \%$ de la varianza, sin embargo se busca que estos factores 0 dimensiones expliquen la mayor cantidad de varianza posible.
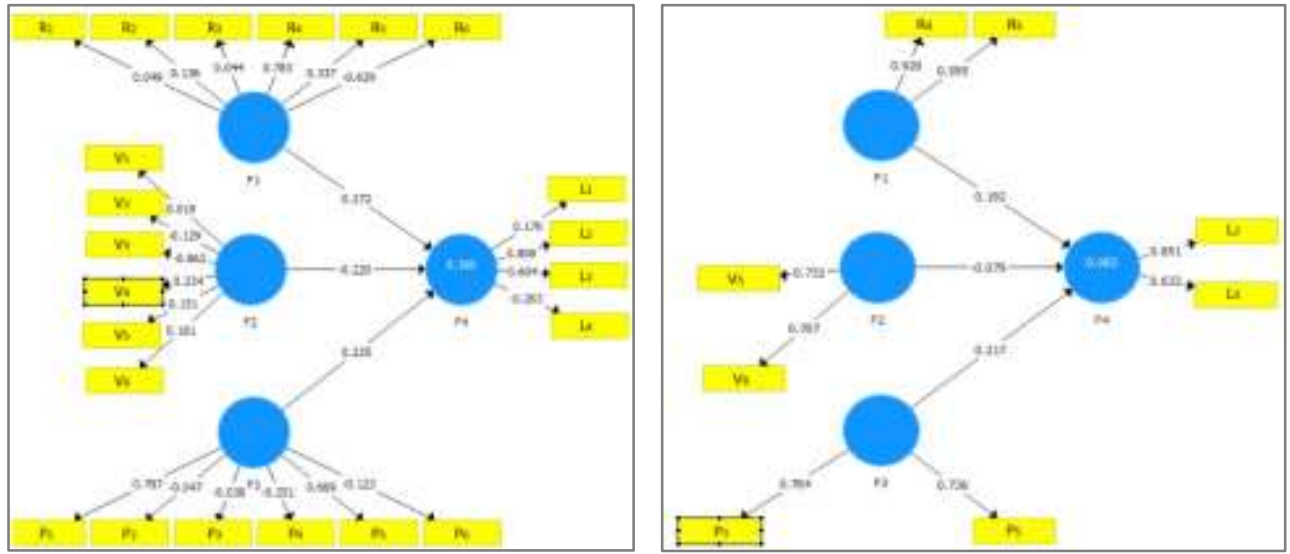

Gráfico 14: Resultados del modelo planteado 
Nuestro planteamiento (gráfico 14) presenta en los modelos de medida saturaciones muy pequeñas (próximas a 0) y algunas negativas. Lo que se espera es que todas sean positivas y superiores a 0.5 aproximadamente, por lo que este modelo no resulta sostenible. Existen reactivos que se comportan mal y eliminamos aquellos que tienen saturaciones negativas o muy bajas. Si bien ahora los modelos de medida son aceptables, la varianza explicada en la variable dependiente es muy pequeña $(8.2 \%)$.

Encontramos como causas posibles del mal comportamiento del modelo planteado, el hecho de haber mantenido ítems a pesar de su comportamiento atípico, pero creemos que justifican la base teórica del trabajo. La característica no aleatoria de la muestra de conveniencia y su tamaño también influyen en estos resultados, que consideramos exploratorios. No obstante, creemos que el planteamiento teórico permite el ensayo de otros modelos y la creación de otro tipo de cuestionario para profundizar en la relación de estos u otros aspectos del constructo del PV.

En el modelo lineal del análisis de varianza solo encontramos una correlación significativa entre el factor de visualización y la variable de referencia horizontal visual (ítem L2) en la lectura de imagen. La ecuación del modelo ajustado es:

\begin{tabular}{|c|c|c|c|c|c|c|c|c|}
\hline \multirow{2}{*}{\multicolumn{2}{|c|}{$\begin{array}{l}\text { Variable dependiente: L2 (item 28) } \\
\text { Variables independientes: } \\
\text { V1 (item 1) }\end{array}$}} & & & Error & Estadistico & \\
\hline & & Pard & metro & & Estimación & Estándar & $T$ & Valor-P \\
\hline \multicolumn{2}{|c|}{$\begin{array}{l}\text { V1 (item1) } \\
\text { V2 (iter2) }\end{array}$} & \multicolumn{3}{|c|}{ CONSTANTE } & 0,590355 & 0,211985 & 2,7849 & 0,0059 \\
\hline \multicolumn{2}{|l|}{ V3 (item 5) } & \multicolumn{3}{|l|}{ V1 } & 0,17672 & 0,132651 & 1,33222 & 0,1844 \\
\hline \multicolumn{2}{|l|}{ V4 (item 12) } & \multicolumn{3}{|l|}{ V2 } & 0,0632564 & 0,129188 & 0,489646 & 0,6250 \\
\hline \multicolumn{2}{|l|}{ V5 (item 17) } & \multicolumn{3}{|l|}{ V3 } & 0,166102 & 0,0734659 & 2,26094 & 0,0249 \\
\hline & & \multicolumn{3}{|l|}{ V4 } & 0,0499719 & 0,0728878 & 0,6856 & 0,4938 \\
\hline & & \multicolumn{3}{|l|}{\begin{tabular}{|l} 
V5 \\
\end{tabular}} & $-0,356619$ & 0,169353 & $-2,10577$ & 0,0366 \\
\hline \multicolumn{8}{|c|}{ Análisis de Varianza } & \\
\hline Fuente & \multicolumn{2}{|c|}{ Suma de Cuadrados } & Gl & \multicolumn{2}{|c|}{ Cuadrado Medio } & Razón-F & Valor-P & \\
\hline Modelo & \multicolumn{2}{|l|}{3,25884} & 5 & \multicolumn{2}{|c|}{0,651769} & 2,72 & 0,0215 & \\
\hline Residuo & \multicolumn{2}{|l|}{44,8862} & 187 & \multicolumn{2}{|c|}{0,240033} & & & \\
\hline Total (Corr.) & \multicolumn{2}{|l|}{48,1451} & 192 & & & & & \\
\hline
\end{tabular}

Gráfico 15: Resultados del factor de Visualización estática.

El valor de la variabilidad entre e inter grupos $(P=0,021)$ muestra una relación estadísticamente significativa entre las variables del factor de visualización con un nivel de confianza del 95,0\%. 
La correlación de las variables, tanto del factor de visualización dinámica (relaciones espaciales) como del análisis de proporción, con el factor de lectura de imagen no ofrece resultados significativos.

En este aspecto, no hemos encontrado ningún trabajo que relacione razonamiento espacial y razonamiento proporcional o alguno de ellos con la lectura de imagen, que nos permitiera hacer un estudio comparativo. Si bien la visualización y las relaciones espaciales son factores utilizados en las pruebas y textos consultados en el ámbito de la inteligencia técnica y la aptitud espacial, hemos comprobado que no se interpretan de igual manera en aspectos como la referencia y orientación espacial o los sistemas de representación.

Por lo general, las pruebas de referencia se basan en planteamientos gráficos específicos del sistema de representación divergente. Considerando que el sistema diédrico de representación plantea una imposibilidad fenoménica de la visión (Gamiz, 2003; Giménez Morell, 2010) o resulta distante de la realidad visual y requiere de un aprendizaje y entrenamiento en el ámbito de la geometría descriptiva (Otxotorena, 1996), parece concluyente la ausencia de interrelación entre las variables del factor de visualización dinámica así medido y su aplicación al análisis visual de la lectura de imagen.

La proporción aparece relacionada en una dirección distinta con aspectos del razonamiento matemático y en la actualidad solo hemos encontrado su relación con el proceso de percepción visual en el Test de Percepción de la Proporción (Carmiol, 2013). En nuestro caso, hemos adaptado los reactivos de las diferentes pruebas, sin la consideración del tiempo de respuesta y sin supervisión, posibilitando cálculos y medidas en los modelos planteados en los ítems. Creemos que esta variación de las condiciones en que se pasa la prueba ha podido anular la consistencia que los reactivos muestran en la prueba original.

Encontramos aquí reflejado el conflicto que parece existir a la hora de evaluar de manera conjunta dos factores contradictorios. Por un lado, los aspectos invariantes de la forma de la representación axonométrica que busca la simplicidad, y por otro lado, los aspectos 
variacionales de la percepción de la proporción que explican los cambios relativos de las formas y en los que la posición del observador juega un papel definitivo. En el modelo de relación lineal, son los ítems que plantean la posición del horizonte visual, V2 y V4, los que peor se comportan estadísticamente, siendo estos los que implican al observador.

Podemos concluir que la posición del observador no parece tener relevancia psicometrica en las operaciones mentales que realizamos en la visualización interna. Relacionar los aspectos variables del pensamiento visual con un modelo de representación invariante plantea problemas de significación estadística. No obstante, creemos de manera apriorística que el concepto de las relaciones espaciales no puede entenderse sin la capacidad de excluir o incluir al propio observador en el espacio. En este sentido, la capacidad descriptiva de los resultados permite extraer algunas conclusiones. 


\section{9.- Conclusiones y perspectivas de futuro}

Los aspectos del razonamiento espacial y variacional estan en estrecha relación a partir de la percepción visual. El pensamiento variacional aborda la explicación de las cosas que cambian con los conceptos de razón y función, pero su aplicación en la educación se relaciona cada vez más con otros factores no sólo matemáticos. La percepción de los cambios y la ley de constancia conviven en la construcción de nuestro pensamiento abstracto.

Sin embargo no se analizan estos aspectos conjuntamente, y tampoco los planteamos de manera conjunta en la enseñanza. Pero, en realidad, aprendemos a ver, relacionando aspectos como medidas, líneas, tensiones y formas, que traducimos con razonamientos y, a partir de su estabilidad, construimos modelos visuales de representación de la realidad. Ahora bien, hemos de considerar que todos los modelos son igual de válidos en el mundo personal representado y, por tanto, utilizar un solo modelo en la competencia visual supone dejar de lado otros. Pero eso es lo que estamos haciendo desde el planteamiento de los aspectos visuales de la inteligencia, eso que hemos convenido en denominar aptitud espacial.

Nuestro trabajo detecta y confirma la hipótesis planteada, en las dos pruebas realizadas, que los estudiantes del grado de educación no establecen una relación clara entre las referencias espaciales (perceptivas) y la formación de imágenes mentales. La falta de percepción de las líneas físicas de referencia espacial, y su correlación con la dificultad en posicionarse como espectador ante la modelo de la imagen, indican que las nociones de orientación espacial responden a un planteamiento teórico básico, y que su carácter experimental está poco desarrollado.

Consideramos que si planteamos dos niveles, uno físico de la realidad óptica y otro cognitivo de su representación, ambos tienen que guardar relación en la construcción interna que hacemos del mundo. Si bien existe un acuerdo en la comunidad científica respecto a que las personas realizamos similares operaciones mentales de razonamiento abstracto, este consenso parece que se diluye cuando se refiere al pensamiento visual. 
Los resultados confirman a su vez que los futuros docentes de educación básica, encuentran dificultades para vincular sus ejes de referencias espaciales en los sistemas de representación mental y gráfica, del que se deducen los cálculos de distancias, ángulos y dimensiones.

Ciertamente, podemos establecer en cualquier punto del espacio un eje de coordenadas espaciales, pero lo hacemos a un nivel de abstracción tal que no nos permite considerarnos a nosotros mismos en ese espacio creado. La dificultad que muestran los futuros docentes para analizar las tres líneas de confluencia en una esquina del aula debe hacernos pensar que algo se está haciendo mal. Hemos comprobado que no es una dificultad matemática en el concepto de ángulo, ni una dificultad en utilizar el sistema de representación estudiado. Se trata de una dificultad en operar en el espacio visual y poder relacionar el mundo que percibe con los diferentes modelos de representación gráfica.

La frase, que se atribuye a Dalí, "mirar es pensar" (cit. en Brites de Vila, y Almoño de Jenichen, 2008, p. 125), sugiere que la percepción de una forma no tiene una única solución en su representación (Pinker, 1997), de igual manera que no existe el pensamiento único. La ausencia de 'verdad' en los modelos representacionales de los diferentes sistemas de perspectiva, así como en la fotografía, debe impulsarnos a profundizar en los procesos cognitivos y de desarrollo de la habilidad visual, en vez de centrarnos en el aprendizaje de unos contenidos sesgados. La habilidad espacial entendida como la habilidad de reconocer piezas tridimensionales mediante plegado y desplegado de sus caras y el proceso de realizar mentalmente rotaciones (Zacks et al., 2000; De la Torre, 2011) es un aspecto de la inteligencia técnica que no debería condicionar los planteamientos educativos de la habilidad visual.

Por otra parte, en este modelo de sociedad de la comunicación, existe un interés en la comunidad científica por establecer un rizoma, un modelo epistemológico de la comunicación visual. Las siguientes áreas o nodos establecen el campo emergente de la comunicación visual, asumiendo que existen áreas adyacentes y que el carácter 
dinámico de este sistema permite solapar en importancia unas a otras (Moriarty, S. en Smith et al., 2011):

- Inteligencia / Cognición / Percepción Visual.

Alfabetización Visual (visual literacy).

- Diseño gráfico / Estética.

- Creatividad / Visualización.

- Cultura Visual / Semiótica Visual.

- Desempeño profesional: Fotografía, Cine, Vídeo, Internetmedia, Publicidad, Programación...

Resulta interesante destacar que el diseño gráfico no aparece como un rendimiento profesional, sino como un nodo más que puede aludir a diferentes profesiones. Adquiere aquí el sentido de graficidad (graphicacy) o alfabetismo gráfico, siendo que se define en el nivel de la alfabetización visual y más allá del ejercicio de una profesión concreta.

En este sentido, el diseño gráfico, la graficidad, pertenece al desempeño de los docentes de una manera especial, en cuanto que la educación se entiende por encima de cualquier disquisición como un acto de comunicación y esta área afecta a los aspectos visuales del proceso de enseñanza-aprendizaje y de comunicación visual. La necesidad de la alfabetización gráfica, entendida como la capacidad para construir imágenes, requiere de un proceso de aprendizaje que permita a su vez la reflexión sobre el propio conocimiento (Pozo y Perez, 2009). Algunos aspectos básicos de esta alfabetización se plantean en la educación básica y media, pero el conocimiento de los sistemas de representación gráfica se debe adquirir en la formación universitaria específica. Entendemos que el papel profesional del educador debe contemplar su formación gráfica básica y flexible, por su influencia en la posterior especialización gráfica de los futuros científicos, artistas o técnicos (gráficos, mapas, modelos, diseños...).

Es relativamente reciente la introducción en el currículo de contenidos en educación visual. Estamos añadiendo contenidos visuales y audiovisuales a la tradicional educación plástica (el siguiente es el digital) y al mismo tiempo reduciendo su carga horaria. La revolución audiovisual de la década de los 60 no parece superada (Aparici, 1992; Prieto, 2004), pero no es la falta de motivación docente 
la causa. Los estudiantes de nuestro estudio valoran negativamente su formación en este aspecto, pero de forma positiva la importancia de los contenidos del pensamiento visual.

Estamos inmersos en una convivencia de medios visuales que se alternan entre los contextos educativos más o menos abiertos. Los recursos audiovisuales más atractivos y los diseños gráficos más creativos no suelen encontrarse en los entornos educativos, y cuando lo están, pueden perder su riqueza expresiva para someterse a viejas formas de pasar información de los textos impresos o los discursos del aula. Aunque no hemos analizado el aspecto gráfico de los participantes, la producción de imágenes de los educadores se reconoce en general muy pobre, a tal punto que se puede hablar de una verdadera cultura oral (Prieto, 2004): "se logra una mayor relación de aprendizaje cuando un material es elaborado jugando al máximo las posibilidades comunicacionales del lenguaje en que está armado el mensaje y del medio a través del cual se ofrece" (p.5).

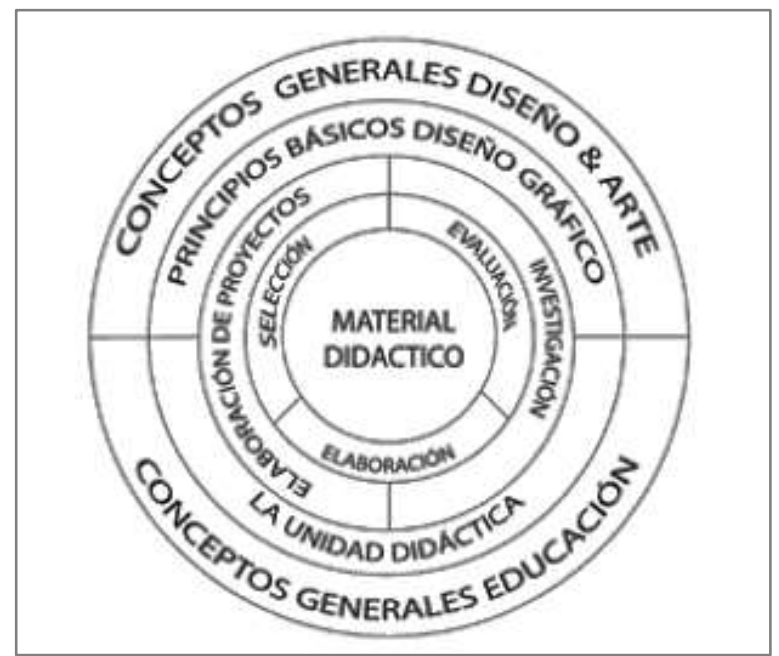

Fig. 111: Esquema del diseño de materiales didácticos (Moreno Rodríguez, 2009)

Se aprende más con una mejor elaboración de materiales didácticos. Pero en la propia percepción docente, la asociación que se hace de la graficidad con el diseño gráfico y el arte (fig.111), puede resultar en cierta medida contraproducente, en la medida que atribuimos el desarrollo de la habilidad al talento. Sin embargo, la formación artística del docente no es un requisito especialmente elevado, al tiempo que el concepto de habilidad gráfica en el arte se dispersa desde el propio cuestionamiento del dibujo, que se hace 
desde el paradigma figurativo e informal de las artes visuales. En este sentido, tanto la comprensión del arte contemporáneo como del diseño gráfico siguen siendo un reto en el entorno educativo (Paredes, 2011; Huerta, 2011; Moreno Montoro, 2007; Acaso, 2009; Moreno Rodríguez, 2009); y ello a pesar de la implicación de los artistas en algunos casos (Suárez et al., 2011).

La graficidad que afecta a la representación de formas y espacio, a la generación de modelos educativos, no parece estar más vinculada al arte de lo que puede estar la oratoria, como arte de hablar en público, que tanto caracteriza la labor docente. Al igual que ocurre con la influencia que han tenido el software de edición de texto en la producción literaria científica, los programas de tratamiento de imagen se están conduciendo en la consideración del arte en su manejo, para "rebautizar el arte, desmitificarlo y verlo en todo lo que nos rodea" (Ohler, 2003, p.7). Pero antes que arte, es conocimiento de la constitución de la imagen, que tiene un origen gráfico: unidades gráficas de información distribuida en un eje de coordenadas del formato.

El hecho de que Darley (2002) se pregunte en la conclusión de su libro sobre el lugar que ocupan y la función que tienen los efectos ópticos, nos sugiere que el análisis visual se encuentra detrás de la tecnología que producimos en nuestra cultura y permanece latente en el debate estético que el uso de la tecnología suscita.

Necesitamos resolver el paradigma artístico-científico de la representación. Aparici (1992) se hace eco de la queja de los profesores sobre sus estudiantes que, a la hora de producir sus propias imágenes, tienden a adoptar una actitud mimética de reproducción. Su reflexión nos recuerda de alguna forma, a la actitud de aquellos padres que quieren que sus hijos pequeños expresen en sus dibujos la profundidad de la perspectiva, cuando ellos mismos se reconocen incapaces de expresarla. Resaltemos que la capacidad gráfica, como otra habilidad, se desarrolla a lo largo de la vida y con diferentes finalidades, acompañando o no el itinerario educativo. El sector educativo está viendo cómo el sector empresarial le gana terreno en la difusión y el fomento de la competencia visual, a tenor del éxito de las obras de Roam (2010) y Sibbet (2013) sobre pensamiento visual. 
El pensamiento proporcional de los estudiantes de la muestra plantean un buen nivel en las tareas de asociación de números fraccionarios con proporciones lineales, aunque resulta algo menor, con las proporciones de superficie. Sin embargo, se muestra deficitario en el análisis de proporción de las imágenes.

La imagen digital moderna técnicamente tiene un fuerte componente de pensamiento computacional, de lógica de programación, que requiere de formación en procesos cognitivos y lenguajes que no están reñidos con la sensibilidad y la estética. Hemos apuntado en este trabajo a la necesidad de compaginar ambos procesos, el de la sensibilidad de la percepción y del gesto gráfico con el del pensamiento variacional y, en este sentido, creemos que se abre una vía de investigación para profundizar en las posibilidades gráficas de las nuevas tecnologías: el desarrollo de herramientas y aplicaciones en entornos móviles que entrenen en las habilidades del pensamiento visual.

La informática ya toca virtualmente todos los aspectos de la actividad humana. Su impacto en la sociedad se ve en la proliferación de sistemas de información, editores de texto, gráficos e imagen, hojas de cálculo, bases de datos y aplicaciones para hacer equipos más fáciles de usar y más productivos para las personas. Una parte importante del campo de la informática se ocupa de que la programación y el software sean más usables y fiables. Fundamentalmente se ocupa de crear el modelo adecuado para pensar en un problema y poder visualizarlo, abstraerlo y resolverlo de manera mecánica (Cooper et al., 2014). Si bien las máquinas nos ayudan en estos procesos, entendemos que comprenderlos es una tarea docente principal.

En este sentido, nos planteamos como un trabajo futuro el diseño y validación en distintos ámbitos educativos de un instrumento que registre la competencia visual, de visualización y razonamiento. Una aplicación multimedia adaptada a los diferentes niveles educativos y con un planteamiento interactivo que registre la respuesta inicial y permita introducir un feedback o respuesta para el aprendizaje. La expresión espontánea de algunos participantes tras cumplimentar el cuestionario nos ha mostrado una mezcla de 
extrañeza por algunas preguntas y su interés por las respuestas. Aunque no se hizo así para evitar contaminar la situación de evaluación, creemos que hubiera resultado más interesante y enriquecedor, aprovechando la oportunidad de su colaboración, ofrecerles una respuesta a su curiosidad en el mismo momento de la reflexión.

Asimismo, como una posible línea de investigación encontramos la (re)educación del gesto gráfico. En gran medida hemos evitado en este trabajo utilizar el término dibujo y lo hemos sustituido por el de gesto gráfico, aun sabiendo que éste adquiere las connotaciones de la escritura y, en demasiadas ocasiones, connotaciones y vínculos con la creatividad artística (Calbó, 2010), pero entendemos que es un gesto utilitario en el que se necesita profundizar. El estudio del control de la mayor o menor sensibilidad y coordinación en los desplazamientos visomotrices no es algo que se pueda asignar sólo al talento.

La habilidad visual y la destreza manual tienen un punto de encuentro con más posibilidades que las de la escritura y la geometría, sin desmerecer por ello su logro. Sin embargo, el sentido de eficacia y linealidad, que acompañan al aprendizaje de la escritura y del dibujo geométrico perjudica ciertos aspectos de sensibilidad y coordinación motriz que no están suficientemente desarrollados. Acometer la representación y el dibujo de modelos y gráficos, tanto en el ámbito científico como en el artístico, se relaciona con la sensibilidad perceptiva visual y requiere de un replanteamiento del gesto gráfico en su relación con la visualización.

No hemos encontrado ningún trabajo aplicado sobre la coordinación visomanual en este sentido, a la manera en que existen sobre la educación auditiva, de la voz o el canto. La propuesta de Edwards (1994) sobre la anticipación cognitiva en la coordinación visomanual según la actividad que se realiza aun hoy queda sin aplicación en la educación y esperemos que la tenga en los planteamientos de la incipiente neuroeducación. Esta anticipación cognitiva es atribuida al carácter dominante de las funciones verbales del hemisferio izquierdo. El procesamiento simbólico del lenguaje es inevitable, pero inhibe en parte el proceso de la percepción. Es probable que si existiera la consideración de este hecho en el 
aprendizaje de la escritura, el entrenamiento visomotor permitiría hacernos más conscientes de la percepción y poder discriminar mejor desde nuestra posición, las formas que nos rodean, las líneas que interpretamos y las texturas, consideradas por algunos autores como el principal elemento para la aprehensión del espacio (Gibson, 1974).

La percepción visual de las formas, en estrecha colaboración con nuestro pensamiento, se torna un proceso activo. No podemos conformarnos con la consideración de una materia física cohesionada, de una línea recta o de una superficie de color uniforme, cuando sabemos que no es así. Sin duda, podemos funcionar de una manera práctica y utilitaria, pero no porque nuestro pensamiento esté limitado a una respuesta adaptativa, sino porque éste se caracteriza por la capacidad de reflexión y creación.

Las relaciones espaciales tienen una singular relación con los esquemas internos de los ejes, la simetría, la orientación y la proporción, con mayor o menor preponderancia del punto de vista del sujeto que se reflejan en una interacción entre sus "cartas espaciales" y las de los objetos (Cabanellas y Hoyuelos, 1995, p.75). Esta interacción está mediada por pensamientos y sentimientos, que van a seleccionar y sintetizar el material cognitivo perceptual (Araújo, 2000). De ahí que los planteamientos gráficos adquieran independencia y estén en función de las intenciones que tengamos en la representación de los objetos y el espacio.

En un nivel operativo, nos planteamos la hipótesis de que la habilidad visual mejora el proceso de lectura y construcción de imágenes. Aunque los estudiantes responden de manera óptima a las pruebas de razonamiento espacial, no siempre tienen claras las referencias de su campo visual ante el planteamiento espacial de una imagen fotográfica. Aunque parecen reconocer el equilibrio formal (figura-fondo) y las líneas de fuerza de una imagen, muestran dificultades para la interpretación de la posición del autor de la imagen y la de ellos como espectadores. Confirmamos una relación entre los resultados negativos de la visualización estática y los del posicionamiento en la lectura de la imagen, que nos anima a sugerir que un entrenamiento visoperceptivo puede mejorar la interpretación de imágenes. 
La percepción visual del espacio está en la raíz de nuestra adaptación al medio y a nuestra capacidad de modificarlo contribuye su representación. Permítasenos insistir en que, habiendo pasado los mejores años de nuestra vida, en términos de plasticidad cerebral y de aprendizaje, dentro de un aula, por lo general planteemos problemas para su representación. Convivimos la mayor parte del día en paralelepípedos (construcciones formadas por seis paralelogramos, iguales y paralelos los opuestos entre sí) pero nos cuesta representar estos espacios y nuestra relación con ellos.

Consideramos que esta situación es indicadora de un problema de conexión de la actividad educativa con la realidad inmediata, la cual permite explicar gran parte de los contenidos experimentales. Pero también un problema cognitivo, en la medida que postergamos los aspectos visuales en la construcción del pensamiento, y dejamos que el texto explique aquello que no puede explicar.

La consideración equilibrada de las dos formas de procesamiento, visual y verbal, nos permite diferenciar una imagen, una poesía o una canción, de los enunciados lógicos del lenguaje práctico. De alguna manera sabemos que la utilidad del lenguaje sacrifica la capacidad de estos lenguajes de apelar directamente a nuestra sensibilidad, sentimientos y emociones: "el lenguaje visual puede transmitir hechos e ideas con un margen más amplio y más profundo que otro medio de comunicación" (Kepes, 1976, p. 23).

Considerando solo el aspecto lineal del procesamiento verbal, en ocasiones adjudicamos la lectura de lo visual a un proceso subjetivo. La interpretación de las imágenes no es un proceso lineal y plantea una compleja relación entre lo definido por la realidad tridimensional, la percepción, la imagen mental y su representación bidimensional (fig. 112): 


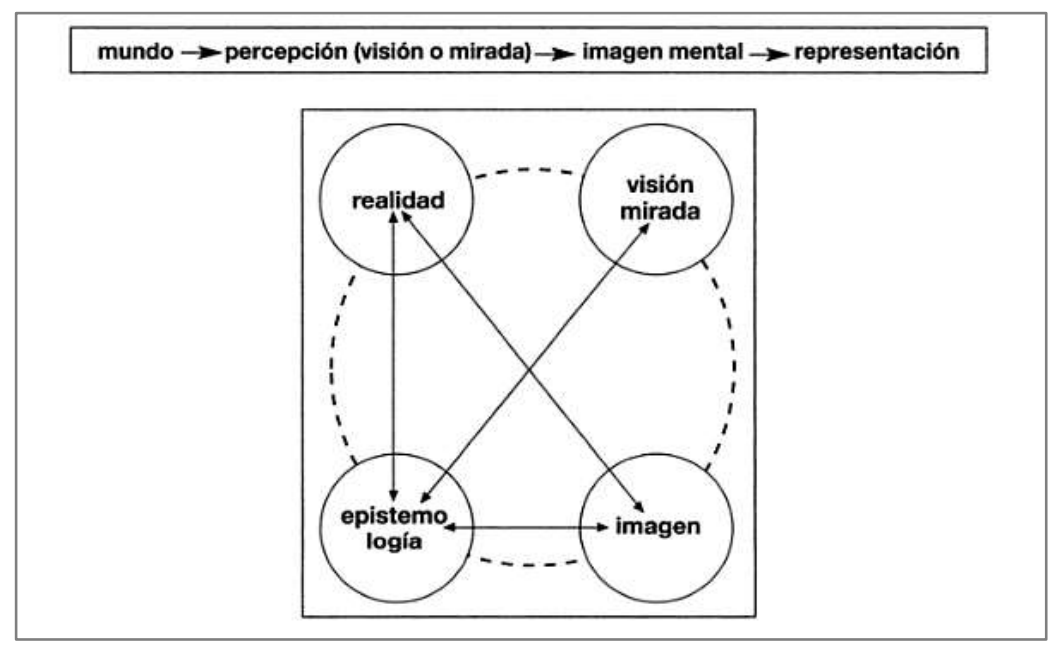

Fig. 112: La imagen compleja (Català Domènech, 2005)

Solemos decir que las personas 'vemos' las cosas de distinta manera. Pero esta afirmación vale tanto para lo netamente visual como para nuestros pensamientos e interpretaciones. A pesar del aspecto cambiante de los elementos implicados en el proceso de la visión, a pesar de las modificaciones que cualquiera de los polos del esquema de la figura 112 puede producir en los demás, la consideración de verdad, tanto en la realidad como en nuestras cogniciones y representaciones gráficas, tiene los mismos parámetros que los que establecemos en el lenguaje.

Consideramos que estos parámetros no están tan claramente establecidos y difundidos como ocurre en la gramática. Es posible que esta falta de definición produzca el efecto de asociar la lectura e interpretación de las imágenes con procesos subjetivos y artísticos: "se trata de saber cómo diferenciamos las imágenes del mundo (real) de las imágenes de nuestra concepción del mundo. De manera que no caigamos en la tentación de adjudicar las primeras a la ciencia y las segundas al arte, sin darnos cuenta de que las dosis de ciencia y arte están presentes tanto en unas como en otras" (Català Domènech, 2005, p.204).

Nos preguntarnos en qué medida cuestionamos el sentido de verdad, en cuanto explicación de la realidad, en el caso de que esta explicación se nos muestre a través de un modelo visual y no textual. 


\section{Referencias bibliográficas.}

Abramowski, A. (2009). El lenguaje de las imágenes y la escuela: ¿es posible enseñar y aprender a mirar? Revista Monitor de la Educación, núm. 13. Buenos Aires: Ministerio de Educación.

Acaso, M. (2006). El lenguaje visual. Barcelona: Paidós.

Acaso, M. (2000). Simbolización, expresión y creatividad: tres propuestas sobre la necesidad de desarrollar la expresión plástica infantil. Arte, individuo y sociedad, (12), 41-60.

Acaso, M. (2009). La educación artística no son manualidades. Madrid: Catarata.

Acosta, J. A., Rondero, C. y Tarasenko, A. (2010). La resignificación de la noción de linealidad. En: Lestón, P. (Ed.), Acta Latinoamericana de Matemática Educativa, 65-73.

Acosta, J. A. (2011). Análisis epistemológico, cognitivo y sociocultural de la noción de linealidad. Tesis doctoral no publicada. Centro de Investigación en Ciencia Aplicada y Tecnología Avanzada-Instituto Politécnico Nacional. México D.F.

Acosta, J. A., Rondero, C. y Tarasenko, A. (2013). Las nociones de linealidad y promediación como elementos articuladores en la didáctica. En Lestón, Patricia (Ed.), Acta Latinoamericana de Matemática Educativa, 99-107.

Adánez, G. P. y Vega, J. L. (1981). Cambios cuntitativos en la evolución estructural de la inteligencia. Estudios de Psicología, (7), pp. 15-28.

Aguaded, J. I. y Pérez, M. A. (1995). La imagen de la imagen. Comunicar: Revista Científica de Comunicación y Educación, 2(4), 64-69.

Cabanellas, M. y Hoyuelos, A. (1995). Sentimiento, pensamiento y acción en el dibujo del natural. Revista interuniversitaria de formación del profesorado, (24), 65-82.

Aiken, L. R. (2003). Tests psicológicos y evaluación. México: Pearson Educación.

Alaminos, A. y Castejón, J. L. (2006). Elaboración, análisis e interpretación de encuestas, cuestionarios de escalas de opinión. Alicante: Marfil. 
Albers, J. (1979). La interacción del color. Madrid: Alianza Forma.

Alvarez-Duque, M. E., Vega, O. y Viñals, F. (2003). Aproximación neurocognitiva de las alteraciones de la lecto-escritura como base de los programas de recuperación en pacientes con daño cerebral. Revista española de neuropsicología, 5(3), 227-249.

Alonso, Á. y Bermúdez, T. (2002). De conejos y números. La sorprendente sucesión de Fibonacci. Gaceta de la Real Sociedad Matemática Española, 5(1), 175-196.

Alonso, C. Gallego D. y Honey, P. (1994). Los Estilos de Aprendizaje: Procedimientos de diagnóstico y mejora. Bilbao: Ediciones Mensajero

Anderson, J. R. y Bower, G. H. (2014). Human associative memory. Washington D. C.: Winston y Sons.

Anderson, J. R. (2013). Language, Memory, and Thought. New York: Psychology Press.

Anderson, L. et al (2001). A Taxonomy for Learning, Teching, and Assessing A Revision of Bloom's: Taxonomy of Educational Objectives. New York: Addison Wesley Longman.

Aparici, R. y García Matilla, A. (1987). Lectura de imágenes. Madrid: Ediciones de la Torre.

Aparici, R. (1992). La educación para los medios de comunicación. European conference about information technology in education: a critical insight. Barcelona, Congreso TIE (p. 546).

Aparici, R. y García Matilla, A. (2008). Lectura de imágenes en la era digital. Madrid: Ediciones de la Torre.

Aparici, R. (Coord.) (2013). Conectados en el ciberespacio. Madrid: Editorial UNED.

Apellániz, J.M. (2001). La abstracción en el arte figurativo del Paleolítico: Análisis del componente abstracto en la figuración naturalista del grafismo paleolítico. Bilbao: Universidad de Deusto.

Aragón, L.E. (2015). Evaluación psicológica: Historia, fundamentos teóricoconceptuales y psicometría. Bogotá: Editorial El Manual Moderno.

Aranda, R. (2008). Atención temprana en educación infantil. Madrid: Wolters Kluwer. 
Araújo, I. (2000). La percepción. El dibujo y la visión. Arte, Individuo y Sociedad, (12), 273-280.

Arcavi, A. (2003). The role of visual representations in the learning of mathematics. Educational studies in mathematics, 52(3), 215241.

Ardila, A. A. y Ostrosky-Solís, F. (2008). Desarrollo histórico de las funciones ejecutivas. Revista Neuropsicología, Neuropsiquiatría y Neurociencias, 8(1), 1-21.

Arias, B. (2008). Desarrollo de un ejemplo de análisis factorial confirmatorio con LISREL, AMOS y SAS. Publicaciones del INICO, actas 52008 , p. 75.

Armillas, J.A. (2000) Introducción a la Historia Moderna (coautor). Madrid: Istmo-Akal.

Arnheim, R. (1979). Arte y percepción visual. Barcelona: Paidós.

Arnheim, R. (1986/1998). El pensamiento visual. Barcelona: Paidós.

Arrieta, M. (2003). Capacidad espacial y educación matemática: tres problemas para el futuro de la investigación. Educación Matemática, 15(3), 57-76.

Arterberry, M. E. (2008). Perceptual development. Encyclopedia of Infant and Early Childhood Development, 522-531.

Artigas, J.M. (2002). Fundamentos de colorimetría. Publicaciones de la Universitat de València.

Artigas, J.M., Capilla, P., y Pujol i Ramo, J. (2002). Tecnología del color. Publicaciones de la Universitat de València.

Atalay, B. (2008). Las Matemáticas y la Mona Lisa: el arte y la ciencia de Leonardo da Vinci. Cordoba: Almuzara.

Aumont, J. (1992). La imagen. Barcelona: Editorial Paidós.

Baddeley, A.D. (1997). Human Memory: Theory and Practice. New York: Psychology Press.

Badillo Jiménez, E., Font, V., Martínez, M. y Figueiras, L. (2013). Visualización gráfica y análisis comparativo de la práctica matemática en el aula. Enseñanza de las ciencias, Vol. 31, 207-225. 
Bal, M. (2004). El esencialismo visual y el objeto de los Estudios Visuales. Estudios visuales: Ensayo, teoría y crítica de la cultura visual y el arte contemporáneo, (2), 11-50. Murcia: CENDEAC.

Balchin W. and Coleman W. (1965) Graphicacy should be the Fourth Ace in the Pack. Times Educational Supplement, 3. Londres: TES Global.

Ballester C. (2012) Educación audiovisual en la escuela: un enfoque práctico. En: Carpio Castaño, E. (Coord.). Formas de expresión y creaciones propias. La competencia cultural y artística. Madrid: Ministerio de Educación (pp.129-140).

Ballesteros, S. (1993). Representaciones analógicas en percepción y memoria: imágenes, trasformaciones mentales y representaciones estructurales. Psicothema, 5(1), pp. 5-17.

Ballesteros, S. (1993). Percepción háptica de objetos y patrones realzados: una revisión. Psicothema, 5(2), pp. 311-321.

Ballesteros, S. (1999). Memoria humana: investigación y teoría. Psicothema, 11(4), pp.705-723.

Ballesteros, S. (2014). Cognitive Approaches to Human Perception. New york: Psychology Press.

Basogain, X., Olabe, M., Espinosa, K., Rouèche, C. y Olabe, J.C. (2007). Realidad Aumentada en la Educación: una tecnología emergente. $7^{a}$ Conferencia Internacional de la Educación y la Formación basada en las Tecnologías. Madrid:ONLINE EDUCAMADRID'2007 Proceedings (pp.24-29).

Barsalou, L. (1999). Perceptual symbol systems. Behavioral and Brain Sciences, 4(22), 577-660.

Barthes, R. (1990). La aventura semiológica. Barcelona: Paidós.

Barthes, R. (2009). La Cámara Lucida. Barcelona: Paidós.

Baudrillard, J. (2000). Pantalla total. Barcelona: Anagrama.

Bayo, J. (1987) Percepción, desarrollo cognitivo y artes visuales. Barcelona: Anthropos.

Beattie, J. A. (2011). Un acercamiento al pensamiento creativo en el campo de las letras. Piedra de Toque, (1), pp. 68-83. 
Bellido, M. L. (2007). Fotografía y artes plásticas: un siglo de interrelaciones 1837-1937. En Quintas Jornadas Imagen, Cultura $y$ Tecnología (pp. 255-264). Madrid: Editorial Archiviana.

Beltrán J. y Beltrán J.M. (2011). Material didáctico en el espacio real y en 3d virtual para el estudio del sistema diédrico y las perspectivas. Grupo de Investigación Comunicación Visual HUM 228. Universidad de Granada. Disponible en url: http://digibug.ugr.es/bitstream/10481/13804/17/Material\%20di d\%C3\%A1ctico.pdf

Belting, H. (2012). Florencia y Bagdad: Una historia de la mirada entre Oriente y Occidente. Madrid: Ed. Akal / Estudios Visuales.

Benarroch, A., Mingorance, Á., Ortiz, J. y Rico, A. (2009). Los planes de estudio en la formación del maestro en Educación Primaria en el Espacio Europeo de Educación Superior. Un estudio empírico para conocer de dónde venimos y adónde vamos. Publicaciones, 39, pp. 135-160. Universidad de Granada.

Ben-Chaim, D., Keret, Y. y llany, B. (2012) Ratio and Proportion: Research and Teaching in Mathematics Teachers' Education. Rotterdam: Springer Science \& Business Media.

Bender, L. (1977). Test Guestáltico Visomotor. Usos y Aplicaciones Clínicas. Buenos Aires: Paidós.

Bennasar. B. (1985). Pintura de paisaje en Mallorca durante la segunda mitad del siglo XIX. Mayurqa, (21), pp. 303-323.

Benton, A.L. (1981). Test de retención visual. Madrid: TEA.

Bermejo, V. (1981). Investigaciones sobre la constancia visual del tamaño. tendencia y estrategias experimentales. Anuario de psicología/The UB Journal of psychology, (24), pp. 57-84.

Bernard, C. (1865; 1960). Introducción a la medicina experimental $2^{\underline{a}}$ ed. J.J. Izquierdo (trad.). Mexico: UNAM.

Bernson, M. (1962). Del garabato al dibujo. Buenos Aires: Kapelusz.

Berthelot, R. y Salin, M. H. (1994a). L'enseignement de la géométrie à l'école primaire. Grand N, 53, pp. 39-56. Grenoble.

Berthelot, R. y Salin, M. H. (1994b). Un processus d'enseignement des angles au cycle III. Grand N, 56, pp. 69-116. Grenoble

Beuchot, M. (2013). La semiótica: teorías del signo y el lenguaje en la historia. Mexico: Fondo de Cultura Económica. 
Biggio, M.N., Vázquez, S.M. y García, S.M. (2011). Componentes de la competencia espacial. Exploración en ingresantes a la Facultad de Arquitectura, diseño y urbanismo. Revista de Orientación Educacional, 25, (47), pp. 95-112.

Binet, A. (1902/2015). La Psicología del Razonamiento: Investigaciones experimentales por el hipnotismo. Aigle: Éditions FV.

Binet, A. (1985). Las ideas modernas acerca de los niños. México: Fondo de Cultura Económica

Birkerts, S. (1999). Elegía a Gutenberg: el futuro de la lectura en la era electrónica. Madrid: Alianza Editorial.

Bisquert, A. (1977). Las artes plásticas en la escuela. INCIE, Instituto Nacional de Ciencias de la Educación. Madrid: Servicio de publicaciones del Ministerio de Educación y Ciencia.

Bloom et al. (1977) Taxonomía de los Objetivos de la Educación. Buenos Aires: El Ateneo.

Bohorquez, H. J., Boscán, L. F., Hernández, A. I., Salcedo, S., y Morán, R. (2009). La concepción de la simetría en estudiantes como un obstáculo epistemológico para el aprendizaje de la geometría. Educere, 13(45), pp. 477-489.

Borowski, E. J. y Borwein, J. M. (2002). Collins dictionary of mathematics. London: Harper Collins.

Bouleau, C (1996) Tramas: La geometría secreta de los pintores. Madrid: Ediciones Akal.

Brea, J. L. (2005). Estudios visuales (Vol. 1). Madrid: Ediciones Akal.

Brites de Vila, G. y Almoño de Jenichen, L. (2008, 5ªE.). Inteligencias múltiples. Buenos Aires: Bonum

Bruner, E., De la Cuétara, J.M, Colom, R., Martin-Loeches, M. (2012). Gender-based differences in the shape of the human corpus callosum are associated with allometric variations. Journal of Anatomy, 220,417-421.

Bruner, J. S. (1988). Desarrollo cognitivo y educación. Madrid: Morata.

Bruner J.S., Goodnow, J. y Austin, G. (2001) El proceso mental en el aprendizaje. Madrid: Narcea. 
Bunge, M. (2000). La investigación científica: su estrategia y su filosofía. Buenos Aires: Siglo XXI.

Burin, D. I., Barreyro, J. P. y Duarte, D. A. (2004). Memoria de trabajo, razonamiento y visualización espacial. En XI Jornadas de Investigación. Facultad de Psicología-Universidad de Buenos Aires. Disponible en url: http://www.aacademica.com/000029/280

Byrne, R. M. y Johnson-Laird, P. N. (1989). Spatial reasoning. Journal of memory and language, 28(5), pp. 564-575.

Byrnes, J.P. y Fox, N. (1998).The educational relevance of research in cognitive neuroscience. Educational Psychology Review, 10(3), pp. 297-342.

Caballero, P. A. (2002). Desarrollo de la representación espacial. EduPsykhé: Revista de psicología y psicopedagogía, 1(1), pp. 41-68.

Cabanyes, J. (2000). Percepción normal y patológica: una aproximación a sus implicaciones pedagógicas. Revista complutense de educación, vol. 11, num.1, pp. 15-37.

Cacheiro, M.L. (2014) Educación y Tecnología: Estrategias didácticas para la integración de las TIC. Madrid: Editorial UNED.

Calbet, J. y Castelo, L. (1997) La Fotografía. Madrid: Acento editorial.

Calbó, M. (1997). ¿Tienen que dibujar los estudiantes en la clase de didáctica del arte? Arte, Individuo y Sociedad, (9), 33. Madrid: Universidad complutense.

Calbó, M. (2010). Dibujo didáctico. Girona: CiDd, II Congrés Internacional de Didàctiques. Disponible en url: http://hdl.handle.net/10256/2800

Calmy, G. (1977). La educación del gesto gráfico. Barcelona: Fontanella.

Calvo Serraller, F. (2014). El arte contemporáneo. Madrid: Taurus.

Camacho y Zulueta, S. (2009). Daguerrotipo. Alquimia, (38), pp. 30-34.

Cano García, M.E. (2008). La evaluación por competencias en la educación superior. Revista de curriculum y formación de profesorado, 12(3), pp.1-16. 
Cánovas, R. (2011) Estudio de la memoria y la orientación espacial en el ser humano. Tesis Doctoral. Universidad Almería.

Cañizares, M. J. y Batanero, C. (1997). Influencia del razonamiento proporcional y de las creencias subjetivas en la comparación de probabilidades. Uno: Revista de didáctica de las matematicas, (14), pp. 99-114.

Carlson, N.R. (2006). Fisiología de la conducta. México: Pearson educación.

Carlson, N.R. (1996). Fundamentos de Psicología Fisiológica. México: Pearson educación.

Carmiol, V. M. (2013). Desarrollo y validación de una prueba de percepción de la proporción visual. Tesis doctoral. Depto. de Métodos de Investigación y Diagnóstico en Educación. Universidad de Valencia.

Carrillo-Mora, P. (2010). Sistemas de memoria: reseña histórica, clasificación y conceptos actuales. Segunda parte: sistemas de memoria de largo plazo: memoria episódica, sistemas de memoria no declarativa y memoria de trabajo. Salud mental, 33(2), pp. 197-205.

Castañer, M. y Camerino, O. (2006). Manifestaciones básicas de la motricidad. Edicions de la Universitat de Lleida.

Castillo, J.M. (2012). La composición de la imagen. Madrid: Editorial Paraninfo.

Català Domènech, J.M. (2011). La forma de lo real. Introducción a los estudios visuales. Barcelona: Editorial UOC.

Català Domènech, J.M. (2005). La imagen compleja: la fenomenología de las imágenes en la era de la cultura visual. Barcelona: Servei de publicacions de la Universidad Autónoma.

CE (2006). Recomendación del Parlamento Europeo y del Consejo de 18 de diciembre de 2006 sobre las competencias clave para el aprendizaje permanente (2006/962/CE). Diario Oficial de la Unión europea, (30 diciembre).

Cerro Jiménez, S. (2010) Grafología Pedagógica Aplicada a la Orientación Vocacional. Madrid: Narcea Ediciones.

Chaparro A. (Ed.) (2006) Los límites de la estética de la representación. Bogotá: Universidad del Rosario. 
Chase, H.W., Clark, L., Myers, C.E., Gluck, M.A., Sahakian, B.J., Bullmore, E.T. y Robbins, T.W. (2008). The role of the orbitofrontal cortex in human discrimination learning. Neuropsychologia, 46 (5), 1326-1337.

Chevallard, Y. (1991) La transposición didáctica: del saber sabio al saber enseñado. Buenos Aires: Aique.

Ching, Francis D.K. (1999) Dibujo y proyecto. México: Gustavo Gili.

Chipp. H.B. (1995) Teorías del arte contemporáneo. Madrid: Ediciones Akal.

Chiron, C., Jambaque, I., Nabbout, R., Lounes, R., Syrota, A. y Dulac, O. (1997). The right brain hemisphere is dominant in human infants. Brain, 120(6), pp. 1057-1065.

Chomsky, N. (1981). Problemas actuales en teoría lingüística: temas teóricos de gramática generativa. Buenos Aires: Siglo XXI.

Civarolo, M., Amblard de Elía, S. y Cartechini, S. (2010) Bleichmar, Gardner y Piaget : apreciaciones sobre la inteligencia. Córdoba: Eduvim.

Codina, M., Vidal, J., Rodán, A., García, M., Gimeno, P., Javaloyes, B., Muiños, M. y Rifá, M. (2009). Training activities for visualperceptual skills. Visual-sequential memory (Basic Level). Solutions for Learning and Research, SL (SEARA). Disponible en url: http://www.saera.es

Colom Marañón, R. y Andrés-Pueyo, A (1999). El estudio de la inteligencia humana: recapitulación ante el cambio de milenio. Psicothema, 11, (3), pp. 453-476.

Coffield, F., Moseley, D., Hall, E. y Ecclestone, K. (2004). Learning styles and pedagogy in post-16 learning: A systematic and critical review. Disponible en url: http://sxills.nl/lerenlerennu/bronnen/Learning\%20styles\%20by $\% 20$ Coffield\%20e.a..pdf

Coll, C. y Monereo, C. (2008). Psicología de la educación virtual. Madrid: Morata.

Consejo Europeo (2009). Conclusiones sobre un marco estratégico para la cooperación europea en el ámbito de la educación y la formación (ET 2020). Diario Oficial de la Unión Europea, 2009C 119/2.

Contreras Domingo, J. y Perez, N. (2010). Investigar la experiencia educativa. Madrid: Morata. 
Contreras González, N. (2013). Manual para la exploracion neurologica y las funciones cerebrales superiores. México: manual moderno.

Cooper, L.A. y Hochberg, J. (2014). Objects of the mind: mental representations in visual perception and cognition. En: Ballesteros, S. (1994/2014). Cognitive Approaches to Human Perception. New York: Psychology Press.

Cooper, S., Bookey, L., y Gruenbaum, P. (2014). Future Directions in Computing Education Summit Part One: Important Computing Education Research Questions. Technical Report CS-TR-140108-SC, Stanford University.

Correa Pabón, G. (2010). Teoría de la proporción pitagórica. Escritos, 14(33), pp. 600-617.

Corry, L. (1994). La teoría de las proporciones de Eudoxio interpretada por Dedekind. Mathesis. Filosofía e Historia de las Matemáticas, 10(1), pp. 1-24.

Costa, J. y Moles, A. (1992). Imagen Didactica. Barcelona: Ceac.

Cowan, J. y George, J. (2004). A Handbook of Techniques for Formative Evaluation: Mapping the Students' Learning Experience. London: RoutledgeFalmer.

Cramer, K. y Post, T. (1993). Proportional reasoning. The Mathematics Teacher, 86(5), pp. 404-407.

Crary, J. (2008). Las técnicas del observador. Visión y modernidad en el siglo XIX. Murcia: Cendeac.

Cuatrecasas, J. (1981). Psicología de la percepción visual (Vol. 4). Buenos aires: Ediciones Tres Tiempos.

Cubero, R. (2005). Perspectivas constructivistas: La intersección entre el significado, la interacción y el discurso. Barcelona: Grao.

Cuenca, A. M. (1997). El área de educación artística-plástica en la escuela infantil y primaria y en los diseños para la formación del profesorado. Tendencias pedagógicas, (3), 99-106.

CUE (2010): Informe conjunto de 2010 del Consejo y de la Comisión sobre la puesta en práctica del programa de trabajo «Educación y formación 2010». Diario Oficial de la Unión Europea, 2010/C $117 / 01$.

Danos, X., Norman, E.W.L. (2009). The development of a new taxonomy for graphicacy. The Design and Technology Association 
International Research. Loughborough University. Disponible en url: https://dspace.lboro.ac.uk/dspacejspui/bitstream/2134/5100/1/XDanos.pdf

Darley, A. (2002). Cultura visual digital. Barcelona: Paidós

Darling-Hammond y Bransford, J. (2007). Preparing Teachers for a Changing World: What Teachers Should Learn and Be Able to Do. San Francisco: John Wiley \& Sons.

Davido, R. (2006). Descubra a su hijo a través de sus dibujos. Málaga: Ed. Sirio.

Da Vinci, L. (2011) El tratado de la pintura. Valladolid: Editorial Maxtor.

Debray, R. (1994) Vida y muerte de la imagen. Historia de la mirada en occidente. Barcelona: Paidós.

De la Torre, J., Martin, N., Saorín, J. L., Carbonell, C. y Contero, M. (2013). Entorno de aprendizaje ubicuo con realidad aumentada y tabletas para estimular la comprensión del espacio tridimensional. RED. Revista de Educación a Distancia. Número, 37.

De la Torre, J., Navarro, R., Saorín, J. L., Carbonell, C. y Contero, M. (2011). Rediseño y Validación de niveles de un curso intensivo de mejora de habilidades espaciales. XIX Congreso Universitario de Innovación Educativa en las Enseñanzas Técnicas.

Deleuze, G. (2005). Lógica del sentido. Barcelona: Editorial Paidós.

Delval, J. (2002) El desarrollo humano. Madrid: Siglo XXI.

DeSeCo, Informe. (2003). OCDE-CERI. Definition and selection of competencies. Theoretical and conceptual foundations: strategy paper on key competencies. Disponible en: http://mt.educarchile.cl/MT/jjbrunner/archives/libros/Competen cias/OECD2005.pdf

Díaz Padilla, R. (2007) El dibujo del natural. Barcelona: Ediciones AKAL.

Diccionario de la lengua española, 22 $2^{\mathrm{a}}$ edición. (2014). Real Academia Española, REA. Madrid: Espasa

Dondis, D.A. (2008). La sintaxis de la imagen. Barcelona: Gustavo Gili.

Dossi, P. (2007). Hype! Kunst und Geld. Munich: Deutscher Taschenbuch Verlag. 
Douady, R. y Parzysz, B. (1998). Geometry in the classroom. Perspectives on the teaching of Geometry for the 21st Century (pp. 159192). Springer Netherlands.

Drubach, D., Benarroch, E. E. y Mateen, F. J. (2007). Imaginación: definición, utilidad y neurobiología. Rev Neurol, 45(6), pp. 353358.

Dunn, R. y Dunn, K. (1984). La enseñanza y el estilo individual del aprendizaje. Madrid: Anaya.

Dussel, I., Abramoswski, A., Igarzábal, B. y Laguzzi, G. (2010). Aportes de la imagen en la formación docente. Abordajes conceptuales y pedagógicos. Instituto nacional de formación docente. Proyecto red de Centros de actualización e innovación educativa (C.A.I.E).

Dussel, I. y Gutierrez, D. (2010). Educar la mirada: políticas y pedagogías de la imagen. Buenos Aires: Ed. Manantial.

Echavarri, M., Carlos Godoy, J. y Olaz, F. (2007). Diferencias de género en habilidades cognitivas y rendimiento académico en estudiantes universitarios. Universitas Psychologica, 6(2), 319-329.

Eco, U. (2012). La estrategia de la ilusión. Barcelona: Debolsillo.

Eco, U. (2011). La estructura ausente. Barcelona: Debolsillo.

Edwards, B. (1994). Aprender a dibujar con el lado derecho del cerebro. Barcelona: Urano.

Edwards, B. (2012). Drawing on the Artist Within. New York: Simon and Schuster.

Edwards, B. (2013). Drawing on the Right Side of the Brain: A Course in Enhancing Creativity and Artistic Confidence. London: Souvenir Press.

Eisner, E. W. (1995). Educar la visión artística. Barcelona: Paidós.

Eisner, E. W. (2004). El arte y la creación de la mente: el papel de las artes visuales en la transformación de la conciencia. Barcelona: Paidós.

Eisner, E. y Day, M. (2004). Handbook of Research and Policy in Art Education. New Jersey: Lawrence Erlbaum Associates. 
Ekstrom, R., French, J. y Harman, H. (1976). Manual for kit of factor referenced cognitive tests (pp. 109-113). Princeton, NJ: Educational Testing Service.

Elam, K. (2006). Sistemas reticulares. Barcelona: Gustavo Gili.

Elorza I. y Carbonell, O. (2010). Análisis textual en la comunicación intercultural. Actas del Congreso Internacional de Topografías del lenguaje entre culturas. Salamanca: Ed. Universidad.

Embretson, S. (2013). Test design: Developments in psychology and psychometrics. London: Academic Press.

Escaño, C. (2010). Hacia una educación artística 4.0. Arte, Individuo y Sociedad, 22(1), 135-144.

Escarza, S., Castro, S. M. y Martig, S. R. (2008). Desafíos en el camino desde el Modelo Unificado Visualización hasta la construcción de visualizaciones. $X$ Workshop de Investigadores en Ciencias de la Computación, pp. 297-300.

Escudero, T. y Lacasta, E. (1984). Las actitudes científicas de los futuros maestros en relación con sus conocimientos. Enseñanza de las Ciencias, Vol. 2, pp. 175-180.

Escudero, T. (1975). Las actitudes en la enseñanza de las ciencias: un panorama complejo. Revista de educación, 5, pp.236-241.

Espel, M. (2013). El mercado del arte: reflexiones y experiencias de un marchante. Gijón: Ediciones Trea.

Estany, A. (1993). Introducción a la filosofía de la ciencia. Barcelona: Editorial Crítica.

Etayo, F. (2009). La geometría de la representación visual. Revista de la Real Academia de Ciencias Exactas, Físicas y Naturales, 103(2), pp. 297-304.

Etchepareborda, M. C. y Abad-Mas, L. (2005). Memoria de trabajo en los procesos básicos del aprendizaje. Rev Neurol, 40 (Supl 1), pp. S79-S83.

EURYDICE (2002). Key Competencies: A Developing Concept in General Compulsory Education (Vol. 5). Madrid: Ministerio de Educación. CIDE.

Evamy M. (2003). Graphics Explained: 7 Top Designers, 7 Briefs, 49 Solutions... in Their Own Words. Amazon. 
Extremiana, J. I., Hernández, L. J. y Rivas, M. T. (2005). La divina razón de la belleza. Sigma: revista de matemáticas (Matematika aldizkaria), (27), pp. 145-178.

Farías, F. (2009). La epistemología de las ciencias sociales en la formación por competencias del pregrado. Cinta de moebio, (34), pp. 5866.

Febvre L. y Martin H. (1971). L'apparition du livre. Paris: Les Editions Albin Michel.

Fernández, H. (2013). Memoria humana (1ra. parte) estructuras y procesos: el modelo multi-almacén. Psicología y Psicopedagogía, 1(4).

Fernández, T., Pegito, J. A. C. y Godino, J. D. (2008). Configuraciones epistémicas y cognitivas en tareas de visualización $y$ razonamiento espacial. En Investigación en educación matemática: comunicaciones de los grupos de investigación del XI Simposio de la SEIEM, celebrado en La Laguna del 4 al 7 de septiembre de 2007 (pp. 189-198). Sociedad Española de Investigación en Educación Matemática, SEIEM.

Fernández Ballesteros, R. (1995). Mariano Yela: práctica y teoría, una sintesis personal. Revista de psicología general y aplicada: Revista de la Federación Española de Asociaciones de Psicología, 48(4), 485-496.

Fernández Blanco, T. (2013). La investigación en visualización y razonamiento espacial. Pasado, presente y futuro. En: Berciano, A., Gutiérrez, G., Climent, N. y Estepa, A. (Eds.). Investigación en Educación Matemática XVII. (XVII Simposio de SEIEM), pp.19-42. Bilbao: Sociedad Española de Investigación en Educación Matemática (SEIEM).

Fernández García, E., Gardoqui, M.L. y Sánchez, F. (2007). Evaluación de las habilidades motrices básicas: determinación de escalas para la evaluación de desplazamientos, giros y manejo de móviles. Madrid: INDE.

Fernández March, A. (2008). La gestión de la formación del profesorado en la universidad. Teoría de la educación, (20), pp. 275-312.

Fenández, T., Cajaraville, J.A. y Godino, J.D. (2008). Configuraciones epistémicas y cognitivas en tareas de visualización y razonamiento espacial. Investigación en educación matemática: comunicaciones de los grupos de investigación del XI Simposio de la SEIEM, La Laguna, 4 al 7 de septiembre de 2007 (coord.) M. Camacho, P. Flores, y M.P. Bolea, 2008, ISBN 978-84-612-5856-7, p. 189-198. Sociedad Española de 
Investigación en Educación Matemática. Simposio (11. 2007. La Laguna)

Fernández Pulido, R..(2008). Modelos de medida y análisis factorial confirmatorio. Publicaciones del INICO, actas 5-2008, p. 29.

Fernández Serrato, J. C. (2011). Imagen hipertextual, identidades problemáticas. Signa: Revista de la Asociación Española de Semiótica, (20), 183-199.

Fernández Verdú, C. y Llinares, S. (2012). Características del desarrollo del razonamiento proporcional en la educación primaria y secundaria. Enseñanza de las Ciencias. Vol. 30, pp. 129-142.

Ferradini, S. y Prieto, R. T. (1997). Lectura de imagen. Comunicar: Revista Científica de Comunicación y Educación, 4(8), 157-160.

Ferrando, M., Prieto, M. D., Ferrándiz, C. y Sánchez, C. (2005). Inteligencia y creatividad. Electronic Journal of research in educational psychology, 7(3), pp. 21-50.

Ferrando, P. J. y Anguiano, C. (2010). El análisis factorial como técnica de investigación en psicología. Papeles del psicólogo, 31(1), pp. 18-33.

Ferrés i Prats, J. (2014). Las pantallas y el cerebro emocional. Barcelona: Editorial GEDISA.

Finke, R. A., Pinker, S., \& Farah, M. J. (1989). Reinterpreting visual patterns in mental imagery. Cognitive Science, 13(1), pp. 51-78.

Finke, R. A. (1990/2014, $4^{\circ} \stackrel{\circ}{\text { ed.) }}$ Creative Imagery: Discoveries and Inventions in Visualization. New York: Psychology Press.

FitzGerald, M.J., Gruener, G. y Mtui, E. (2012). Neuroanatomía clínica y neurociencia. Barcelona: Elsevier.

Flam, J. (1995). Matisse on Art. Londres: University of California Press,

Flecha, R., García, C. y Melgar, P. (2005). El proceso educativo de convergencia europea, una mirada crítica. Revista Interuniversitaria de Formación del Profesorado, 18(3), pp.8189

Fleming, N. (2006). VARK, a guide to learning styles. Disponible en url: http://www.vark-learn.com (consulta en Octubre de 2014). 
Flusser, V. (2005). La sociedad alfanumérica. Revista Austral de Ciencias Sociales, 9, pp. 95-109.

Flusser, V. (1990). Hacia una filosofía de la fotografía. México: Trillas.

Foucault, M. (1989). Esto no es una pipa: ensayo sobre Magritte. Madrid: Anagrama.

Fox Talbot, W.H. (1844/2014). El lápiz de la naturaleza. Madrid: Casimiro Libros.

Foster, H., Bois,Y., Krauss,R. y Buchloh,B (2006) Arte desde 1900. Madrid: Ediciones AKAL.

Frostig, M. (1964/2009). DTVP-2. Test de desarrollo de la percepción visual. Madrid: TEA.

Frutos, F. J. (2008). De la cámara oscura a la cinematografía: Tres siglos de tecnología al servicio de la creación visual. Área abierta, (19), pp. 1-14.

Furió, V. (2014) Ideas y formas en la representación pictórica. Barcelona: Edicions Universitat Barcelona.

Gabaldón, N. (1980) Algunos conceptos de muestreo. Caracas: UCV, Universidad Central de Venezuela.

Galagovsky, L. R., Di Giacomo, M. A. y Castelo, V. (2009). Modelos vs. dibujos: el caso de la enseñanza de las fuerzas intermoleculares. REEC: Revista electrónica de enseñanza de las ciencias, 8(1), 1.

Galagovsky, L. y Adúriz-Bravo, A. (2001). Modelos y analogías en la enseñanza de las ciencias naturales. El concepto de modelo didáctico analógico. Enseñanza de las Ciencias, Vol. 19, pp. 231-242.

Gámiz, A. (2003) Ideas sobre análisis, dibujo y arquitectura. Universidad de Sevilla: Secretariado de publicaciones.

García, I. G. (1996). La simetría en el arte: La lógica del esquema. Imafronte, (12), 135-150.

García, J. J. y Perales, F. J. (2005). ¿Influye la formación académica de los estudiantes en su comprensión de las representaciones gráficas cartesianas? Enseñanza de las Ciencias, número extra, VII Congreso, pp. 1-5. 
García-Molina A, Tirapu-Ustárroz J, Luna-Lario P, Ibáñez J, Duque P. (2010). ¿Son lo mismo inteligencia y funciones ejecutivas? Rev Neurol, (50), 738-46.

García Muñoz, G. (2008). Arte por Necesidad. Arte Mediúmnico, Visionarios y Espectadores. Arteterapia. Papeles de arteterapia $y$ educación artística para la inclusión social, (3), 103-116.

García Ramos. J.M. (1989). Los estilos cognitivos y su medida. Madrid: Ministerio de Educación.

García Ruiz, M.J. (2008). El impacto de la globalización en la universidad occidental del siglo XXI. Tendencias pedagógicas, (13), 59-78.

García-Sípido, A. (2003). Saber ver, una cuestión de aprendizaje. La educación visual a debate. Arte, individuo y sociedad, 15, pp. 61-72.

Gardié, O. (2000). Determinación del perfil de estilos de pensamiento y análisis de sus posibles implicaciones en el desempeño de profesionales universitarios venezolanos. Estudios pedagógicos (Valdivia), (26), pp. 25-38.

Gardner, H. (1994). Estructuras de la mente: la teoría de las inteligencias múltiples. México: Fondo de Cultura Económica.

Gardner, H. (1999). Mentes extraordinarias: cuatro retratos para descubrir nuestra propia excepcionalidad. Barcelona: Kairós.

Gardner, H. (2003). La inteligencia reformulada: Las inteligencias múltiples en el siglo XXI. Madrid: Grupo Planeta.

Gardner, H. (2011). Inteligencias múltiples: La teoría en la práctica. Barcelona: Paidos.

Gardner, M.F. (1986). Test of visual-motor skills. Seattle: Health Publishing Company.

Garrido-Román, M. (2011). Aproximación al estudio del vacío como espacio negativo y sus aportaciones en el campo de la creación. Revista de bellas artes: revista de artes plásticas, estética, diseño e imagen, (9), pp. 87-106.

Gascón, J. (2002). Geometría sintética en la ESO y analítica en el Bachillerato. ¿Dos mundos completamente separados?. Revista Suma, 39, 13-25. Univ. De Zaragoza.

Gaulin, C. (1985). The need for emphasizing various graphical representations of 3-dimensional shapes and relations. En: 
Streefland, L. (Ed.), Proceedings of the 9th P.M.E. Conference, 2, pp. 53-71.

Gazzaniga, M. (1998). El pasado de la mente. Barcelona: Ed. Andrés Bello.

Gernsheim, H.; Gernsheim, A. (1965). A concise history of photography. Londres: Thames and Hudson.

Gero, J.S (2014) Studying Visual and Spatial Reasoning for Design Creativity. New York: Springer.

Gersmehl, P. J. y Gersmehl, C. A. (2011). 48 spatial thinking: where pedagogy meets neuroscience. Problems of education in the 21st century. Vol. 27, pp. 48-66.

Ghazanfar, A. A., Maier, J. X., Hoffman, K. L. y Logothetis, N. K. (2005). Multisensory integration of dynamic faces and voices in rhesus monkey auditory cortex. The Journal of Neuroscience, 25(20), pp. 5004-5012.

Gibson, J. (1974). La Percepción del mundo visual. Buenos Aires: Ediciones Infinito.

Giménez-Amaya, J.M. (2000). Anatomia funcional de la corteza cerebral implicada en los procesos visuales. Rev. Neurol, 30(7), 656662.

Giménez Morell, R. V., Grassa-Miranda, V., y Vidal Alamar, M. D. (2010). Consideraciones sobre las imágenes mentales en el sistema diédrico español. Arte, individuo y sociedad, 22(1), 111-120.

Gimeno Sacristán, J. (Comp.) (2008). Educar por competencias, ¿qué hay de nuevo? Madrid: Ediciones Morata.

Gilchrist, A., Kossyfidis, Ch., Bonato, F., Agostini, T., Cataliotti, J., Li, X., Spehar, B., Annan, V. y Economou, E. (1999). An anchoring theory of lightness perception. Psychological Review, Vol 106(4), pp. 795-834.

Giudice J. y Galagovsky, L. (2008). Modelizar la naturaleza discontinua de la materia: una propuesta para escuela media. Revista Electrónica de Enseñanza de las Ciencias 7,(3), pp.629-658.

Goldberg, E. (2009). El cerebro ejecutivo: Lóbulos frontales y mente civilizada. Barcelona: Editorial Critica.

Goldberg, E.,Possel K.y Lovell, M. (1994). Lateralization of frontal lobe functions and cognitive novelty. Journal of Neuropsychiatry, 6. pp.315-372. 
Goldstein, N. (1989). Design and composition. New Jersey: Prentice Hall.

Goldstein, N. (2006). The art of responsive drawing. New Jersey: Prentice Hall.

Goleman, D. (1996). Inteligencia emocional. Barcelona: Editorial Kairós.

Gombrich, E. H. (1987). La imagen y el ojo: nuevos estudios sobre la psicología de la representación pictórica. Madrid: Alianza Editorial.

Gombrich, E. H., \& Ferrater, G. (1979). Arte e ilusión: estudio sobre la psicología de la representación pictórica. Barcelona: Editorial Gustavo Gili.

Gómez Molina, J. J., Bordes, J., y Cabezas, L. (2005). El manual de dibujo: estrategias de su enseñanza en el siglo XX. Madrid: Cátedra.

Gómez Molina, J. J. (2002) Máquinas y herramientas de dibujo. Madrid: Cátedra.

González-Quevedo A. (2004). Evaluación neuroquímica de la neuropatía óptica epidémica. Tesis Doctoral. Universidad de Ciencias Médicas de La Habana.

Gonzato, M., Blanco, M. T. F. y Godino, J. D. (2011). Tareas para el desarrollo de habilidades de visualización y orientación espacial. Números, (77), pp. 99-117.

Gonzato, M., Godino, J. D. y Contreras, J. M. (2011). Evaluación de conocimientos sobre la visualización de objetos tridimensionales en maestros en formación. En: Marín, M. et al. (Eds.). Investigación en Educación Matemática. Ciudad Real: SEIEM. pp. 383-392.

Gooder S. (2006). Brain Man. Documental. Disponible en url: http://www.nuevoordenmundial.es/videos/canal-odisea/brainman/

Goodnow, J. (2001). El dibujo infantil. Madrid: Ediciones Morata.

Gordejuela, F. E. (2009). La geometría de la representación visual. Revista de la Real Academia de Ciencias Exactas, Físicas $y$ Naturales, 103(2), 297-304.

Gorgorió, N. (1998). Exploring the functionality of visual and non-visual strategies in solving rotation problems. Educational Studies in Mathematics, (35), pp. 207-231. 
Grandin T. (1992). An inside view of autism. En Schopler E and Mesibov GB, eds. High Functioning Individuals with Autism. New York: Ed. Plenem Press.

Grandin T. (2006). Pensar con imágenes: mi vida con el autismo. Barcelona: Alba.

Grady, J. E. (2005). Image schemas and perception: Refining a definition. En: Hampe, B. (Ed.) From perception to meaning: Image schemas in cognitive linguistics. Berlín: Gruyter.

Gras, J. A., Mena, M. B., \& Beltrán, F. S. (1992). Diferenciación hemisférica, estilos cognitivos y procesamiento de la información visual. Psicothema, 4(1), 237-252.

Grassa-Miranda, V., y Gimenez Morell, R. (2010). Aproximación al análisis del sistema diédrico español como lenguaje. EGA. Revista de expresión gráfica arquitectónica, 15(15), 156-161.

Grassa-Miranda, V. (2014). Didáctica de la representación gráficogeométrica: reconstrucción de un concepto espacial aplicado. Ponencia presentada en el "Encuentro FIPPU sobre Experiencias e Innovación Educativa". Disponible en url: http://www.dcomg.upv.es/ chernan/encuentro_fippu/Ponencia s/Victor\%20Manuel\%20Grassa\%20Miranda\%20\%20Ponencia\%20Encuentro\%20FIPPU\%202007.pdf

Gray, D. (2012). Gamestorming: 83 juegos para innovadores, inconformistas y generadores del cambio. Barcelona: Planeta

Gregorc, Anthony F. (1982). An adult's guide to style. Columbia: Gregorc associates.

Greimas, A. y Courtes, J. (1982). Diccionario razonado de la teoría del lenguaje. Madrid: Gredos.

Guasch, A. M. (2003). Los Estudios Visuales. Un estado de la cuestión. Estudios Visuales, no 1, pp. 8-16. Murcia: CENDEAC.

Guasch, A.M. (2000). Los manifiestos del arte posmoderno. Madrid: Akal.

Gubern, R. (1996). Del bisonte a la realidad virtual. La escena y el laberinto. Madrid: Anagrama.

Guilford, J. P. (1972). Thurstone's primary mental abilities and structure-ofintellect abilities. Psychological Bulletin, 77(2), 129.

Guilford J.P. (1986) La Naturaleza de la Inteligencia Humana. Barcelona: Paidos. 
Gutiérrez, A. (2006). La investigación sobre enseñanza y aprendizaje de la geometría. En: Flores, P., Ruíz, F. y De la Fuente, M. (Eds.), Geometría para el siglo XXI (pp.13-58). Badajoz: Federación Española de Profesores de Matemáticas y SAEM THALES.

Gutiérrez, A. (1991). Procesos y habilidades en visualización espacial. In Memorias del 3er Congreso Internacional sobre Investigación en Educación Matemática. Valencia, España (pp. 44-59).

Gutiérrez, M., Palacios, A. y Torrego, L. (2010). La formación de los futuros maestros y la integración de las TIC en la educación: anatomía de un desencuentro. Revista de Educación, 352, pp. 215-231.

Hall, S. (1980). Codificar y decodificar. Cultura, media y lenguaje, pp. 129139. Disponible en url: http://www.felsemiotica.org/site/wpcontent/uploads/2014/10/Hall-Stuart-Codificar-ydecodificar.pdf

Hartley, T., Lever, C., Burgess, N. y O'Keefe, J. (2014). Space in the brain: how the hippocampal formation supports spatial cognition. Philosophical Transactions of the Royal Society of London B: Biological Sciences, 369(1635).

Hauck, S. M. y Ueffing, M. (2009). Factores neurotróficos derivados de las células de Müller: En el camino hacia la terapia neuroprotectora en la retina. Archivos de la Sociedad Española de Oftalmología, 84(9), pp. 423-426.

Hawkins, J. y Blakeslee, S. (2005). Sobre la inteligencia. Espasa Calpe.

Heidrich, F. E. y Redondo, E. (2011) Especulación sobre un proceso de construcción de una imagen esférica. IX International Conference on Graphics Engineering for Arts and Design. Rio de Janeiro: Expressão Gráfica Conexões entre Ciência, Arte e Tecnologia. UFRJ.

Herrmann, N. (1991). The creative brain. The Journal of Creative Behavior, 25(4), pp. 275-295.

Hernández-Muela, S., Mulas,F., Mattos, L. (2004). Plasticidad neuronal funcional. NEUROL, 38 (1), pp.S58-S68.

Herrero-Solana, V., y Hassan-Montero, Y. (2006). Metodologías para el desarrollo de Interfaces Visuales de recuperación de información: análisis y comparación. Information Research: an international electronic journal, 11(3). 
Hershkowitz, R., Parzysz, B. y Van Dormolen, J. (1997). Space and Shape. En: Bishop, A.J. et al. International Handbook of Mathematics Education. Dordrecht: Kluwer. Cap. 4, pp. 161.

Hyman, I. E., y Neisser, U. (1991). Reconstruing mental images. Problems of method. Emory Cognition Project Tech. Rep. No. 19. Atlanta, GA: Emory University.

Hochberg, J. (1968). In the mind's eye. En: Haber, R. (Ed.), Contemporary Theory and research in visual perception. New York: Winston, pp. 309-331.

Hoffman, D. D., (2000). Inteligencia visual: cómo creamos lo que vemos. Barcelona: Paidós Ibérica.

Hollman, V (2008). Geografía y cultura visual: apuntes para la discusión de una agenda de indagación. Revista de Geografía ,7, pp. 120135.

Hudson, L. (1968). Contrary Imaginations: A Psychological Study of the Young Student, Convergers and Divergers. New York: Schoken Books.

Huerta, M. P. (1999). Los niveles de Van Hiele y la taxonomía SOLO. Enseñanza de las Ciencias, (17), pp. 291-309.

Huerta, R. (2011). Maestros, museos y artes visuales: construyendo un imaginario educativo. Arte, individuo y sociedad, 23(1), pp. 5572.

Ibáñez, R. (2007). Cognición y comprensión: Una aproximación histórica y crítica al trabajo investigativo de Rolf Zwaan. Revista signos, 40(63), pp. 81-100.

Indow, T. y Watanabe, T. (1988). Alleys on an extensive apparent frontoparallel plane: A second experiment. Perception, 17(5), pp. 647-666.

Institute for the Advancement of Research in Education (IARE) at AEL (2003). Graphic organizers: A review of scientifically based research. Portland, OR: Inspiration Software

Jardí, E. (2014). Pensar con imágenes. Barcelona: Gustavo Gili.

Jastrow, J. (1893). On the judgment of angles and position of lines. American Journal of Psychology, (5), pp. 214-248

Jensen, Eric. (2004). Cerebro y Aprendizaje: Competencias e Implicaciones Educativas. Madrid: Narcea Ediciones. 
Jiménez, C.A. (2003). Neuropedagogía, lúdica y competencias. Bogotá: Coop. Editorial Magisterio.

Joao Abdounur, O. (2009) Razones, proporciones y pensamiento proporcional en la música pitagórica: un abordaje históricodidáctico. En: Corbalán Yuste, F. et al. La proporción: arte y matemáticas. Barcelona: Graó, pp. 61-86.

Jobard, G., Crivello, F. y Tzourio-Mazoyer, N. (2003). Evaluation of the dual route theory of reading: a metanalysis of 35 neuroimaging studies. Neuroimage, 20(2), 693-712.

Johnson-Laird, P. N. (1987). The mental representation of the meaning of words. Cognition, 25(1), 189-211.

Kaku, M. (2005). El universo de Einstein: cómo la visión de Albert Einstein transformó nuestra comprensión del espacio y el tiempo. Barcelona: Antoni Bosch.

Karam, T. (2007). Lenguaje y comunicación en Wittgenstein. Razón y Palabra, (57).

Kelly D. (2004). Uncovering the History of Children's Drawing and Art. Westport: Praeger Publishers.

Kellogg, R. (1979). Análisis de la expresión plástica del preescolar. Madrid: Ed. Cincel.

Kellogg, R. (1973). Misunderstanding children's art. Art Education, 26(6), pp. 7-9.

Kennedy, J. M. (2003). Drawings by Gaia, a blind girl. Perception, (32), pp. 321-340.

Kepes, G. (1976). El lenguaje de la visión. Buenos Aires: Editorial Infinito.

Kerlinger, F.N. \& Lee, H.B. (2002). Investigación del Comportamiento: Métodos de Investigación en ciencias sociales. México: McGraw-Hill Interamericana Editores.

Klinkenberg, J. M. (2006). Manual de semiótica general. Bogotá: Universidad Jorge Tadeo Lozano.

Koffka, K. (1922). Percepción: Introducción a la Teoría de la Gestalt. Psychological Bulletin, 19, 531-585

Köhler, W. (1930). Gestalt psychology. New York: Liveright. London: Bell 
Kolb, A. Y. y Kolb, D. A. (2005). Learning styles and learning spaces: Enhancing experiential learning in higher education. Academy of management learning \& education, 4(2), 193-212.

Kosinsky, D. (2000) El artista y la cámara: de Degas a Pizarro. Bilbao: Museo Guggenheim.

Kosslyn, S. M., Brunn, J. L., Cave, K. R. y Wallach, R. W. (1984). Individual differences in mental imageryability: a computational analysis. Cognition, (18), pp. 195-243.

Kozhevnikov, M., Hegarty, M. y Mayer, R. E. (2002). Revising the VisulizerVerbalizer Dimension: Evidence for Two Types of Visualizers. Cognition and Instruction, (20), pp. 47-77.

Kress, G. R. y Van Leeuwen, T. (1996). Reading images: The grammar of visual design. New York: Psychology Press.

Lambert, S. (1986) El dibujo: técnica y utilidad. Barcelona; Ediciones AKAL.

Langston, R. F., Ainge, J. A., Couey, J. J., Canto, C. B., Bjerknes, T. L., Witter, M. P., Moser, E. I. y Moser, M. B. (2010). Development of the spatial representation system in the rat. Science, 328(5985), pp. 1576-1580.

Leontiev, A.N. (1981). Problemas del desarrollo de la psique. Moscú: Universidad Estatal de Moscú.

Lesh, R. (1997). Matematización: la necesidad "real" de la fluidez en las representaciones. Enseñanza de las Ciencias, 15(3), pp. 377391.

Lévy Mangin, J. P. y Varela ,J. (2006) Modelización con estructuras de covarianzas en Ciencias Sociales: temas esenciales, avanzados y aportaciones especiales. A Coruña: Netbiblo.

Lewis, D. (2012). Reading Contemporary Picturebooks: Picturing Text. New York:Routledge

Ley Orgánica 8/2013, de 9 de diciembre, para la mejora de la calidad educativa. LOMCE. Boletín Oficial del Estado, ㄲo 295.

Lidwell, W., Holden, K. y Butler, J. (2011). Principios universales de diseño. Barcelona: Blume.

Linn, M.C. y Peterson, A.C. (1985). Emergence and characterization of sex differences in spatial ability: A meta-analysis. Child Development, 56 (6), pp. 1479-1498. 
Lizarazo, D. (2004). Iconos, figuraciones, sueños: Hermenéutica de las imágenes. Madrid: Siglo XXI.

Lohman, D.F. (1979). Spatial ability: A review and reanálisis of the correlational literature. Tech. Rep., (9). Stanford, C.A. Stanford University, School of Education.

Lohman, D. F., Pellegrino, J. W., Alderton, D. L. y Regian, J. W. (1987). Dimensions and components of individual differences in spatial abilities. En: Irvine, S. H. Intelligence and cognition: Contemporary frames of reference. Vol. 38, pp. 253-312. Heidelberg: Springer.

Lopez Casillas, F. (2013). El cerebro transparente. Revista de la Facultad de Medicina de la UNAM, vol. 56, num. 5, pp.58-61.

López Tamés, R. (1990). Introducción a la literatura infantil. Universidad de Murcia: EDITUM.

Lowenfeld, V. y Lambert, W. (1993) Desarrollo de la capacidad creadora. Buenos Aires: Kapelusz.

Luquet, G. (1981). El dibujo infantil. Barcelona: Ed. Médica y Técnica.

Lluch, G. (2003). Análisis de narrativas infantiles y juveniles. Universidad de Castilla La Mancha: Arcadia.

Luna, A. N., Estibález, J. A., Franco, E. A., López, A. G., Coronado, J. P., Astorqui, J. S. C., y García, I. G. (2007). Dibujo técnico y matemáticas: una consideración interdisciplinar. ISFP. Ministerio de Educación. Madrid: Taravilla.

Lurçat, L. (1979). El niño y el espacio: la función del cuerpo. México: Fondo de Cultura Económica.

Lurçat, L. (1988). Pintar, dibujar, escribir, pensar: el grafismo en el preescolar. Madrid: Cincel.

Luria, A.R. (1973). Neuropsychological studies in the USSR. A review. I. Proc Natl Acad Sci USA, 70, 959-964

Lyotard, J.F (1998). Lo inhumano: charlas sobre el tiempo. Buenos Aires: Manantial.

Mcclinntock, R. (1993). Comunicación, tecnología y diseños de instrucción: la construcción del conocimiento escolar y el uso de los ordenadores. Madrid: Ministerio de Educación. 
Maclagan, D. (2014). Line Let Loose: Scribbling, Doodling and Automatic Drawing. Londres: Reaktion Books.

MacLean, P. (1970). The Triune Brain, Emotion, and Scientific Bias. New York: Schmitt.

Machón, A. (2009) Los dibujos de los niños. Madrid: Cátedra.

Madi, I. (2012). La Creatividad y el Niño. Bloomington: Palibrio.

Maffei, A. y Turrigiano, G. (2008). Multiple modes of network homeostasis in visual cortical layer 2/3. The Journal of neuroscience, 28(17), pp. 4377-4384.

Malamed, C. (2011). Visual Language for Designers: Principles for Creating Graphics that People Understand. London: Rockport Publishers.

Maldonado, A (coord.) (2005). Libro blanco: Título de grado en Magisterio. Madrid: ANECA.

Malosetti Costa, L. (2006). Algunas reflexiones sobre el lugar de las imágenes en el ámbito escolar. En: Dussel, I. y Gutierrez, D. Educar la mirada: políticas y pedagogías de la imagen. Buenos Aires: Ed. Manantial. (pp. 155-164).

Mandler, J. M. (1998). Representation. Handbook of child psychology: Vol. 2: Cognition, perception, and language, pp. 255-308. Hoboken, NJ, US: John Wiley \& Sons Inc.

Mañero, A. y Arañó, J. (2003). Actas Congreso INARS: la investigación en las artes plásticas y visuales (Vol. 61). Universidad de Sevilla.

Markman, A.B. (2013) Knowledge Representation. New York: Psychology Press.

Martin, N. A. (2006). Test of visual perceptual skills. (TVPS-3). Flórida: PAR.

Marr, D. (1985). Visión: una investigacion basada en el cálculo acerca de la representación y el procesamiento humano de la información visual. Madrid: Alianza Editorial.

Martín, J., Julià, M.A. y Riera, C. (2003) Diccionari de palinología. Edicions Universitat Barcelona.

Martí Ferrer, F. (2009). Inmersión en la imagen visual: espacio, visión y presencia. Tesis Doctoral. Universidad de Valencia. 
Martín Gutiérrez, J. (2010). Estudio y evaluación de contenidos didácticos en el desarrollo de las habilidades espaciales en el ámbito de la ingeniería. Tesis Doctoral. Universidad Politécnica de Valencia.

Martín Gutiérrez, J., Contero, M. y Alcañiz, M. (2012). Curso para la mejora de la capacidad espacial. AR-Books.com

Martin, M. (1987). Semiología de la imagen y pedagogía: Por una pedagogía de la investigación. Madrid: Narcea Ediciones.

Martinez Bonafé, J. (2004). La formación del profesorado y el discurso de las competencias. Revista interuniversitaria de formación del profesorado, (51), pp. 127-144.

Mast, F. W. y Kosslyn, S. M. (2002). Visual mental images can be ambiguous: Insights from individual differences in spatial transformation abilities. Cognition, 86(1), pp. 57-70.

Mayer, R. (Ed.). (2005). The Cambridge handbook of multimedia learning. New York: Cambridge University Press.

Mckim, Robert H. (1973). Experiences in Visual Thinking. California: Brooks/Cole Publishing Co.

McLean H. (2012, noviembre 13). New ICT curriculum proposed by Royal Academy of Engineering and BCS. En The Guardian, url: http://www.theguardian.com/education/series/digital-literacycampaign

Medrano, S. M. (2011). Influencia del sistema visual en el aprendizaje del proceso de lectura. Ciencia \& Tecnología para la Salud Visual y Ocular, 9(2), 91-103.

Méndez, M. S. (2000). El factor espacial en el moderno concepto de la inteligencia en los procesos mentales y su relación con la expresión plástica. Arte, Individuo y Sociedad, (12), 11.

Michavila, F. (2005). No sin los profesores. Revista de educación, 337, pp. 37-49.

Michelon, P. y Zacks, J. M. (2006). Two kinds of visual perspective taking. Perception \& Psychophysics, 68(2), pp. 327-337.

Migliore, T. (2008). Paolo Fabbri: Estrategias del camuflaje. Revista de Occidente, (330), pp. 89-110. 
Mitchelmore, M. C. (1980). Prediction of developmental stages in the representation of regular space figures. Journal for Research in Mathematics Education, pp. 83-93.

Millar, A. V., Maclin, E. S. y Markwardt, L. J. (1922). Descriptive geometry. Madison: Tracy \& Kilgore.

Mirzoeff, N. (2003). Una introducción a la cultura visual. Barcelona: Arte y Educación, Paidós.

Mitchell, W.J.T. (2003). Mostrando el ver: una crítica de la cultura visual. Estudios Visuales, (1), 17-40. Murcia: CENDEAC.

Mitchell, W.J.T. (2009). Teoría de la imagen. Madrid: Ediciones Akal.

Mohamed Maanan, N. y Ortiz de Haro, J. J. (2012). Evaluación de conocimientos de profesores en formación sobre el juego equitativo. Números, (80), pp. 103-117.

Molholm, S., Sehatpour, P., Mehta, A. D., Shpaner, M., Gomez-Ramirez, M., Ortigue, S., y Foxe, J. J. (2006). Audio-visual multisensory integration in superior parietal lobule revealed by human intracranial recordings. Journal of neurophysiology, 96(2), pp. 721-729.

Monge, G. (1803). Geometría descriptiva. Madrid: Imprenta Real.

Montero, Y. H., Herrero-Solana, V., y Guerrero-Bote, V. (2010). Usabilidad de los tag-clouds: estudio mediante eye-tracking. Scire: representación y organización del conocimiento, 16(1), pp.1533.

Montessori, M. (1909/2013) El método de la pedagogía científica. Madrid: Biblioteca Nueva.

Mora, F. (2011). Cómo funciona el cerebro. Alianza Editorial.

Mora, F. (2013). Neuroeducación. Solo se puede aprender aquello que se ama. Madrid: Alianza Editorial.

Mora, J.A. (1995). Evolución histórica de las teorías y medidas sobre la inteligencia. Revista de Historia de la Psicología, Vol. 16, ํo 34, pp.3-16.

Mora, J.A. (1991). La inteligencia como proceso básico. Universidad de Murcia: Anales de psicología, 1991, 7, 57-64. 
Moreira, M. A. (2004). La teoría de los campos conceptuales de Vergnaud, la enseñanza de las ciencias y la investigación en el área. En: Investigaciones en Enseñanza de las Ciencias, 7(1).

Morell, R. V. G., Miranda, V. G., y Alamar, M. D. V. (2010). Consideraciones sobre las imágenes mentales en el sistema diédrico español. Arte, individuo y sociedad, 22(1), 111-120.

Moreno, M. J. (2007). Psicoanálisis y Escritura: actos fallidos en el registro gráfico. Medicina naturista, 1(2), pp. 3-10.

Moreno Montoro, M. I. (2007). Educar espectadores: propuestas expositivas y dinamización. Comunicar. Revista Científica de Comunicación y Educación, núm. 28, pp. 221-228.

Moreno Rivero, T. (1995). El color: Historia, teoría y aplicaciones. Barcelona: Ariel.

Moreno Rodríguez, C. (2009). El diseño gráfico en materiales didácticos. Bruselas: Centre d'Etudes Sociales sur Amerique Latine (CESAL).

Morchón Miranda, L. (2011). Eficacia de un programa de intervención con terapia visual en la escuela. Treball final de màster. Universitat Politècnica de Catalunya.

Moser, M. B. y Moser, E. I. (2011). Crystals of the brain. EMBO molecular medicine, 3(2), pp. 69-71.

Mounoud, P. (2001). El desarrollo cognitivo del niño: desde los descubrimientos de Piaget hasta las investigaciones actuales. Contextos educativos, (4), pp. 53-77.

Moya, J. y Luengo, F. (2010) La concreción curricular de las competencias básicas: un modelo adaptativo e integrado. Consejo Escolar del Estado. Participación Educativa, 15, pp. 127-141.

Munier, V., Merle, H. y Devichi, C. (2006). La construction du concept d'angle à l'école élémentaire à travers la notion de champ visuel. Repères-IREM. (64), pp. 65-84.

Muñoz, F. I. y Sacristán, J. G. (2006). Una oportunidad perdida. Cuadernos de pedagogía, (357), 96-101.

Muñoz Marrón, E. (Coord.) (2011). Estimulación cognitiva y rehabilitación neuropsicológica. Barcelona: Editorial UOC.

Muñoz-Rivas, M. y Agustín, S. (2005). La adicción al teléfono móvil. Behavioral Psychology, 13, pp. 481-493 
Muñoz Vicente, M. D. (2008). Aportaciones al estudio de la anisotropía y modelado espacial de información. Tesis Doctoral, Universidad de Salamanca.

National Research Council (2006). Learning to Think Spatially: GIS as a Support System in the K-12 Curriculum. Washington: National Academies Press.

Nava, R., Gallego, A., y Cristóbal, G. (2006). Una nueva herramienta para la evaluación de la calidad perceptible en imágenes. Congreso Anual de la Sociedad Española de Ingeniería Biomédica CASEIB (pp. 77-80).

Navarro, J. (2008). Forma y representación. Madrid: Ediciones Akal.

Necuzzi, C. (2013). Estado del arte sobre el desarrollo cognitivo involucrado en los procesos de aprendizaje y enseñanza con integración de las TIC. Buenos Aires: UNICEF.

Neisser, U (1967). Cognitive psychology. New York: Appleton-Century-Crofts

Neisser, U. (1997) Inteligencia: Lo conocido y lo Desconocido. American Psychologist. 51, 77-101. Lima: Facultad de Psicología.

Nietzsche, F. (1987) La gaya ciencia. Madrid: Ediciones Busma.

Noguera, J. (2004). Las competencias básicas. Ponencia de la XIX. Semana Monográfica de la Educación, Fundación Santillana, 2004. Disponible en url: http://www.fundacionsantillana.org/Contenidos/Publicaciones/ SemanaMonografica/Ponencias/XIX/ponencias_19.htm

Obando, G., Vasco, C. E. y Arboleda, L. C. (2014). Enseñanza y aprendizaje de la razón, la proporción y la proporcionalidad: un estado del arte. Revista latinoamericana de investigación en matemática educativa, 17(1), 59-81.

OCDE (2002) Muestra de reactivos empleados en la evaluación PISA 2000. Aptitudes para lectura, matemáticas y ciencias. Madrid: Santillana.

OCDE (2009). La comprensión del cerebro: el nacimiento de una ciencia del aprendizaje. Santiago: Ediciones Universidad Católica Silva Henríquez (UCSH).

O'Halloran, K. (2008). Mathematical Discourse: Language, Symbolism and Visual Images. London: Continuum. 
Ohler, J. (2003). Arte: La Cuarta Competencia Básica en esta Era Digital. Disponible en eduteka, url: http://www.jasonohler.com/translations/spanishart_fourth_r.pdf

Oliva, J. M. (2004). El pensamiento analógico desde la investigación educativa y desde la perspectiva del profesor de ciencias. Revista Electrónica de Enseñanza de las Ciencias, 3(3), pp. 123.

Oliva, J. M. (2003). Rutinas y guiones del profesorado de ciencias ante el uso de analogías como recurso de aula. Revista electrónica de enseñanza de las ciencias, 2(1), pp. 31-44.

Olivares, R., Lucena, V., Pino, M. J. y Herruzo, J. (2010). Análisis de comportamientos relacionados con el uso/abuso de Internet, teléfono móvil, compras y juego en estudiantes universitarios. Adicciones, 22 (4), pp. 301-310.

Olson, D.R. (1998). El mundo sobre el papel: el impacto de la escritura y la lectura en la estructura del conocimiento. Barcelona: Editorial Gedisa.

ORDEN EDU/519/2014, de 17 de junio, por la que se establece el currículo y se regula la implantación, evaluación y desarrollo de la educación primaria en la Comunidad de Castilla y León. Boletin oficial de castilla y león, BOCYL no 117.

Ortega, I. (2009). Ángel Ferrant y la Escuela de Artes y Oficios de Viena. Pulso: revista de educación, (32), pp. 25-54.

Ortega, J. A. (2003). La alfabetización digital: perspectivas creativas y éticas. En Aguiar, M. y Farray, J (coord.): Sociedad de la Información y Cultura Mediática. La Coruña: Netbiblo, pp. 91-118.

Ortega, J. A. (1999). Comunicación visual y Tecnología Educativa. Granada: Grupo Editorial Universitario.

Osterlind, S. J. (1998). Constructing Test Ítems: Multiple-Choice, Constructed-Response, Performance and Other Formats. London: Kluwer.

Otero, M. R. (1999). Psicología cognitiva, representaciones mentales e investigación en enseñanza de las ciencias. Investigações em Ensino de Ciências, 4(2), pp. 93-119.

Otxotorena, J. M. (1996). Sobre dibujo y diseño: a propósito de la proyectividad de la representación de la arquitectura (Vol. 4). Pamplona: Servicio Publicaciones ETSA. 
Pacioli, L. (1991). La divina proporción. Madrid: Ediciones Akal.

Palacios, F. J. (2006). Uso (y abuso) de la imagen en la enseñanza de las ciencias. Enseñanza de las ciencias: revista de investigación y experiencias didácticas, 24(1), pp. 13-30.

Paivio, A. (2013) Imagery and Verbal Processes. New York: Psychology Press.

Paivio, A. (1990). Mental Representations. Oxford University Press.

Palomino, M. (2000). El dibujo desde el gesto. Canarias: Bibiloteca Universitaria ULPGC.

Panofsky, E. (1983). La perspectiva como forma simbolica. Barcelona: Tusquets Editores.

Panofsky, E. (1969). Renaissance and Renaissances in Western Art. New York: Harper Torchbook.

Paredes, J. (2011). Cambiar el panorama de las escuelas. Indagación narrativa, artes visuales y TIC en una escuela activa radical. En: Bautista, A. y Velasco, H. (Eds.). Antropología audiovisual, medios e investigación en educación. Madrid: Trotta, pp. 152176.

Parra Salazar, E. (2008). Arquímedes: su vida, obras y aportes a la matemática moderna. Revista Digital: Matemática, Educación e Internet, 9(1).

Parzysz, B. (1991). Representation of space and students' conceptions at high school level. Educational Studies in Mathematics, 22(6), pp. $575-593$.

Pascual, M. P. (1997). Marcelo pascual y la investigación sobre las " aptitudes" y la" inteligencia técnica". Psicothema, 9(2), pp. 441-455.

Pedoe, D. (1979). La geometría en el arte. Barcelona: Gustavo Gili.

Pellegrino, J. W. y Kail, R. (1982). Process analyses of spatial aptitude. Advances in the psychology of human intelligence, 1, pp. 311365.

Pellicer, C. (2000). Los dibujos de los zurdos: percepción y lateralidad. Castelló de la Plana: Universitat Jaume I.

Peltzer, G. (1991). Periodismo iconográfico. Madrid: Ediciones Rialp. 
Perales, F. J. (2008). La imagen en la enseñanza de las ciencias: algunos resultados de investigación en la Univ. de Granada. Formación Universitaria, 1(4), pp. 13-22.

Perez-Bermúdez, C. (2000). Lo que enseña el arte: la percepción estética en Arnheim. Valencia: Publicacions de la Universitat de València.

Pérez Gómez, A.I. (2010). Aprender a educar. Nuevos desafíos para la formación de docentes. Revista Interuniversitaria de Formación del Profesorado, 68 (24,2), pp. 37-60.

Pérez Tornero, J.M. (2012) Alfabetización mediática y nuevo humanismo. Barcelona: Ed. UOC.

Piaget, J. (1948). La Représentation de l'espace chez l'enfant. París: Presse Universitaire de France.

Piaget, J. e Inhelder, B. (1997). Psicología del niño. Madrid: Ediciones Morata.

Piaget, J. (2001). La representación del mundo en el niño. Madrid: Ediciones Morata.

Piaget, J. (2009). La psicología de la inteligencia. Barcelona: Editorial Crítica.

Piantoni, C. (1997). Expresión, comunicación y discapacidad: modelos pedagógicos y didácticos para la integración escolar y social. Madrid: Narcea Ediciones.

Pinker, S. (1997) How the Mind Works. New York: W. W. Norton \& Company.

Pinker, S. (1988). A computational theory of the mental imagery medium. En: Denis, $\mathrm{M}$ et al. Cognitive and neuropsychological approaches to mental imagery. Springer Netherlands, pp. 17-32.

Portellano, J.A., García, J. (2014). Neuropsicología de la Atención, las funciones ejecutivas y la memoria. Madrid: Sintesis.

Pozo, J.I. (1989). Teorías cognitivas del aprendizaje. Madrid: Ediciones Morata.

Pozo, J.I. y Perez, M.(coord.) (2009) Psicología del aprendizaje universitario. Madrid: Morata.

Presmeg, N. C. (2008). An overarching theory for research in visualization in mathematics education. ICME11. Plenary paper, Topic Study Group 20: Visualization in the teaching and learning of 
mathematics. Disponible

http://tsg.icme11.org/document/get/97

en

url:

Prieto, G., Carro, J., Orgaz, B. y Pulido, R. F. (1993). Análisis cognitivo de un test informatizado de visualización espacial. Psicothema, 5(2), pp. 293-301.

Prieto, D. (2004). La comunicación en la educación. Buenos Aires: La Crujía.

Proyecto DeSeCo (2002). Definition and Selection of Competencies. Disponible en: www.OECD.org/edu/statistics/deseco

Rabazas, A. (2002). El dibujo y el diagrama: infraestructura proyectual de Eulália Valldosera. En: Gómez Molina, J. J. (2002), pp. 435524. Madrid: Cátedra.

Ramachandran, V.S. (2012). Lo que el cerebro nos dice: Los misterios de la mente humana al descubierto. Barcelona: Paidos.

Razumiejczyk, E., López Alonso, A. y Macbeth, G. (2013). El efecto de priming y sus variantes experimentales. Psicología $y$ Psicopedagogía, 7(18).

Read, H. (1982). Educación por el arte. Buenos Aires: Paidós.

Real Decreto 1190/2012, de 3 de agosto, por el que se modifican el Real Decreto 1513/2006, de 7 de diciembre, por el que se establecen las enseñanzas mínimas de la Educación Primaria. Boletín Oficial del Estado, BOE oㅜ 186.

Real Decreto 1146/2011, de 29 de julio, por el que se modifica el Real Decreto 1631/2006, de 29 de diciembre, por el que se establecen las enseñanzas mínimas correspondientes a la Educación Secundaria Obligatoria. Boletín Oficial del Estado, BOE no 182.

Real Decreto 126/2014, de 28 de febrero, por el que se establece el currículo básico de la Educación Primaria. Boletín Oficial del Estado, BOE nำ 52 .

Regot, J. (1986). Perspectiva curvilínea de pantalla esférica. Tesis Doctoral, Universitat Politècnica de Catalunya.

Reig D. y Vílchez L. F. (2013). Los jóvenes en la era de la hiperconectividad: tendencias, claves y miradas. Madrid: Fundación Telefónica y Fundación Encuentro.

Renaud, A. (1990). Comprender la imagen hoy. Video culturas de fin de siglo. Madrid: Catedra. 
Rey, A. (1980). Test de copia de una figura compleja. Madrid: TEA.

Richardson, A. (1994). Individual differences in imaging: their measurement, origins, and consequences. NewYork: Baywood.

Rigui, L. (2006). Conservar el arte contemporáneo. San Sebastián: Editorial NEREA.

Roam, D. (2010). Tu mundo en una servilleta. Barcelona: Planeta.

Robbins, S (1996/2004) Comportamiento organizacional. México: Pearson Educación.

Rock, I. (1985). La percepción. Barcelona: Ed. Labor.

Rodríguez, J. A. (2010). Los libros de viaje y las imágenes. Antropología. Boletín Oficial del INAH, (89), pp. 75-84.

Rodríguez, S. y Chacón, M. (2008). Bases teóricas y consideraciones prácticas en la elaboración de material multimedia para un curso de cálculo. Actualidades investigativas en Educación. Vol. 8, Núm. 1, pp. 1-30. Universidad de Costa Rica.

Rodriguez M. y Bermúdez, R (2001) Psicología del pensamiento científico. La Habana: Ed. Pueblo y Educación.

Rodríguez, M. y Bermúdez, R. (2002). ¿Pensamiento visual por acciones o percepción resolutiva? Revista Cubana de Psicología, 19(2), 183-187.

Rogoff, B. (1997). Los tres planos de la actividad sociocultural: apropiación participativa, participación guiada y aprendizaje, en: Wertsch, J.; del Río, P. Y Alvarez, A. (Eds.): La mente sociocultural. Aproximaciones teóricas y aplicadas. Madrid: Fundación Infancia y Aprendizaje (pp.111-128).

Rojas, M. E. (2004). La conducta individual como respuesta a los factores formales organizacionales. Academia, 3(6), pp. 4-11.

Rollano, D. (2005) Educación plástica y artística en educación infantil: una metodología para el desarrollo de la creatividad. Vigo: Ideaspropias Editorial.

Romero, J. y Gómez, A. (2007). ¿Sirven las políticas y prácticas de formación del profesorado para mejorar la educación? Una respuesta desde el análisis de la construcción social de la docencia. Archivos Analíticos de Políticas Educativas, 15(19). Recuperado [24-05-2015] de http://epaa.asu.edu/epaa/v15n19 
Romero, I. (1996) El mito del hemisferio derecho del cerebro y la creatividad. Arte, Individuo y Sociedad (Revista), n.0 8. Madrid: Universidad Complutense.

Rubio, M. (2000). Género y diferencias cognitivas en la solución de problemas de razonamiento espacial. Tecné, episteme $y$ didaxis: revista de la Facultad de Ciencia y Tecnología, (8), 25-30.

Ruiz, A. (2003). Historia y filosofía de las matemáticas. San José: EUNED.

Ruiz, E. y Lupiáñez, J. (2009). Detección de obstáculos psicopedagógicos en la enseñanza y el aprendizaje de los tópicos de razón y proporción en alumnos de sexto grado de Educación Primaria. Electronic Journal of Research in Educational Psychology, $17(7), 1$.

Ruiz del Olmo, F.J. (2012) El papel de la imagen y su presencia en los textos publicados en las revistas científicas del ámbito de la Comunicación recogidas en JCR Social Science Edition. Estudios sobre el Mensaje Periodístico, Vol. 18. Madrid: Universidad Complutense.

Rushkoff, D. (2010). Program or be programmed: Ten commands for a digital age. Or Books.

Ruskin, J. (1999). Técnicas del dibujo. Barcelona: Laertes.

Ruskin, J. (1983). The Elements of Drawing. Barcelona: Laertes.

Ryu, H., Chong, Y., Song, S. (2007). Mathematically gifted students spatial visualization abiltiy of solid figures. Proceedings of the 31st Conference of the International Group for PME, Vol. 4, pp. 137-144. Seoul: PME.

Sainz Martín, A. (2013). El arte infantil: conocer al niño a través de sus dibujos. Madrid: Eneida Editorial.

Salas Silva, R.E. (2008). Estilos de aprendizaje a la luz de la neurociencia. Bogotá: Coop. Editorial Magisterio.

Salazar, M. y Díaz, L. (2009). La actividad de medir aporta significados a fracciones y razones. Acta Latinoamericana de Matemática Educativa, (22), pp. 207-216.

Salgado, M. (2013). Valor percibido por los maestros en formación inicial hacia la Plástica. Educación artística: revista de investigación (EARI), (4), pp. 277-288. 
Sanchez Marcos, E. (2010). Representaciones de un mundo complejo: No tinc paraules de Arnal Ballester. Bellaterra: journal of teaching and learning language and literature, 2(1), pp. 17-34.

Santos Guerra, M. A. (1984) Imagen y Educación. Madrid: Anaya.

Saura Pérez, Á. (2012). E@: Educación Artística 3.0. Educación artística: revista de investigación, (3), 77-86.

Scheaffer, R., Mendenhall, W. y Lyman Ott, R. (2007) Elementos de muestreo. Madrid: Editorial Paraninfo.

Schnotz, W. (2002). Towards an integrated view of learning from text and visual displays. Educational Psychology Review, 14(1), pp. 101-120.

Sebreli, J. J. (2011). Las aventuras de la vanguardia. Buenos Aires: Penguin Random House Ed.

Sebreli, J. J. (2013). El asedio a la modernidad. Buenos Aires: Penguin Random House Ed.

Seel, N. M. (2012). Encyclopedia of the Sciences of Learning. New York: Springer.

Serrano, O.E. (2003). El concepto de competencia en la semiótica discursiva. Disponible en: http://www.icfes.gov.co/index.php?option=com_docman\&task= doc_view\&gid=1462

Serrano, M. (2009). El proceso de derivación de las competencias básicas en los centros docentes. Aula de Innovación Educativa, 16(180), 14-19.

Seymour S. (1988). Bringing Art to Mind:Theory and Practice in the Teaching of Drawing. Harvard: Graduate School of Education.

Sheppard L. y Aldrich F. (2000). Graphicacy: la cuarta 'R'. Primary Science Review, (64), pp.8-11.

Shepard, R. N. y Cooper, L.A. (1986). Mental images and their transformations. Cambridge, MA: MIT Press.

Shepard, R. N. (1984). Ecological constraints on internal representation: resonant kinematics of perceiving, imagining, thinking, and dreaming. Psychological review, 91(4), p. 417. 
Shepard, R. N. y Metzler, J. (2004). Mental rotation of three-dimensional objects. En: Balota, D. y Marsh, E. Cognitive Psychology: Key Readings. New York: Psychology Press, (pp. 254-257).

Sibbet, D. (2013). Liderazgo visual : nuevas herramientas visuales para dinamizar y reinventar tu empresa. Madrid: Anaya multimedia.

Silvestre, A. I. y Ponte, J. P. (2011). Una experiencia de enseñanza dirigida al desarrollo del razonamiento proporcional. Educación y Pedagogía, (59), pp. 137-158.

Sima, J. F. (2014). A Computational Theory of Visuo-Spatial Mental Imagery. Doctoral dissertation. Consultada en:http://cosy.informatik.unibremen.de/sites/cosy/files/sima/thesis_imagery.pdf

Simmons, J. (1998). Como medir la inteligencia emocional. Madrid: EDAF.

Simonton, D. K. (2003). Scientific creativity as constrained stochastic behavior: the integration of product, person, and process perspectives. Psychological bulletin, 129(4), 475.

Smith,K., Moriarty,S., Kenney,K. y Barbatsis,G. (2011) Handbook of Visual Communication: Theory, Methods, and Media. New York: Routledge.

Sobel, R.S. y Rothemberg A. (1980) Artistic Creation as simulated by superimposed versus separated visual images. Journal of Personality and Social Psychology, Vol 39(5), pp. 953-961.

Sola Fernández, M. (2004). La Formación del Profesorado en el contexto del Espacio Europeo de Educación Superior. Avances alternativos. Revista interuniversitaria de formación del profesorado, N. 51, pp. 91-106.

Soler Fiérrez, E.(1992). La educación sensorial en la escuela infantil. Ediciones Rialp.

Sougez, M. (1988). Historia de la fotografía. Madrid: Cuadernos de arte Cátedra.

Soto-Andrade, J. (2008). Mathematics as the art of seeing the invisible. ICME11. Plenary paper, Topic StudyvGroup 20: Visualization in the teaching and learning of mathematics. Disponible en url: http://tsg.icme11.org/ document/get/771

Suárez, A. D., Cano, R., Cruz, A., Márquez, C., Viana, M. y Rodríguez, I. (2011). De artista a andragogo. Experiencias educativas de docencia no reglada en cursos dirigidos por artistas contemporáneos. Arte, individuo y sociedad, 23(1), pp. 29-44. 
Suárez Riaño, B. (2004). El desafío de la escritura: en busca de la grafomotricidad. Revista iberoamericana de psicomotricidad y técnicas corporales, (16), pp. 5-16.

Spengler, O. (1947). El hombre y la técnica y otros ensayos. Buenos Aires: Espasa-Calpe.

Spearman, C.E. (1923) The nature of "intelligence" and the principles of cognition. London: Macmillan.

Springer, S. y Deutsch, G. (2001). Cerebro izquierdo, cerebro derecho. Barcelona: Ariel.

Stefen, W. (2008). Video Documental en url: https://www.youtube.com/watch?v=COW2Eis2UyY

Sternberg, R. J. (1987). Inteligencia humana. Barcelona: Paidós.

Sternberg, R. J. (1985) The triarchic mind. Nueva York: Penguin Books

Sternberg, R. J. y Detterman, D.K. (Coords.) (1992) ¿Qué es la inteligencia? Enfoque actual de su naturaleza y definición. Madrid: Ediciones Pirámide.

Sternberg, R. J., Castejón, J. L. y Bermejo, M. R. (1999). Estilo intelectual y rendimiento académico. Revista de investigación educativa, 17(1), pp. 33-46.

Stylianou, D. (2001). On the reluctance to visualize in mathematics: Is the picture changing? En: Van den Heuvel-Panhuizen, M. (Ed.), Proceedings of the 25th PME International Conference, (4), pp. 225-232.

Suazo, I., Trujillo, E. G., Cantín, M. y Zavando, D. (2008). Determinación de proporciones áureas craneofaciales para la reconstrucción con fines de identificación médicolegal. International Journal of Morphology, 26(2), pp. 331-335.

Sweller, J. (2002). Visualisation and instructional design. Tübingen, Germany: Proceedings of the International Workshop on Dynamic Visualizations and Learning. Disponible en url: http://www.iwm-kmrc.de/workshops/visualization/

Talizina, N., Solovieva, Y. y Quintanar, L. (2010). La aproximación de la actividad en psicología y su relación con el enfoque históricocultural de LS Vigotsky. Novedades educativas, 230, pp. 4-8.

Tapias, C. (2014). Espacios negativos: contra y anti como partículas reveladoras en el espacio. En: Basini, J. et al. (Org.): Os 
estudos socioespaciais: cidades, fronteiras e mobilidade humana. Universidade Federal do Amazonas. (pp. 124-140)

Taylor, B. (1749). New Principles of Linear Perspective. London: John Ward.

Tesouro de Grosso, S. (2006) Grafología Científica. Buenos Aires: Ed. Kier.

Thayer, G. H. y Thayer, A. H. (1918). Concealing-coloration in the Animal Kingdom: An Exposition of the Laws of Disguise Through Color and Pattern: Being a Summary of Abbott H. Thayer's Discoveries. Londres: Macmillan Company, 1909.

Thurstone, L.L. (1950). Some primary abilities in visual thinking. Proceedings of the American Philosophical Society, 94 (6), pp. 517-521.

Thurstone, L. (1948). Primary mental abilities. Science (New York, NY), 108(2813), pp. 585.

Thurstone, L. L. (1938). The perceptual factor. Psychometrika, 3(1), pp. 1-17.

Tirado, F., Backhoff, E., Larrazolo, N. y Rosas, M. (1997). Validez predictiva del examen de habilidades y conocimientos básicos (EXHCOBA). Revista Mexicana de Investigación Educativa, 2(3), pp. 67-84.

Todorov, A. y Duchaine, B. (2008). Reading trustworthiness in faces without recognizing faces. Cognitive Neuropsychology, 25 (3), 395410.

Torrents Gómez, A. (2011). Nuevas evidencias sobre la anisotropía del espacio visual y la influencia del entorno en el rendimiento visual. Tesis Doctorales en Red. Consultada (1-06-2015) en: http://www.tdx.cbuc.es/handle/10803/83637

Treffert, D. A. (2011). Islands of Genius: The Bountiful Mind of the Autistic, Acquired, and Sudden Savant. London: Jessica Kingsley Publishers.

UNLD (2013). Conferencia: Observancia del Decenio de las Naciones Unidas de la Alfabetización (2003-2012) y recomendaciones específicas para despues del decenio. Disponible en: http://unesdoc.unesco.org/images/0022/002243/224374s.pdf

UNESCO (2011). Programa PIPT. Disponible en: http://www.unesco.org/new/es/communication-andinformation/intergovernmental-programmes/information-for-allprogramme-ifap/priorities/information-literacy/ 
UNESCO (2005). Hacia las sociedades del conocimiento. Disponible en: http://unesdoc.unesco.org/images/0014/001419/141908s.pdf

UNESCO (2003). Programa LAMP (Literacy Assessment and Monitoring Programme). Disponible en: http://www.uis.unesco.org/Literacy/Pages/default.aspx

UNESCO (1997). La educación encierra un tesoro. Informe de la Comisión Internacional sobre la Educación para el Siglo Veintiuno. UNESCO-Santillana.

Unzueta, S. (2002). El mercado del arte. Boletín económico de ICE, Información Comercial Española, (2747), pp. 35-44.

Valdez, J. C. (2009). Calotipo, colotipo y kallytipo. Alquimia, (37), pp.84-85.

Valero Muñoz, A. (2012).Principios de color y holopintura. Alicante: Editorial Club Universitario.

Vallugera, A. (2011). El mercado artístico como herramienta de estudio para el historiador del arte. Una aproximación. ASRI: Arte y sociedad. Revista de investigación, (0), p. 22.

Vandenberg, S. G. y Kuse, A. R. (1978). Mental rotations, a group test of three-dimensional spatial visualization. Perceptual and motor skills, 47(2), 599-604.

Van Dooren, W., De Bock, D., Janssens, D. y Verschaffel, L. (2008). The linear imperative: An inventory and conceptual analysis of students' overuse of linearity. Journal for Research in Mathematics Education, pp. 311-342.

Van Giffen, K., \& Haith, M. (1984). Infant visual response to Gestalt geometric forms. Infant Behavior and Development, 7(3), pp. 335-346.

Van Hiele, P. (1986). Structure and insight: a theory of mathematics education. Orlando: Academic Press.

Vázquez, S. M. y Noriega Biggio, M. (2010). La competencia espacial: Evaluación en alumnos de nuevo ingreso a la universidad. Educación matemática, 22(2), pp. 65-91.

Vega Montiel, A., Portillo, M. y Repoll, J. (Coords.) (2008) Las claves necesarias de una comunicación para la democracia. Mexico: AMIC, Universidad Juarez Autónoma de Tabasco.

Vega Rodríguez, M.(1984). Introducción a la Psicología Cognitiva. Vol. 3. Madrid: Alianza Psicología. 
Verdejo-García, A., \& Bechara, A. (2010). Neuropsicología de las funciones ejecutivas. Psicothema, 22(2), 227-235.

Vergnaud, G. (1996). Alguna ideas fundamentales de Piaget en torno a la didáctica. Perspectivas: Revista trimestral de educación comparada, (1), 195-207.

Vergnaud, G. (1990). La teoría de los campos conceptuales. Recherches en didactique des mathématiques, 10(2), 3.

Vieira Barros, D. M. (Org.) (2011). Estilos de Aprendizagem na Atualidade: vol. 1. Disponible en url: http://estilosdeaprendizagemvol01.blogspot.com

Villa-Ochoa, J. y Ruiz, M. (2010). Pensamiento variacional: seres-humanoscon-GeoGebra en la visualización de nociones variacionales. Educação matematica pesquisa, 12(3), pp. 514-528.

Villafañe, J. (2006). Introducción a la teoría de la imagen. Madrid: Pirámide.

Vigotsky, L. S. (2003). La imaginación y el arte en la infancia. Madrid: Akal.

Vigotsky , L. S.(1934/2013). Pensamiento y lenguaje. Madrid: Planeta.

Vilches, L. (1997). La lectura de la imagen. Prensa, cine, televisión. Barcelona: Paidós.

Villardón Gallego, M. L. (2006). Evaluación del aprendizaje para promover el desarrollo de competencias. Educación siglo XXI, (24), Dpp. $57-76$.

Vivanco, M. (2005). Muestreo estadístico. Diseño y aplicaciones. Santiago de Chile: Editorial Universitaria.

Wallon, P., Cambier, A. y Engelhart, D. (1992). El dibujo del niño. Buenos Aires: Siglo XXI.

Wallon, H. y Lurçat, L. (1958). Le dessin du personnage par l'enfant. En: Enfance. Tome 11, (3), pp.177-221.

Wechsler, D. (1990, 2009). WPPSI III Escala de inteligencia para preescolar. Madrid: TEA Ediciones.

Weinert, F. E. (1999). Definition and selection of competencies: Concepts of Competence. OECD, Organization for Economic Cooperation and Development. Disponible en url: http://citeseerx.ist.psu.edu/viewdoc/download?doi=10.1.1.111. $1152 \&$ rep=rep $1 \&$ type $=$ pdf 
Wertheimer, M. (1960). Principios de organización perceptual. Buenos Aires: Ediciones Tres.

Williams, L. V. (1986). Aprender con todo el cerebro. Barcelona: Ediciones Martínez Roca.

Wilson, F. M. (1921). A class at Professor Cizek's. Children's Art Exhibition Fund, (3), pp.3-24. Disponible en url: http://www.thefreelibrary.com/The+classes+of+Franz+Cizek.a08934232

Wittgenstein, L. (1953/2008) Investigaciones filosóficas. Madrid: Editorial Crítica.

Wolf Unruh, V. (1983). El mundo disputado al nivel del lenguaje. Revista Iberoamericana, 49(122), pp. 193-202.

Wolohojian, S. (2003). A Private Passion: 19th-century Paintings and Drawings from the Grenville. New York: Metropolitan Museum.

Woolfolk, A. (2006). Psicología educativa. México: Pearson educación.

Yela, M. (1967) El factor espacial en la estructura de la inteligencia técnica. Revista de psicología general y aplicada: Revista de la Federación Española de Asociaciones de Psicología, 22(88), pp. 609-635.

Zabala, A. y Arnau, L. (2007). Cómo aprender y enseñar competencias: 11 ideas clave. Barcelona: Grao.

Zacks, J. M. y Tversky, B. (2005). Multiple systems for spatial imagery: transformations of objects and bodies. Spatial Cognition and Computation, 5(4), pp. 271-306.

Zacks, J. M., Vettel, J. M. y Michelon, P. (2003). Imagined viewer and object rotations dissociated with event-related fMRI. Journal of Cognitive Neuroscience, 15(7), pp. 1002-1018.

Zacks, J. M., Mires, J., Tversky, B. y Hazeltine, E. (2000). Mental spatial transformations of objects and perspective. Spatial Cognition and Computation, 2(4), 315-332.

Zamora, F. (2007). Filosofía de la imagen: lenguaje, imagen y representación. México: UNAM.

Zunzunegui, S. (2007). Pensar la imagen. Madrid: Ediciones Cátedra. 


\section{Imágenes reproducidas.}

Adelson, Edward H. (2005). Checkershadow Illusion. Disponible en url: http://web.mit.edu/persci/gaz/gaz-teaching/index.html

Ballestas Rincón, L. H. (2010). Las formas esquemáticas del diseño precolombino de Colombia: relaciones formales $y$ conceptuales de la gráfica en el contexto cultural colombiano. Universidad Complutense de Madrid, Servicio de Publicaciones.

Braidot, N. (2008). Neuromanagement. Buenos Aires: Ediciones Granica.

Cardinali, D. (2007). Neurociencia aplicada: sus fundamentos. Buenos Aires: Ed. Médica Panamericana.

Fox Talbot, W.H. (2014). El lápiz de la naturaleza. Madrid: Casimiro Libros.

Goldstein, E.B. (2006). Sensación y percepción. Madrid: Ediciones Paraninfo.

Hann, M. (2014). Structure and Form in Design: Critical Ideas for Creative Practice. Madison: Bloomsbury.

Loomis, A. (1956). Drawing the Head and Hands. New York: Viking.

Martí Ferrer, F. (2009). Inmersión en la imagen visual: espacio, visión y presencia. Tesis Doctoral. Universidad de Valencia

Moreaux, A. (2005). Anatomia artistica. Madrid: Capitel.

Puche, C. (2002). Dibujar la naturaleza: ilustradores naturalistas en el Jardín Botánico. Universidad de Vàlencia.

Rodríguez, M. R., Aceituno, D. H., González, L. H., de Vega Fernández, V. M. y Carrascoso, J. (2013). Imagen de tractografía 3T: anatomía y aplicaciones clínicas. Radiología, 55(1), 57-68.

Taibo, Á. (1983). Geometría descriptiva y sus aplicaciones: Curvas y superficies (Vol. 2). Albacete: Tebar.

Sander, A. (1904). Maestra de Escuela. Fotografía original. 


\section{Legislación educativa}

Real Decreto 126/2014, de 28 de febrero, por el que se establece el currículo básico de la Educación Primaria. Boletín Oficial del Estado, oㅡ 52.

Real Decreto 1190/2012, de 3 de agosto, por el que se modifican el Real Decreto 1513/2006, de 7 de diciembre, por el que se establecen las enseñanzas mínimas de la Educación Primaria. Boletín Oficial del Estado, ํo-186.

Real Decreto 1146/2011, de 29 de julio, por el que se modifica el Real Decreto 1631/2006, de 29 de diciembre, por el que se esteblecen las enseñanzas mínimas correspondientes a la Educación Secundaria Obligatoria. Boletín Oficial del Estado, no 182.

Parlamento Europeo (2006). Recomendación del Parlamento Europeo y del Consejo de 18 de diciembre de 2006 sobre las competencias clave para el aprendizaje permanente (2006/962/CE). Diario Oficial de la Unión europea, (30 diciembre)

Consejo Europeo (2009) Conclusiones sobre un marco estratégico para la cooperación europea en el ámbito de la educación y la formación (ET 2020). Diario Oficial de la Unión Europea C $119 / 2$ (28 de mayo)

CUE (2010): Informe conjunto de 2010 del Consejo y de la Comisión sobre la puesta en práctica del programa de trabajo «Educación y formación 2010» (2010/C 117/01). Diario Oficial de la Unión Europea.

ORDEN EDU/519/2014, de 17 de junio, por la que se establece el currículo y se regula la implantación, evaluación y desarrollo de la educación primaria en la Comunidad de Castilla y León. Boletín oficial de Castilla y León, № 117.

Decreto 40/2007, de 3 de mayo, por el que se establece el Currículo de la Educación Primaria en la Comunidad de Castilla y León. Boletín oficial de Castilla y León, (89).

Ley Orgánica 8/2013, de 9 de diciembre, para la mejora de la calidad educativa. Boletín Oficial del Estado. Disponible en: www. boe. es/diario_boe/txt. php. 
Escala de Pensamiento Visual. EVPV 


\section{Escala de Pensamiento Visual. EVPV}

Esta escala registra la manera en que nos relacionamos visualmente con el espacio y la capacidad de representarlo.

No se pretende una respuesta correcta sino el registro de sus referencias espaciales y su experiencia.

\section{Gracias por su colaboración.}

(Por favor, rodee con un círculo la respuesta elegida)
Sexo: M (Masc.) F (Fem.)

Año de nacimiento: $19 .$.

Estudios:...

\section{Apreciación del espacio visual. Referencias espaciales.}

Cuando tomamos la línea horizontal como referencia visual, dividimos el espacio que hay ante nosotros entre las partes superior e inferior, y cuando lo hacemos con la línea vertical, lo dividimos entre las partes izquierda y derecha.

1 - Cuando utilizamos ambas referencias, horizontal y vertical, a la vez, hablamos de cuadrantes: Desde su posición, ¿cuál de los cuadrantes de la imagen representarían el espacio superior derecho y el inferior izquierdo?

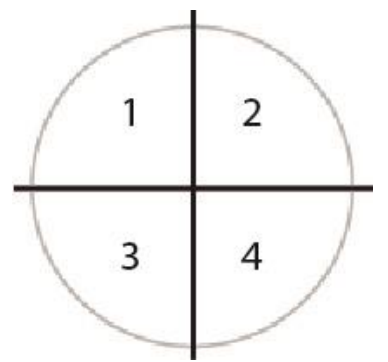
a.- El 1 y el 3.
b. - El 2 y el 3.
c. - El 2 y el 4.
d.- El 1 y el 4.

Imagine que está de pie en la playa frente al mar, mirando la línea de horizonte (separación del mar y el cielo); y se pone de cuclillas... ¿Qué hace esta línea?:
a.- Sube, en relación a mi posición.
b. - Permanece donde está.
c. - Baja, en relación a mi posición.
d. - No tiene que ver con mi posición. 
¿Qué significado tiene para Ud. el denominado 'punto de fuga'?
a.- Lo desconozco.
b.- Es el punto de convergencia de todas las líneas en el horizonte.
c. - Es un punto aleatorio de nuestro campo visual.
d. - Es el punto de convergencia de nuestro campo visual en el horizonte.

Sabiendo que dos puntos definen una recta, ¿Qué puntos definen la vertical de su cuerpo?

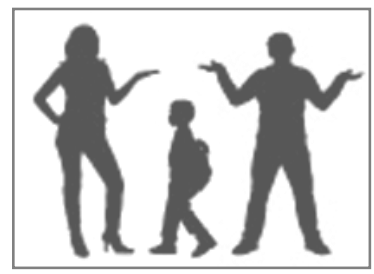
a. - La frente y el esternón.
b. - La nuca y el coxis.
c. - El entrecejo y la garganta.
d. - La nariz y el ombligo.

Cree que la situación del punto de fuga, en su campo visual,...

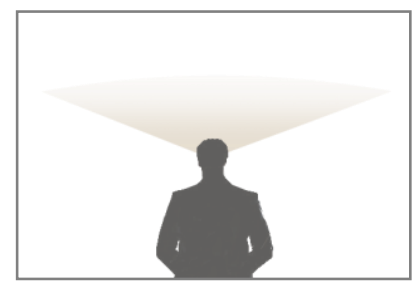

a. - depende de su posición horizontal y vertical.

b. - depende de su posición horizontal.

c. - depende de su posición vertical.

d. - no depende de su posición.

¿De las siguientes representaciones, cuál considera que responde mejor a su visión de un cubo?

a.-

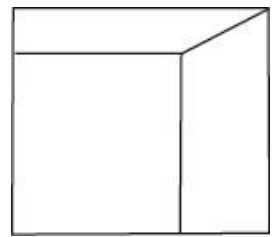

b. -

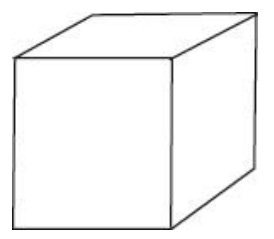

C. -

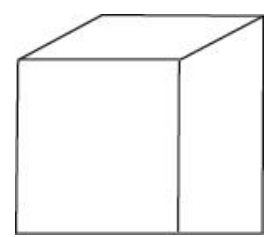

d. -

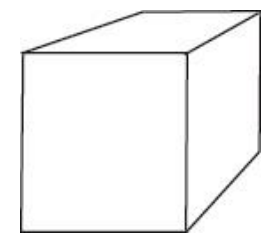

¿Qué es lo primero que reconoce en esta imagen?:
a. - Un asa.
b. - Dos medios círculos equidistantes.
c. - La letra c invertida.
d. - Ninguna de las anteriores: ... 


\section{Apreciación de las relaciones espaciales.}

El aspecto, la forma y la posición en el espacio de los objetos visuales que nos rodean guardan una relación entre ellos y para con nosotros.
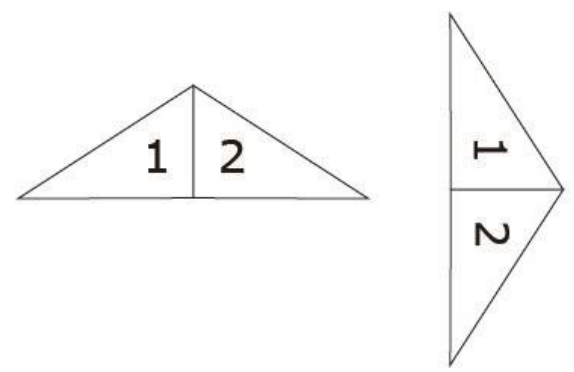

C. -

d. -

a.-

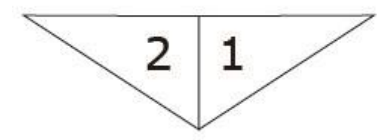

b. -

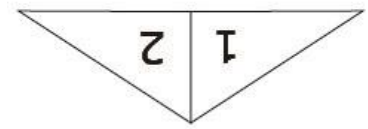

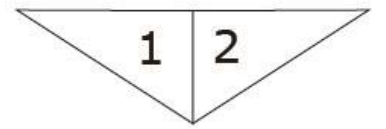

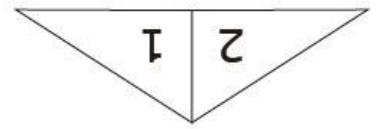

¿Cuál de las siguientes figuras construiría con el siguiente modelo?:

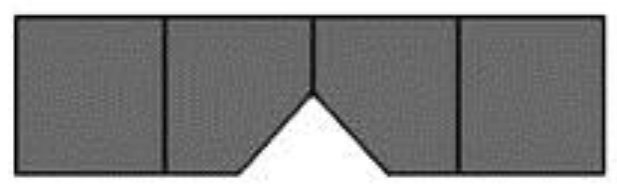

a.-

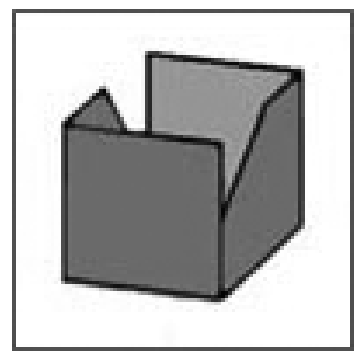

b. -

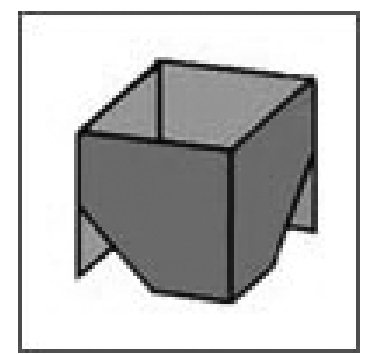

C. -

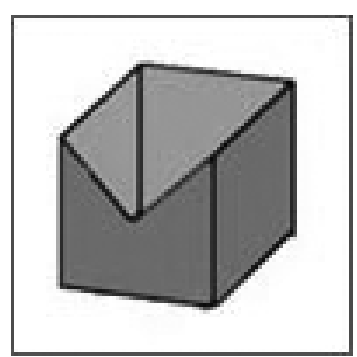

d. -

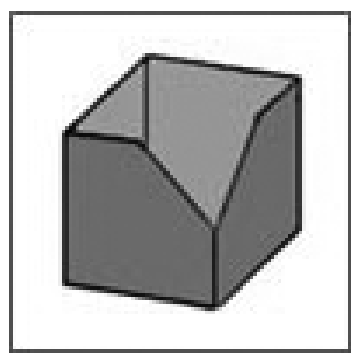


Imagine que pliega el siguiente cuadrado por la línea de puntos, ¿Cómo quedaría la figura?

a.-

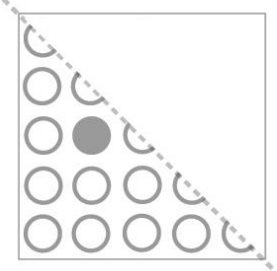

b.-

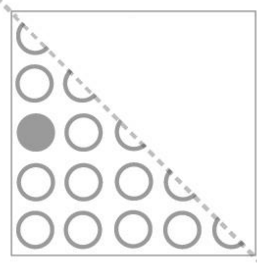

C.-

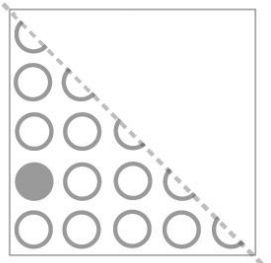

d. -

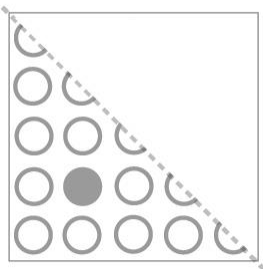

11 - ¿En cuál de las siguientes imágenes está incluida la siguiente figura?:

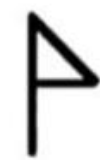

a.-

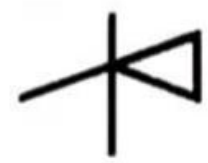

b. -

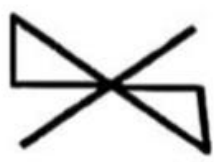

C.-

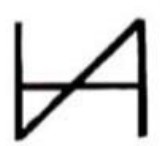

d. -

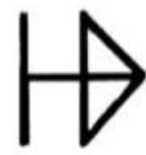

12 - ¿Cuál de estas líneas oblicuas plantea el ángulo menor con respecto a la horizontal?:

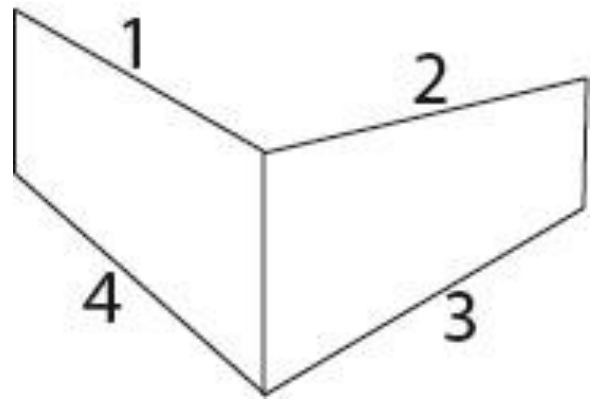
a.- La línea 2.
b.- La línea 1.
c. - La línea 4.
d.- La línea 3.

13 - ¿Qué es lo primero que reconoce en la siguiente imagen?:
a. - Una persona.
b. - La letra $v$.
c. - Una señal.
d. - Ninguna de las anteriores: ...

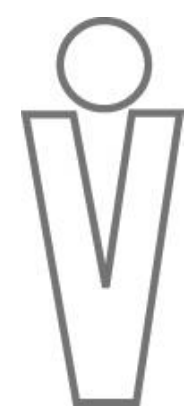




\section{Constancia de la forma.}

La constancia de la forma nos permite reconocer los objetos, a pesar de los cambios de su imagen a nuestra vista.

14 - ¿Cuál de las siguientes figuras abatidas diría que corresponde al rectángulo?

(n)

15 - ¿Cuál de las siguientes figuras no se corresponde con el giro de esta figura?:

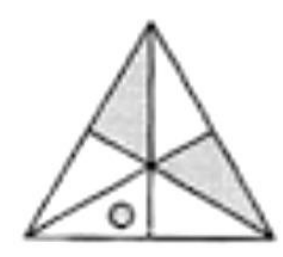

(..-

16 - Con cuál de estas afirmaciones está más de acuerdo:

a. - La forma de los objetos es una: lo que son en realidad. (por ejemplo: "Un folio es un rectángulo").

b.- Los objetos adoptan diferentes formas.

(por ejemplo: "Un folio puede ser un rectángulo, un trapecio o una línea").

c.- Los objetos tienen la forma del objeto en sí.

(por ejemplo: "Un folio tiene forma de folio")

d. - No puedo establecer una forma simple a un objeto. 
17 - ¿Cuál es el menor de los ángulos formados por las manecillas del reloj?

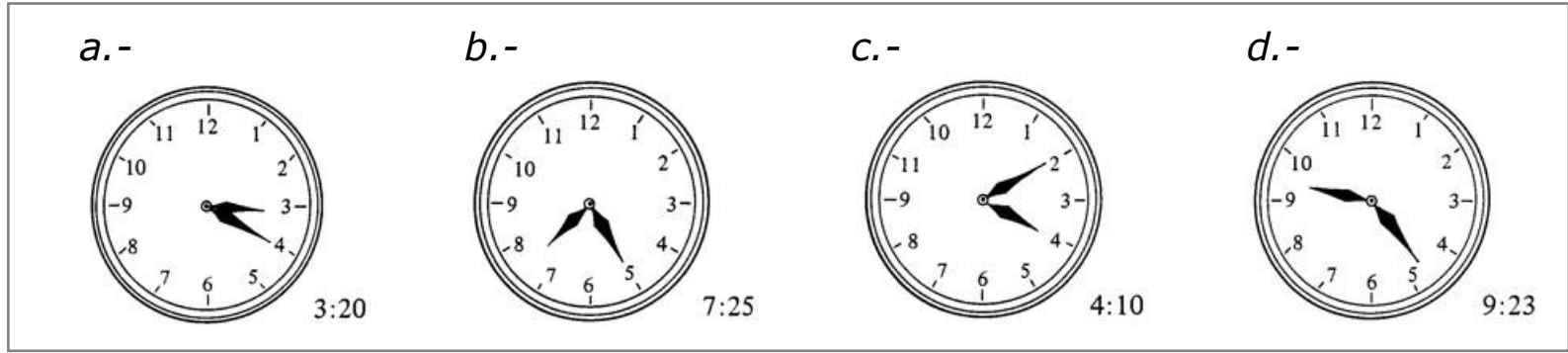

\section{La medida de la forma.}

Tendemos a analizar las formas que vemos relacionando sus medidas.

La proporción establece la relación entre dos medidas o entre las partes de un objeto. El resultado lo solemos expresar con una fracción o con un número geométrico.

18 - ¿Qué proporción establecería la relación de la línea menor $\boldsymbol{r}$ con la línea mayor $\boldsymbol{s}$ ?

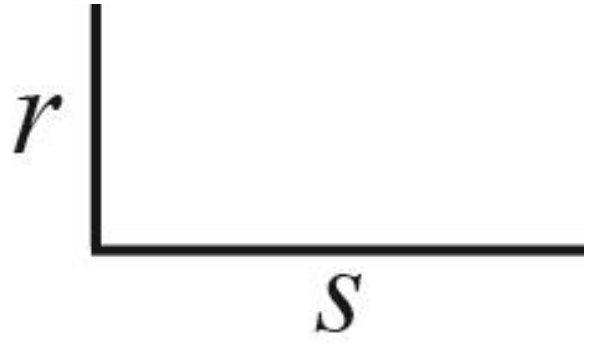
a. $-1 / 3$.
b. $-3 / 4$.
c. $-1 / 2$.
d. $-2 / 3$.

19 - ¿Con qué proporción establecería la relación del rectángulo a con el rectángulo total?

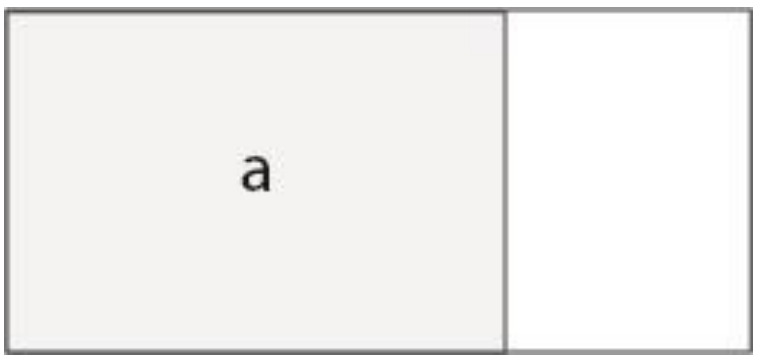
a. - $1 / 3$.
b. $-3 / 4$.
c. $-1 / 2$.
d. $-2 / 3$. 
20 - De las siguientes figuras, ¿Cuál cree, a simple vista, que tiene la misma altura y anchura?:

a.-

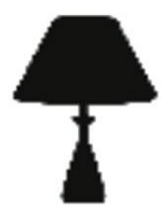

b. -

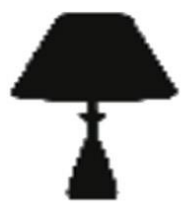

C. -

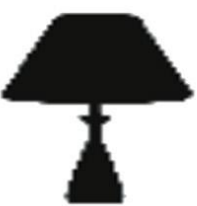

d. -

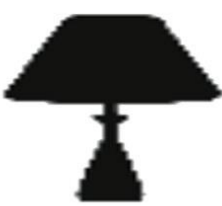

21 - De las siguientes figuras, ¿Cuál cree que tiene, a simple vista, el doble de medida en anchura que en altura?:

a.-

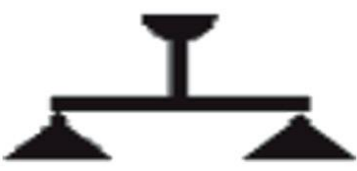

b. -

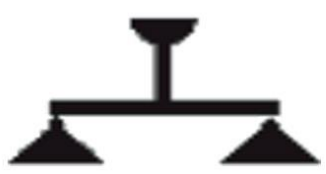

C. -

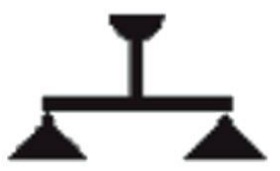

d. -

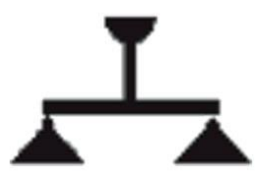

22 - De las siguientes figuras, ¿Cuál cree que tiene, a simple vista, el doble de medida en altura que en anchura?:
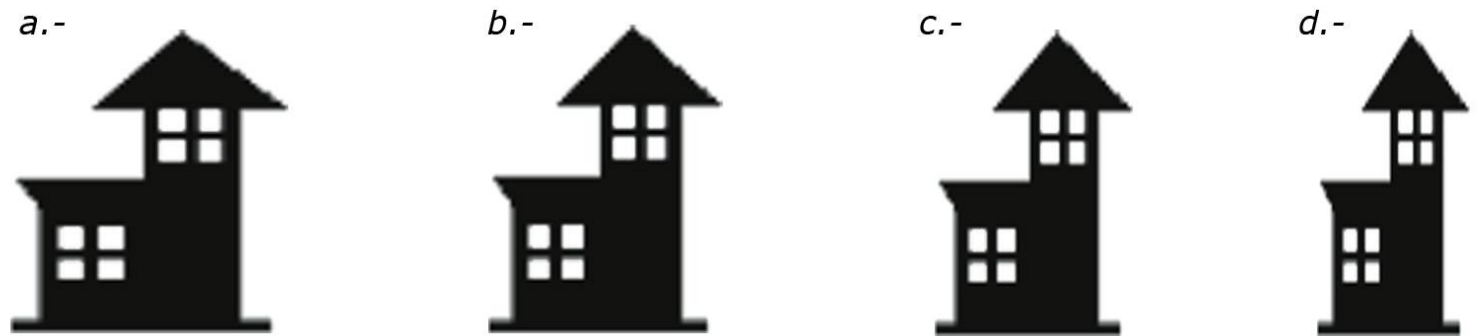
23 - Considerando la cabeza de un adulto como un óvalo,

¿Cuál de estas líneas cree que define la altura de la posición de los ojos?

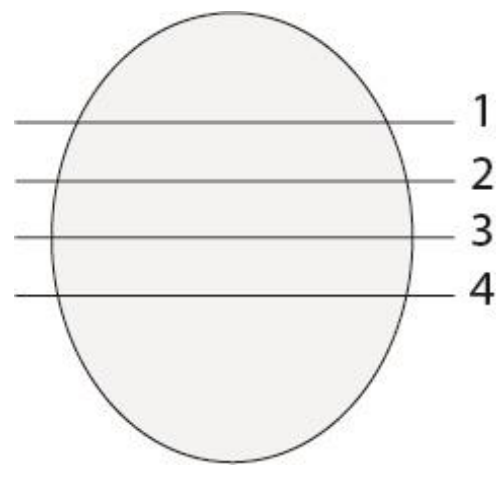
a.- 1 .
b. -2.
c. -3 .
d. -4.

Este folio mide $21 \times 29,5 \mathrm{~cm} . .$.

Las medidas de anchura y altura de los folios que utilizamos, ¿cree que guardan alguna relación entre sí?
a.- Si, tienen una relación de proporción.
b. - Si, tienen una relación de fabricación.
c. - No tienen relación con un número concreto.
d. - No tienen ninguna relación.

25 - Las medidas de anchura y altura de las pantallas de los dispositivos tecnológicos, ¿cree que guardan alguna relación entre sí?
a. - Si, tienen una relación de proporción.
b. - Si, tienen una relación de fabricación.
c. - No tienen relación con un número concreto.
d. - No tienen ninguna relación.

26 - ¿Qué es lo primero que reconoce en esta imagen?:

a. - La letra e mayúscula.

b. - Líneas quebradas.

c.- Escalera.

d. - Ninguna de las anteriores: ...

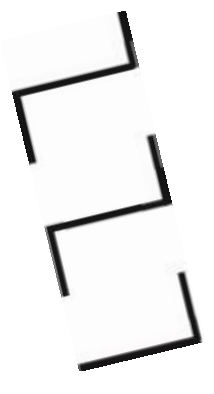




\section{Lectura de imagen.}

Interpretamos las imágenes en relación a códigos objetivos y subjetivos.

Observe por un momento la siguiente imagen ('Maestra de Escuela' fotografía de August Sander, 1904) y responda a las siguientes cuestiones:

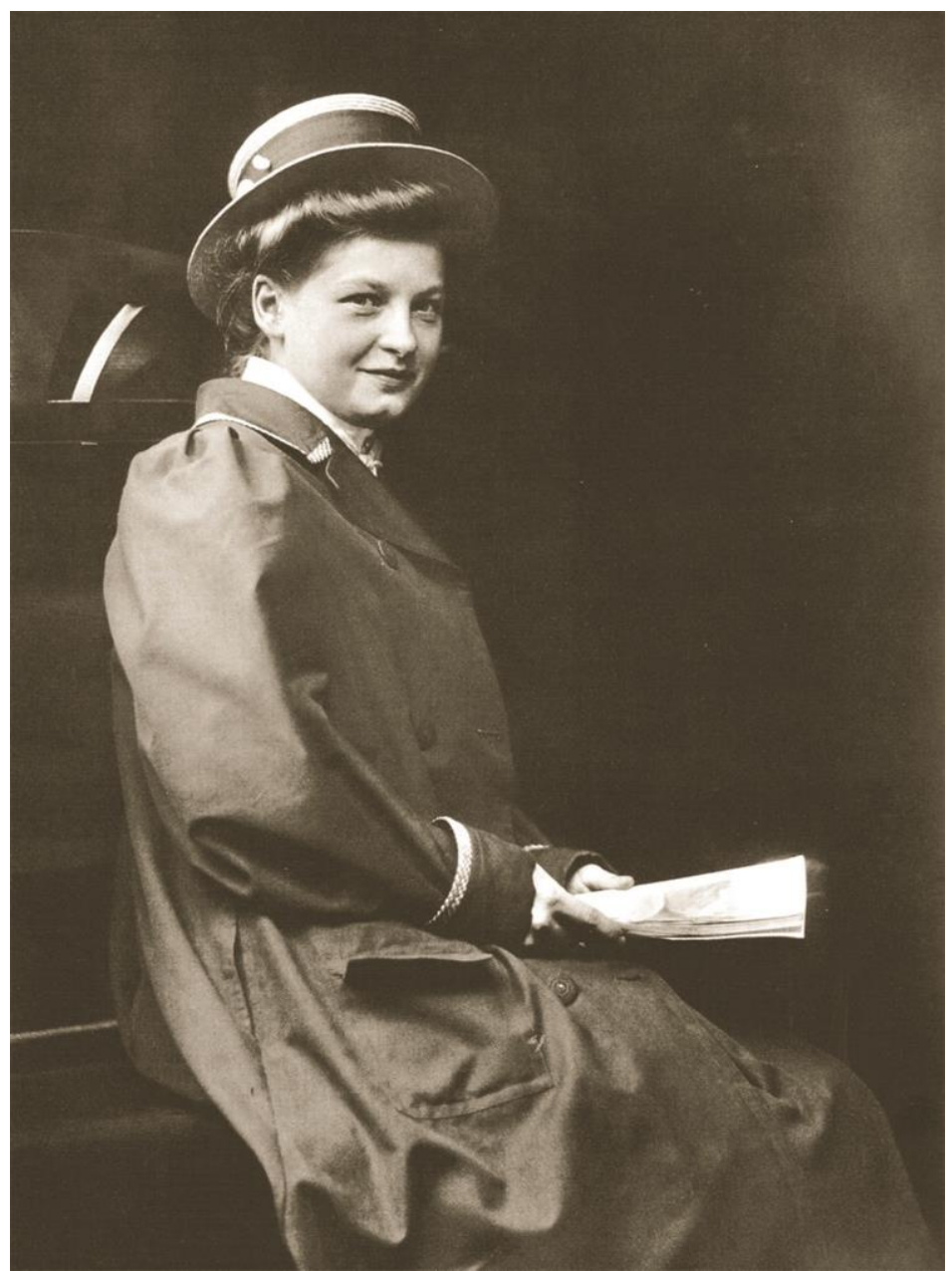

27 - De las siguientes miniaturas, ¿cuál reconoce que corresponde a la composición de la imagen?

a.-

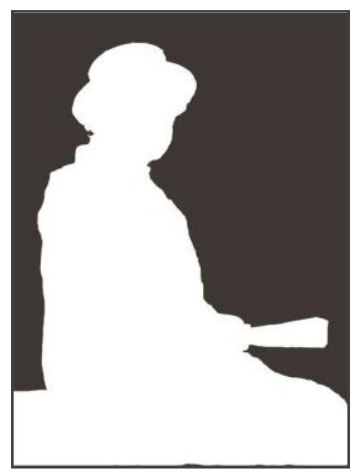

b. -

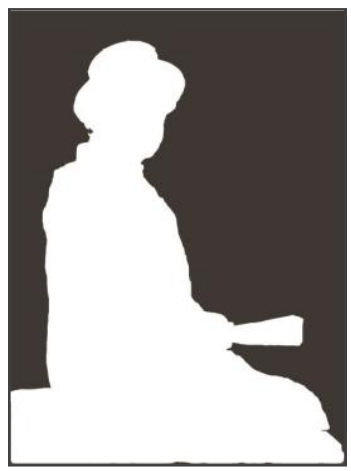

C.-

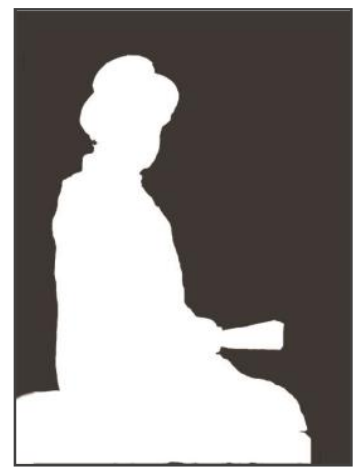

d.-

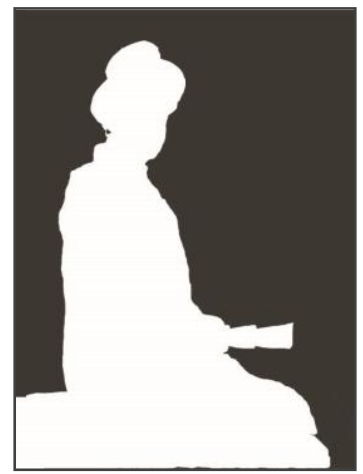


28 - Considera que, en el momento de tomar la fotografía, el fotógrafo estaba situado:

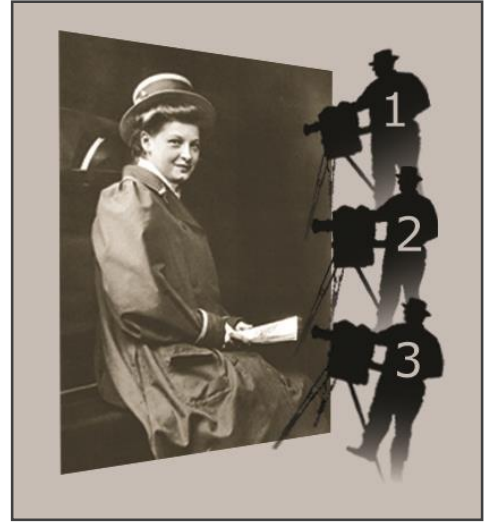

a.- ligeramente por encima de la modelo (silueta 1).

b. - a la misma altura de la modelo (silueta 2).

c. - ligeramente por debajo de la modelo (silueta 3).

d.- no lo puedo saber.

Considera que el fotógrafo le sitúa a Ud. como espectador frente a la modelo:

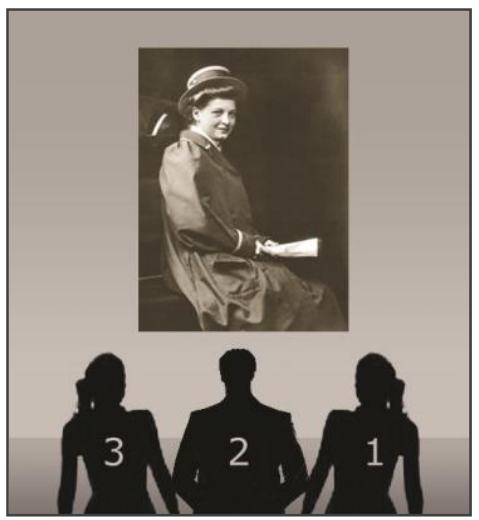

a.- ligeramente a la derecha (silueta 1).

b. - centrado frente a la modelo (silueta 2).

c. - ligeramente a la izquierda (silueta 3).

d.- no lo puedo saber.

30 - ¿Cuál de estas divisiones representa mejor el eje vertical de la figura en el rectángulo de la fotografía?
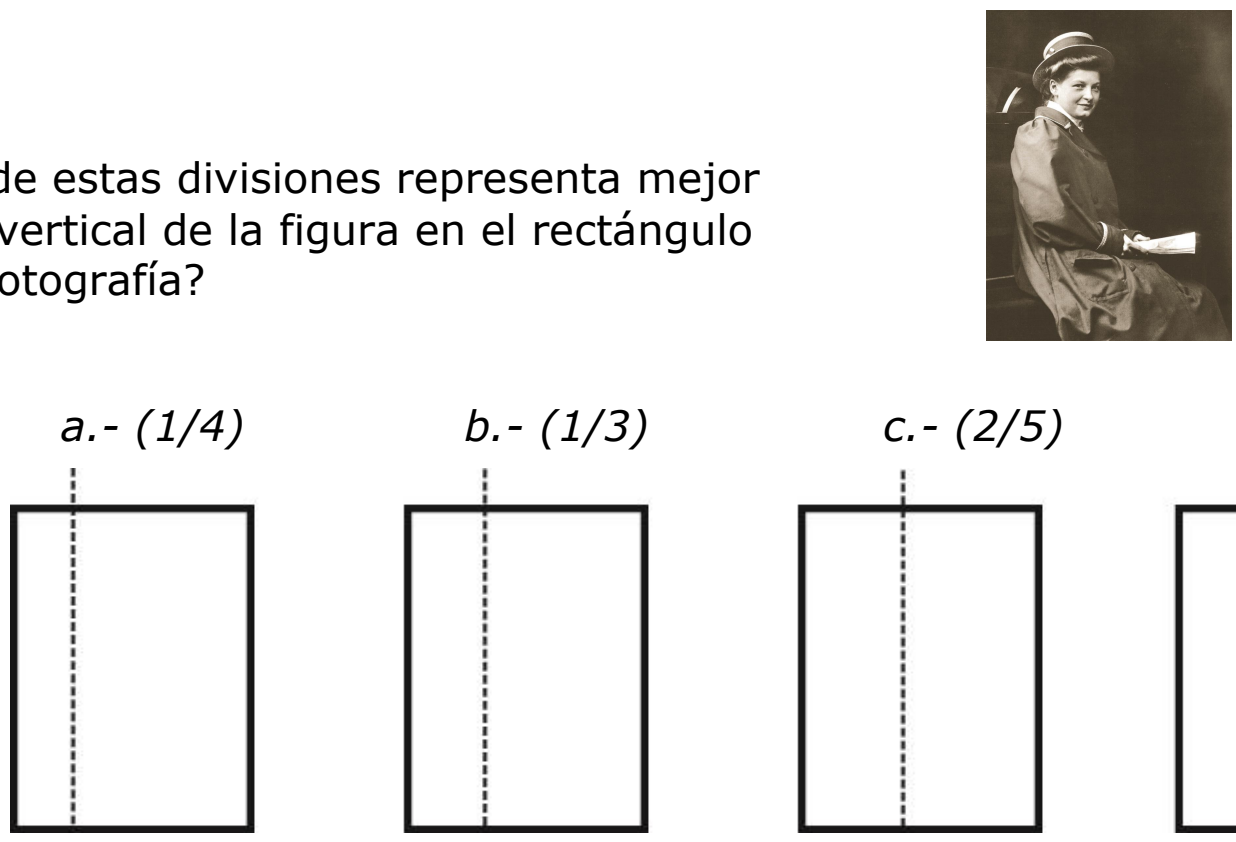

b. - (1/3)

C. $-(2 / 5)$

d. $-(1 / 2)$
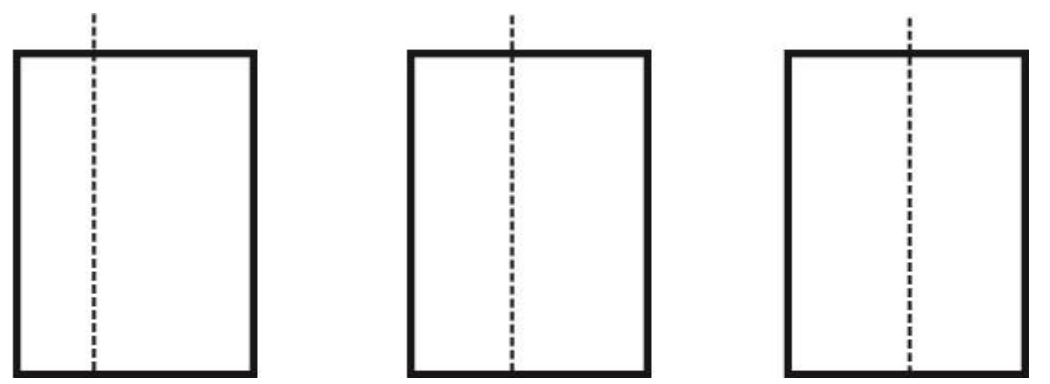


\section{Valoración del pensamiento visual.}

Valore su opinión sobre la incidencia de los planteamientos viso-espaciales en la didáctica y la educación.

\section{Rodee el número que mejor refleje su valoración de cada afirmación de (0) nada a (5) mucho.}

31. - El Pensamiento Visual está relacionado con la elaboración de mapas cognitivos, infografías, videos u otros recursos educativos ...

\begin{tabular}{|llllll|}
\hline 0 & 1 & 2 & 3 & 4 & 5 \\
\hline
\end{tabular}

32. - La competencia o inteligencia espacial es necesaria para el uso de las nuevas tecnologías en educación...

\begin{tabular}{|llllll|}
\hline 0 & 1 & 2 & 3 & 4 & 5 \\
\hline
\end{tabular}

33. - La formación en competencia o inteligencia espacial, en mis estudios de grado, ha sido satisfactoria o suficiente...

\begin{tabular}{|llllll|}
\hline 0 & 1 & 2 & 3 & 4 & 5 \\
\hline
\end{tabular}

34. - La habilidad representativa del dibujo está en estrecha relación con el talento artístico...

\begin{tabular}{|llllll|}
\hline 0 & 1 & 2 & 3 & 4 & 5 \\
\hline
\end{tabular}

35. - El aprendizaje de la competencia gráfica del dibujo es importante en la formación del grado en educación:

\begin{tabular}{|llllll|}
\hline 0 & 1 & 2 & 3 & 4 & 5 \\
\hline
\end{tabular}

Ha terminado. Gracias por su colaboración. 